$$
\text { إزالة إيهام القائلين بوجود }
$$

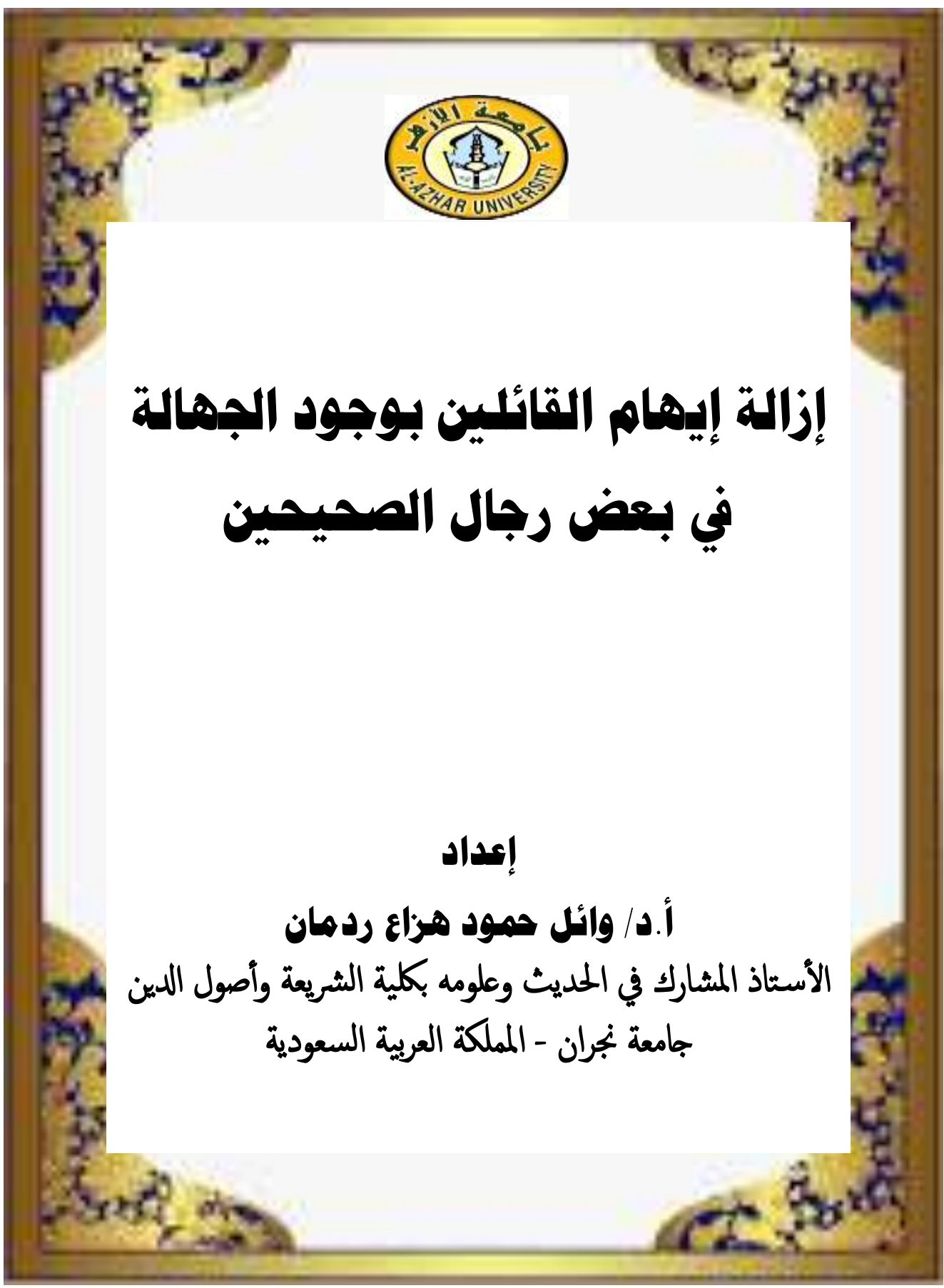

مجلة كلية أصول الدين والدعوة بأسيوط / العدد السابع والثثلاثون 9 ـ بام - الجزء الثالث 
إزالة إيهام القائلين بوجود

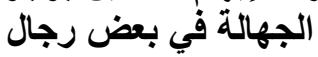

\section{ملنص البحث}

اسـم البحث: " إز الــة إيهام القائلــين بوجـود الجهالـة في بعض رجـال

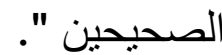

اسم الباحث: د/ وائل حمود هزاع ردمـان - كليـة الثريعة - جامعة

نجران - المملكة العربية السعودية.

كلمات مفتاحية: الجهالة - التوثيق الصريح - التوثيق الضمني - رجال

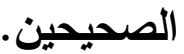

الحمد لله والصلاة والسلام على رسول الله وآله وصحبه وسلم، أمسا بعد،

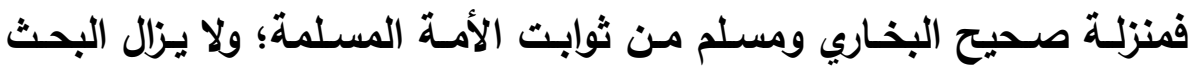

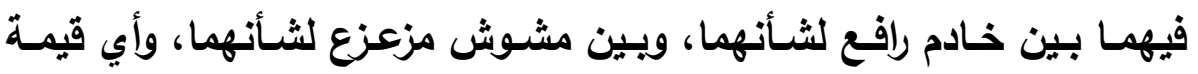

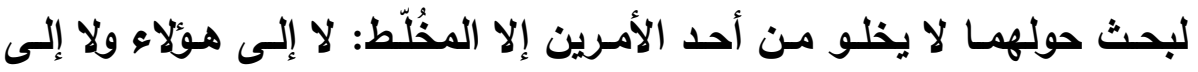
هؤلاء، ولما رأيت بعض الأبحاث تتطرق إلى أمر لـ يطرق من قبل الاهل بتوسيع:

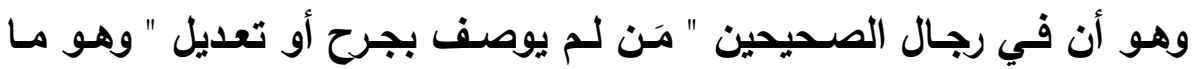

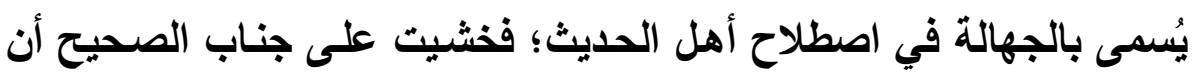
يسعف بحث كهذا الطاعن على الصحيح ولزيما شكلك المسلمين في عقيدتهم وشريعتهم. فكتبت هذا البحث موضحا كلام علماء الحديث في ذلك بيحث

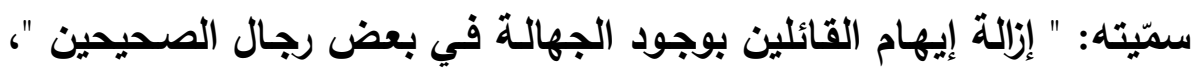

$$
\text { وهذه معالم البحث: }
$$

1 - معنى الجهالة، وأنها إحدى أسباب عدم قبول الحديث. والراوي المجهول

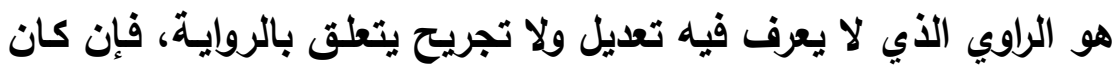

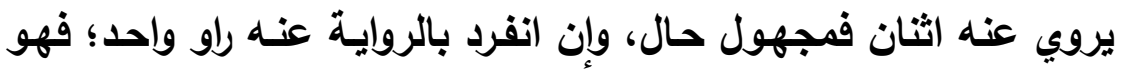


إزالة إيهام القائلين بوجود

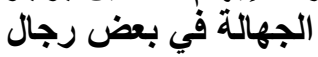

مجهول العين.

r - زوال هذه الجهالة يكون بالتوثيق، والتوثيق نوعان: توثيق بلفظ صريح

ممن يقبل قوله. وتوثيق ضمني: هو أن يدل صنيع محدث على اعتماد

روايـة من ليس عنده توثيق صريح كاعتمـاد البخاري أو مسلم بـاخراج

مرويات لهوّلاء في كتابهم الصحيح، وللتوثيق الضمني صور أخرى لا

تقل عن هذه في العمل.

ب- يمـر البحث بذكر قواعد التعامـل مـع الرواة الذين لـم يوصفوا بجرح أو

تعديل، ولا بـ من مراعاتها في الصنعة الحديثية، ومنها ضبط الروايـة

ومقارنة المرويات وخلو الرواية من التفرد والنكارة وغير ذلك من القواعد

التي يتكامل فهمها الاقيق بأخذها جملة واحدة لا تنقك.

ع - قيمة البحث العلمي في بحوث كهذه حول الصحيح؛ لا ينبغي أن يعتورها

الخلل الأي يعود إلى سوء فهم منهج المتقدمين في الصناعة الحديثية الجـامع بـين النظريـة والتطبيـق مسن غيـر اخـتلال. ولا تكـون أحكـام المتأخرين العامة بمثل حكم "مقبول" عند ابن حجر؛ حكما على رصين علم المتقدين كالباخري ومسلم في صحيحيهما، ولا يكون الباحث فيها تائها في تعامله مع نصوص أو قواعد أطلقها الأئمة في هذا العلم. ه- يقـر الباحسث فـي جمـع رواة لـم يوصـفوا بجـرح أو تعـديل مسن رواة الصحيحين؛ بأنهم من رواة الإسناد لا أنه ورد ذكر الواحد منهم في غير ذلك، وكذا خلو ذكر اسم الراوي من الوهم أو الخطأ وملتبسا براو آخر؛ إن كان الوهم ونحوه مؤثرا في إثبات كونها من رواة الصحيح. 
إزالة إيهام القائلين بوجود

الجهالة في بعض الفالين بوجال

צ- الظاهر أن قول الذهبي أقرب من اعتراض ابن حجر عليه،، أمـا قول

الذهبي فهو في ميزلان الاعتدال: "في رواة الصحيحين عدد كثير مـا فئ

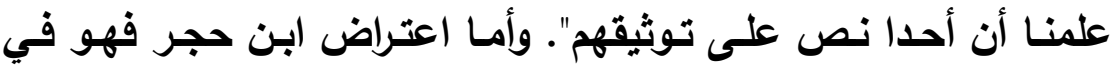
لسـان الميزان وقولـه: " ليس كذلكك بـل هذا شـيء نـادر؛ لأن غـالبهم معرفون بالثقة إلا من خرجا له في الاستشهاد".

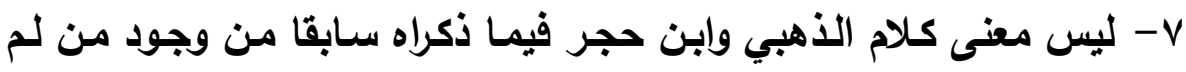
يوصف بتوثيق؛ إلا مجرد التوصيف الذي ليس لهه أثر في الحكم على الزراوي أو روايته في الصحيح، والتوصيف بوجود من لم يوصف بجرح أو الو

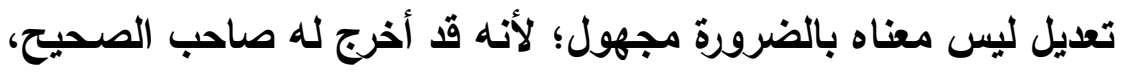
ويدل عليه نص الذهبي وهو يتعقب ابن القطان الفاسسي بقولـه: "ابن

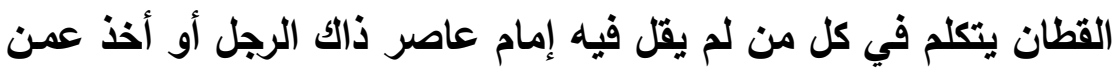
عاصره ما يال على عدالته. وهذا شيء كثير، ففي الصحيحين من هذا النمط خلق كثير مستورون، مـا ضعفهم أحد ولا هم بمجاهيل"، أي أن

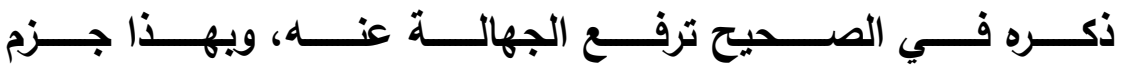
ابن حجر في هدي الساري بقولهه: "فمن زعم أن أحدا منهم مجهول؛

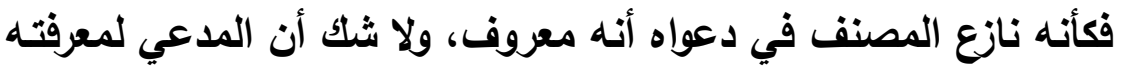

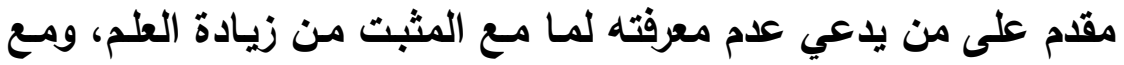
ذلك فلا تجد في رجال الصحيح أحدا ممن يسوغ إطلاق اسم الجهالة

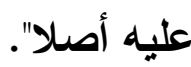
^- ليس هنـاك مـن صنّف من المتقدمين كتابـا خاصـا يجمـع فيـه مـن لـ يوصف بجرح أو تعديل من رجال الصحيح أو أفرد مصنفا خاصا لنقد مجلة كلية أصول الدين والدعوة بأسيوط / العدد السابع والثثلاثون 9 ا ـ بم - الجزء الثالث 
إزالة إيهام القائلين بوجود

الجهالة في بعض المالين بوجال

أحاديث الصحيح بعلة كهذه، وفي هذا دليل كاف لرد مزاعم من رام حول

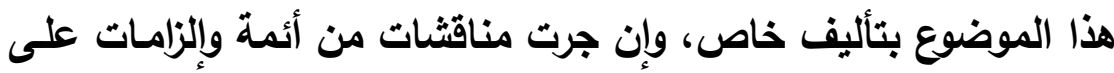

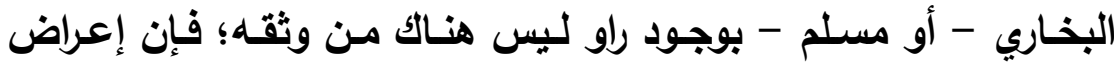

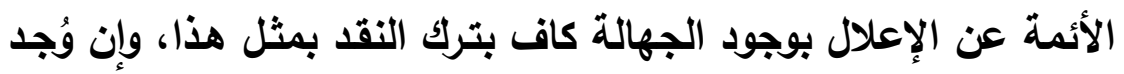
على سبيل الإثـكال فتلقفه مـ باحث خطير على صـاحبه إن سلمت الإل

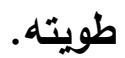

9- كل من ذكرته ممن يردده المثبت بوجود مجهول في الصحيح - لا أرى وصف الجهالة واقعا على أحد من هؤلاء، وهم في بحثي (9 9) تسعة

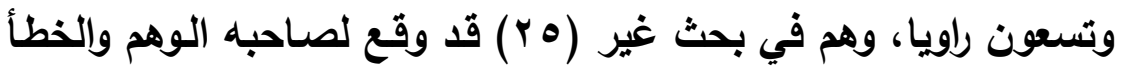

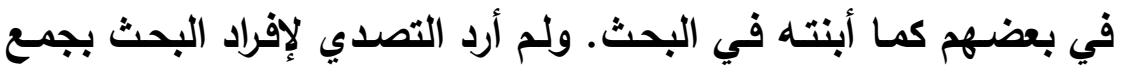

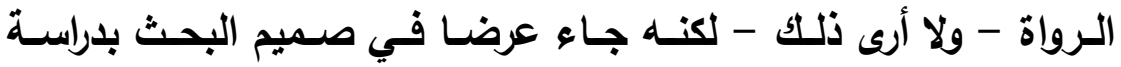

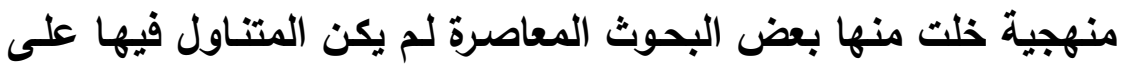

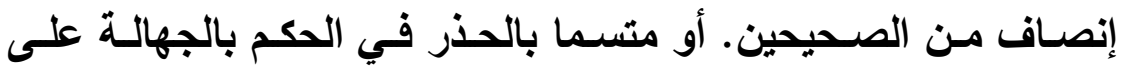

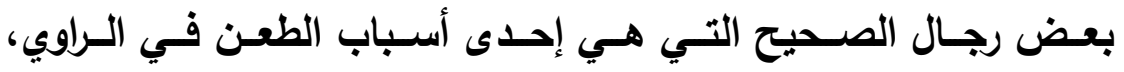

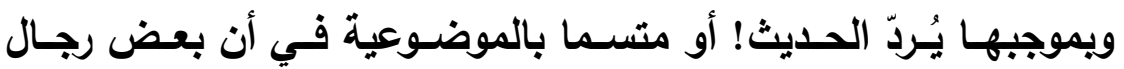
الصحيح لم يوصفوا بجرح أو تعديل!.

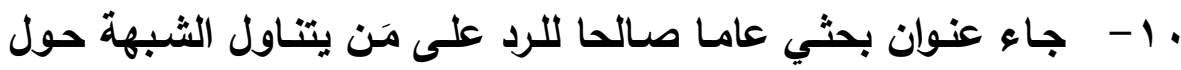
الصحيح بوجود جهالة في بعض رواته ليعم التناول وتكثر المنفعة! والله الموفق، و وعليه توكلت و وإليه أنيب

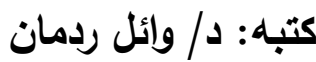
مجلة كلية أصول الدين والدعوة بأسيوط / العدد السابع والثلاثون 9 الـ بم - الجزء الثالث 
Removing the words of the existence of ignorance in some of the men of Sahihs

\section{Abstract}

Praise be to Allaah and prayers and peace be upon the Messenger of Allah and his family and companions. After that, the status of Sahih al - Bukhari and Muslim is one of the fundamentals of the Muslim nations(ummah). The research is still between the servant to raise them, and the confusion of their affairs, and any value of searching about them is not without one of them but the mixture. Not to these and not to these, and I saw some research touches on something that was not touched before by the expansion: that the men of Sahihs "who was not described as a hurt or modification," which is called ignorance in the terminology of the Ahl al - Hadith; I was afraid on the Al sahih to seek such research appellant and perhaps questioned the Muslims in their faith and legitimacy. I wrote this research, explaining the words of al - Hadith Scientists in that research called "Removing the words of the existence of ignorance in some of the men of Sahihs," and these features of the research:

The meaning of ignorance, and it is one of the reasons for not accepting al - Hadith. The unknown narrator is the narrator who does not know of any modification or dissatisfaction with the narration. If narrates about him two, he unknown status, and if one narrates, he is unknown person.

The disappearance of this ignorance is documented, and documentation two types: documenting the words of 
إزالة إيهام القائلين بوجود

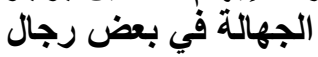

express who accept the saying. And implicit documentation: is to indicate an updated work on the adoption of a narration who does not have explicit documentation such as the adoption of al - Bukhari or Muslim to produce narrations for those in their correct books, and the tacit documentation of other forms not less than these at work.

The research goes through mentioning the rules of dealing with narrators who have not been described as a hurt or modification that must be observed in al Hadith work, such as controlling the narration and comparing the narrates and the absence of the narration from the singularity and the denial and other rules that complement their precise understanding by taking one sentence.

The value of scientific research in such research about Al Sahih ; it should not be a misunderstanding of the applicants approach in al - Hadith work that combines theory and practice without disruption. And the researcher is not lost in dealing with the texts or rules launched by the imams in this science.

The researcher decides to collect narrators who have not been described as hurts or modified by the narrators of the Al Sahihs that they are narrators of attribution, but that the mention of one of them in the other, as well as the absence of mentioning the name of the narrator of the illusion or error and implicated another narrator ; if the illusion and so influential in proving that Al Sahihs narrators.

The apparent that the saying of Al Dahabi closest to 
إزالة إيهام القائلين بوجود

الجهالة في بعض رجال الزفن بوجال

the objection of Ibn Hajar it, but the saying of Al Dahabi is in the balance of moderation: "In the narrators of the Al Sahihs a number of many we learned that no one has documented them." As for the objection of Ibn Hajar, it is in the balance, and he said: "It is not so, but this is rare because most of them are known for trust except those who came out in citation."

The meaning of the words of Al - Dhahabi and Ibn Hajar is not what he mentioned earlier from the existence of those who were not described with documentation; only a description that has no effect on the narrator's judgment or his narration in the Al Sahihs. "The Ibn al - Qattan Al fasi speaks in all those who did not say the imam of that man's age or took his contemporaries as evidence of his justice, and this is a lot of things. In the Al Sahihs view of this pattern, What is weak by one and they are unknown, "that is to say in the Al Sahihs raises ignorance from him, and thus Ibn Hajar in the guidance of Al sari said : It is claimed that none of them is unknown; as if he is a dissenting worker in his claim that he is known, no doubt that the plaintiff to know him is submitted to those who claim not to know with the installer to increase the science, yet you find in the Al Sahih men anyone to justify the name of ignorance on it originally.

14. There is no class of applicants who have a special book in which a person who has not been prescribed a hurt or modified of the Al Sahih men or a specific individual is assigned a critique of the hadiths of the Sahih like this. This is sufficient evidence to respond to 
إزالة إيهام القائلين بوجود

الجهالة في بعض رجال الزفن بوجال

claims on this subject, And the obligations of Bukhari or Muslim - in the presence of narrator there is no confidence; the reluctance of the imams about the announcement of the existence of ignorance enough to leave criticism like this, if found is serious.

15 - Each of those mentioned by the installer of the existence of unknown in Al Sahih - I do not see the description of ignorance on one of them, and they are in my research(99), and in a search other than (25) has occurred to the owner illusion and error in some of them as mentioned in the research. I did not want to deal with the authors of the research by collecting all the narrators - and I do not see this - but it was an offer at the core of the research, a methodical study devoid of some contemporary research that could not be equated with fairness. Or is cautious in ruling ignorance on some of the Al Sahih men, which is one of the reasons to challenge the narrator, and under which the talk is given! Or objectively objected to that some of the Al Sahih men were not described as a hurt or modification !.

17. The title of my research is a good one to respond to those who deal with the similarities about the Al Sahih of ignorance in some of its narrations, so it is related to the hadeeth of the saheeh, and I think that what I have done - as a researcher in Al Hadeeth sciences - In this era, where our enemies are quick to undermine our constants, and it becomes more dangerous when some of these similarities are issued by the Muslims in good faith !. 
God is the conciliator

Key words: ignorance - explicit documentation - implicit documentation - Al Sahihs men

Researcher: Wail Hamood Hazaa Radman

Academic profile: Associated Professor of Hadith \& its Sciences, Department of the fundamentals of religion College of Sharia \& the fundamentals of religion Najran University - Email: wailradman@gmail.com 


\section{بسم الاله الرحمن الرحيم \\ المقدهة}

إن الحمد لله أحمده وأستعينه، من يهده الله فلا مضل لله ومن يضلل فلا

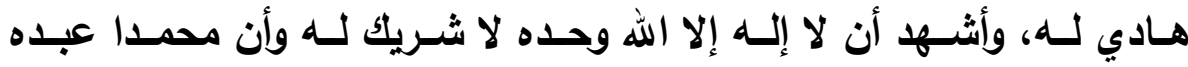

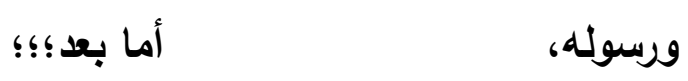

فكم هي جهود الإمام البخاري محمد بن إسماعيل (ت ؟ ب بهـ) وتلميذه

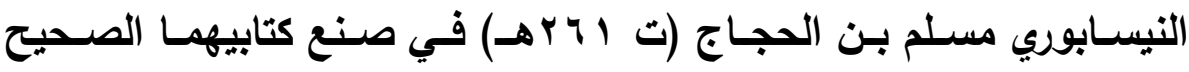

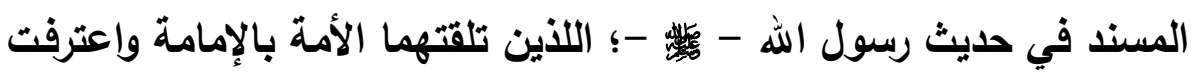
لهما بالفضل والسبق، وأجمعت على صحة ما ورد في كتابيهما من حديثٍ

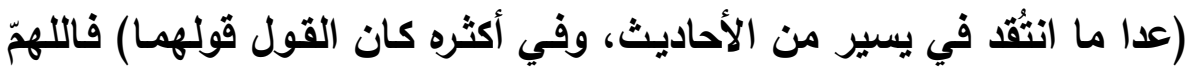
اجزهما عن الإسلام وأهله خير الجزاء.

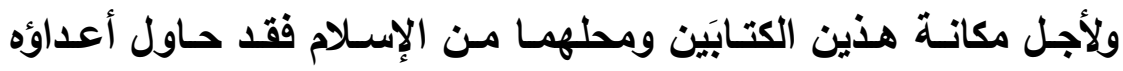

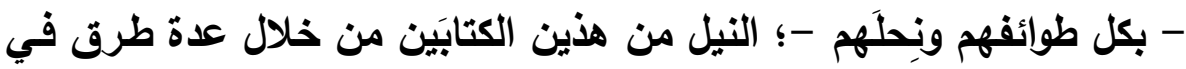
محاولات زائفة لما كتب الله حفظه ...

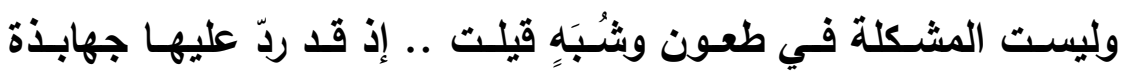

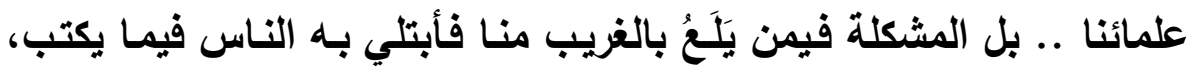
وتلقف الملحدون وأهل الأهواء مـا كتب لولعهم بكل مـا يهام السنن والآتثار وراقهم ذلك .. ومنه ما استوققني لأستاذ مشارك في الحديث وعلومه حول الجهالة في

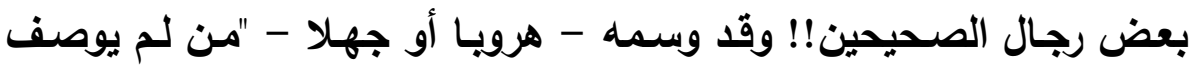
بجرح أو تعديل في رجال الصحيحين - جمع ودراسـة - !!!"، جرى صاحبه مجلة كلية أصول الدين والدعوة بأسيوط / العدد السابع والثلاثون 9 الـ بم - الجزء الثالث 
في عرضسه وأسلويه على عدم تحرير! سبيُه تصور مسبق بالخطأ أو على غموض محفوفا بالريبة! وما جاء فيه من نقولات جيدة لم يكن الباحث بها مجليا دفاعه عن الصحيح؛ كيف وفي بعض شرحه غمز فاضـح؛ كقولـه عن البخـاري أنـه حين أخرج البخـاري لحديث شـيخه المجهول (كذا حُكمُهه عند الباحـث، ويعنـي بـه حمـاد بـن حميـ الخراسـاني): إنمـا أخـرج لـه البخـاري مجاملة؛ لكونه جارا له! .. - فواغوثاه - بالله - من الباحث المنسوب للسنة المتخصص في علومهها: كأستاذ مشـارك!! فكم ترك مجـالا للعائب والطاعن على الكتابَين اللذين همـا أصـح الكتب بعد كتاب الله "القـرآن"؛ والباحث لـه بحث سـابق يتأصل فيه المعنى الذي ذكرت، بعنـوان "مجهول العين دراسـة نظريـة وتطبيقية"(1)، وذكر من مباحثه مبحثين حول الصحيحين، فالمبحث السابع: موقف الإمامين البخاري ومسلم من مجهول العين. والمبحث الثامن: حيث مجهول العين في الصحيحين. وكان ذا في ترقيته لأستاذ مشـارك ثم جاء ببحث للأستاذية يضخم هذين المبحثين ببحث عنوانـه: "من لـ يوصف بجرح أو تعديل من رجال الصحيحين - جمع ودراسـة - مـع تحقيق مذاهب الأئمة في حمم رواية المستور، وتأصيل قاعدة أن كل مدني روى عنه مالك

محكم في كلية أصول الدين والدعوة بالمنوفية، مصر ـ يُنظر موقع الباحث، ولتحميله:

https://nu.edu.sa/web/aalebbe/cv

https://dpgs.nu.edu.sa/documents/618654/16091016/\% D9\%85 \%D8\% AC\%D9\%87\% D9\% 88\% D9\%84\% 20\% D8\% A7\% D9 \%84\%D8\% B9\%D9\%8A\% D9\%86\% 20\% D8\% AF\%D8\%B1 \%D8\% A7\% D8\%B3\%D8\% A9\% 20\%D9\%86\% D8\% B8\%D8 \%B1\%D9\%8A\%D8\%A9\% 20\% D9\% 88\% D8\%AA\%D8\%B7 \%D8\%A8\% D9\%8A\%D9\%82\%D9\%8A\%D8\%A9.pdf مجلة كلية أصول الدين والدعوة بأسيوط / العدد السابع والثلاثون 9 ا ـ بم - الجزع الثالث 
إزالة إيهام القائلين بوجود

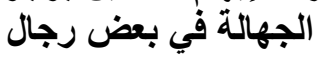

فهو ثقة، وأن رواية الشيخين لراو في الأصول هي توثيق له"(')، ومع عجبي من طول عنوانه فقيه ما أهو أعجب؟ وأعجب منه مـا جرى فيـه من استمالة عقولٍ إلى بحثّه! ثم يصفه بعض هؤلاء بـالتحقيق والتدقيق!! ولا ينقضسي العجب أن تعرف أنه بحث محكم من إحدى المجامع العلمية المشهورة!! ويـه جرت ترقيته للأستاذية!!! فمـاذا ترك للحاقدين على السنة من عقلانيين .. وملحدين .. وزنادقة ليبراليين! بـل هؤلاء - لا كثّرهم الله - لـ يكسبوا بحوثـا كهذه بلين الجاتب، ولا وطاءة الكنف، ولا خفض الجناح، ولا لبسط أو إيناس حتى يتألّقوا مؤلِّف كهذا - هداه الله - بـ بمحض فكرة طرأت منـه كمختص - يُرَى -؛ ظنـا بحسسه تحسين مستواه العلمس، ثـم الروم عن الصـيحين بقضية كهذه سيخرجه سالما دون تداعيات!! فالقضية خطيرة جدا؛ فأول مفاسدها إمكان الطعن في "صحيح البخاري"

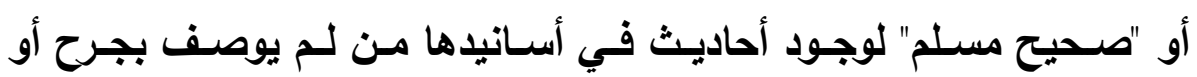
تعديل"؛ فيسهّل للمغرضين بابا مدعوما من باحث في مجال الحديث والسنة النبويـة!! وآخر هذه المفاسـ العائـد من مثلبـة على الصـروح المشيدة في الجامعات ذات الكليات الشـرعية الحاملـة على عاتقها تخريج أجيال تنصر وتتافح عن الاين الحنيف وتعلّم وترشد بالكتاب والسنة الصحيحة؛ أن يوجد بها من يدرس ويعلّم علوم الحديث عنده أفكار كهذه .. ثم مـا لبث الباحث تماديا إلا أن عكف بعد هذا البحث لشرح صحيح البخاري! على طريقة التتبع لمن تُكلم فيه من رجال الصحيح أو يظهر مظان النقد حول عنعنة الأئمـة

(1) يُنظر : حولية كلية أصول الدين والدعوة بالمنوفية، العدد بr لعام هب ؛ أه، إيداع

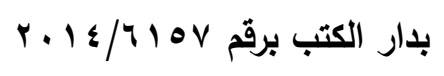
مجلة كلية أصول الدين والدعوة بأسيوط / العدد السابع والثلاثون 9 ـ بم - الجزء الثالث 
إزالة إيهام القائلين بوجود

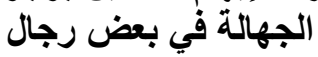

الأثبات ممن وصف بتدليس، ولم يسعه في ذلك ما وسع الأئمة من قبولها(1) . لذلك أحبيت التأسيس بالبيان والتوضيح والنصسح والإرشـاد للصـيح في هذه المسـألة "وجـود المجهول مـن رجـال الصـحيحين" ومـا الـلازم اعثقـاده للباحث قبل الخوض في مسـألة كهذه، مستعرضـا من هذا البحث "مـن لـم يوصف بجرح أو تعديل من رجال الصحيحين ..." ما يجب التنبيه عليه دون ذكر اسـم الباحث؛ ليُستعظم في التفـوس إجـلال الصـحيحين، ويحترس مـن دواهي سنقطة الغافلِ، وتخيب مقاصد الطاعنين بالكَلّ، وتُضحي آمـالهم في الظلّ، مسميا بحثي "إزالـة إيهام القائلين: بوجود الجهالـة في بعض رجـال الصحيحين" ليتبيّن من بعده علو منزلة الصحيح وإبعاد شبهة الجهالة بأحد رجالـه في تلأك الأحاديث المرويـة، وأن القائل بوجود مجهول داخل أسـانيد الصحيح؛ مآله إلى الطعن والنيل من أحسن وأصح الكتب بعد كتاب الله .. فالبحث يهدف إلى القيام بواجب الدفاع عن الإسـلام من خـلال ردّ شبهة "وجـود رواة مجهولين في أسـانيا صـيح البخـاري ومسـلم"، ولا زال العلمـاء يقومسون بواجب الدفاع عمومـا في كل مـا يتــاول المسـاس بثوابت الإسـلام خاصة مكانة الصحيحين، وهذا سبيل العلماء، وقد قام بهذا الواجب عدد من

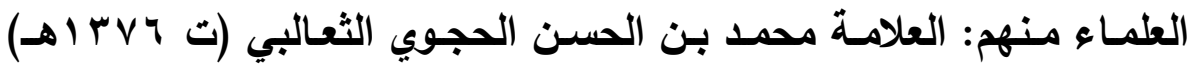
بكتابـه المســى: "الـدفاع عن الصـحيحين دفـاع عن الإسـلام"(؟)، والعلامـة

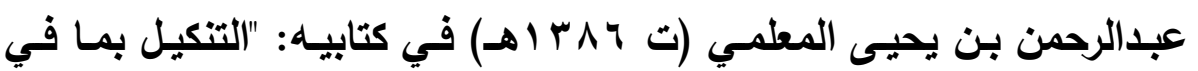

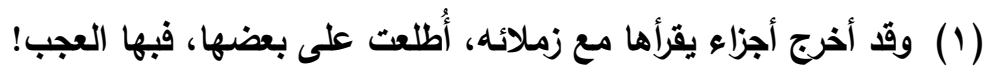

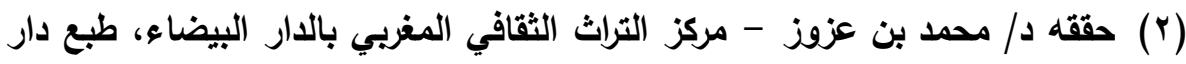

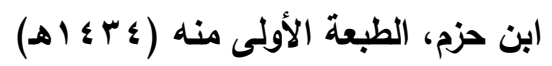
مجلة كلية أصول الدين والدعوة بأسيوط / العدد السابع والثثلاثون 9 ـ ـ بم - الجزع الثالث 
تأنيب الكوثري من الأباطيل"(1)، و"الأنوار الكاشفة لما في كتاب "أضواء على هل

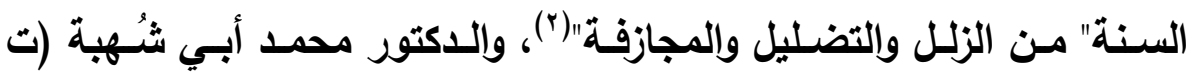

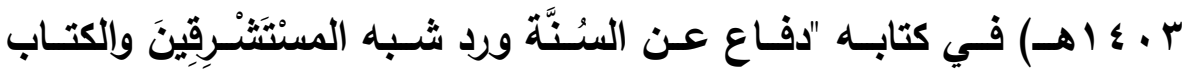

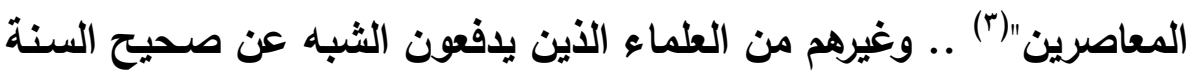

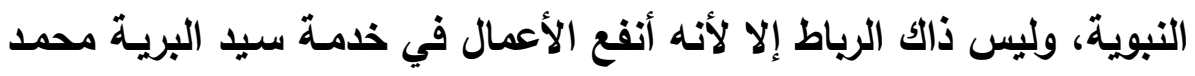
-

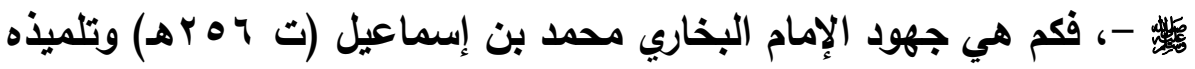

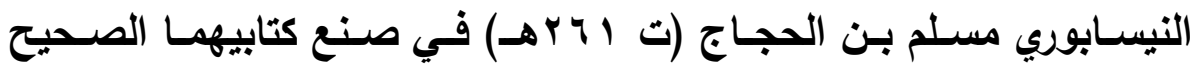

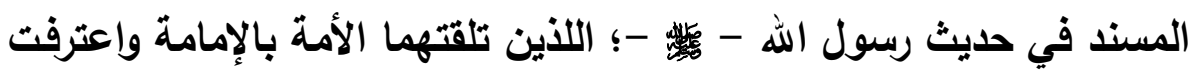
لهما بالفضل والسبق، وأجمعت على صحة ما ورد فيهما من حديث (عدا ما

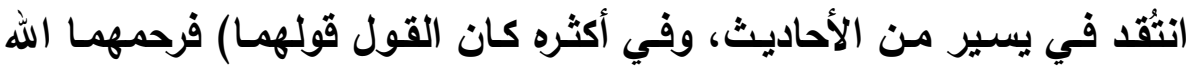
وجزاهما عن الدين وأهله خير الجزاء. أهمبة البحث وهدفه تظهي من رائه وائز البحث التي تدور حول:

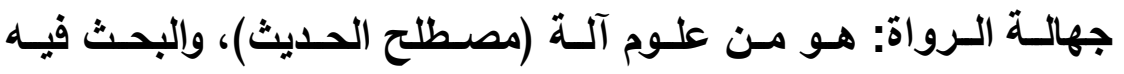

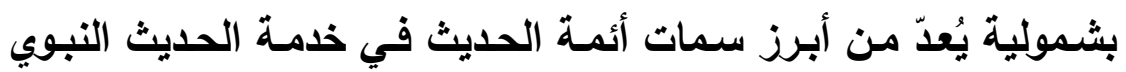

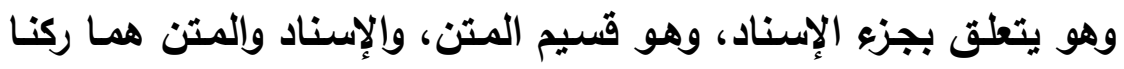
الحديث.

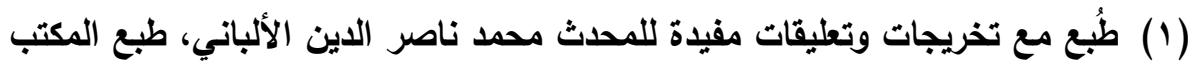

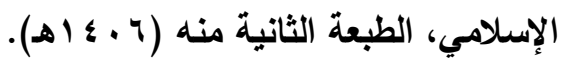

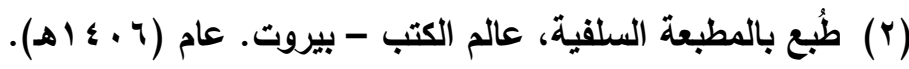

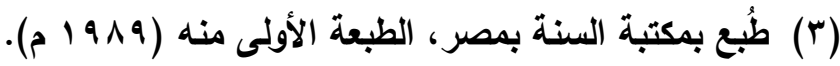
مجلة كلية أصول الدين والدعوة بأسيوط / العدد السابع والثثلاثون 9 ا بـم - الجزء الثالث 
إزالة إيهام القائلين بوجود

الجهالة في بعض الفالين بوجال

الجهالة: هي إحدى وجوه الطعن لرواة الإسناد والذي يعود بدوره إلى عدم قبول الحديث، أو لنقل على الأقل: الجهالة موجبة للتوقف فيه حتى تزاح عن إسناده تلك الجهالة؛ لأن الحديث المقبول هو ما اتصل إسناده وتـرجح صـدق راويـه فيــا رواه ونقلـه، والمجهـول لـم يُعـرف بجرح ولا تعديل. الراوي المجهول في الاصطلاح الثـائع: هو الراوي الذي لا يعرف فيه تعديل ولا تجريح يتعلق بالروايـة، فبإن كان يـروي عنـه اثنـان فمجهول حال، وإن انفرد بالرواية عنه راو واحد؛ فهو مجهول العين. وزوال هذه الجهالة بنوعيها يكون بتوثيق إمام معتبر، أو قرينة تغلّب زوال جهالته. التوثيق نوعان: أ- توثيق صريح من إمام معروف يقبل قوله في الرجال، كقوله: "فلان ثقة" أو "صدوق" أو غير ذلك مما فيه معنى التوثيق. ب- توثيـق ضـمني: هـو وجـود قرينـة عمليـة: تظلّب قبـول روايتـهـه وزوال جهالته، وله صور عدة منها قيام إماٍٍ من أئمة الحديث في كتابٍ اشترط فيه الصحة ثم نجد في أسانيده من لم نقف على إمام ضعفهم ولا وثقهم صراحة؛ فإدخال هذا الإمـام هذا الراوي في كتابـه الصـيح يُعدّ توثيقا ضمنيا عنده. •خير مثال على التوثيق الضمني هو ما نجده في صحيح البخاري ومسلم من وجود رجال لـم نقف على مَن ضعفهم ولا مَن وثُقهم صراحة؛ لكنّ وجود رواة كهوّلاء في صحيح البخاري ومسلم يُعدّ توثيقـا ضمنيا عند إمامي الصنعة البخاري ومسلم، وهما: مجلة كلية أصول الدين والدعوة بأسيوط / العدد السابع والثثلاثون 9 اــم - الجزء الثالث 
إزالة إيهام القائلين بوجود

الجهالة في بعض الفالين بوجال

الإمام محمد بن إسماعيل بن إبراهيم بن المغيرة أبو عبدالله البخاري، وُلد

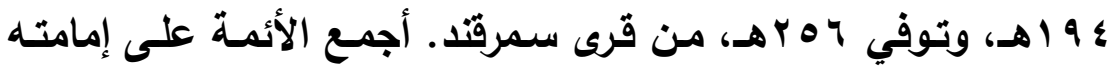
وحفظه وعلمه، وقال فيه الإمام الأهبي: "الإمام صاحب "الصحيح"، وكان

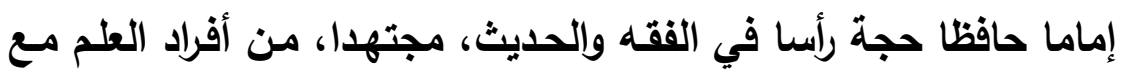
الاين والورع والتأله"( ). وقال الحافظ ابن حجر فيه: "جبل الحفظ، وإمام الانيا في فقه الحديث"(؟). أمـا الإمـام مسـلم فهـو بـن الحجـاج بـن مســلم القشـيري، أبـو الحسـين

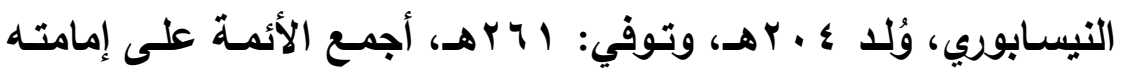
وحفظه، وقال فيه الإمسام الذهبي: "الحافظ، صـاحب "الصحيح"(). وقال

الحافظ ابن حجر فيه: " ثقة حافظ إمام "(؛) وهئ. • اسم كتاب الإمام البخاري: "الجامع المسند الصحيح المختصر من أمور

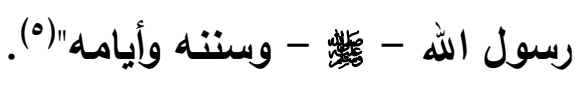

اسـم كتـاب الإمـام مسـلم: " المسند الصـيح المختصر من السنن بنقل

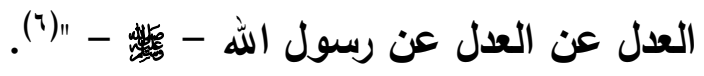

$$
\begin{aligned}
& \text { (1) الكاشف (Y/Y (107 - 10V). }
\end{aligned}
$$

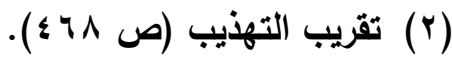

$$
\begin{aligned}
& \text { (r) الكاشف (r०N/r) }
\end{aligned}
$$

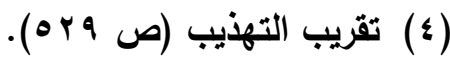

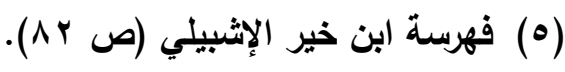

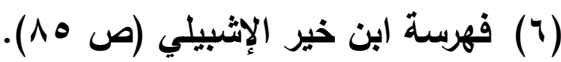




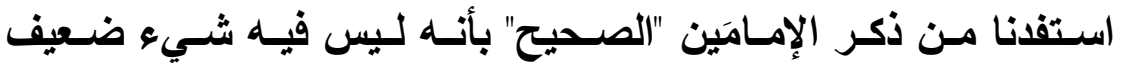

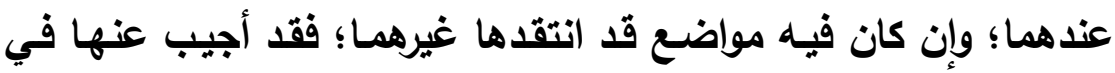

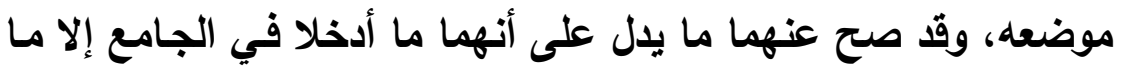

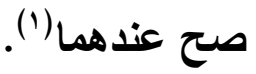
• جلالة قدر الكتابَين قام الأئمة والعلماء سلفا وخلفا بخدمتهما بين شرح

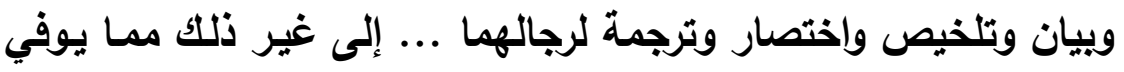
قدرهما ومنزلتهما فجزى الله هؤلاء العلماء خير الجزاء.

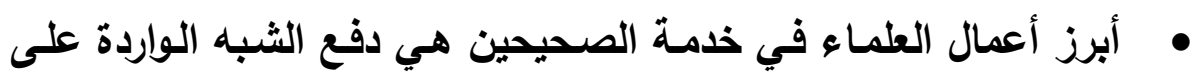

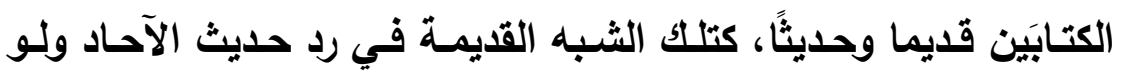

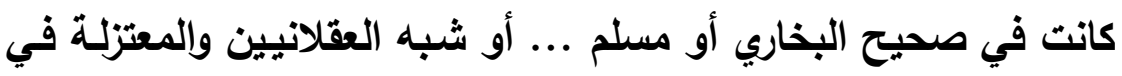
ردّ المشكل معناه من حديث الصحيحين إلى غير تلك الأعمال الجليلة التي هي رصيد ذاخر لهم وللأمة . .

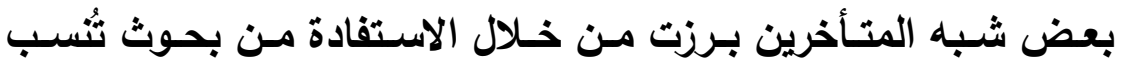

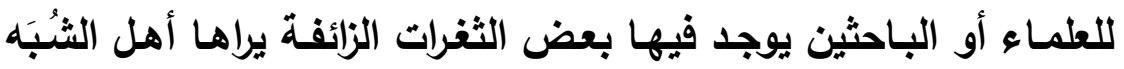

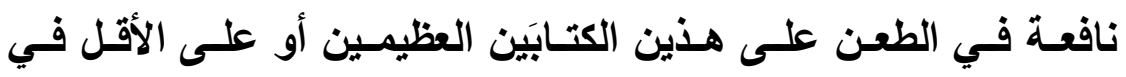

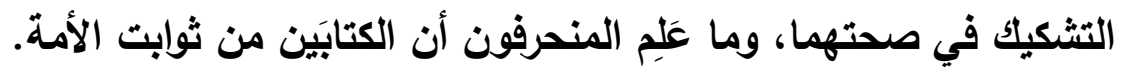

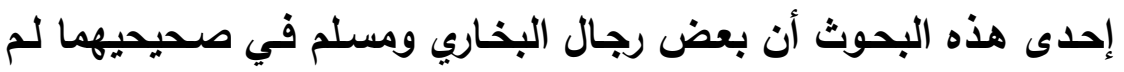
يوصفوا بجرح أو تعديل، وعليه فإن حكم هؤلاء: الجهالة، وهي إحدى لئى

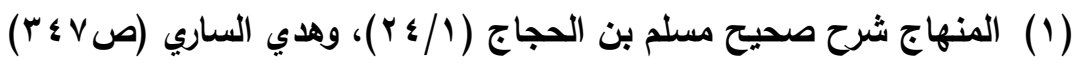
مجلة كلية أصول الدين والدعوة بأسيوط / العدد السابع والثثلثون 9 ا ـ بم - الجزء الثالث 
أسباب الطعن في الراوي، ويموجبها يُردّ الحديث أو يعذر فيه من لا يقبل ذللك الحديث !! • لذا وجب عليّ - كباحث في علوم الحديث - وأمثالي صيانة الصحيحين

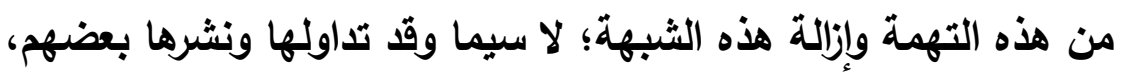

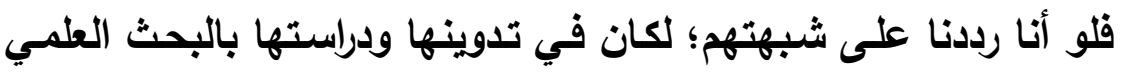
الرصين نفع عظيم مهم للباحثين والمحبين للسنة النبوية وأهل نحلتها. بحثي هذا يعتبر شاملا في موضوعه في الرد على شبهة جهالة بعض

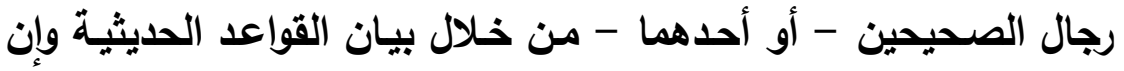
اختير العرض والنقد لبحث "من لم يوصف بجرح أو تعديل في رجال الصحيحين - عرض ونقد - !!!"، لأحد المنسوبين لتخصص الحديث

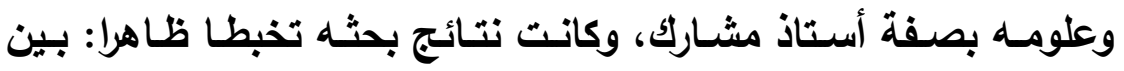
إثبات الجهالـة في بعض رجـال الصحيحين ويبين رفعها بمجرد إخراج صاحبي الصحيح الأي لم يجد له الباحث دليلا' (1).

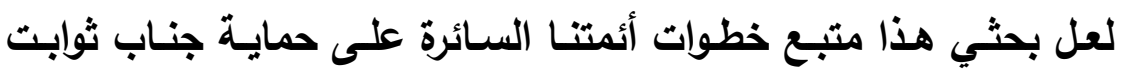

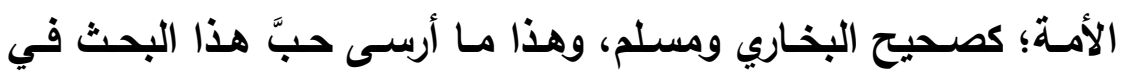

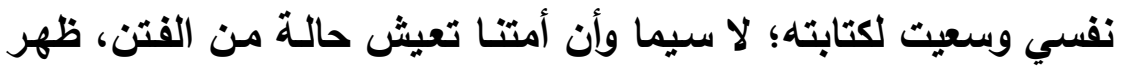
فيها مَن يتطاول على ثُوابت اللدين، ويشكك المسـلمين في عقيدتهم وشريعتهم. والله الموفق، والهادي لسواء السبيل.

(1) "من لم يوصف بجرح أو تعديل من رجال الصحيحين .." (ص ب01 - ؛ 1). مجلة كلية أصول الدين والدعوة بأسيوط / العدد السابع والثثلاثون 9 ـ بام - الجزء الثالث 
يقوم البحث على منهج البحث الحديثي الاستقرائي بالآتي: مقدمة وثلاثة مباحث.

وفي المقدمـة ذكرت فيها: سبب البحث وأهميته وهدفه بكونـه يتعلق بصحيح البخاري ومسلم، وعلاقة ذلك بعلوم السنة النبوية، وبيان مدى تأثثر الأبحاث التي تتناول المساس بهما، وخطورة مـآلات الأبحاث التي يستقيد منها الطـاعنون على الصحيحين خاصـة، والسـنة عمومـا، مـع ذكر ركائز

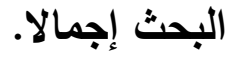

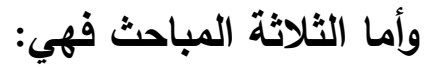

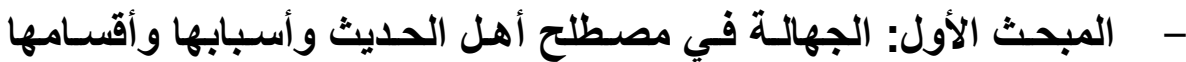

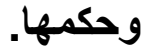

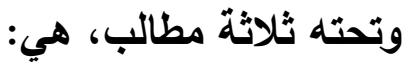
المطلب الأول: تعريف "الجهالة" لغة واصطلاحا وأقسامها. المطلب الثاني: أسباب الجهالة. المطلب الثالث: مكم الجهالة. - المبحث الثاني: "أسباب الخلل عند الباحث في وجود من لم يُوصف بجرح أو تعديل في بعض لنائ رجال الصحيح".

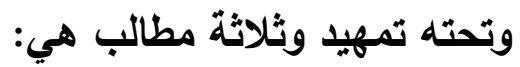
المطلب الأول: ضعف التصور وسابقية الاعتقاد. المطلب الثاني: الباحث مع قواعد المحدثين. المطلب الثالث: دعوى الإحصاء والجمع. 
- المبحث الثالث: "الاستقراء والدراسـة بين دعوى الباحث والمنهجية العلمية". وتحته تمهيد ومطلبان هي: المطلب الأول: محاور قصور الاستقراء والدراسة. المطلب الثاني: المثال العلمي للجمع والدراسة.

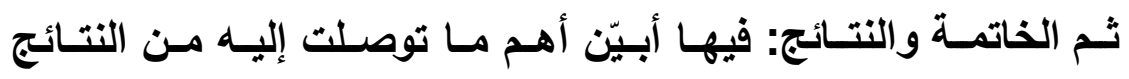
والتوصيات. ويعدها أرفق فهرسة للمراجع والمصادر والموضوعات. 
إزالة إيهام القائلين بوجود

الجهالة في بعض الفالين بوجال

\section{المبحث الأول}

الجهالة في هصطلح أهل الهديث وأسبابها وأقساهها وحكمها

\section{المطلب الأول}

\section{تعريف " الجهالة " لغة واصطلاحا وأقتساهها}

\section{الجهالة لغة: هي عدم المعرفة والعطم والخبرة(').}

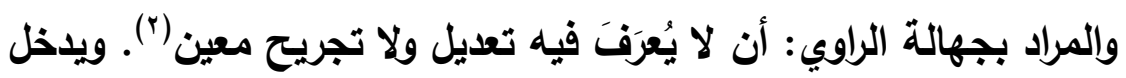

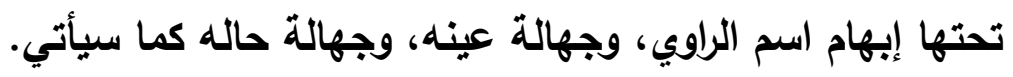

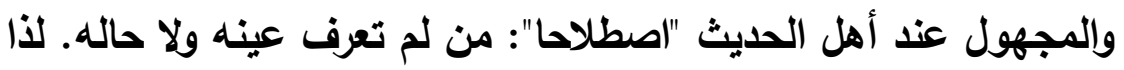

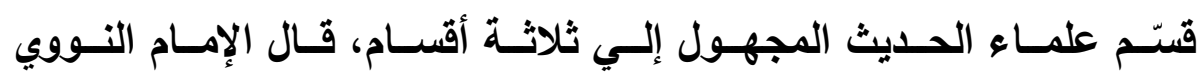

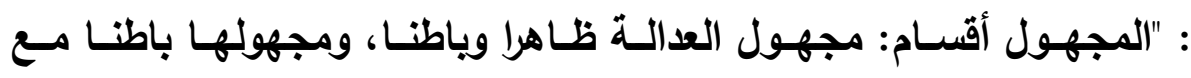

وجودها ظاهرا وهو المستور، ومجهول العين"(").

وأما ابن حجر فقد جعل مجهول الحال والمستور قسما واحدا وأطلق علي

هذا القسم كلا التسميتين(؛). وهذا تعريف كل منها باختصار:

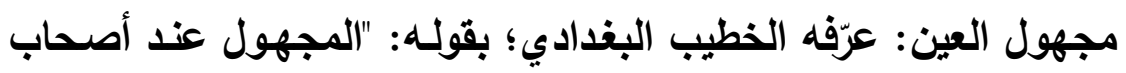

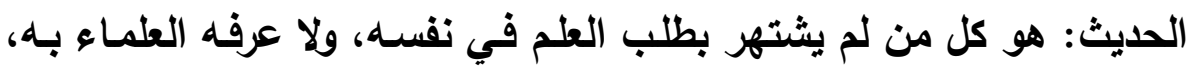

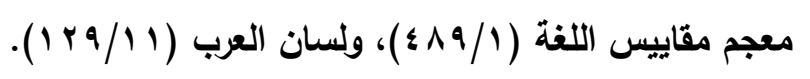

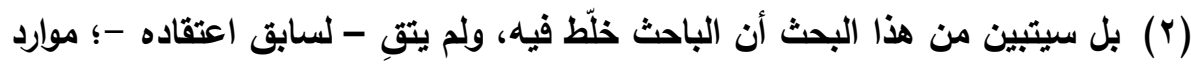

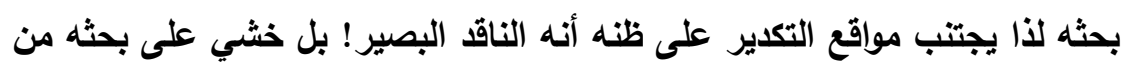

$$
\begin{aligned}
& \text { السرقة فأخفاه وقتا حتى وجد النصير! }
\end{aligned}
$$

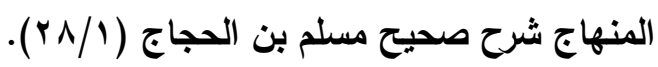

$$
\begin{aligned}
& \text { نزهة النظر (صזr (1). }
\end{aligned}
$$


إزالة إيهام القائلين بوجود

الجهالة في بعض الفالين بوجال

ومن لم يعرف حديثه إلا من جهة راو واحد"(1).

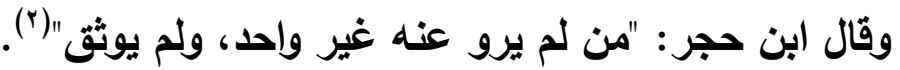
مجهول الحال: "هو من جهلت حاله الظاهرة والباطنة مـع كونـه معروف العين برواية عدلين عنه"(").

أمسا المستور فهو من جهلت عدالته الباطنة وهو عدل في الظاهر (؛). والفرق بينه ويين القسم الثاني أن المستور معروف العدالة ظاهرا. وقد جعل ابن حجر؛ مجهول الحال والمستور قسما واحدا؛ فقال: "إن روى عنه اثـان

فصاعدا - ولم يوثق - فهو مجهول الحال، وهو المستور"(•). والغالب إرادة جهالـة العين من إطـلاق لفظ "مجهول" علي أحد الرواة - دون تقييل -؛ وفي هذا يقول اللكنوي: "هو غالب اصطلاح أهل الشأن في هذا الإطـلاق" (")، ويعض الأئمسة ليست لـه طريقة واحدة في هذا الاطلاق،

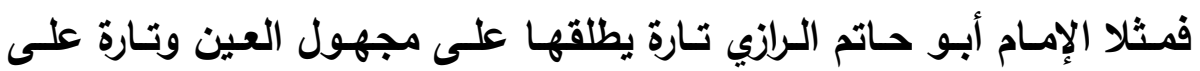
مجهول الحال، بـل وأبعد من ذلك يأتي على من ثبت صحبته فيقول فيهم:

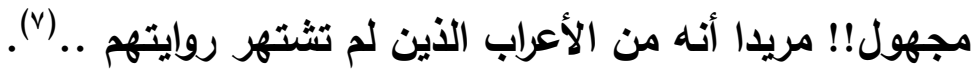

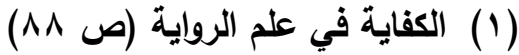

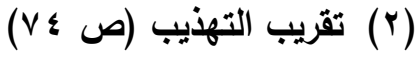

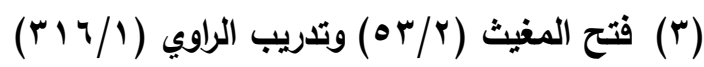

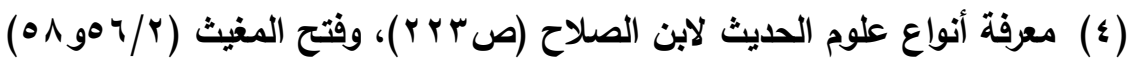

$$
\text { نزهة النظر (ص r r l ) }
$$

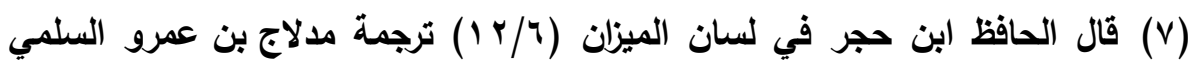
- 


\section{الاطلب الثاني \\ أسباب الجهالة}

ذكر ابن حجر سببين:

الأول: أن الراوي قد تكثر نعوتهـه من اسـ أو كنية أو لقب أو صفة أو

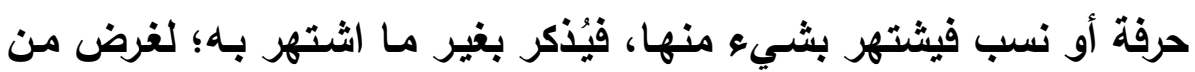

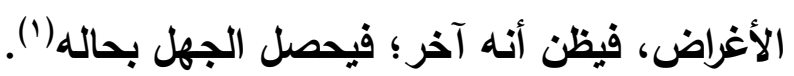

والثاني: أن الراوي قد يكون مقلا من الحديث فلا يكثر الأخذ عنه(؟).

= جماعة من الصحابة يطلق عليها اسم الجهالة؛ لا يريد جهالة العدالة، وإنما يريد

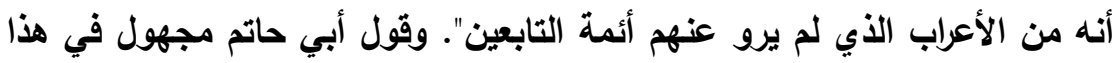

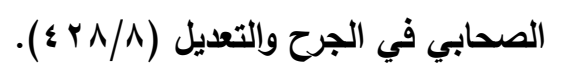

(1) وللخطيب البذدادي كتاب: نافع مطبوع في هذا الباب، وهو "موضح أوهام الجمع

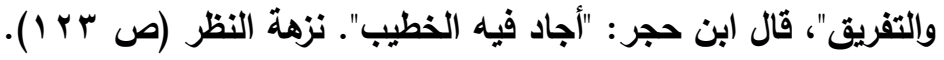
نزهة النظر (صبr ا )، وقال ابن حجر: "ومن المصنفات في هذا النوع: الوحدان. وهو من لم يرو عنه إلا راو واحد ولم يسم. وممن جمعه: الإمام مسلم - I ل كتابه "المنفردات والوحدان" والحسن بن سفيان وغيرهما. نزهة النظر (ص ع ع ا ). 


\section{المطاب الثالث \\ حكم الجهالة}

يختلف الحكم في كل قسم من الأقسام الثُلاثة السـابقة، وهذا ذكر حكم

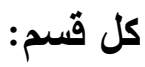

القسم الأول: مجهول: العين:

القول الأول: أنه لا يقبل، لأن المجهول لا يعلم صدقه في النقل، ونُسب

هذا القول لأكثر العلماء من أهل الحديث وغيرهم، بـل قال الحافظ ابن كثير: "فأمـا المبـهم الذي لـم يسـم، أو ســي ولا تعرف عينـه، فهذا ممن لا يقبـل

روايته أحد علمناه"(1).

القول الثاني: يقبل مطلقا، وهذا مبني على أنه لا مزيد على الإسـلام في

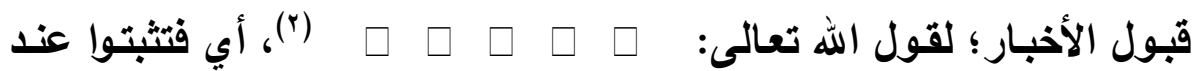

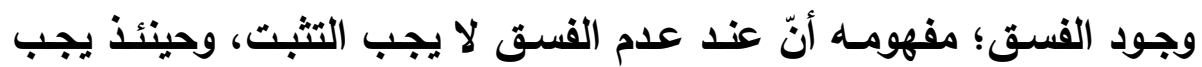
قبول خبره()، لكن هذا مردود بأنه في حال عدم معرفة وجود الفسق لا يلزم توفر العدالة والضبط المطلويين في صحة الأحاديث والآثار !. القـول الثالـث: إن كـان المنفـرد بالروايـة عنـهـه لا يـروي إلا عـن عـل كابن مهابي ويحي بن سعيد ونحوهما - ممن ينتقون مشـايخهم -؛ اكتقينا

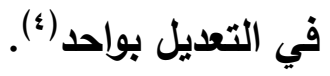

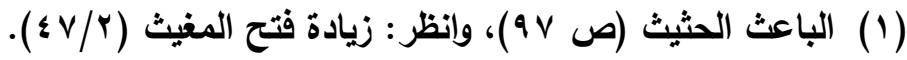

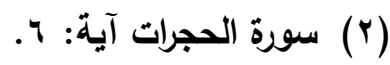

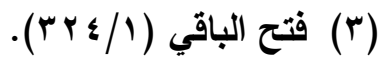

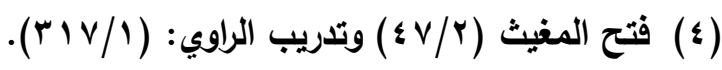


إزالة إيهام القائلين بوجود

الجهالة في بعض الفالين بوجال

القول الرابع: إن كان مشـهورا في غير العلم بالزهد أو النجدة قبل وإلا

فلا. وهو قول مشهور عن بن عبدالبر (1).

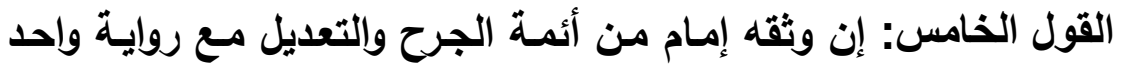

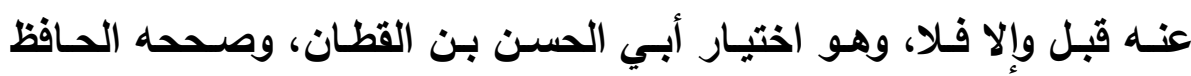

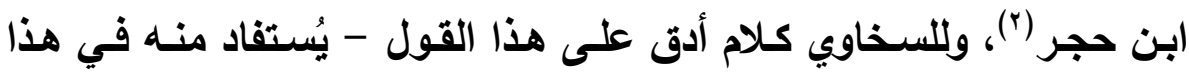

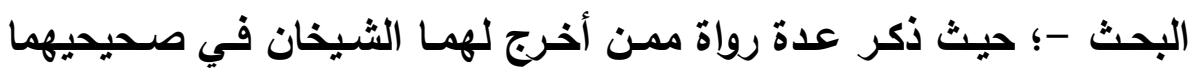

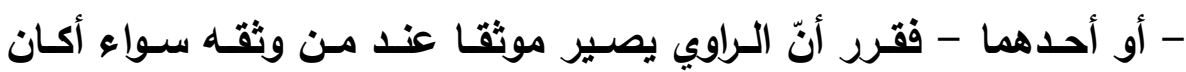

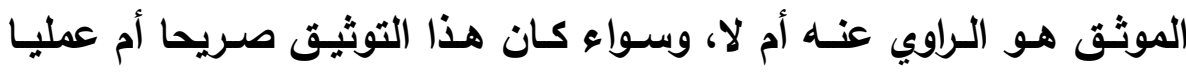
ضمنيا، ويقول: "وعليه يتمشى تخريج الثيخين في صحيحيهما لجماعـة،

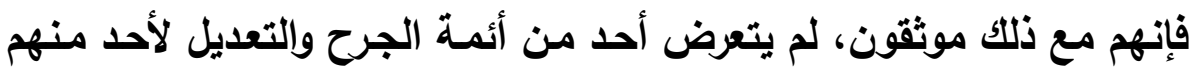

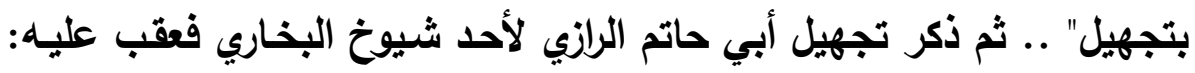

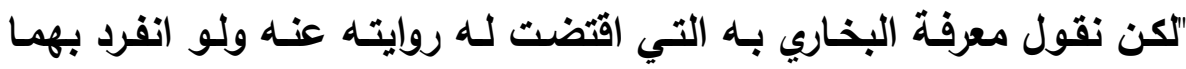

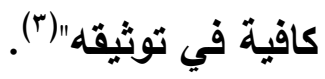
وتزول جهالة عين الراوي بروايـة اثنين عنـه فصاعدا من المشهورين بالعلم ولا تثبت له بروايتهما عنه حكم العدالة له؛ بل يكون من القسم الذي لـي

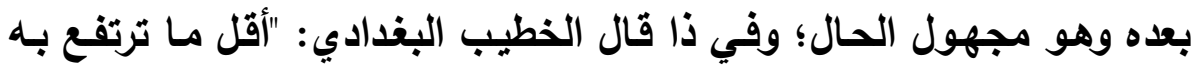
الجهالة أن يروي عن الرجل اثتان فصاعدا من المشهورين بالعلم كذلك؛ إلا

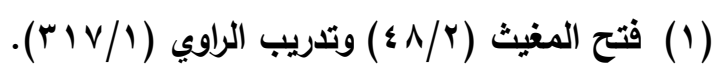

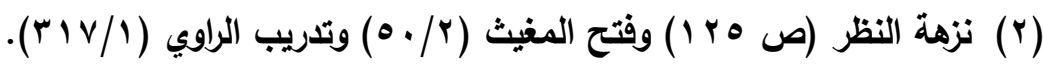

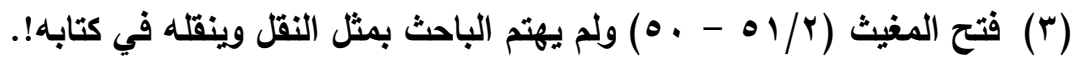
مجلة كلية أصول الدين والدعوة بأسيوط / العدد السابع والثلاثون 9 الـ بم - الجزء الثالث 
إزالة إيهام القائلين بوجود

الجهالة في بعض الفالين بوجال

أنه لا يثبث له حكم العدالة بروايتهما عنه"(1). حكم القسم الثاني "مجهول الحال": وهو مجهول الظاهر والباطن مع أنه معروف العين برواية عدلين عنه، وفيه أقوال:

القول الأول: أن روايته غير مقبولة. وهو رأي جمهور العلماء، فلا يثبت برونه للراوي حكم العدالة برواية الاثنين عنه(؟). قال الزركثي: "ذهب المحققون من أهـل الحديث وغيرهم إلى التوقف عن الاحتجـاج بهذا الضـرب حتى تثبت عـدالتهم ممـن ذهـب إلـى ذلـــ أبـو حـاتم الـرازي وأبـو عيسـى الترمـذي وغيرهما"(ז). ونقل السخاوي عن ابن رشيد قوله: "لا فرق في جهالة الحال بين رواية واحد واثنين مـا لم يصرح الواحد - أو غيره -؛ بعدالته"، ثم قال السخاوي: "تعم كثرة روايـة الثقات عن الثخص تقوي حسن الظن بـه، وأمـا المجاهيل الذين لـ يرو عنهم إلا الضعفاء فهم متروكون كما قال ابن حبان على الأحوال كلها"(؛)، وقال السخاوي أيضـا: "توجيه هذا القول - أي عدم

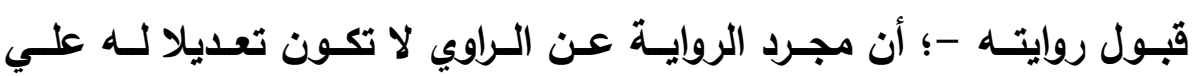
(الصحيح"(0) القول الثاني: تقبل مطلقا، قال الزركشي - I - : "ذهب أكثر أهل الحديث إلى قبول رواياتهم والاحتجاج بها، منهم البزار واللدارقطني، أمسا البزار فنص

$$
\begin{aligned}
& \text { (1) الكفاية في علم الرواية (ص ^^ - (^)). } \\
& \text { (r) المرجع السابق نفسه. }
\end{aligned}
$$

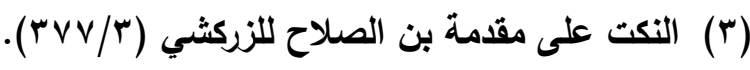

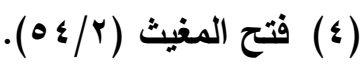

$$
\begin{aligned}
& \text { (0) المرجع السابق نفسه. }
\end{aligned}
$$


إزالة إيهام القائلين بوجود

الجهالة في بعض الفالين بوجال

عليه في كتابـه "الأشرية" وغيره؛ على أن من روى عنـه ثقتـان فقد ارتفعت جهالته وثبتت عدالته، ونحو ذلك قال الدارقطني في "الديات" من "سنته" لما تكلم على حديث خِشْف بن مالك عن بن مسعود في الدية"(1).

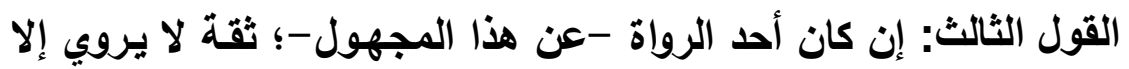
عن الثقة أو إن سَمّى لا يُسمي إلا ثقةة؛ فِإن هذا توثيق لـه ويرفع جهالته، كمالك وشعبة وغيرهما ممن لا يستجيز نقل الأحاديث الضعيفة ..(؟). حكم القسم الثالث من أقسام المجهول: المستور: وهو عدل الظاهر خفي الباطن: وفي الاحتجاج به أقوال: القول الأول: تقبل رواية المستور . ويه قطع الإمام سليم بن أيوب الرازي الشافعي شيخ الخطيب، حيث قال: "لأن أمر الإخبار مبني علي حسن الظن بالراوي، ولأن روايـة الأخبار تكون عند من يتعذر عليهه معرفة العدالـة في الباطن فاقتصر فيها علي معرفة ذلك في الظاهر"("). وقال ابن الصـلاح: "ويشبه أن يكون العمل علي هذا الرأي في كثير من كتب الحديث المشههورة

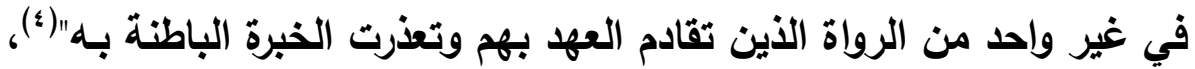
وعزاه النووي لكثير من المحققين وصححه(ه). القـول الثـاني: عدم قبـول روايـة المسـتور وهـو رأي بعض المحدثين

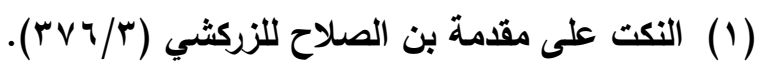

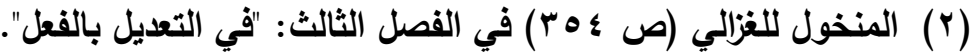

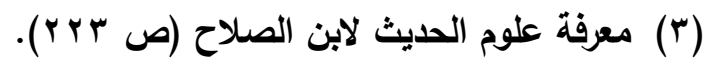

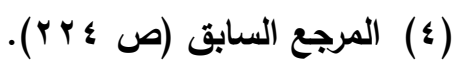

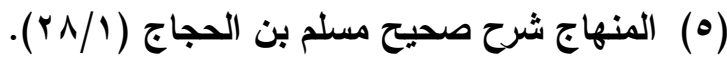


إزالة إيهام القائلين بوجود

الجهالة في بعض الفالين بوجال

كالثـافعي والذي صـار إليه المعتبرون من الأصوليين. قال إمـام الحرمين:

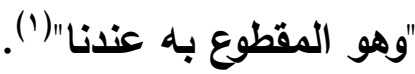

القول الثالث: التوقف في رواية المستور إلـي أن تتبين حاله، وهو رأي

الجويني وابن حجر(ץ)، ومعنى التوقف في خبر المستور حتى تتبين حاله لا يختلف كثيرا عن عدم قبول روايته، لأن غايته أن الجهالة ليست جرحا حتى

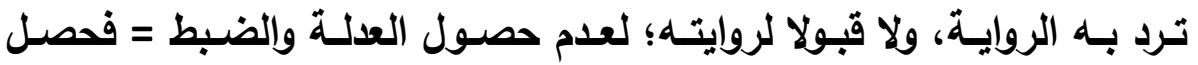

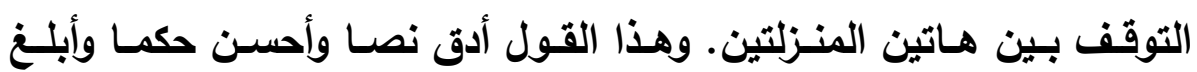
احتياطا، فرد حديثه يتضمن الجرح، وقبول روايته يعني تعديلا بـلا معرفة

بوثاقته .. فالاحتياط في التوقف حتى يثبت الجرح أو التعديل. والله أعلم.

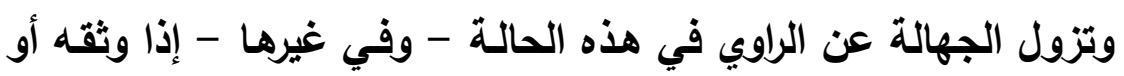

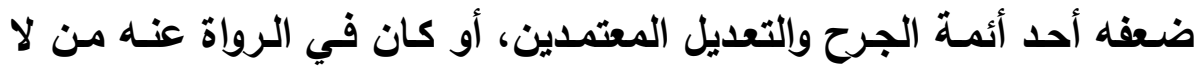

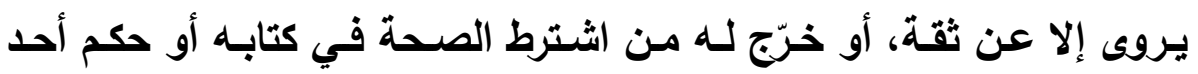

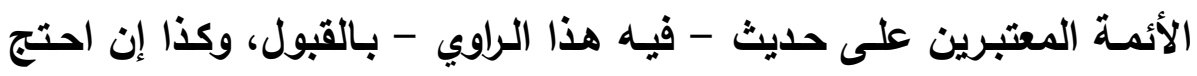
بحديثه إمام في مسألة ما (ॅ). والله أعلم. تتبيه: الباحث في بحثه سوّى بين مجهول الحال والمستور (؛)، والأمر قريب، وإن كان مقتضى البحث العلمي الإشارة إلى كلام أهل العلم السابق.

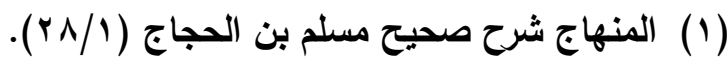

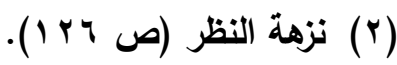

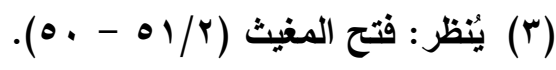

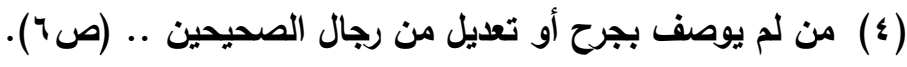
مجلة كلية أصول الدين والدعوة بأسيوط / العدد السابع والثلاثون 9 الـ بم - الجزء الثالث 
إزالة إيهام القائلين بوجود

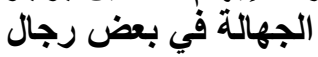

\section{المبمث الثاني}

أسباب الغلل عند الباحث في وجود هن لم يُوصف بجرح أو تعديل

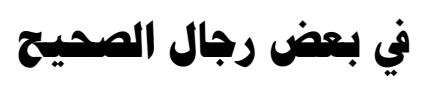

تهمدهـد:

جرى التصنيف عند المتقدمين في الصناعة الحديثية جمعا بين التظرية والتطبيق من غير اختلال .. والتطبيق عندهم إنما حكاية النظرية، فقلمـا تجد تتصيصـا - للمتقدمين - في قواعدهم .. بـل يجد المتتبع - الفطن - في تصنيفاتهم (كالبخاري ومسلم في صحيحيهما) قواعد الصناعة الصرفة؛ التي يفهمهـا حذاق العـم - وأتبـاعهم -؛ فـلا يجد هـؤلاء حسال تتبعهم عِيّا لأيّ إثكال قا يعرض على ما يخالف - في الظاهر - المتعارف عليه في الصنعة

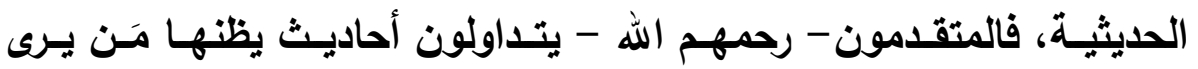
بنفسه علما أنها معلولة - بل أعجب منه يرى فيها ضعفا ظاهرا -؛ ولا يخفى عند المتقدم ذلك الفهم الظاهر الوارد عند قائلـه! ولذا يخرج المتقدم الحَذِق تلك الأحاديث، وهو يعلم أن علماء عصره يعرفونها ولا يعيبونها! ألا ترى بيان الإمام مسلم لمن عاب عليه إخراجه لحديث قطن بن نُسير وغيره، في القصة التي رواها الخطيب بإسناد عالٍ صحيح: عن سعيد بن عمرو البرذعي قال:

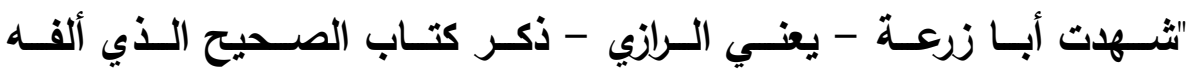

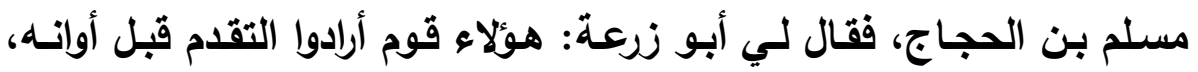
فعملوا شيئًا يتشوفون به: ألفوا كتابا لم يسبقوا إليه؛ ليقيموا لأنفسهم رياسـة قبل وقتها|'!) وأتاه ذات يوم - وأنا شاهد -؛ رجل بكتاب الصحيح من روايـة

(1) فكيف لو لأى أبو زرعة الناقدين على الصحيحين بمجرد النظر من غير ظفر! .. مجلة كلية أصول الدين والدعوة بأسيوط / العدد السابع والثثلاثون 9 ا ـ بم - الجزء الثالث 
مسلم، فجعل ينظر فيه .. فإذا حديث عن أسباط بن نصر! فقال أبو زرعة:

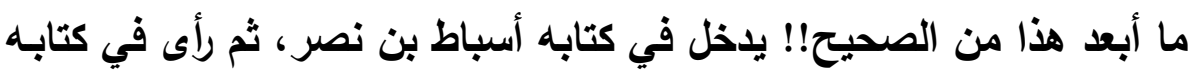

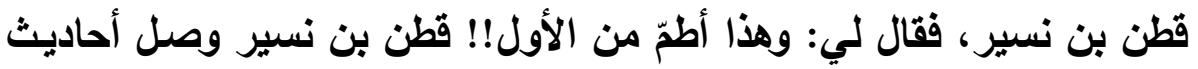

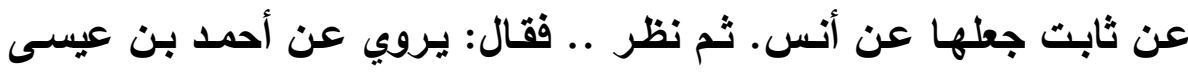

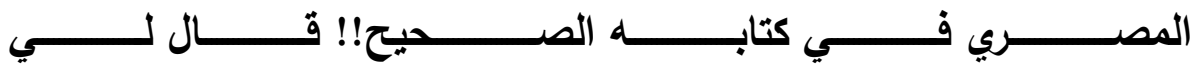
أبو زرعـة: مـا رأيت أهل مصر يثكّون في أن أحمد بن عيسى - وأثـار

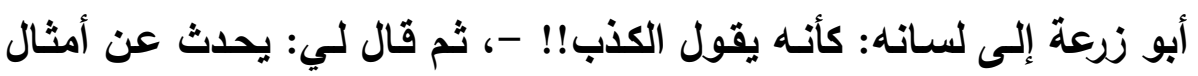

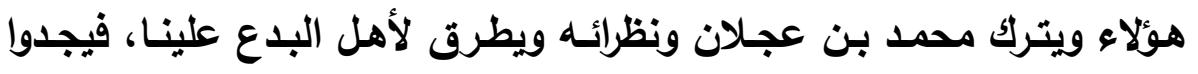

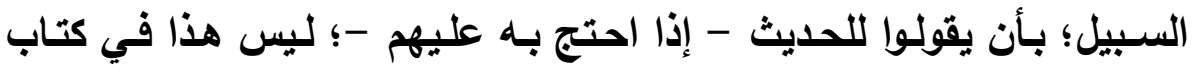

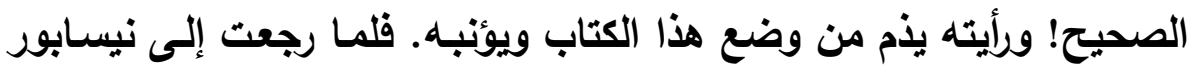

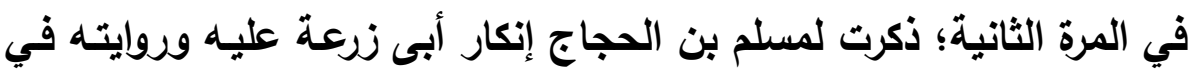
كتاب الصحيح عن أسباط بن نصر وقطن بن نسير وأحمد بن عيسى، فقدال

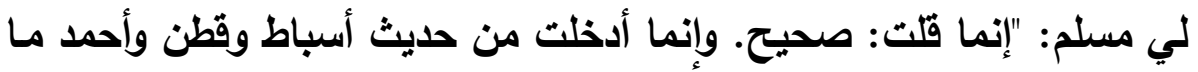

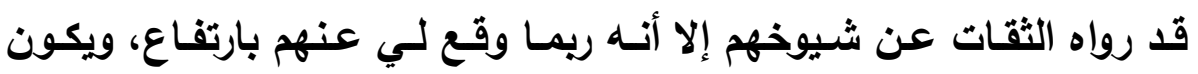

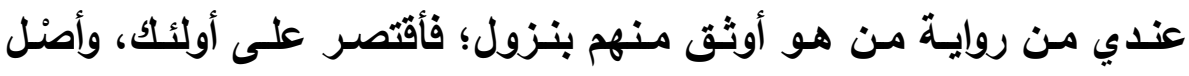

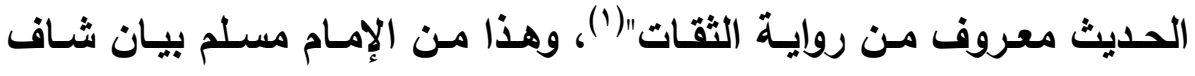

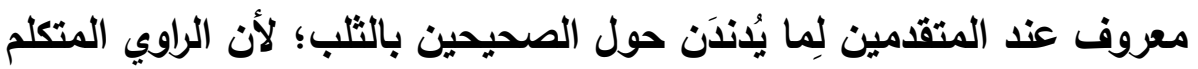

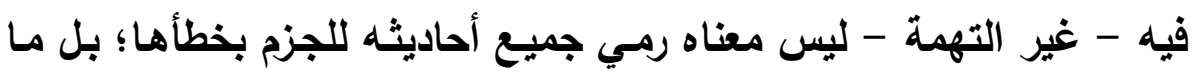

(1) تاريخ بذاد (0/0 ؛ ) وسند الخطيب فيه: أخبرنا أبو بكر البرقاني، حدثنا

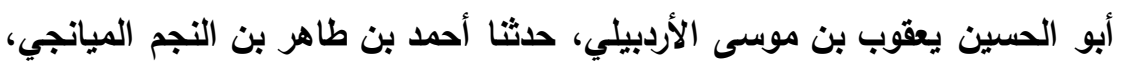
حثثنا سعيد بن عمرو البرذعي قال: فذكره. مجلة كلية أصول الدين والدعوة بأسيوط / العدد السابع والثلاثون 9 ـ ب م - الجزء الثالث 
وافق الثقات دل على حفظه وإلا فـالمنكر منكر !! وهذا الصنيع عند مسلم

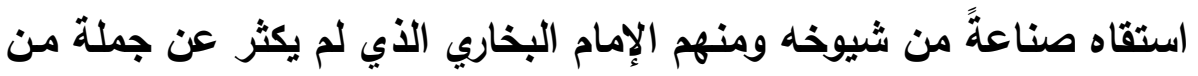

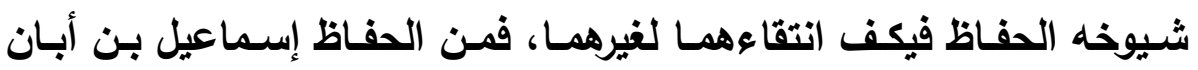

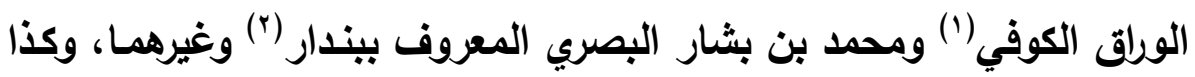

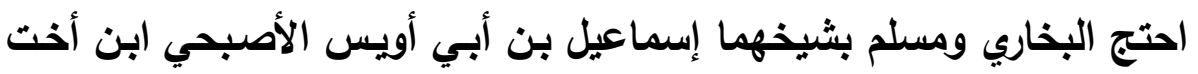

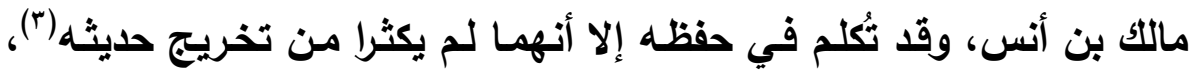
وغيره كثير ، فإذا كان هذا الأمر فيمن تُكلّم فيهم فكيف بمن يرميهم الباحث

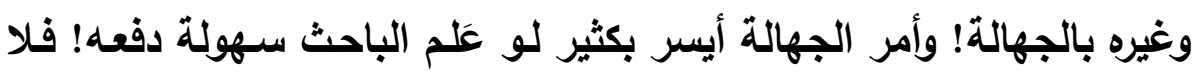

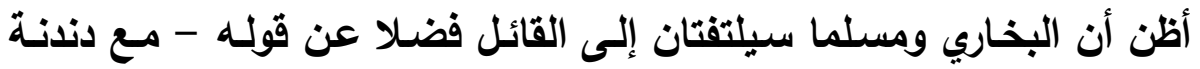

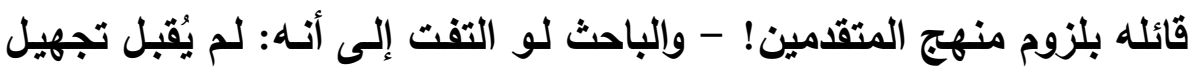

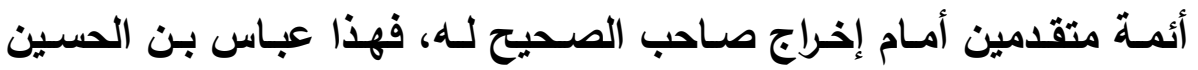

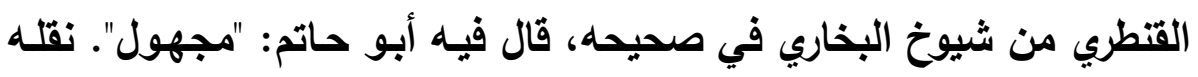

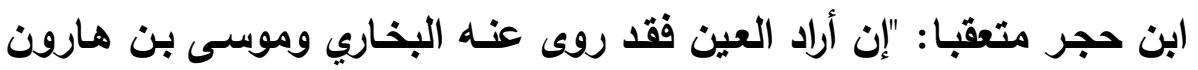

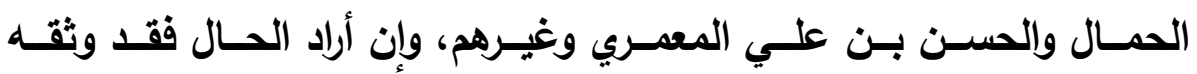

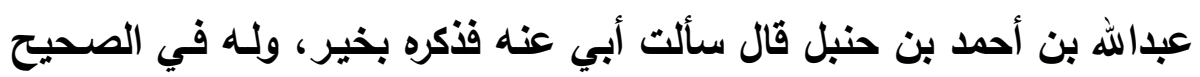

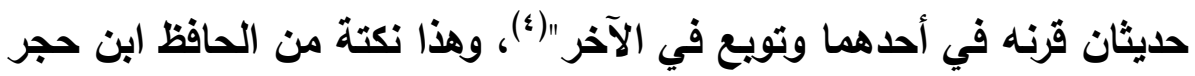

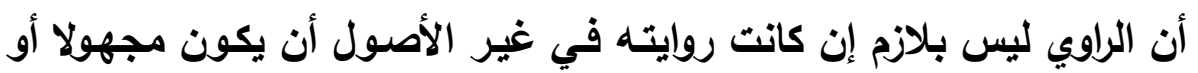

$$
\begin{aligned}
& \text { (1) هدي الساري (ص • (ץ). } \\
& \text { (r) المرجع السابق (ص V (Yr) ). }
\end{aligned}
$$

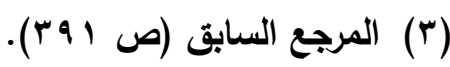

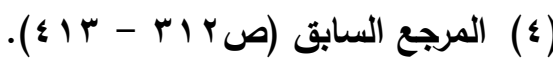


إزالة إيهام القائلين بوجود

الجهالة في بعض الفالين بوجال

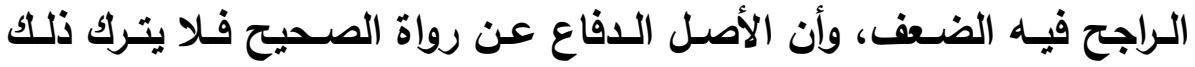
لمجرد حديثهما في غير الأصول، إن كان مـا قيل فيهم يمكن ردّه، والباحث

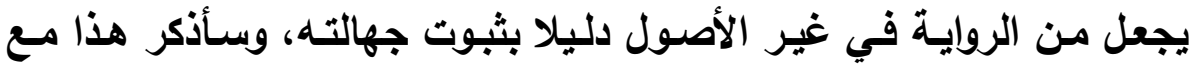

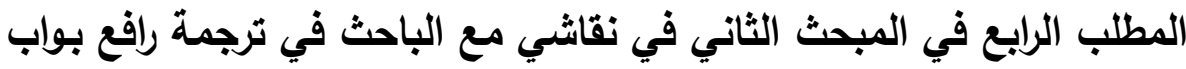

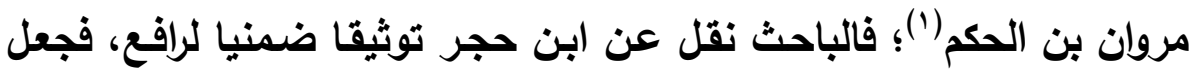

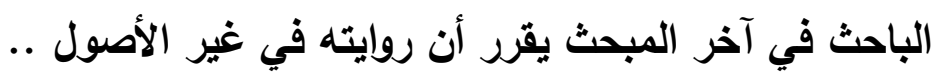

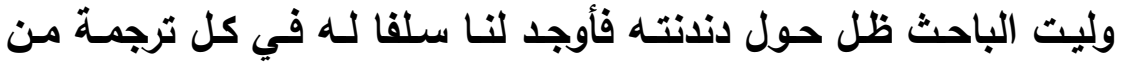

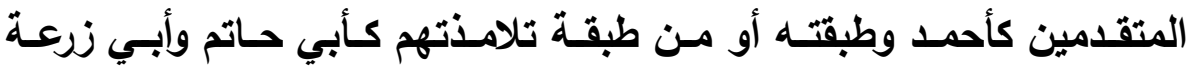

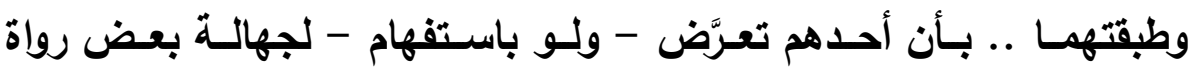
الصحيح كما حدث في القصة السابقة عن أبي حاتم، ثم يناقش هذا لهاب الباحث

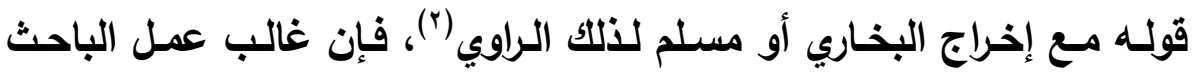

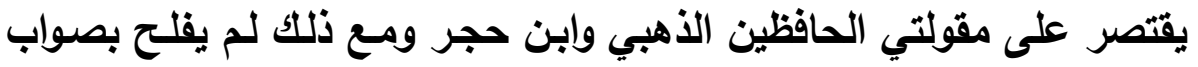

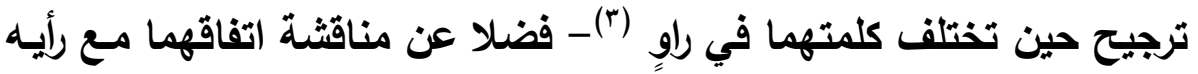

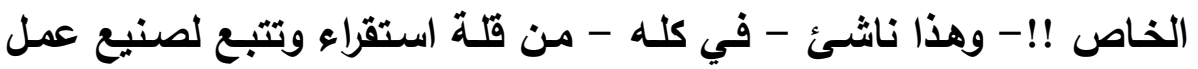

$$
\text { انظر (ص r^9^) من هذا البحث. }
$$

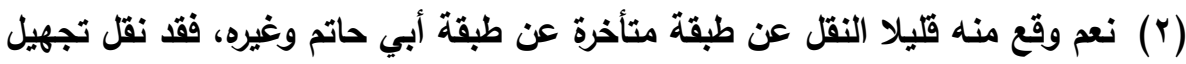

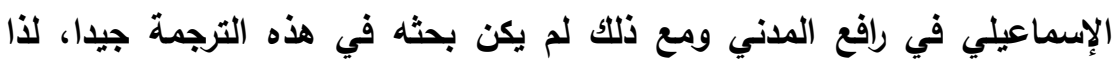
اصطفينا الحديث عن هذه الترجمة بصور أوسع في المبحث الثئ الثاثث: المطلب الثاني:

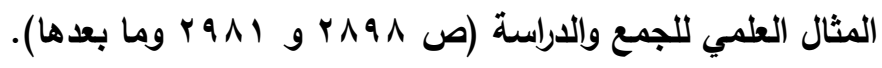

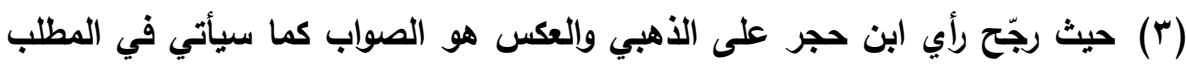

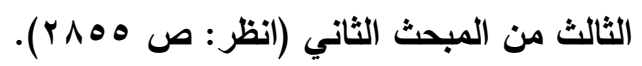


المتقدمين وسوء فهم كلام المتأخرين = يقوده ذلك إلى تضعيف روايات في صحيح البخاري ومسلم(') - فضلا عن الحوم حول توثيق رجال الصحيح -؛ بسلم التحقيق الواهي المعتمد على نصوص وقواعد يفهمها هو بمزاج النقد الفاســ .. إذ لـو كـان نقــا صـحيحا لعمـل بـالجمع بـين النظريــة وصـنيع المتقدمين في مؤلفاتهم معتبرا بجهود الأئمسة الحفاظ الذين يعتقدون تعظيم السنة وكون الصحيحين من ثوابت المسلمين .. فهذا تمهيد لمطالب تزيـه توضيحا وتثبيتا في بيان ضعف بحث الباحث في جهالة بعض رجال الصحيح وأن عمله بعيا من واقع عمل صاحبي الصحيح وفهم الأئمة المتقدمين ..

(1) حدثي بعض طلابه في تدريسه لهم في الدراسات العليا في حليث بتهمه على طلابه: "احتسوا سما .. ثم كلوا سبع تمرات ... لننظر هل تثفون من سمكم!! راميا

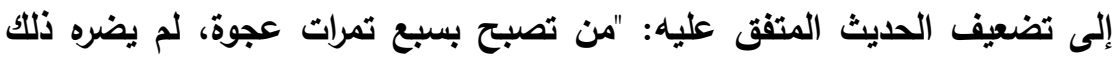

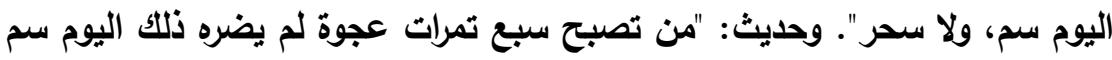

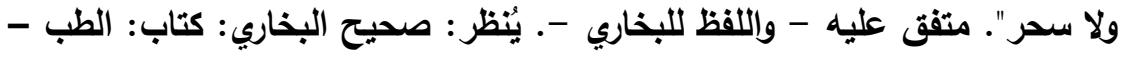

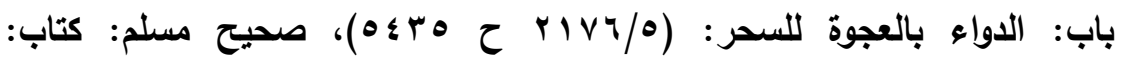

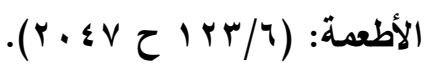


إزالة إيهام القائلين بوجود

الجهالة في بعض الفالين بوجال

\section{المطب الأول}

\section{ضعف التصور وسابقية الاعتقاد}

الباحث لم يكن لله همّ في الدفاع عن الصحيحين أن يُطال بتجهيل بعض

رواته أو يكون مآل بحثه مفهوما منـه ذاك؛ لذا لـ ينتج عن بحثه تصريح:

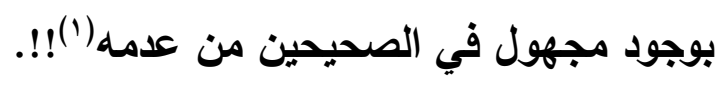

إن عدم مطابقة الأبحاث المتعلقة بدواوين أصول الإسـلام كالصحيحين

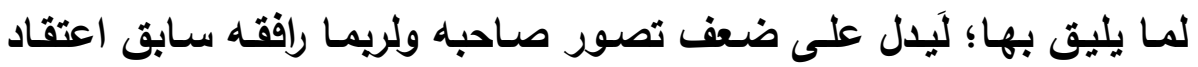
سيع تدل عليه القرينة: دندنة نقد غير مسبوق حول مجموعة أحاديث فيهما قبلتها الأمة بعلمائها، شأن هذا: شأن من قال عنه ابن الجوزي: "جاء أقوام فأظهروا التزهد، وابتكروا طريقة زينها لهم الهوى، ثم تطلبوا لها الدليل، وإنما ينبغي للإنسان أن يتبع الاليل لا أن يتبع طريقا ويتطلب دليلها"(؟). وقال ابن تيمية: "والمقصود أن مثل هؤلاء اعتقدوا لأيا ثم حملوا ألفاظ القرآن عليه، وليس لهم سلف من الصحابة والتابعين لهم بإحسان ولا من أئمـة المسلمين

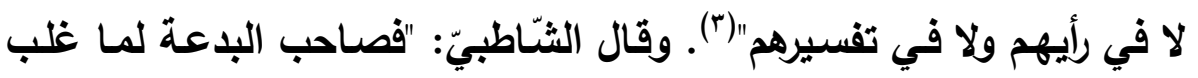
عليه الهوى مع الجهل بطريق السنّة، توهّم أنّ ما ظهر له بعقله هو الطّريق

(1) لكن راح يقول: من روى في الأصول موثق بذلك ولوكان مستورا - ولم أجد من

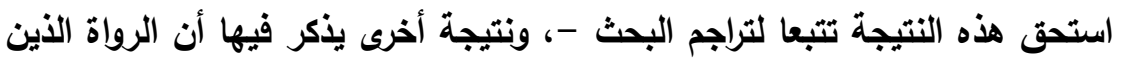

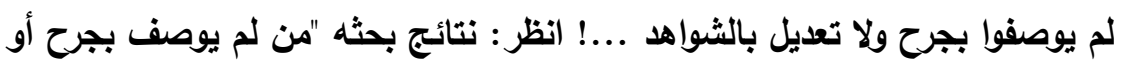

$$
\begin{aligned}
& \text { تعديل من رجال الصحيحين .." (صسه ا 1). }
\end{aligned}
$$

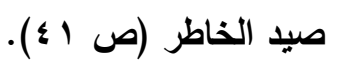

$$
\begin{aligned}
& \text { مجموع فتاوى بن تيمية (r/ }
\end{aligned}
$$
مجلة كلية أصول الدين والدعوة بأسيوط / العدد السابع والثلاثون 9 الـ بم - الجزء الثالث 
القويم دون غيره، فمضسى عليـه؛ فحساد بسببه عن الطريق المستقيم، فهو

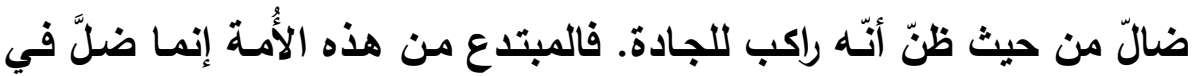
أدلتها حيث أخذها مأْخذ الهوى والثـهوة، لا مأخذ الانقياد تحث أحكام اللّه. وهذا هو الفرق بين المبتدع وغيره؛ لأنّ المبتدع جعل الهوى أول مطالبه،

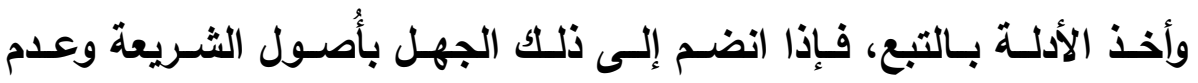
الاضطلاع بمقاصــها، كـان الأمسر أشـدّ وأقرب إلى التحريـف والخـروج عن مقاصد الشرع، والدّليل على ذلك أنك لا تجد مبتدعًا ممن ينسب إلى الملة إلا وهو يستشهر على بلاعته بدليل شرعيّ، فينزّله على ما وافق عقله وشتهوته، بخلاف غير المبتداع؛ فإنّهـه إنّمـا جعل الهدايـة إلى الحق أوّل مطالبه؛ وأخَّر هواه فجعله بـالتبع"(1). وياحثنا يتلمس مذذب المتقدمين في قضـاياه حول الصحيح نازعا اللهالة حول الصحيح .. وما كنت أنتظر يوما يأتي فيه باحث يزعم الجمع والبحث في رفع جهالة من لم يوصف بجرح أو تعديل من رجال الصحيحين()! فيفيدُ بعضَ أصحاب الثبه ممن لهم غيظ حول الصحيحين، ولهم نـارٌ تحرق أحشـاءهم ولا يبدو لها ضرام! فالواحد منهم هجيّراه تضعيف بعض أحاديث الصحيحين بحجة الجهالة تارة، ويحجة عدم مواققتها العقل أخرى، وقد تجتمعان كما اشتهر عند بعضهم غمز الصحيحين في بعض حديثهما كالحديث الذي في صحيح البخاري: "إذا وقع الاباب في شراب أحدكم فليغمسه ثم لينزعه؛ فإن في إحدى

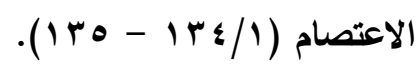

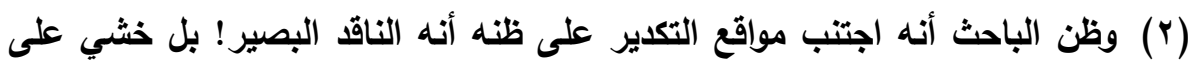

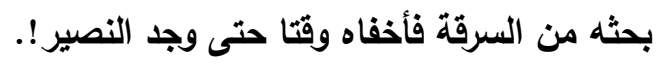
مجلة كلية أصول الدين والدعوة بأسيوط / العدد السابع والثلاثون 9 ـ ب م - الجزء الثالث 
إزالة إيهام القائلين بوجود

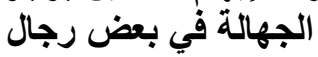

جناحيه داء والأخرى شفاء"(1)؛ فقد ضعفه بعضهم للعقل تـارة ولأن فيه راويـا مجهولا تـارة أخرى!! ... ويتمشى الباحث مـع هذا وليس لـه في ذلك إمسام سابق أو لاحق إلا أبا رية وأمثاله!! فهذا مثال ظاهر في عبثه! والعجيب أني وجدت باحثنا ينتسب لهذا العلـم الثـريف سيؤسسس للمنكرين قواعد جديدة للطعن على السنة، فمثلا هذا الحديث تجد اعتراض من سبقه بمحض الرد العقلي، وقد رد الثبسه المثارة -عقـلا- حول هذا الحديث وغيره عدد مسن عن العلمـاء، وأبرز من كتب في الرد هو الشيخ د/ محمد أبو شُهبة في كتابها الحافل "دفاع عن السنة ورد شبه المستثرقين"(؟)، فيأتي هذا الباحث ويقول: "بـل في إسـناده جهالـة!"(") فيضـع كمنتسـب للسـنة تأسيسـا جديـا للطعن!

(1) أخرجه البخاري من طريقين عن عتبة بن مسلم قال: أخبرني عبيد بن حنين قال: سمعت

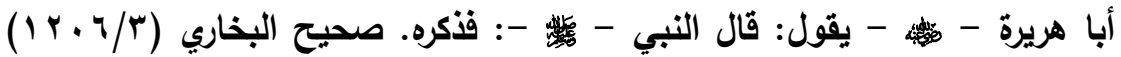
"كتاب: بدء الخلق - باب: إذا وقع الذباب في شراب أحدكم فليغمسه فإن في إحدى

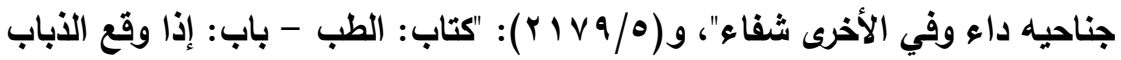

$$
\text { في الإناء". }
$$

(r) وقد دافع عنه بعضهم بقوله أن الباحث: "لا يرى مجهولين اعتُمد على روايتهم في

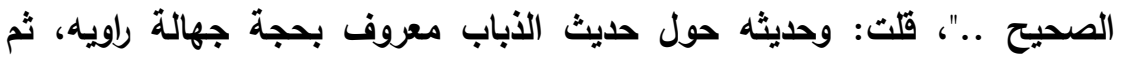

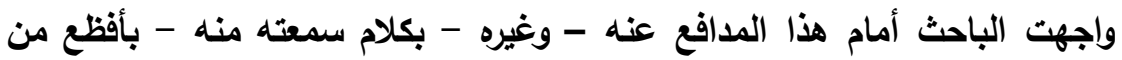
ذلك!! -؛ وهو قوله: بأن البخاري يخرج لمجهولين، ويعضهم يخرج لهم البخاري -

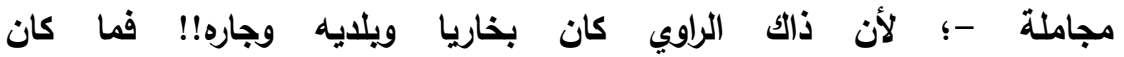
من هذا الباحث إلا أن دافع عن نفسه - أمام الحاضرين -؛ بانيائة وبلة أعظم مما هو عليها، فقال: "ذاك نقوله فيما بينتا ولا ننشره"!! فصدق الله إذ يقول: = مجلة كلية أصول الدين والدعوة بأسيوط / العدد السابع والثلاثون 9 ابـآم - الجزيء الثالث 
ومجالا للعبث في السنة، فذا يذكرني بمجلة الدفاع عن السنة، وهي مجلة

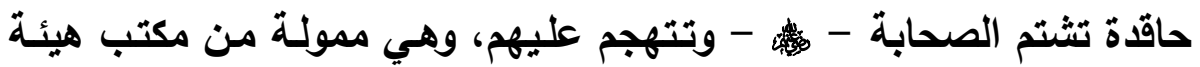

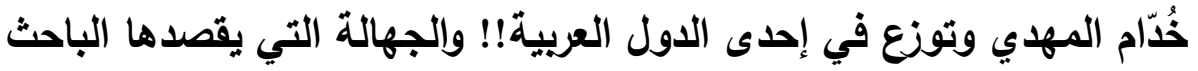
في حديث "إذا وقع الذباب في .." هي جهالة عتبة بن مسلم مولى بنـي تيم

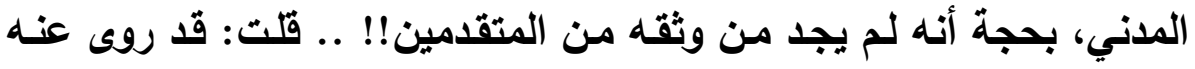

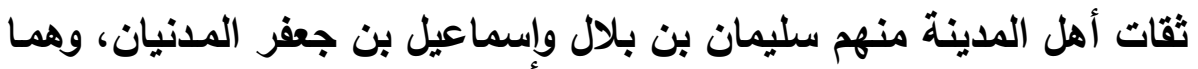
اللذان اعتمـد البخـاري على روايتهمـا في الصـيح فأوردهـا مـن طريقهمـا

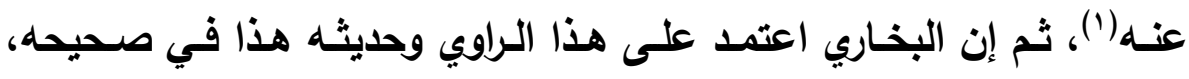

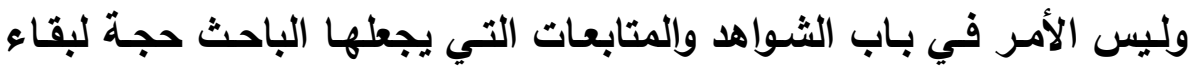
الراوي في جهالته .. وهنا وقعت لي مفاجأة حيث إن الأستاذ يدندن حول هذا

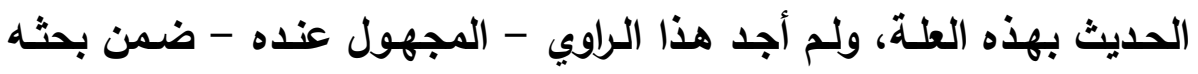
الذي خصصه في الرواة المجهولين في الصحيحين!! ويكتب في نتائج بحثه هـنه - مزعوم الاستقصاء - أن غالب رواية المستورين - الذين هم في الصحيح

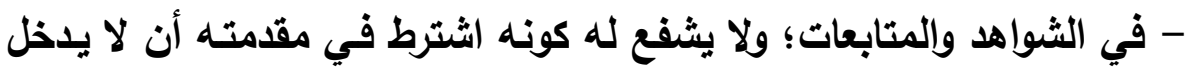

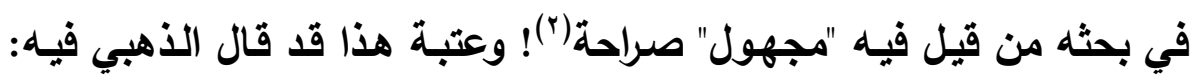

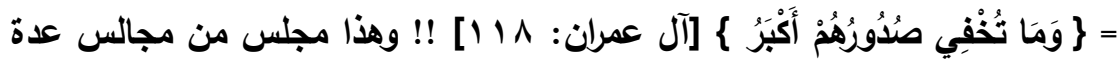

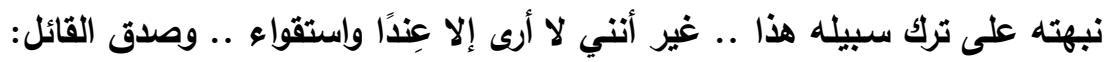

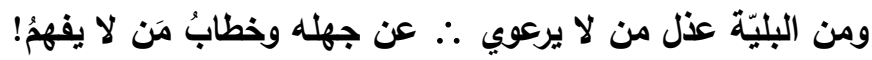

$$
\text { (r) انظرم تخريجه قريبا. }
$$
مجلة كلية أصول الدين والدعوة بأسيوط / العدد السابع والثلاثون 9 الـ بم - الجزء الثالث 
صدوق، ووثقه (بن حجر (')، فإن قيل لم يدخله الباحث في بحثه لأجل توثيق

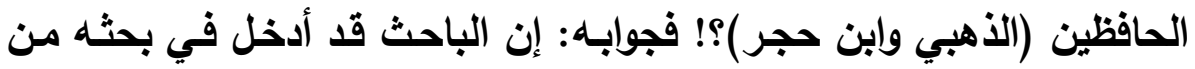

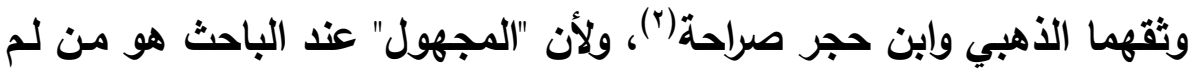
يوصف بجرح ولا تعديل عند المتقدمين، وفي عنوان بحثه دليل هذا كمـا

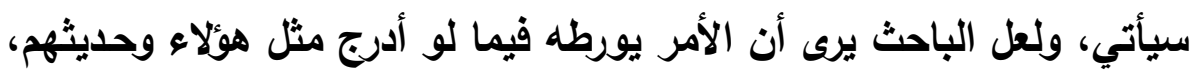

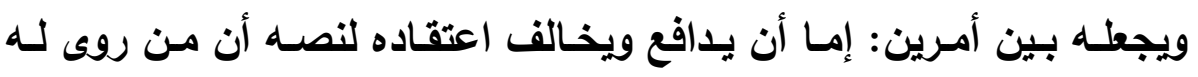
صاحب الصحيح في الأصول فهو ثقة؛ وعليه: فإن حديثه صحيح، أو ييقيه إنها

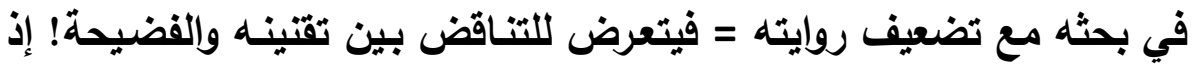

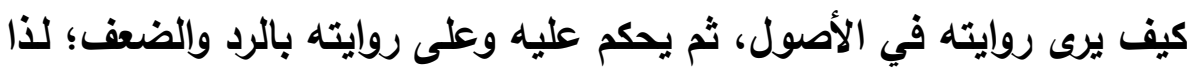
حصل الاستثناء من بحثه لكثير من أولئك الرواة! ومن هنا وجب تعقبه بمن

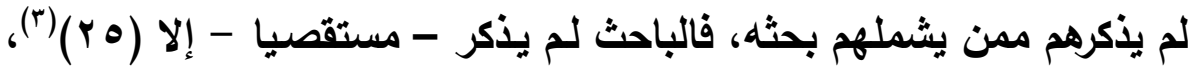

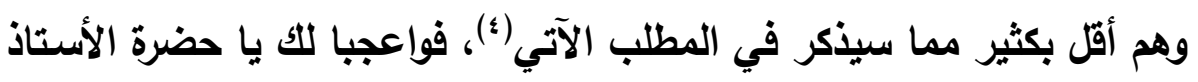
المختص بالحديث وعلومه حين تُحسِن التخلص والتورية عن الغرض ..!

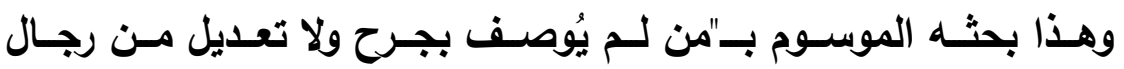

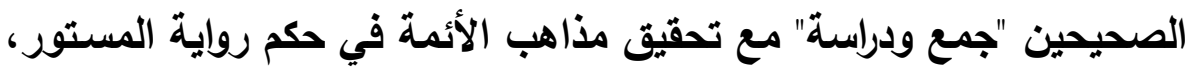

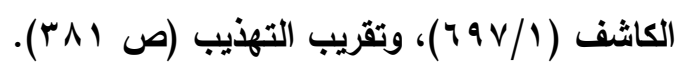

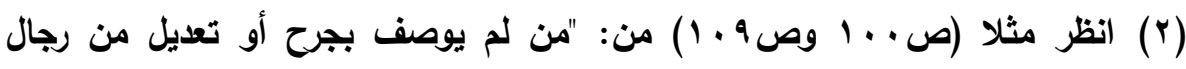

$$
\text { الصحيحين ..". }
$$

(r) بل هم في الواقع العلمي (r) كما سيأتي بيان خلل ذكر الباقين الخمسة

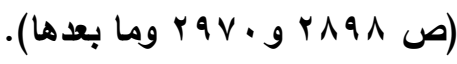

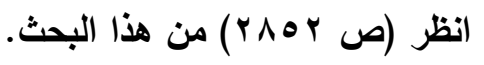


وتأصيل قاعدة أن كل مدني روى عنه مالكك فهو ثقة، وأن روايـة الثيخين لراو في الأصول هي توثيق له"؛ فتعجبت من طول عنوانه - ولن تجد أطول

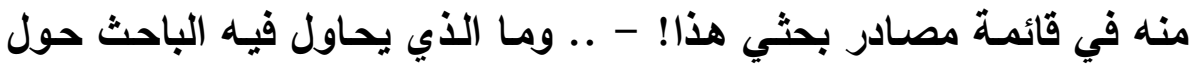
الصحيحين! والنصح متواتر له بالكف عن رومـه حول الصحيحين بالإسـاءة، بل واستخدامه للعقل في بعض الأحاديث الصحيحة!.

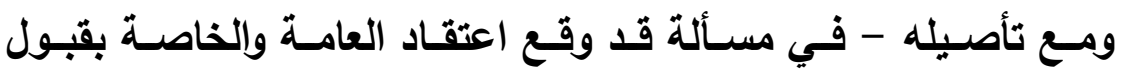
المستورين من رجال الصحيحين المخرّج لهم في الأصول -؛ هان عليّ تركهـ

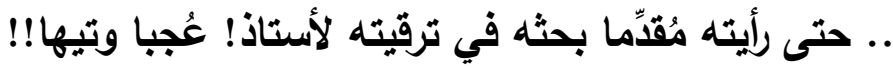

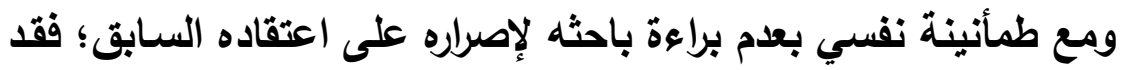

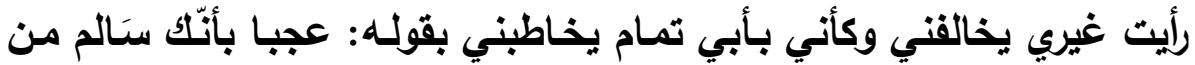
وحشةٍ ... في غايةٍ ما زلت فيها مفرَدا(').

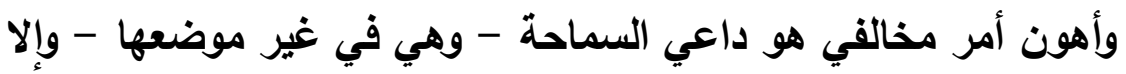

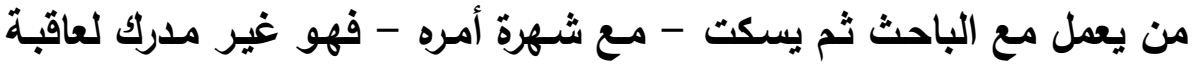

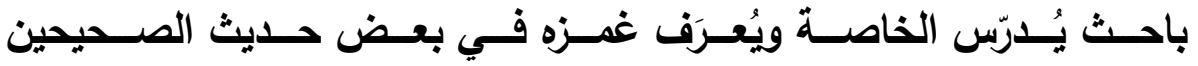
- وهو غير مسبوق بذلك - ومن الناس مَن يعرف الحقيقة ولكنه يتجاهلها لهوى لله!

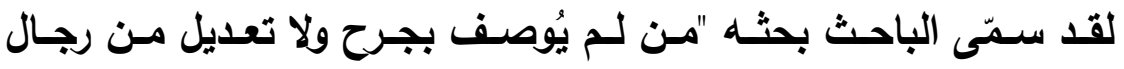

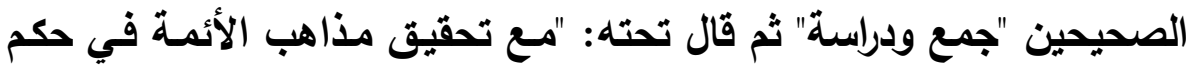

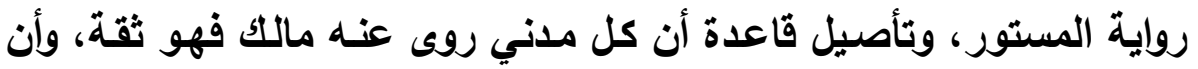

(1) والحق أنني لست وحيدا؛ ففي الساحة من لهم قدم صدق في التيقظ، والردّ - على من يستحق - من غير تحفظ؛ فجزاهم الله خيرا. مجلة كلية أصول الدين والدعوة بأسيوط / العدد السابع والثلاثون 9 ا ـآم - الجزء الثالث 
إزالة إيهام القائلين بوجود

الجهالة في بعض الفالين بوجال

روايـة الشيخين لـراو في الأصـول هـي توثيق لـه" كذا أطلق الباحث بحثـه

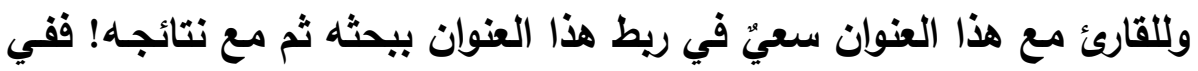

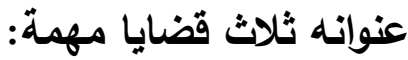

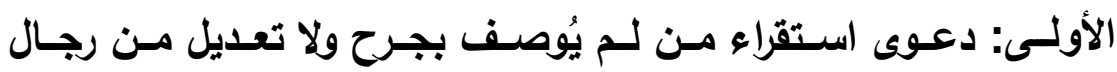

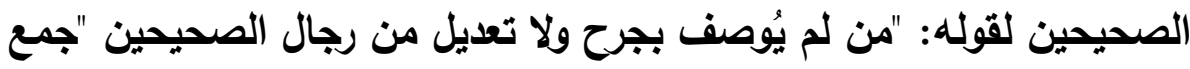

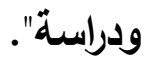
الثانية: إقامة الدراسة الوافية الموصِلة لتأصيل قاعدته "روايـة الثيخين

$$
\text { لراو في الأصول هي توثيق له". }
$$

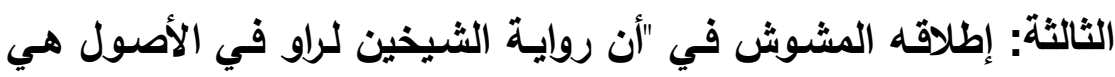

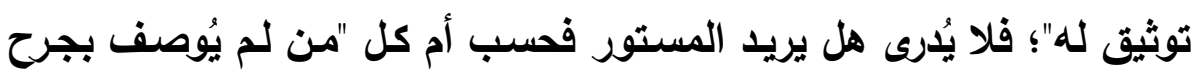

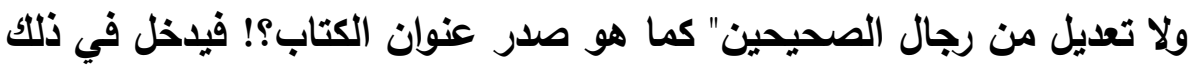

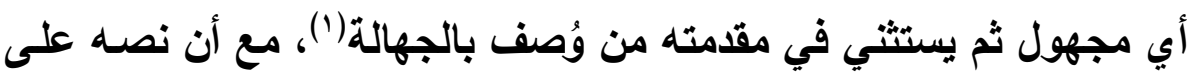

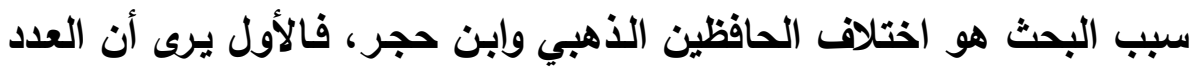

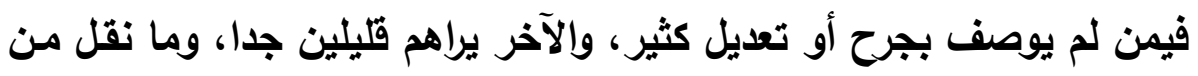

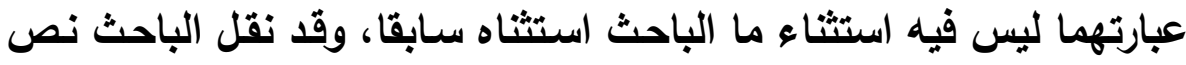
الذهبي الأي في الميزان: "في رواة الصحيحين عدد كثير مـا علمنا أن أحدا

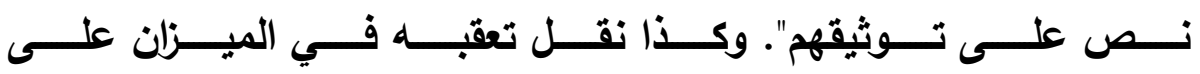
ابن القطان الفاسي وقولها: "ابن القطان يتكلم في كل من لم يقل فيها إمام

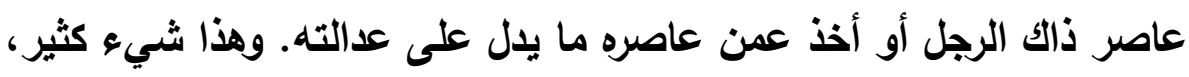

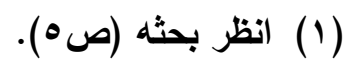
مجلة كلية أصول الدين والدعوة بأسيوط / العدد السابع والثلاثون 9 ابـام - الجزء الثاثث 
فقي الصحيحين من هذا النمط خلق كثير مستورون، مـا ضعفهم أحد ولا هم بمجاهيل(')"(r). ثم نقل اعتراض ابن حجر - على الكثرة المحكية في قول الأهبي - بقوله: "ليس كذلك بل هذا شيع نادر؛ لأن غالبهم معرفون بالثقة

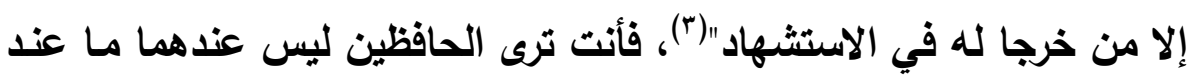
الباحث من تخصيص للجهالة بمعنى معين كما هو عند الباحث، فلو أراد أن يطلع بنتيجة لبحثه الأي سببه اختلاف الحافظين فلا يستثي شيئا وإلا فكيف هذا التأسيس للبحث، وكيف سيكون الحكم والتمييز بين من روي لهم في الأصـول أو بالشـواهد ..!! فـلا بـ عليهه أن يعمـ البحث في جميع مدلولاتـه حتى يقوّي مستثد ذاك الاستقراء المنصوص عليه بقوله: جمع ودراسة ..!!. لقد آثر الباحث اعتقاده وسـابق تصسوره لوضـع بحث غير مكتمل ولا واضح الاستقراء بالأدلة، وقد أجراه هواه - غير متثبت - في استعجالٍ حتى بدا واضحا في اختزال بعض الألفاظ المهمة التي لا بـ من إضافتها والتصريح بها؛ كإضـافة "أو أحدهما" بعد لفظ "الصـحيحين" وكذا بعد لفظ "الثـيخين"، وكذا إضافة "عنده" بعد قوله "تأصيل قاعدة أن كل مدني روى عنه مالك فهو ثقة" ليصبح العنوان رصينا واضحا هكا "من لـم يُوصف بجرح ولا تعديل من رجال الصحيحين - أو أحدهما - "جمع ودراسـة"، مـع تحقيق مذاهب الأئمـة

(1) يحتمل كلامه "ولا هم بمجاهيل" أي نصا ويحتمل أنهم ليسوا بمجاهيل لإخراج صاحب الصحيح لهم ..

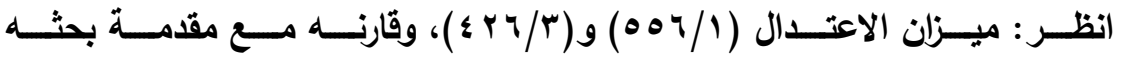

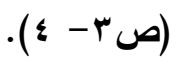

$$
\begin{aligned}
& \text { (r) لسان الميزان (ب/ (ب). }
\end{aligned}
$$
مجلة كلية أصول الدين والدعوة بأسيوط / العدد السابع والثلاثون 9 الـ بم - الجزء الثالث 
في حكم روايـة المستور، وتأصيل قاعدة أن كل مدني روى عنـه مالك فهو ثقة عنده، وأن رواية الشيخين - أو أحدهما - لراوٍ في الأصول هي توثيق لـه" .. وهذه القضـايا الثلاث يـدور عليها رحى بحثي على بحث الباحث ونتائجه. 


\section{الماطب الثاني}

\section{الباحث هع قواعد المدثين}

لا تقع الغُنية - بزعم التأصيل في أي بحث حديثي نقدي -؛ عن نهج

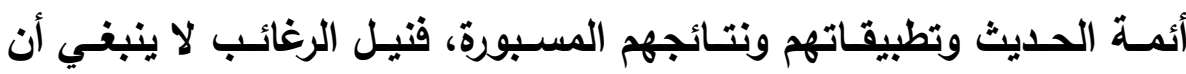

يخرق العوائد إلا باتباع أكمل القواعد.

فبمعرفة أقوالهم وقواعدهم مع تلكك التطبيقات - الموجودة في مصنفات

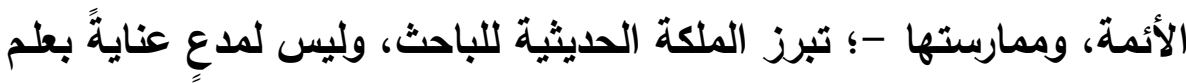

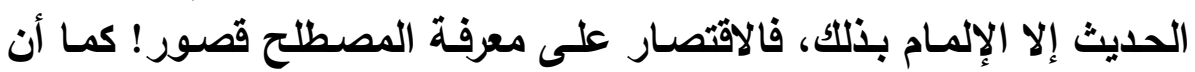
البعد عن تعرّف أصول الصنعة عند أئمتها ضعف همّة وفتور، وهنا نذكر

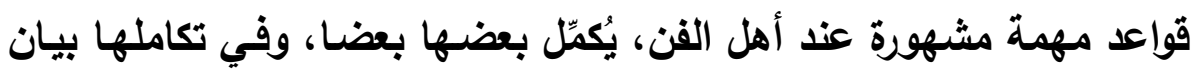
رسوخ شأن الصحيحين المتلقى بالقبول عند الخاصة والعامة:

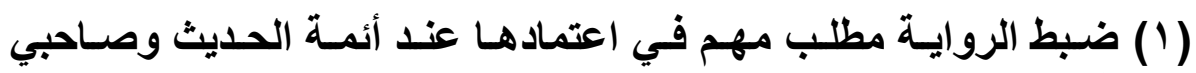

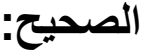

سعى الأئمة في خدمة السنة وتدوينها لتحصيلها منتقاة مضبوطة من

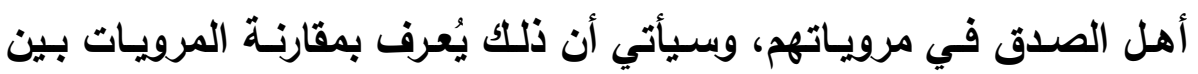

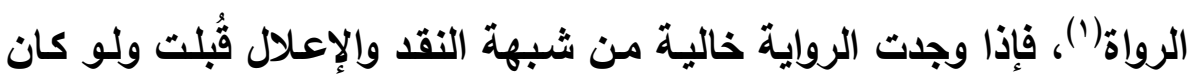

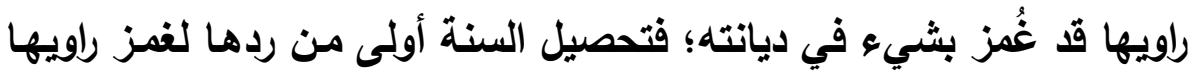

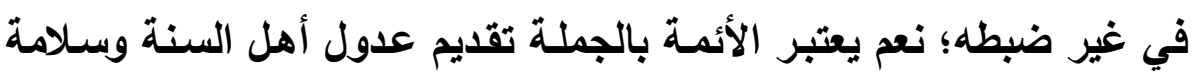

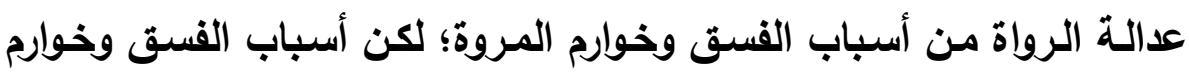

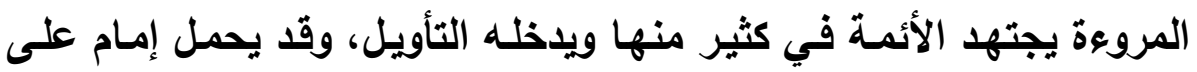

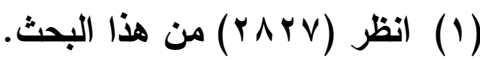
مجلة كلية أصول الدين والدعوة بأسيوط / العدد السابع والثلاثون 9 ـ ب م - الجزء الثالث 
إزالة إيهام القائلين بوجود

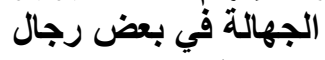

رواة لقوة تسنته فيترك الروايـة عن رواة قد احتملها آخرون لإنصسافهم لا سيما إن كاتـ أحسن من غيرها؛ فلا يحول دون أخذ السنة ومـا فيها من أحكام بحجة كلام واقع على أحد الرواة في عدالته، وقد صحت روايته وخلت من إعلال في إسناد أو متن، وحفت القرينة بصدق راويها، وأمثلة هذا كثيرة

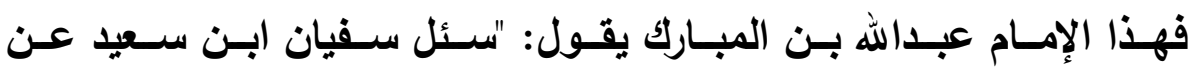
ثور بن يزيد الثامي؟ فقال: خذوا عنه واتقوا قرنيه. يعني أنه كان قدريًا"(1). وعكسـه لـو كان الـراوي عدلا مرضيا ولـم يكن من أهل الضبط = لا يتردد الأئمسة في رد حديثه، ولريمـا بالغ الأئمسة في تكذيب صسالحين لبعد عنايتهم بضبط الروايـة، فهذا جعفر بن الزبيز الحنفي كان عابـا صسالحا في نفسـه،

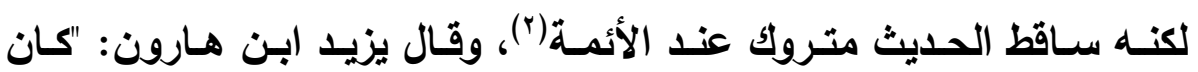
جعفر بن الزبيز وعمران بن حدير في مسجد وإحد مصدلاهما، وكان الزحام على جعفر وليس عند عمران أحد!! وكان شـعبة يمر بهما، فيقول: يا عجبا للنـاس؛ اجتمعوا على أكذب النـاس - يعني جعفرا - وتركوا أصدق النـاس. يعني عمران"("). قلت : وعمران بن حدير هو السدوسي كان عابدا أيضـا، لكنه

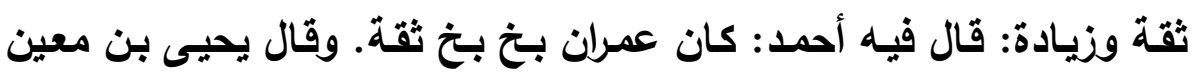
وابن المديني: ثقة. زاد ابن المديني: "أوثق شيخ بالبصرة"(؛). وقال ابن رجب لهب

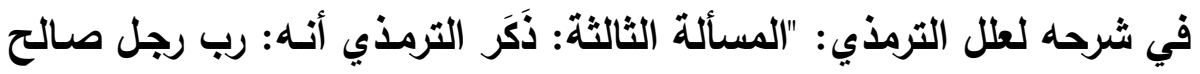

$$
\begin{aligned}
& \text { (الجرح والتعديل لابن أبي حاتم ( / ع V). } \\
& \text { المرجع السابق نفسه. }
\end{aligned}
$$

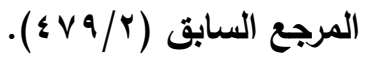

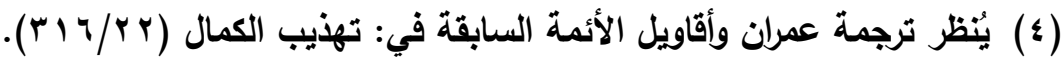
مجلة كلية أصول الدين والدعوة بأسيوط / العدد السابع والثثلثون 9 ا ـ بم - الجزء الثالث 
إزالة إيهام القائلين بوجود

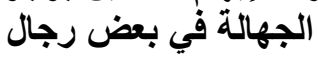

مجته في العبادة، ولا يقيم الثـهادة ولا يحفظها - وكذلك الحديث - ؛ لسوع حفظه، وكثرة غقلته ..." ثم نقل الحافظ ابن رجب كلام الأئمـة التي توئيل هذا المعنى، منه قول الإمـام يحيى القطان: "مـا رأيت الصالحين أكذب منهم في الحديث؛ لأنهم يكتبون عن كل من يلقون لا تمييز لهم فيه"، ورواه مسلم في مقدمة كتابه، وقال مسلم: "يجري الكذب على ألسنتهم، ولا يتعمدون الكذب". ويُروى عن أبي عبدالله بن منده، قال: "إذا رأيت في حديث: (ثنا) فلان الزاهد فاغسل يالك منه". قال ابن عدي: "الصالحون قـ وسموا بهذا الاسم أن يرووا أحاديث في فضائل الأعمال، موضوعة بواطيل، ويُتهم جماعة منهم بوضعها". قال ابن رجب عقب ذلك: "وهؤلاء المشتظلون بالتعبد الذين يترك حديثهم على قسمين: منهم من شـغلته العبادة عن الحفظ، فكثر الوهم في حديثه، فرفع الموقوف، ووصل المرسل .. ومنهم من كان يتعمد الوضـع .."، وختم ابن رجب كتابه بقواعد أولها: "قاعدة: الصالحون غير العلماء يظلب على حديثهم الوهم والغلط"(1)، والحاصل أن ضبط الراوي أهم مـا يكون عند الأئمسة، وفي الصحيحين مـا لا يُحصسي الباحث من رجالهمـا ممن اعتمـد البخاري ومسـلم على مرويات رجالٍ لضبطهم مـع وجود غمز في عدالتهم، وسيأتي في آخر البحث زيادة مثال في ترجمة مروان بن الحكم(؟)، وللشيخ طاهر الجزائري في توجيه النظر كلام مفيد أحب سطره هنـا، وهو قولـه: "والذي ينبغي أن يقف عليه كل راغب في علم الأثر أن الإمـام البخاري كـان جل قصده أن يكون

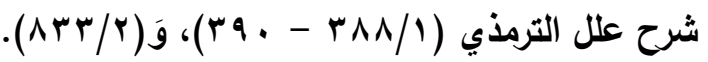

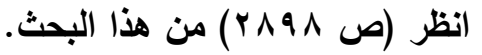


إزالة إيهام القائلين بوجود

الجهالة في بعض الفالين بوجال

الراوي قد صدق فيما رواه عنه من غير نظر إلى أمر آخر .."(1). وهذا منه دقة فهم ورصانة عقل ومتانـة ديانـة، وليس الأمر قاصرا عند البخـاري ومسلم وغيرهما على ظواهر الجرح والتعديل بل ويالوقوف على متون الروايـة بدقة السبر والتقسيم وإعمال القرائن؛ فلربما دلتهم القصة الموجودة في الحديث على ضبط راويها، وفي هذا يقول الإمام أحمد بن حنبل: "إذا كان في الحديث قصة دل على أن اويه حفظه"()، فهل لو وجد باحثنا قصة في الصحيح حديثها التـي إســنادها فيـه مسن لـم يوصـف بجـرح ولا تعـديل سـيعمل كـلام الأئمـة المتقدمين هـا؟! لا أظتـه فـاعلا لخلـو دراسـته النظريـة الطويلـة مـن قواعد الأئمـة هذه! ولقـا جاء في بعض تراجم بحثّه مـا يلزمسه استخدام هذا فلم

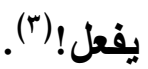
(Y) تعريف الحديث الصحيح الاصطلاحي لا ينفصل عن تطبيقاتهه الموجودة في صحيحي البخاري ومسلم:

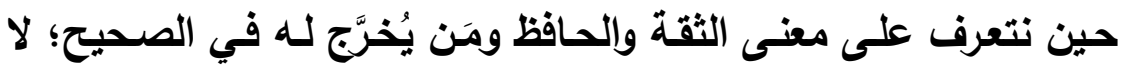
نقف عند هذا الحد! بـل لابـد من معرفة كيف كانـت طريقة إخراج البخـاري ومسلم - أو أحدهما - لهذا الراوي - أو ذاك - في شيخه أو لحديثه وكذا من المعتمدون في الرواية عنه، فمثلا ليس حديث يحيى القطان عن الثوري كحيث ابن علية عن الثوري، فالأول مجمع على تقدمسه في الثوري بخـلاف

$$
\begin{aligned}
& \text { توجيه النظر إلى أصول الأثر ( / / / (YV). }
\end{aligned}
$$

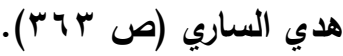

(r) سيأتي التنبيه على تركه في ترجمة رافع المدني في المطلب الثاني من المبحث

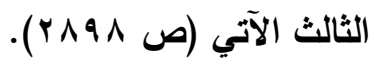


إزالة إيهام القائلين بوجود

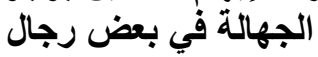

الآخر؛ لذا نجد حديث القطان عن الثوري كثيرا في الصحيحين بخلاف الآخر

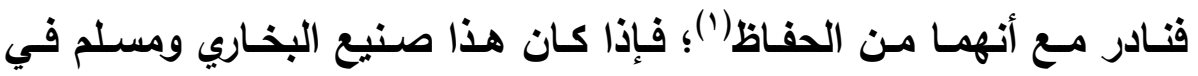

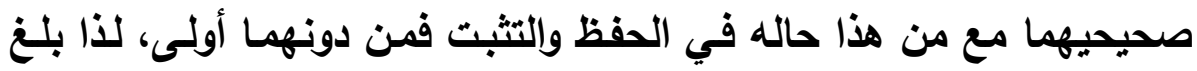
البخاري ومسلم في صحيحيهما العناية الفائقة في الإخراج والانتقاء للرجال فئ دونال ولحديثهم، وجاءت أنظار المشتفلين بالحديث إلى تنزيل صحيحي الإمامين

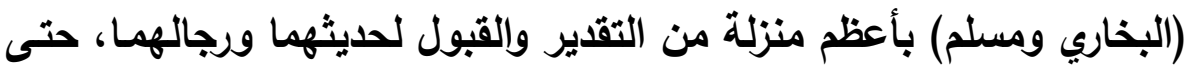

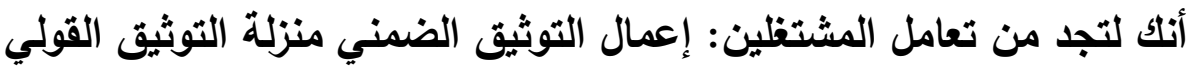

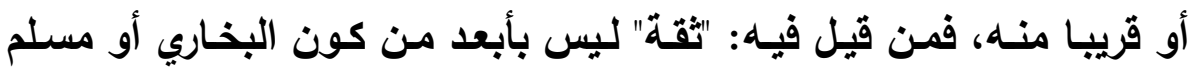

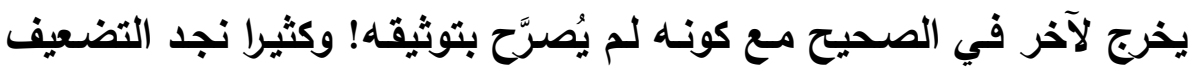

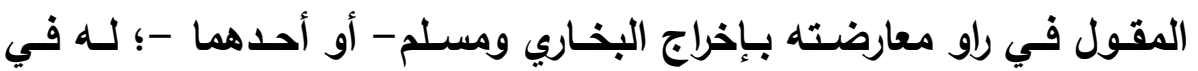

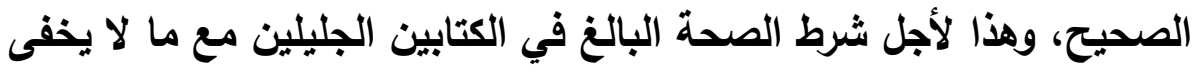

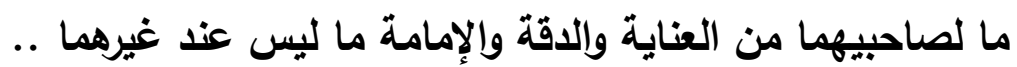

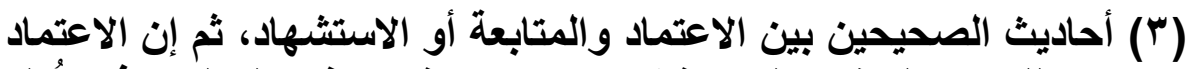

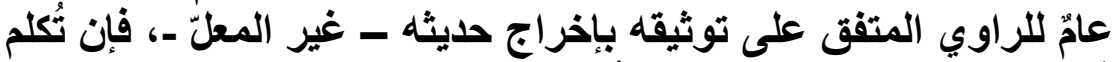
في الراوي يكون حديثّه انتقاء، أو بالثشواج الهد و المتابعات:

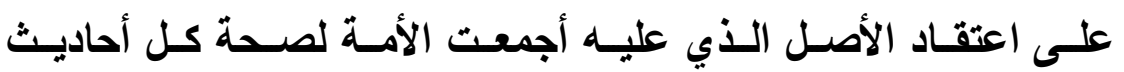

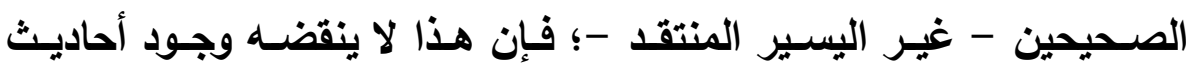

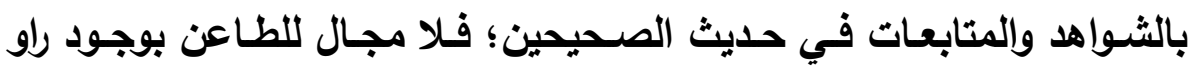

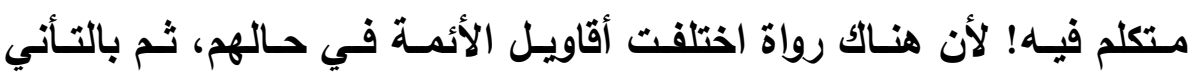
والسبر نجد الحفـاظ يفرقون بين الاعتمـاد ويبين المتابعة والاستشـهاد لهـا

$$
\text { (1) ترجمتهما في تقريب التهذيب (ص ه ـ او 19ه). }
$$


القسم؛ فإن ظهر لهم اعتماد صاحبي الصحيح - أو أحدهما - لذاك الرجل فإن الميل لتوثيقه في حديثه الذي في الصحيح يسترعي استظهار توثيقه

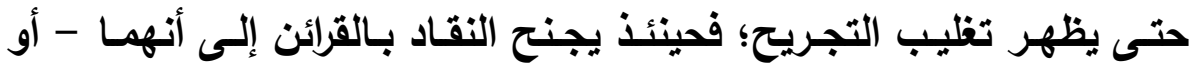

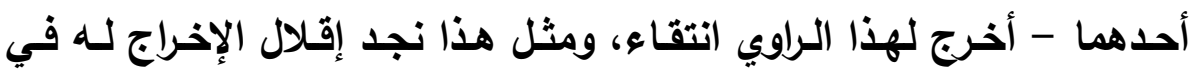
الصحيح؛ كأن يخرج لـه الحديث والحديثين .. كما لا يُففل عن التفريق بين التهن

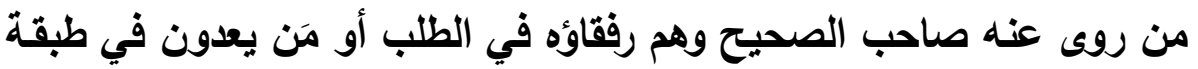

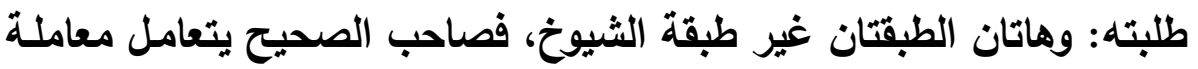

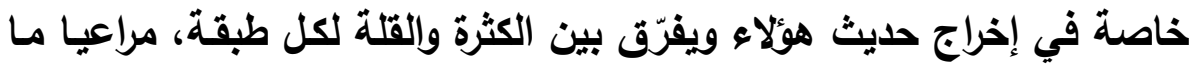
يحتاجه من كل طبقة مراعاة للصحيح وموضوع الجامع، فمثلا رفقاء البخاري

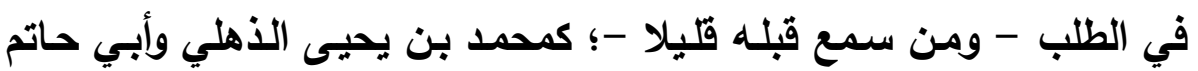

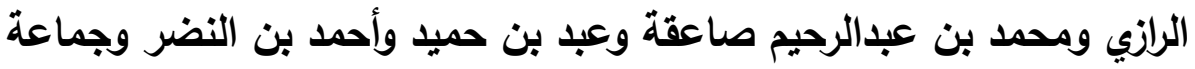

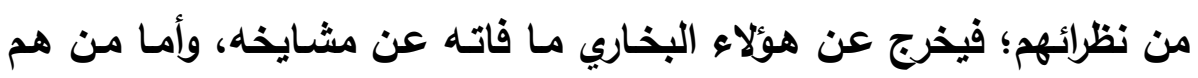

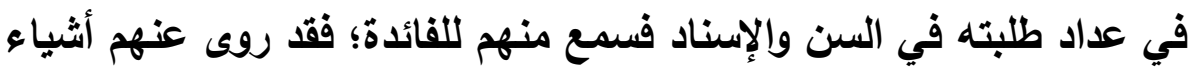

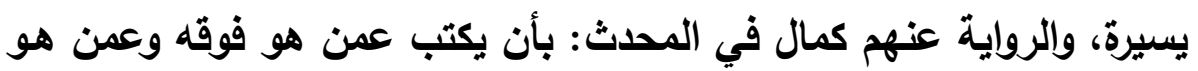

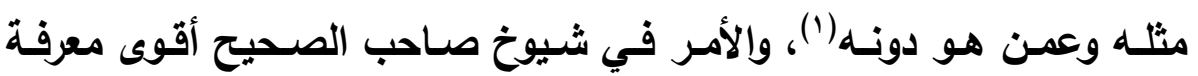

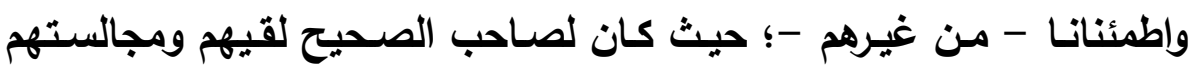

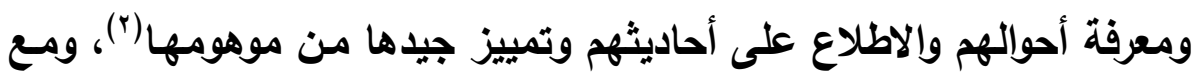

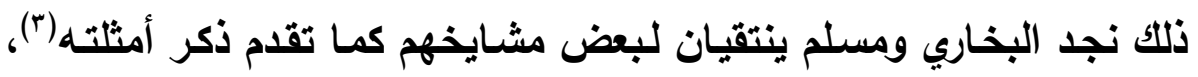

(1) ينظر تفصيله بزيادة في: طبقات شيوخ البخاري في هدي الساري (ص 9 \؛).

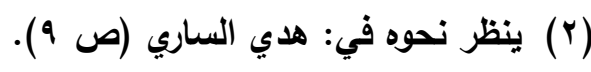

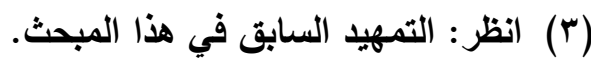
مجلة كلية أصول الدين والدعوة بأسيوط / العدد السابع والثلاثون 9 ـ ب م - الجزء الثالث 
إزالة إيهام القائلين بوجود

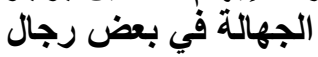

والأمر أقل حظوة فيمن هم فوق طبقة شيوخهم - ومن فوقها - مـع وجود معرفته وسبره لحيثهم كإمامين عارفين، فالأمر نسبي، وفي جميع ذلك يتبـه أن الحكم في أمثال هؤلاء - الأين أخرج لهم صاحبا الصحيح وتُكلم فيهم -؛

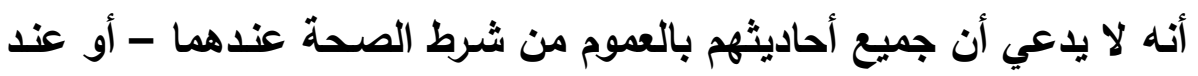

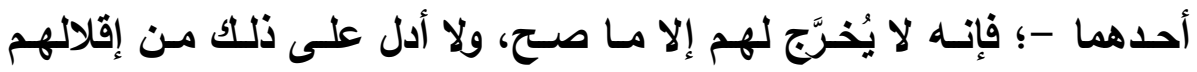
لمرويات هؤلاء فتببه(')، ولعل ابن عدي - صـاحب الكامل - وغيرَه - ممن يكتب في مناكير وغرائب الرواة - يستقصون أحاديث أمثال هؤلاء ويخلصون إلى أن باقي حديثه مستقيم؛ وإنما أتوا بهذا المنهج متابعة لصنيع صاحبي الصحيح. أما طبقة التابعين فهولاء ينزلون - بالجملة - تحث التعديل العام لقول

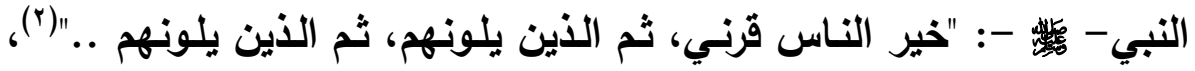
ولذا وجد الحافظ الذهبي - باستقرائه التام -؛ مـا قال فيه: "وأمـا التابعون؛ فيكاد يعدم فيهم من يكذب عمدا، ولكن لهم غلط وأوهام، فمن ندر غلطه في جنب مـا قـ حصل؛ احتُمل، ومـن تعدد غلطه - وكان مـن أوعيـة العلم -؛ اغتُفر له - أيضا - ونُقل حديثه، وعُمل بـه؛ على تردد بين الأئمسة الأثبات

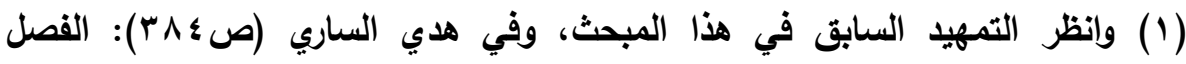
التاسع في سياق أسماء من طعن فيه من رجال (الصحيح) .. نجد تراجم كثير من في فئ رجال الصحيح تُكلم فيهم ومع ذلك نجد الحافظ ابن حجر يختم تراجمهم بالإحصاء ونه لحديثهم بأنه قليل، فانظره تعرف صواب ما قلت فئ.

(Y) متفق عليه: صحيح البخاري: كتاب: الثهادات - باب: لا يشهد على شهادة جور إذاب

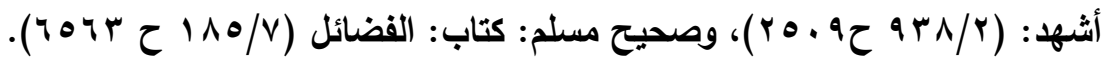
مجلة كلية أصول الدين والدعوة بأسيوط / العدد السابع والثثلاثون 9 ا ـ بم - الجزء الثالث 
إزالة إيهام القائلين بوجود

الجهالة في بعض الفالين بوجال

في الاحتجاج عمن هذا نعتهـ ... ومـن فحش خطأه وكثر تفرده لـم يحتج بحديثه، ولا يكاد يقع ذلك في التابعين الأولين، ويوجد ذلك في صغار التابعين

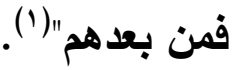

وإذا كان هذا حالهم فكيف بمن أخرج لهم البخاري ومسلم وانتقى من حديثهم .. ثم يأني الباحث ويضع أكثر من سماهم في بحثه من التابعين

معرضا عن تفعيل هذه النصوص الشريفة!!

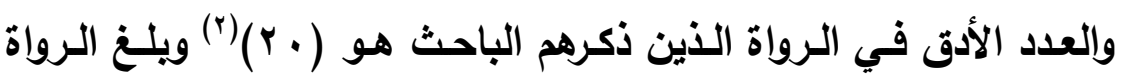

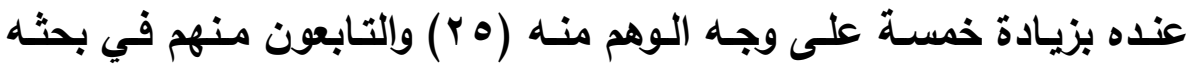
( • (1) ويَبعُد في عـرف الصـناعة الحديثيـة جهـالتهم .. ولا يقـال: إن كـلام الأهبي - صاحب السبر والاستقراء التام - استثثى في كلامـه السـابق صغار التابعين ..؟ والمهم هنـا في طبقة التابعين - ومن دونهم - عدم المجيء بمنكر من الحديث وإلا فمـا فائدة سبر الأئمـة والنقاد لحديث فلان وفـلان .. ولو عملوا كعمل الباحث لضاعت هذه الصناعة وذوقها ولذهب تعظيم فحول أئمسة وصنيعهم؛ فـإن أعظم مـا تميـزوا بـه ذلكـ السـبر لحديث المقلين بـل

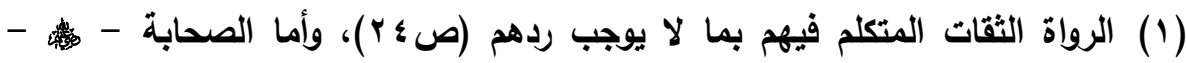

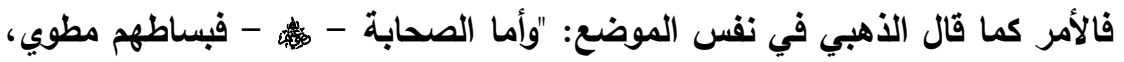
وإن جرى ما جرى، وإن غلطوا كما غلط غيرهم من الثقات؛ فما يكاد يسلم من الغلط

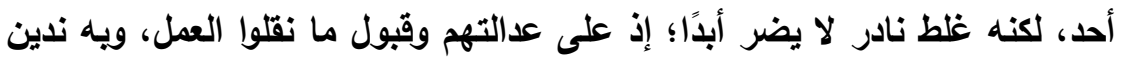

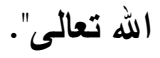

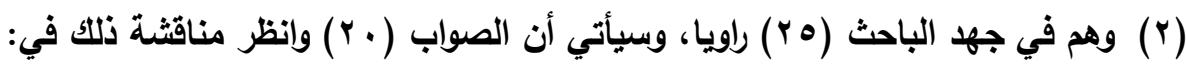

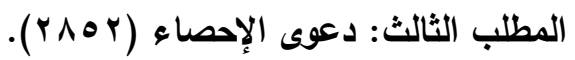


والمكثرين، ولم نجد إعمالا لهذه القاعدة عند الباحث - كغيرها من القواعد المذكورة هنا -؛ بحيث يتساعل عند كل ترجمة: هل ذاك ناتج عن سبر!! لقد فرّ الباحث القهقرى؛ فبدلا من أن يتقدم بصنيع الأئمـة؛ ظل في بحثه جامدا على قاعدة المجهول = مجهول مردود الرواية، ثم تحاشيا نسبته أنه يشوش على روايـات في الصحيحين بحجة وجود الجهالة في بعض الرواة؛ تزلف بالتوثيق الضمني، وهذا أوان تجلية هذه القاعدة:

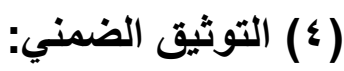
هذه وقفة مهمـة مـع الباحث وغيره ممن يمرون على التوثيث الضمني دون تفعيل، والباحث قد ذكر التوثيق الضمني دون تجلية في مبحثه الثانيمع

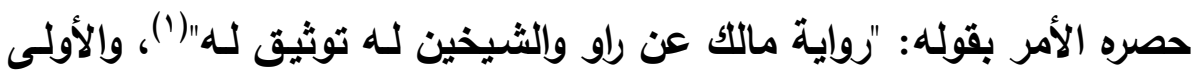
منـه لو قال: "التوثيق الضمني وحكمسه" لقوة دلالـة النص وصسراحة عمومسه وواقعه الحديثي في أفراده، فِذِكر التوثيق الضمني - بدون تقييد - أولى؛ حيث نص عليه الباحث في أول كلامه في المبحث(؟)، وذكر له ثلاث صور، الأولىى: من روى لـه مالك في موطأه، والثانية: من روى لـه البخـاري في صحيحه، والثالثة: مـن روى لـه مسلم في صحيحه، وذكر أقوالا عدة عن مون الأئمة موئدة لألك، ثم ذكر التفريق بين من أخرج لـه الشيخان في الأصول ويسين من أخرجا لـه بالثـواهد والمتابعات، ثم ذكر مـا يتعلث بصلب البحث: وهم من لم يذكروا بجرح ولا تعديل وقد أخرج لهم الشيخان، وقرر أن هوّلاء

(1) انظر (ص \& 0) من مبحثه "من لم يوصف بجرح أو تعديل من رجال الصحيحين ..".

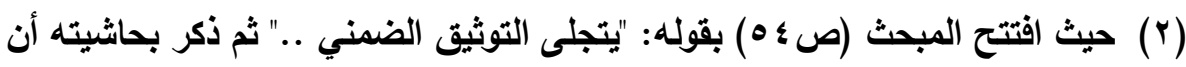
أول من وقف عليه يستخدم هذه العبارة هو إمام الحرمين في كتابه البرهان ...". مجلة كلية أصول الدين والدعوة بأسيوط / العدد السابع والثلاثون 9 ـ بم - الجزء الثالث 
ثقات برواية الشيخين - أو أحدهما - لهم في الصحيح، وذكر من نص على ذلك من الأئمة، وقرر أن من احتج به الشيخان في الأصول فهو ثقة بـاء على تلقي الأمسة لكتابيهمـا بـالقبول. وأن من أورداه في المتابعات والثـواهد فهو على درجات. وأن من رويا لـه في الأصول وليس فيه جرح ولا تعديل

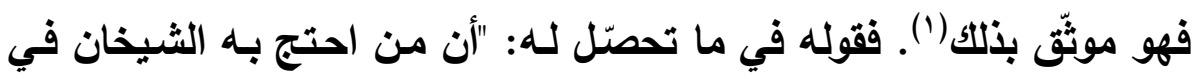
الأصول فهو ثقة"؛ ليس بدقيق - ولو قيل: إنـه يعني: "ثقة عندهما" لكان مقبولا إلى حد ما-؛ فإن هناك من هم مختلف فيهم ولو احتج بهم الشيخان، ولا بل من الإثـارة أن المحتج بهم من رجال الشيخين منهم الأئمسة والحفاظ المتفـق عليهم ومـنهم مسن جرحـوا في نصـوص بعض الأئمسة، ثم الـراجح الاحتجـاج بهم وفق القرائن الدالة على ذلك، وهناك رجال ممن احتج بهم الشيخان - في مواضع - ليس على اطلاقهم محتج بهم - لِما وجده صساحبا الصحيح من تليين أمرهم عند غيرهما من الأئمـة -؛ ويؤكد ذلك قرائن، منها حين نجد انتقـاء الثـيخين لهم في مـواطن، ففرق بـين تصـيح حديثهم الموجود في الصحيح، وكونهم ثقات عند أصحاب الصحيح بالجملة!! ولو تعرّف الباحث على الفصل التاسـع من هدي السـاري - الذي أهمل الباحث الاسـتفادة منـه - وهـو في مقدمـة شـرح الصـيح للحسافظ ابن حجر لحرر الباحث عبارته على وجه يليق بمكانة الصحيح؛ ولتبيّن له دفاع الأئمـة عمن تُكلِّم فيهم، فهي هذا الفصل بيان لأسماء من طُعن فيهم من رجال البخاري وطرق تحرير الجرح وييانـه بـالرد تـارة وترجيح اعتمـاد البخـاري على أولئك

(1) انظر (صب^) من مبحثه "من لم يوصف بجرح أو تعديل من رجال الصحيحين ..". مجلة كلية أصول الدين والدعوة بأسيوط / العدد السابع والثلاثون 9 ا ـ بم - الجزء الثالث 
الرواة أو التماس عذر البخاري ببيان طريقة إخراجه لحديث هؤلاء إن غلب جانب الجرح، ثم إن في انتقاء البخاري - أو مسلم - لمثل هؤلاء الرواة بيان بأن مثل هويلاء الرواة ليسـوا محل اتفاق وليسـوا كغيرهم ممن يعتمد على حيثهم فيكثر منه - أو يعتمد على تفردهم فلا يُخشى منه -؛ فالأولى تحرير مثل هذا وفذلكته بما يدل عليه،، أمّا من لا يُعتمد على حدثيهم فليسوا محل البحث هنا، وفي نفس الفصل المشار إليه بيان لألك، ويذا يقيس الباحث مـا في هذا الفصل على جميع من ذكرهم في بحثه بما يبرزه خادما للصحيحين حقا، وسيدلنا على ذلك تقريرات منها لو قال: "وأن الثقات المحتج بهم في الصـحيحين علـى درجـات"! وهـو الأمسر الــي قالـه فـي أصـحاب الثــواهد والمتابعات؛ فإنـه يقرر أن من أورداه في المتابعات والشـواهد على درجـات. وأن من رويـا لـه في الأصول وليس فيه جرح ولا تعديل فهو موثِّق بـذلك. والأخير يحتاج منـه إجابـة عن السؤال: لمـاذا جميع التراجم التي أوردها هم بالثواهد والمتابعات؟!

وقد أهمل الباحث بابـا مهمـا من التوثيق الضمني يكثر من استخدامه والعناية به عند الأئمة: وهو إخراج مَن يشترط الصحة - ولهو على تسـاهله فإنه موثق عنده ضمنا -؛ فعلى الباحث التنصيص على هذا في مبحثه هذا الأي يقرر فيه التوثيق الضمني، ولكان ذلك مفيدا ومقويا لـه في كثير من تراجمه التي ذكرها لو فعل! فلا أدري لََّ لم يذكره مع وضوحه وشهرته!. والباحث مع إقراره - جملة - بالتوثيق الضمني بإخراج صاحبي الصحيح

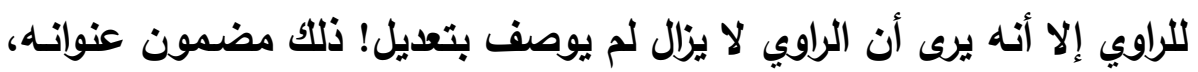
ولو قيل: إنه أراد التوثيق صراحة؛ لكان الجواب: سيكون محصنّ بحثه مجرد مجلة كلية أصول الدين والدعوة بأسيوط / العدد السابع والثلاثون 9 ـ ـ بم - الجزع الثالث 
إزالة إيهام القائلين بوجود

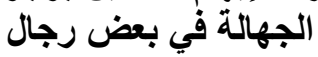

إحصاء وراءه التشويش؛ فإذا كان الراوي موثقا بـإخراج صساحب الصحيح لـه؛ فمـا الثمرة من البحث حول التوثيق صراحة إن كان الباحث يعتقد توثيقهم بإخراج صاحب الصحيح لهم؟ لذا لم نجد الأئمة يعتنون بالبحث حولهم جمعا ودراسة كما فعل الباحث، فأبرز من اعتنى بصحيح البخاري وهو الحافظ ابن حجر لم نجده أبرزهم - جمعا ودراسـة - كما فعل بمن تُكلّم فيهم في فصله التاسع في هدي الساري مقدمة الفتح، هذا مع معرفتي التامة بأنتي أتكلم عن عنوان الباحث الأي لا وجود له! وهو "إخراج للراو في الأصول توثيق له"! وجاء كـل الـرواة روايـتهم فـي غيـر الأصسول، وهـم فـي عـدّ الباحـث بلغـوا خمسـة وعشرين (1)؛ فهؤلاء مجهولـون لا يـفعهم التوثيق الضـني بـإخراج صـاحب الصحيح لهم؛ لأنه روايتهم في غير الأصول كما يقول ()، وليس في تراجمهم في البحث التطبيق العملي لباقي موارد التوثيق الضمني الأي ينفعهم أو ما يبيّن استقامة روايتهم وإخراجهم من حيز الجهالة إلا أن تكون هناك لهم مرويات خارج الصحيح قد توقف فيها الأئمة أو أنكروها عليهم؛ وهذا مـا لـ يـكره بـه الباحث! ويكون في عمل صاحبي الصحيح مرشد لهذا التطبيق، وهو في سبر حديث الرواة ومعرفة مواققة مـن هذا حالـه لأصسول الروايـات التـي تثـهـ لمرويـاتهم وتُتبابعهـا؛ وذا موجـود عمـلا عند المتقدمين في حديث الحفـاظ والمعروفين من الثقات، فمن دونهم أولهى وأسـهل(ّ)، وذا كان يهيـئ الباحث لتفهم تعامـل الإمـامين - وغيرهمـا - في إخـراج الأحاديـث وإعتمـاد رجـال

$$
\begin{aligned}
& \text { انظر: نتائج بحثه (ص س 10 - ع 10) }
\end{aligned}
$$

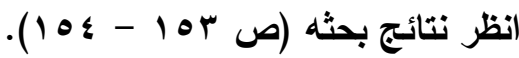

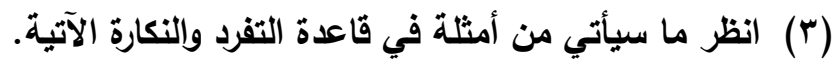


إزالة إيهام القائلين بوجود

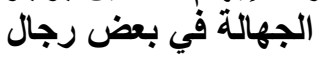

أسانيدها؛ لذا لم أجازف بقولي: إنه تزلف بذكره التوثيق الضمني الذي معناه أن إخراج صاحب الصحيح للمجهول توثيق له، لماذا لم أجازف؟ لأنسه لو أراد العمل بهذا التوثيق الضـمني - أصـلا - فلن يخفى على مختص مثلهـه أن موارد التوثيق الضمني - ولو يذكرها - أوسع من هذا، فماذا عن الكتب التي اشترطت الصحة ومـا قاريها في كتبها كصحيح ابن خزيمـة .. وكذا الأئمـة الذين لا يـروون إلا عن الثقـات، ومـاذا عن تصـيح إمـام - غير البخـاري ومسلم - لحديث مـا لهذا الموصوف بالجهالة- عند الباحث-، أو استدلال إمام بحديث فيه أحد هؤلاء الرواة .. = أليس هذا توثيقا ضمنيا ينفع في رفع جهالة من زعم جهالته! على الأقل عنــ ذاك الإمسام الذي لا يروي إلا عن

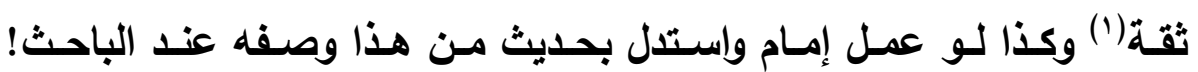
والباحث على دراية بهذا ويخفيه عمدا!! فإنه ذكر التوثيق الضمني الخاص بإخراج الشيخين للمستورين بقولهه: روايـة الشيخين للمستورين توثيق لهم: ونقل تحته قول الإمام الذهبي: "الثقة : من وثقـه كثير، ولم يضعف. ودونـه: من لم يوثق ولا ضعف. فإن خرج حديث هذا في "الصحيحين"، فهو موثق

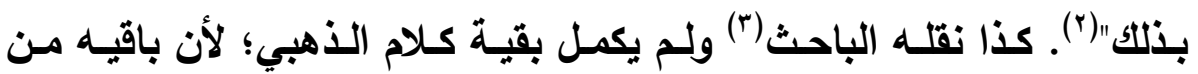

هناك جماعة من الأئمة ممن لا يروون إلا عن الثقات كشعبة وابن مهاي ويحيى القطان وحريز بن عثمان وسليمان بن حرب ... وغيرهم كثير يطول ذكرهم. يُنظر : الانه

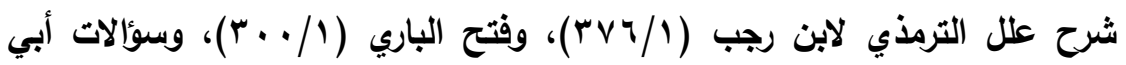

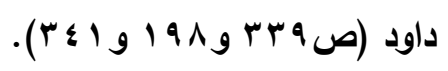

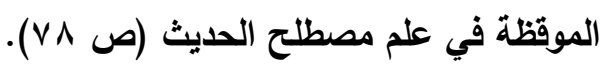
"من لم يوصف بجرح أو تعديل من رجال الصحيحين .." (ص 4 "^). مجلة كلية أصول الدين والدعوة بأسيوط / العدد السابع والثلاثون 9 ـ ب م - الجزء الثالث 
إزالة إيهام القائلين بوجود

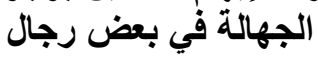

التوثيـق الضـمني، الـذي سـبق أن أثـرث إليـه - ولا يرتضـيه الباحـث -؛ وتمامه: "وإن صحح له مثل الترمذي وابن خزيمة، فجيد أيضا. وإن صحح لـه كالدارقطني والحساكم، فأقل أحوالـه: حسن حديثهه". ألـيس - الآن - الـرواة المذكورون في كتاب الباحث - وقد خلوا من تتبع الباحث للتوثيق الضمني الشـامل بصـوره السـابقة -؛ سـترتفع عنهم الجهالـة بوضـوح!! وهـو يعرف التوثيق الضمني بصوره التي لا تقتصر على إخراج الشيخين بهذا اللاليل، وأيضـا بكونـه ذكر في بحثنه نوعا من التوثيق الضـني في مبحثه الثاني:

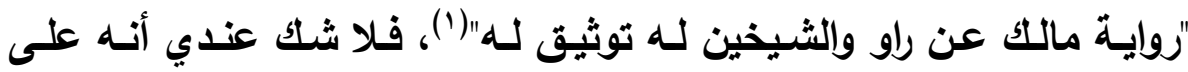
معرفة تامة- لا يحبها - بالتوثيق الضمني الأي يسـهل عليه - وعلى الناس - دفع الشبه عن رواة الصحيح، فليس بعد تركه لهذا إلا التشويش! هل غقل عـن أئمسة عـدة بـالغوا فـي انتقـاء الشـيوخ والتحـديث عـن الثقــات، قـال يعقوب بن شيبة: "قلثُ ليحيى بن معين: متى يكون الرجل معروفًا؟ قال: إذا روى عن الرجل مثلُ ابن سيرين والشـبي - وهوولاء أهل العلم - فهو غير مجهول، قلت: فإذا روى عن الرجل مثل سماك بن حرب وأبي إسحاق؟ قال: هؤلاء يروون عن مجاهيل"، نقله بن رجب ثم قال: "وهذا تفصيل حَسَنْ، وهو

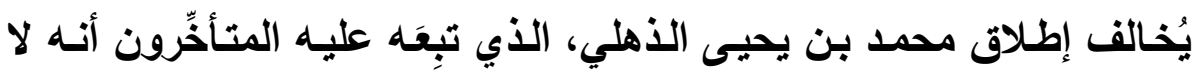
يخرُج الرجلُ من الجهالة إلَّا برواية رجلين فصاعدا، وابن المديني يشترطُ أكثر من ذلك، فإنه يقول فيمن يروي عنه يحيى بن أبي كثير وزيـا بن أسلم معًا:

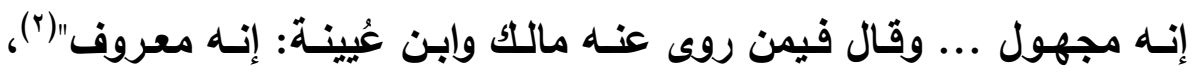

(1) (نظر : "من لم يوصف بجرح أو تعديل من رجال الصحيحين .." (صه و ؛ ه).

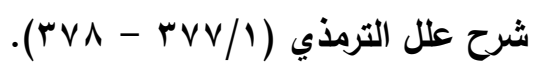
مجلة كلية أصول الدين والدعوة بأسيوط / العدد السابع والثثلاثون 9 ا ـ بم - الجزء الثالث 
إزالة إيهام القائلين بوجود

الجهالة في بعض الفالين بوجال

وأبعد منه عمل بعض الأئمسة في توثيق الراوي لمجرد روايـة الثقة عنه كمـا

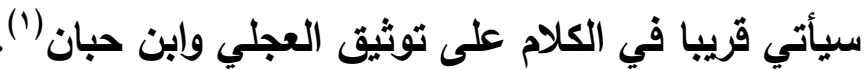

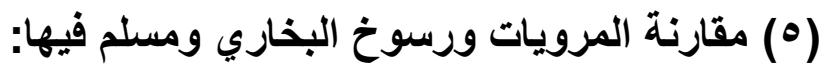

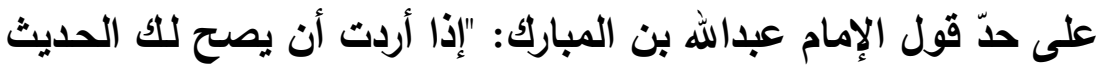

فاضرب بعضه ببعض"(†): نعرف أنه لا تتأتى مقارنة المرويات إلا بعد جمعها جمع متيقظ؛ لذا أبرز من جاءت عبارتهم في تأصيل هذا الباب هم أئمة هذا

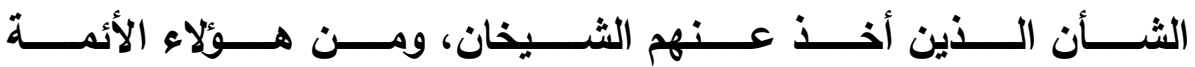
ابن المديني وأحمد وابن معين، وهذه بعض أقوالهم:

- -

- مقال علي بن المديني: "الباب إذا لم تجمع طرقه لم يتبيَّن خطؤه"(ء). - وقال أحمد بن حنبل: "الحديث إذا لـم تجمع طرقه لـم تفهمهـ، والحديث

يفسر بعضه بعضًا "(ه).

- وقال الحافظ محمد بن بحيى الذهي: "رأيث لعلي بن المديني كتابـا على ظهره مكتوب: المئة وإلنيف والستين من علل الحديث"، أسنده الخطيب البغدادي ثم عقب بقوله: "والسبيل إلى معرفة علة الحديث أن يجمع بين

(1) أنظره (ص Y Y Y من هذا البحث، والباحث استثى من انفرد بتوثيقهم بن حبان أو

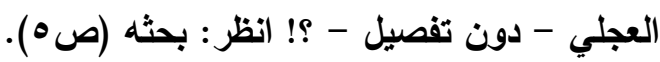

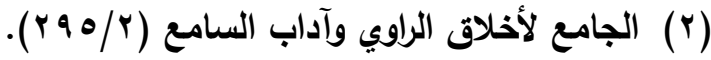

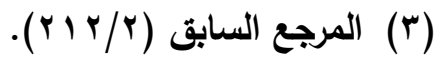

( ) (المرجع السابق نفسه.

(0) (المرجع السابق نفسه. 
إزالة إيهام القائلين بوجود

الجهالة في بعض الفالين بوجال

طرقه وينظر في اختلاف رواته ويعتبر بمكانهم من الحفظ ومنزلتهم في

الإتقان وإلضبط" (1)

بل للأئمسة ممارسـة عميقة مستقصية جعلت لهم فهما خاصـا لا ندركهـ

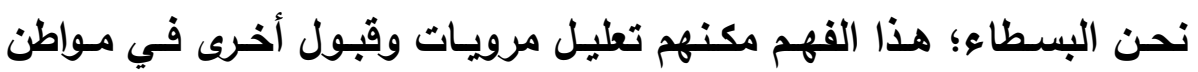
يصعب فيها التعليل أو القياس، قال الحافظ ابن رجب: "قاعدة: حذاق النقاد

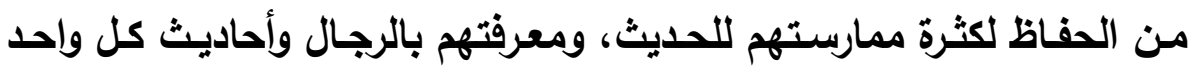
منهم، لهم فهم خاص يفهمون به أن هذا الحديث يشبه حديث فلان ولا يشبه بـائه حديث فلان فيعللون الأحاديث بذلك. وهذا مما لا يعبر عنه بعبارة تحصره

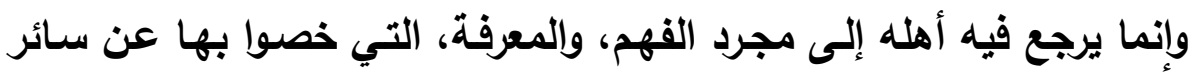

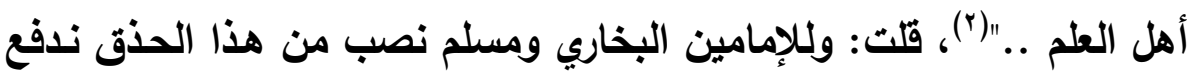

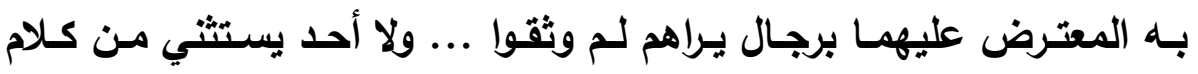

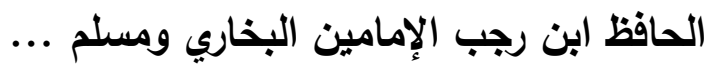
ولا أجد مبررا لتغافل الباحث عن هذا الأصل البفاري وملث الذي تبناه المتقدمون في

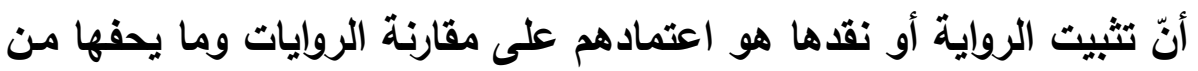

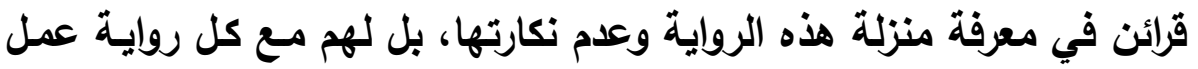

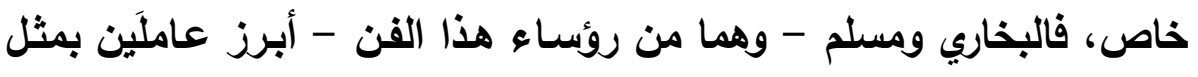
هذا الأصل، ولذا قال بن رجب الحنبلي عن تعامل أكثر الحفاظ في هذا الباب:

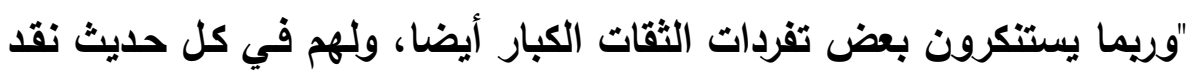

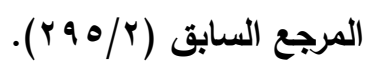

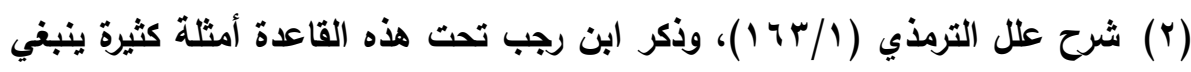

للمختص رعايتها. 
إزالة إيهام القائلين بوجود

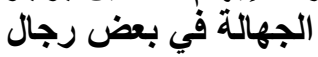

خاص، وليس عندهم لألك ضابط يضبطه"(1)، فلو تأمل هذا الباحث مثل هذا

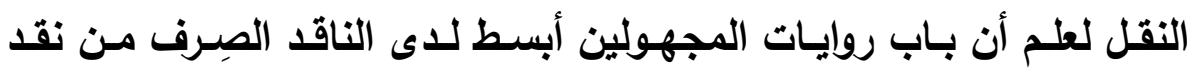
مرويات الكبار، فـلا مانع حين ذاك من القول: إن ذاك الراوي المجهول -

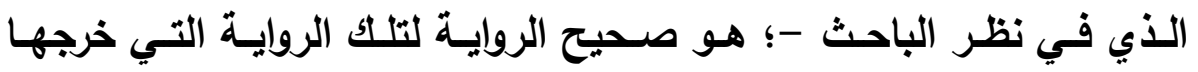

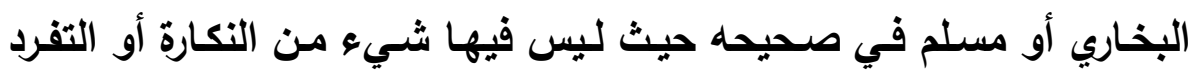
المطلق عندهما - أو عند أحدها -؛ وإذا كان كثير من الثقات - وليو تُكلِّم

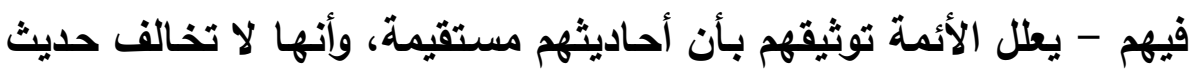
الثقات، والعكس: فكم من مشهور يتعجب الأئمـة من روايته وتفرده فيها،

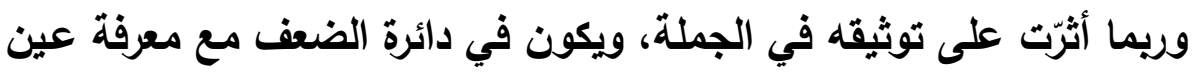

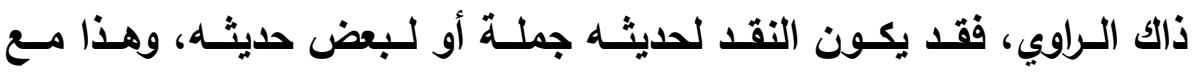

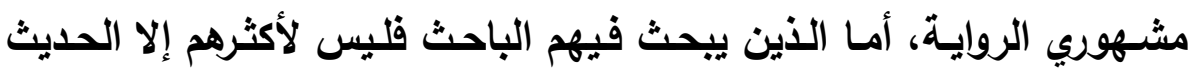

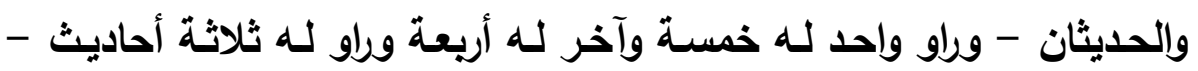

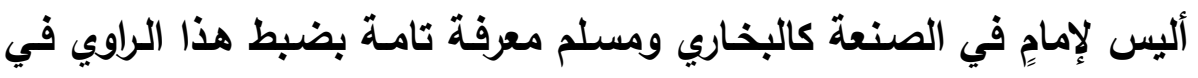

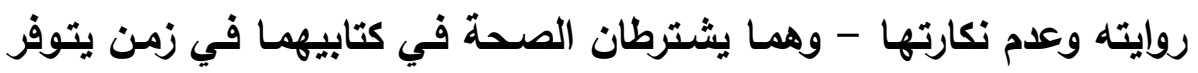

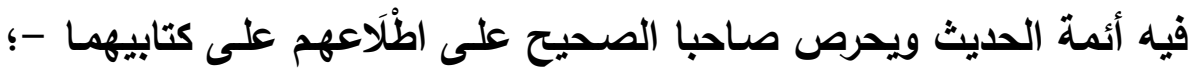

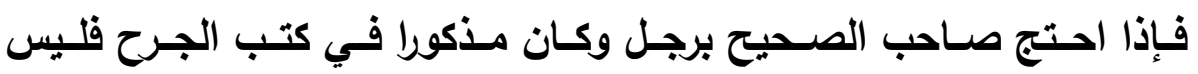

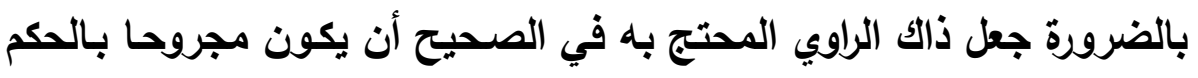

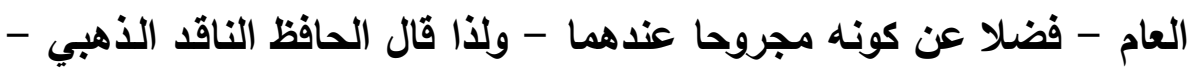

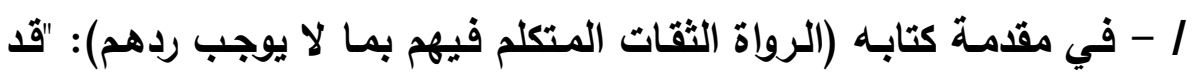
كتبت في مصنفي الميزلان عددا كثيرا من الثقات الذين احتج البخاري أو مسلم

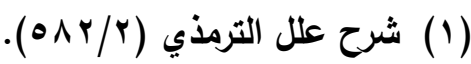
مجلة كلية أصول الدين والدعوة بأسيوط / العدد السابع والثلاثون 9 ـ ـ بم - الجزع الثالث 
- أو غيرهما - بهم؛ لكون الرجل منهم قد دون اسمه في مصنفات الجرح،

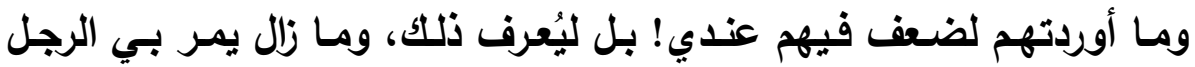
الثبت وفيه مقال من لا يعبأ به!! ولو فتحنا هذا الباب على نفوسنا لاخل فيه

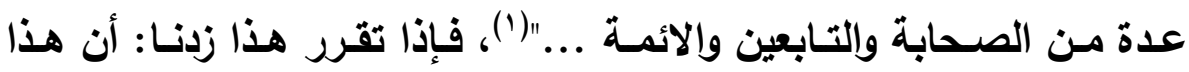

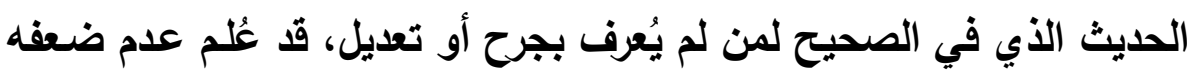

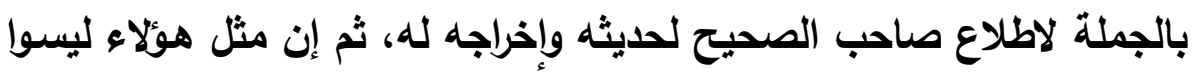

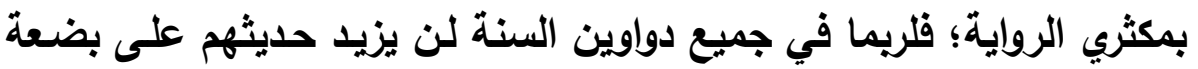

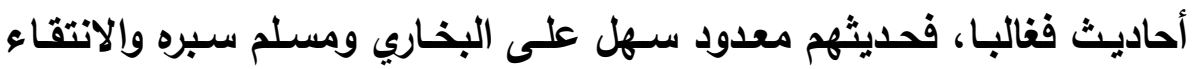

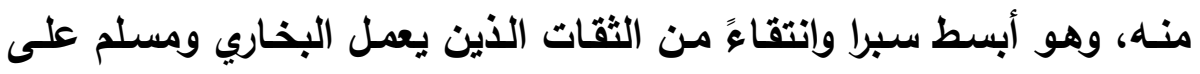

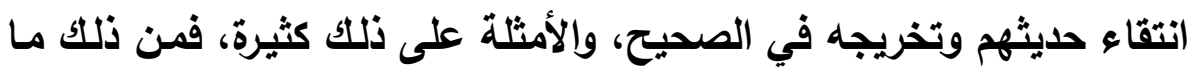

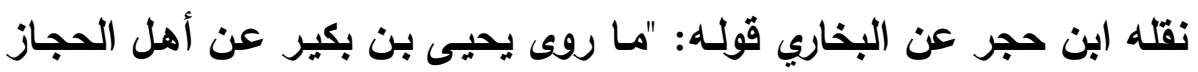

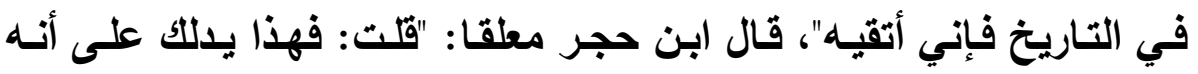
ينتقى حديث شيوخه .."(")، قلت: وقد ضعفه النسائي، وتعقبه الذهبي بقوليه:

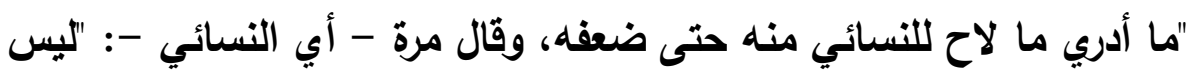

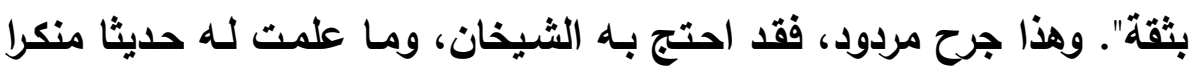

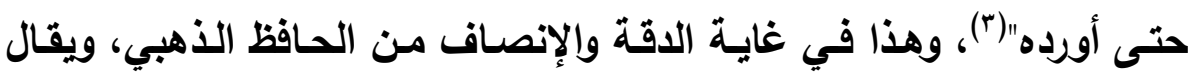

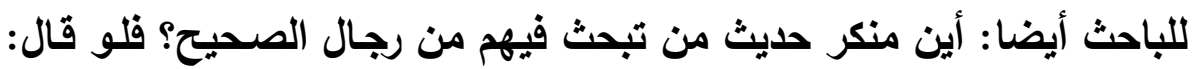

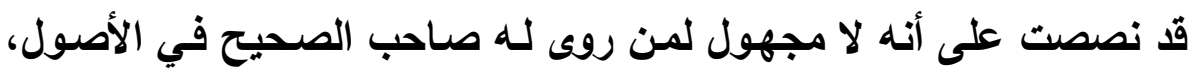

(1) الرواة الثقات المتكلم فيهم بما لا يوجب ردهم (ص بr (ب).

$$
\begin{aligned}
& \text { هدي الساري (ص ro ؛ ؛). }
\end{aligned}
$$

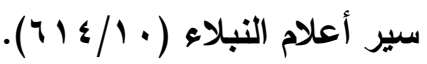


فأولئكت عندي هم المحتج بهم! قلنا: لكن غـاب عنـك إعمال قواعد الفن، ويحثك ليس فيه راو ينطبق عليه وصفك - مـع نقاش في إدراجه أصلالا' (') -

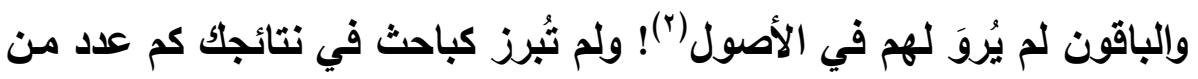

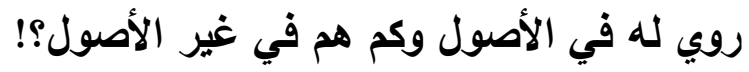

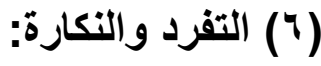
على التـزل بـأن كل مـن يحصيهم الراصد مـن مستورين في رجـال الصحيح ينبغي أن يتوجه له سؤال: هل هؤلاء المستورون في أنهان أحاديثهم نكارة

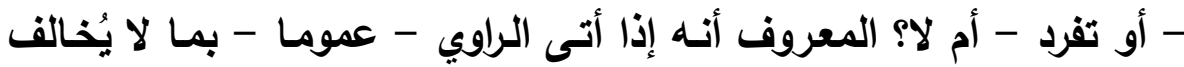

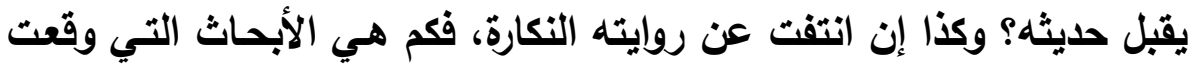

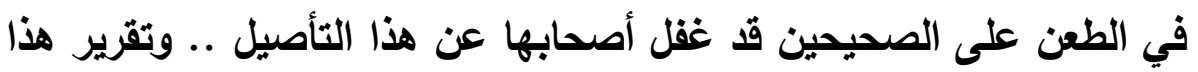
يجيب بعمق عن إثـكال الطعن على حديث الصـحيحين بالمستور .. إن

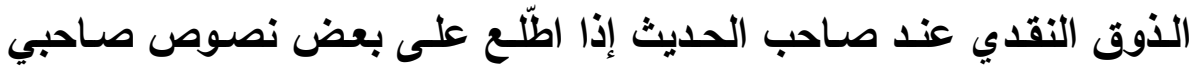
الصحيح في هذا الباب دله على عدم إغفال صاحبي الصحيح عن حديث

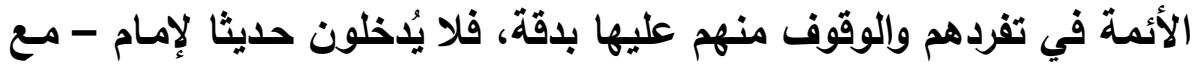

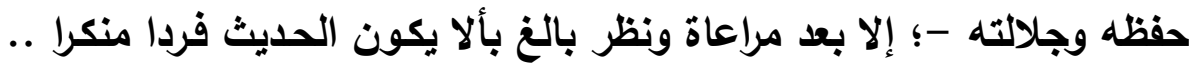

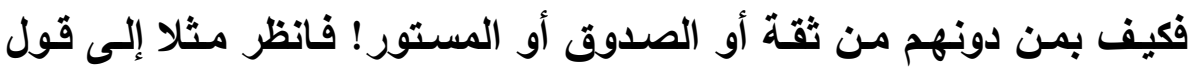

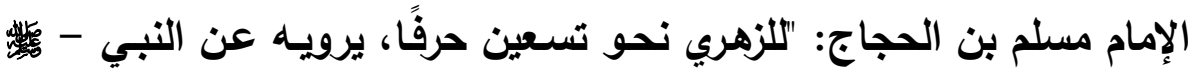

(1) وهو رافع مولى مروان وسيأتي نقاشه في مطلب آخر المطلب الرابع من المبحث

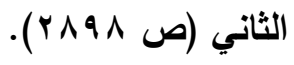

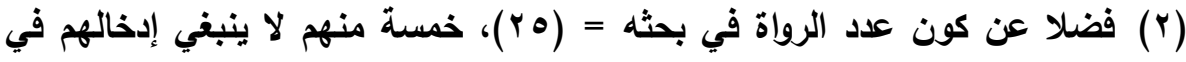

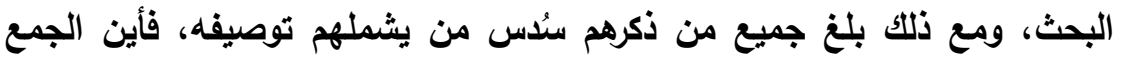

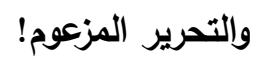


- لا يشاركه فيها أحد، بأسانيد جياد"(1). وهذا قاله بعد حديث أخرجه لـه في صحيحه؛ خشي فيه الإمـام مسلم أن يغمز حديث في صحيحه لتفرد الزهري بهذا الحديث، والذي يهم هنا أن نظر الإمـام مسلم حاضر في مراعاة عدم نكارة وتفرد رجاله في أحاديثهم، فتصيصه على الإمام الزهري في قبول تفرده لجلالته كاف في إلقاء تمحيص حفظ من دونـه وإخراج حديثهم عنده؛ فِإذا كان هذا في مسلم وهو دون شيخه البخـاري في المعرفـة، وصـحيحه دون صحيح البخاري؛ فكيف القول في البخاري وصحيحه، والعناية بهذا الأمر عند الإمامين مشهور معروف في زمنهم وعند شيوخهم، فخذ مثلا صنيع شيخهما الإمام أحمد فقد توقف في زيادة الإمسام مالك: لامن المسلمينه الواردة في

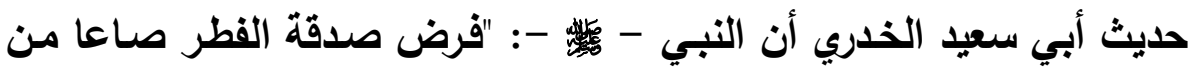

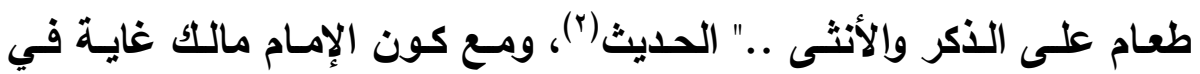
الحفظ والإتقان فقد قال أحمد في روايـة عنهـ: كنت أتهيب حديث مالك "من المسلمين" سيعني حتى وجده من حديث العمريين - قيل لـه: أمحفوظ هو

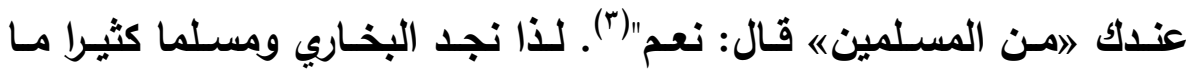
يأكرون عقب الروايات متابعات للرواة في مروياتهم دفعا للنكارة والغرابة، فإذا وجد صـاحب الصـيح مـا ينفع غرضـه في الجـامع من حديث لراو - يظتهـ

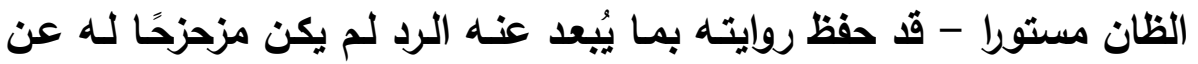
حيز الصحيح احتجاج؛ هذا في التفرد أما في المتابعة فالأمر ظاهر، ثم مراتب

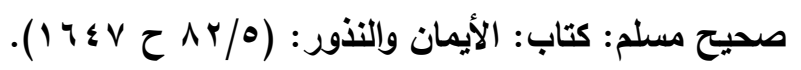

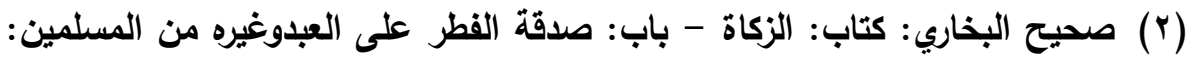

$$
\begin{aligned}
& \text { ( }
\end{aligned}
$$

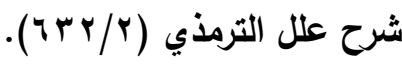


الرواة متفاوتـة بحسب الحال: فإن كان المنفرد بالروايـة غير حافظ وضابط

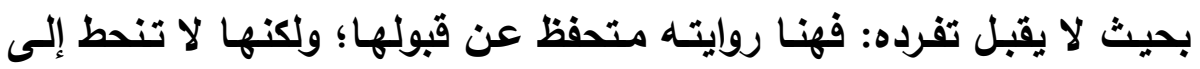

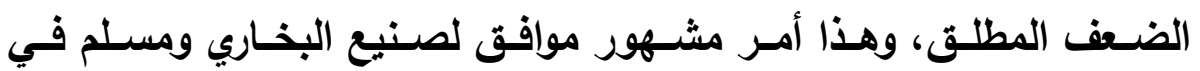

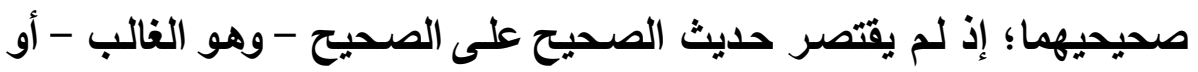

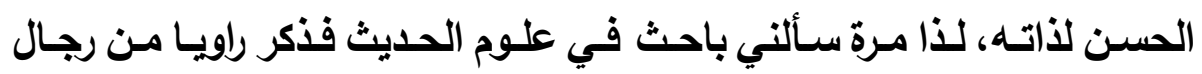

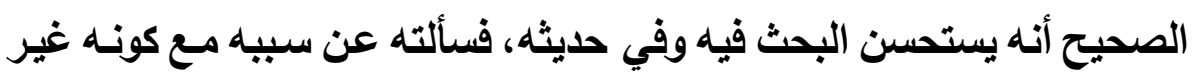

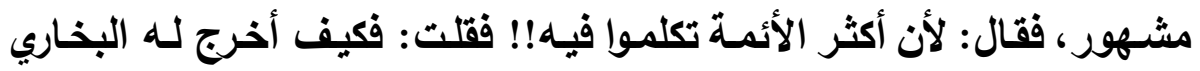
حديثه!! هل أحاديثه في الصحيح تفرد بها، وهل هذا التفرد نسبي أم مطلق!!

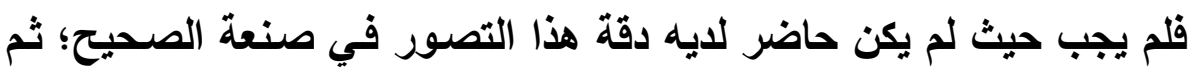

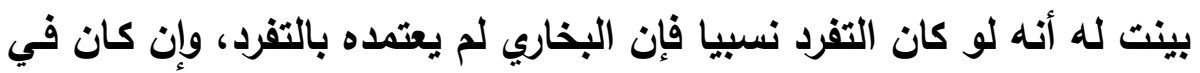

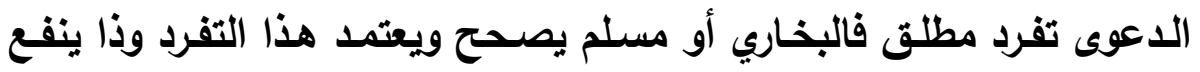

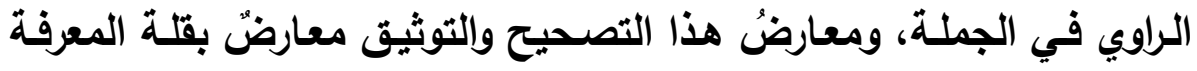

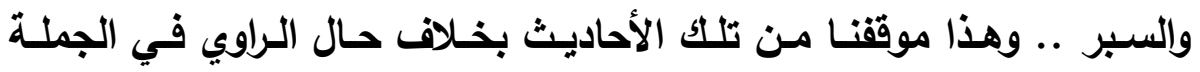

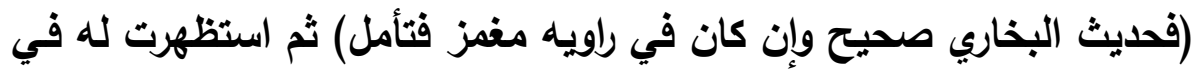

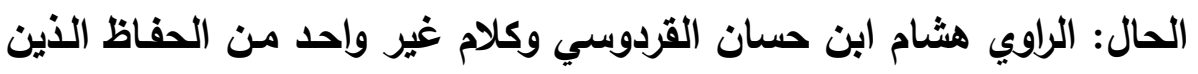

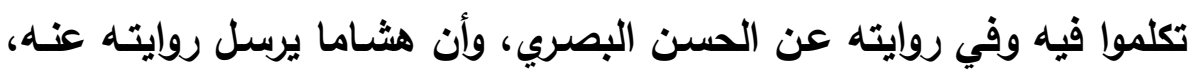

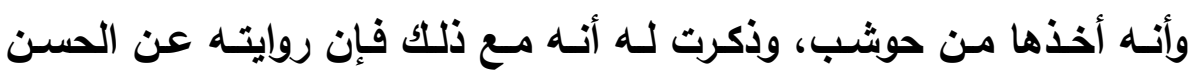

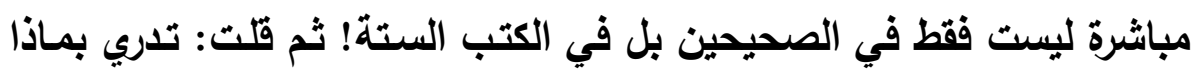

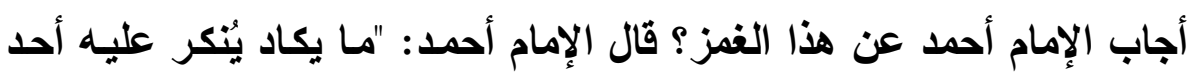

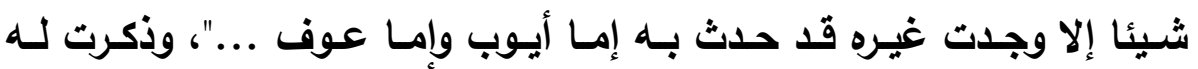
مجلة كلية أصول الدين والدعوة بأسيوط / العدد السابع والثلاثون 9 ـ ب م - الجزء الثالث 
إعجابي بهذا النص ويتعليق الحافظ ابن حجر عليهه بقولـه: "فهذا يؤيــ مـا

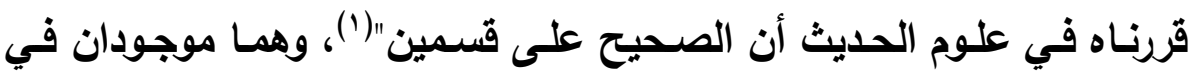
الصحيحين، وهذا يؤكد دقة البخاري ومسلم في السبر ودراسـة حال الراوي، فهذا حال الثقة هشام فكيف بمن هو قليل الرواية ممن يقال بجهالتهم! ألا يمكن لإمـام كالبخـاري أو مسلم معرفة تلك الروايـة وصـاحبها .. حقا مـا قال الحافظ ابن حجر في رد دعوى الجهالـة بأنها: "مندفعة عن جميع من أخرج لهم في الصحيح .. فمن زعم أن أحدا منهم مجهول = فكأنه نازع المصنف في دعواه: "أنه معروف"، ولا شك أن المدعي لمعرفته مقدم على من يدعي

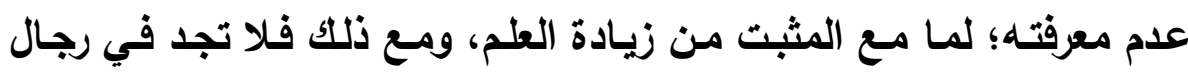

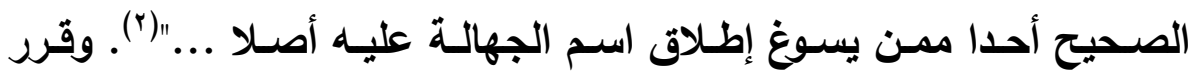
السخاوي نحوه بأن معرفة صساحبي الصحيح التي اقتضت روايـة عمن هذا حاله = كافيـة في توثيقه، وقرر أن جميعهم موثقون ولـم يتعرض أحد من أئمة الجرح والتعديل لأحد منهم بتجهيل، واستدرك بقوله: "تعم، جهل أبو حاتم محمد ابن الحكم المروزي الأحول أحد شيوخ البخاري في صحيحه، والمنفرد عنه بالرواية؛ لكونه لم يعرفه. ولكن نقول: معرفة البخاري به التي اقتضت لله

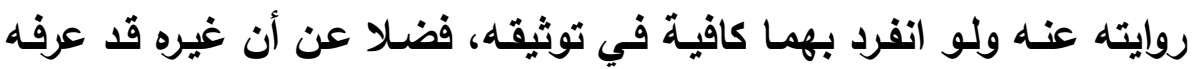

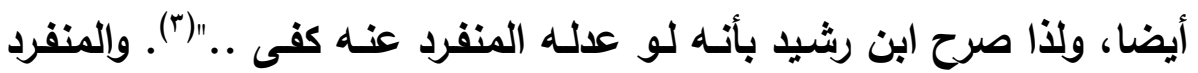
عنه هنا إمام مشترط الصحة في كتابه، وذكر السخاوي عدم تعرّض أحد من أئمة الجرح والتعديل لأحد من رواة الصحيح بتجهيل؛ لو حذّق مَن يروم طعنا

$$
\begin{aligned}
& \text { هاي الساري (ص ^ ؟ ؛ ). } \\
& \text { هاي الساري (ص ع ع ب). }
\end{aligned}
$$

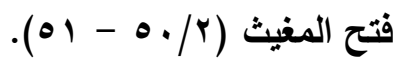


في الصحيح سيجده أبسط تركا له من نقد أحاديث الصحيحين، لكن أولئك جعلوا الأول وسيلة - أو تكملة - الطعن بحق البحث العلمي الخـارج عن فن فئ مساره؛ أما الأحاديث التي يذكرونها بالرد فعند خاصة العلماءع قد تم الدفاع عنها ورد وجوه النقد وقد سدد الله أقوالهم ووفقهم مثبتين صحة قواعد الأئمة السابقين في كتابة حديث رسول الله - سكئد - على قواعد متينة تقبلها العقول السليمة.

إنّ تفهم ذلك يغني عن البحث، حتى لو كان هذا الحديث قد حكم عليه أحمد أو غير بالنكارة - ومعناه التفرد -؛ فقد ظهرت صحة هذا التفرد بوجوده في الجامع الصحيح، وعلى التتزل أيضا فِإن إخراج البخاري ومسلم أو أحدهما لهذا الحديث مبعد لشبهة معنى النكارة - أو لمعارِض لها - كحديث "إنما الأعمال بالنيات"، فقد قال أحمد بن حنبل في راويه المتفرد بهذا الحديث، وهو "محمد بن إبراهيم التيمي" قال: "يروي أحاديث مناكير"، وقد اتفق على حديثه له بله البخاري ومسلم، وقال ابن حجر معلقا على كلام الإمـام أحمد: "قلت: المنكر أطلقه أحمد بن حنبل وجماعة على الحديث الفرد الذي لا متابع لله، فيحمل هذا على ذلك، وقد احتج بـه الجماعـة"(1)، فما يقول الباحث بعد هذا في حديث "إذا وقع الابباب ..." الأي أخرجه البخاري وقد تفرد به عتبة ابن مسلم ألا يستحق أن يكون راويه ثقة كما قال ابن حجر أو صدوقا على الأقل كما قال الأهبي(َ)؛ لأن إخراج البخاري لحديثه في الصحيح مـع تفرد عتبـة يعني

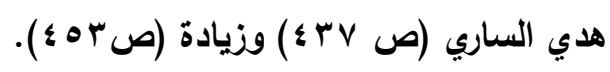

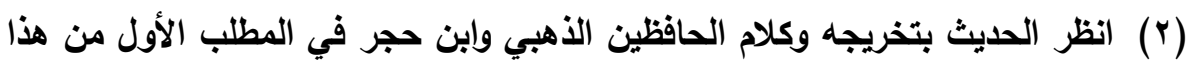

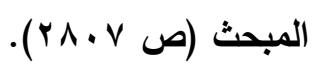


إزالة إيهام القائلين بوجود

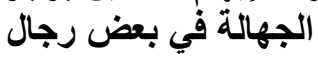

اعتماده وتوثيقه ولو لم نجد من وصفه بجرح ولا تعديل ..

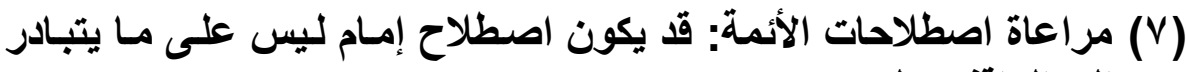
إلى الواقف عليه:

وققت على من يستفيد من إطلاق الأئمسة - كأحمد والبرديجي وجماعة الماهة

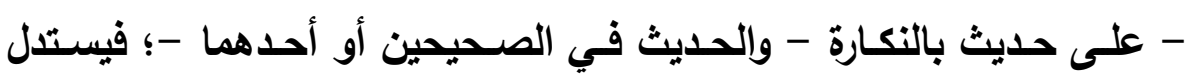
الطاعن على تضعيف هذا الحديث في الصحيحين - أو أحدهما - بإطلاق إمـام ممن ذكرتهم على هذا الحديث بالنكارة! ويخفى عليـه أن المـذكورين:

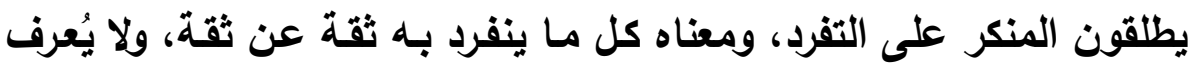
المتن من غير ذلك الطريق، وهذا ما ذكره غير واحد من الحفاظ كابن رجب

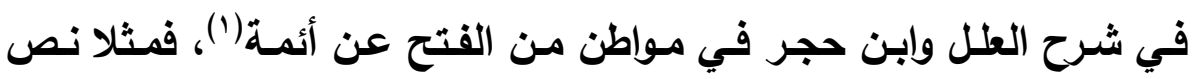
ابن حجر أن ذلك عُرف بالاستقراء عن أحمد(؟)، وهو نص كـلام البرديجي نقله عنه ابن رجب()، وعليه ليس كل حديث - أو راو - يقال فيه: منكر -

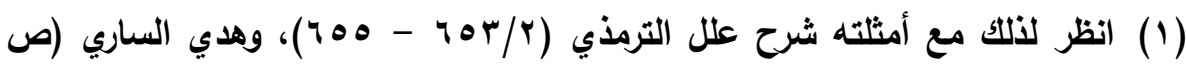

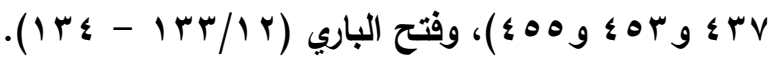

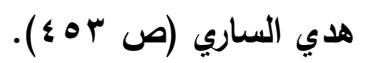

(r) قال بن رجب: "ذأكره أبو بكر البرديجي الحافظ، وكان من أعيان الحفاظ المبرزين في

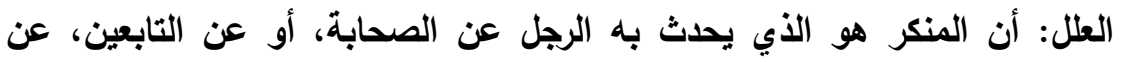

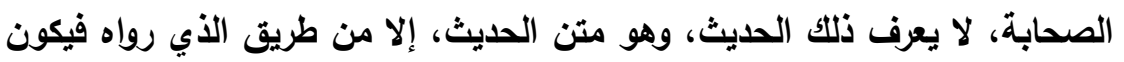

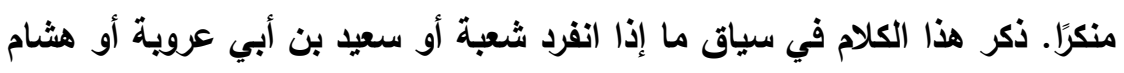

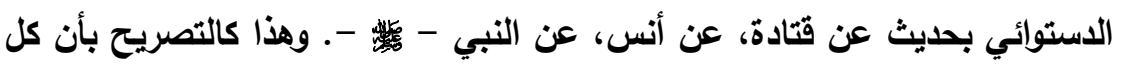

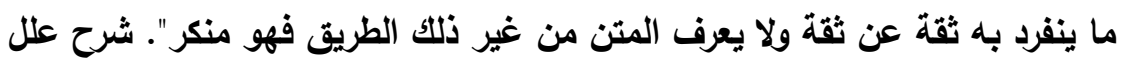

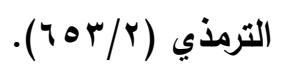


أو حديثه منكر على حديث موجود في الصحيح -؛ يعد مردودًا أو جرحا في راويه - كيف وراويه وحديثه في الصحيحين أو أحدهما - حتى يعلم اصطلاح

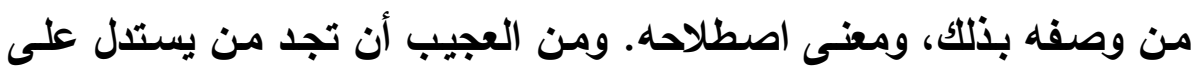

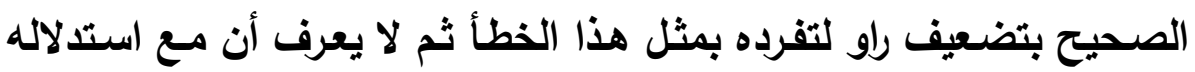

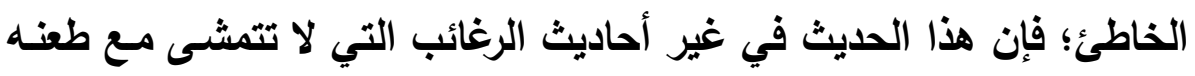
على رواة الصحيح، لذا وجب قراءة الآتي: (^) عدم انتفاع رواة بـالتوثيق الضـمني لتفردهم بحديثٍ وحديثهم هذا في الأني فضائل الأعمال:

التفريق بين أحاديث الحلال والحرام من غيرها في باب الروايـة وشرطها

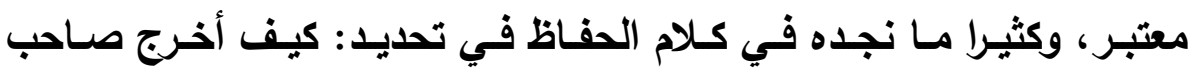

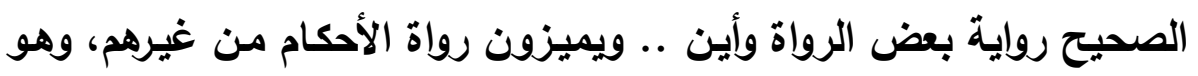

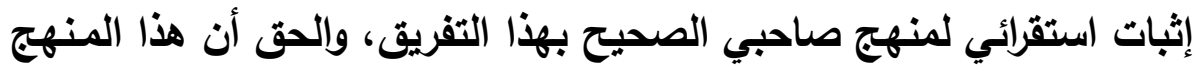

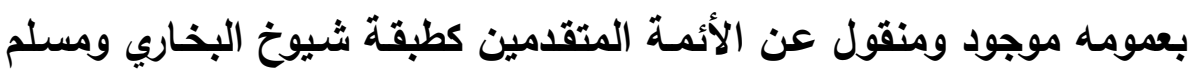

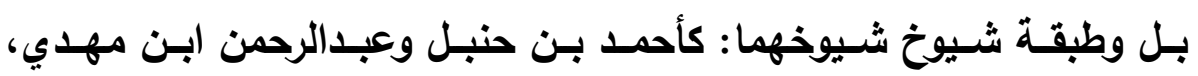

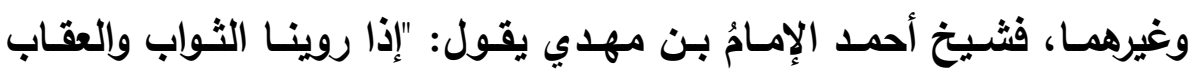

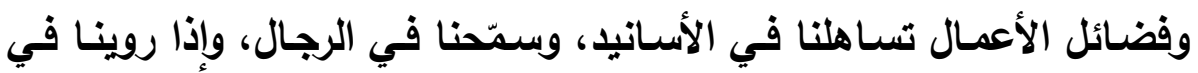

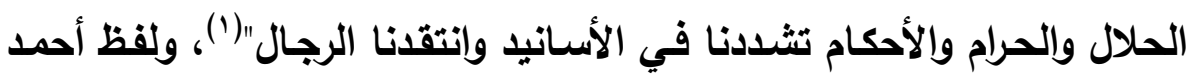

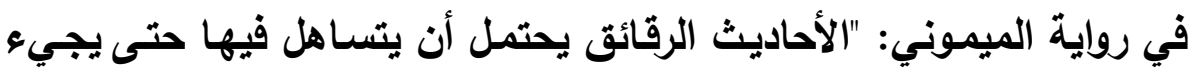

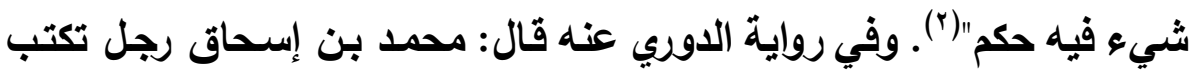

$$
\begin{aligned}
& \text { المدخل إلى كتاب: الإكليل (ص } 9 \text { ؟r). } \\
& \text { (الكفاية في علم الرواية (ص ع ع ا). }
\end{aligned}
$$


عنه هذه الأحاديث - يعنـي: المغـازي - ونحوهـا، وإذا جـاء الحـلال وإلحرام

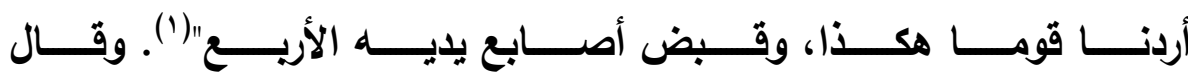

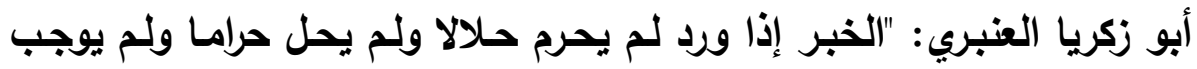

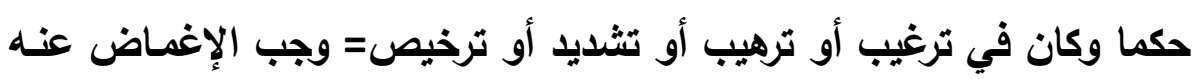

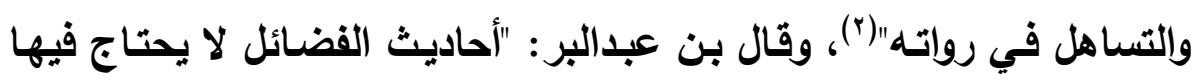
إلى من يحتج به "(").

وإلتنبيه هنا على مدلول هذه العبارات بأن لا يُحتجّ بها في إثبات الحديث

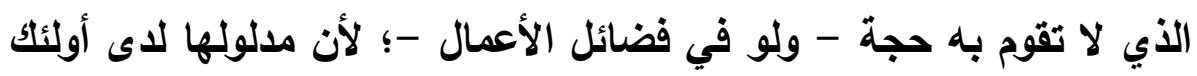

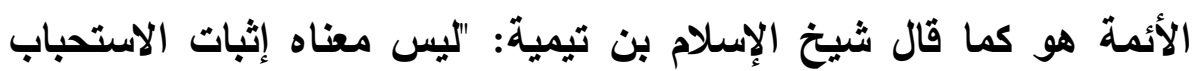

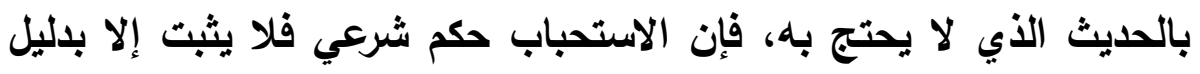

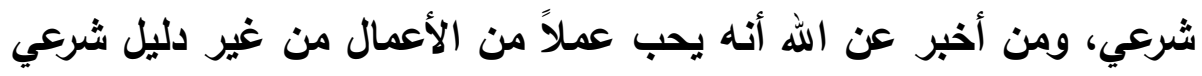

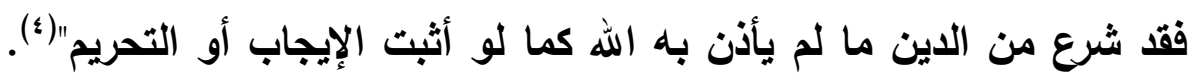

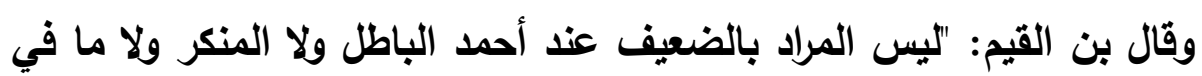

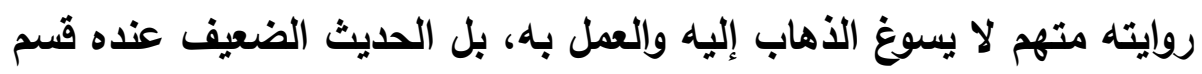
من الصحيح وقسم من أقسام الحسن ولم يكن يقسم الحديث إلى صحيح

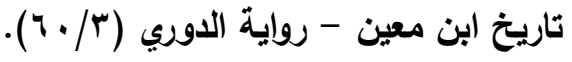

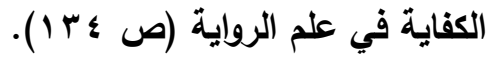

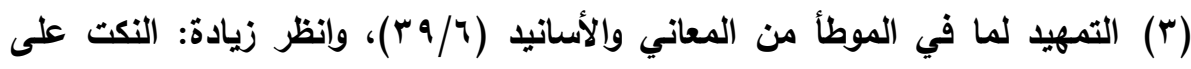

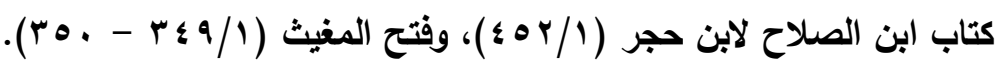

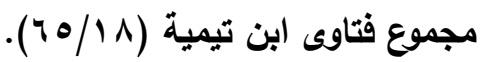


وحسن وضعيف بل إلى صحيح وضعيف، وللضعيف عنده مراتب"(1)، فالأمر يبقى على ما في قولُ ابن الصَّلاح: "ويجوزُ عند أهلِ الحديثِ وغيرِمم التساهلُ في الأسانيدِ، وروايةِ ما سوى الموضوع من أنواع الأحاديث الضعيفة من غير اهتمام بييان ضعفها فيما سوى صفات اللَّه وأحكام الشريعة من الحلال والحرام وغيرهما، وذلك كالمواعظٍ والقصص وفضائل الأعمال، وسائر فنون الترغيب والترهيب، وسائر مالا تعلُّقَ لله بالأحكام والعقائد"(؟). وهذا

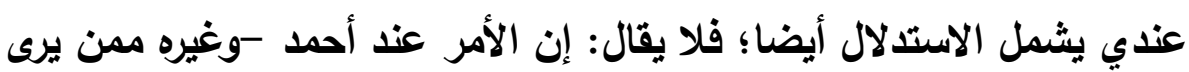
لأيه- يعني من كلامه السابث: الروايةَّ لا الاستدلال، لأنه قد نُقل عن أحمد وغيره تقيم الضعيف على القياس بما هو أوسع من حديث الترغيب ونحوه بشرط أن لا يكون منكرا ولا باطلا كما سيأتي في كلام ابن القيم؛ فأحاديث غير الأحكام أخف بالشرط السابق، وقال ابن القيم: "يؤخذ بالحديث المرسل والضعيف إذا لم يكن في الباب شئ يافعه، وهو الأي قدمه الإمام أحمد على القياس، وقال: وليس المراد بالضعيف عنده الباطل ولا المنكر ولا ما في روايته متهم بحيث لا يسوغ الأهاب إليه والعمل به.... فإذا لم يجد في الباب أثر يدفعه ولا قول صاحب ولا إجماع على خلافه كان العمل به عنده أولى من القياس، وليس أحد من الأئمة إلا وهو واققةه على هذا الأصل من حيث الجملة؛ فإنه ما منهم أحد إلا وقد قدم الحديث الضعيف على القياس"(َّ).

$$
\begin{aligned}
& \text { إعلام الموقعين (T/1/ (r). }
\end{aligned}
$$

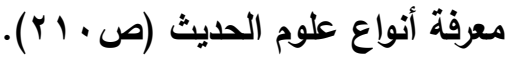

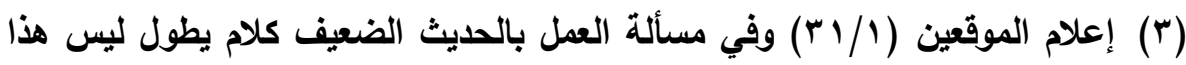

$$
\text { موضعه. }
$$


إزالة إيهام القائلين بوجود

الجهالة في بعض الفالين بوجال

والمستفاد من هذا أن ليس كل تفرد لراو - تُكلِّم فيه - يعني توثيقهـ لكون حديثه المتفرِدِ فيه في الصحيح حتى يكون حديثه هذا في غير الرقائق ونحوها، ومن أمثثة مَن يتوهم انتفاع رواة بـالتوثيث الضمني لتفردهم بحديثٍ وحديثهم هذا في فضائل الأعمال:

- محمد بن عبدالرحمن الطفـاوي من شيوخ أحمد بـن حنبل مـن رجـال

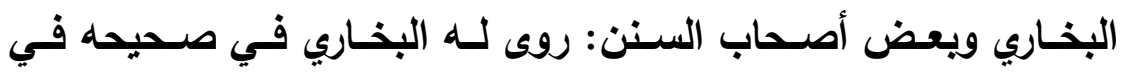
الرقائق: عن علي عنه: عن الأعمش، عن مجاهد عن بن عمر حديث:

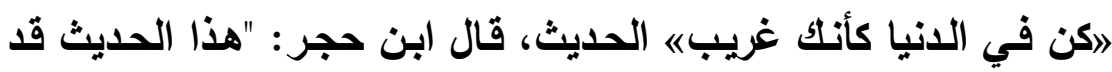
تفرد به الطفاوي، وهو من غرائب الصحيح؛ وكأن البخاري لـ يشدد فيه لكونه من أحاديث الترغيب والترهيب" (1). - محمد بن طلحة بن مصرف الكوفي شيخ لابن مهدي وطبقته، وهو من من رجال الجماعة: "له ثلاثة أحاديث في صحيح البخاري منها في الجهاد: عنه، عن أبيه، عن مصعب بن سعد، عن أبيه: في الانتصار بالضعفاء،

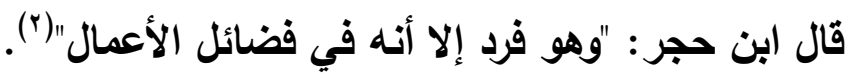

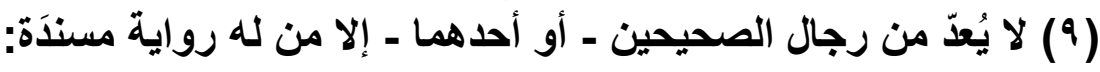

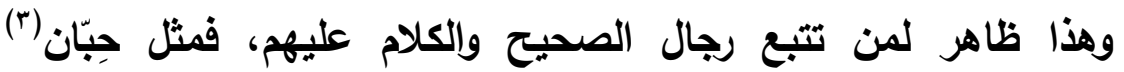
ابن عطية السلمي - من الثانية -، خ)؛. لم يذكره الحافظ ابن حجر بجرح

$$
\begin{aligned}
& \text { هدي الساري (ص أ؟ ؟). }
\end{aligned}
$$

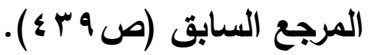

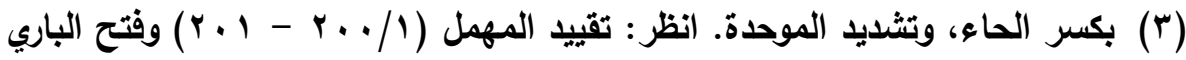

$$
\begin{aligned}
& \cdot(r \cdot \tau / 1 r) \\
& \text { تقريب التهذيب (ص } 9 \text { § 1). }
\end{aligned}
$$


إزالة إيهام القائلين بوجود

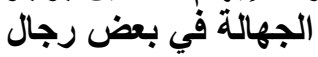

أو تعديل، وإنما قال: "لا أعرف له رواية، وإنما له ذكر في البخاري"(1)، قلت: هي في قصة صحيفة حاطب بن أبي بلتعة إلى المشركين (ّ). ونَوف بن فَضالة الحميري البِكالي، من الثانية. خ م "مستور"(")، قلت: ليست لله رواية، وإنما له له ذكر في الصحيحين في حديث سعيد بن جبير، عن ابن عباس، عن أبي بن كعب في حديث موسى والخضر (؛). ورزيق - بالتصغير - ابن حكيم الأيلي، ثقة، من السادسة(•) ويزيا بن أبى كبشة السكسكي الشامي الدمثقي. خُ من

تقريب التهذيب (ص 9 \ 1) وجاء ذكره في صحيح البخاري - باب: ما جاء في (1)

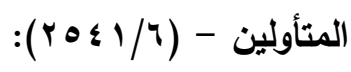

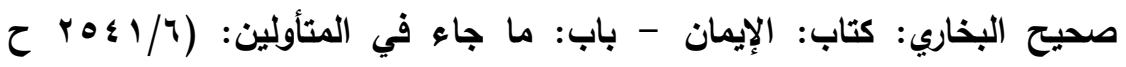

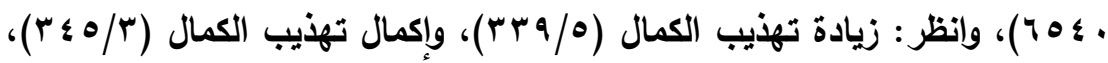

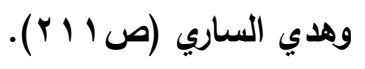

تقريب التهذيب (ص و هIV)، والبِكالي: بكسر الموحدة وتخفيف الكاف، وتمام كلام

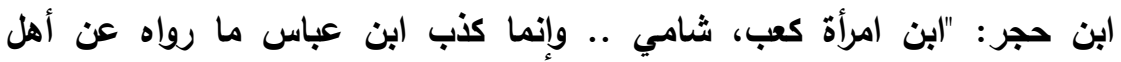

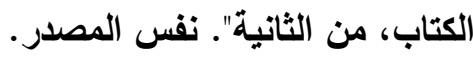

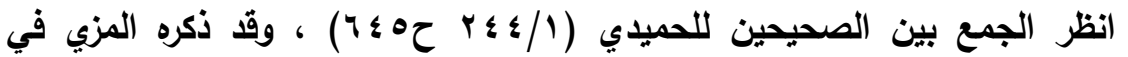

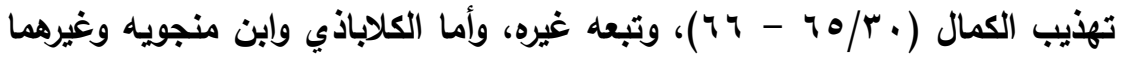
ممن يذكر رجال الصحيحين فلم يذكروه؛ لأنه ليست له له رواية.

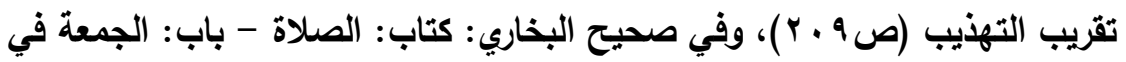

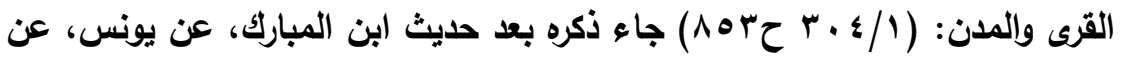

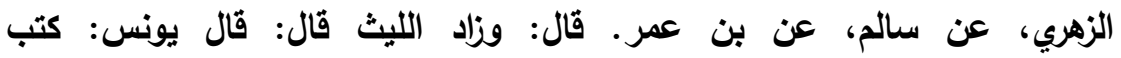

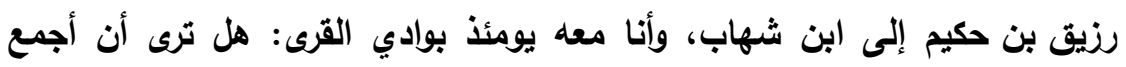

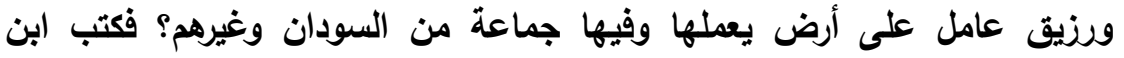

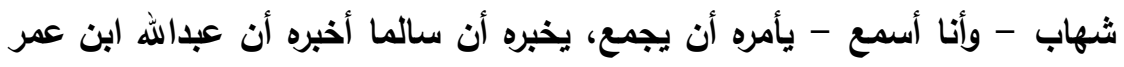

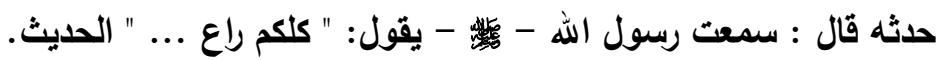
مجلة كلية أصول الدين واللدعوة بأسيوط / العدد السابع والثلاثون 9 أ بام - الجزء الثالث 
الثالثة، "مقبول"(1): له ذكر في كتاب "الجهاد" من "صحيح البخاري" في

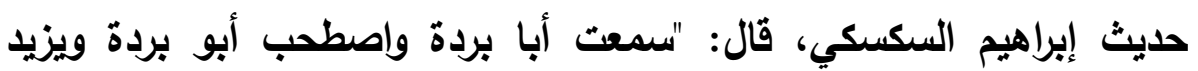

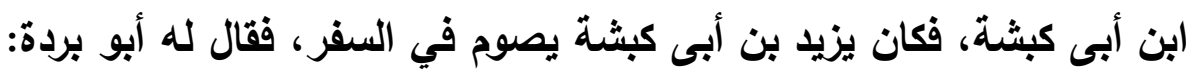

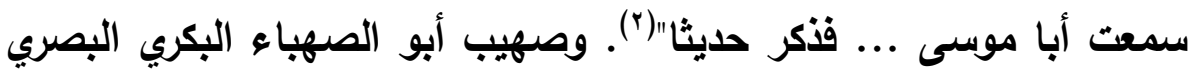

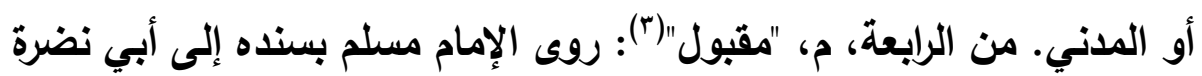

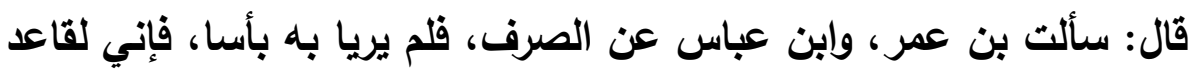

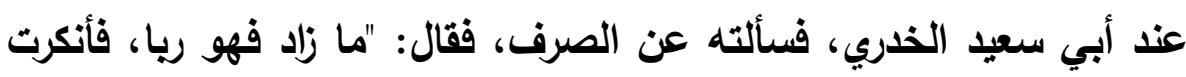

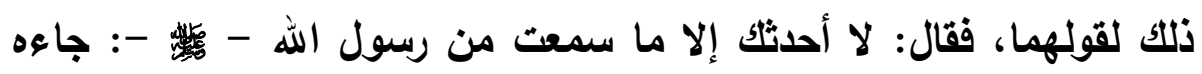

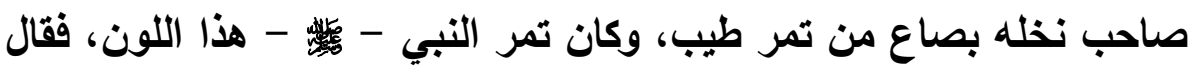

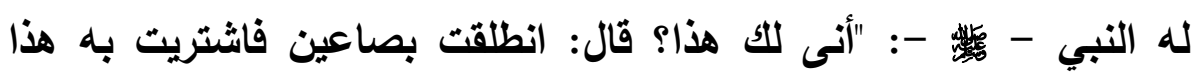

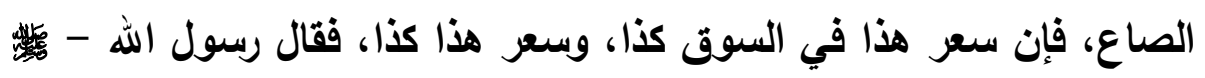

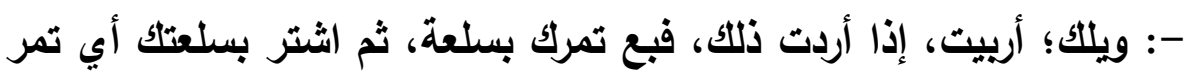

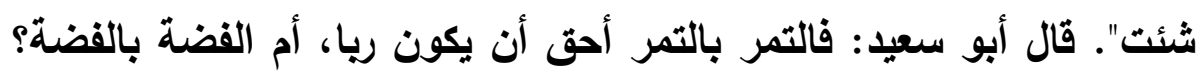

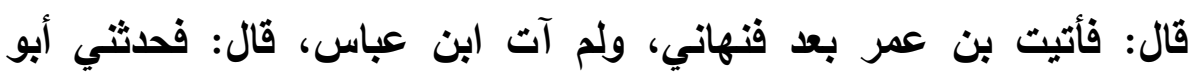

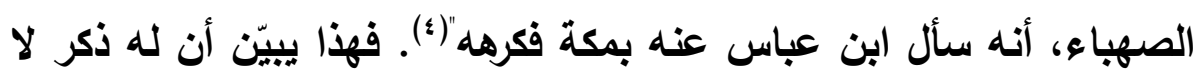

$$
\text { (1) تقريب التهذيب (ص ع • ؟). }
$$

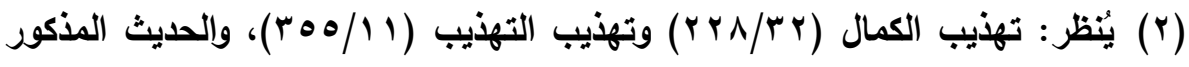

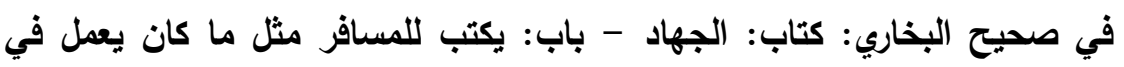

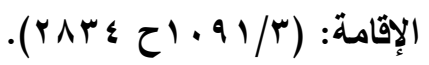

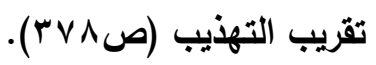

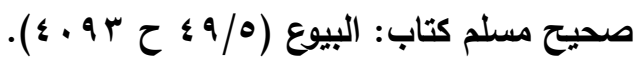


رواية، والمزي ذكره في الأسماء بأن مسلما ذكره في الحديث السابق(')، وفي

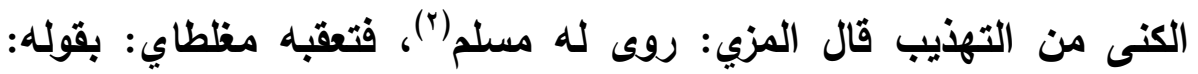

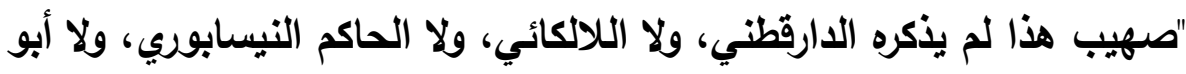

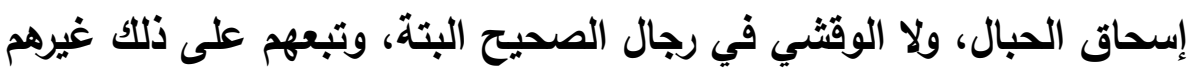

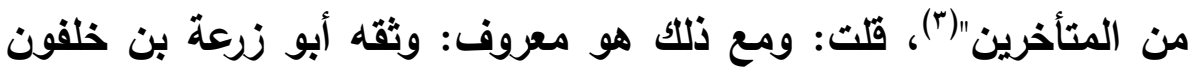

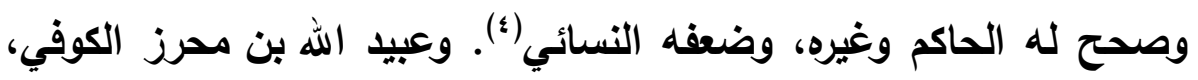

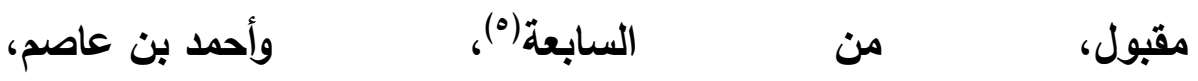

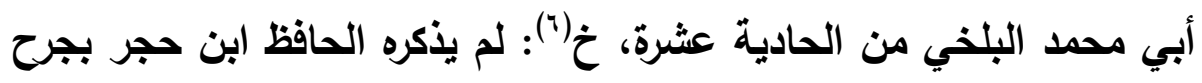

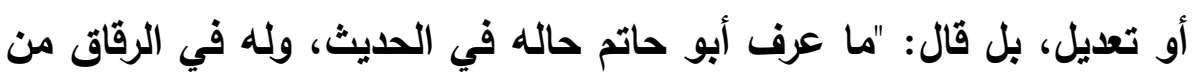

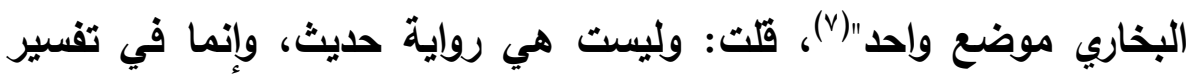

$$
\begin{aligned}
& \text { تهذيب الكمال (r/T }
\end{aligned}
$$

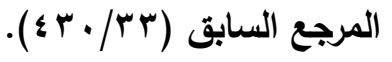

$$
\begin{aligned}
& \text { إكمال تهذيب الكمال (^/v). }
\end{aligned}
$$

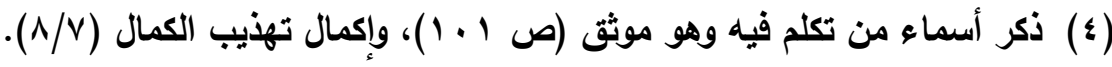

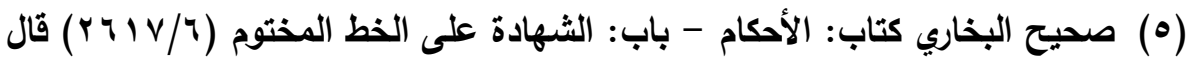

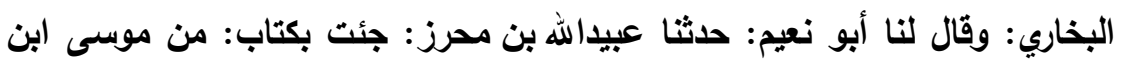

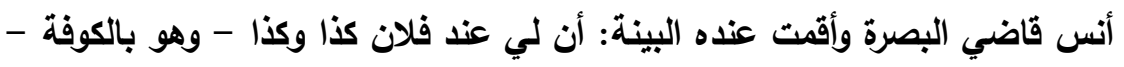
وجئت به القاسم بن عبدالرحمن فأجازه.

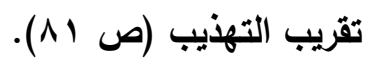

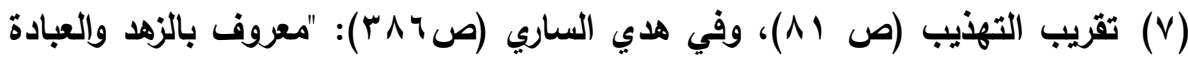

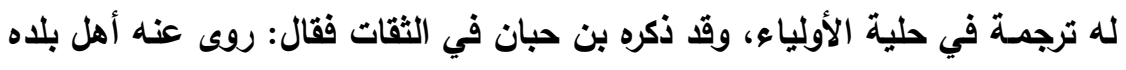
مجلة كلية أصول الدين والدعوة بأسيوط / العدد السابع والثلاثون 9 الـ بم - الجزء الثالث 
غريب الحديث"')، ومع ذلك هي في رواية المستملي وحده، أفاده بنفسه الحافظ في مقدمة القتح(؟)، فجميع هؤلاء أمثلة تذكر للتتبيه على أنهم ليسوا من رجال الصحيح رواية وإن وضع لهم رمز الصحيح، إنما يُّكر الراوي من هؤلاء في قصة أو نحوها في الصحيح، ولذا نجد المزي على عادته في تراجمهم لا يقول: "روى لله .." وإنما يقول: "له ذكر .."، ولذا لن أذكرهم في الاستدراك على الباحث في المطلب الثالث الآتي في "دعوى الإحصاء"(")، فلا يغتر الباحث مجيء مثل هولاء الرواة في كتب التراجم حتى لو وُضع له رمز (خ) أو (م) حتى يتحقق من وجود رواية له مسندة؛ لأن الرواية المسندة هي موضوع الصحيح وعنوانه، والباحث لريما وجد رمز (خ) أو (م) في التقريب مع وصفه بـ "مقبول" فظن أنه من الرواة، وليس كذلك، وقد وقع منه عدم

(1) جاء في آخر باب: رفع الأمانة من كتاب: الرقائق من صحيح البخاري (Y r r/0)

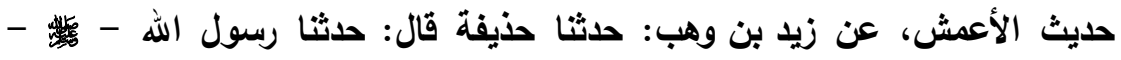

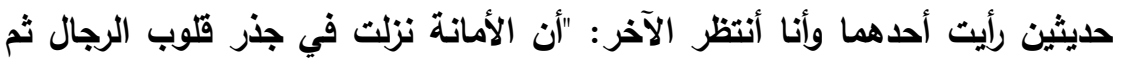

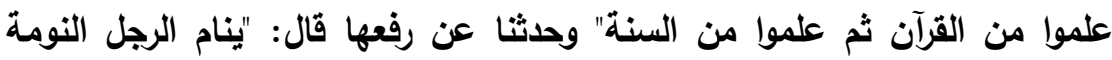

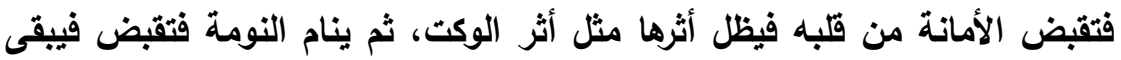

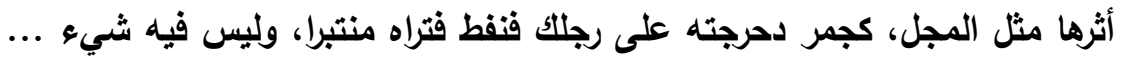
وذكر باقي الحديث. قال الفربري: قال أبو جعفر : حدثت أبا عبدالله فقال: سمعت أبراه أحمد بن عاصم يقول: سمعت أبا عبيد يقول: قال الأصمعي وأبو عمرو وغيرهما:

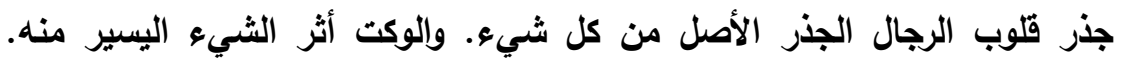

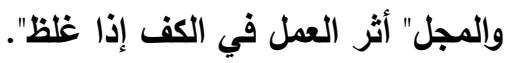

$$
\begin{aligned}
& \text { هلي الساري (ص זمیr). } \\
& \text {. ( r }
\end{aligned}
$$


التفات لهذه القاعدة في رافع المدني حين ذكره في أول تراجم بحثه، والأقرب أنه ليس راويا من رواة الإسناد، لكن الباحث استفاد من ذكره في التقريب بأنه مقبول وعليه رمز (خ) فذكره وأطال النفس فيه بما لا طائل تحته إلا الكدّ الضائع! ولألك جرى إلزامي الباحث بعدم دخوله في بحثه - مع أربعة رواة آخرين من رجال بحثه(')- كما سيأتي ذكره في المطلب الثاني من المبحث الثالث الآتي، وترجمة رافع عند الباحث جاء فيها خلط كثير وجب عليّ مناقثته بالتفصيل في المطلب المذكور (r).

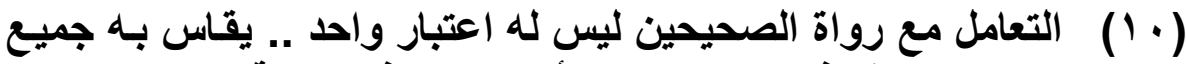
الرواة دون النظر في مقدار الإكثار أو الانتقاء في رواية لهاية الثيخين لهم: يخصص الحفاظ في شيوخ البخاري ومسلم تعاملا لا يكون مقياسـا واحدا لجميع الرواة، وياعث ذلك عندهما غايات الرواية في صناعة الصحيح، وهذا مطلب موجود عند غيرهما أيضا من أئمة الحديث - على تنوع مصنفاتهم -؛

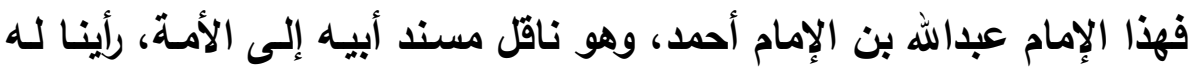
زيادات وضعها للتثميم بـل أبعد من ذلك أن يذكر في المسند بعض روايات أبيه التي ليست من المسند وينص أنه حدثه أبوه بها خارج المسند، وهذا في المسند الأي مقاصده وفوائده دون جامع البخاري ومسلم، ومن ذلك فشيوخ البخـاري هـم على طبقـات ومراتب تبعـا لمقاصـ معينـة مهمـة في الصـنعة الحديثية في التصنيف: قال ابن حجر في حديثه عن شيوخ البخاري في الصسحيح: "ينحصسرون في خمس طبقات: الطبقة الأولـى: مسن حدثـه عن

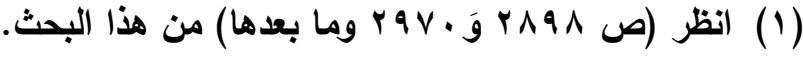

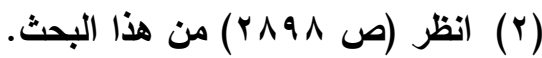


التابعين ... الطبقة الثاتية: من كان في عصر هؤلاء لكن لـ يسمع من ثقات التابعين كآدم بن أبي إياس ... الطبقة الثالثة: هي الوسطى من مشـايخه، وهم من لم يلق التابعين بل أخذ عن كبار تبع الأتباع كسليمان بن حرب .. وأحمد بن حنبل .. وهذه الطبقة قد شـاركه مسلم في الأخذ عنهم. الطبقة الرابعة: رفقاؤه في الطلب ومن سمع قبله قليلا كمحد ابن يحيى الأهلي وأبي حاتم الرازي ... وإنما يخرج عن هؤلاء مـا فاته عن مشايخه أو مـا لـ يجده عند غيرهم. الطبقة الخامسة: قوم في عداد طلبته في السن والإسناد سمع منهم للفائدة كعبدالله بن حماد الآملي وعبدالله ابن أبي العاص الخوارزمي وحسين بن محمد القباني وغيرهم، وقد روى عنهم أشياء يسيرة وعمل في الرواية عنهم بما روى عثمان بن أبي شيبة عن وكيع قال: لا يكون الرجل عالمـا حتى يحدث عمن هو فوقه وعمن هو مثله وعمن هو دونـه. وعن البخاري أنه قال: لا يكون المحدث كاملا حتى يكتب عمن هو فوقه وعمن هو مثثله وعمن هو دونـه"(1). فالباحث لم يكن لله تأمل في هذه القضية على الأقل في الطبقتين الأخيرتين حتى يتبين له الكم والكيف المعني به في هذه القاعدة وإلا لأفاد وأجاد بالسبر والتقسيم والتدقيق والتحليل لجماعة من المستورين هم من أبناء الطبقة الأخيرة على الأقل مما يستدعي مراعاة الانتقاء عندهما. (1) (1)

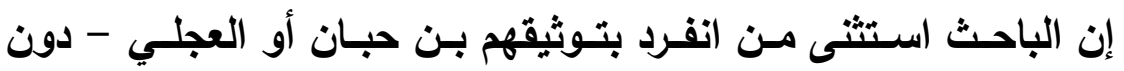
تفصيل - ؟!()، وعلى الرغم من أنه مقلا لواقع من يحترز من توثيق العجلي

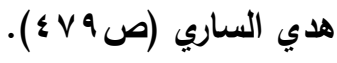

$$
\begin{aligned}
& \text { انظر بحثه (صه). }
\end{aligned}
$$


وابن حبان إلا أنه ليس على إطلاقه كما سيأتي، وقد وققت فيما يأكره الباحث من توثيق بن حبان في مبحثه الأول "مذاهب الأئمة في رواية المستور" وفي القول الثاني في قبول رواية المستور، ذكر الباحث نقولات في ذلك، ثم قال: "وشذ الحافظ ابن حبان عن جمهور أهل الحديث فاكتفى في الراوي بأن لا يُعرف فيـه جرح دون نص لعدالته ..."(1)، ثم استدل بكلامسه على مـا في مقدمة كتاب بن حبان في الثقات، ولم يزد على ذلك!! وأظن أن الباحث على علـم بكـلام العلامـة المعلمـي اليمساني وتفصـيله المسـبور المشـهور - في معرض رده على الكوثري - فيمن وثقهم بن حبان، وكلامه نفيس في ذلك؛ فإن لم يكن مقتعا لاى الباحث فما شأنه لا يحرره وهو في صلب بحثه! الذي توسع فيه نحو خمسين صفحة في مبحثه النظري الأول: "مذاهب الأئمسة في رواية المستور"!! وهذا كلام المعلمي أسوقه هنا للفائدة حيث قال: "التحقيق أن توثيقهـ (أي بـن حبـان) على درجـات، الأولـى: أن بصـرح بـه كأن يقول: 》كان متقنا《 أو 》مستقيم الحديث《 أو نحو ذلك. الثانية: أن يكون الرجل من شيوخه الأين جالسهم وخبرهم. الثالثة: أن يكون من المعروفين بكثرة الحديث بحيث يعلم أن بن حبان وقف لله على أحاديث كثيرة. الرابعة: أن يظهر من سياق كلامه أنه قد عرف ذاك الرجل معرفة جيدة. الخامسةة: مـا دون ذلك. فالأولى لا تقل عن توثيق غيره من الأئمـة بـل لعلها أثبت من توثيق كثير منهم، والثانيـة قريب منهـا، والثالثة مقبولـة، والرابعة صـالحة، والخامسـة لا يؤمن فيها الخلل. والله أعلم". وعلّق عليه العلامة الألباني في نفس الموضع

$$
\text { (1) (1) ( انظر بحثه (ص •r) }
$$


(حاثية): "هذا تفصيل دقيق، يدل على معرفة المؤلف - I - وتمكنه من

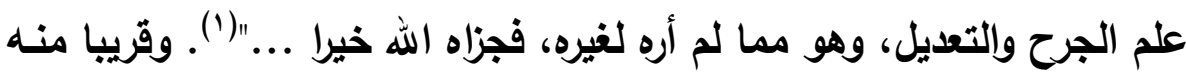

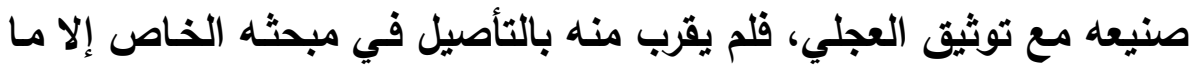

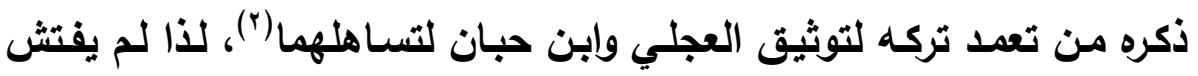

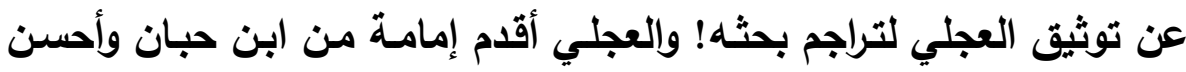

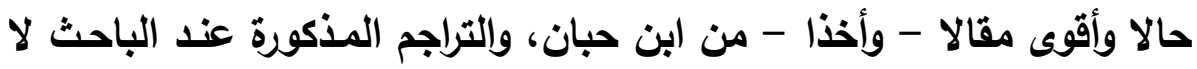
تخلو من توثيقهما في كثير منها. وهذه المسألة تلتقي مع التوثيق الضمني في بعض مض أفراده المذكورة فيه

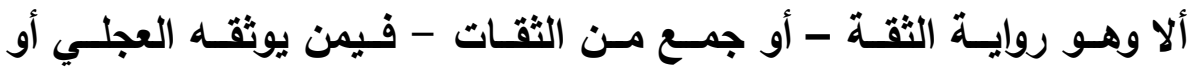

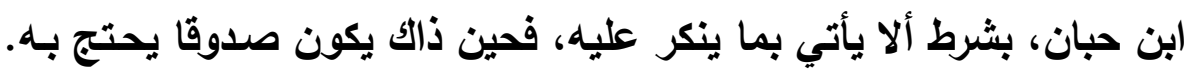

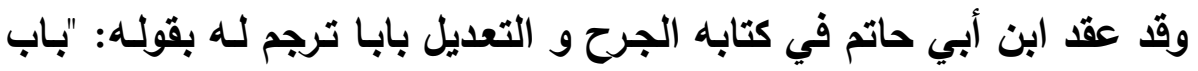

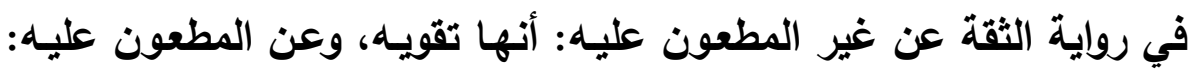

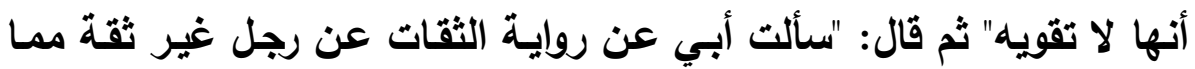

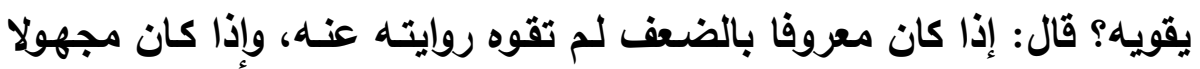

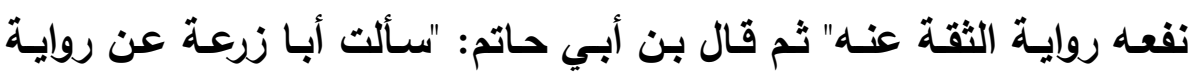
الثقات عن رجل مما يقوي حديثه؟ قال: إي لعمري! ..."(").

(1) التكيل بما في تأنيب الكوثري من الأباطيل (r/979) تعليق ا.

$$
\begin{aligned}
& \text { انظر نص كلامه في بحثه (ص ه). }
\end{aligned}
$$

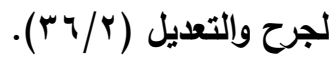


إزالة إيهام القائلين بوجود

الجهالة في بعض الفالين بوجال

وقال ابن القطان الفاسي في سعيد بن محمد بن جبير بن مطعم: "لا

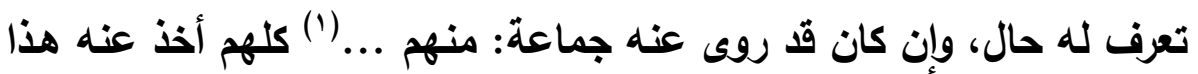
الحديث، ولا أعرف لله من العلم غيره، وإن كان معروف البيت والنسب، ولـه أخ اسمه عمر، وأخ ثان اسمه الحارث، يروي أيضا عن أبيه، وثالث اسمه جبير بـن محمد بـن جبير، يـروي أيضـا عن أبيـه ... فالحديث مسن أجله

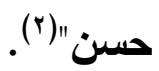

قال الذهبي: "الجمهور على أن مسن كـان مسن المشـايخ قـ روى عنه جماعة، ولم يأت بما ينكر عليه أن حديثه صحيح"("). قلث: فهذه النصوص المسبورة تفيد أن روايـة الثقة عن الرجل الذي لا يعرف بجرح وتعديل تتفعه، وشرط منفعته إذا لم يأت بحديث منكر، فكيف إذا انضـاف إلى ذلك توثيق ابن حبان أو العجلي، فإعمـال التوثيق أولـى مـن إهمالـه، وواقع الصـحيحين شـهد لـه - كمـا قررنـاه مـرارا -؛ فةـي الاعتــاء بشرطية نفي المنكر في حديثه أمر جلي في إخراجهم لمن لم يوصف بجرح أو تعديل - على حد تعبيز الباحث -؛ فمنزلة الراوي إنما تأتي من أحاديثه.. هذا ما يمكن ذكره في هذا الباب، وتتبع القواعد كثير ويقع فيها التداخل، لكن في هذه الجملة كفاية للبيب ومقتع للأريب. ولو تأمل من رام في البحث حول الصحيح بغير سلوك الجادة - لما يـور بين علمـاء الحديث - ويغير

(1) ذكر منهم ابن أبى ذئب المدني الإمام المعروف قرين مالك.

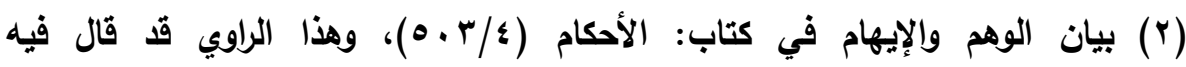

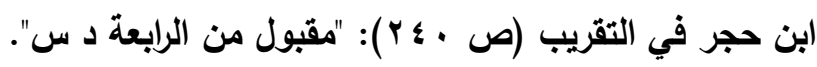

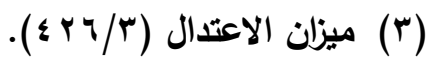
مجلة كلية أصول الدين والدعوة بأسيوط / العدد السابع والثثلاثون 9 اــم - الجزء الثالث 
الاصطبار = فقد طلب خطيرا خـاطر وإن تجاسـر بغـرة غـامر، فـالقعود عن الإقدام أولى من زلة الأقلام، فالصحيحان من عرى الإسلام .. تتبيه: ما تقدم من قواعد يتكامل فهمها الدقيق بأخذها جملة واحدة لا تنفك، وهذا ظاهر لمن قرأ هذا المطلب بتمعن؛ فمثلا يمكن أن نخلص من مجموعها أن من يروي لـه صاحب الصحيح في غير الأحكام ينتفع بـإخراج صاحب الصحيح له في حديثه خارج الصحيح إن لم يكن حديثه منكرا .. 


\section{المطاب الثالث}

\section{دعوى الإحصاء والجمع البه}

دعـوى الباحـث إحصـاء مسن لـم يُوصـف بجـرح ولا تعـديل مـن رجـال

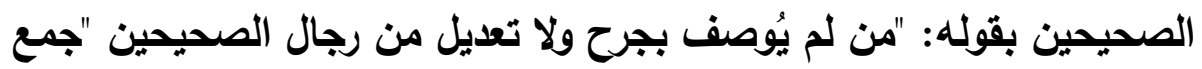

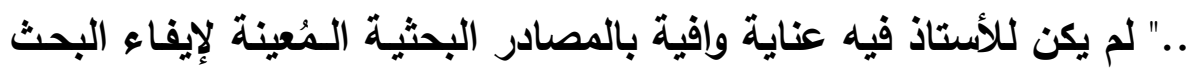

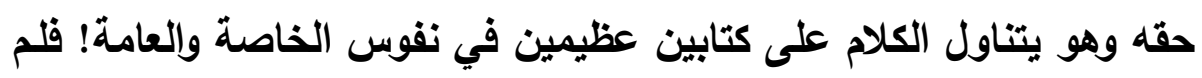

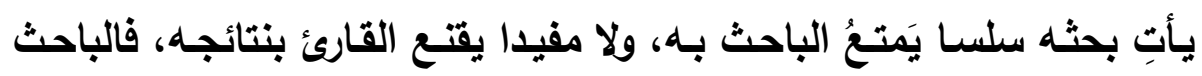

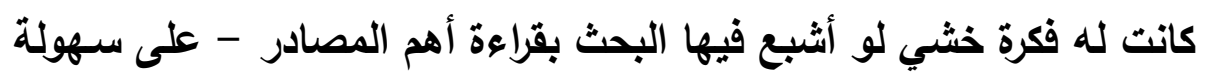

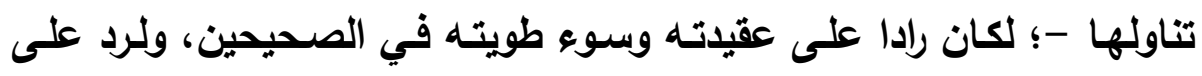

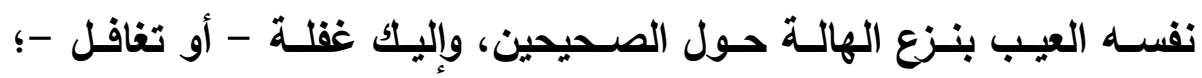

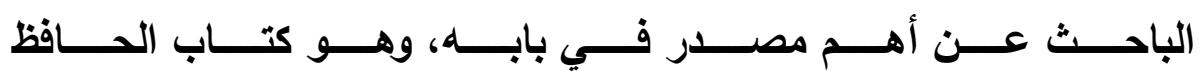

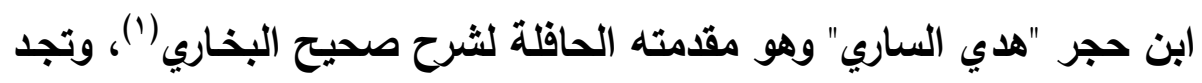
الباحث من أول كتابه لآخره يعتمد على كتب التراجم كتهذيب الكمال والتقريب

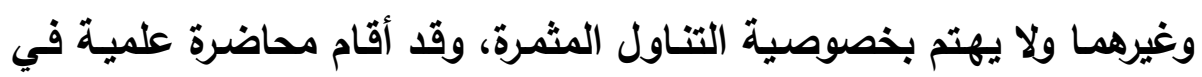

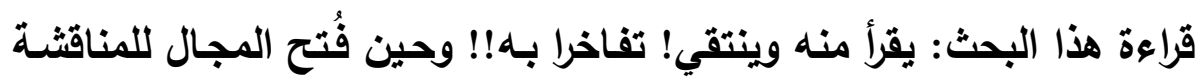

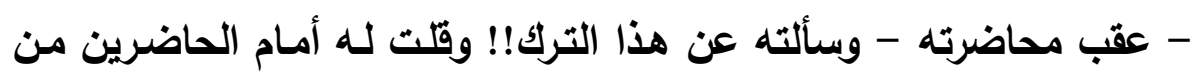

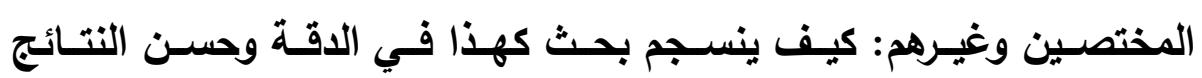

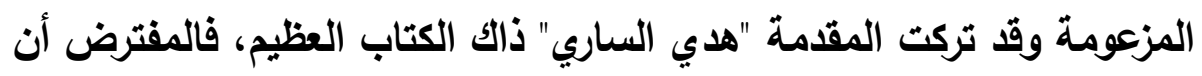

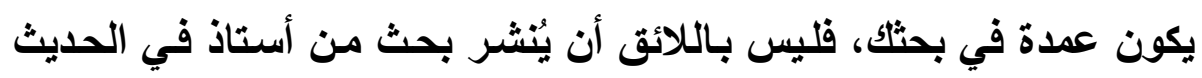

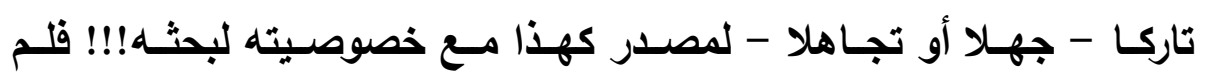

(1) مع كون "قتح الباري" من مصادر بحثه؛ لكنه ينتقي منه ما يريد!. 
يجبني!!. وإن تعجب فاعجب لما قاله في طيات محاضرته أن البخاري أخرج

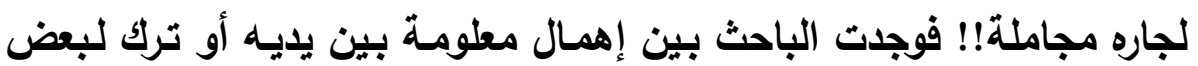

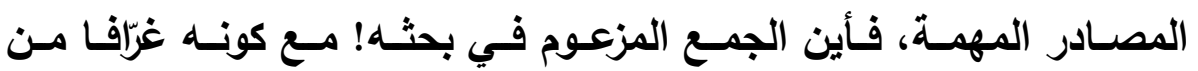

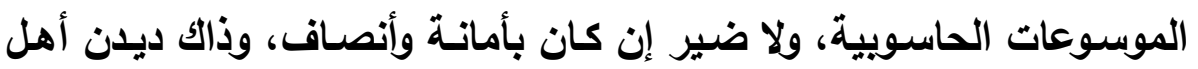

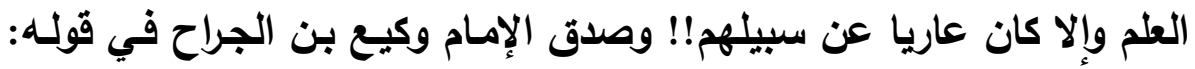

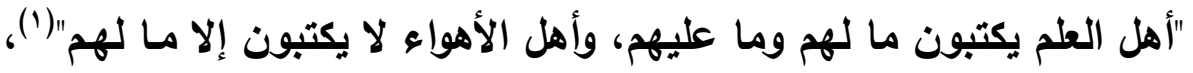

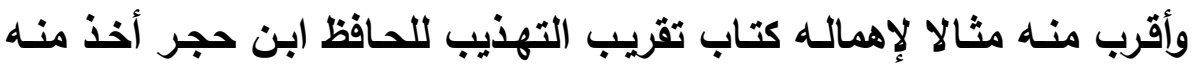

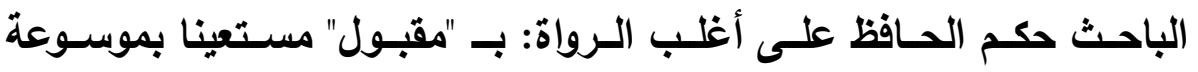

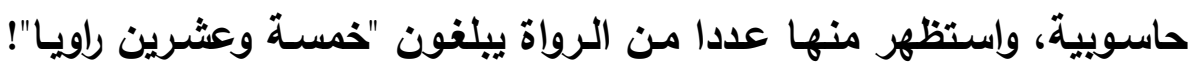

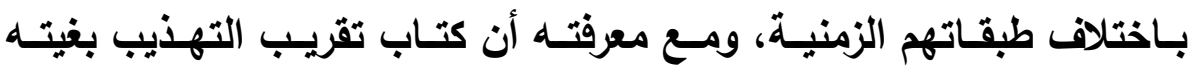

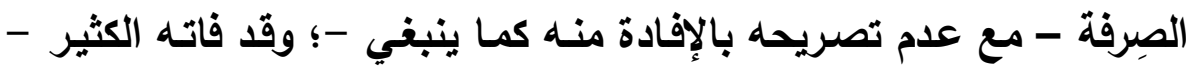

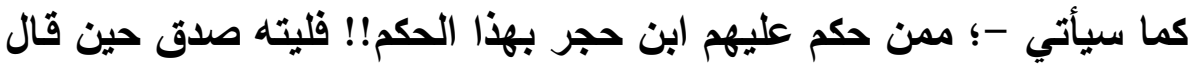

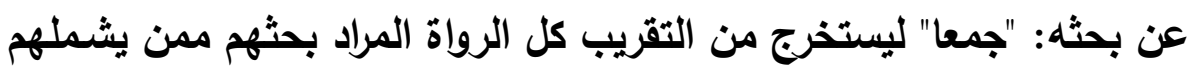

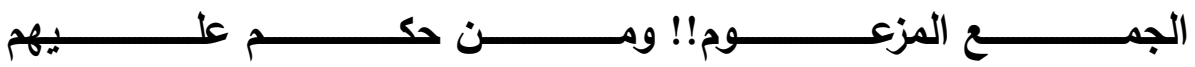
ابن حجر في التقريب بـ "مجهول" أو نحوه ممـا أهمله الباحث! ولا يثفع لـه وله

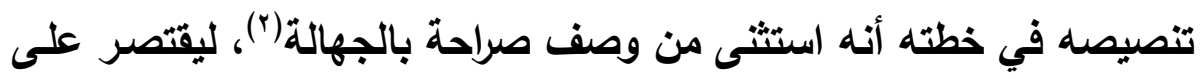

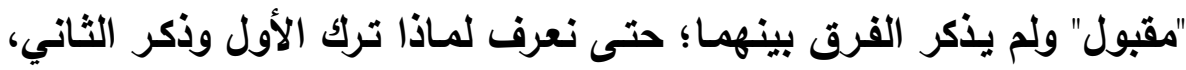

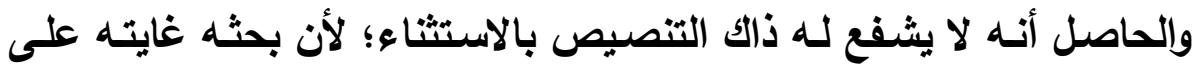

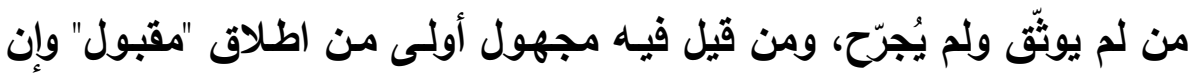

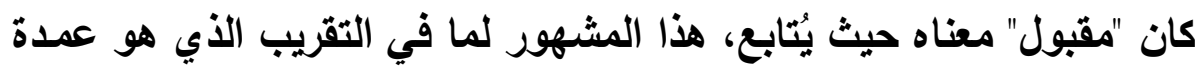

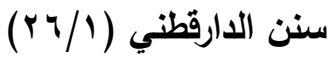

$$
\begin{aligned}
& \text { (ص •) في "منهج الباحث". }
\end{aligned}
$$


الباحث، وهو حكم المجهول أيضـا؛ لذا الباحث نفسـه لـم يفرّق بينهما في الحكم حيث جاء في عنوان بحثه في الغلاف: "تحقيق مذاهب الأئمة في حكم رواية المستور"، وكذا في مبحثه الأول من كتابه: حول مذاهب الأئمسة في

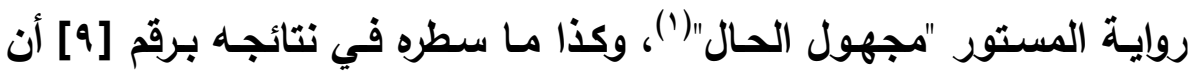

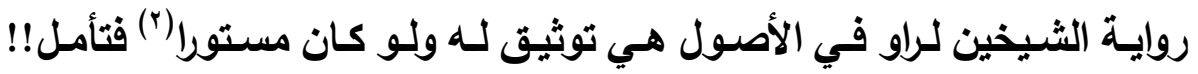

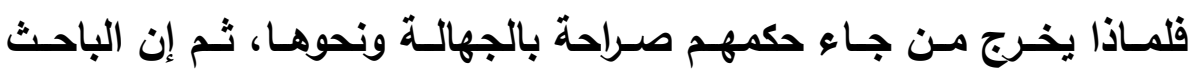

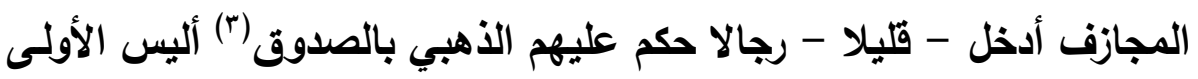
أن يذكر من قال فيهم الذهبي: "مجهول"!! وكذا يذكر - قليلا - من قال فيهم

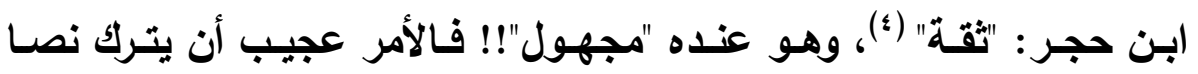
بمجهول - وهو أولى بمسار البحث - ويذهب لمن قيل فيه: صدوق أو ثقة عند من يعتبر قوله ويراعى حكمه ويهتم بسبره، فالباحث لا يرى هذه الأحكام - من الحافظين الذهبي وابن حجر ومن في طبقتهما - صوابا كما هو ظاهر

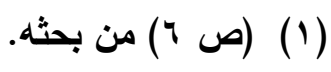

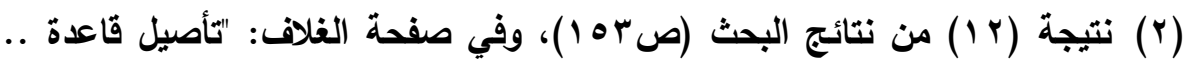
أن رواية الشيخين لراو في الأصول - وإن كان مستورا - تعتبر توثيقا لهه".

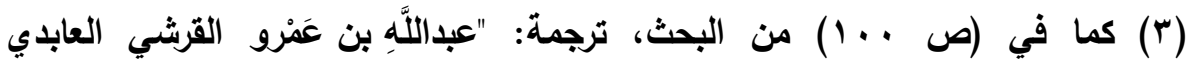

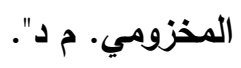

"من لم يوصف بجرح أو تعديل .." (ص 9 ـ 1 ) ترجمة: "محمد بن كعب بن مالك ابن

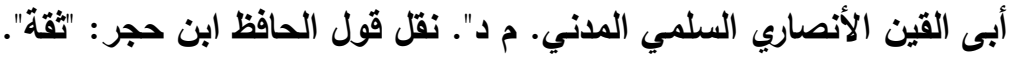
وفي (ص1 ا I ) من البحث ترجمة: "محمد بن جعفر السمناني القومسي، أبو جعفر

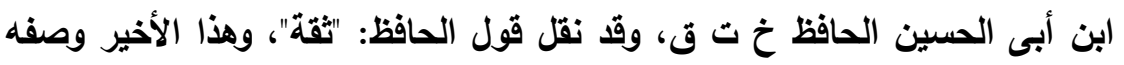
الباحث بـ "الحافظ"! ثم يعده لم يوصف فيه جرح ولا تعديل! مجلة كلية أصول الدين والدعوة بأسيوط / العدد السابع والثثلاثون 9 ا ـ بم - الجزء الثالث 
تصرفه!! مع أنهما يعتمدان قرينة التوثيق الضمني الذي نص عليه - على قصور في الفهم والتطبيق عنده(') - فلم أجده يحرر خلاف الحافظين الذهبي الضئي

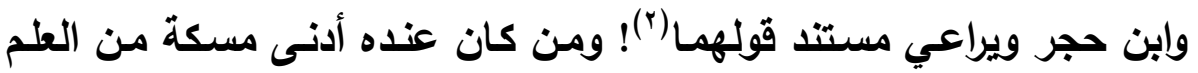

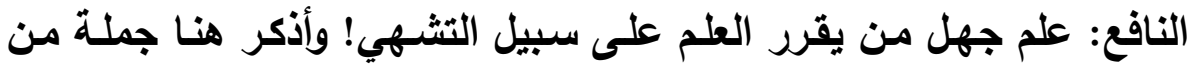

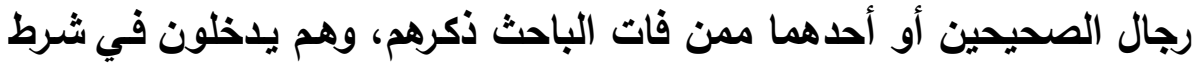

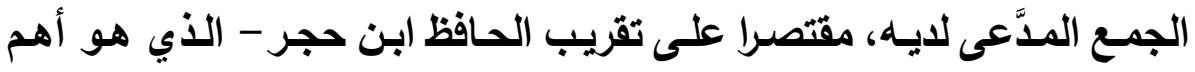

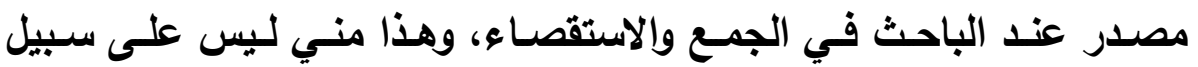

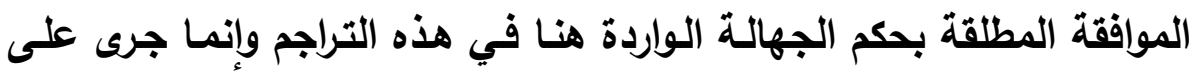

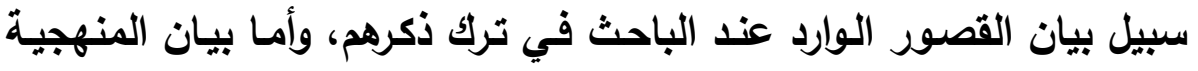

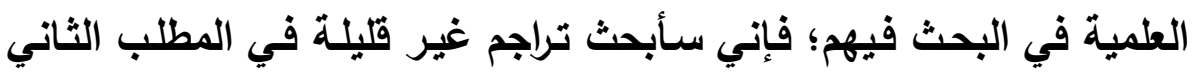

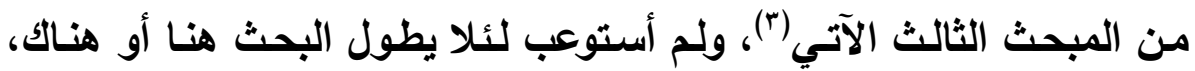
فالأمر يجرى على ضرب المثال الوافي بمنهجية.

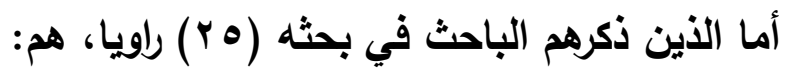

(1) انظر المطلب الثاني السابق في قاعدة التوثيق الضمني (ص r Y Y Y).

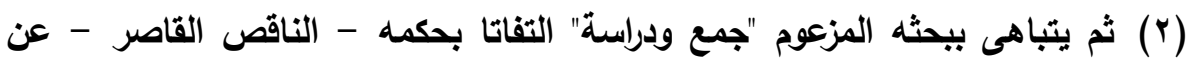

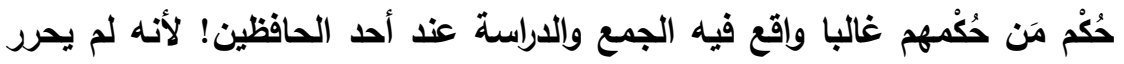
خلاف الحافظين حين يختلفان بإنصاف، فلا يلتفت إلى توثئ وليق أحدهما مع وجود بغيته - في التجهيل - عند الآخر، وليته ترك ذللك لما فيه سلامته في الدنيا والآخرة، وقد قيل: بونه

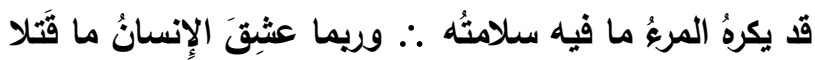

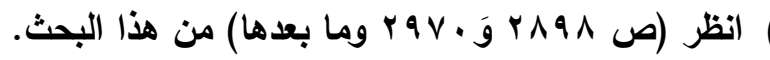
مجلة كلية أصول الدين والدعوة بأسيوط / العدد السابع والثلاثون 9 الـ بم - الجزء الثالث 
- - أحمد بن جعفر المعقري، أبو الحسن البزاز. م (').

r - بور -بضم أوله- بن أصرم أبو بكر المروزي مشهور بكنيته. خَ(r).

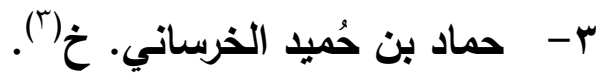

ع - رفاعة بن الهيثم بن الحكم أبو سعيد الواسطي. م(ع). ه - شجاع بن الوليد أبو الليث البخاري.خ('). צ- عبد الرحمن بن مطيع العدوي أبو عبدالله المدني. خ م) آ.

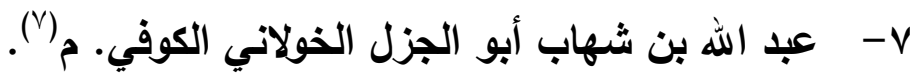
^- عبد الله بن هاتئ أبو الحسين العامري البصري. م)(^). 9- عبدالله بن عمرو المخزومي العابدي. م(9). • 1 - عبيد الله بن محمد بن يزيد بن خنيس المكي. م(").

(1) "من لم يوصف بجرح أو تعديل من رجال الصحيحين.." (ص V ( I I).

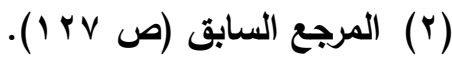

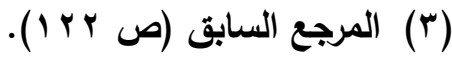

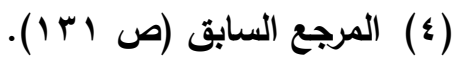

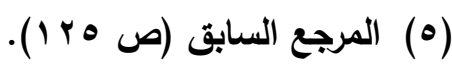

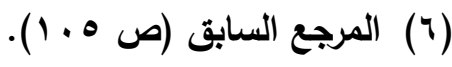
( المرجع السابق (ص ( V) (

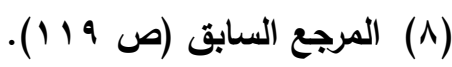

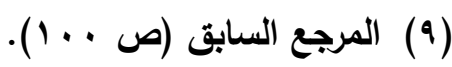

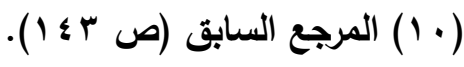


1 - عطاء أبو الحسن السوائي. خ'(').

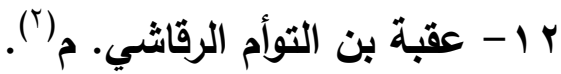

rا - علي بن الهيثم البغدادي. خَ").

ع ا - محمد بن بكار أبو عبد الله الصيرفي البصري. م(£).

ه - موسى بن قريش أبو عمران التميمي البخاري. م)(.

7 - 17 نبهان القرشي، أبو صالح المدني. خآ).

IV

^ا - يحيى بن محمد بن معاوية أبو زكريا المروزي، نزيل بخارى. م(^).

9 ا 1 أبو عبيدة بن عبد الله بن زمعة الأسدي القرشي. م)(9.).

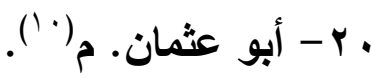

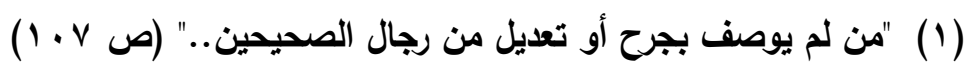

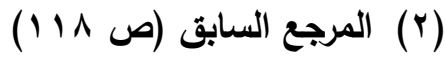

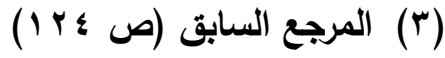

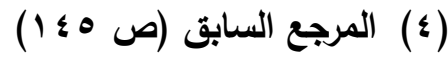

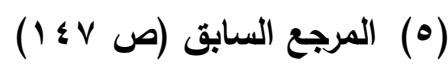

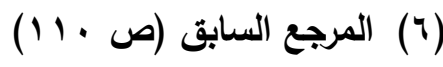

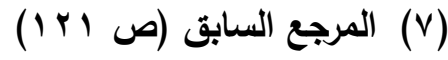

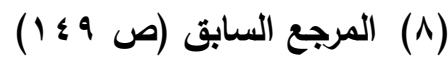

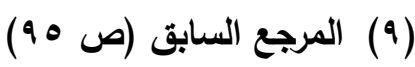

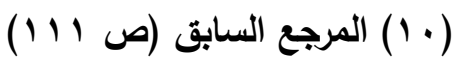


إزالة إيهام القائلين بوجود

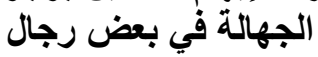

فهوّلاء عشرون لاويا، والخمسة الباقية لا ينبغي للباحث أن يكونوا من

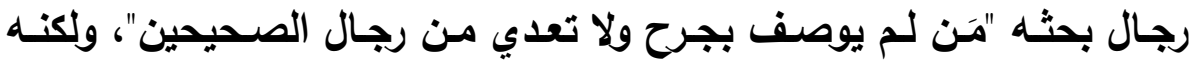

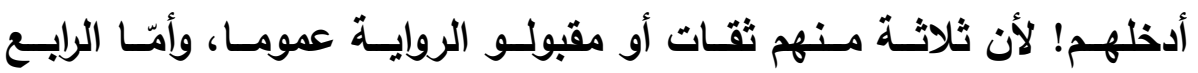

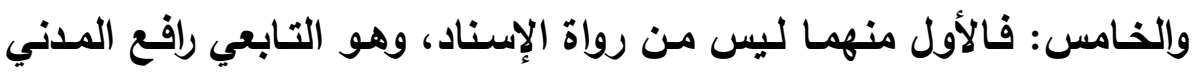

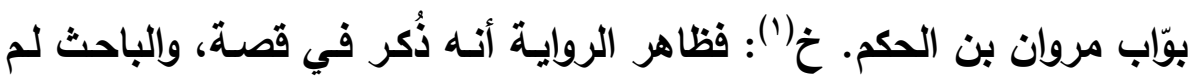

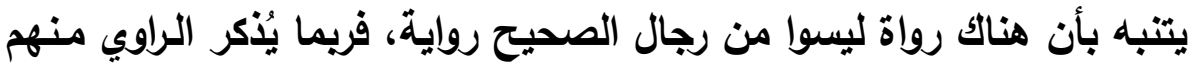

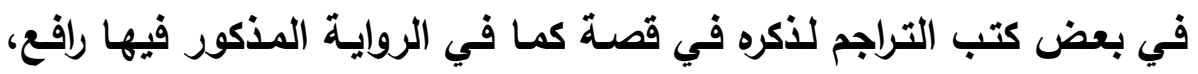

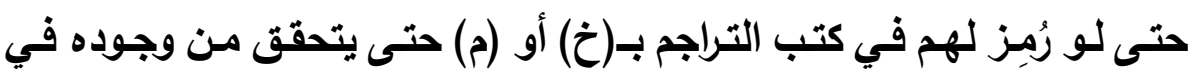

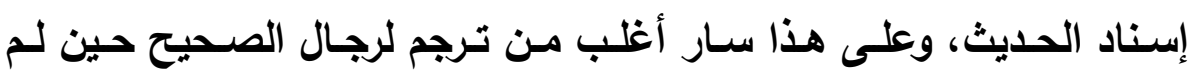

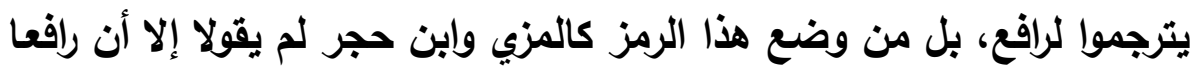

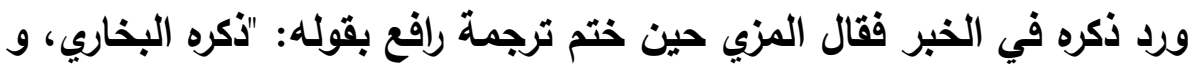

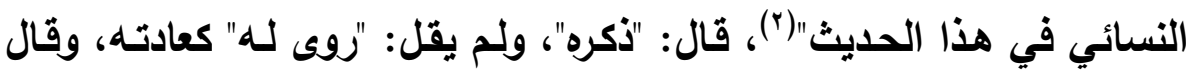

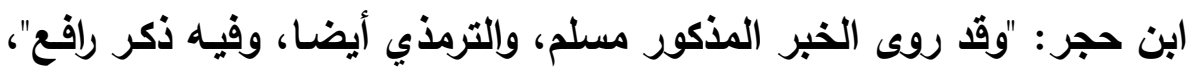

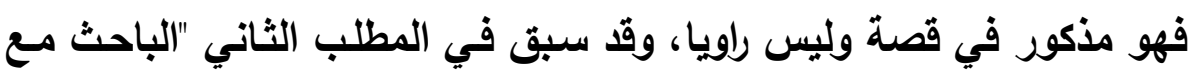

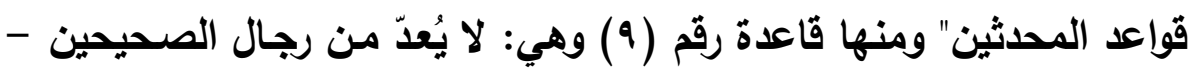

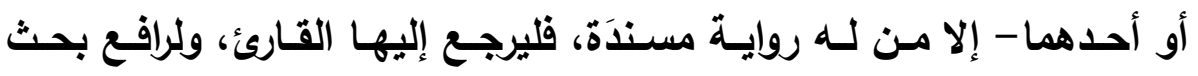
مفصّل مع بقية رواة في المطلب الثاني في المبحث الثالث الآتي، وقد أفردناه ولثاه

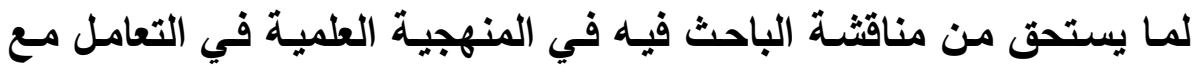

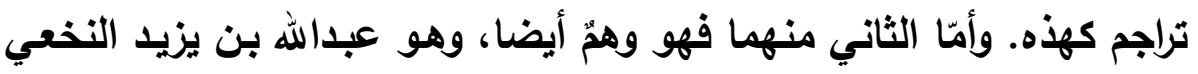

سيأتي البحث فيه مفصلا في المطلب الثاني في المبحث الثالث.

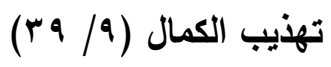


إزالة إيهام القائلين بوجود

الجهالة في بعض الفالين بوجال

الكوفي. م (1)، وصوابه سلم بن عبدالرحمن النخعي الكوفي وهو ثقة، وسيأتي في نفس المطلب تفصيله.

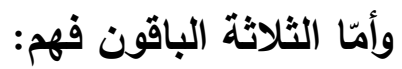
1- التابعي الجليل محمد بن كعب بن مالك بن أبى القين الأنصاري السلمي

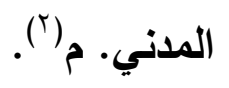

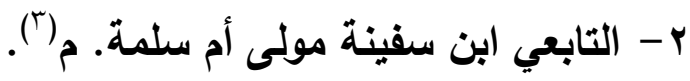

r- شيخ البخاري: محمد بن جعفر السِمناني خَ(أ).

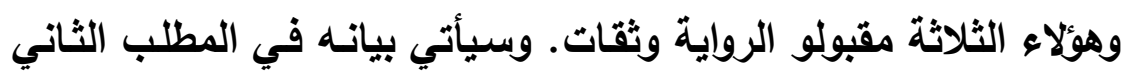

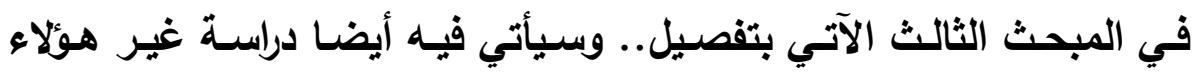
الخمسة؛ غير أنني أنبه على خطأ الباحث في ذكرهم في بحثئه، وأردتهم هنا

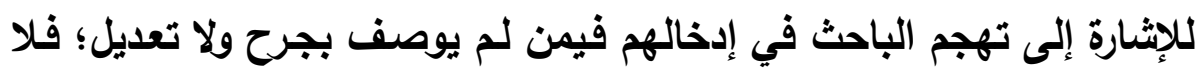
عتب على التجهم.

ثم إن الباحث يأكر في بحثه من لم يوصف بجرح أو تعديل ولو وثقهم

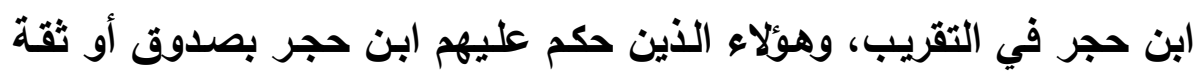

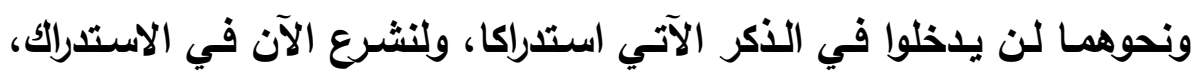

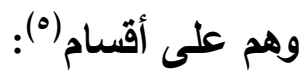

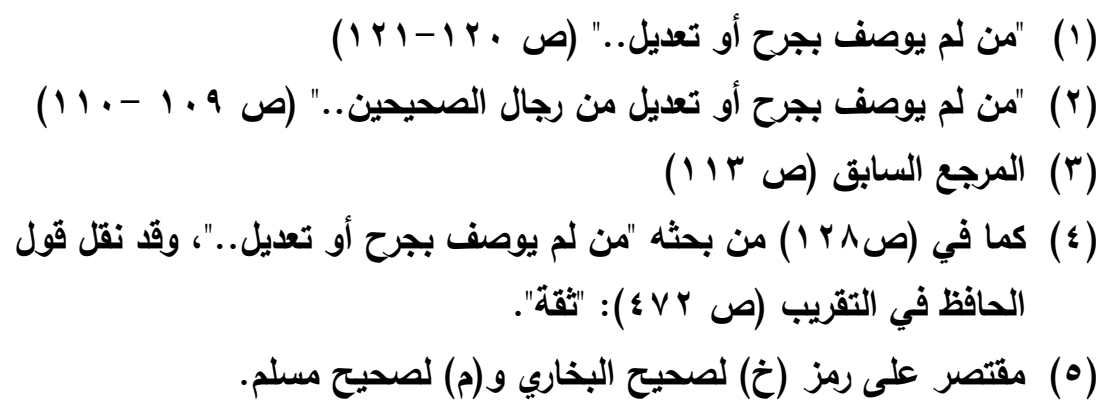
مجلة كلية أصول اللين والدعوة بأسيوط / العدد السابع والثلاثون 9 ا بام - الجزء الثاثث 
إزالة إيهام القائلين بوجود

الجهالة في بعض الفالين بوجال

القسـم الأول: مـن صـرّح الحـافظ ابـن حجـر قولـه فيهم: "مجهـول" أو

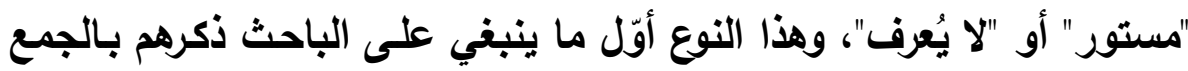
والبحث، ولكنه لم يأكرهم، ولم يبحث فيهم! نعم قد استثى الباحث في منهجه

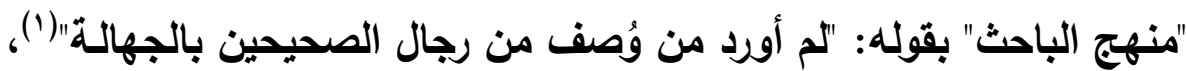
وهذا مخالف لصنيعه في صلب البحث حيث أورد تصريح بعض الأئمسة متقدمين ومتأخرين - بجهالتهم (ץ)، ثم هذا الاستثناء من لا يتمشسى مـع أول نقاط عنوإنه "منهج الباحث" بقوله: "أوردت من لـ يوصف بتوثيق أو تجريح

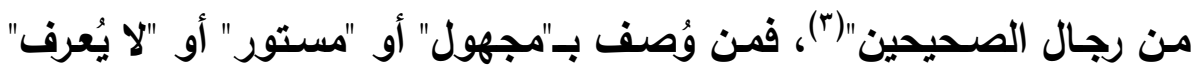
ياخل فيه ولا يجعله في تناقض مع عبارته اللاحقة في منهجهـ: "لم أورد من وُصف من رجال الصحيحين بالجهالة"! ومِن هذا القسم ممن تركهم الباحث:

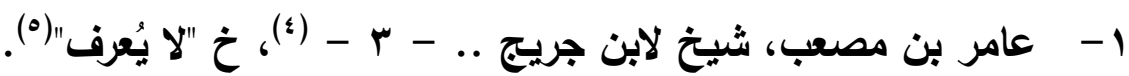

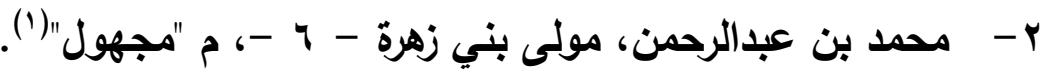

$$
\text { مَن لم يوصف بجرح ولا تعديل (ص ه). }
$$

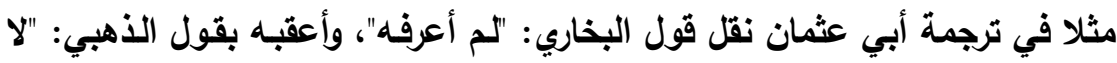

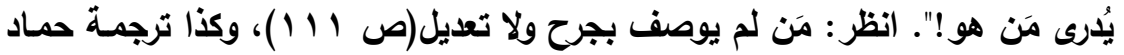
بن حُميد الخراساني، نقل الباحث فيه قول ابن عدي: "لا يُعرف"، وقول الذهبي: "لا

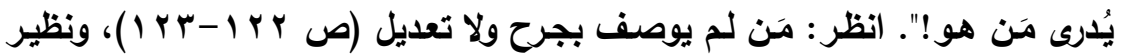

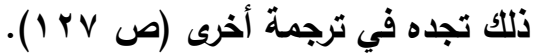

$$
\begin{aligned}
& \text { مَن لم يوصف بجرح ولا تعديل (ص ه ه). } \\
& \text { هذا رمز لرقم الطبقة. }
\end{aligned}
$$

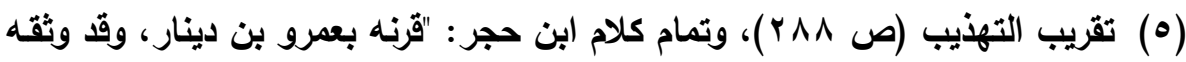

ابن حبان على عادته". 
إزالة إيهام القائلين بوجود

الجهالة في بعض الفالين بوجال

r- ن - نافع مولى عامر بن سعد بن أبى وقاص - r - م "مستور" (ץ).

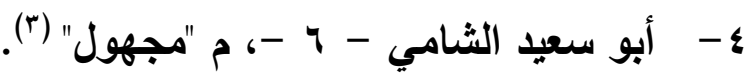
القسم الثاني: مَن لم يذكرهم الحافظ ابن حجر بجرح أو تعديل، ولا قال فيهم: "مقبول"، والباحث يُدخل في بحثه قليلا من هذا القسم ومنهم -في بحثه- كبار التابعين ومَن اختُفف في صحبتهم، وتوثيق هؤلاء هو الظاهر حتى وإن لم يُّكَر فيهم جرح ولا تعديل، وإنما جرى الاستدراك عليه هنـا بذكر كبار التابعين ومن اختلف في صحبتهم بناء وهمه المعتمد على عدم ذكر ابن

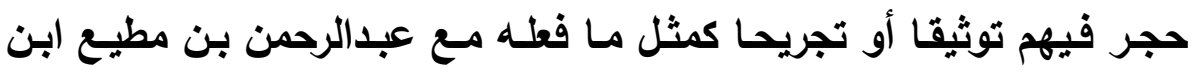
الأسـود القرشـي العـدوي أبسي عبــ الله المـدني، فقــ ذكـره، وهـو مـن كبـار

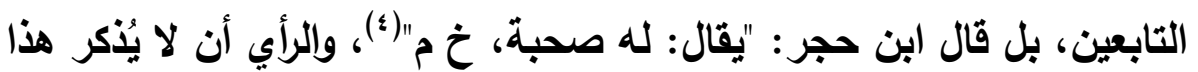

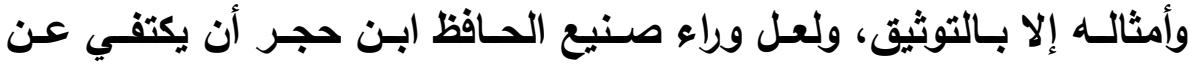
توثيقهم صراحة بكونهم مختلف في صحبتهم، فمَن تركهم الباحث في هذا القسم:

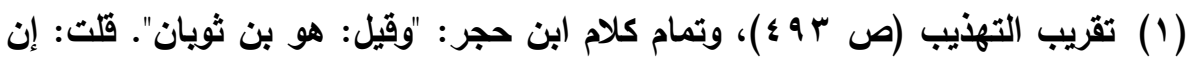

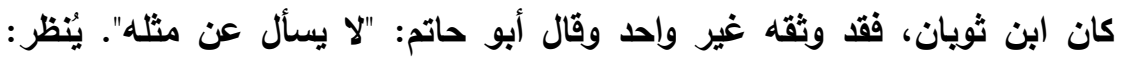

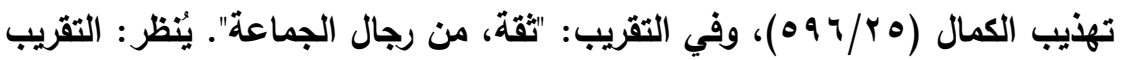

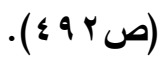

$$
\begin{aligned}
& \text { تقريب التهذيب (ص } 9 \text { (صهـ). }
\end{aligned}
$$

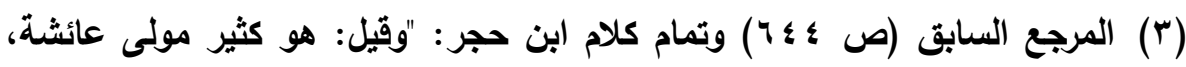
وقيل: عمرو بن سعيد الثقفي، وقيل: عبدريه، وقيل: هو الحسن البصرى، وقئ أبيل

$$
\text { آخر، مجهول لا يعرف اسمهة". }
$$

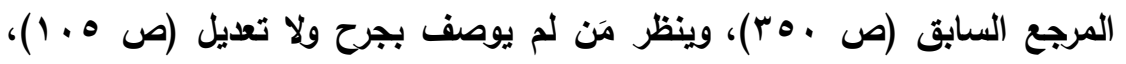

$$
\text { وهناك قد نقل الباحث احتمال صحبة هذا الراوي. }
$$


- - إبراهيم بن عبدالرحمن بن عوف القرشي الزهري - r - خ خ م) (1).

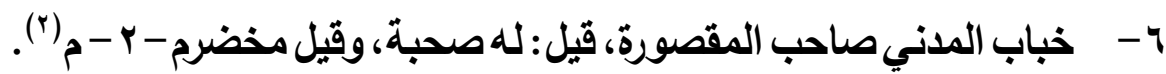
-V سفيان بن هانئ المصري، أبو سـالم الجَيْشـاني، تـابعي مخضرم، شـهـ فتح مصر، ويقال: لله صحبة، مج (َّ). - - سلمان بن ريبعة بن يزيد الباهلي، أبو عبد الله سلمان الخيل، يقال له:

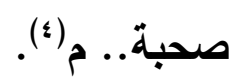

- - سويد بن غقلة بن عوسجة الجعفي، أبو أمية الكوفي - r -، خ م) مُ0.

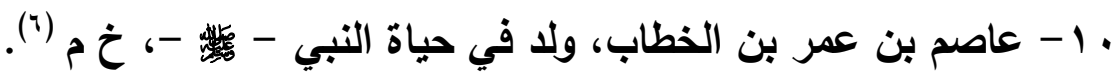
1 - عبد الله بن صفوان بن أمبة بن خلف، أبو صفوان المكي، ولد على ولى

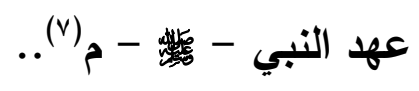

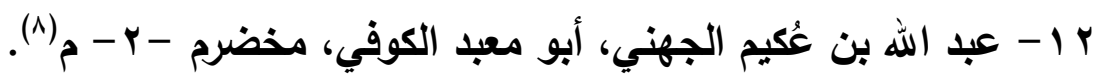
r ا - فروة بن نوفل الأثجعي، مختلف في صحبته، والصواب أن الصحبة الصدية

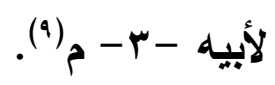

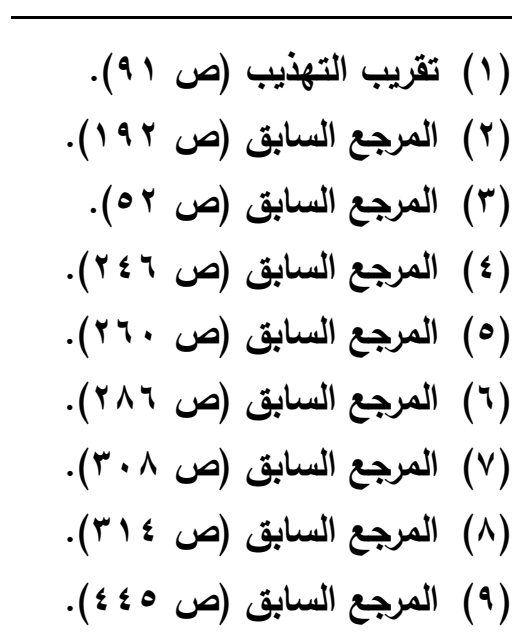


إزالة إيهام القائلين بوجود

الجهالة في بعض الفالين بوجال

وجميع هؤلاء من كبار التابعين ونحوهم، وقد اختلف في صسبتهم،

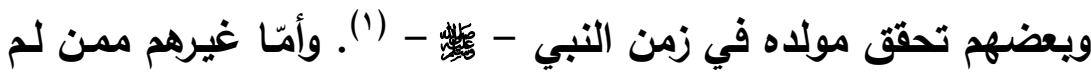
يذكر لهم ابن حجر رتبة فهم:

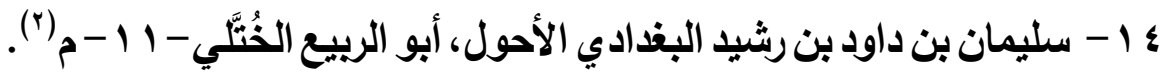

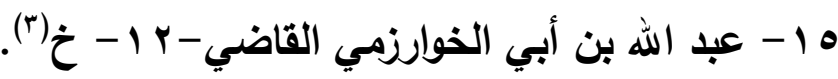

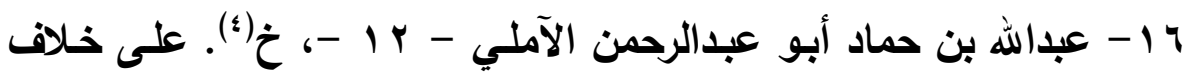
هل هو الذي في صحيح البخاري أم الخوارزمي الذي قبله(ه).

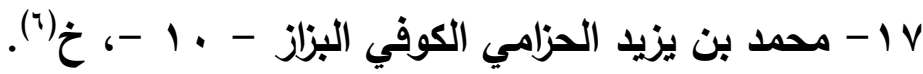
وهولاء أيضا إمّا شيخ للبخاري أو مسلم ولهم وضع خاص في التعامل معهم (v)

فلا نحتاج للبحث فيهم؛ لكن الباحث - هداه الله - جرى مذهبه على ذكر بعض كبار

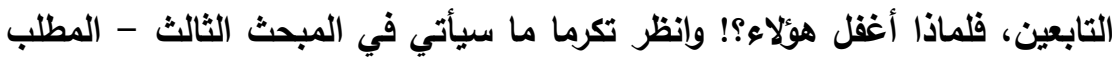

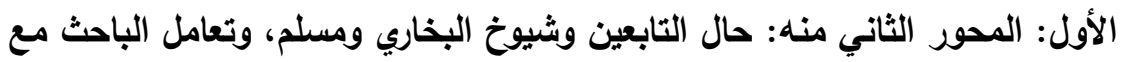

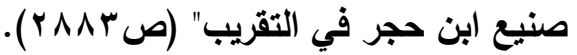

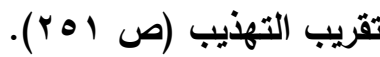

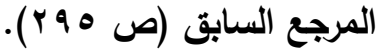

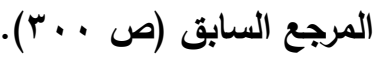

(•) ويُنظر تحريره زيادة في المطلب الثاني: "المثال العلمي للجمع والدراسة: مثال

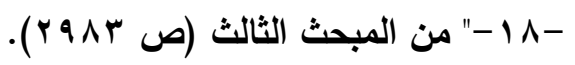

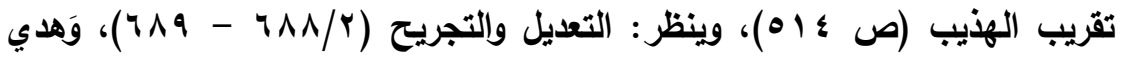

$$
\text { الساري (ص بr § \&). }
$$

= وانظر ما تقدم في القاعدة ( • ( ) من المطلب السابق، وما سيأتي في المحور (V) 
القسم الثالث: أما من أهملهم الباحث -وهم على طريقة بحثه-؛ فهم (AY) راويا، وهم باعتبار الطبقات على وفق ما في تقريب التهذيب لابن حجر: من الطبقة الثانية:

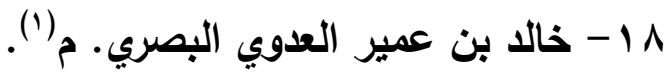
9 ا - طلق بن معاوية النخعي أبو غياث الكوفي. م) (؟).

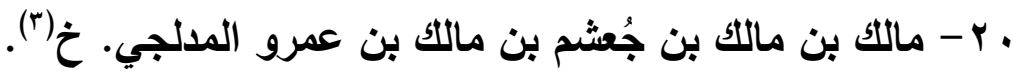
من الطبقة الثالثة: مالث ماته

ا Y - إبراهيم بن عبدالرحمن بن عبدالله بن أبي ربيعة المخزومي المدني. خ (؛) r r - جعفر بن أبى ثور السوائي، أبو ثور الكوفي. م(•) r r - جعفر بن عمرو بن حريث القرشي المخزومي الكوفي. م م"آ.

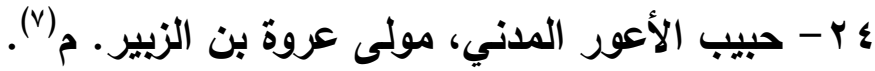
ه - خالد بن غلاق القيسي أبو حسان البصري. م)(^).

= الثاني من محاور القصور عند الباحث في المبحث الثالث: "حال التابعين وشيوخ

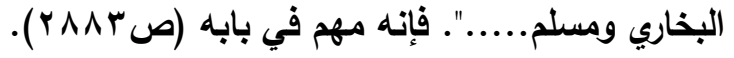

$$
\begin{aligned}
& \text { تقريب التهذيب (ص م 19 1). } \\
& \text { المرجع السابق (ص r r r r). }
\end{aligned}
$$

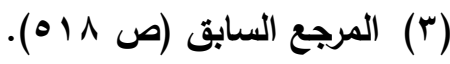

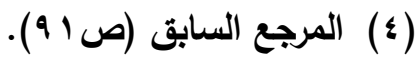

$$
\begin{aligned}
& \text { (0) المرجع السابق (ص • ـ 1 ). } \\
& \text { (آ) المرجع السابق نفسه. }
\end{aligned}
$$

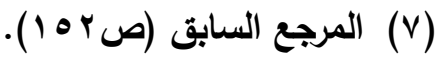

$$
\begin{aligned}
& \text { (^) المرجع السابق (ص • } 9 \text { (1). }
\end{aligned}
$$


צr - عامر بن سعد البجلي الكوفي. م)('). rV - عبــالرحمن بـن المسـور بـن مخرمسـة بـن نوفـل القرشـي الزهــري

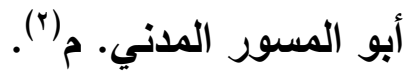

^ r - عبدالرحمن بن بشر بن مسعود أبو بشر المدني الأنصاري الأزرق. م(). q - عبدالرحمن بن مهـران المـني أبـو محمد مـلى الأزد، ويقال: مـلحى

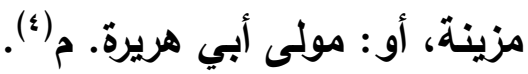

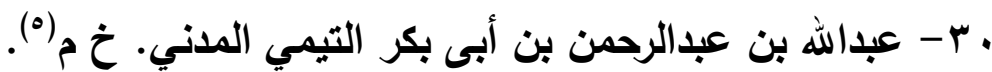

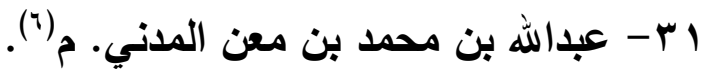

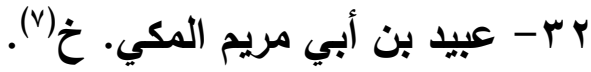

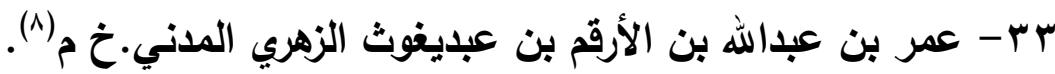
ع - - عوف بن الحارث بن الطفيل بن سخبرة بن جرثومة الأزدي. خَ(9).

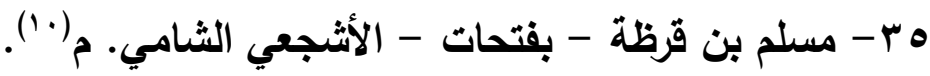

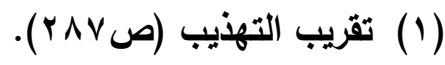

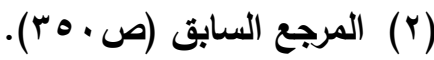

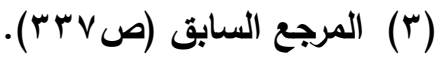

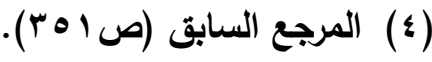

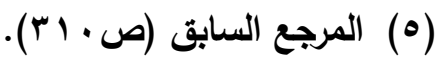

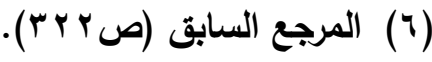

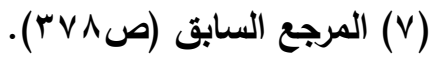

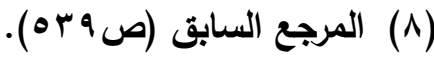

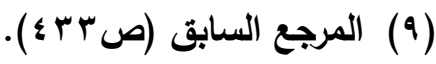

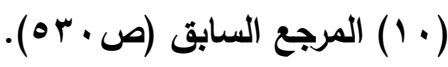


צب - مصدع - بكسر أوله وسكون ثانيه وفتح ثالثه -؛ أبو يحيى، الأعرج،

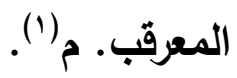

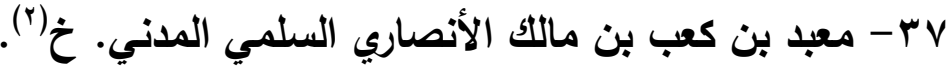

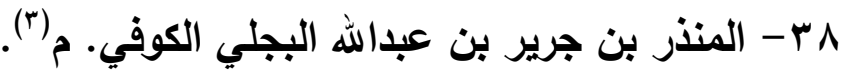

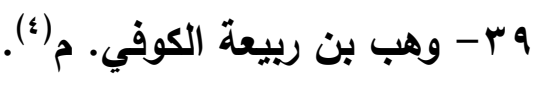

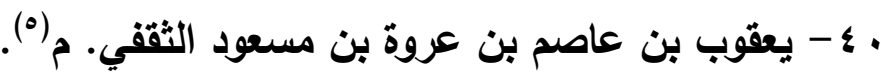

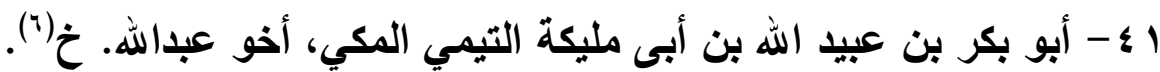

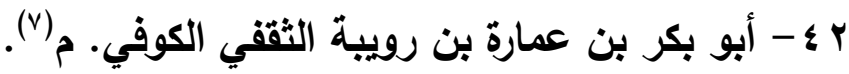

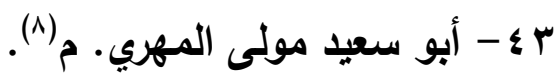

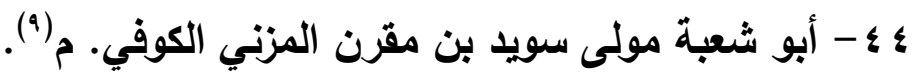

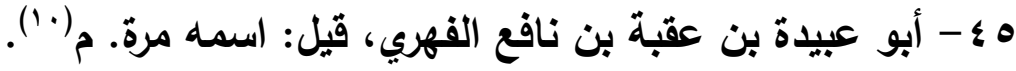

(1) تقريب التهذيب (صبr (1) (1).

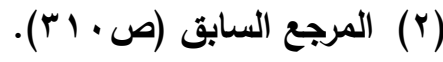

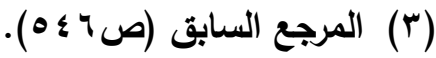

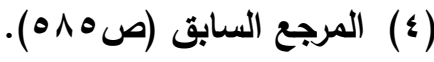

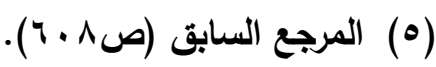

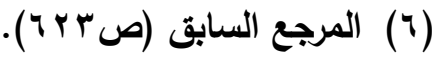

(V) المرجع السابق (ص \& צr).

(^) المرجع السابق (ص \& \& ؟7).

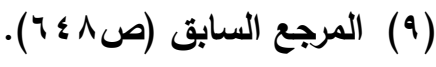

( • (1) المرجع السابق (ص זه 7). 
إزالة إيهام القائلين بوجود

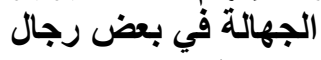

من الطبقة الرابعة: 7 צ - سالم بن أبي سالم - سفيان بن هانئ - الجيشاني - بجيم مفتوحة ثم تحتانية ساكنة ثم معجمة -، المصري. مم('). \& V

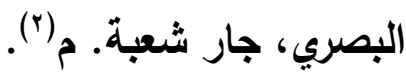

^ء - عبدالله بن واقد بن عبدالله بن عمر العدوي المدني. م) مَّ). 9 ـ - القاسم بن عاصم التميمي، ويقال الكليني. خ م (ء).

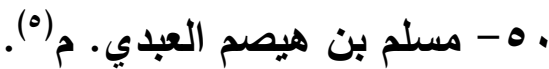
اه - مسلم بن يسار المصري أبو عثمـان الطنبذي، مولى الأنصار، جليس

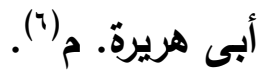

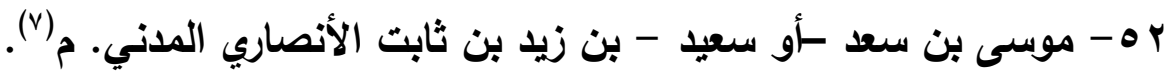
(v) rه - أبو الوليد المكي عن جابر • م.

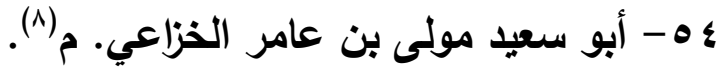

تقريب التهذيب (ص r r r).

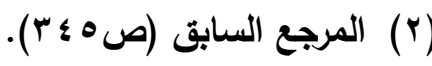

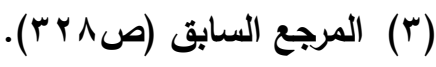

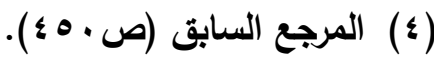

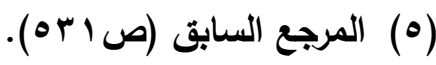

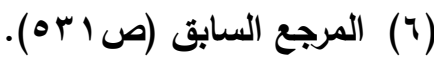

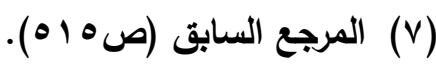

(^) (المرجع السابق (ص \& ؛ ؟ ). 
هـ أبو شمر - بكسر أوله وسكون الميم - الضبعي البصري. م)(').

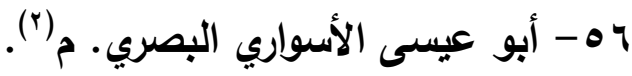

- أبو يحيى مولى آل جعدة المخزومي. م) م آ).

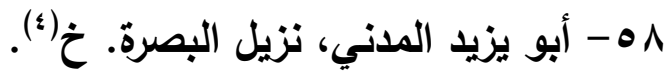
من الطبقة الخامسة:

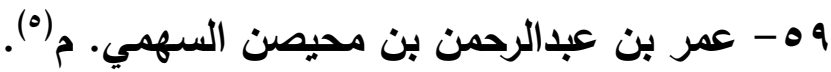

• צ - يحيى بن يزيد الهنائي أبو نصر البصري. م(").

ا

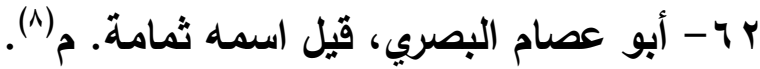

$$
\begin{aligned}
& \text { (1) تقريب التهذيب (ص^مء ؟ ). }
\end{aligned}
$$

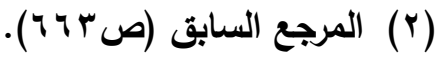

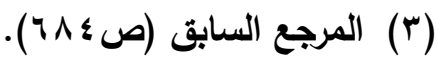

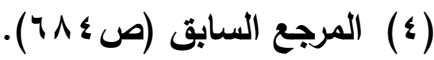

(•) المرجع السابق (صه اء؛)، تمام كلام الحافظ (بن حجر: "قارى ؛ أهل مكة ويقال:

(†) المرجع السابق (ص^هه)، تمام كلام الحافظ ابن حجر: "ويقال هو: أبي إسحاق المتقلم"، وإلمتقدم في تقريب التهذيب (ص ه ه ه): "يحيى بن أبي إسحاق الهنائي،

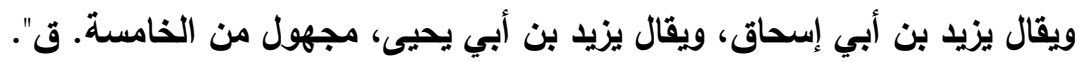

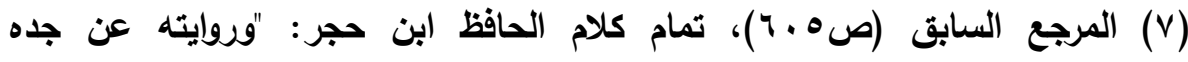

$$
\begin{aligned}
& \text { مرسلة..". }
\end{aligned}
$$

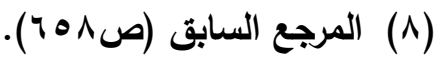


إزالة إيهام القائلين بوجود

الجهالة في بعض الفالين بوجال

من الطبقة السادسة:

ب ا - أمية بن صفوان بن عبدالله بن صفوان بن أمية بن خلف الجمحي. م) ('). ع - بكير بـن عبدالله - أو ابن أبي عبدالله - الطـائي الكوفي، الطويـل،

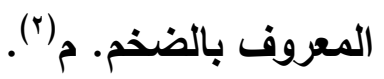

ه - خالد بن عبدالله بن حرملة المدلجي. م)(). צ - - عبدالرحمن بن أبى الثعثاء المحاربي الكوفي. م(؛).

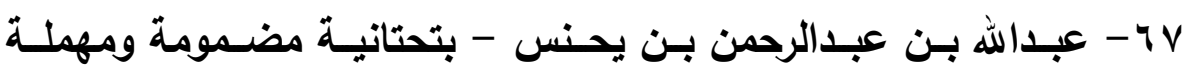
مفتوحة ونون ثقيلة مكسورة -، الحجازي. مم(ه).

^ - عبدالله بن عبيد الله بن أبي رافع المدني، مولى بني هاشم. م(").

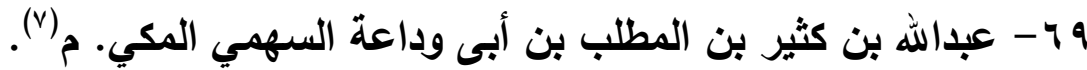
• - عبيد الله بن عبدالله بن عبدالله بن الأصم العامري. م (^). - ع ا عمر بن إسحاق المدني، مولحى زائدة. م (9).

$$
\begin{aligned}
& \text { (1) تقريب التهذيب (ص \& 11) ). }
\end{aligned}
$$

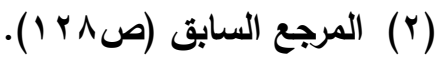

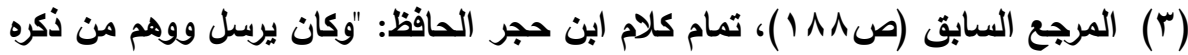
في الصحابة".

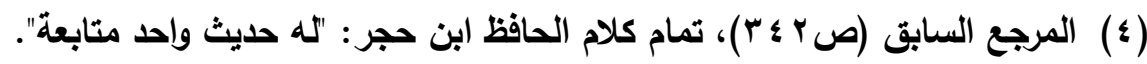

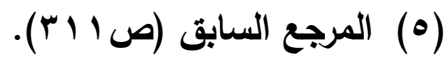

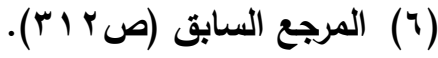

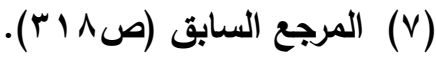

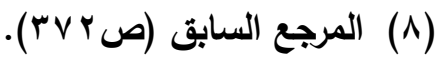

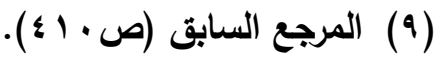


r - عمر بن عبدالله بن عروة بن الزبير بن العوام الأسدي المدني. خ م(').

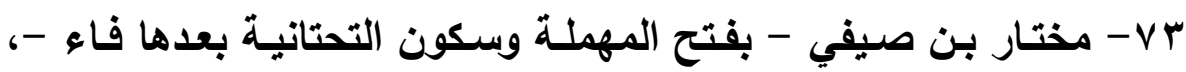

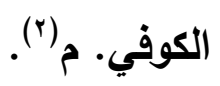

ع - مسعود بن مالك بن معبدالأسدي الكوفي. م م"َ). ه - معمر بن يحيى بن سام الضبي الكوفي، وقد ينسب لجده، ويقال: معمر

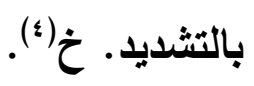

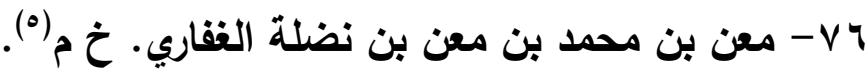
- الوليد بن حرب الأثنعري الكوفي، لقبه ولاد. م (؟V - الوليد بن عطاء بن خباب الحجازي. م) - V^ - Vq 9 • - أبو بكر بن عثمان بن سهل بن حنيف الأنصاري الأوسي المدني. خ خم (9).

(1) تقريب التهذيب (ص \& اء))، وقال ابن حجر : "وَهِمِ مَن زعم أنه عمر بن عروة، وأن عبدالله في نسبه وهم".

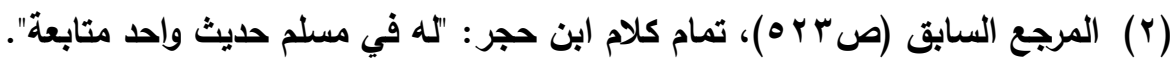

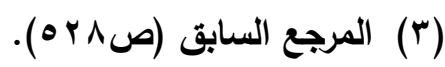

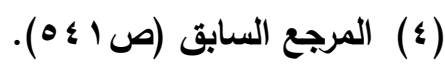

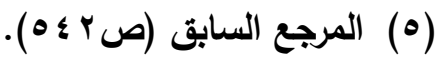

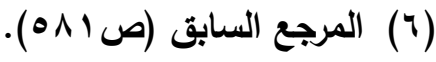

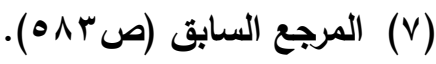

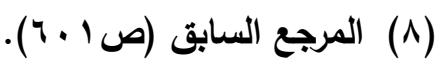

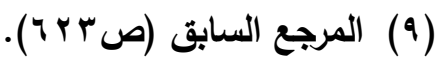


إزالة إيهام القائلين بوجود

الجهالة في بعض الفين بوجال

من الطبقة السابعة:

1 - سعيد بن عبدالرحمن بن أبى سعيد الخدري، الأنصاري، المدني. م)(').

r r - شعيب بن صفوان بن الربيع الثقفي، أبو يحيى الكوفي، الكاتب. م) (؟).

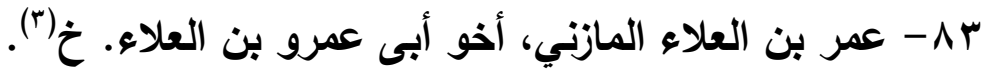

ع ـ- محمد بن شيبة بن نعامة الضبي الكوفي. م (؛).

ه - محمد بن عبدالرحمن بن غنج - بفتح المعجمة والنون بعدها جيم المدني، نزيل مصر • م)(•).

\ 1 - محمد بن عبدالله بن أبى عتيق محمد بن عبدالرحمن بن أبى بكر

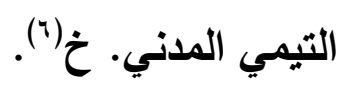

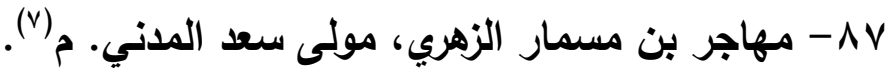

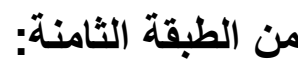

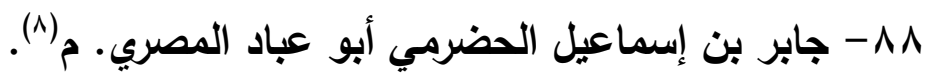

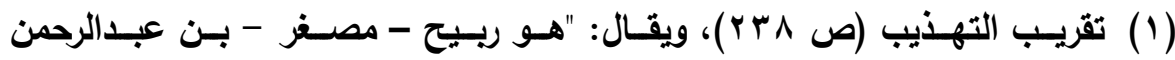

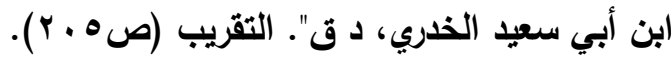

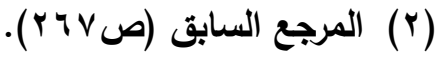

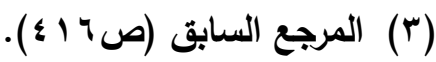

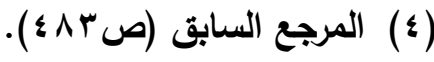

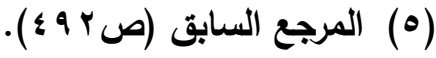

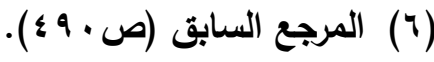

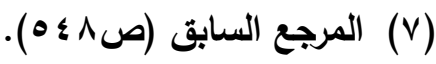

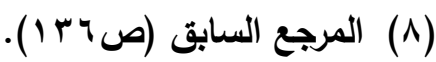


إزالة إيهام القائلين بوجود

الجهالة في بعض الفين بوجال

9 - - هشام بن سليمان بن عكرمة بن خالد بن العاص المخزومي المكي. م ('). الطبقة التاسعة: لا يوجد.

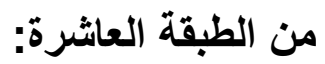
• 9 - عبدالعزيز بن عثمان بن جبلة - بفتح الجيم والموحدة - أبو الفضل المروزي، لقبه شاذان. خخ(').

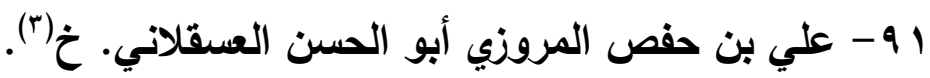
r q - عيسى بن المنذر السلمي أبو موسى الحمصي. م) (؛). بو - موسى بن خالد الشامي أبو الوليد الحلبي ختن أبي إسحاق الفزاري. م (ه).

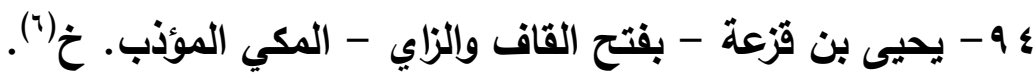
من الطبقة الحادية عشرة:

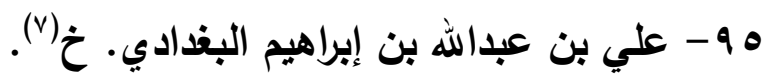

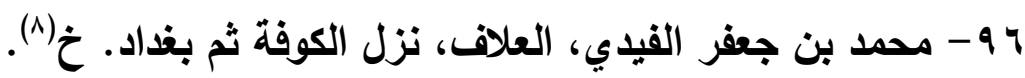

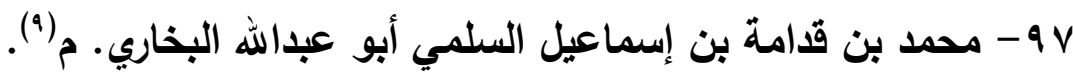
من الطبقة الثانية عشرة:

$$
\begin{aligned}
& \text { (1) تقريب التهذيب (ص r (1). } \\
& \text { (ץ) المرجع السابق (ص (ب^هץ). }
\end{aligned}
$$

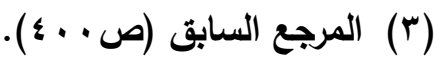

$$
\begin{aligned}
& \text { ( ) المرجع السابق (ص أ؟ ؛ ). } \\
& \text { (0) المرجع السابق (ص •000). }
\end{aligned}
$$

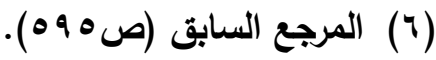

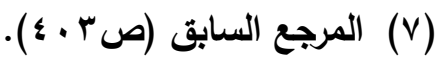

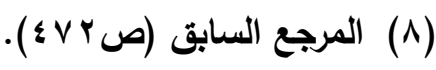

$$
\begin{aligned}
& \text { (9) المرجع السابق (ص المجابق (ه). }
\end{aligned}
$$


^ه - الحسين بن يحيى بن جعفر بن أعين البارقي البخاري . خ(').

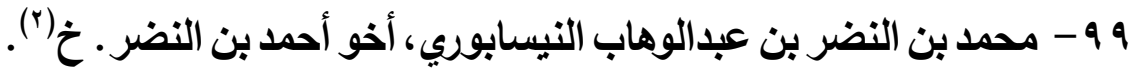
فعدة ما ينبغي أن يحتوي عليه بحثه هذا العدد هو (9 9) راويا بحسب ما وققت عليه عند ابن حجر من التقريب، من غير (Y) ترجمة التي ذكرها الباحث(َ)؛ فكيف لو زدنا من وثقهم ابن حجر وليس فيهم وصف بجرح أو من تعديل صريح لمتقدم(؛)، وليس هذا العدّ إلا إلزاما لزاعم الجمع والدراسة غير

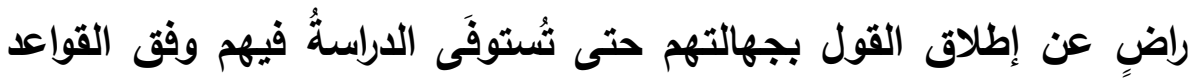
العلمية السابث ذكرها، وفي المطلب الثاني من المبحث الثالث الآتي الاراسةُ

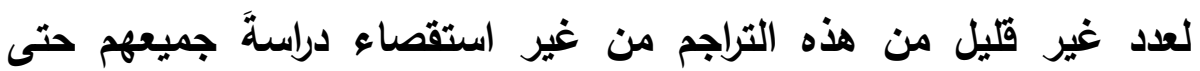
أفردهم في مؤلف خاص؛ ليتبين من خلال الدراسة الآتية عدم وجود الجهالة في تلكك النماذج؛ وليستبين بوضوح كيفية التعامل مع هذه التراجم إن فُعلّت قواعد أهل العلم في ذلك. ويالعموم اطلاق الحكم بالجهالة في تراجم رجال الصحيح دعوى مردودة؛ لأن الأمر كما قال الحافظ ابن حجر في ردّ الدعوى: بأنها: "مندفعة عن جميع من أخرج لهم في الصحيح؛ لأن شرط الصحيح أن يكون راويه معروفا

$$
\begin{aligned}
& \text { تقريب التهزيب (ص99 } 7 \text { (1). } \\
& \text { (المرجع السابق (ص • 1ه). }
\end{aligned}
$$

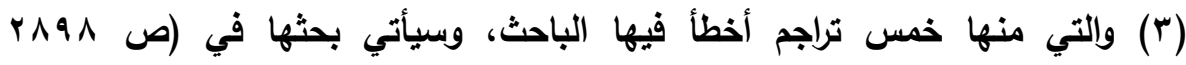

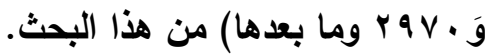

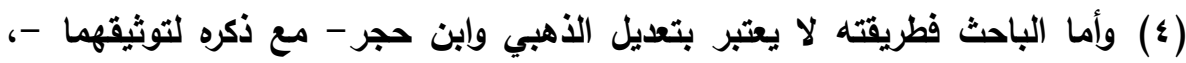

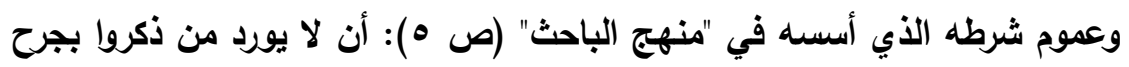
ولا تعديل! مجلة كلية أصول الدين والدعوة بأسيوط / العدد السابع والثثلاثون 9 اــم - الجزء الثالث 
بالعدالة، فمن زعم أن أحدا منهم مجهول= فكأنه نازع المصنف في دعواه:

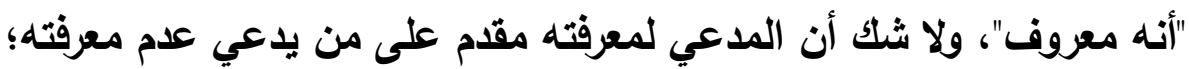

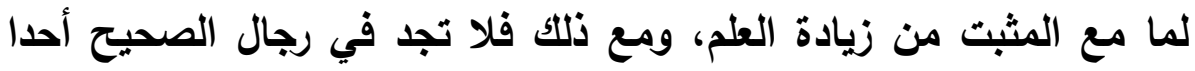
ممن يسوغ إطلاق اسم الجهالة عليه أصلا..." (1). ثم إن للباحث هرويا بقوله في عنوان البحث: "تأصيل قاعدة.. أن رواية

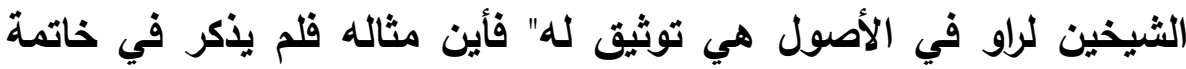

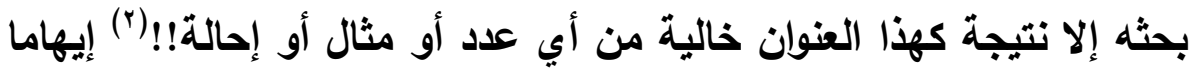
وتوهيما ليس فيه إيفاءُ مطلبه؛ فمن تتبعي لبحثه ما وجلت من هو تحت

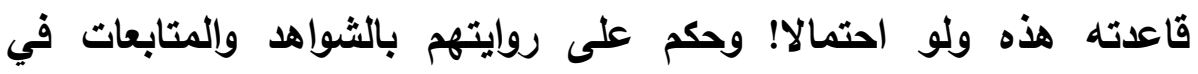

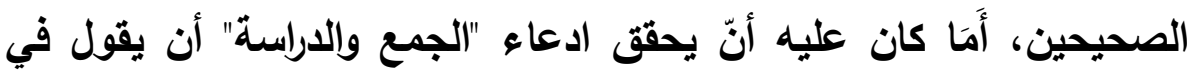

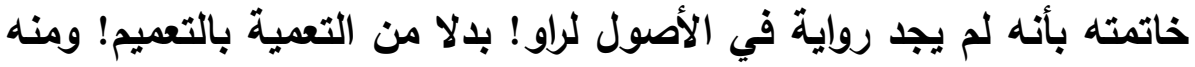

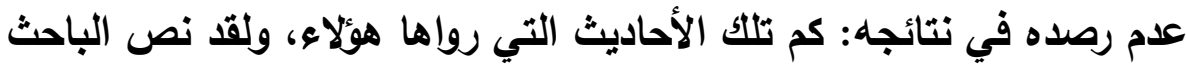

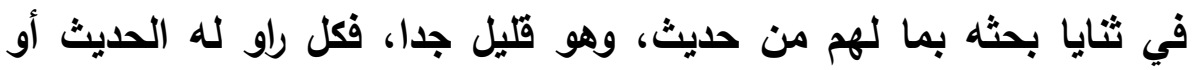

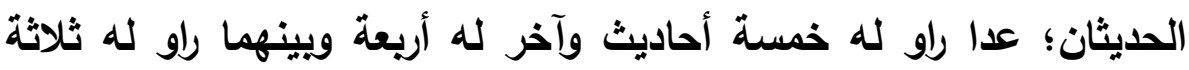

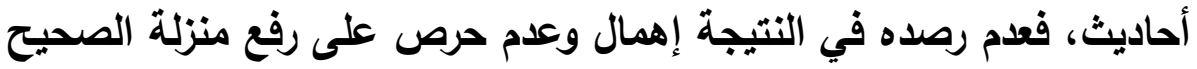

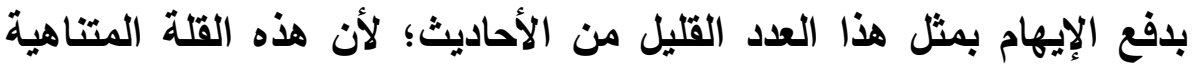

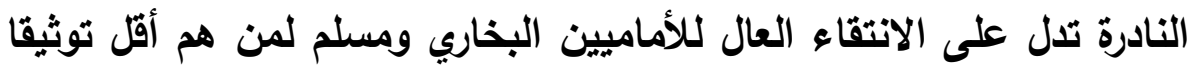

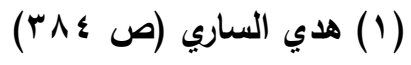

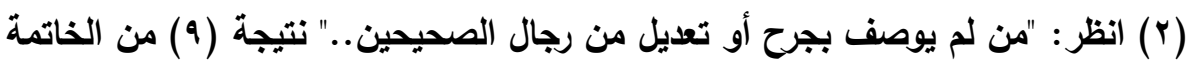

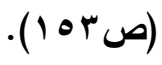


صريحا من غيرهم ممن أخرجوا لهم عشرات بل مئات الأحاديث، فكيف الأمر إذا ثبت أن روايتهم جميعا بالثواهد والمتابعات عنده. والباحث لا يرى هناك راويا روى له أصحاب الصحيح في الأصول حيث باني

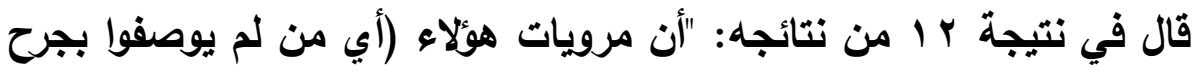

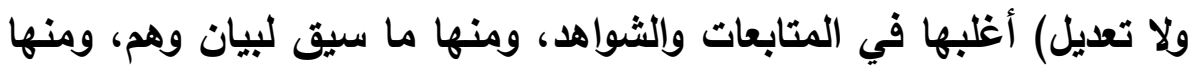

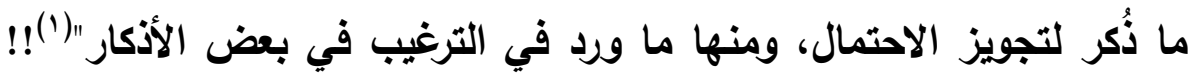

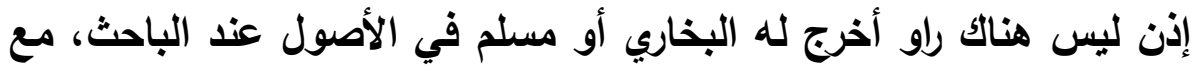

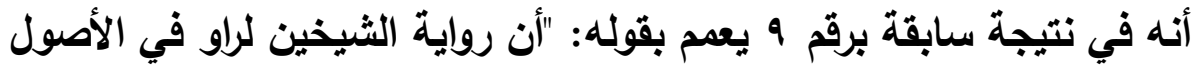

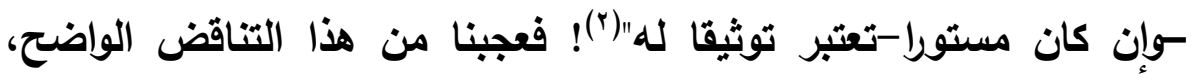

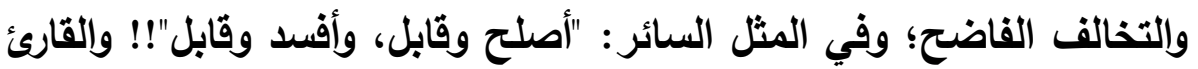
البسيط يرى بعد هذا أن مثل هذه الأبحاث خطيرة في نتائجها؛ فإن لم تكن

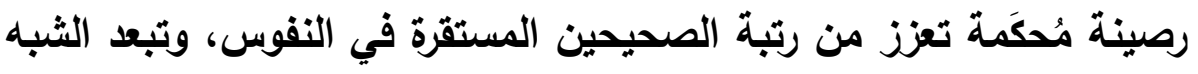

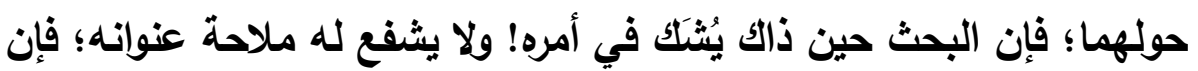
أكتثر المساوئ تَحت قَناعها:

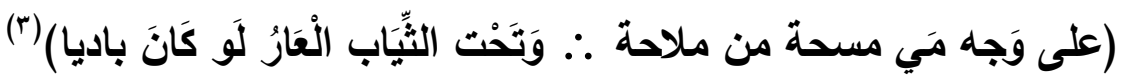

(1) "من لم يوصف بجرح أو تعديل من رجال الصحيحين.." الخاتمة والنتائج (ص \& 1 ).

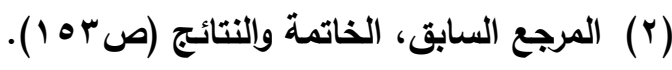

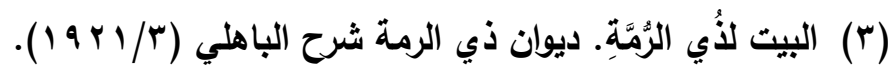
مجلة كلية أصول الدين والدعوة بأسيوط / العدد السابع والثلاثون 9 الـ بم - الجزء الثالث 
إزالة إيهام القائلين بوجود

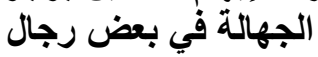

\section{المبحث الثالث}

الاستقراء والدراسة بين دعوى الباحث والمنهبية العلمية

أسس الباحث دعوى الدراسـة الوافية الموصِلة لقولهه: "تأصيل قاعدة أن

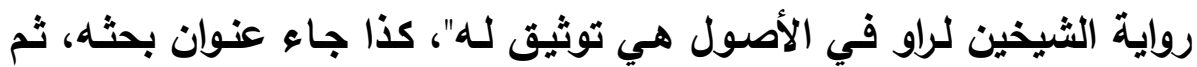

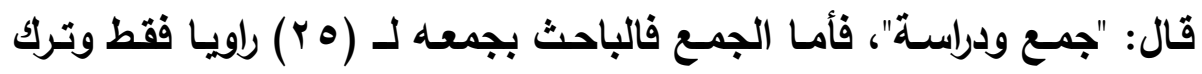

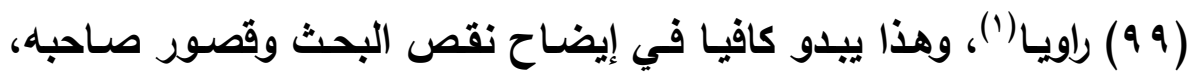

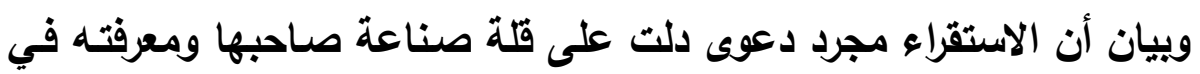
الكتابة في هذا الفن؛ فدراسته قاصرة عن منهج "التقصي" و "الإنصاف".

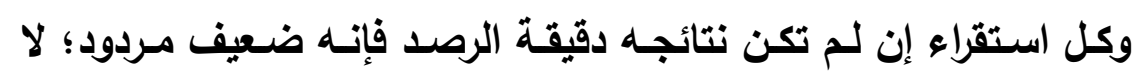

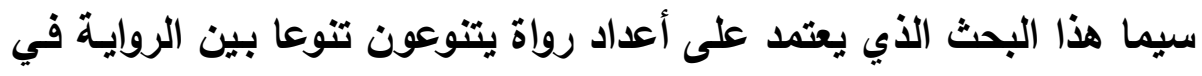

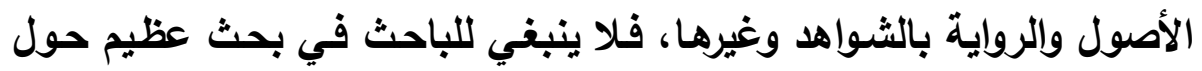

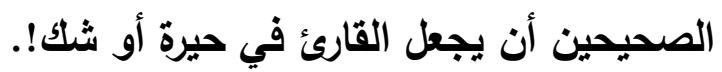

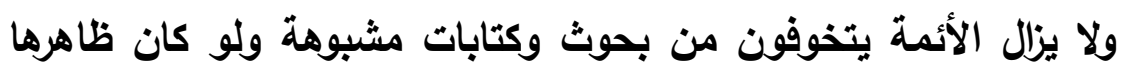

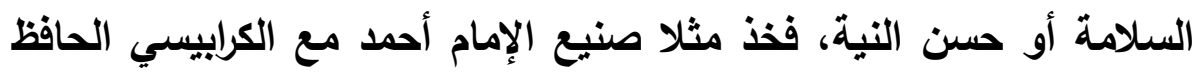

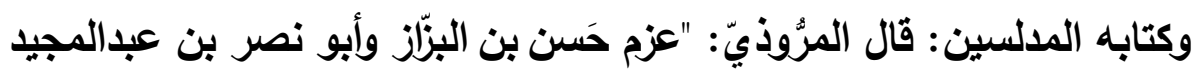

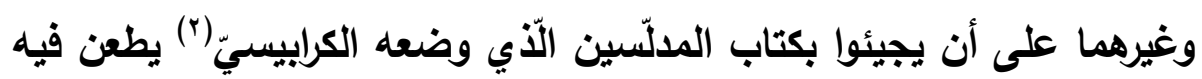

انظر : المطلب السابق: دعوى الإحصاء (ص r بهم) .

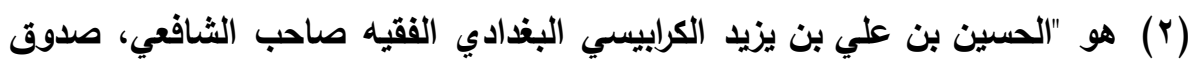

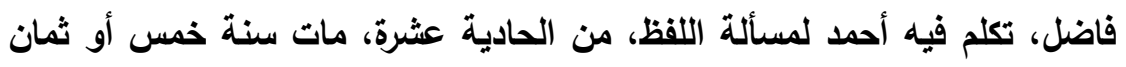

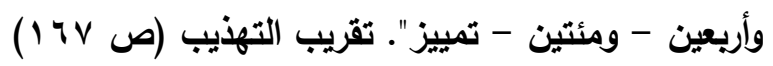


على الأعمش، وسليمان التَّْميّ. فضضيثُ إليه في سنة أريعٍ وثثلاثينِ

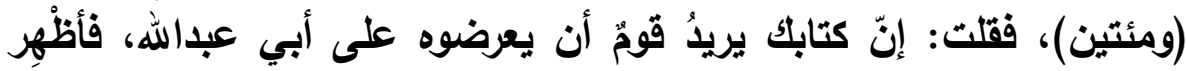

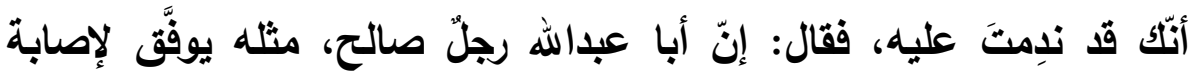

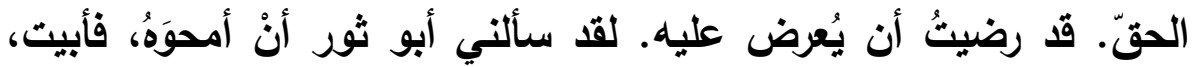

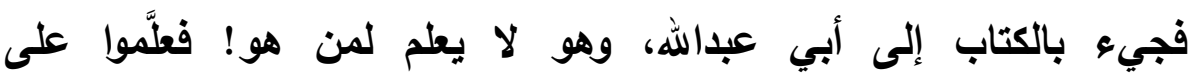

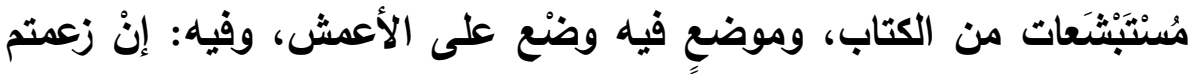

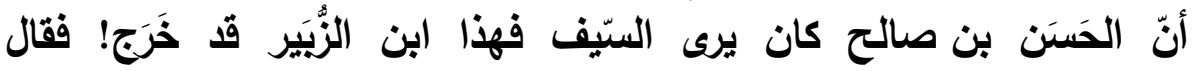

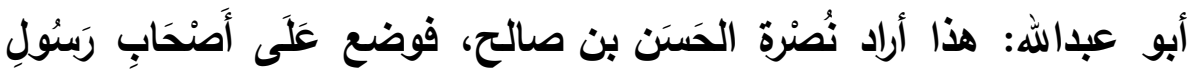

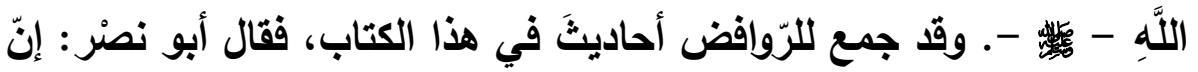
فتيانتا يختلفون إلى صاحب هذا الكتاب، فقال: حذروا عنه، ثم انكثف أنف أمره

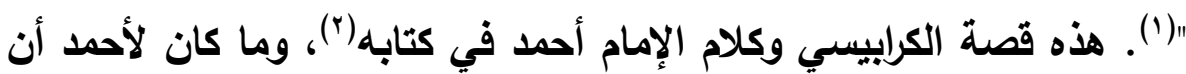
يرضى بالكتاب وفيه دخل يشوش على صحيح العلم.

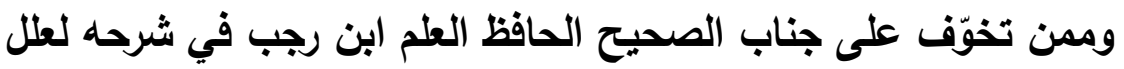
الترمذي فقال منبها: "تنبيه: اعلم أنه قد يخرج في الصحيح لبعض من من تُكلم

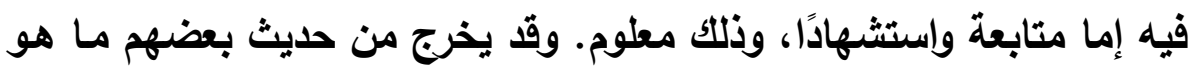
معروف عن شيوخه من طرق أخرى، ولكن لم يكن وقع لصاحب الصحيح

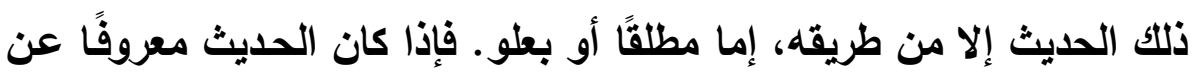

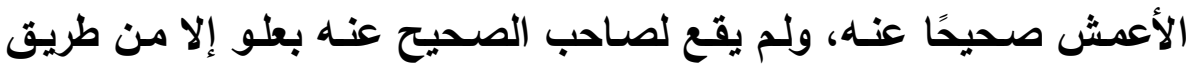

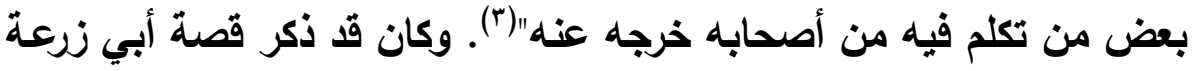

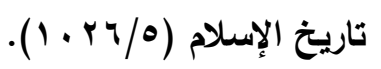

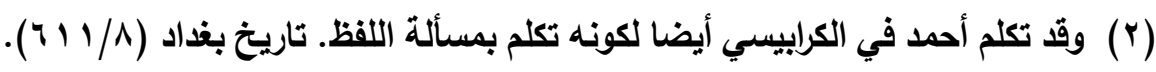

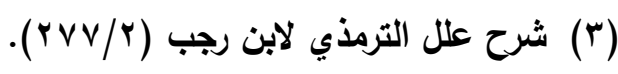


إزالة إيهام القائلين بوجود

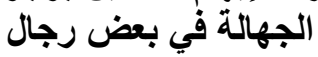

مع مسلم في صحيحه، ويهمني هنا منها خشية أبي زرعة وتخوفه من إخراج

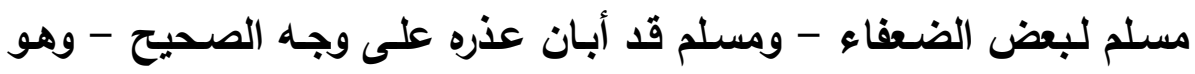

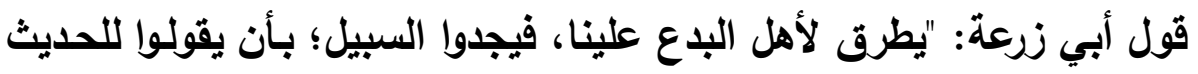

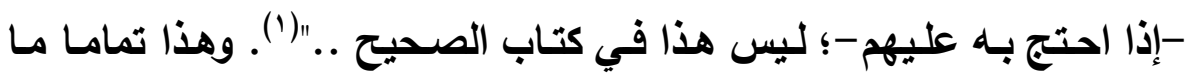
أقوله هنا في البحث والباحث يطرق لأهل البدع علينا، فيجدون السبيل؛ بأن يقولوا: في الصحيح مجاهيل وحديث ضعيف .. . وعلى نسيج ذلكت الحرص الثديد من أئمتنـا ينبغي أن تصرف أبحاث

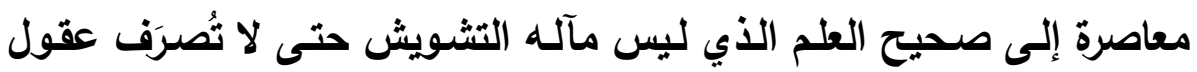
النـاس وأفهامهم عن الثوابت المعلومـة .. وقــ شُُخل النـاس في الأزمسان

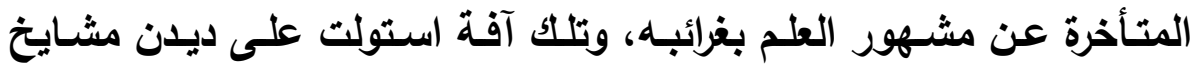
وطلاب رغبوا عن المتواتر المشهور واعتكفوا على تتبع الغريب، ولست متكلما

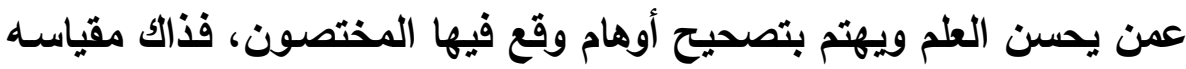

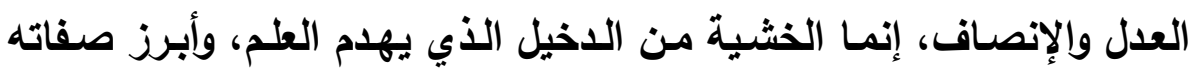

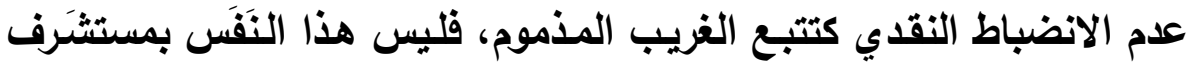

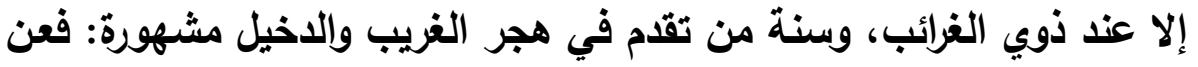

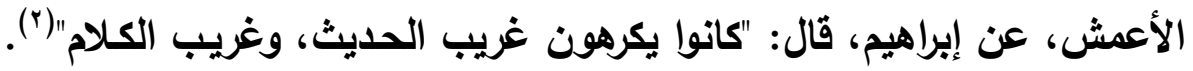

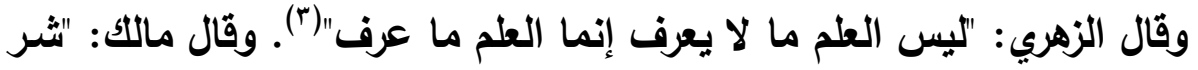

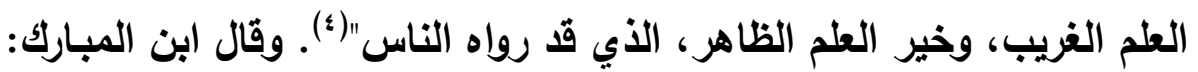

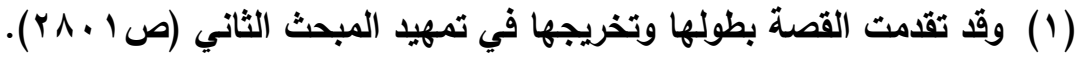

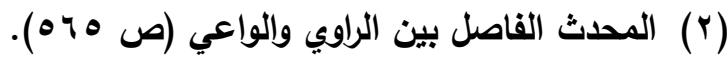

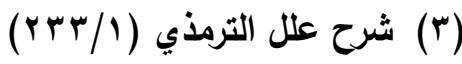

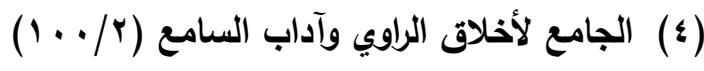
مجلة كلية أصول الدين والدعوة بأسيوط / العدد السابع والثلاثون 9 ـ ب م - الجزء الثالث 
"خير العلم الذي يأتيك من هـا هنـا، وهـا هنـا يعني المشهور"(1). وأظن من يكتب حول الصحيحين ببحث حول المجهولين ينالـه من ذم هولاء الأئمـة؛ حيث لم يسبق بتأليف ولا دراسة سابقة عند أهل الحديث بطريقة كهذه!. ومهـم أن نفهم مـن حـرص الإمـام أحمــ وغيـره مسن الأئمسة السـابقين خثـيتهم مسن مـآلات تلـك الأبحـاث، والنظـر في المـآلات قاعدتـه كبيـرة في الإسلام، فالعلماء والمفتون أول من يحرص على تطبيقها، لذا نجدهم يُقدرون العواقب في التأليفات والفتاوى .. ولهو راعى الباحث الدفاع عن الصحيحين بأن لا يُطال بتجهيل بعض رواته أو يكون مآل بحثه مفهوما منه ذاتك لصرّح بكلمـة واحدة في النتائج وهي: "لا يوجد مجهول في الصحيحين"! لكن راح يقول: "من رُوي في الأصول فهو موثث بذلك ولو كان مستورا"، ولم أجد من

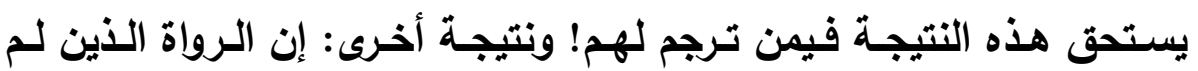
يوصفوا بجرح ولا تعديل هم بالشواهد ... () ومن تتبعي ومعرفتي أرى في البحث ضعفا وقصورا واضطرابا؛ فَقََ باحثه الحسَّ الأي يجعله لا يكاد يمر به شيء إلا التقطه التقاطًا يبزز حقيقة عمله له ومراده! ولعل الباحث يتدارك الخلل ويعود إلى صراحة نفسـه بالملامـة، والله خير مسؤول أن يتولاني وإياه بصلاح النية وحسن الطوية وخير العمل..

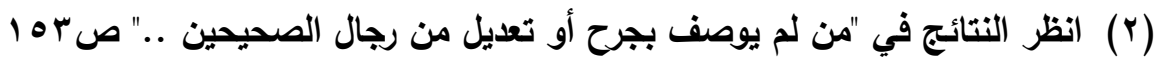
مجلة كلية أصول الدين والدعوة بأسيوط / العدد السابع والثثلاثون 9 اـ بم - الجزء الثالث 


\section{المطاب الأول \\ هماور قصور الاستقراء والدراسة}

حتى يتضح الأمر في معنى هذا المطلب - تبعا لعنوان مبحثه - أبيّن

هاهنا محاور هذا القصور بشيء من التفصيل: 1- الدارسة النظرية:

في المبحث الأول في بحثه المتعلق بمعنى الجهالـة لم يذكر الباحث

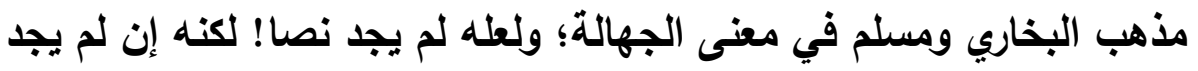

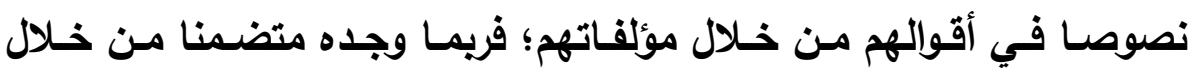

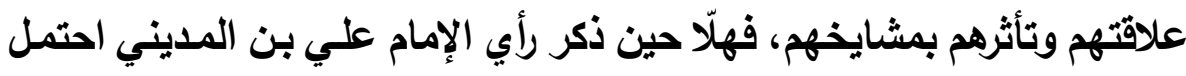

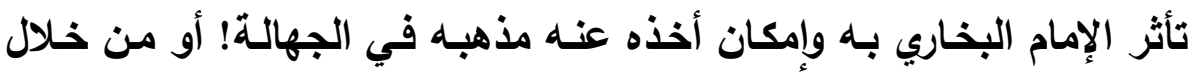

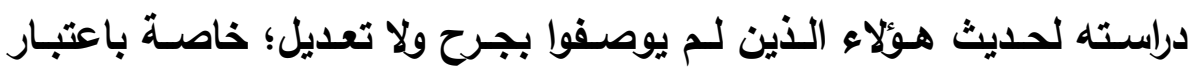

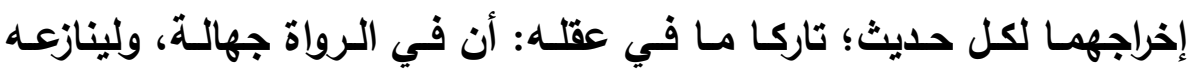
الاعتدال بمقولة الحافظ ابن حجر في هذا الباب خاصـة: "فأمسا جهالة الحال

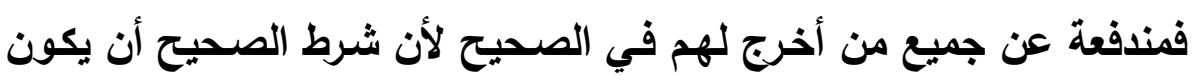

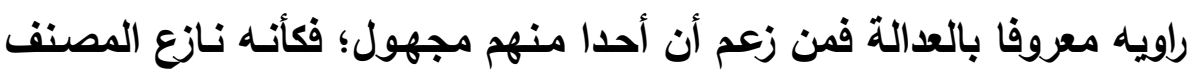
في دعواه أنه معروف. ولا شك أن المدعي لمعرفته مقدم على من يدعي عدام

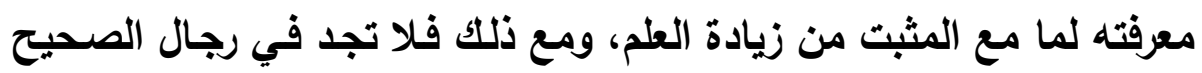

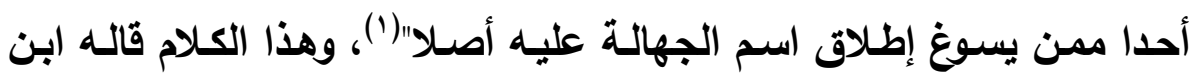

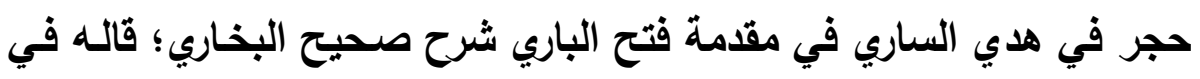

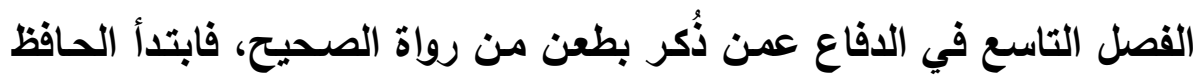

(1) هدي الساري ص (ع بـ). مجلة كلية أصول الدين والدعوة بأسيوط / العدد السابع والثثلثون 9 ـ بام - الجزء الثالث 
ببيان أنواع الطعن في الرواة، وذكر الجهالة من أنواعه، وذكر فيـه الكلام السابق، وليس للباحث حظ في هذا الكتاب فضـلا عن هذا الفصل العزيز ..

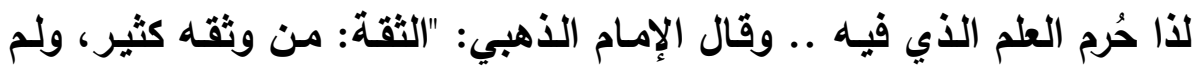

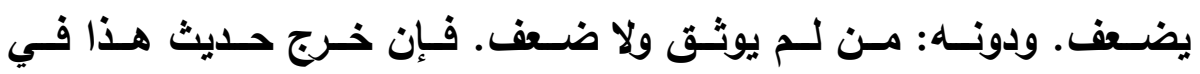

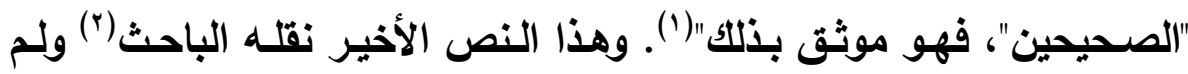

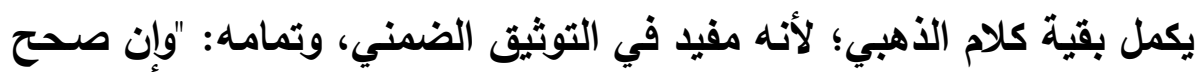

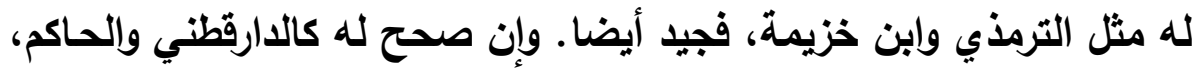

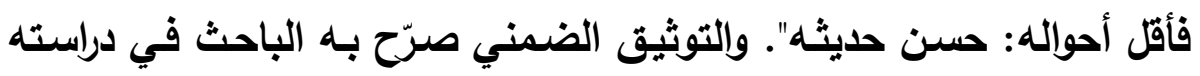
النظرية، وفيه قصور: حيث ذكر الباحث التوثيق الضمني في بحثنه مقتصرا

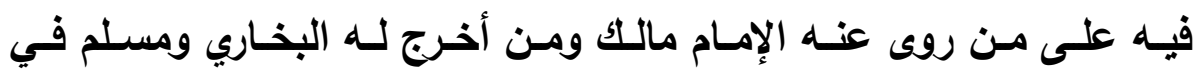

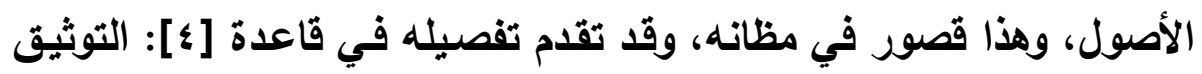

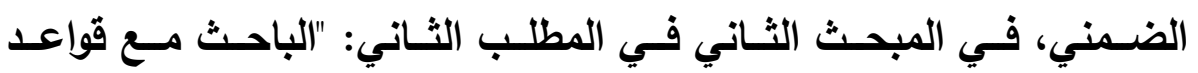

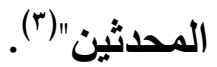

وعلى نقله في توثيقه الضمني لمن أخرج لله صاحب الصحيح لم يعزز

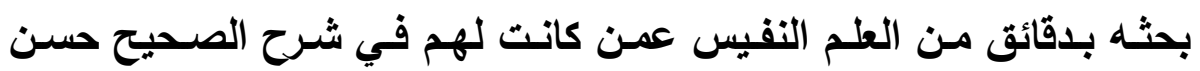

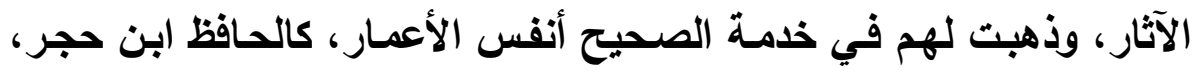

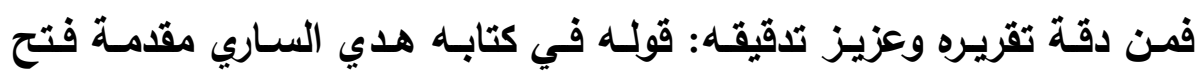

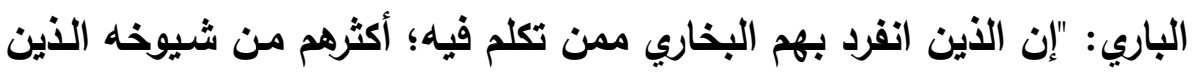

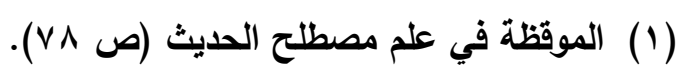

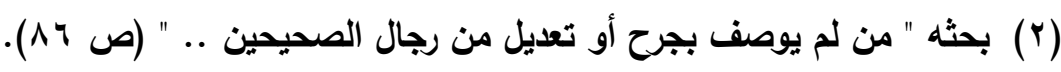

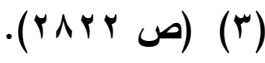
مجلة كلية أصول الدين والدعوة بأسيوط / العدد السابع والثلاثون 9 ا ـ rم - الجزء الثالث 
لقيهم وجالسـهم وعـرف أحسوالهم واطلـع على أحساديثهم وميـز جيـدها مـن موهومهها"(1). ومن هؤلاء مَن ذكرهم الباحث دون تتبه لمثل هذا التقرير فضـلا عن العمل به أو مناقشته على الأقل! وكذا لم يطلع على قول ابن حجر أيضـا في أحد المتكلَّم فيهم: "والحكم في أمثال هؤلاء الثيوخ الذين لقيهم البخاري وميز صسيح حديثهم من سقيمه وتكلم فيهم؛ غير أنسه لا يدعي أن جميع أحاديثهم من شرطه فإنها لا يخرج لهم إلا مـا تبين لـه صحته، والدليل على هلى ذلك أنه ما أخرج لعثمان هذا في صحيحه سوى ثلاثة أحاديث ..."(ז) .. فكم تحب هذا النقل وغيره من فوائـد وفرائـد توجب صيانة الصـيح من الزيـف الدخيل: منها أن البخـاري ينتقي للمتكلم فيهم، وأن أكثر من تُكلّم فيهـ من شيوخه الأي يعرفهم ويعرف حديثهم معرفة الناقد البصير، وأهم من ذلك أن الأمر عنده على الانتقاء، وهذا النقل في المُتكلم فيهم - لا فيمن يبحث عنهم الباحث وهم في حيز الجهالة عنده! والفرق ظاهر عندنا ومكتوم عند الباحث -؛ فمن يجمعهم الباحث أقرب في نيل التوثيق؛ لذا كفانا توثيق البخاري - أو مسلم - حيث أخرج له في الصحيح سواء أصولا أو بالشواهد والمتابعات أمـا أصولا فظاهر وأما بالثواهد والمتابعات؛ فلأن من تُكلّم فيه من رجال الصحيح لم يستحق حديثه الطرح الكلي = تعديل نوعي لا يستحق الترك بالكلية، فكان

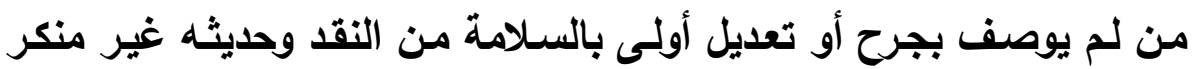
لاسيما وقد تويـ، فتأمـل .. وفي سبب إخراج حديث المتكلم فيهم صراحة وجود غرض من أغراض صناعة التصنيف في الجـامع الصـيح لا تبلغـه

$$
\text { هالمي الساري (ص 9 9). }
$$


إزالة إيهام القائلين بوجود

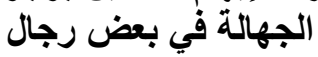

عقـول هـؤلاء نبّهه عليهـا الفحـول؛ لـئلا يتصسيد ذوو المغالطـات والشـبهات، فيكتبون الكتابة العائدة على الصحيح بالخطأ! جهلا أو عمدا! فهنا أقول: لا يشفع لـه - بعد هذا - قولـه: "تأصيل قاعدة: إن روايـة الشيخين لراو في الأصول هي توثيق لله" لعدم وجود هؤلاء الرواة في نظره

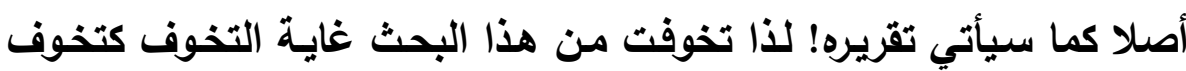
الأئمة - السابق ذكرهم في تمهيد المطلب -؛ من دخيل العلم .. r - حال التابعين وشيوخ البخاري ومسلم، وتعامل الباحث مع صنيع ابن حجر في "التقريب": لم يتميز في بحثّه فرقٌ بين حال التابعين من غيرهم، فالتابعون لهم عند الأئمة من التعديل العام قوة بقول النبي الناس قرني، ثم الذين يلونهه، ثم الذين يلونهم.."('). مِن هنا قال الحافظ الأهبي: "أما التابعون؛ فيكاد يعدم فيهم من يكذب عمدا، ولكن لهم غلط وأوهام، فمن ندر غلطه في جنب ما قد حصل؛ احتُمل، ومن تعدد غلطه -

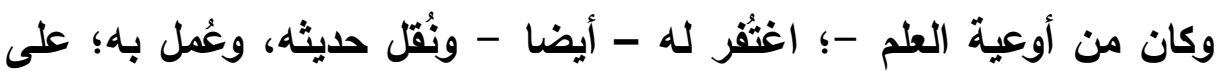
ترددٍ بين الأئمة الأثبات في الاحتجاج عمن هذا نعته ... ومن فحش خطأه وكثر تفرده لم يحتج بحديثه، ولا يكاد يقع ذلك في التابعين الأولين، ويوجد ذلك

\section{في صغار التابعين فمن بعدهم"(r).}

(1) متفق عليه، وقد تقام تخريجه في المبحث الثاني- المطلب الثاني (ص • Y Y (Y).

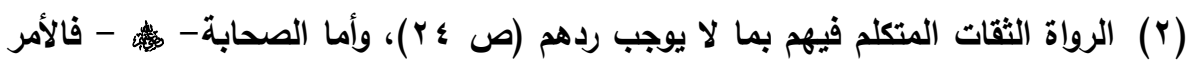

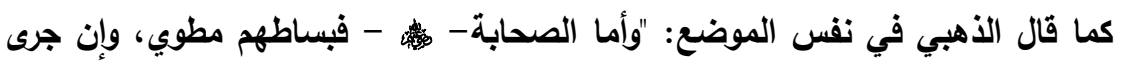
ما جرى، وإن غلطوا كما غلط غيرهم من الثقات؛ فما يكاد يسلم من الغلط أحد، لكنا لكنه

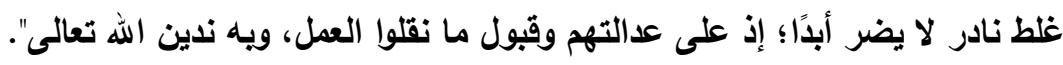
مجلة كلية أصول الاين والدعوة بأسيوط / العدد السابع والثلاثون 9 الـ بم - الجزء الثالث 
إزالة إيهام القائلين بوجود

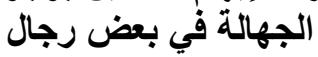

ونحو هذا ذكرَ ابنُ مفلح، فقد استدل في الآداب على أفضلية صلاة النساء في بيوتهن بما رواه الإمام أحمد في مسنده(')-وذكر الإسناد ابن مفلح إلى داود بن قيس، عن عبد الله بن سويد الأنصاري، عن عمته أم حميد امرأة

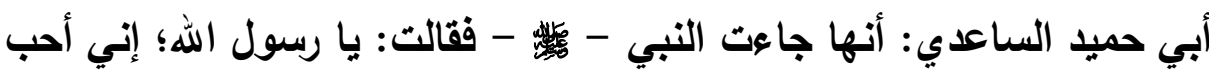
الصلاة معلك. قال: 》قا علمثُ أنكك تحبين الصلاة معي، وصلاتك في بيتك خير من صلاتك في حجرتك، وصلاتك في حجرتك خير من صلاتك في داركي الحديث، قال ابن مفلح عقبه: "عبد الله بن سويد ذكره البخاري في تاريخه، وقال: روى عنه داود بن قيس. ولم يزد على ذللك(r)، فقيه جهالة؛ لكن المتقدمون حالهم حسن، وياقي رجاله ثقات"(־ّ). وأكثر طبقة جهّلهم الباحث في البحث هم هذه الطبقة من التابعين،

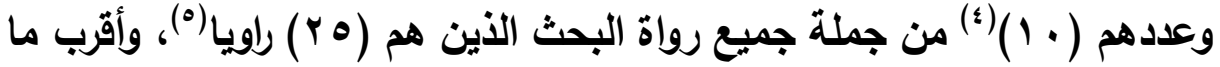

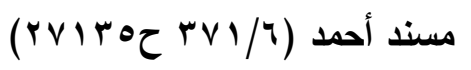

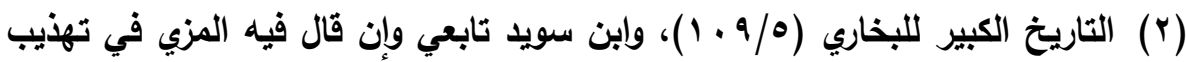

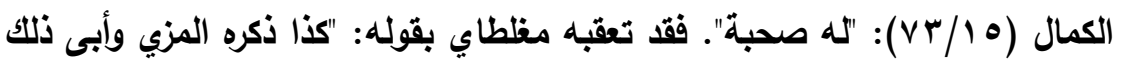
أبو أحمد العسكري فقال: قال بعضهم: لا يصح له صحبة قال: وروى عنه عن أم حميد

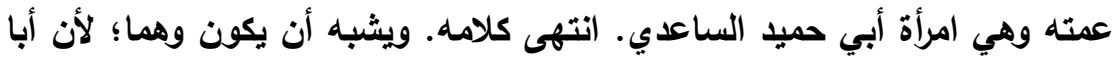
حاتم جعهما ترجمتين، وكذلك البخاري مع تصريحهما بصحبة الأول، وكذا فعله

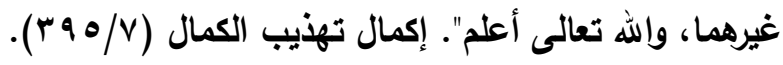

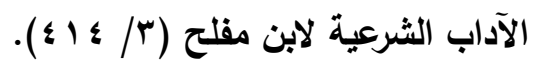

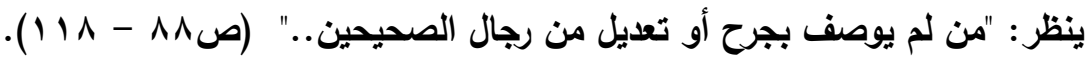

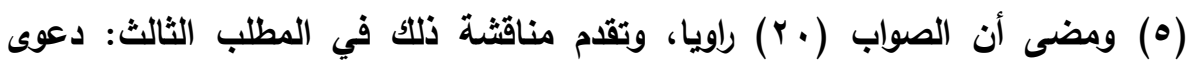

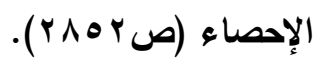
مجلة كلية أصول الدين والدعوة بأسيوط / العدد السابع والثلاثون 9 الـ بم - الجزء الثالث 
إزالة إيهام القائلين بوجود

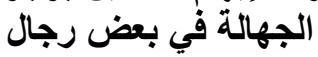

يكون أبعدُ عن الجهالة من هؤلاء هم التابعون وطبقة رفقاء وشيوخ صاحبي

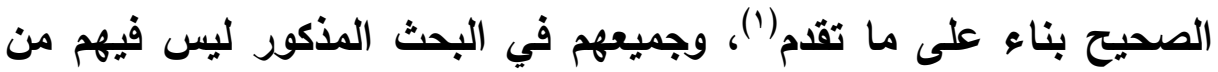
صغار التابعين بنص الباحث عند كل ترجمة إلا واحدا وهو عطاء أبو الحسن

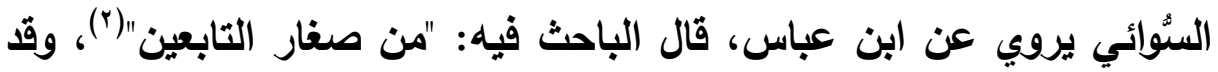
أخطأ فيه! ولم يَنسب هذا القول لأحد، وصوابه من الرابعة كما في التقريب(")

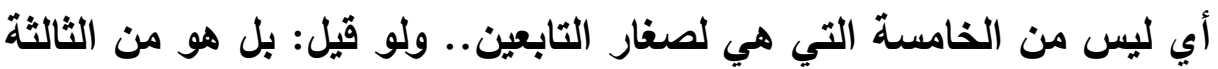

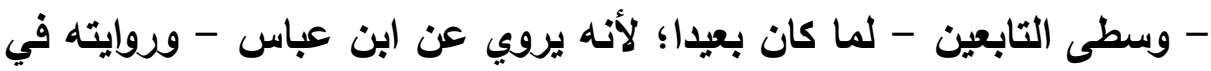

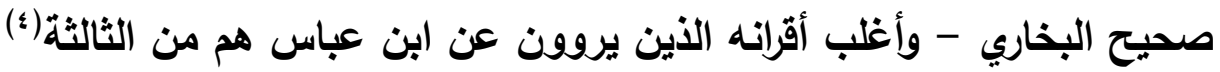

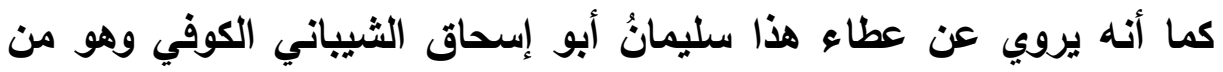
الخامسة(0)، فلو كان كما زعم الباحث - بأن عطاء من صغار التهائ التابعين - لكان

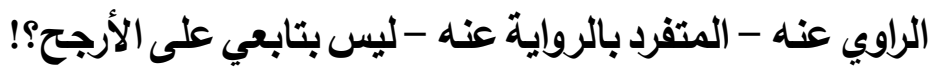

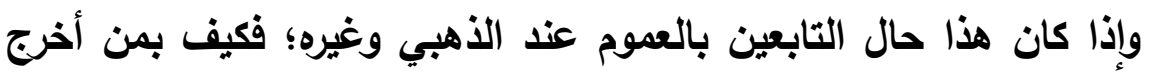

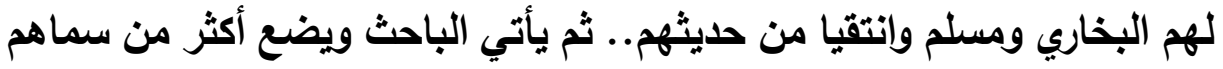
في بحثه منهم معرضا عن تفعيل هذه النصوص الشريفة أو مناقشتها!! ثم إنّ الباحث يغتر في هذا القسم من التابعين فيضع كبار التابعين في بحثه مستأنسا بعمل ابن حجر في "التقريب" حيث لم يضع لهم رتبة، كمثل فين فئ فئ

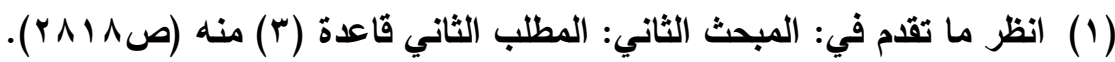
(r) ينظر : "من لم يوصف بجرح أو تعديل من رجال الصحيحين.." (ص V + 1).

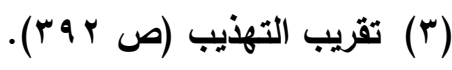

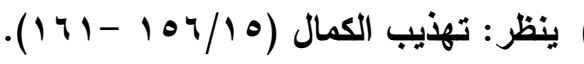

$$
\begin{aligned}
& \text { تقريب التهذيب (ص ror) }
\end{aligned}
$$


عمل الباحث مع عبدالرحمن بن مطيع القرشي أبي عبدالله المدني -خ م- فقد ذكره في بحثه(1)، مع كونه من كبار التابعين، بل قال ابن حجر في التقريب: "يقال: له صحبة"(ז)، وعلى نسقه ممن قيل لهم صحبة؛ جرى ذكر نظائره إلزاما له حيث أهملهم في دعواه الجمع (")، ولا يغتر بمن لم يذكر لهم الحافظ في "التقريب" جرحا أو تعديلا، فإن ذلك لا يعني بالضرورة أنه لم يرد فيهم جرح أو تعديل، وقد يكون لترك ذكر المنزلة عند ابن حجر هو وضوح الأمر في كبار التابعين، وقد جرى على هذا أئمة منهم العجلي وغيره، فإنه يكتفون عن صراحة التوثيث بكون الأمر يدور بين الصحبة وكبار التابعين، وقا يثبر ابن حجر على هذا المعنى تراجم تقلم ذكر كثير منها في المبحث الثاني: المطلب الثاني: القسم الثاني: "مَن لم يذكرهم الحافظ ابن حجر بجرح أو تعديل، ولا قال

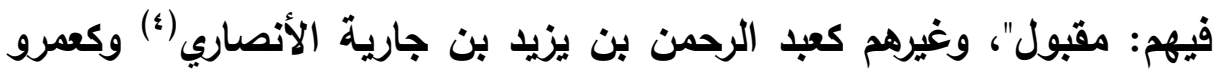
بن أوس بن أبى أوس الثقفي(•)، وعبيد الله بن عدي ابن الخيار المدني(').

$$
\begin{aligned}
& \text { مَن لم يوصف بجرح ولا تعديل (ص ه ه 1 ). }
\end{aligned}
$$

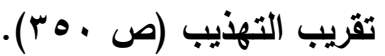

انظر المبحث الثاني - المطلب الثالث: دعوى الإحصاء- القسم الثاني: مَن لم

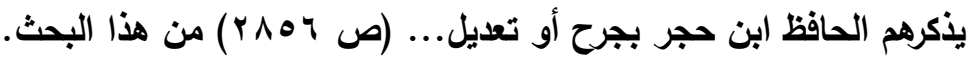

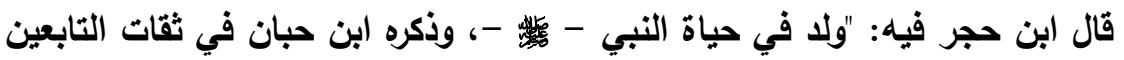

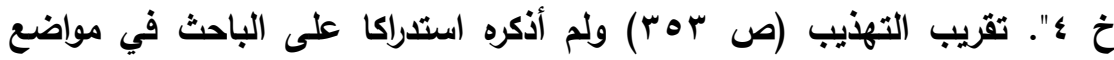

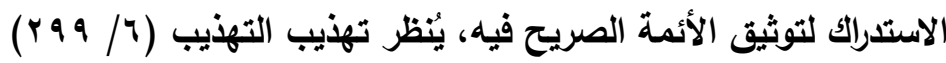

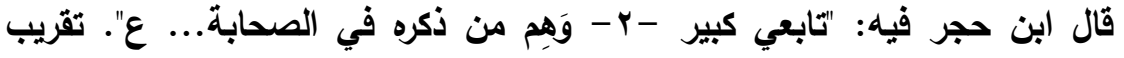

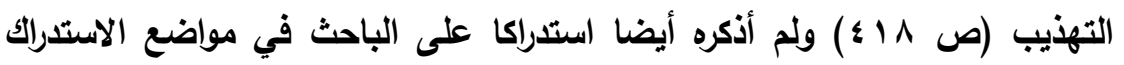

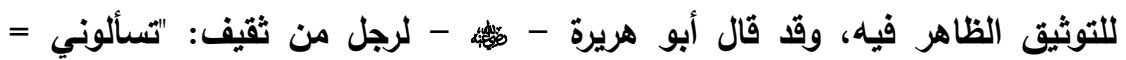


إزالة إيهام القائلين بوجود

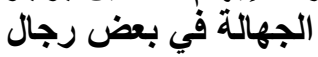

ومثله مروان بن الحكم بن أبى العاص المدني، وسيأتي مزيد تفصيل يخصه في ترجمة بوّابه رافع في آخر المبحث الثالث: المطلب الثاني.. وهذا الأمر ليس قاصرا في كبار التابعين بل ولغيرهم إلا أنّ عدم مراعاته في كبار التابعين تهاون شديد، ومن أمثلته في غير التابعين في صورة دقيقة هي ترك ذكر المرتبة عند ابن حجر لقوة الاختلاف في كون الراوي مبهم في الإسناد ووقع الاختلاف في تعيينه، ومثاله: عبد الله بن أبي الخوارزمي من الطبقة (r I) لم يذكر فيه ابن حجر غير قوله: "قيل: إن البخاري روى عنه"(؟). وقد وقع

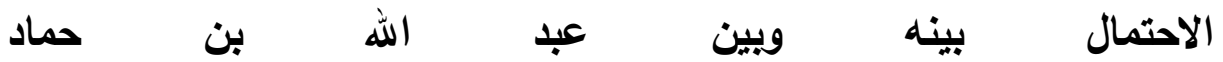
أبي عبد الرحمن الآملي(ّ). ونحوه الثقة محمد بن مقاتل المروزي أبو الحسن الكسائي، لقبه "رخ" من طبقة شيوخ البخاري، لم يأكر له ابنُ حجر مرتبة؛ لأن في الصحيح قال البخاري قال: "عن محمد: عن عثمان بن فرق"، وذا في حديث واحد، وقال المزي في ترجمته من التهذيب: "روى البخاري حديثا عن محمد عن عثمان بن فرقد، فقيل: إنه محمد بن مقاتل هذا، وقيل: محمد

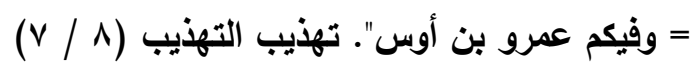

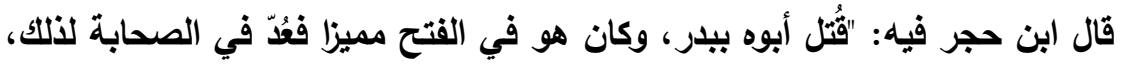

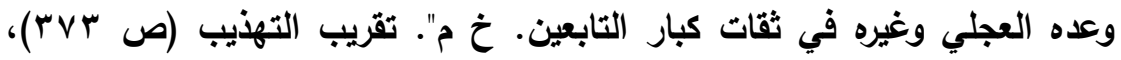
ولظهور توثيقه لم أستدركه على الباحث في موطنه، وينظر : زيادة تهذيب التهذيب

$$
\text { تقريب التهذيب (ص م9 r) ). }
$$

وسيأتي مزيد تفصيل في المبحث الثالث (المطلب الثاني)، وكلا الترجمتين السابقتين وقع الاستدراك على الباحث فيهما جريا على قاعدته حيث لم أجد من وثئهما من المتقدمين. مجلة كلية أصول الدين واللدعوة بأسيوط / العدد السابع والثلاثون 9 ا ـ بم - الجزع الثالث 
إزالة إيهام القائلين بوجود

الجهالة في بعض الفالين بوجال

ابن سلام، وقيل: محمد بن عقبة"(1). قلت: ولو كان هو فهو ثقة وزيادة عند

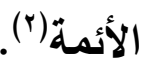

وأمّا إن كان الراوي ليست له رواية مرفوعة فيكتفي الحافظ ابن حجر بالتنبيه على ذلك دون ذكر قول له في جرح أو تعديل صريح، مثل: "الهرمزان:

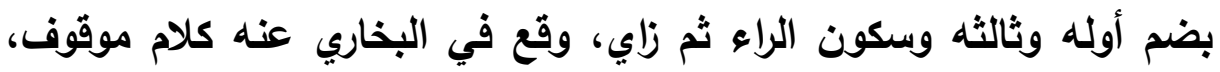

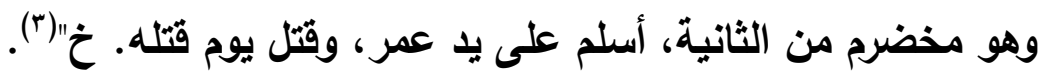
وتارة ابن حجر يكتفي عن وضع الرتبة بذكر الخلاف بين كونهه صحابي

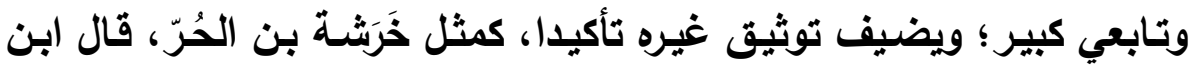

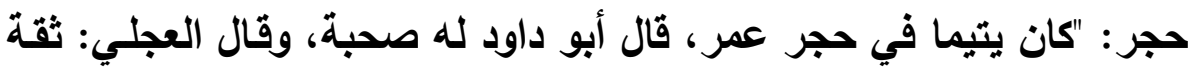

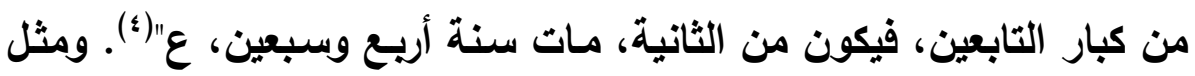

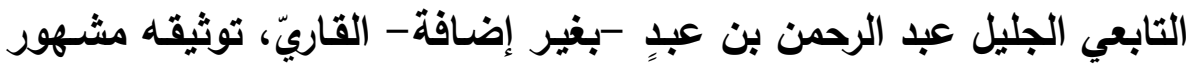

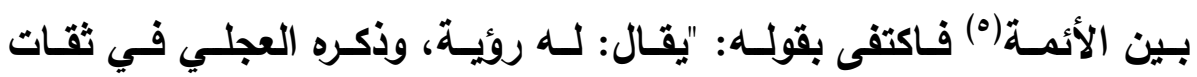

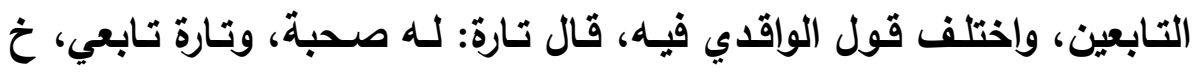

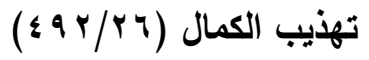
يُنظر: تهذيب التهذيب (9/9 (9)؛)، ولظهور توثيقه لم أستدركه على الباحث في موطنه، ونحوه كثير ..

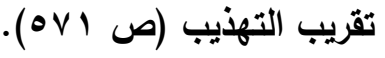

$$
\begin{aligned}
& \text { المرجع السابق (ص بـ 1). }
\end{aligned}
$$

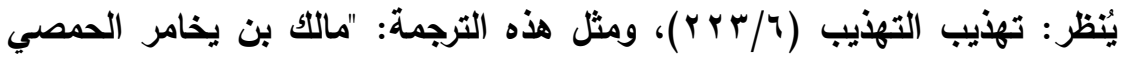

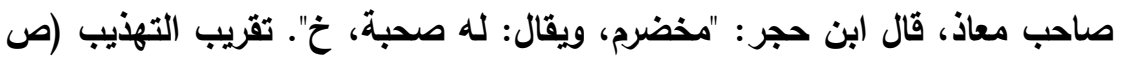

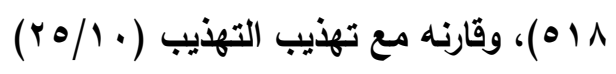


إزالة إيهام القائلين بوجود

الجهالة في بعض الفالين بوجال

م"(") والحاصل أنا نجد ابن حجر يترك هذا ذكر المنزلة لكونهم إمـا صحابة

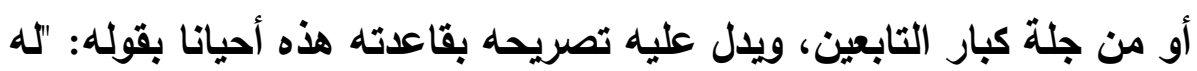

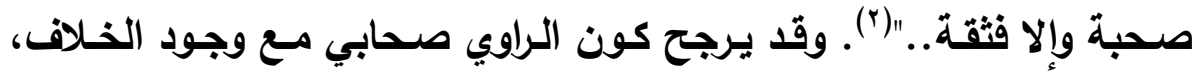

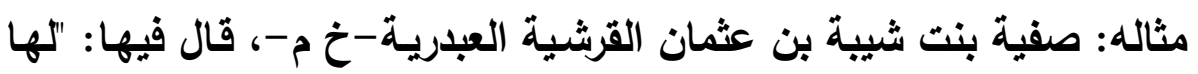

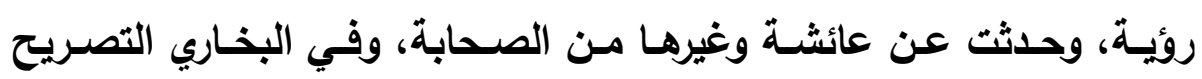

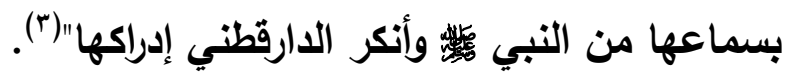

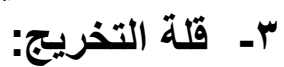

لم أجد الباحث يتعدى الصحيحين في حديث رجل من رجال الصحيح

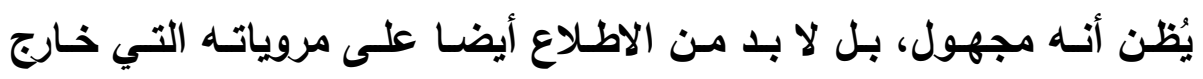

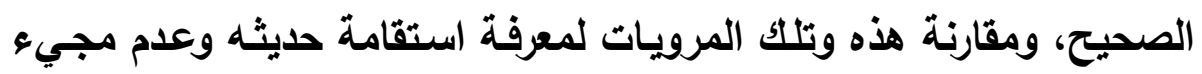

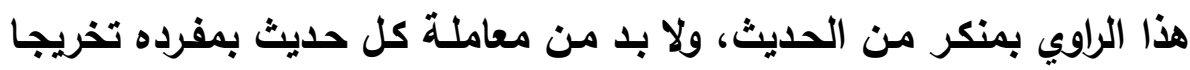

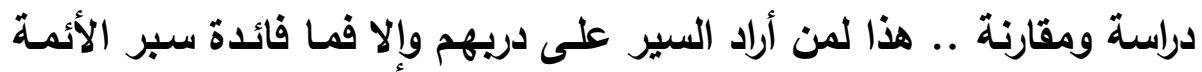

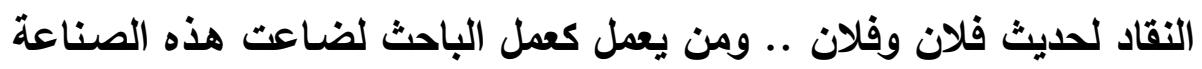

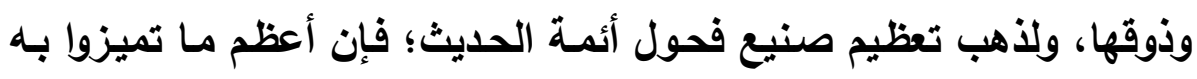
ذلك السبر لحديث المقلين والمكثرين وتمييز صحيحه من معلوله، وإنظر مـا

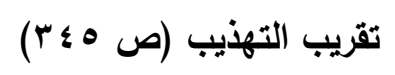

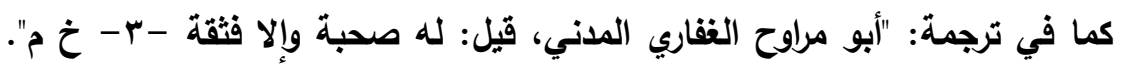

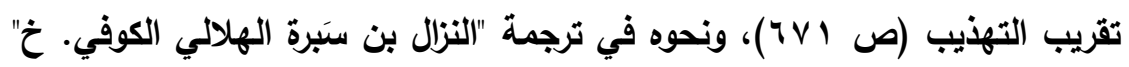

$$
\text { تقريب التهذيب (ص م ب ه). }
$$

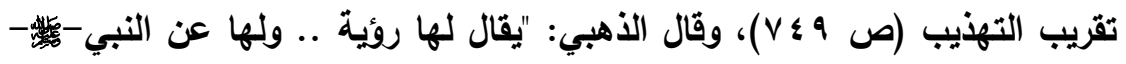

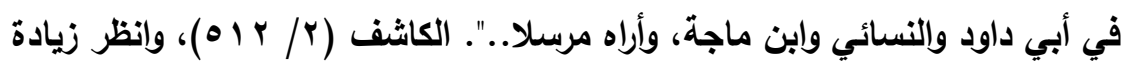

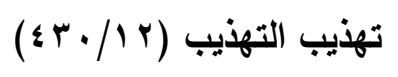


إزالة إيهام القائلين بوجود

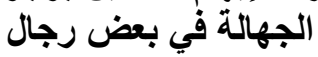

تقدم فـي المبحث الثـاني: المطلب الثـاني: "؟ - مقارنــة المرويـات. وَهـ التعامل مع رواة الصحيحين ليس لله اعتبار واحد .. فيقاس بألك جميع الرواة دون النظر إلى مقدار الإكثار أو الانتقاء في رواية الثيخين لهم، وقد ضعفت همة الباحث عن تفصيله والتفريق بين طبقات رواة إسناد البخاري ومسلم، وإنظر زيادة القاعدة ( • 1) في المطلب الثاني في المبحث الثاني.

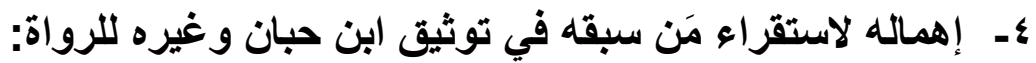

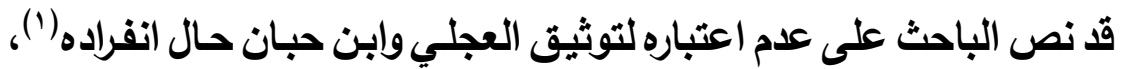
وانظر زيادة القاعدة (1 1) في المطلب الثاني السابق في المبحث الثاني. هـ دخوله في المحاكمة بين رأي الأهبي وابن حجر بقلة جمع ودراسة: وكان رأي الذهبي أن في الصحيحين رواة كثيرين لـ يوصفوا بجرح ولا تعديل بينما رأي ابن حجر : أن عددهم قليل جدا(؟)، وأنهما رويا لهم بالثهواهد لا بالأصـول - كـا نصسه - ممـا دفعـه للكتابـة، فكـان ذلـك سـبب البحـث

(1) انظر بحثه "من لم يوصف بجرح أو تعديل من رجال الصحيحين .." (صه). (Y) نقل الباحث النصوص عن الحافظين، وهي قول الأهبي في ميزلان الاعتدال

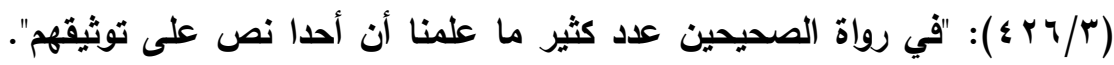
وكذا تعقبه في ميزان الاعتدال (1/7هـه) بن القطان الفاسي وقوله: "ابن القطان يتكلم في كل من لم يقل فيه إمام عاصر ذالك الرجل أو أخذ عمن عاصره ما يدل

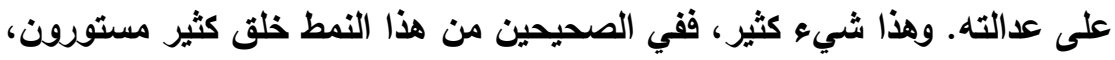

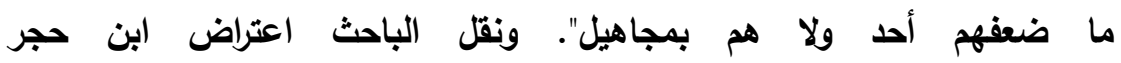
- على الكثرة المحكية في قول الأهبي - بقوله: "ليس كذلك بل هذا هذا شئ فئ نادر؛ لأن غالبهم معرفون بالثقة إلا من خرجا له في الاستشهاد". لسان الميزان (ب/0). مجلة كلية أصول الدين والدعوة بأسيوط / العدد السابع والثثلاثون 9 ا بام - الجزء الثالث 
لديها!!(')، ثم ذكر في نتائجها: النتيجة الأخيرة (ب ا ): "في ضوع مـا سبق

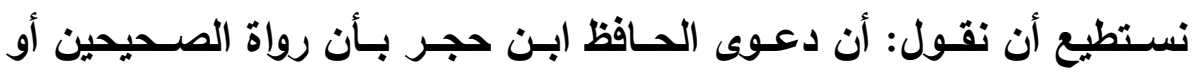

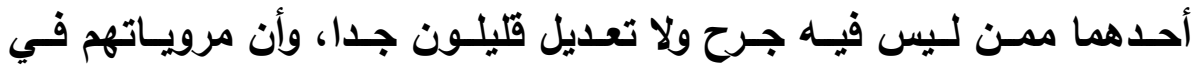
المتابعات والثشواهد لا في الأصول دعوى صحيحة، أما دعوى الحافظ الذهبي

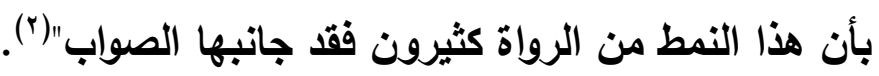

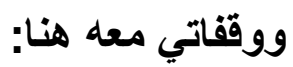

الأولى: تصحيحه لدعوى ابن حجر بأن مرويات من لم يوصفوا بجرح ولا

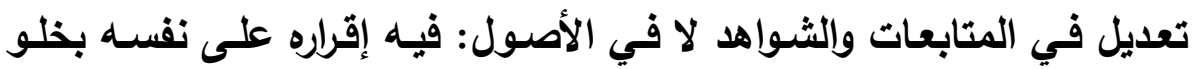
بحثه من روايات في الأصول لمن ترجم لهم والذين بلغ عددهم عنده (ro (r) وعليه كان خطأ ما جاء في غلاف بحثّ: "تأصيل قاعدة: أن رواية الثيخين

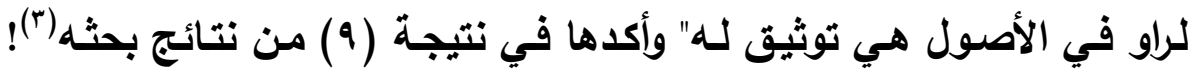

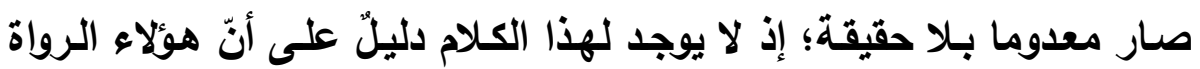
يوجد فيهم من حديثه في الأصول حتى يكون موثتقا بذلك، وهو بذلك يهام

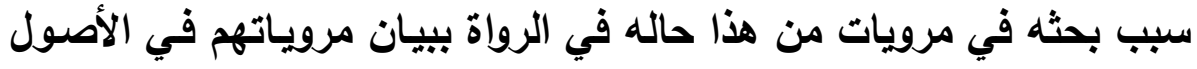

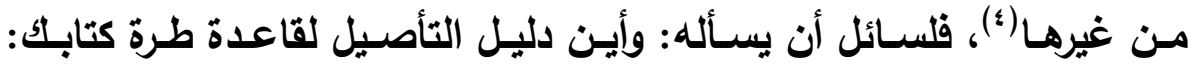

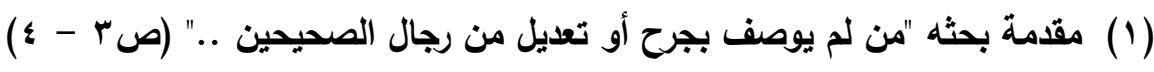

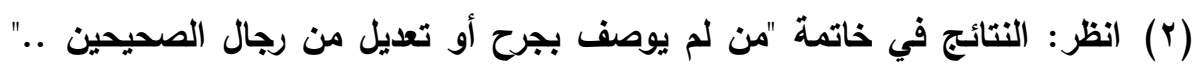

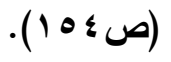

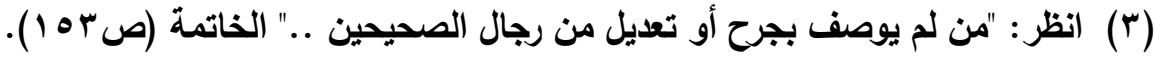

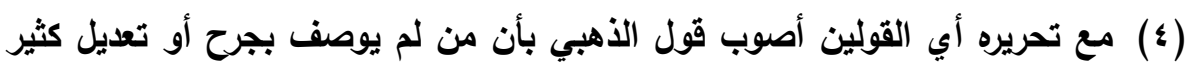

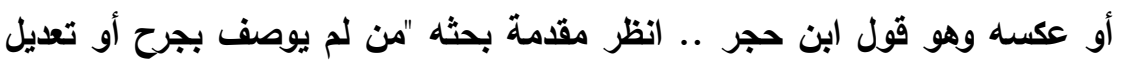

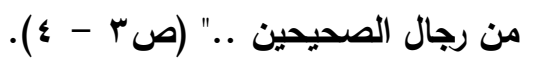
مجلة كلية أصول الدين والدعوة بأسيوط / العدد السابع والثثلاثون 9 ابـ بم - الجزء الثالث 
"تأصيل قاعدة: أن رواية الشيخين لراو في الأصول هي توثيق لله"، وذيلت

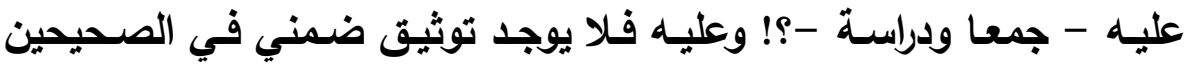
بهذه الحيثية التي جزم الباحث بوجودها في الصحيح؛.

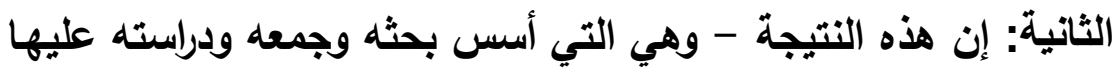

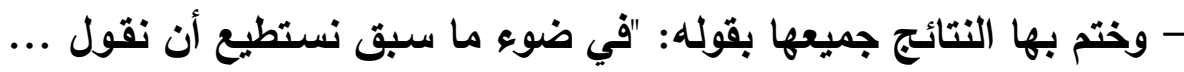

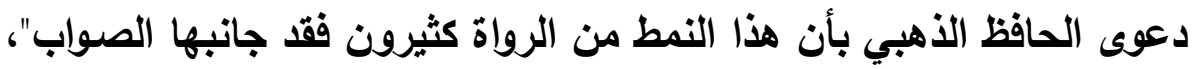

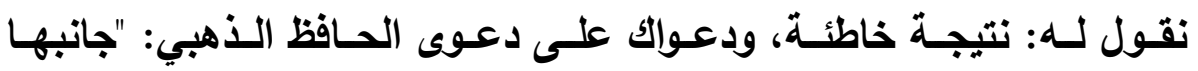

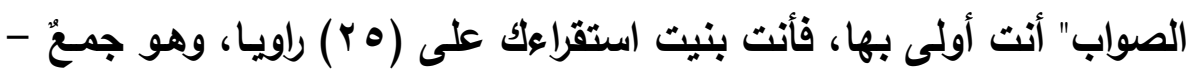

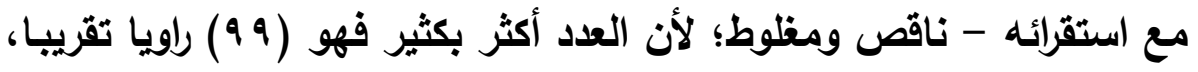

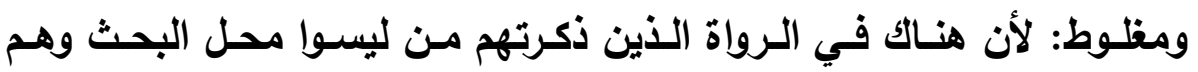

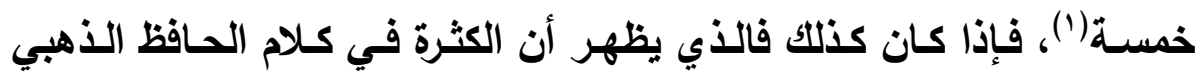

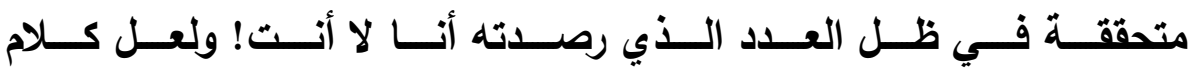

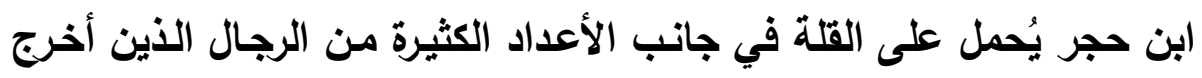
لهم صاحبا الصحيح، والله أعلم.

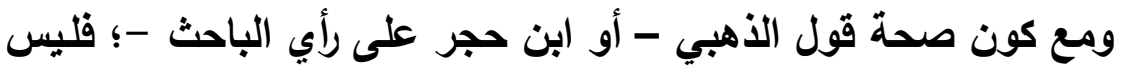

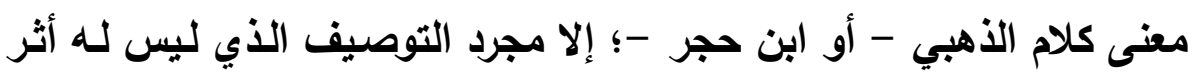

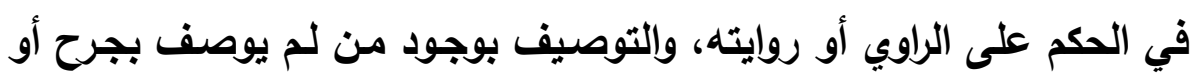

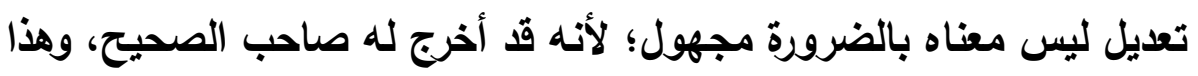

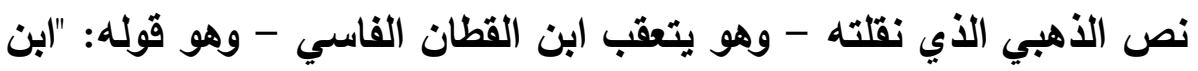
القطان يتكلم في كل من لم يقل فيه إمـام عاصر ذالك الرجل أو أخذ عمن التهن

(1) سيأتي ذكرهم بتفصيل في: المطلب الثاني في هذا المبحث. مجلة كلية أصول الدين والدعوة بأسيوط / العدد السابع والثثلثون 9 ـ بام - الجزء الثالث 
إزالة إيهام القائلين بوجود

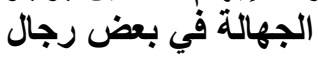

عاصره ما يدل على عدالته. وهذا شيء كثير، ففي الصحيحين من هذا النمط

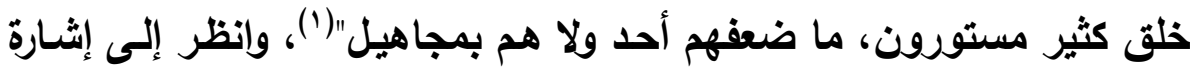

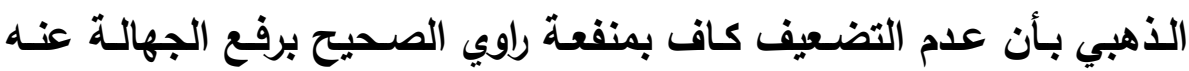

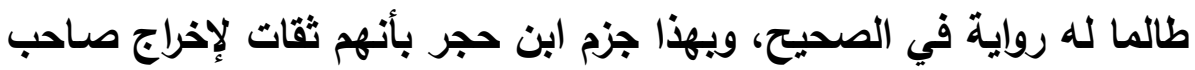

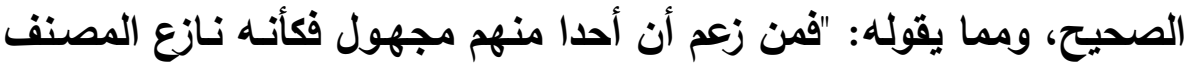

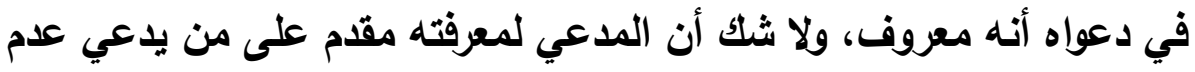

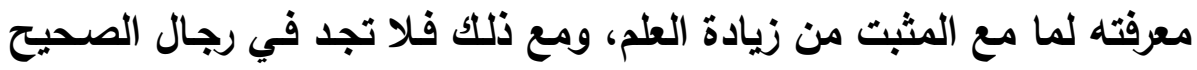

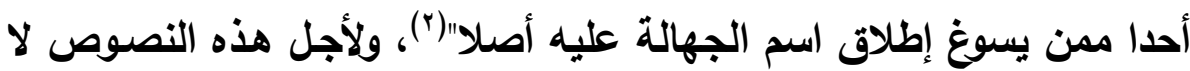

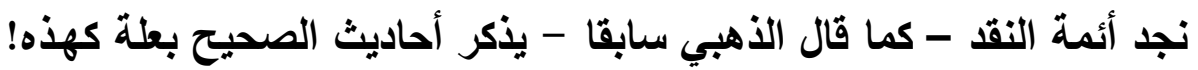
إلا من أمثال الباحث فنعم والباحث في طيات كتابه ينقل في غير ترجمـة

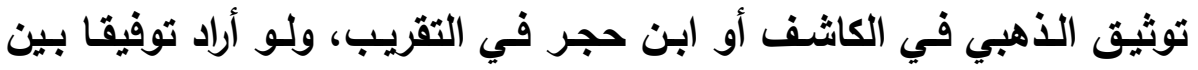

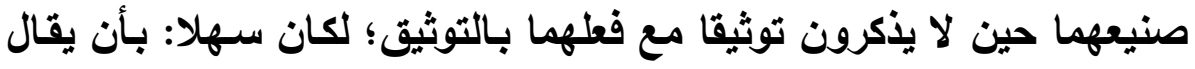

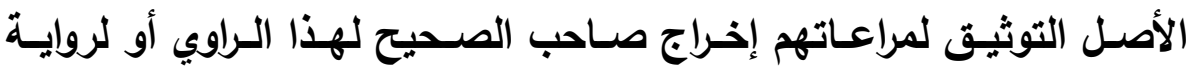

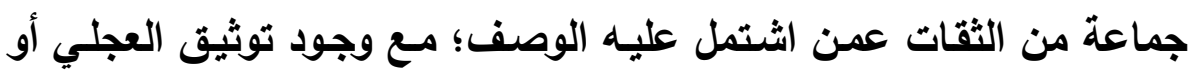

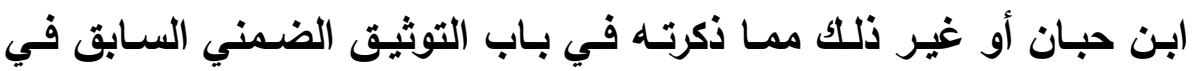

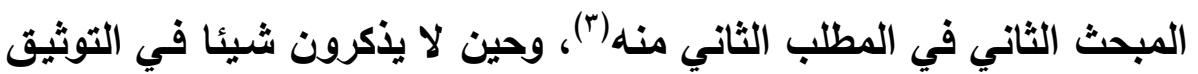

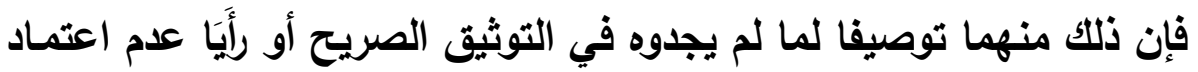

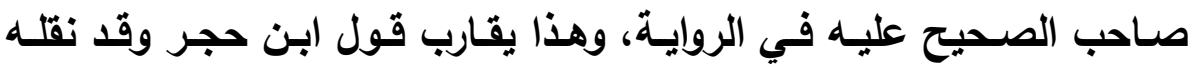

(1) ميزان الاعتدال (1/007)، وانظر مقدمة بحثه "من لم يوصف بجرح أو تعديل من

$$
\begin{aligned}
& \text { رجال الصحيحين .." (صبr). } \\
& \text { هدي الساري (ص ع^^r). }
\end{aligned}
$$

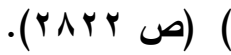


الباحث عنه: "غالبهم معرفون بالثقة إلا من خرجا لله في الاستثـهاد"( (). ومن

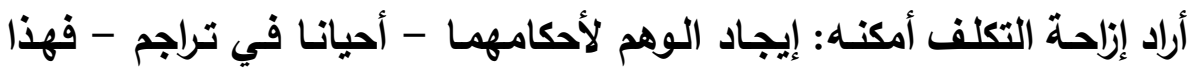

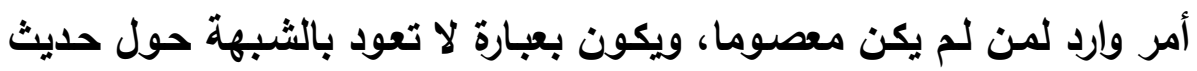
الصحيحين، والله أعلم.

وهنا أتساءل: الباحث لا يلتفت بعد نقله التوثيق الصريح من الذهبي(؟)

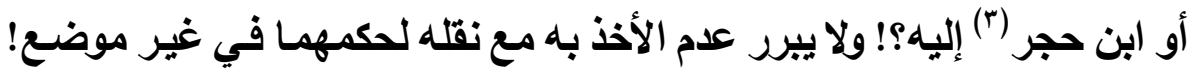
وهذا مـن حيث البحث العملي ينـاقض في كون أن الترجمـة التي يسوقها قاعدتها عنده لـم توصف بجرح ولا تعديل! بعمومـه وغنوان كتابـه "من لـ لـ

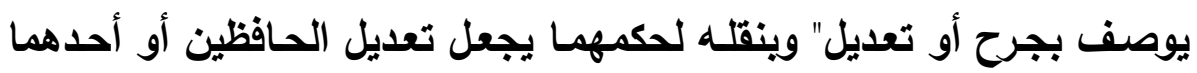

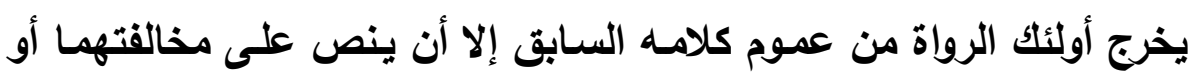

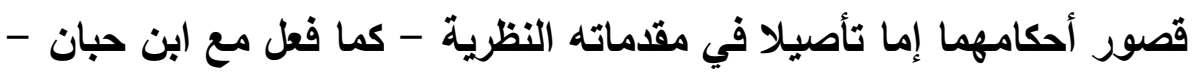

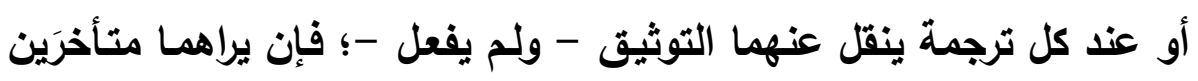

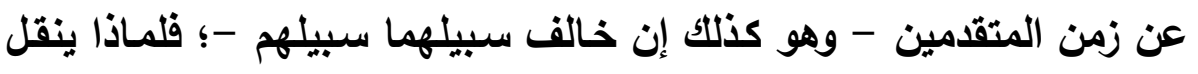
عنهما أصلا دون تعقب؛ بل لماذا أصلا يلتفت إلى خلافهما في كثرة - أو قلة كلة - عدد من لم يوصف بجرح أو تعديل، ويجعل خلافهما سبب تأليف بحثنه

(1) لسان الميزان (Y/0)، وانظر : مقدمة بحثه "من لم يوصف بجرح أو تعديل من رجال

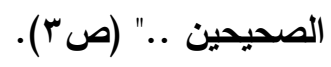

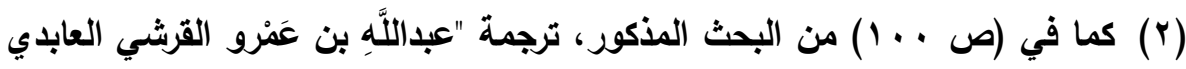

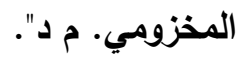

(r) كما في (ص 9 9 ـ 1) من البحث، ترجمة "محمد بن كعب بن مالك بن أبى القين

$$
\text { الأنصاري السلمي المدني. م دل". }
$$


إزالة إيهام القائلين بوجود

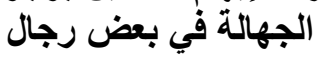

لينظر الراجح في قولهما؟! فالمتقلمون لم يخوضوا في ذلك ولم يعللوا حديثا به، وهم أعرف الناس بالصحيح، وأحرص الناس على العلم والقيام بالنصح

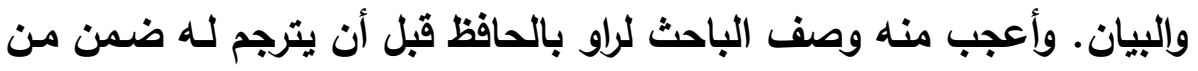

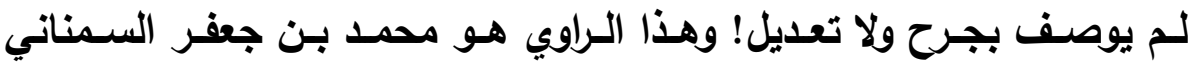

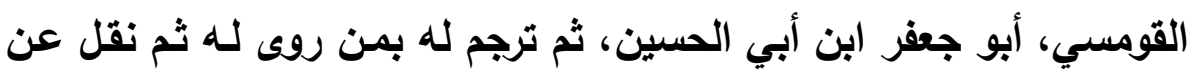

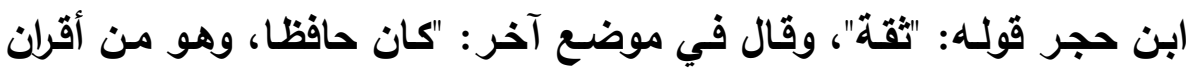

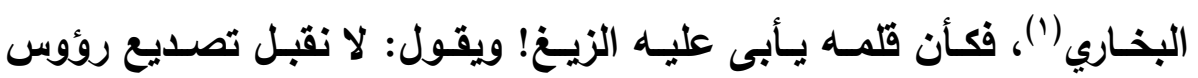

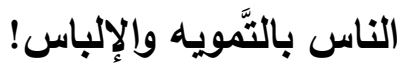

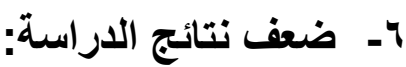

موضوع عمل الباحث في جمـع ودراسـة من لم يوصف بجرح أو تعديل،

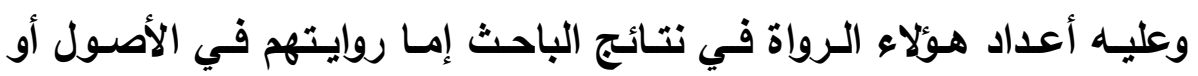

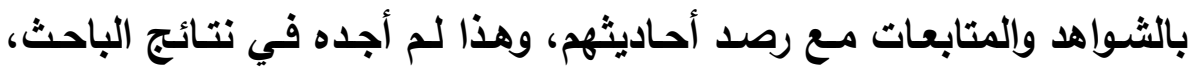

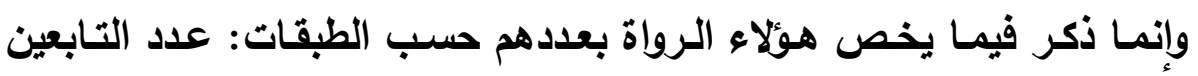

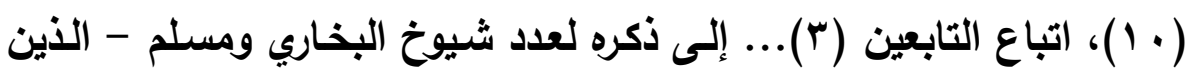

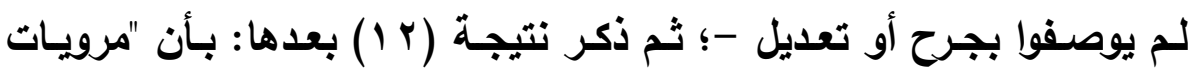

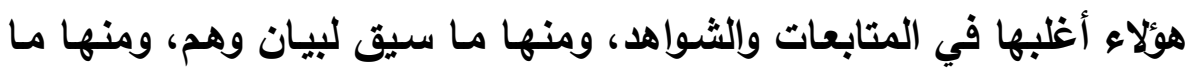

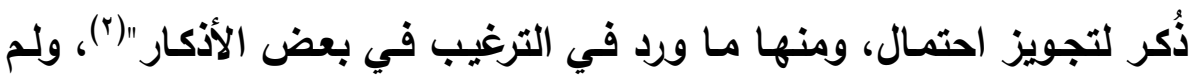

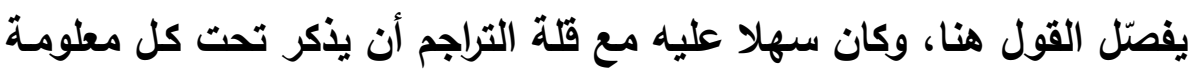

(1) كما في (ص/Y1 1 ) من بحثه "من لم يوصف بجرح أو تعديل من رجال الصحيحين".

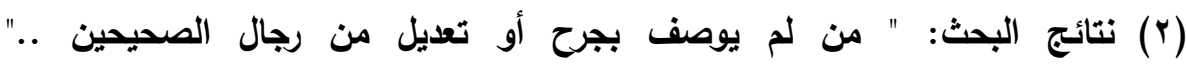

$$
\text { (ص - (10r) }
$$
مجلة كلية أصول الدين والدعوة بأسيوط / العدد السابع والثثلاثون 9 ا ـ بم - الجزء الثالث 
هنـا مَن يستحق مسن الرواة أن يكون فيها! وقولـه: "أغلبها ... ومنهـا ..." يجعلنــي أفهـم أنــه لا يوجــ مرويـات فـي الأصـول لأن الأغلـب بالثــواهد والمتابعات وما يقابله الأقل - حسب نصه - لما ساقه بعدُ بقوله: "ومنها مـا سيق لبيان وهم، ومنها مـا ذُكر لتجويز احتمال، ومنها مـا ورد في الترغيب في بعض الأزكار"، فإن كان كذلك فلا توجد مرويات في الأصول! وهذا الذي وجدته في جميع التراجم على نفس تقسيمه مع ما فيه من تثويش في بعض التراجم حيث لا يـكر تتصيصـه عندها على مـا سبق من تفصيل! فإن قال: قولي: "ومنها ما سيق لبيان وهم، ومنها مـا ذُكر لتجويز احتمال، ومنها مـا ورد في الترغيب في بعض الأذكـار" إنمـا هو تفصيل للأغلب! لقلنـا: وأيـن تنصيصه في صلب البحث عند تلك الروايات أو الرواة الذين مروياتهم في الأصول، وكم هم الأين بالشواهد والمتابعات، وكم عدد أحاديث كل الو اعتمد عليه .. فلما لم نجد بالتتبع صـار الاحتمال الأول والمفهوم من نصك، وهو عدم وجود مرويات في الأصول لرواة لم يـكروا بجرح ولا تعديل، ويصبح مـا في عنوان بحثلك مـع نتيجة (9) - وغيره مما في طيات مقدمتك المعنية بـ "أن رواية الشيخين لراو في الأصول هي توثيق له ولو كان مستورا" = ليس

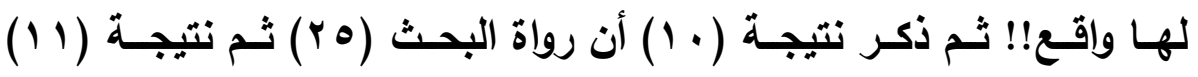
تفصيلهم على الطبقات، ثم نتيجة (Y I ) يقول: "أن مرويات هؤلاء أغلبها في المتابعات وإلثواهد ..."(1)، وجميع النتائج ليس فيها إحصاء دقيق غير عدد الرواة في البحث وتقسيمهم على الطبقات، فلم أجد لـه فنلكـة مفيدة في

(1) نتائج البحث " من لم يوصف بجرح أو تعديل من رجال الصحيحين .."

$$
\text { . (ص - (10r) }
$$


النتائج تريح القارئ عن عيّ التتبع بالرجوع والتفتيش كما أعياني، فإذا رجع وفتش مثلي لم يجد الدقة والبيان ولا صريح الدفاع ولا تحرير يورث الانتفاع! ولالك لم يكن من منهج الباحث غاية مفيدة حين قال: "رواية الشيخين لراو في الأصول هي توثيق له"، فضلا عن كونها قاعدة ادعى التأصيل لها؛ فـلا

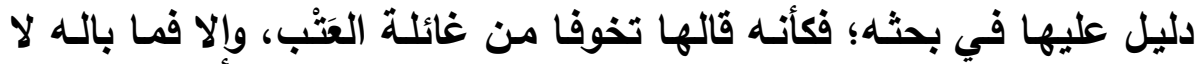
يصرّح بكلمـة واحدة في النتـائج وهـي: "لا يوجد مجهول في الصـيحين"! ليطابق تأسيسه في مقدمته!! فمن لم ينصف بحثه بالدقة والتحري أنى له أن ينصف الصحيحين وصاحبيه!! وهو بذلك لا يُثِّبت مهابة الصحيح في صدره ثم لقرّائسه - وهـي ثابتة بحمد الله في صدور المؤمنين -؛ حتى لا يقدر على التعدي المنطوي الردي!! 


\section{الاملب الثاني \\ المثال العلمي لابمهع والدراسة}

لا يمكن أن ينتهي البحث بما تقدم من تقعيد وتأصيل وشرح دون ذكر فئه

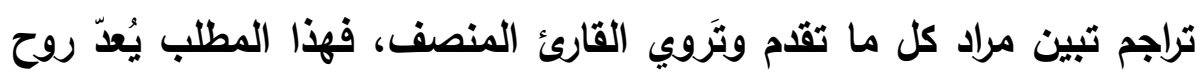

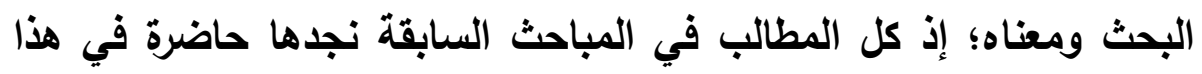

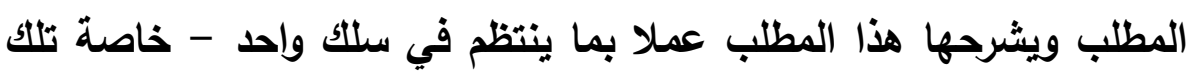
القواعد السابقة المذكورة في المطلب الثاني في المبحث الثاني(')-ـ؛ فليكن

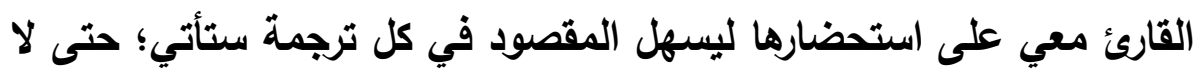

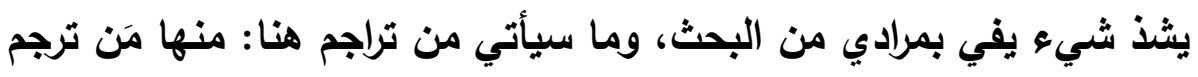

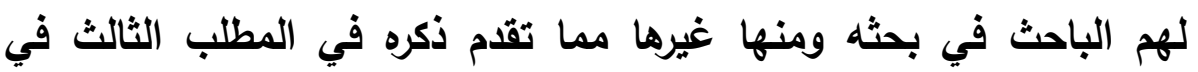

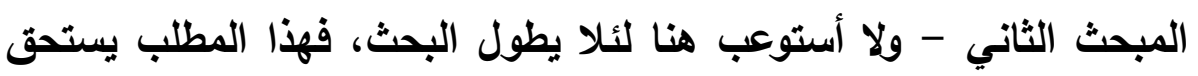
إفرادا في مؤلف خاص؛ وإنما الأمر لبيان القصور الوارد عند الباحث وغيره

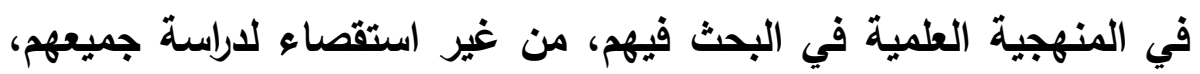

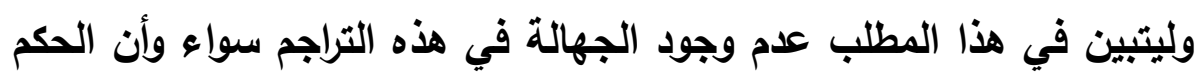

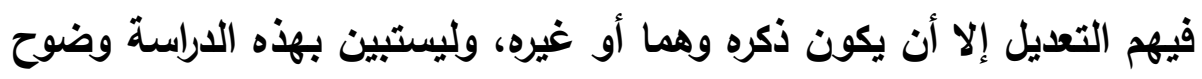

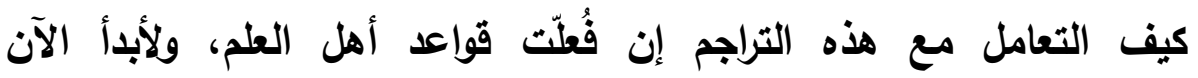
بالمقصود: ا - رافع مولى مروان بن الحكم ويوابه: هذه أول ترجمة عند الباحث، وقد

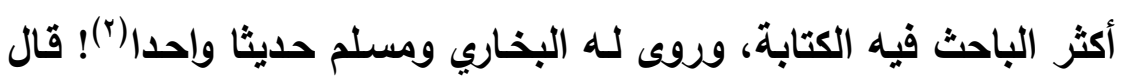

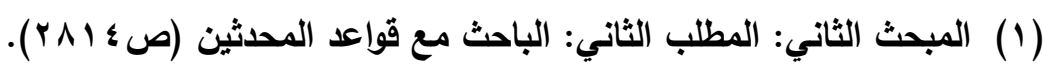
(ץ) من لم يوصف بجرح ولا تعديل (ص^^). مجلة كلية أصول الدين والدعوة بأسيوط / العدد السابع والثثلاثون 9 ا ـ بم - الجزء الثالث 
(بن حجر: "مقبول، من الثالثة"(1).

والباحث ذكـره في أول تـراجم بحثـه، وســأنقل كـلام الباحث هنـا كـاملا - بحواشيه - حتى يكون القارئ على مقارنة بين مـا قالـه وأقولـه عقبه، قال الباحث(ץ): "رافع المدني بواب مروان بن الحكم خ م س ت: هو من الطبة

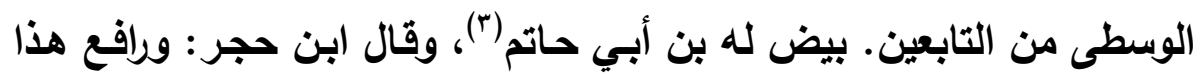

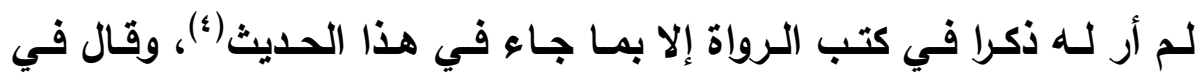
التقريب: "مقبـول"()، يعني عند المتابعـة. وروى لـه البخـاري ومسـلم حديثا واحدا: قال الإمام البخاري: حدثي إبراهيم بن موسسى، أخبرنا هشام(؟) أن بن جريج أخبرهم عن بن أبي مليكة أن علقمـة بن وقاص أخبره أن مروان قال لبوابه: اذهب يا رافع إلى ابن عباس فقل: لئن كان كل امرئ فرح بما أوتي مئ

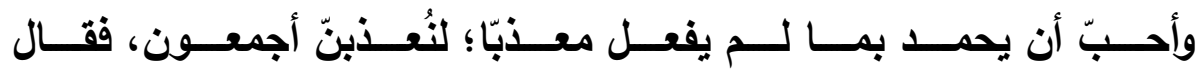

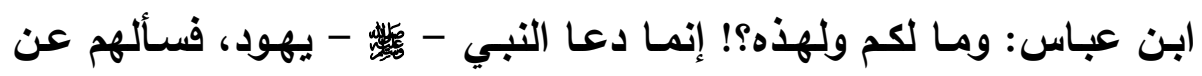
شيع، فكتموه إياه، وأخبروه بغيره، فأروه أن قد استحمدوا إليه بما أخبروه

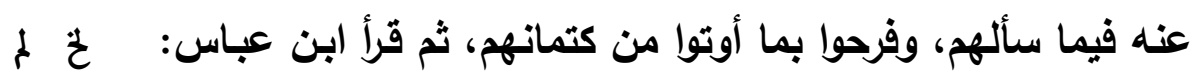

$$
\begin{aligned}
& \text { (1) تقريب التهذيب (ص ه •r). }
\end{aligned}
$$

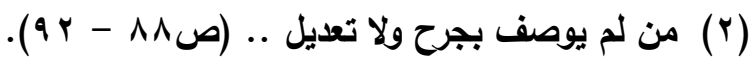

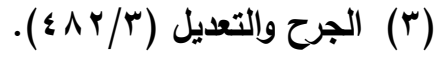

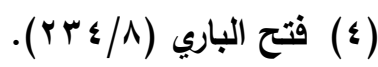

$$
\begin{aligned}
& \text { (0) تقريب التهذيب (ص ه • (Y). } \\
& \text { (7) هو هثام بن يوسف الصنعاني ... }
\end{aligned}
$$


إزالة إيهام القائلين بوجود

الجهالة في بعض الفالين بوجال

(1)

، كذلك حتى قولـه:

له لي

تابعه عبدالرزلق عن بن جريج(؟).

ثـم قـال: حدثنا بـن مقاتلـ، أخبرنـا الحجـاج؛ عن بـن جـيج، أخبرنـي

ابن أبي مليكة، عن حميد بن عبدالرحمن بن عوف أنه أخبر أن مروان بهذا"َ). وقـال الإمـام مسـلم (؛): حـثنا زهيـر بـن حسب وهـارون بـن عبـدالله

- واللفظ لزهير - قالا: حدثنا حجـاج بـن محمد، عن بن جريج، أخبرني ابن أبي مليكة أن حميد بن عبدالرحمن بن عوف، أخبره: أن مروان قال: اذهب يا رافع - لبوابهه - إلى ابن عباس؛ الحديث، ولم يسق مسلم روايـة علقمة بن وقاص.

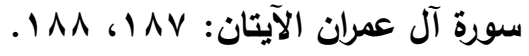

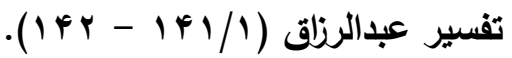

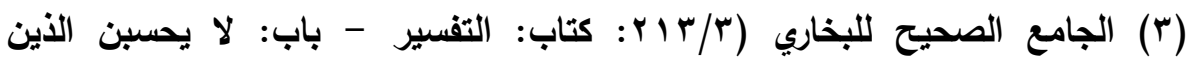

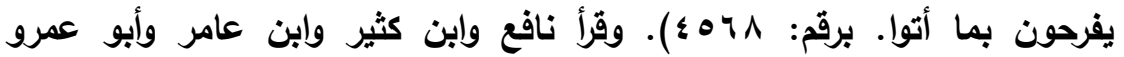

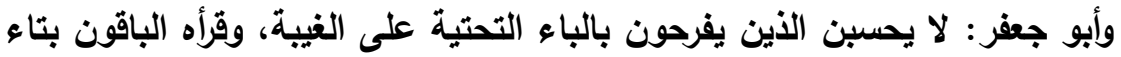

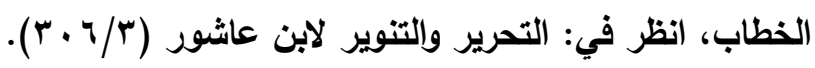

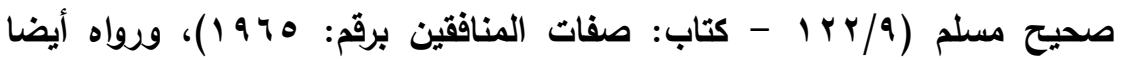

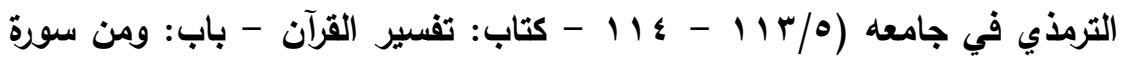

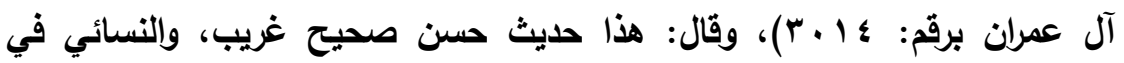

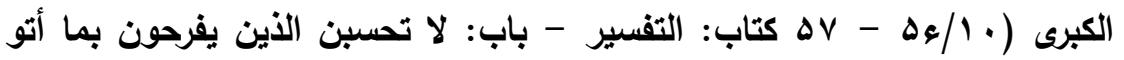

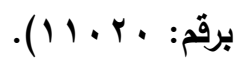


أقـول (الباحـث): رافـع مجهـول العـال فقـط إن كـان كـل مـن علقـــة

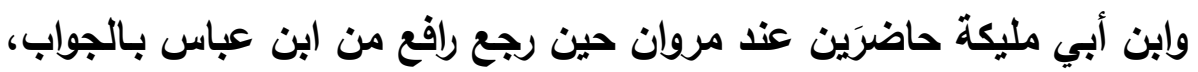

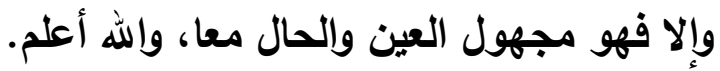
اعتراض الإسماعيلي على البخاري وجواب ابن حجر عنده ومناقشـة العيني

لقـ اعترض الحسافظ الإسـماعيلي على الإمـام البخـاري إخراجـه لحـيث ابن عباس بوجود علتين فيه، إحداهما: الاختلاف على ابن جريج، والأخرى:

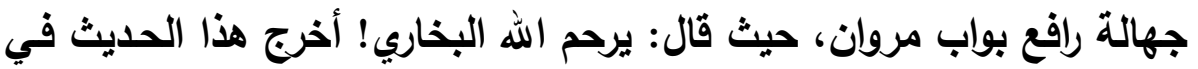

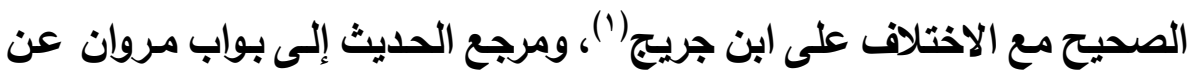
ابن عباس، ومروان ويوابه بمنزلة وإحة، ولم يذكر حديث عروة عن مروان الجان

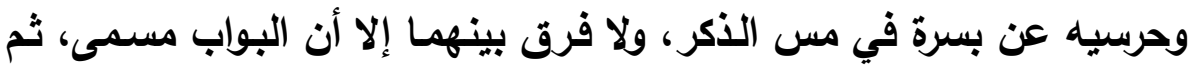
لا يعرف إلا هكذا، والحرسيّ غير مسمى، والله يغفر لنا وليه(؟).

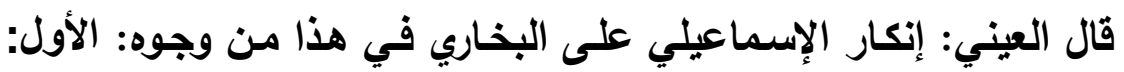

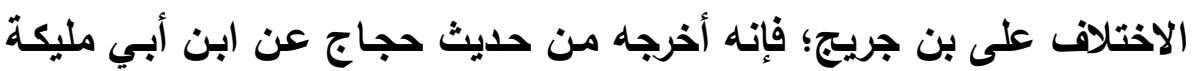
عن حميد، وأخرجه أيضا من حليث هثام عن ابن جريج عن ابن أبي مليكة الآنه

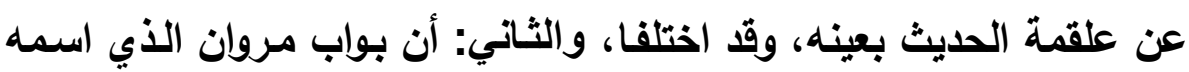
رافع مجهول الحال، ولم يُذكر إلا في هذا الحديث، والثالث: أن البخاري لـ

(1) نقل الباحث في هذا الموضع (الحاشية) كلام الدارقطني في الإلزامات والتتبع، وكلام

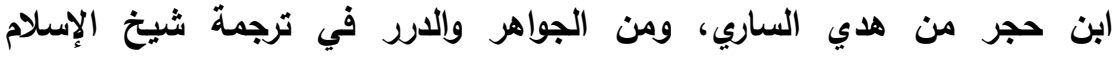
ابن حجر للسخاوي، وسيأتي نقل كلامه في الأصل، وكان ينبغي للباحث أن يجطله

في الأصل كما سأبينه.

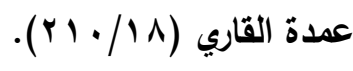
مجلة كلية أصول الدين والدعوة بأسيوط / العدد السابع والثثلاثون 9 ا ـ بم - الجزء الثالث 
إزالة إيهام القائلين بوجود

الجهالة في بعض الفالين بوجال

يورد في صحيحه حديث بسرة بنت صفوان الصحابية في مس الذكر، ولا فرق

بينه ويين حديث الباب لما ذكرنا (1).

وقد أجيب عن جهالة رافع بأمرين:

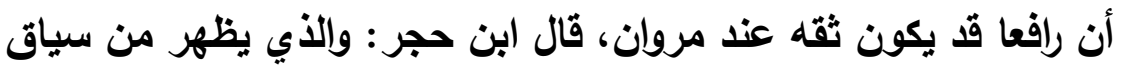

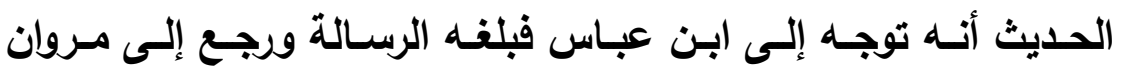

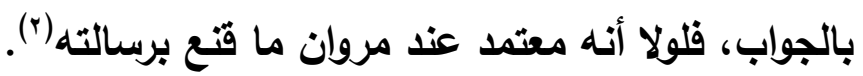

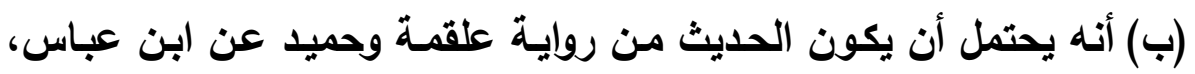

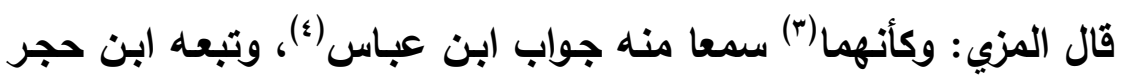
فقال: يحتمل أن يكون علقمة بن وقاص كان حاضرا عند ابن عباس لما

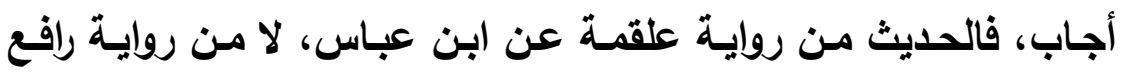

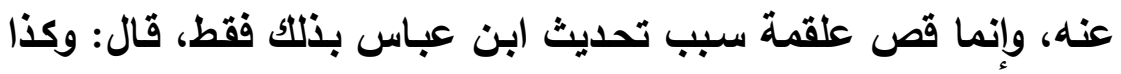

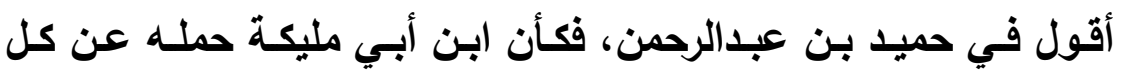
منهما، وحدث بها ابن جريج عن كل منهما؛ فحدث بها ابن جريج تارة

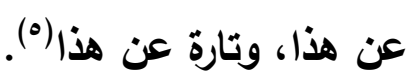

واستبعد العيني احتمال سماعهما جواب ابن عباس فقال: لو كان علقمـة

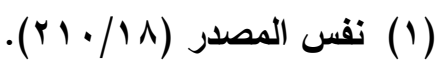

$$
\begin{aligned}
& \text { (r) }
\end{aligned}
$$

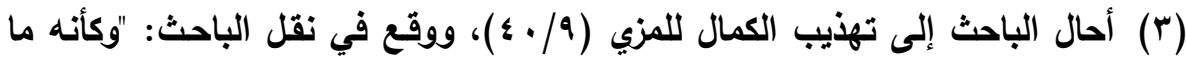

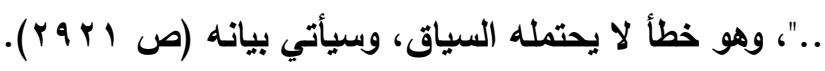

$$
\begin{aligned}
& \text { (ه) تهذيب الكمال (9/9 • ؛). }
\end{aligned}
$$

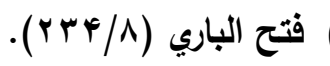


إزالة إيهام القائلين بوجود

الجهالة في بعض الفالين بوجال

حاضرا عند ابن عباس عند جوابـه لكان أخبر ابن أبي مليكة أنها سمع ابن

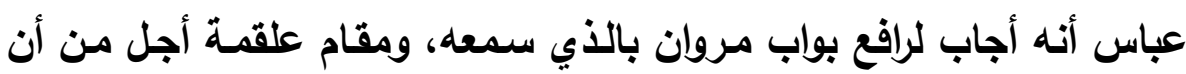
يخبر عن رجل مجهول الحال بخبر قد سمعه عن ابن عباس وترك ابن بـن

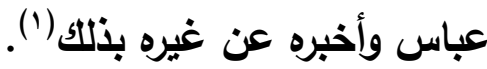

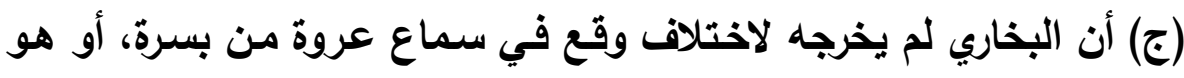

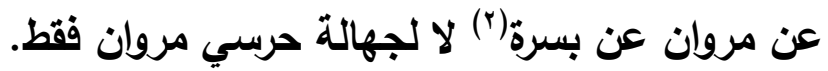

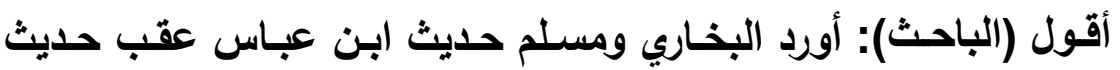

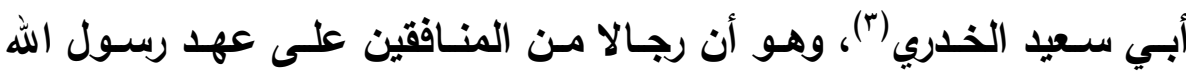
-

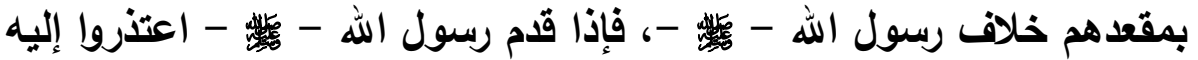

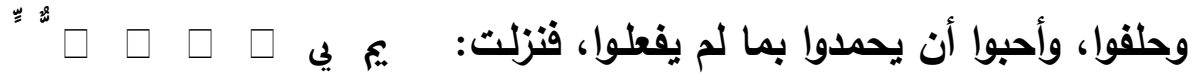

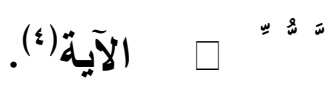

ففي حديث أبي سعيد الخدري أنها نزلت في المنافقين الذين اعتذروا عن الغزوة، وفي حديث ابن عباس أنها فيمن أجاب من اليهود بغير ما سأل،

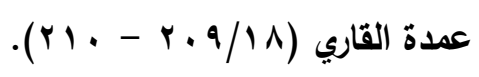

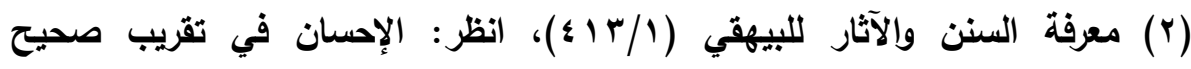

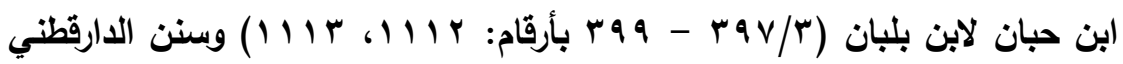

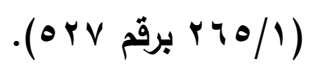

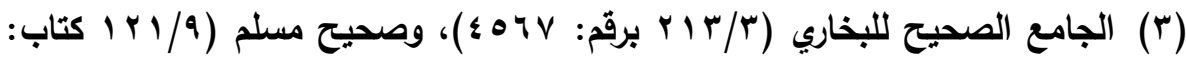

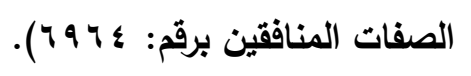

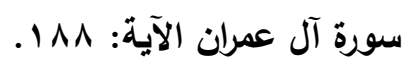


وكتموا ما عندهم من ذلك، وقد يفهم من تصرفهما أن الأصل هو حديث أبي سعيد الخدري، وساقا حديث ابن عباس - مـع كونـه ليس على شرطهما للإثارة إلى احتمال نزول الآية في المنافقين واليهود معا.

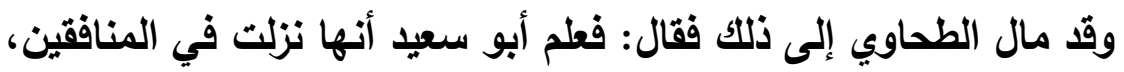
وعلم ابن عباس أنها نزلت في اليهود، ولم يعلم واحد منهما ما علم الآخر،

فكان نزولها في الحقيقة في السببين جميعا لا في أحدهم دون الآخر ('). وقال ابن حجر: ولا مانع أن تكون نزلت في كل ذلكا أو نزلت في في أثبياء

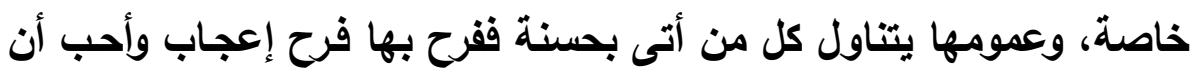

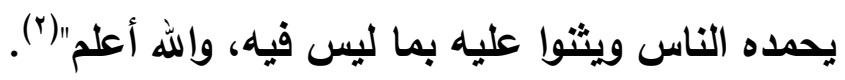

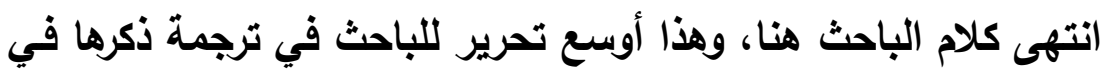

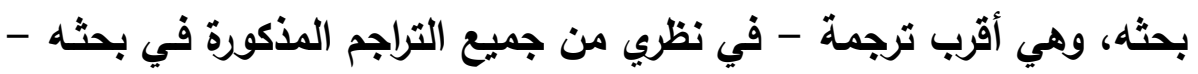

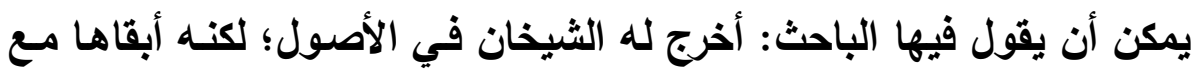

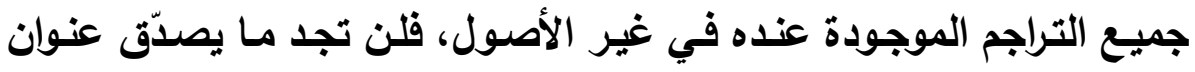

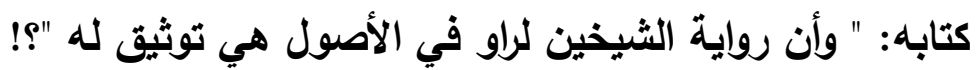

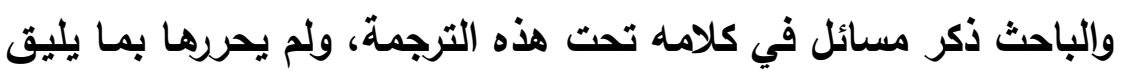
بالبحث، ويما يليق من خدمة الصحيحين، وهي: الأولى: جهالة رافع بواب مروان. الثانية: سماع علقمة وحميد الحديثَّ من ابن عباس. الثالثة: الاختلاف الواقع في الرواية.

$$
\begin{aligned}
& \text { شرح مشكل الآثار (19/0 - . . (9). } \\
& \text { فتح الباري (I/^) }
\end{aligned}
$$
مجلة كلية أصول الدين والدعوة بأسيوط / العدد السابع والثلاثون 9 الـ بم - الجزء الثالث 
الرابعة: إلزام البخاري بحديث آخر (وهو حليث بسرة بنت صفوان ك). الخامسة: رواية رافع عن ابن عباس على غير شرط الصحيحين، وعلاقة ذلك

بتعدد سبب نزول الآية فهذه خمس مسائل سأفصل القول فيها: أما الأولى: وهي جهالة رافع بواب مروان: فبعد ذكر الراوية قال الباحث: "رافع مجهول الحال فقط إن كان كل من علقمة وابن أبي مليكة حاضرَين عند مروان حين رجع رافع من ابن

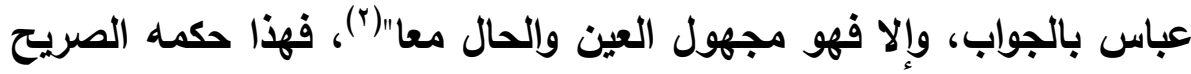
على بواب مروان، وقوله: "إن كان كل من علقمة وابن أبي مليكة حاضرَين

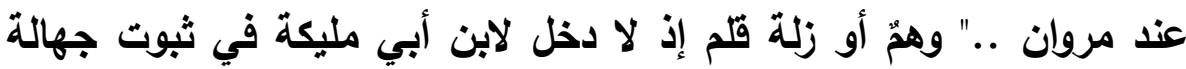

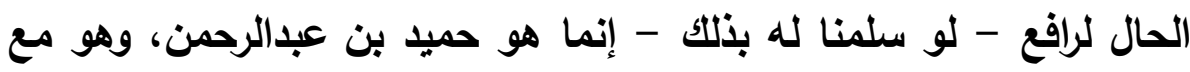
علقمة مَن أخبرا ابن أبي مليكة في الروايتين: أن مروان أرسل بوابه، ثم ثمان

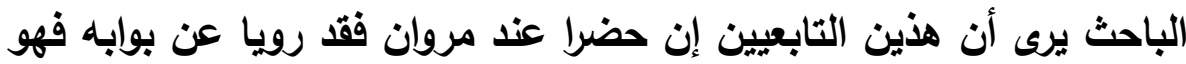
مجهول حال وإلا فهو مجهول عين، ولا أدري لماذا يشترط الباحث حضورهما مجلسَ مروان لرفع جالة العين، أليست الرواية ظاهرة في وجود راويين عن رافع: ففي صحيح البخاري ومسلم رواية حمي وفي صحيح البخاري وحده رواية علقمة، ألا يكفي هذا أن يكون هناك تابعيان كبيران يرويان عن رافع من غير شرطه المذكور بالحضور - فيرفعان جهالة العين التي يتكلم عنها الباحث إلا أن يكون الباحث عنده انقطاع أو يرى الباحث أمرا آخر قويا يعارض وجودهما، وهو الاحتمال الآخر الذي لم يفصح عنه حين عرض إل لئ

$$
\text { "من لم يوصف آل عمران الآية: 11 إ. }
$$
مجلة كلية أصول الدين والدعوة بأسيوط / العدد السابع والثلاثون 9 الـ بم - الجزء الثالث 
الاحتمالين! فلعله متردد في ثبوت روايتي حميا وعلقمة لما ذكره عن الإسماعيلي من اختلاف والباحث قد سكت عما قيل من اختلاف في الرواية!

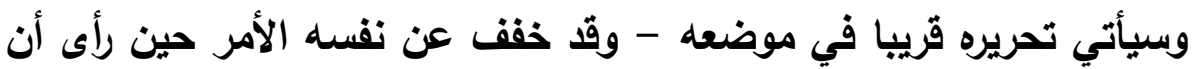
الرواية ليست في الأصول -؛ لأنه لو ثبت الحديث من الطريقين عنده كما

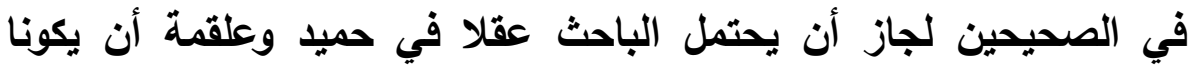

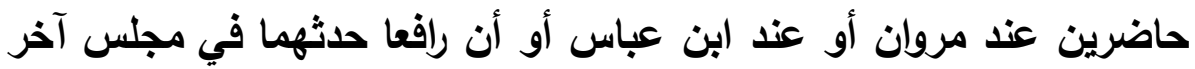

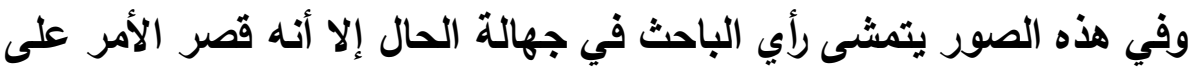
صورة واحدة وهي حضورهما عند مروان؟ وأما جهالة العين فصوره الممكنة:

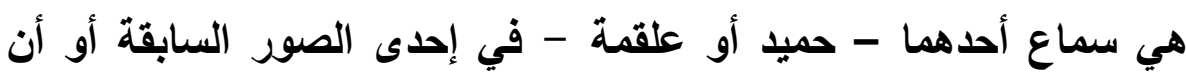

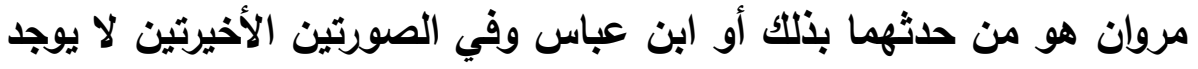

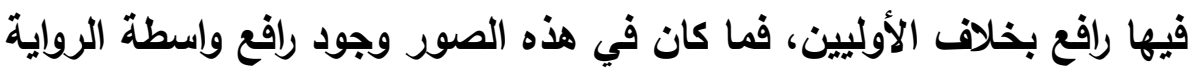

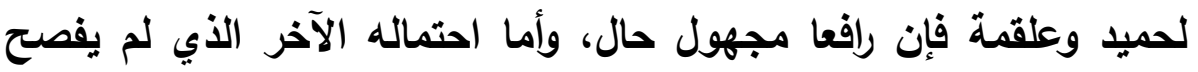

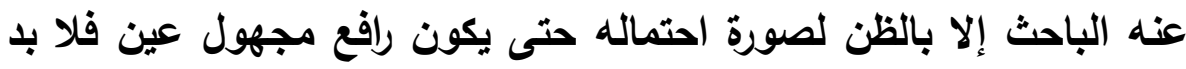

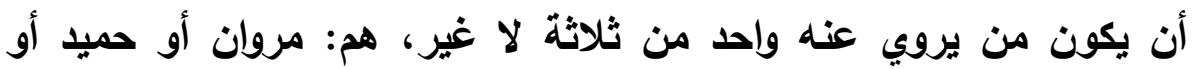
علقمة، والأخيران لا يمكن القول بأحدها إلا لمن يرى أن إحدى الرئه الرايتين

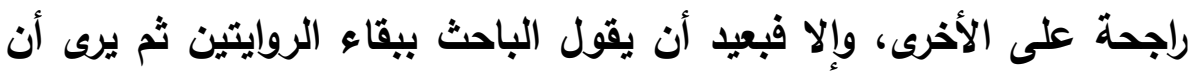

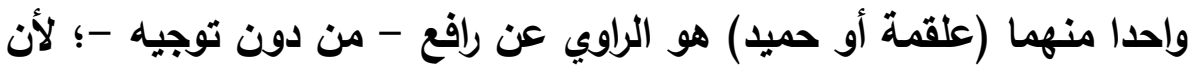

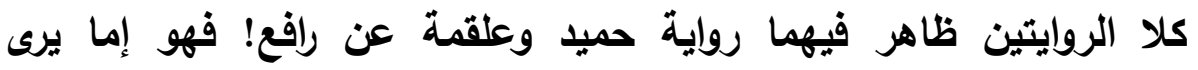

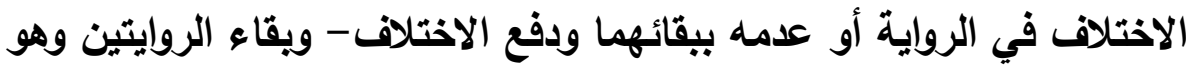

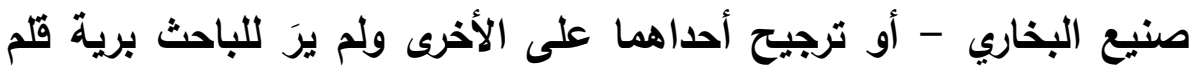

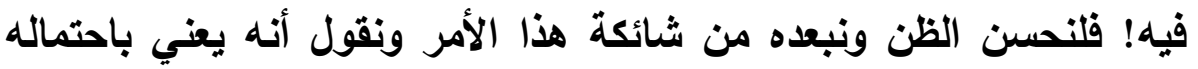
الآخر: أن مروان يروي عن رافع، ويشكل عليه أن مروان سيكون من رجال 
إزالة إيهام القائلين بوجود

الجهالة في بعض الفالين بوجال

الإسناد، ولم يُنكر أن مروان من رجال مسلم- أصلا - عند من يترجم لرجال

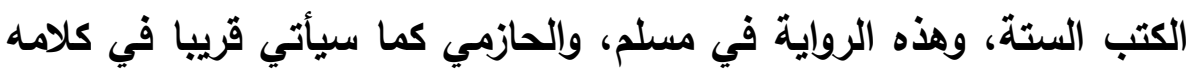
على حديث بسرة إثشارة إلى أن مروان من رجال مسلم، حيث قال: "احتجا أي البخاري ومسلم- بسائر رواة حديثها - أي بسرة -؛ مروان فمن دونه"(')، وليس بيعيد هذا القول اعتمادا على هذه الرواية، ومما سبق يتضح

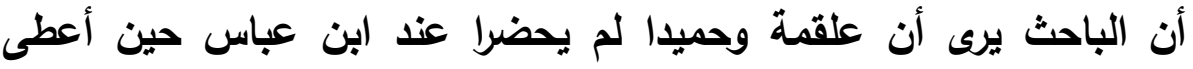
الجواب لرافع؛ لأنه لا يدخل في سياق احتماليه، وهذا أمر مهم سيأتي ذكره

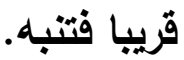

والحاصل أن رافعا مجهول عند الباحث، ومن اعتمد عليهما في بحثه في هذا الرأي هما الإسماعيلي والعيني. ثم ذكر الباحث ردا على رأيها ومن سلفه فيه، فقال(؟): وقد أجيب عن جهالة رافع بأمرين:

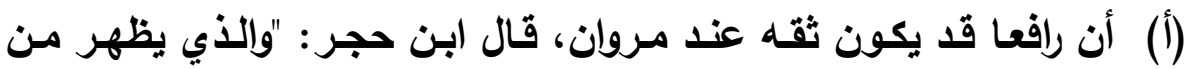
سياق الحديث أنه توجه إلى ابن عباس فبلغه الرسالة ورجع إلى مروان بالجواب، فلولا أنه معتمد عند مروان ما قتع برسالته" (").

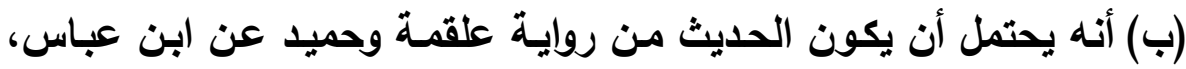

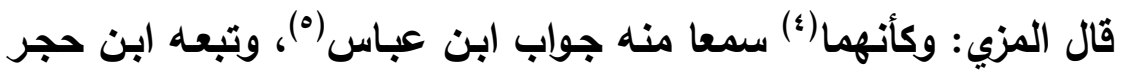

(1) (باله الحازمي في الاعتبار في الناسخ والمنسوخ (ص 0 ؛).

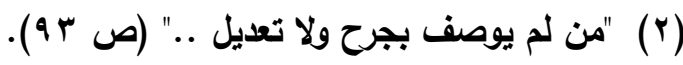

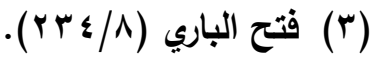

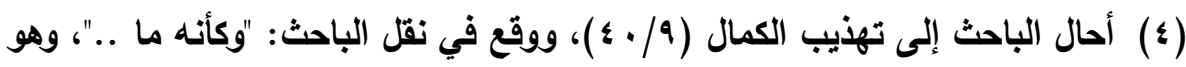

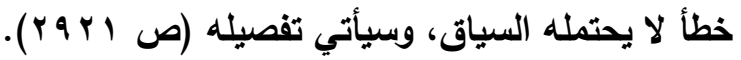

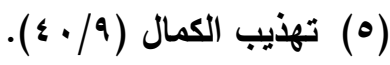
مجلة كلية أصول اللين والدعوة بأسيوط / العدد السابع والثلاثون 9 ا بام - الجزء الثاثث 
إزالة إيهام القائلين بوجود

الجهالة في بعض الفين بوجال

فقال: يحتمل أن يكون علقمة بن وقاص كان حاضرا عند ابن عباس لما

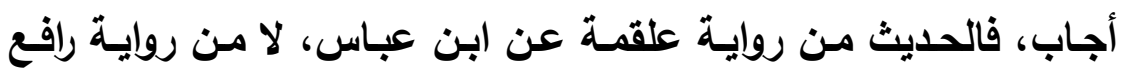
عنه، وإنما قص علقمة سبب تحديث ابن عباس بذلك فقط، قال: وكذا أقول في حميد بن عبدالرحمن، فكأن ابن أبي مليكة حمله عن كل منهما، وحدث بها ابن جريج عن كل منهما؛ فحدث بها ابن جريج تارة

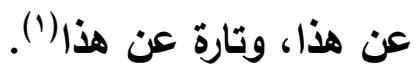

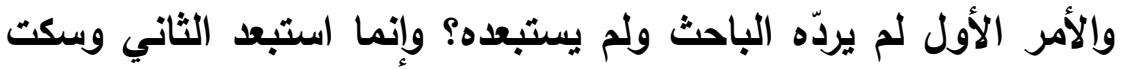
عن الأول؟؟ وستأتي مناقشة الأمر الثاني، لكن الباحث وإن لـ يناقشه؛ فقد صرح بأن الراوي مجهول حال أو عين، فإذن هو لمجرد ذكر رد لابن حجر في دفع الجهالة: بأن رافعا معتمد عند مروان وإلا ما قنع بحمله جواب ابن عباس، وهذا وإن لم يكن محل قناعة عند الباحث؛ فإنه يتمشى مع تلك القواعد التي ذكرتها سابقا في المبحث الثاني، ومنها في التعامل مع التابعين على غير التعامل مع سائر الرواة، والنظر في عدم وجود نكارة فيما يُروى وغير ذلك .. ثم توثيقه يجري على الأصل في كل ترجمة من تراجم رجال الصحيحين، فإخراج صاحبي الصحيح لراو توثيق لله - إن كان في الأصول -، وهذا هو التوثيق الضمني الذي أرجو أن يعتقده الباحث - ولم ينص عليه هاهنا في ثنايا الأخذ والرد الأي يستفيده الباحث بين الإسماعيلي وغيره؛ فكيف إذا انضم إليه قول الإمام الترمذي عقب إخراجه لهذا الحديث: "

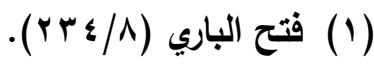
مجلة كلية أصول الدين والدعوة بأسيوط / العدد السابع والثثلاثون 9 اــم - الجزء الثالث 
حَسَنُ غريب صحيح "(1)، وقد نقل ذلك الباحث عند تخريجه للحديث في

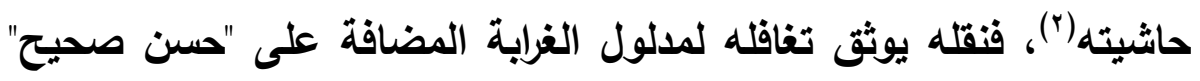
عند الترمذي! وكذا تركه لكلام الإمام الذهبي في قوله - وقد نقل شيئا منه

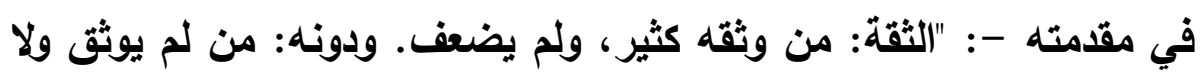

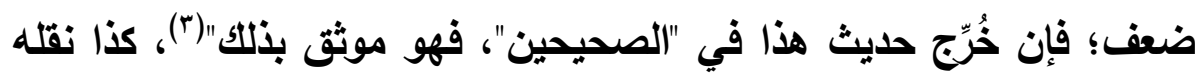

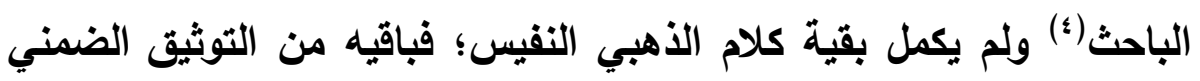

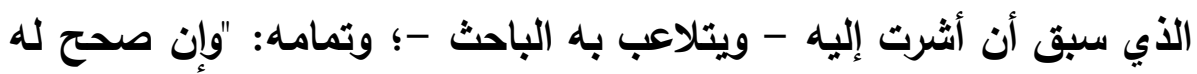

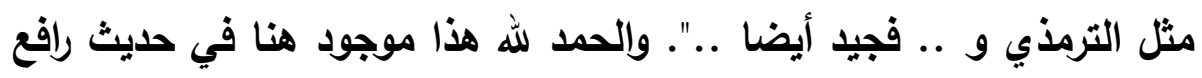
بوّاب مروان فقد خرج حليثه الترمذي ثم قال: "حَسَنْ غريب صحيح" . .. فكلام

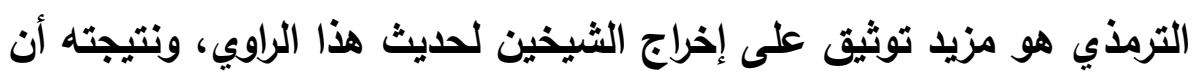

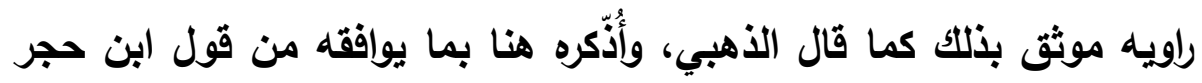

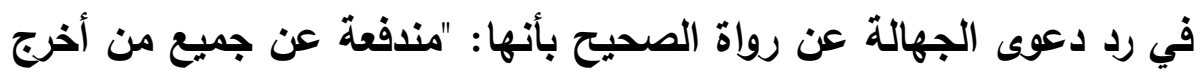

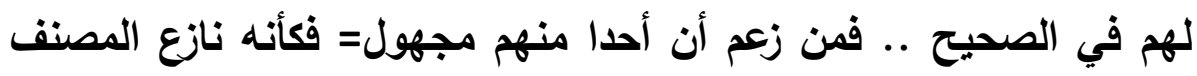

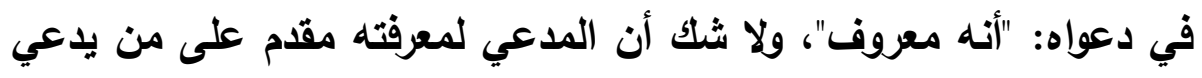

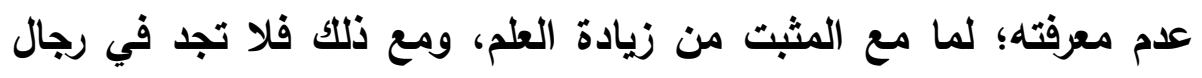

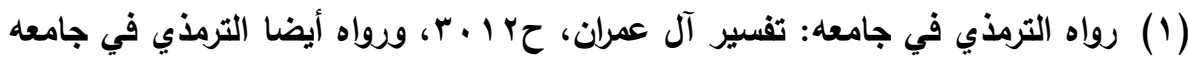

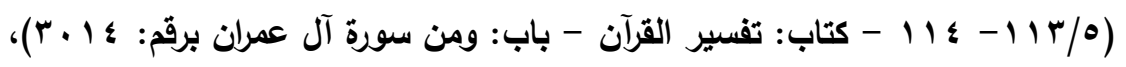

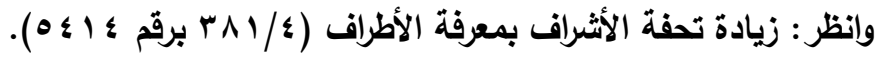

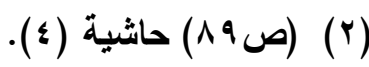

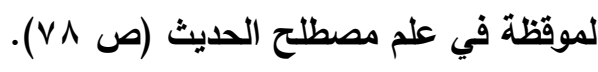

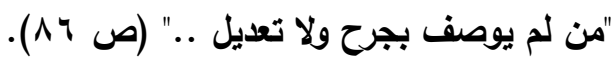


الصحيح أحدا ممن يسوغ إطلاق اسم الجهالة عليه أصلا ..."(1). وقرر السخاوي نحوه بأن معرفة صاحبي الصحيح التي اقتضث رواية عمن هذا حاله = كافية في توثيقه، وقرر أن جميعهم موثقون، ولم يتعرض أحد من

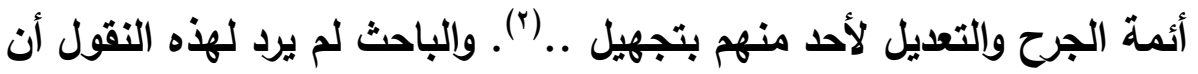
تستقيم ولو حتى في هذا الراوي الأي يراه أحد رواة الإسناد؛ فراح يقرر في خاتمة الترجمة أن هذه الرواية ليست في الأصول، وسيأتي ذكر مستنده ومناقشته في ذلك .. وعمدة الجهالة عند الباحث ما نقله عن الإسماعيلي، لكن الإسماعيلي ليس عنده تعميم كتعميم الباحث "لم يوصف بجرح أو تعديل" وإلا لكان الإسماعيلي - وهو الحافظ المستخرِج - متتبعا لجميع الرواة الذين يشملهم الوصف! ولم يفعل بشهادة الباحث حيث لم نجد في باقي التراجم نقلا من الباحث عن الإسماعيلي بمثل هذا التتبع والاستقصاء والجمع والدراسة .. هذا أمر، والأمر الآخر: إن الأئمة - ومنهم الإسماعيلي - يُعظّم شأن الصحيح ويتفطنون لمآلات خطرة في فتح باب النقد على الصحيح بمثل هذا الرأي، ومن لا يدرك هذا ويفعل خلافه فهو بعيد عن الذوق السليم ويقع في الهنات والمفاسد الخطرة! فالمنخرط في سلك هذا النقد غالبا يكتب على غير قناعة العلم ويشفق بما لا يستطيع البوح به! وهذا الباحث في عنوان بحثه وتقعيده .. ونتائجه: يصرح أن من أخرج له في الأصول في الصحيح فهو موثق بألك، ثم تفصيلا: جَمَع من جمعهم في كتابه ودرسهم بمثل هذه

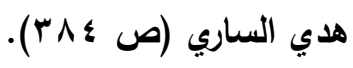

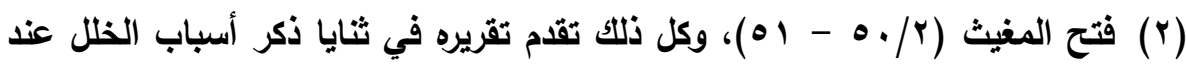

$$
\text { الباحث (في المبحث الثاني). }
$$


الدراسة ثم لم نجد لله على ذلك دليلا في ترجمة واحدة لاعواه! ولو وجد ما يمكن أن يكون صالحا لاعواه = قرر - دون سلف - بتعسف ما يُخرج الترجمة ممن يعتمد عليها صاحب الصحيح؛ فتبقى جميع التراجم عند الباحث على غير شرط الصحيح! لأنه لو ثبث أن هناك رواة في الصحيح وثقوا بالرواية لهم في الصحيح أصولا لسدّ الباب على الطاعن على الصحيح بمتون لا يرتضيها عقله بحجة وجود جهالة في إسنادها(')، وهذا ما لا يريده الباحث! فيبقى أن هناك مجهولين في الصحيح وهم جميع مَن ذكرهم بلدليل أنهم لم يُخرّج لهم في الأصول وعلى هذا النسق ذكر جميع رواة بحثنه، ولعمر لهر الله لو جاء من لا يرتضي منهجية البحث فيكتفي من إحصاء الباحث للرواة بأنهم مجهولون! ولذا بحثه بنتائجه يحقق أن جميع الرواة ممن تنالهم شبهة الجهالة بأن الرواية عنهم على غير شرط الصحة، أما قضية التوثيق الضمني الأي يستفيد منها الرواة بمجرد إخراج صاحب الصحيح لهم = لا نجد لهم مقعد صدق في بحثه إلا تقعيدا يُرضي به مخيفه! فضري ضره وشري شره ووقد تحت الرماد جمره! ولو جاء باحث بعده يريد أن يستفيد من بحثه هذا في هذه الحيثية لما ظفر بالمقصود إلا دندنة: هناك رواة في الصحيح لم

كديث صحيح البخاري: "إذا وقع الذباب في شراب أحلكم فليغمسه ..." الحديث

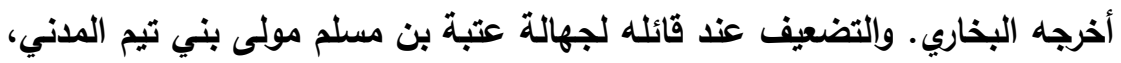
بحجة أنه لم يجد من وثقه من المتقدمين!!. وقد تقدم البحث فيه في المطلب الأول

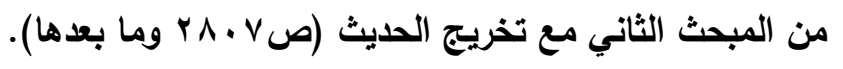


وأما الأمر الثاني (ب) الذي ذكره الباحث: وهو رأي المزي وابن حجر من احتمال سماع علقمة وحميد جواب ابن عباس، فالباحث ذكر هذا إجابة لرفع جهالة رافع، وليس هذا دقيقا؛ وإنما هو لرفع وجود رافع في رواة الإسناد

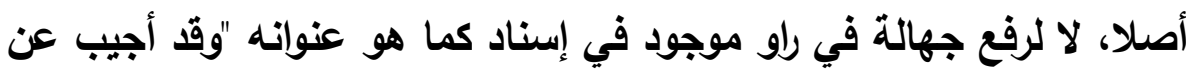
جهالة رافع بأمرين" .. لأن ما ذكره عن المزي وابن حجر ينفي وجود رافع في الدياد سلسلة الإسناد كراو، ويؤكده قول الباحث عقب نقله عن المزي وابن حجر هذا الاحتمال: "واستبعد العيني احتمال سماعهما جواب ابن عباس فقال: لو كان علقمة حاضرا عند ابن عباس عند جوابه لكان أخبر ابن أبي مليكة أنه

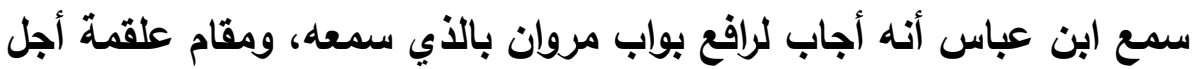
من أن يخبر عن رجل مجهول الحال بخبر قال سمعه عن ابن عباس وترك ابن عباس وأخبره عن غيره بذلك"(')، فظاهره أن الباحث يقدم كلام العيني

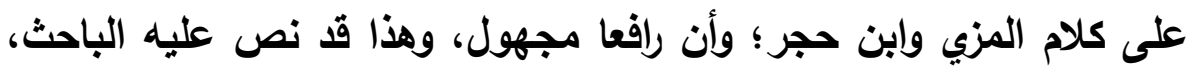
لكنه متردد بين جهالة العين والحال، وتردده جاء لشرط غير سليم! وأما العيني فعنده مجهول حال، ولم يهتم لثرط الباحث المذكور سلفا بحضور علقمة وحميد في المجلس لرفع جهالة العين!! ونقل الباحث في حاثية بحثه كلاما لابن حجر في توجيه الاختلاف الواقع في الرواية مصدره الجواهر والدرر للسخاوي، وسيأتي ذكره في موضعه، ولم يناقش كلام العيني كالمسلّم

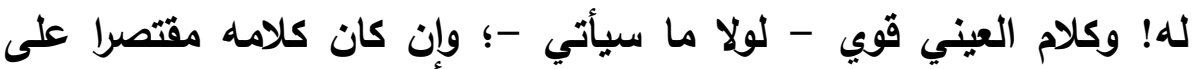
علقمة، وكلام المزي وابن حجر شاملا لحميد أيضا، وحاصل كلام العيني

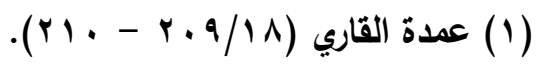


استبعاد أن يترك علقمة - وكذا حمبا - الرواية عن ابن عباس - لو كانا سمعا الحديث من ابن عباس - وما كانا لينزلا بالراوية عن رافع، وما أدري لماذا هذه النفرة من الباحث من تتبع كلام ابن حجر؛ فلعلها من جنس النفرة التي وقت بين ابن حجر والعيني وإلا طالما ينقل عن الحافظ العيني المعتني بالرد على ابن حجر، فالأولى له أن يأتي برد ابن حجر على تعقب العيني عليه إلا إن كان لا يعرف أن ابن حجر دافع عن نفسه في مؤلف خاص! ولا يقال: إن العيني لم يصرح باسم ابن حجر؛ لأن الأمر واضح عند الباحث بأن الكلام المذكور هو لابن حجر، ثم إن من منهج الحافظ العيني في اعتراضاته البعد عن ذكر الحافظ ابن حجر بالاسم ونحوه في جميع المواضع التي اعترضه فيها، وإنما يذكره بكلمة "بعضهم" وعلى هذا تعامل العلامة عبدالرحمن البوصيري في كتابه الفذ "مبتكرات اللآلكئ والدر في المحاكمة بين العيني وابن حجر"(1)، فإن العلامة يأكر كلمة "بعضهم" ويجانبها "(بن حجر"، ولم يستوعب جميع المسائل بينهما، ومما لم يذكره هذه المسألة، والحاصل أن العيني هنا أبهم ابن حجر بنفس التعبير حيث قال العيني: "وقا ساعد بعضهم البخاري فيه بقوله: ويحتمل أن يكون علقمة حاضرا عند ابن عباس أن لما أجاب ..."(ז)، وأحببت أن أذكر هذه مع ظهور هذه الأمور لاى الخاصة إلا أن الباحث لم يحرك همته للنظر فيما يقوله ابن حجر في الرد على العيني، وقد أفرد كتابا سماه "انتقاض الاعتراض في الرد على العيني في شرح البخاري"، واعتراض العيني هنا على ابن حجر من المسائل التي ذكرها ابن

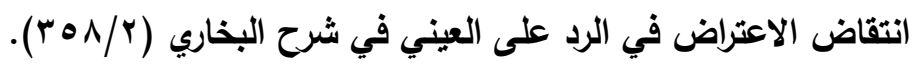

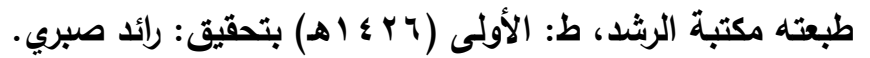


حجر في كتابه هذا، فقد ذكر كلام العيني ثم قال ابن حجر: "ليس في السياق

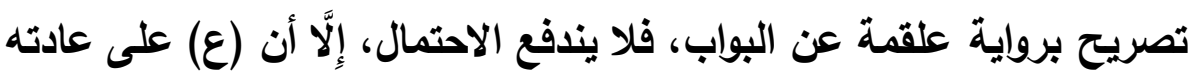

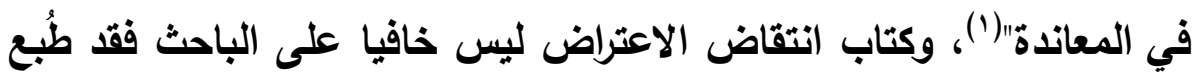
قبل أكثر من عقدين ونصف تقريبا(") ويقصد ابن حجر برد إلزام العيني حين قال: "لو كان حاضرًا عند ابن عبّاس عند جوابه لكان أخبر ابن أبي مليكة أنّه أنها

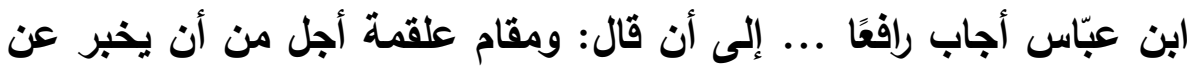

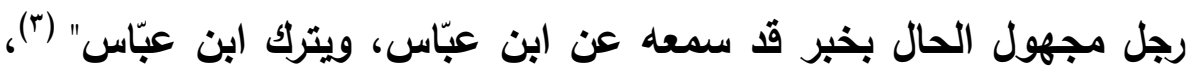

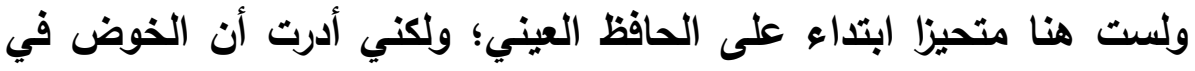

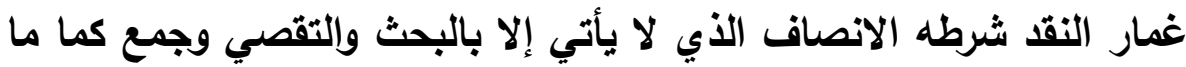

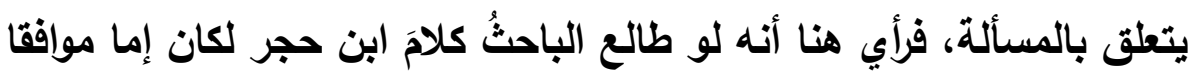

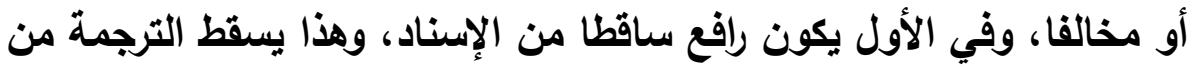

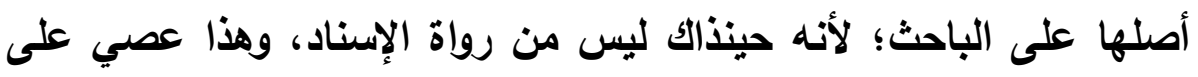
الباحث قبوله! وعلى الثاني فإنه يحتاج إلى رد على ابن حجر أقوى من رد رد

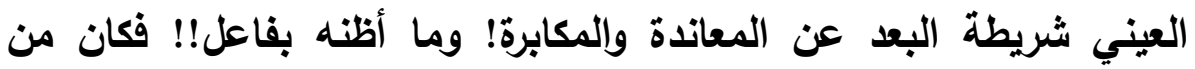

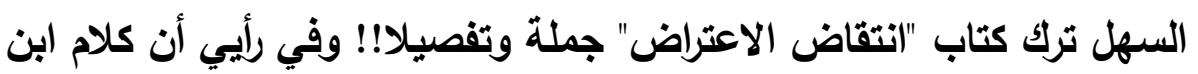

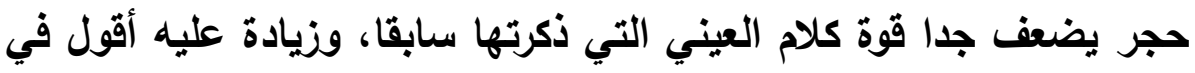

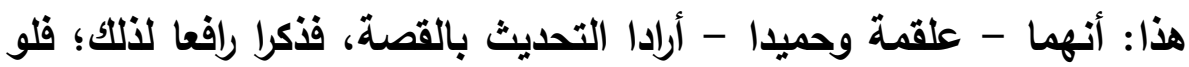

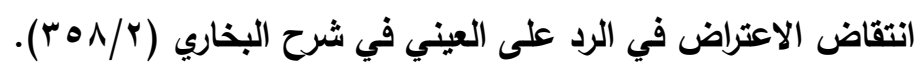

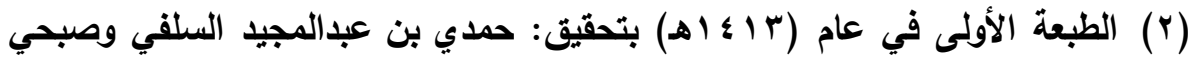

$$
\text { عمدة القاري شرح السامرائي، مكتبة الرشد - الرياض. }
$$


حثثا عن ابن عباس - دون ذكر ما وقع أمر رافع -؛ لما كانت هذه الراوية

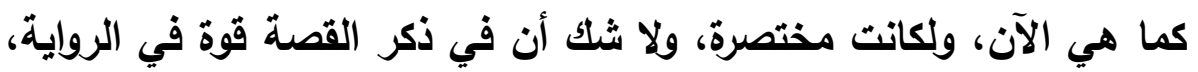

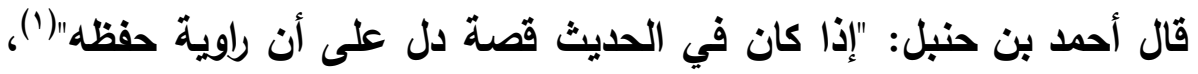

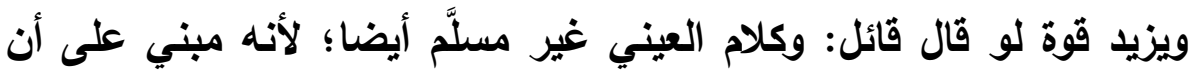

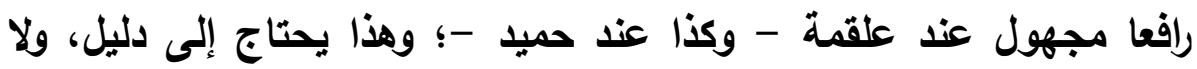

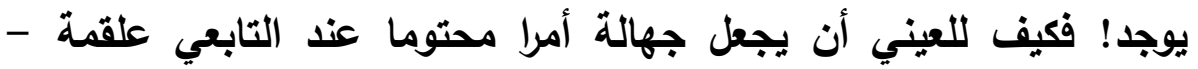
ومثله حميد - ومعارضه لا يسلم له بهذا، فالعيني قد جعل محل النزاع دليلا

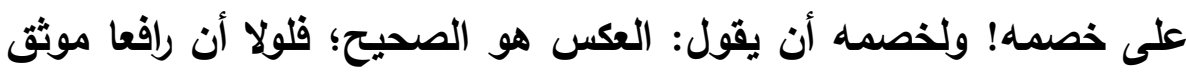

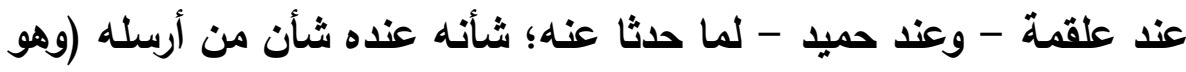

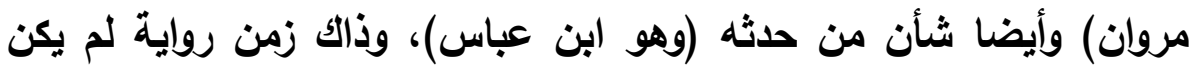

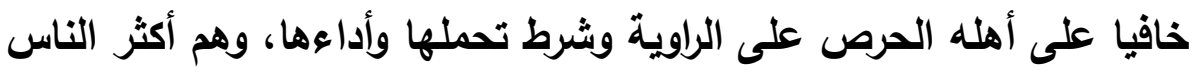

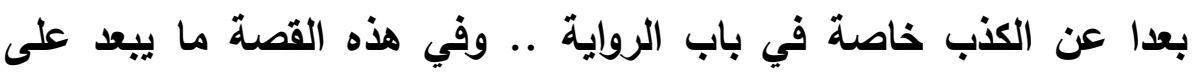
مروان أن يروي لمن حوله سؤاله ابن عباس بواسطة لا يرتضيها من حوله من صحابة أو تابعين - كبار كعلقمة وحميد -، والباحث يحتمل بأنهما

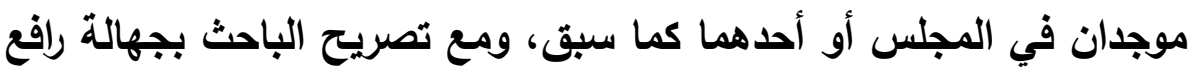
رأى روايته في غير الأصول تحسبا من رفع جهالة رافع بما سبق من قرائن،

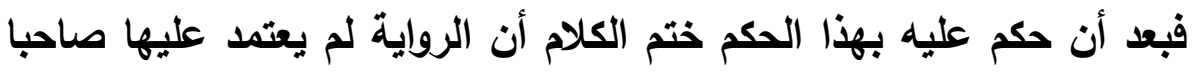

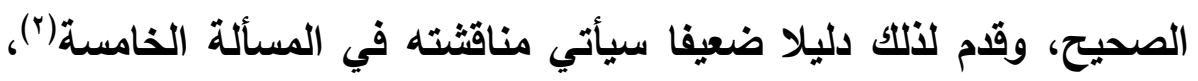
وكان يغنيه أن يسير على الجادة ويوثق الراوي إن لم يكن له مستتد قوي لهي

$$
\begin{aligned}
& \text { هاي الساري (ص بr بr). } \\
& \text { انظر (ص r r r r). }
\end{aligned}
$$


إزالة إيهام القائلين بوجود

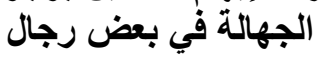

يرجح جهالته، فلا هو رضي باحتمال سماع علقمة وحميد من مروان على احتماله في حضورهما مجلس مروان - وحينذاك تسقط واسطة المجهول عنده -؛ ولا رضي بتوثيق رافع لجميع القرائن المقررة في التعامل مع رواة الصحيح، والباحث لم يذكر توثيق الراوي - ولو احتمالا -؛ لإخراج روايته في

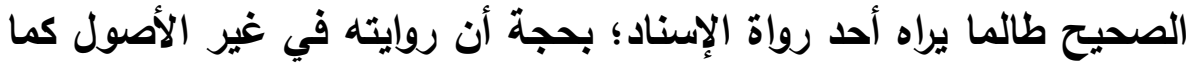
سيأتي في المسألة الخامسة. ثم الباحث لم ينقل كلاما مهما لابن حجر يتعلق بهذين الفرعين (جهالة

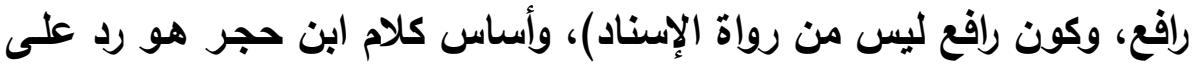
سؤال سأله جلال الدين البلقيني، وقد تعقب في سؤاله المزي حين ذكر في تهذيبه رافعا راويـا للحديث عن ابن عباس، وقال: "والأرجيح مـا صنعه (أي

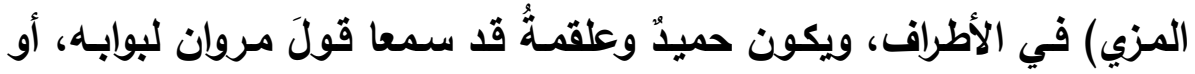

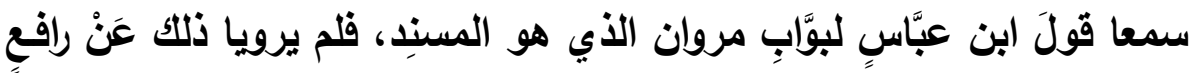

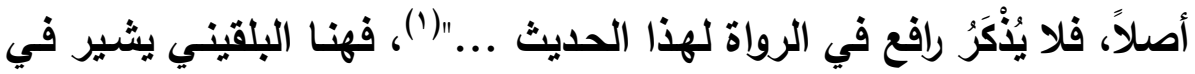

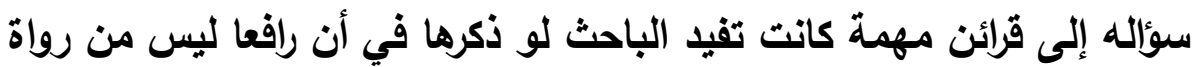

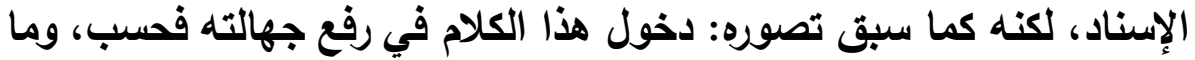
أثشار إليه البلقيني عن المزي في كتابه الأطراف بيانه أن المزي لم يعقد ترجمة

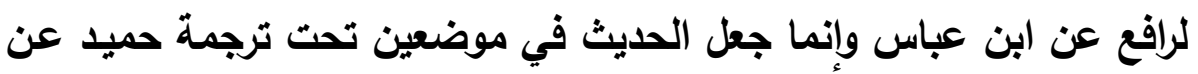

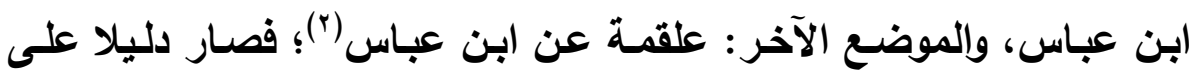
تعامل بعض الأئمة ممن يعتنون بحديث الصحيحين بأن رافعا ليس راويا

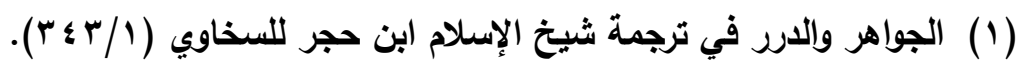

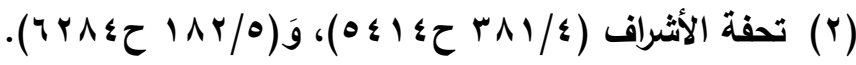
مجلة كلية أصول الدين والدعوة بأسيوط / العدد السابع والثلاثون 9 ـ ب م - الجزء الثالث 
$\ddot{4}$

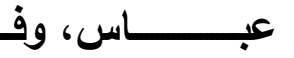
II

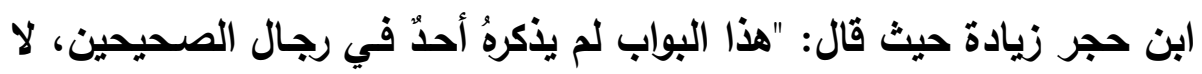

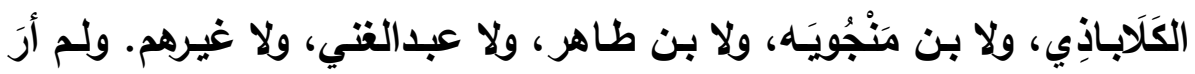

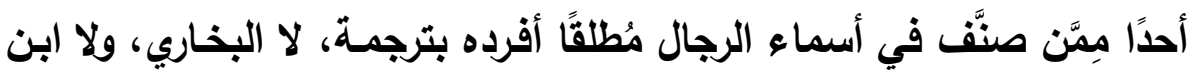

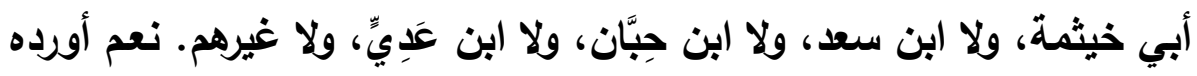

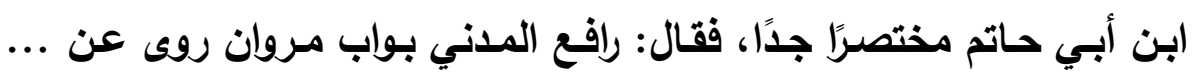

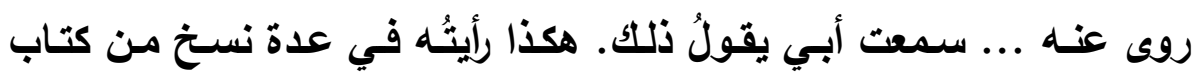

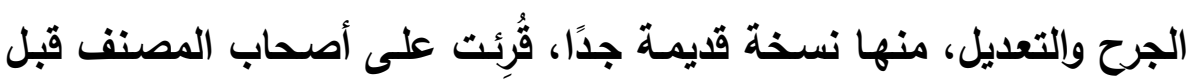

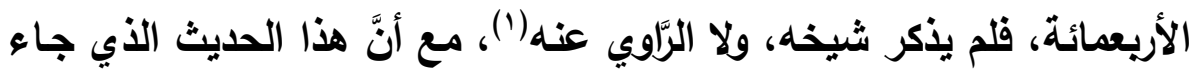

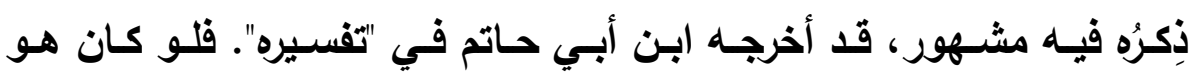

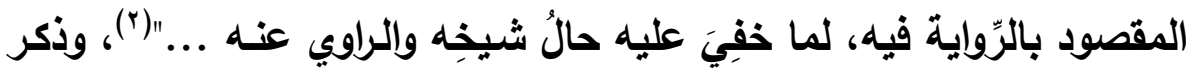

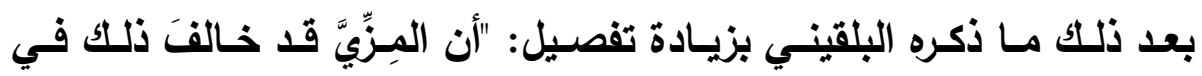

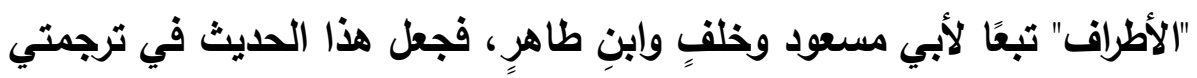

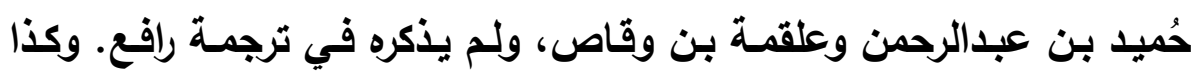

صنع الحُميدي في "الجمع بين الصحيحين" (").

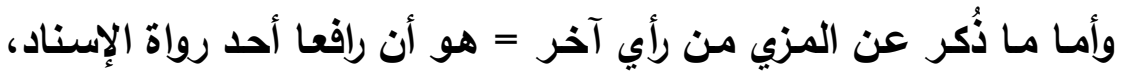

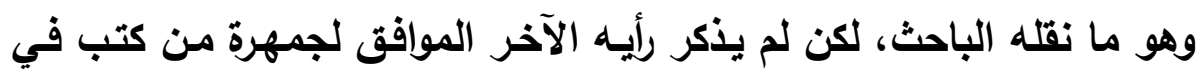

(1) والـنص الـذي نقــهـ ابـن حجر لـم يختــف عـن المطبـوع مـن الجـرح والتعديل

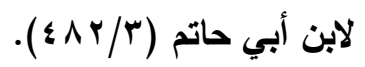

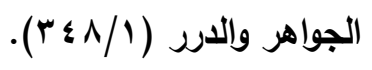

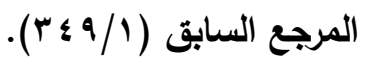


إزالة إيهام القائلين بوجود

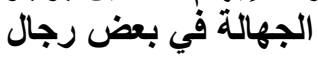

الأطـراف والتـراجم بعـدم الترجمـة لرافـع هــا، وكــلك قـول الباحـث: "ثبعـه ابن حجر ..."، فإنه لم يذكر الكلام السابق لابن حجر ومـا فيه من بيان مـع كون مصدره بين يايه! وفوق هذا وذاك يرى هذا الكلام تحت رفع جهالة رافع! ويقي في الأمر أن البلقيني ينتقد متابعة الذهبي في الكاشف للمزي، وكذلك قال ابن حجر في جوابه حيث قال: "وأما ما وقع في الكاشف مِنْ ترجمة رافع،

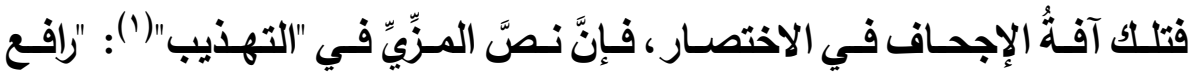
المدني، بواب مروان بن الحكم، أرسله مروانُ إلى ابن عباس يسأله عن قول

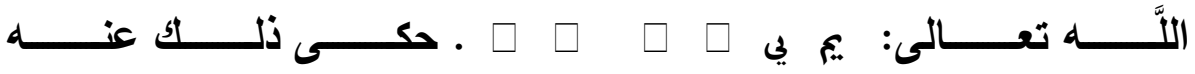
حُمبا بن عبدالرحمن بن عوف، وعلقمةُُ بن وقَّاص، وكأنَّهما سمعا منه جوابَ ابن عباس، روى له البخاري والنَّسائي"(؟). لكن الحافظ ابن حجر أيضـا ترجم للاروي في التقريب بقوله: "رافع مولى مروان بن الحكم ويوابه، مقبول، من الثالثة، خ م ت س"(ّ)، فهو بنفسه كرر الترجمة ولم يشر إلى لأي أو احتمال عدم عده راويا للحديث! نعم الفرق بين الكاشف ويين التقريب أن التقريب زاد (م ت) حيث لـم يـكره المزي - وتابعه الذهبي في الكاشف -، لكن ترجمة الحافظ ابن حجر لله في التقريب تبقيه راويا بدليل تصويب مظان روايته التي لم يذكرها المزي والكاشف! وصرح بتعقبه هذا في التهذيب ثم أكده في إجابة

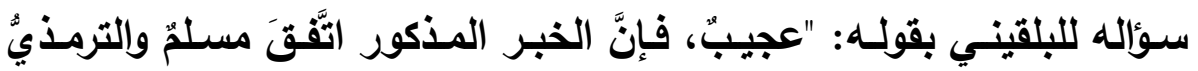
والنسائي جميعًا على تخريجـه مِنْ طريق حجَّاج بن محمد، وسياق الترمذي

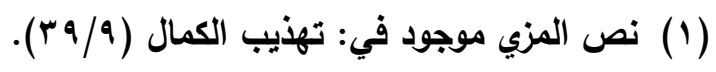

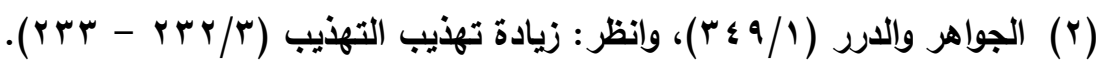

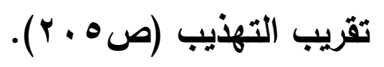


إزالة إيهام القائلين بوجود

الجهالة في بعض الفالين بوجال

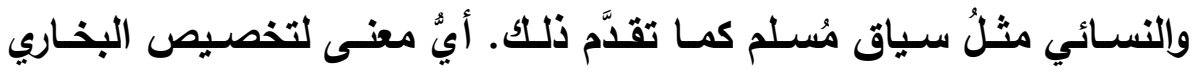
والنسائي بالأكر، والإضراب عَنْ ذكر مسلم والترمذي؟! هذا ذهول شديد! وهذا ف

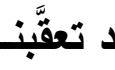

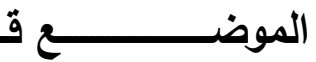
"تلخيص التهذيب"(1) فلاينا أيان متقابلان الأول يرى أن رافعا أحد رواة الإسناد: يروي الحديث عن ابن عباس ويروي عنه علقمة وحميد، والآخر: أن رافعا ليس من رجال الإسناد، ودليل الأول ظاهر الرواية التي في الصحيحين وسنن الترمذي والنسائي في الكبرى: عن ابن أبي مليكة عن حميا بن عبدالرحمن أخبره أن: "مروان قال لبوابه: اذهب - يا رافع - إلى ابن عباس، فقل: لئن كان كل امرئ فرح بما أوتي وأحب أن يحمد بما لا يفعل معذبا؛ لنعذبن أجمعون؟! فقال ابن عباس: وما لكم ولهذه .." الحديث(؟). وكذلك رواية علقمة بن وقاص في البخاري(ّ). وقد استوعب الحافظ ابن حجر طرق الحديث وليس في رواية الأثبات من أصحاب ابن جريج اختلاف في سياق القصة

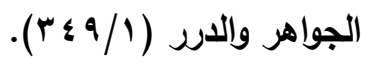

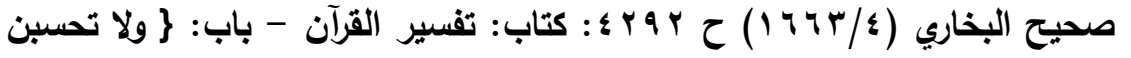

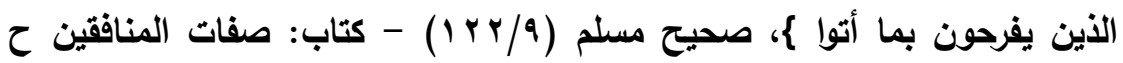

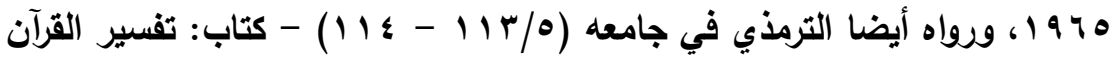

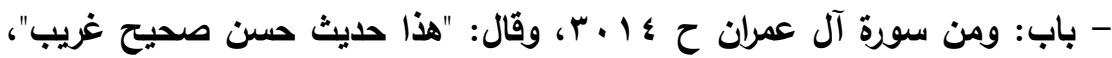

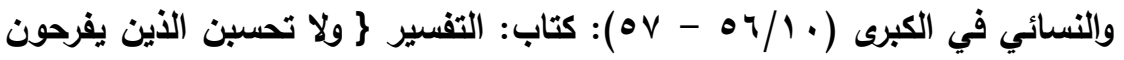

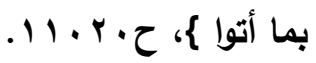

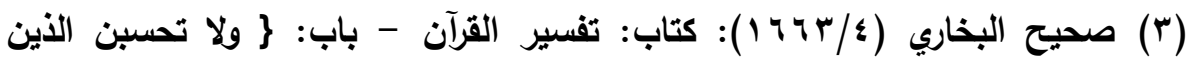

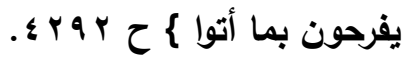
مجلة كلية أصول الدين والدعوة بأسيوط / العدد السابع والثثلاثون 9 اــم - الجزء الثالث 
التي في الصحيحين السابق ذكره " أن: مروان قال لبوابه: اذهب - يا رافع - إلى ابن عباس"، لذا قال ابن حجر: "اتَّقَ هؤلاء الثَّلاثة مِنْ

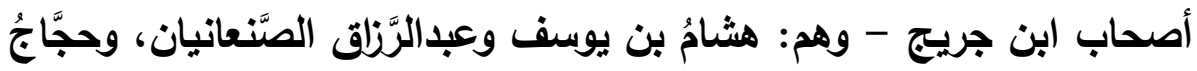

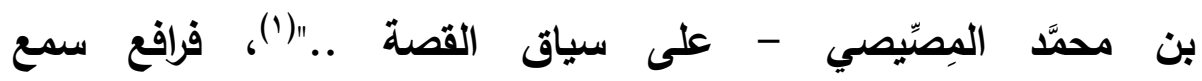
ابن عباس في ظاهر الرواية، وحدث بها مروان، ولم يأت في طرق الحديث

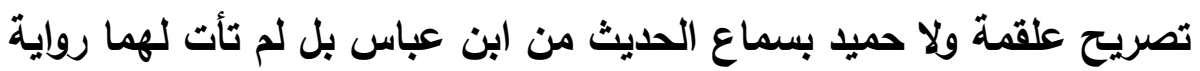
في دواوين السنة عن ابن عباس غير هذه، مع إمكان سماعهما كتابعيين

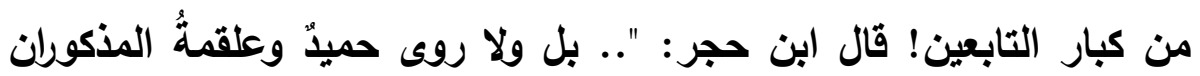

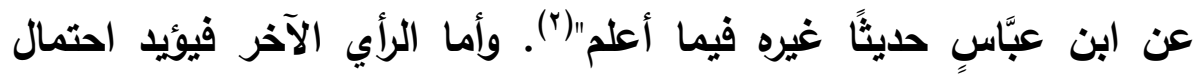

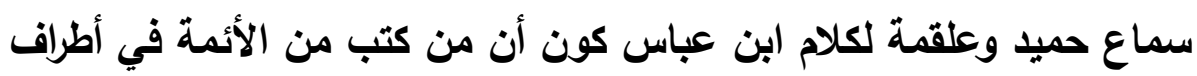

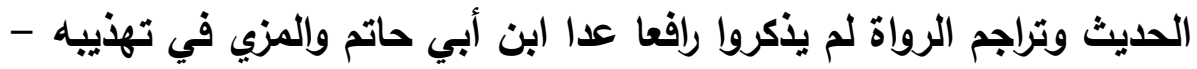

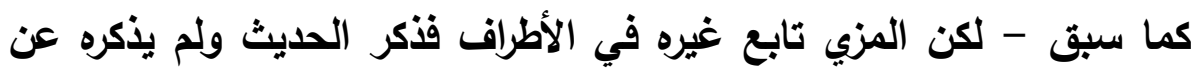

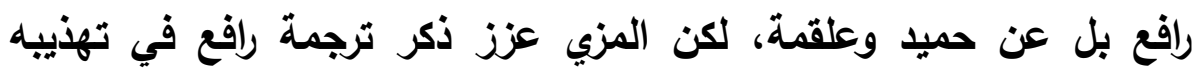

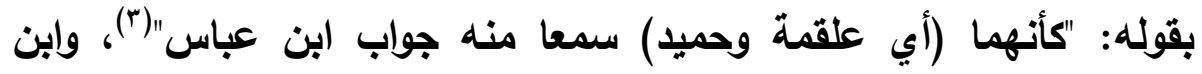

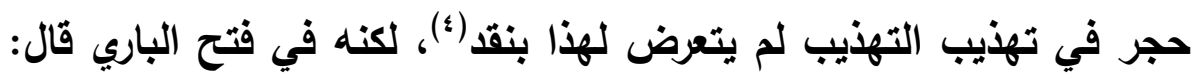
"يحتمل أن يكون علقمة بن وقاص كان حاضرا عند ابن عباس لما أجاب،

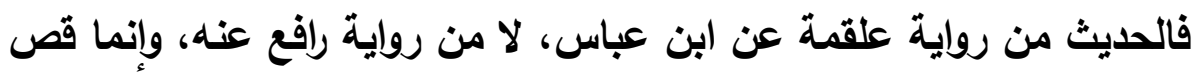

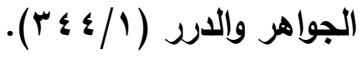

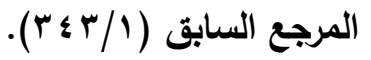

$$
\begin{aligned}
& \text { تهذيب الكمال (q/ • • ع). } \\
& \text { انظر: تهذيب التهذيب (r/r ( }
\end{aligned}
$$


علقمة سبب تحديث ابن عباس بذلك فقط، قال: وكذا أقول في حميد بن

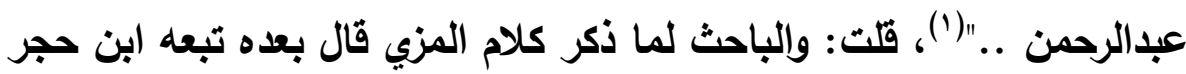
ثم ذكر هذا الكلام، وهذا خطأ واضح يضاف إلى كونه لم يفهم أن هناك رأيين

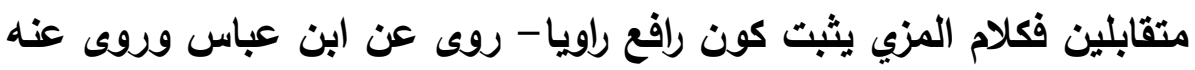

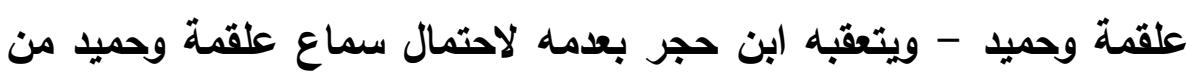

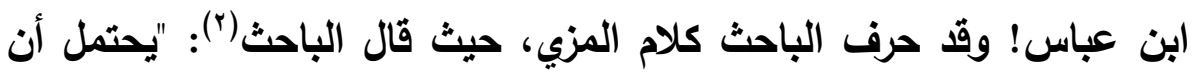
يكون الحديث من رواية علقمة وحميد عن ابن عباس، قال المزي: وكأنها

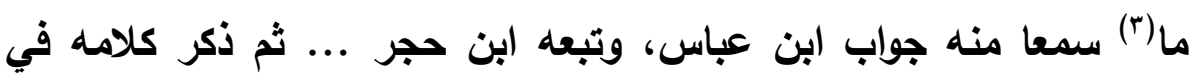

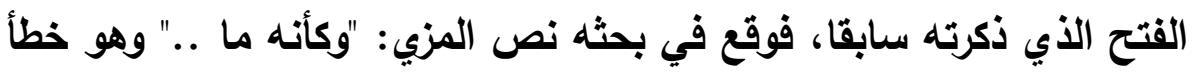

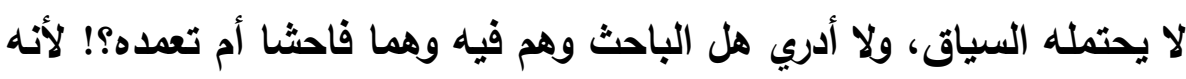
على ما في تهذيب الكمال الذي أحال إليه الباحث فلا يؤيد استدلاله؛ لألأن

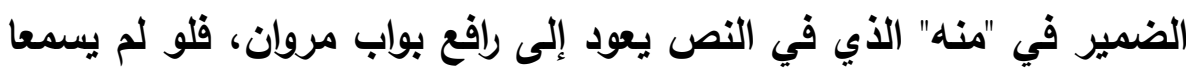
جواب رافع

من ابن عباس؛ فإذن: لماذا المزي يضع لرافع ترجمة! والباحث يقصد الوجه الذي : ألي

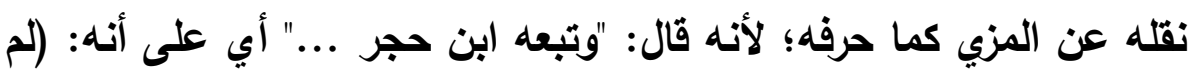
يسمع علقمة وحميد من رافع)، ويذلك سيلتقي كلام المزي المحرف مع كلام

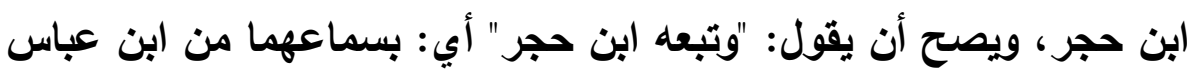

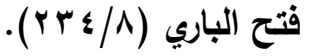

$$
\begin{aligned}
& \text { من لم يوصف بجرح ولا تعديل .. (ص r ra). }
\end{aligned}
$$

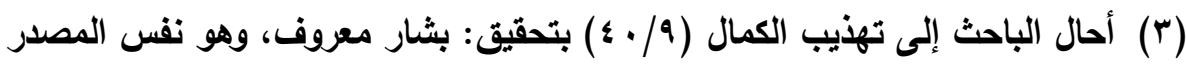
والموضع الذي بين ياديّ. مجلة كلية أصول الدين والدعوة بأسيوط / العدد السابع والثلاثون 9 الـ بم - الجزء الثالث 
مباشرة، لكن على الصواب الذي في تهذيب الكمال فإن المزي وضع لرافع

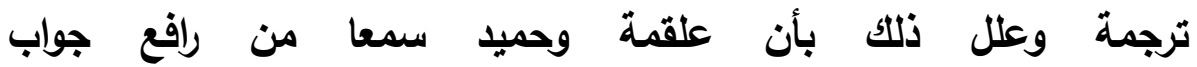
ابن عباس على ظاهر الرواية، وكأن المزي يستثعر في هذا نقدا بترجمته لرافع فعلل لذلك .. ومع تحصل هذان القولان اللأن لم يذكرهما الباحث ولم لمان

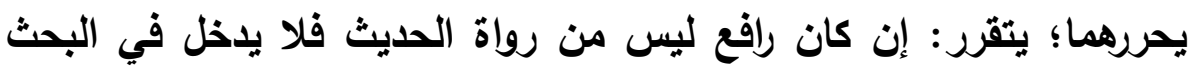

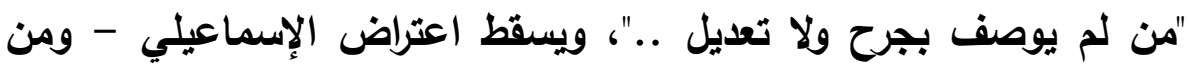
معه - من أصله، وإن كان من رواة الحديث فعليه اعتراض الإسماعيلي

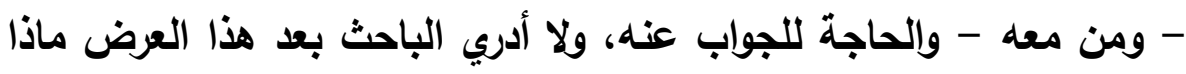

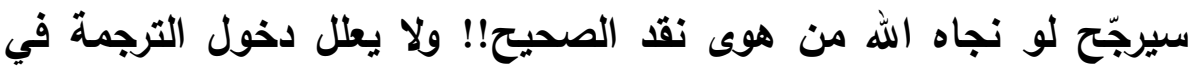
البحث تبعا لوجوده في التقريب؛ فإنه أكثر من ضعفي من ذهاه ذهرهم من الرواة،

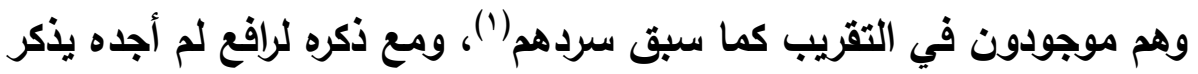

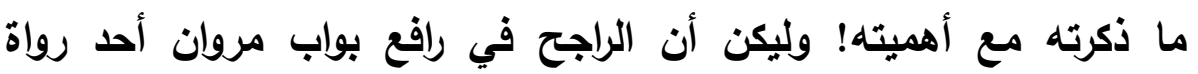

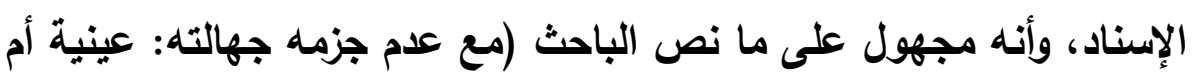

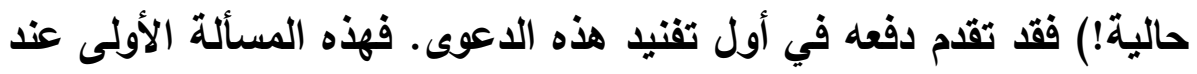
الباحث: جهالة رافع بواب مروان. البهان.

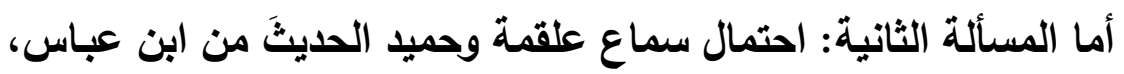

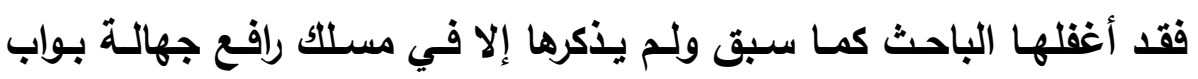
مروان، وذكرنا أن سماعهما من ابن عباس يرفع رافعا أن يكون أحد الرواة

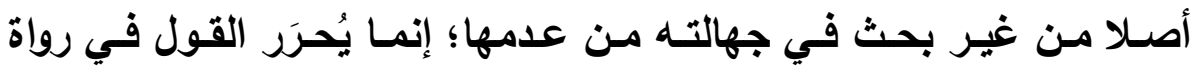

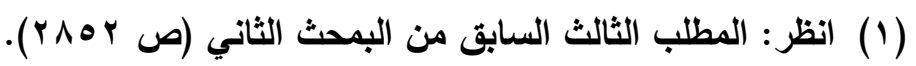


إزالة إيهام القائلين بوجود

الجهالة في بعض المالين بوجال

الإسناد فقط، ويعد هذا النقل يبدو لـي احتمـال عدم اعتبـار رافع من رواة الإسناد أقرب من اعتباره، لأمور : - كون علقمة وحميد من كبار التابعين وقد سمعا ممن هو أقدم وفاة من ابن عباس، فقريب جدا حضورهما الحديث عند ابن عباس، ثم حكيا

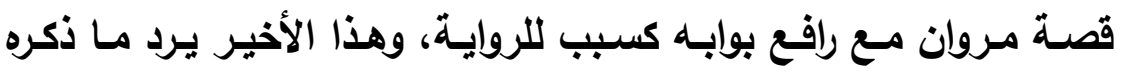
الباحث من استبعاد العيني احتمال سماعهما جواب ابن عباس بقولهه:

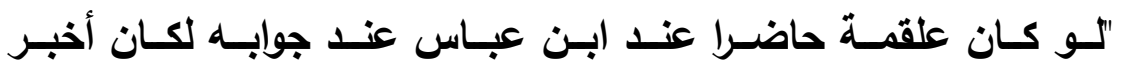

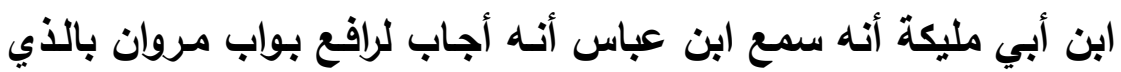

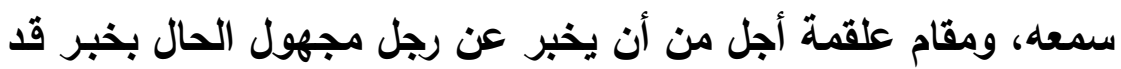
سمعه عن ابن عباس وترك (بن عباس وأخبره عن غيره بذلكت" (1) .

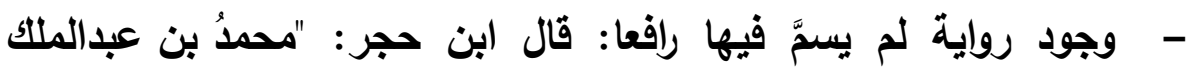

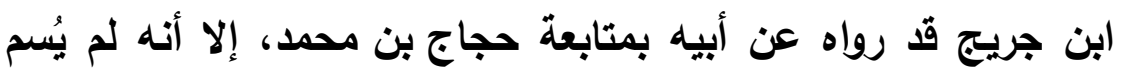
رافعًا، وأخرجه الإمام الكبير أبو محمد إسحاق بن راهويه في "مسنده"

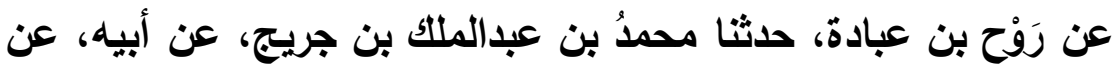

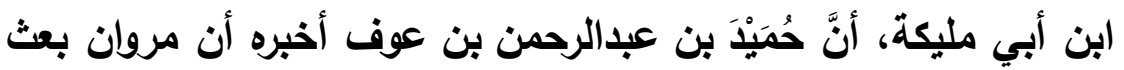

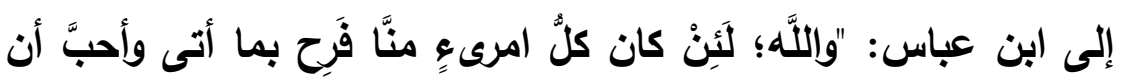

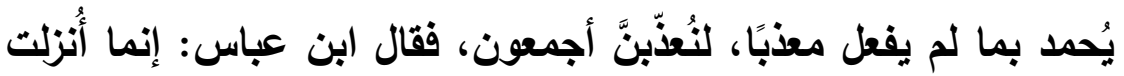

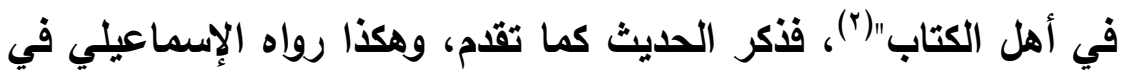

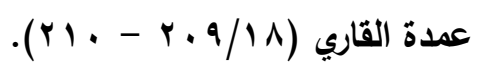

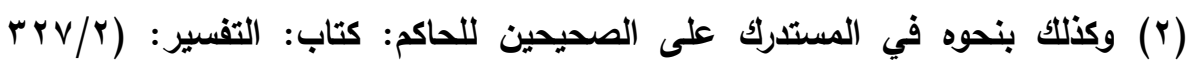
. (r)viz مجلة كلية أصول الدين والدعوة بأسيوط / العدد السابع والثثلاثون 9 اــم - الجزء الثالث 
إزالة إيهام القائلين بوجود

الجهالة في بعض الفالين بوجال

"مستخرجه" من طريق أبي الأزهر أحمد بن الأزهر النَّيسابوريِّ، عن

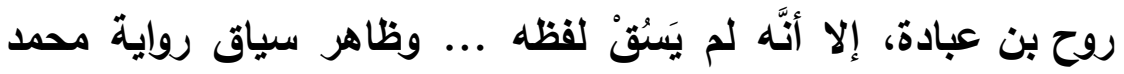
يشعر بأن حُميدَ بن عبدالرحمن كان عند ابن عباس لهمَا جاءه رسول مروان، ويؤيُِّ ذلك عدمُ ذكرِ الرسول هنا وتسميته؛ لأنه غيرُ مقصود بالرواية، وإذا احتمل هذا في السياق الذي عن حميذ بن عبدالرحمن، احتمل مثثله في السياق الذي عن علقمة بن وقاص .."(1)، قلت: محمد ابن عبدالملك القرشي، هو ابن مَن يدور عليه هذا الحديث وهو الإمام ابن جريج فروايته قوية نافعة؛ لذا قال ابن حجر في روايته هذه: "لا هل ريبَ أنَّ آلَ الرجل إذا كانوا عُدُولاً، أولى بِإتقان حديثه مِنْ غيرهم"(r)، قلت: حكم ابن حجر لهذا الراوي في التقريب: "مقبول"(")، لأنه لم يرو عنه غير روح بن عبادة، وذكره ابن حبان في الثقات(؛)، ونقل ابن حجر عن الأهبي قوله: "لا يعرف"(ه)، لكن ينفعه أنه من آل بيث بن جريج وابنه، وأنه ضبط القصة بما لا تخالف رواية الأثبات، وقد صحح له هذا الحلث الحاكم في مستدركه، وإن كان وهم الحاكم بقوله: "ولم يخرجاه"(")؛ لأن الحديث متفق عليه، وعلى ما تقدم فرواية محمد

$$
\begin{aligned}
& \text { (1) الجواهر والارل (1/ ع ع r). }
\end{aligned}
$$

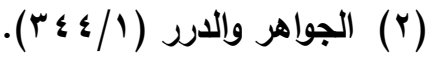

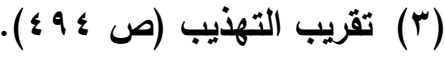

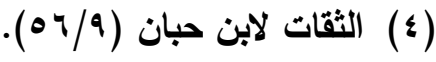

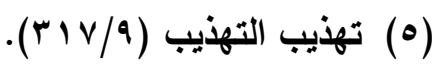

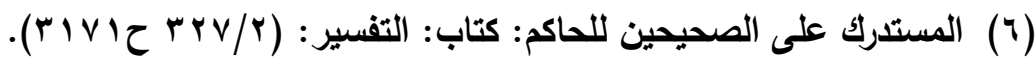


إزالة إيهام القائلين بوجود

الجهالة في بعض الفالين بوجال

ابن عبدالملك - على ما قيل فيه من جهالة - ليست مدفوعة عن استئناس

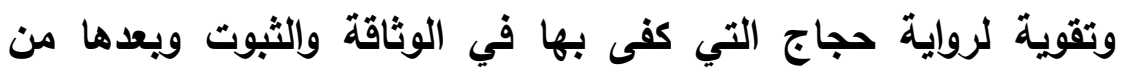
الثذوذ، وكفى باتفاق البخاري ومسلم على إخراجها (1).

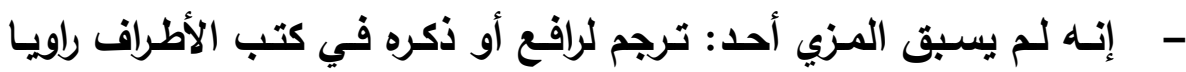

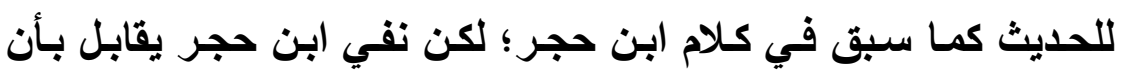

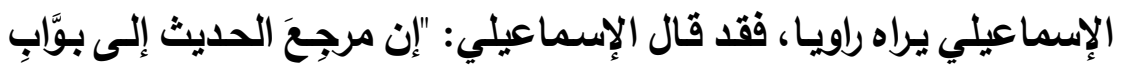

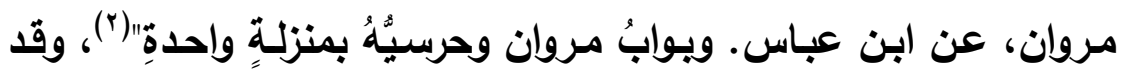

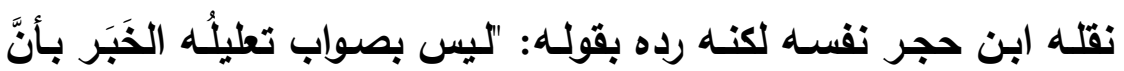

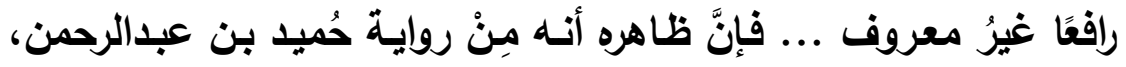

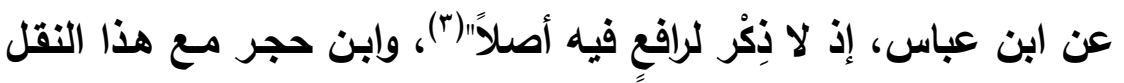

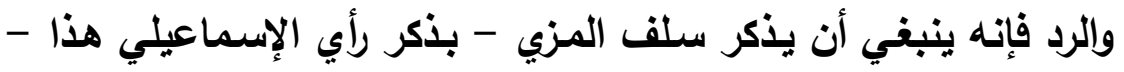

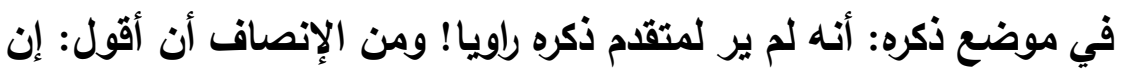

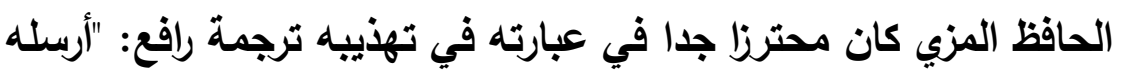

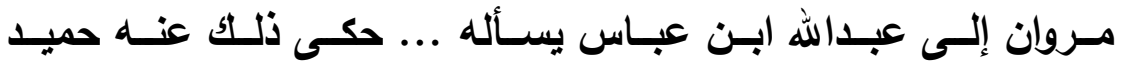
ابن عبدالرحمن بن عوف، وعقلمة بن وقاص الليثي، وكأنهمـا سمعا منـهـ

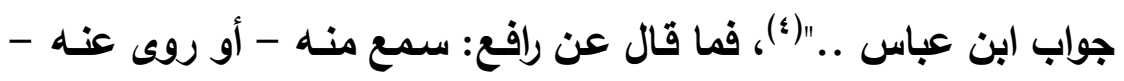

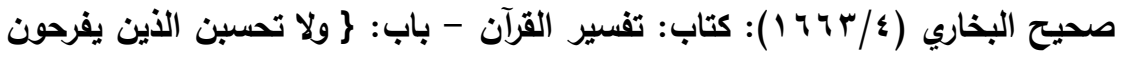

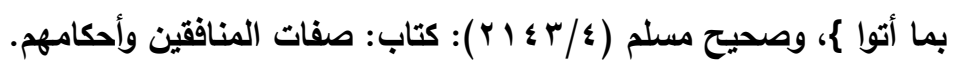

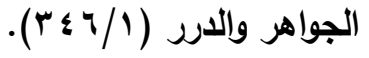

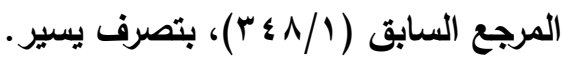

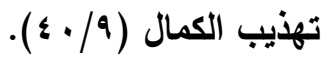
مجلة كلية أصول الدين والدعوة بأسيوط / العدد السابع والثلاثون 9 الـ بم - الجزء الثالث 
إزالة إيهام القائلين بوجود

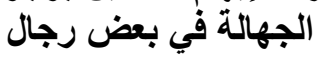

علقمـة وحميد .. على عادة المزي في ذكر الشيخ والرواة عنـه، ولكن الأمر على التشبيه عنده بأنهمـا سـعا منـه جواب ابن عباس، ليقى احتمال آخر أن حميدا وعلقمة حكيا ما وقع من إرسال رافع وسمعا من ابن عباس الجواب، وقرينة الأخير أقوى لما تقدم، وأكثر مـا يُعنى ذكره هنا تقدم في المسألة الأولى بما يغني عن ذكره هنا. وهذا أقرب الأمور عندي لقوة احتمالـه وظاهر الرواية لا يعارضـه، ويهذا يكون الباحث لم يتبه بأن هناك رواة ليسوا من رجال الصحيح رواية، وريما يُذكر الراوي منهم في بعض كتب التراجم للكره في قصـة كما هنـا، فيغتر الباحث بمجيء مثل هؤلاء الرواة في كتب التراجم مستأنسا وضـع رمز (خ) أو (م) في الترجمة دون تحقق وجوده في إسناد الحديث، وعلى كونـه ليس راويا سار أغلب من ترجم لرجال الصحيح فلم يترجموا لرافع، وحتى من ترجم لرافع كان مسلكه جيدا، فإنـه لــ يقل إلا أن رافعا ورد في الخبر فالمزي حين ختم ترجمـة رافـع قال: "ذكره البخـاري، والنسـائي في هذا الحديث"(1)، قال: "ذكره"، ولـم يقل: "روى لـه" كعادته، وقال ابن حجر: "وقا روى الخبر المذكور مسلم، والترمذي أيضا، وفيه ذكر رافع"(r)، فهو مذكور في قصة وليس راويا، وقد ذكرت في المبحث الثاني في المطلب الثاني: "الباحث مع قواعد المحدثين" وفيه قاعدة رقم (9) وهي: "لا يُعدّ

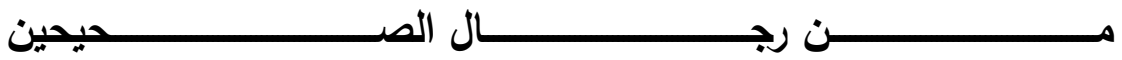
- أو أحدهما - إلا من له رواية مسندَة"، فليرجع إليها القارئ.

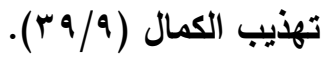

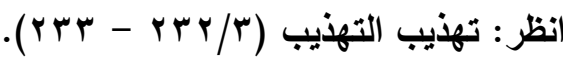


إزالة إيهام القائلين بوجود

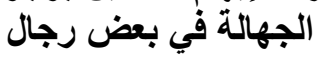

ولنطرق احتمال كون رافع راويا في سلسلة الإسناد - تمشيا مـ صنيع الباحث - لكنه ليس بمجهول لقرينة توثيقه عند من أرسله وعند من سمع منه، وابن حجر في الفتح حين رد جهالة رافع بقوله: "والذي يظهر من سياق الحديث أنه توجه إلى ابن عباس فبلغه الرسـالة ورجع إلى مروان بـالجواب،

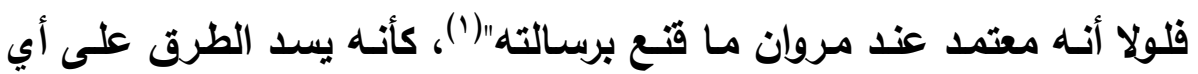
مطعن حول الصحيح، فإما الرواية من طريقه فهي مقبولة وإمـا لسماع حميد وعلقمة حديث ابن عباس كما في رد كلام ابن حجر على سؤال البلقيني ..

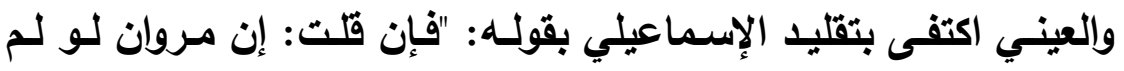
يعتمد عليه لـ يقتع برسـالته. قلت قد سمعت أن الإسـاعيلي قال: مروان

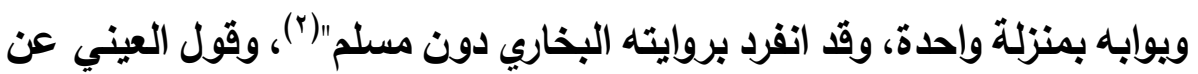
الإســـاعيلي: "مـروان ويوابـه بمنزلـة واحدة" صـوابه "حرسـي مسروان ويوابـه بمنزلة واحدة" ومـا أدري كيف كان النص عند العيني حتى سقط منـه هذا! وسيأتي تفصيله، نعم الإسماعيلي لا يرتضي مروان وعاب على البخاري الرواية

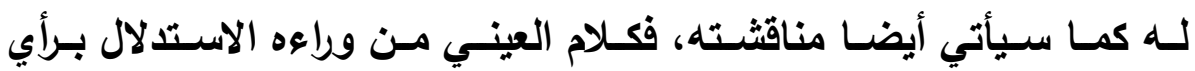
الإسـماعيلي في مروان، وجوابـه أن مروان مقبولـة الروايـة عند أئمـة كمالك والبخاري وغيرهما كما سيأتي فرأي الإسماعيلي يُستدل لله لا به. والمسألة الثالثة: الاختلاف الواقع في الرواية: اكتفى الباحث في بيان اختلاف الروايـة بمجرد النقل عن ابن حجر وغيره: قال الباحث: "اعتراض الإسـماعيلي على البخـاري وجهاب ابن حجر عنـه ومناقشـة العينـي لـه: لقد

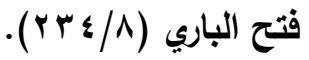

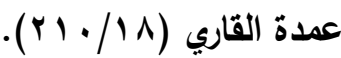
مجلة كلية أصول الدين والدعوة بأسيوط / العدد السابع والثثلاثون 9 ا ـ بم - الجزء الثالث 
إزالة إيهام القائلين بوجود

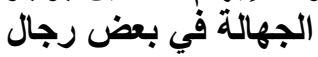

اعترض الحافظ الإسـاعيلي على الإمـام البخاري إخراجه لحديث ابن عباس بوجود علتين فيه، إحداهما: الاختلاف على ابن جريج ... حيث قال: يرحم الله البخاري! أخرج هذا الحديث في الصحيح مع الاختلاف على ابن جريج ... قال العيني: إنكار الإسماعيلي على البخاري في هذا من وجوه: الأول: الاختلاف على ابن جريج؛ فإنه أخرجه من حديث حجاج عن ابن أبي مليكة عن حميا، وأخرجه أيضا من حديث هثام عن ابن جريج عن ابن أبي مليكة عن علقمة الحديث بعينه، وقد اختلفا. والثاني: أن بواب مروان الذي اسمه رافـع مجهول الحال، ولـم يُذكر إلا في هذا الحديث، والثالث: أن البخاري لـ يورد في صحيحه حديث بسرة بنت صفوان الصحابية في مس الأكر، ولا فرق بينه وبين حديث الباب لما ذكرنا "(1). وهذا ضرب من التشعيب الأي لا طائل تحته؛ فقوله: "ومناقشة العيني له": لم يناقش العيني كلام الإسماعيلي بالرد وإنما جاء يحمل كلام الإسماعيلي مع شيء من التوضيح المسلِّم له فيه، وليس فيه مناقشة ومباحثة مع الإسماعيلي كما قال الباحث في عنوانه! إنما الأي ناقشه بالأخذ والرد هو الحافظ ابن حجر في فتح الباري وغيره، وقد أهمله الباحث - مع اطلاعه -؛ فلو نقل كلام ابن حجر بدلا من كلام العيني لكان أولى، وفي نقل العيني اختلال حيث نقل قول الإسماعيلي كالآتي: "ومروان ويوابه بمنزلة واحدة"(r)، وهذا لا يتوافق مع باقي الكلام، وهو قول الإسماعيلي: "ولا فرق

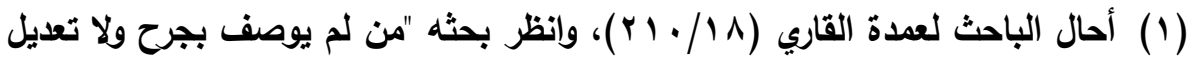

$$
\begin{aligned}
& \text {. }
\end{aligned}
$$

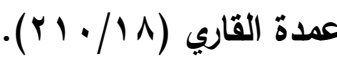


بينهما أن البواب مسمَّى والحَرسيُّ غيرُ مسمَّى، وكلاهما غيرُ معروف"(')،

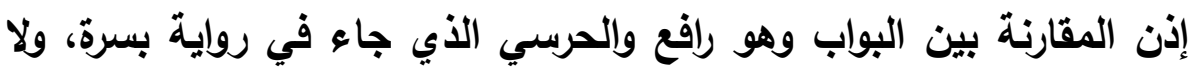
لدل لمقارنة مروان ببوابه لا في النص الأصلي ولا في واقع الإلزام والمقارنة

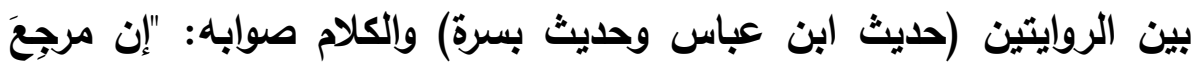

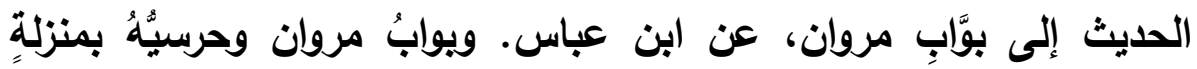

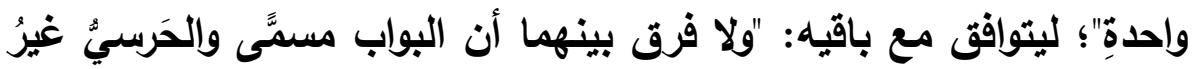
مسمَّى، وكلاهما غيرُ معروف"، وقد نقل ابن حجر كلام الإسماعيلي بنصه

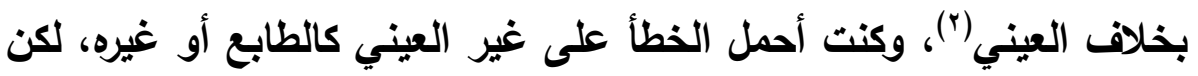

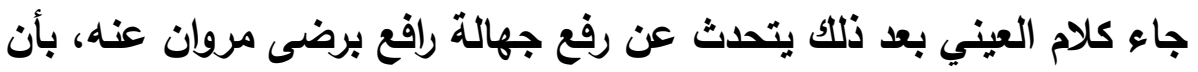

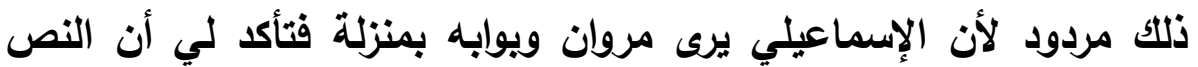

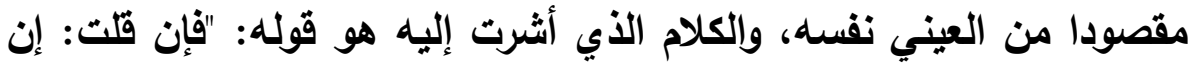

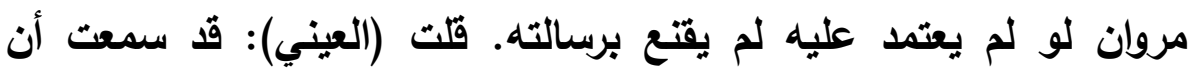
الإسماعيلي قال: مروان ويوابه بمنزلة واحدة، وقد انفرد بروايته البخاري دون منه - كأستاذ - أن يتفطن لمثل هذا ثم يناقش ويحلل كلام الإسماعيلي بنفسه،

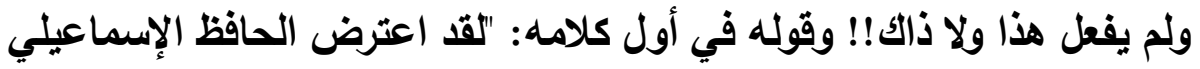

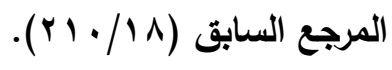

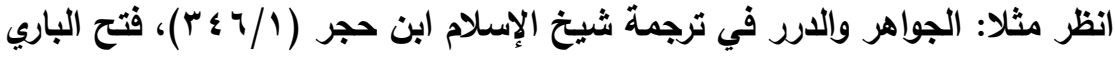

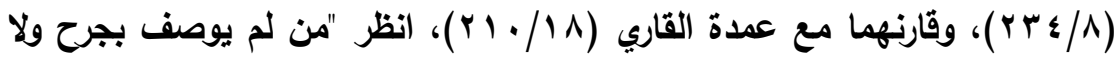

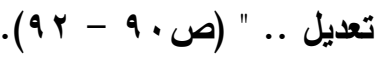

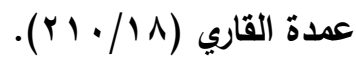


إزالة إيهام القائلين بوجود

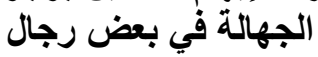

... بوجود علتين فيه"، وصوابه على فنلكة الباحث: ثلاث أمور؛ لأن مجمل اعتراضه ثلاثة = ثالثها الإلزام بتخريج رواية بسرة، وقد نص عليها العيني كما نقل ذلك الباحث حيث قال العيني: إنكار الإسماعيلي على البخاري في

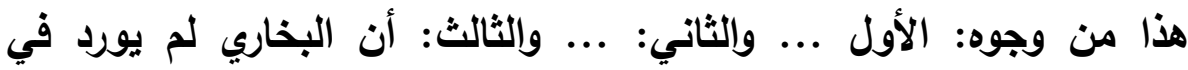
صحيحه حديث بسرة بنت صفوان الصحابية في مس الذكر ..."، والعجيب أن

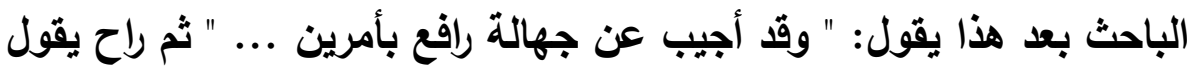

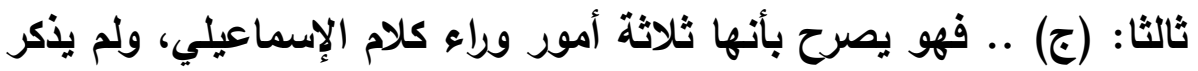

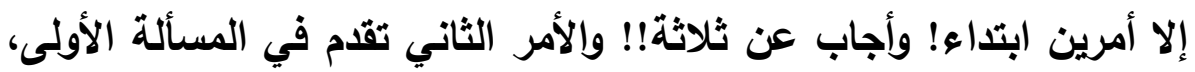

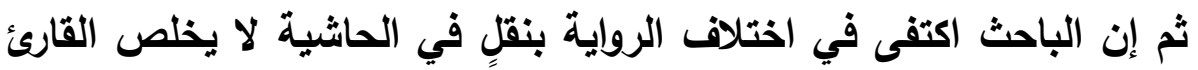

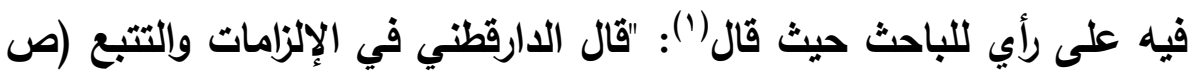
أنه (TYV

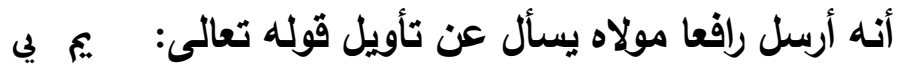

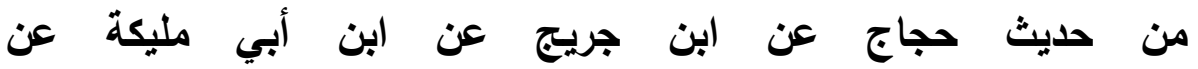
حميد بن عبدالرحمن بن عوف، ومن حيث هشام بن يوسف عن

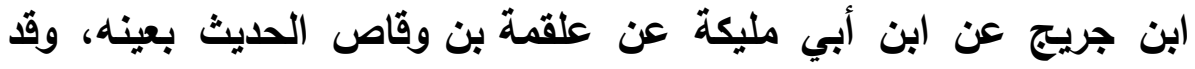

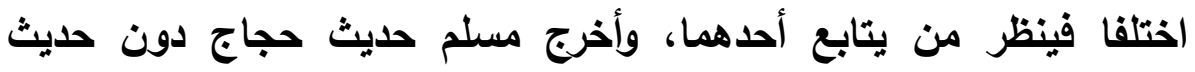

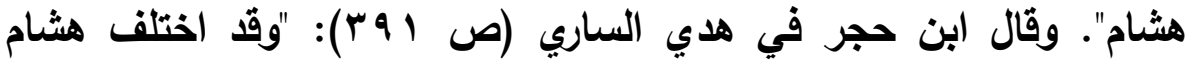
ابن يوسف وحجاج بن محمد في شيخ بن أبي مليكة؛ هشام يجعله علقمة ابن وقاص، وحجاج يجطله حميد بن عبدالرحمن، وقد تابع هشاما عبدالرزلق

$$
\text { (1) من لم يوصف بجرح ولا تعديل .. (ص .9 - حاشية 1). }
$$




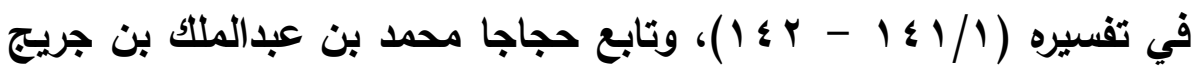
عن أبيه، قال إسحاق بن راهويه في مسنده: حدثنا روح بن عبادة حدثنا

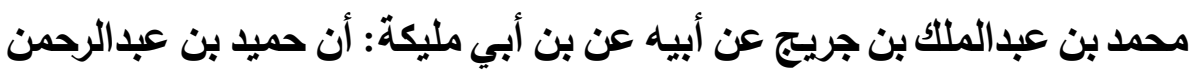

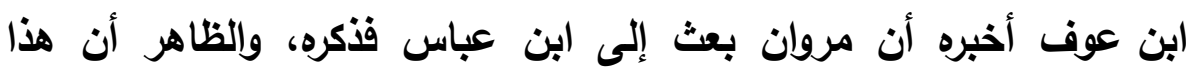
الاختلاف غير قادح؛ لاحتمال أن يكون ابن أبي مليكة سمعه منهما جميعا".

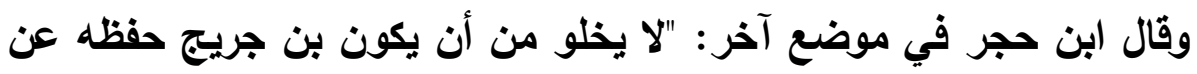

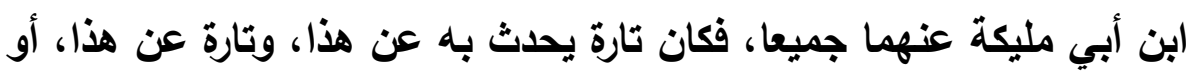

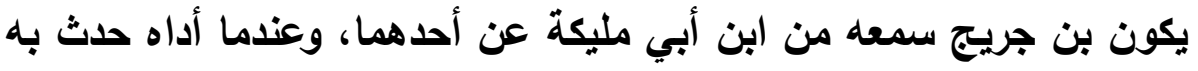

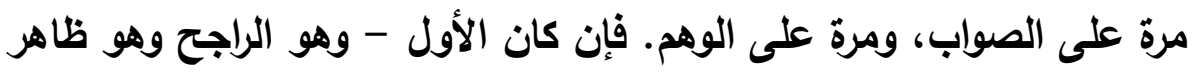

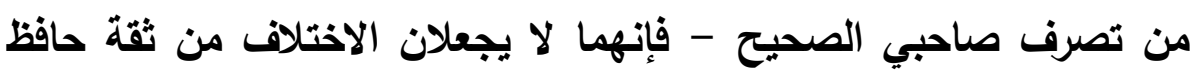

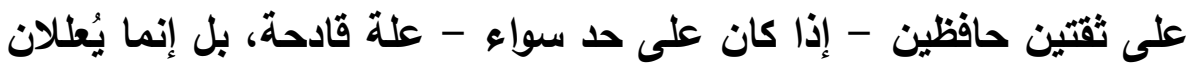

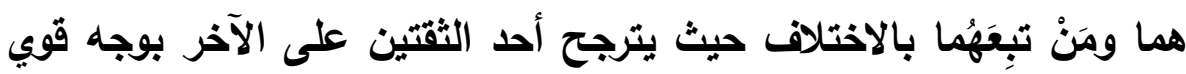

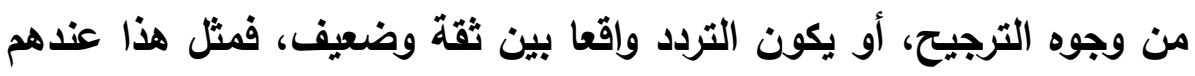

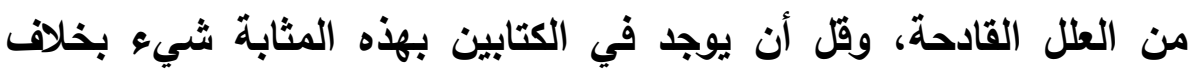

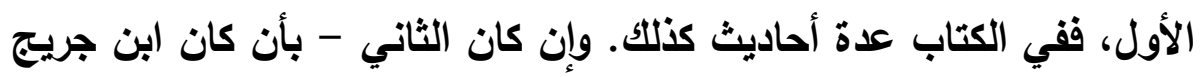

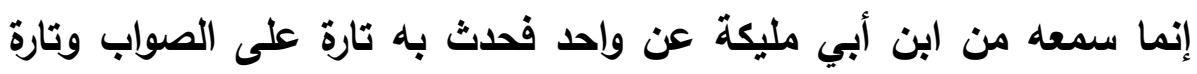

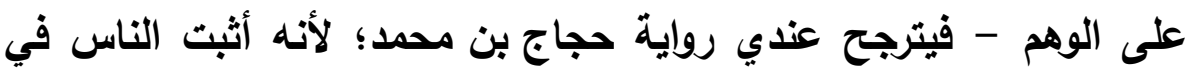
ابن جريج، ويذلك وصفه أحمد بن حنبل ومعلى بن منصور الرازي، وقدمه روايه

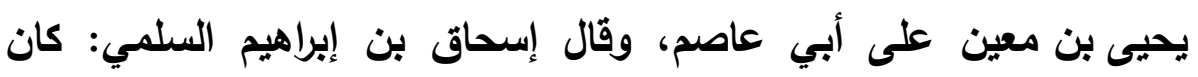

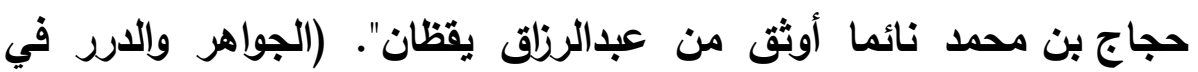

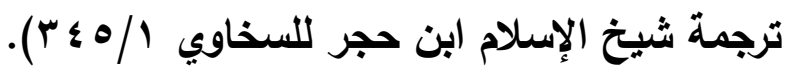


قلت: هذا كما تراه من الباحث في حاشية ولم نعلم له فيه لأيا، وأيضا كونه في حاشية بحثه غير لائق؛ لأنه ذكر في الأصل شبهة اختلاف الرواية، والباحث لم يعمل هنا على طريقة تخريج علل الحليث واستنتاج ما ينقله، فمن مجمل كلام المزي وابن حجر الذي نقلهما الباحث في الأصل حين ذكر عن المزي وابن حجر - وقد تقدم نصهما في المسألة الأولى -: احتمال رفع جهالة باحتمال سماع حميذ وعلقمة من رافع - فيما لو حضرا مجلس مروان - أو سماعهما من ابن عباس - إن حضرا جواب ابن عباس لرافع -؛ هذا رأي الباحث أن فهم من نقلهما رفع الجهالة وهو كما قلنا أن الأدق هو عدم اعتباره راويا في الأصل في حال ثبوت سماعهما الحديث بدون رافع، لكن من لازمه: سماعهما يرفع الاختلاف، لكن الباحث يسرد مجرد نقول يبثها هنا وهناك! والاختلاف (الاضطراب) الأي حكاه الباحث نقلا عن الإسماعيلي في الأصل - والدارقطني - في الحاشية - بأنه على ابن جريج(')، هذا

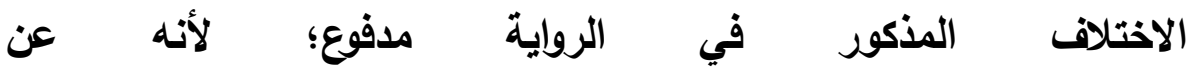
ابن جريج من طريقين: فأما الأولى عن ابن أبي مليكة عن علقمة، فيرويها الثقات الحفاظ: هثام بن يوبف وعبدالرزاق ومحمد بن ثور الصنعانيون: عن ابن جريج عن ابن أبي مليكة به، ويقابلهم حجاج الأعور أثبث الناس في ابن جريج يرويها عن ابن جريج عن ابن أبي مليكة عن حميا به، وقد تابع حجاجا محمد بن عبدالملك بن جريج عن أبيه وقد صححه الحاكم على ما تقدم(ץ)، وروايته- على ما قيل فيه من جهالة - ليست مدفوعة عن

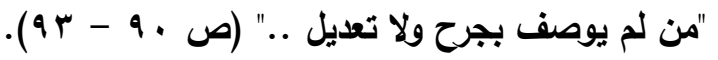

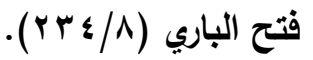


إزالة إيهام القائلين بوجود

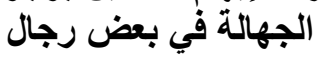

استئناس وتقوية لرواية حجاج التي كفى بها في الوثاقة والثثوت، وكفى

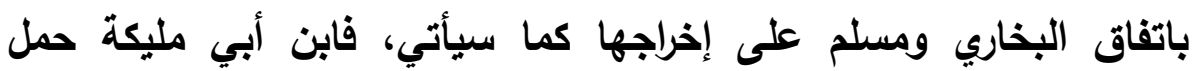

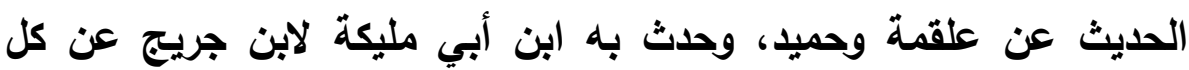

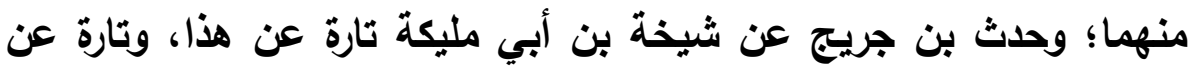

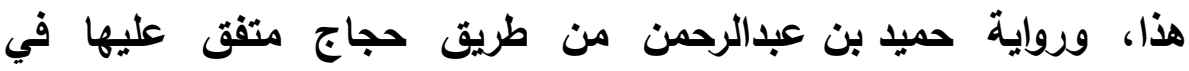

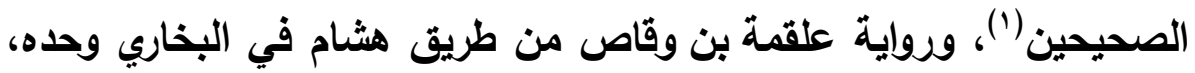

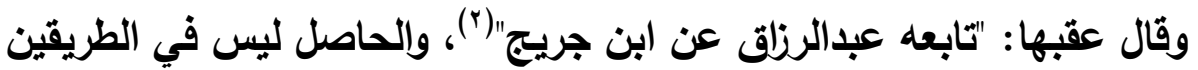

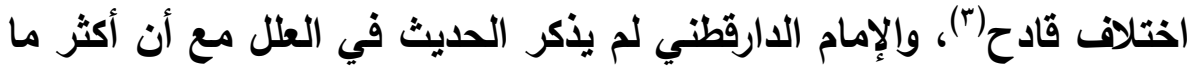

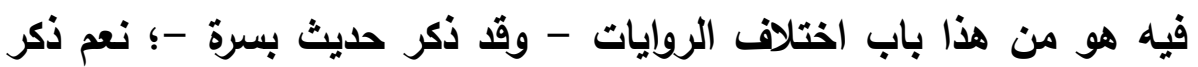

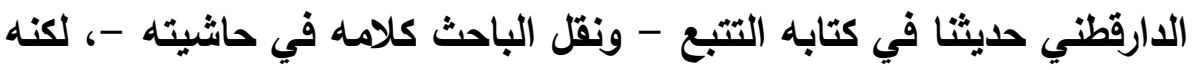

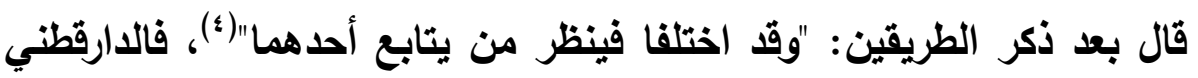
لم يرجح ولم يجزم بشيء! ثم ذكر الباحث عقبه كلام لابن حجر من هلي الائ

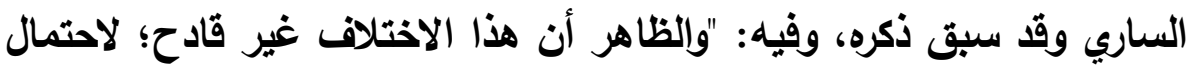

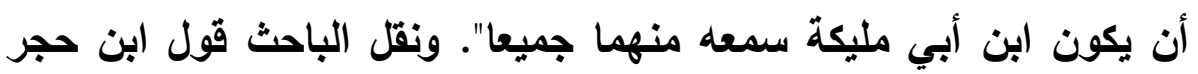

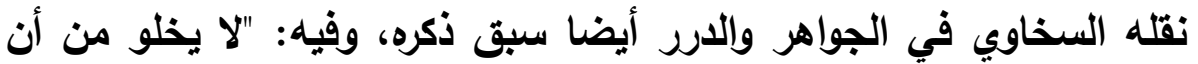

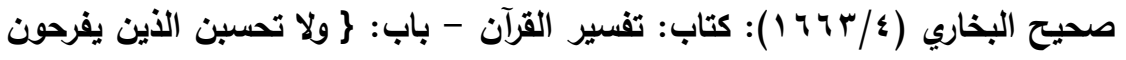

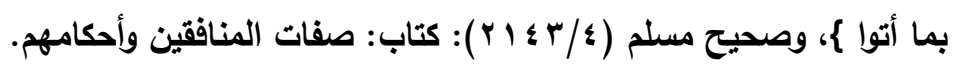

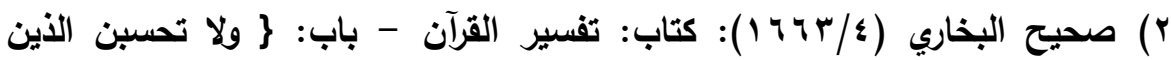
يفرحون بما أتوا \{.

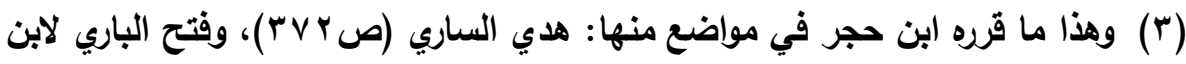

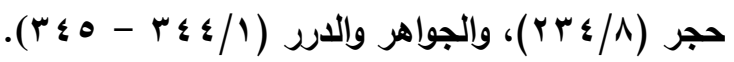

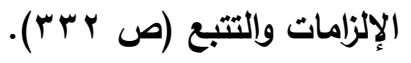
مجلة كلية أصول الاين والدعوة بأسيوط / العدد السابع والثلاثون 9 الـ بم - الجزء الثالث 
إزالة إيهام القائلين بوجود

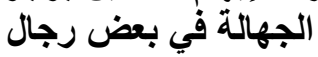

يكون ابن جريج حفظه عن ابن أبي مليكة عنهما جميعا، فكان تارة يحدث به

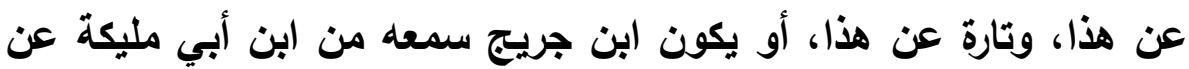

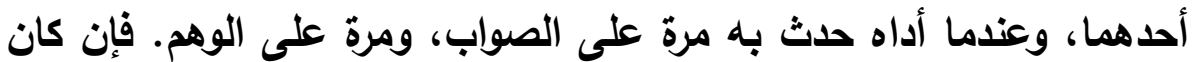
الأول - وهو الراجح وهو ظاهر من تصرف صاحبي الصحيح - فإنهما لا حأل

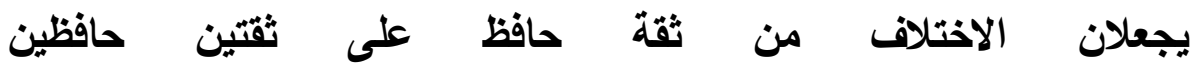
- إذا كان على حد سواء - علة قادحة، بل إنما بُعلان هما ومَنْ تبعَهُهما بالاختلاف حيث يترجح أحد الثقتين على الآخر بوجه قوي من وجوه الترجيح، أو يكون التردد واقعا بين ثثة وضعيف، فمثل هذا عندهم من العلل القادحة،

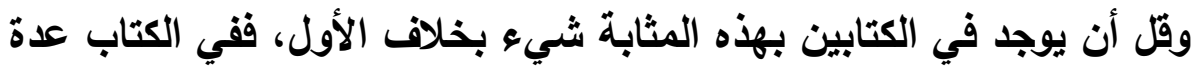

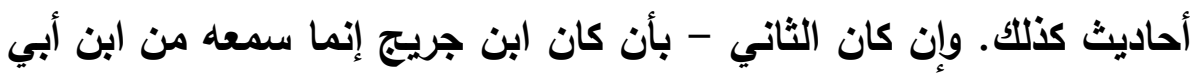
مليكة عن واحد فحدث به تارة على الصواب وتارة على الوهم - فيترجح عندي

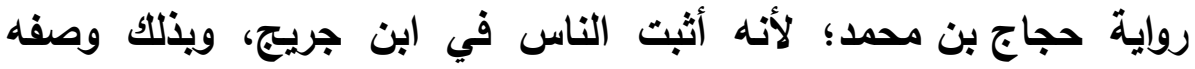

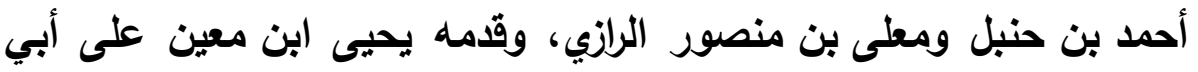

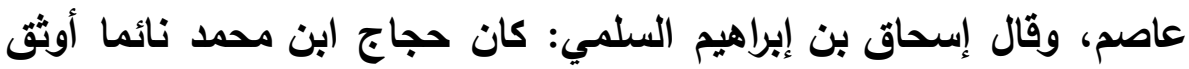
من عبدالرزلق يقظان". قلت: الأول هو الذي يوافق صنيع البخاري حيث ذكر

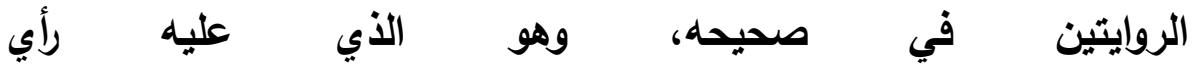
ابن حجر في هلي الساري في رد ذكر الدارقطني للحديث في كتابه التبع

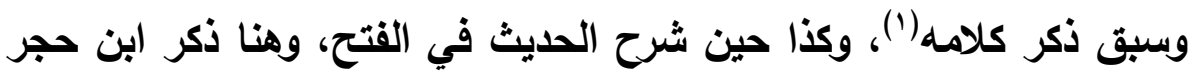

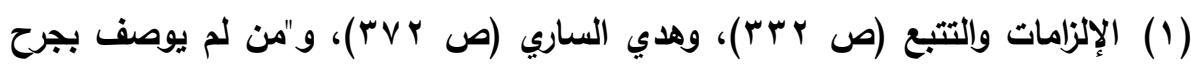
ولا تعديل .." (ص .9 - حاشية ()).

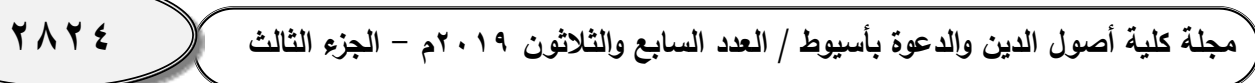


اعتراض الإسماعيلي بنصه بخلاف العيني الأي نقل منه الباحث(1)، فكان

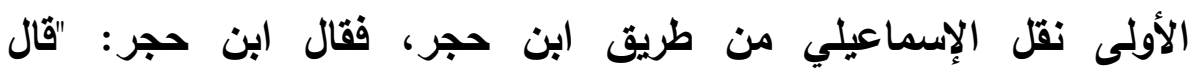
(الإسماعيلي): ومع هذا فاختلف على ابن جريج في شيخ شيخها فئه فقال:

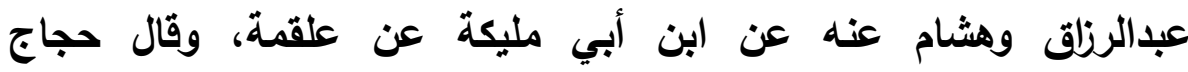

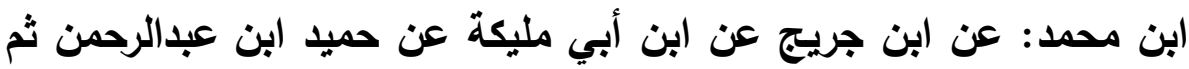
ساقه من رواية محمد بن عبدالملك بن جريج عن أبن أبيه مل عن بن عن أبي مليكة

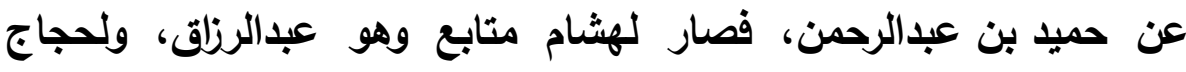

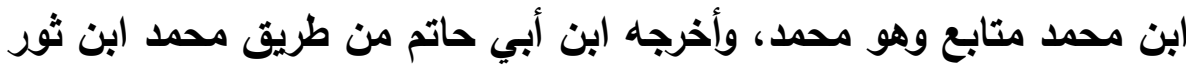

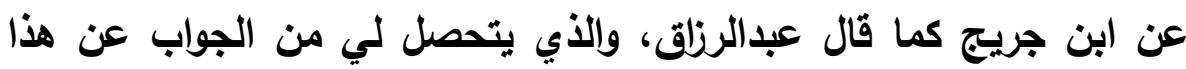

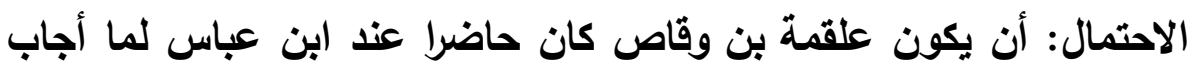

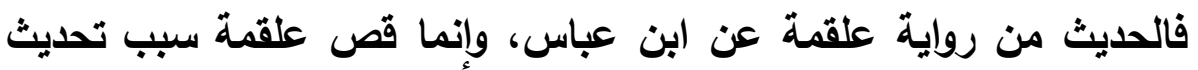
ابن عباس بذلك فقط، وكذا أقول في حميد بن عبن عبدالرحمن؛ فكأن

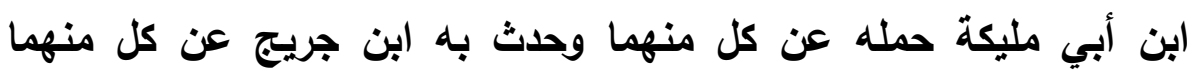

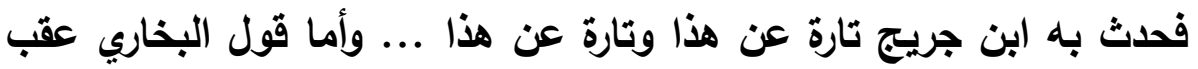

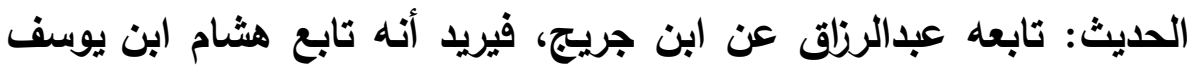

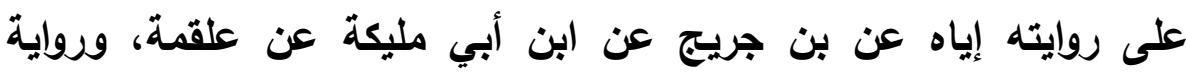

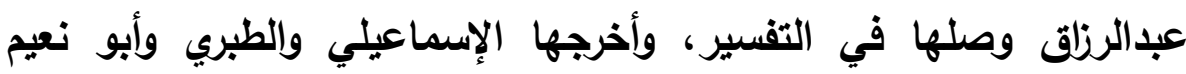

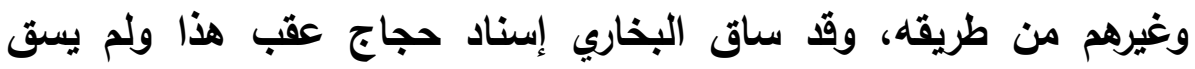

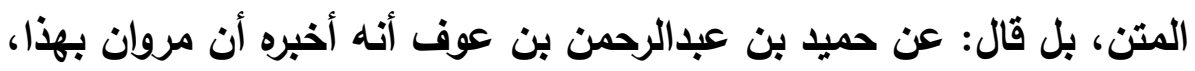

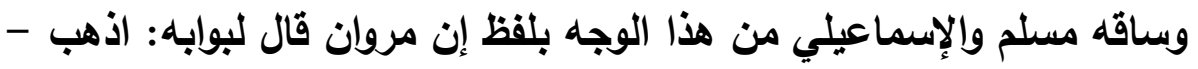

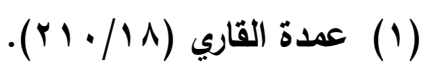


يا رافع - إلى ابن عباس فقل له، فنكر نحو حديث هشام"(1)، فهذا كلام علمي وييان رصين من ابن حجر تركه الباحث، وفيه تفصيل وييان برد الاختلاف؛ يجعل القارئ يطمئن لرد كلام الإسماعيلي، ولا يتوقف على توقف الدارقطني في إزاحة الاختلاف، ولا يتردد القارئ بصحة الحديث بالطريقين بسبب تشويش ناتج عن تصرف الباحث حيث جعل كلام ابن حجر في توجيه الاختلاف في الحاثية وأتى في أصل البحث باستبعاد سماع حميا وعلقمة من ابن عباس من خلال كلام العيني مقرا له من غير تعقب!! نعم الباحث تبعا للعيني - يتكلم عن رفع جهالة رافع وابن حجر يقوي سماع حميا وعلقمة من ابن عباس، فاستبعد ذلك العيني، لكن في استبعاده استبعاد لتوجيه رفع الاختلاف بأن يكونا سمعا الحديث وسمعه منهما ابن أبي مليكة، فقال الباحث(ץ): "واستبعد العيني احتمال سماعهما جواب ابن عباس فقال: لو لو كان علقمة حاضرا عند ابن عباس عند جوابه لكان أخبر ابن أبي مليكة أنه سمع ابن عباس أنه أجاب لرافع بواب مروان بالذي سمعه، ومقام علقمة أجل من أن يخبر عن رجل مجهول الحال بخبر قـ سمعه عن ابن عباس وترك ابن عباس وأخبره عن غيره بذلك"()، لكن كلام ابن حجر في جميع مواضعه مؤداه واحد، ومنه ما نقله الباحث في حاشيته لابن حجر؛ فإنه لا يهمل لنفاسته، وهو قول ابن حجر: "لا يخلو من أن يكون ابن جريج حفظه عن

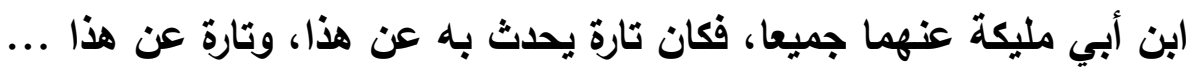

$$
\begin{aligned}
& \text { (1) فتح الباري (^/ع سب). } \\
& \text { (Y) "من لم يوصف بجرح ولا تعديل .." (ص r (Y) (Y). }
\end{aligned}
$$

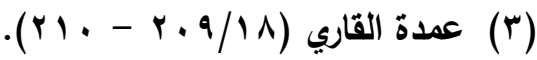


إزالة إيهام القائلين بوجود

الجهالة في بعض الفالين بوجال

وهو الراجح وهو ظاهر من تصرف صاحبي الصحيح؛ فإنهما لا يجعلان الاختلاف من ثقة حافظ على ثقتين حافظين - إذا كان على حد سواء - علة

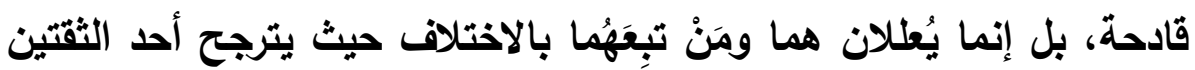

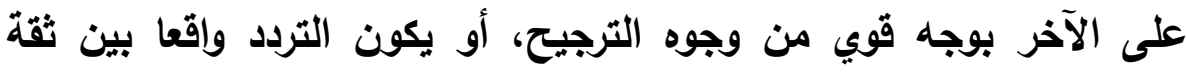
وضعيف، فمثل هذا عندهم من العلل القادحة، وقل أن يوجد في الكتابين بهذه ونها

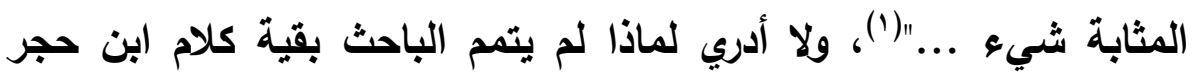

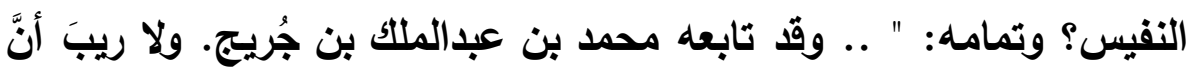

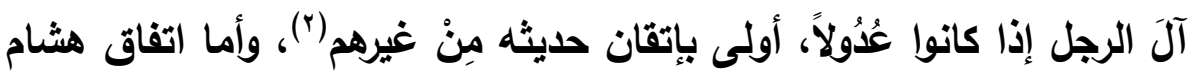

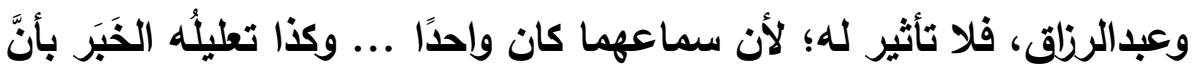

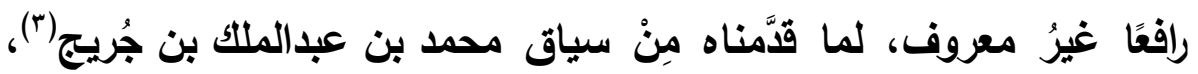

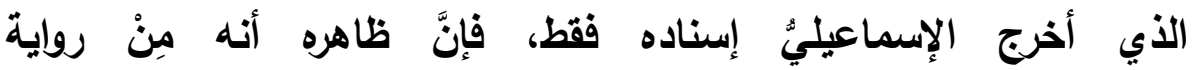
عن

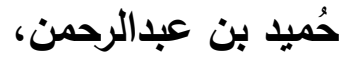

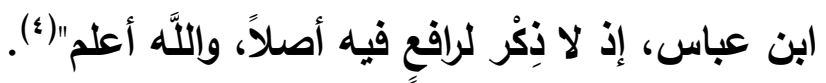

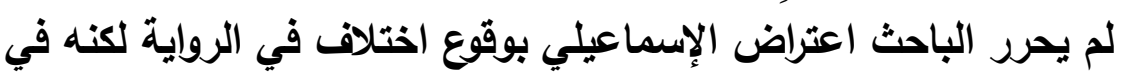

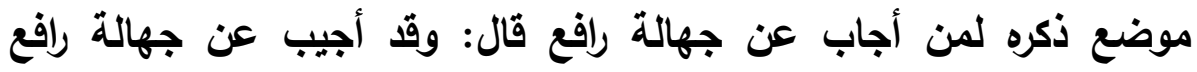
بأمرين: (أ) ... (ب) أنه يحتمل أن يكون الحديث من رواية علقمة وحميد

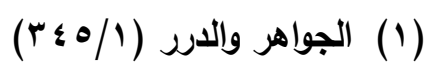

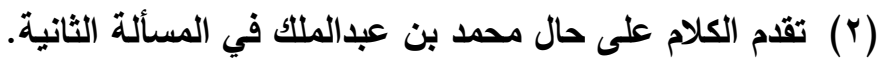
(ץ) تقام ذكر روايته في المسألة الثانية.

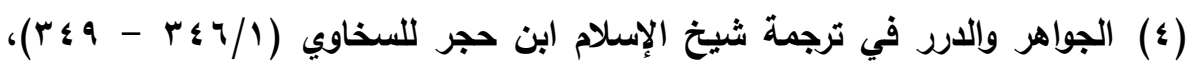

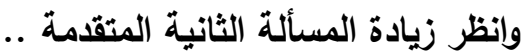
مجلة كلية أصول الدين والدعوة بأسيوط / العدد السابع والثلاثون 9 ا ـ بم - الجزء الثالث 
عن ابن عباس، قال المزي: وكأنهما(') سمعا منه جواب ابن عباس(")، وتبعه

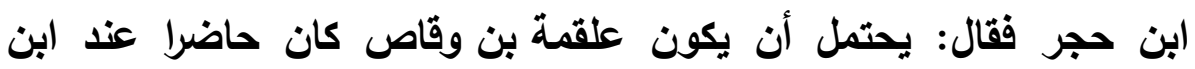

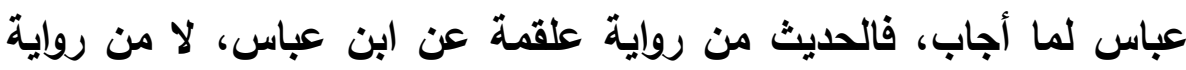

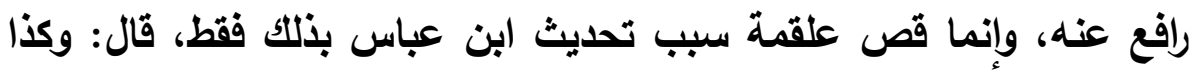

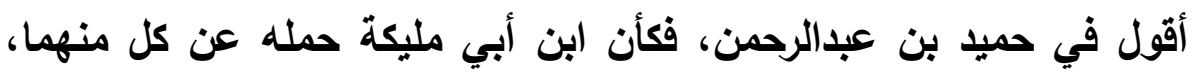

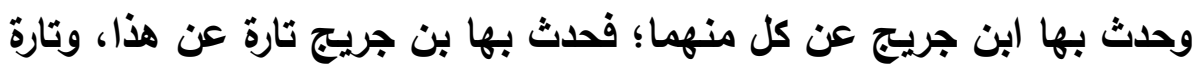
عن هذ|(r).

قلت: هذا يصلح أن يقول فيه الباحث: "وقث أجيب عن وقوع الاختلاف

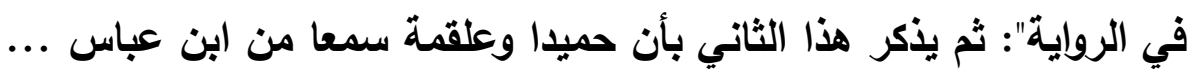
ويذكر ما تقدم من نقل .. ويحسن أن نختم هذا التبع على صاحبي الصحيح بما ذكر الحافظ ابن حجر في هاي الساري حيث قال: "الفصل الثامن في سياق الأحاديث التي انتقدها عليه حافظ عصره أبو الحسن الدارقطني وغيره من النقاد

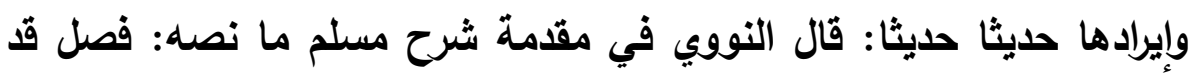



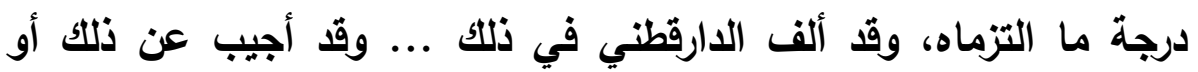
أكثره. أهـ(๕) ... وروى الفريري عن البخاري قال: ما أدخلت في الصحيح

(1) تقدم في المسألة الثانية ما وقع من الباحث من تحريف لهذا النص!

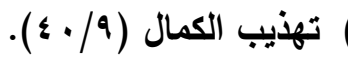

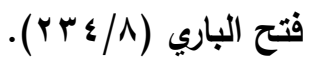

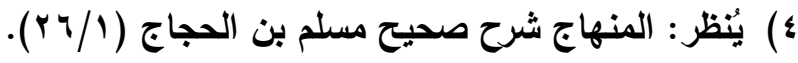


حديثا إلا بعد أن استخرت الله تعالى وتيقتت صحته، وقال مكي بن عبدالله: سمعت مسلم بن الحجاج يقول: عرضت كتابي هذا على أبي زرعة الرازي فكل

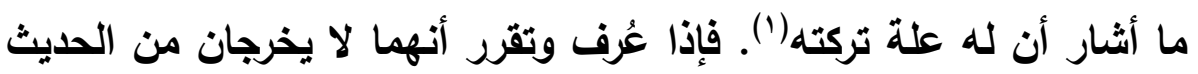
إلا ما لا علة له أو له علة إلا أنها غير مؤثرة عندهما فبتقدير توجيه كلام من انتقد عليهما يكون قوله معارضا لتصحيحهما ولا ريب في تقديمهما في ذلك على غيرهما فيندفع الاعتراض من حيث الجملة وأما من حيث التفصيل: فالأحاديث التي انتقدث عليهما تتقسم أقساما .." فنكر الحافظ أقساما منها قوله: "القسم الثاني: منها ما تختلف الرواة فيه بتغيير رجال بعض الإسناد فالجواب عنه إن أمكن الجمع بأن يكون الحديث عند ذللك الراوي على الوجهين جميعا فأخرجهما المصنف ولم يقتصر على أحدهما حيث يكون المختلفون في ذلك متعادلين في الحفظ والعدد ..."(ז)، فإذا تقرر ذلك كانت دعوى الاضطراب في هذا الحديث منتفية؛ لأن الاختلاف على الحفاظ في الحديث لا يوجب أن يكون مضطريا إلا بشرطين أحدهما استواء وجوه الاختلاف وثانيهما - مع الاستواء - أن يتعذر الجمع على قواعد المحثين ويغلب على الظن أن ذلك الحافظ لم يضبط ذلك الحديث بعينه؛ فحينئ يحكم على تلك الرواية وحدها بالاضطراب ويتوقف عن الحكم بصحة ذلك الحديث لألك، وهنا أمكن إزالة التعارض والاختلاف على وفق ما سبق ذكره.

(1) يُنظر : صيانة صحيح مسلم (ص .1)، وَالمنهاج شرح صحيح مسلم بن الحجاج (r $(r / 1)$

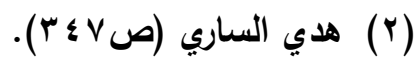
مجلة كلية أصول الدين والدعوة بأسيوط / العدد السابع والثثلاثون 9 ابـ بم - الجزء الثالث 
إزالة إيهام القائلين بوجود

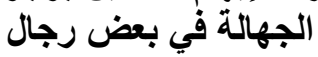

فالحديث صحيح متفق عليه، فهل هذا الحديث صحيح متفق عليه عند الباحث، ظاهر عرضه: "لا"؛ لأن الحديث فيه مجهول عنده (إما جهالة عين أم حال)، وكأنه لو رُفعت الجهالة بقي الاختلاف الذي أورده ولم نعرف رأيه فيه، فكأنه اكتفى عن ذكر رأيه بوجود الجهالة التي نص عليها مع رأيه في أن صاحبي الصحيح ذكرا الحديث بعد حديث أبي سعيد، فعنده عدم

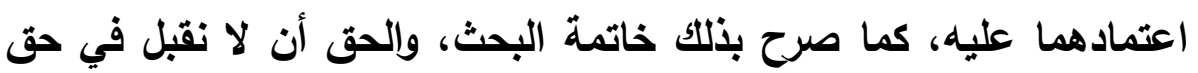
الإمامين البخاري ومسلم - وصحيحيهما - مثل هذا؛ كلا والله. الرابعة: إلزام البخاري بحديث آخر (وهو حديث بسرة بنت صفوان ك): تقدم أن الباحث ذكر من جملة اعتراض الإسماعيلي إلزامه البخاريَّ أن يخرج حديث بسرة في مسّ الأكر، فما وُجد في حديث بسرة يوجد في حديث ابن عباس هذا، وذلك التشابه في علتين: الاختلاف والجهالة: قال الباحث: "اقد اعترض الحافظ الإسماعيلي على الإمام البخاري إخراجه لحديث ابن عباس

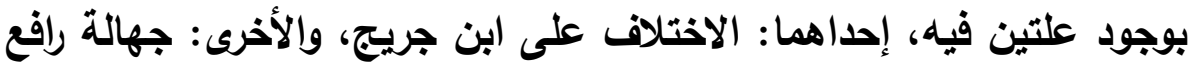
بواب مروان، حيث قال: يرحم الله البخاري! أخرج هذا الحديث في الصحيح مع الاختلاف على بن جريج، ومرجع الحديث إلى بواب مروان عن ابن عباس، ومروان ويوابه بمنزلة واحدة، ولم يذكر حديث عروة عن مروان وحرسيه عن بسرة في مس الأكر(')، ولا فرق بينهما إلا أن البواب مسمى،

(1) قال الباحث هنا: روى النسائي في سننه 1/1 ـ 1 - كتاب: الطهارة- باب: الوضوء من مس الأكر برقم:ء 17 من طريق الزهري عن عبدالله بن أبي بكر بن عمرو

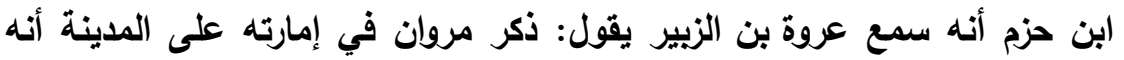

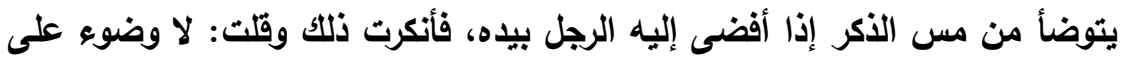


إزالة إيهام القائلين بوجود

الجهالة في بعض الفالين بوجال

ثم لا يعرف إلا هكذا، والحرسيّ غير مسمى، والله يغفر لنا وله(1). قال

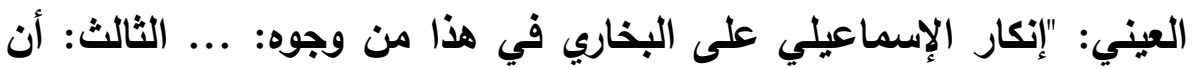

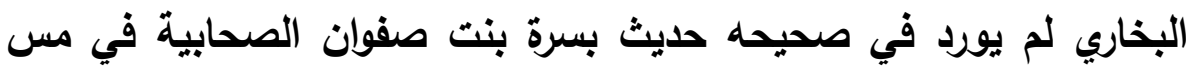

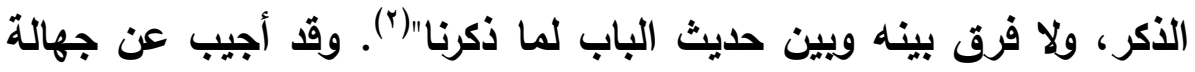

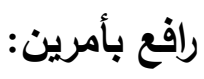

من مسه، فقال مروان: أخبرتني بسرة بنت صفوان أنها سعت رسول الله -

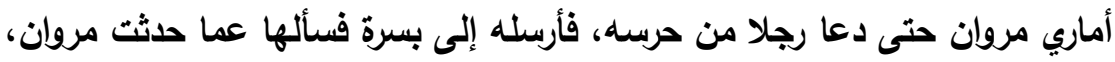

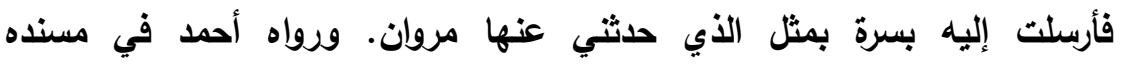

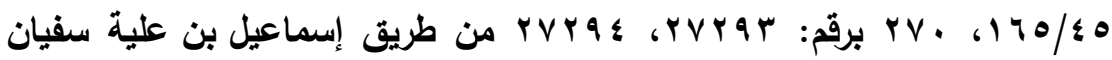

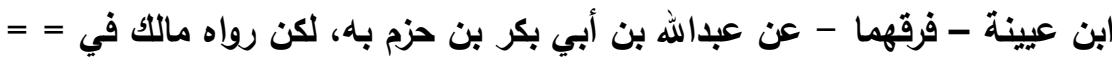

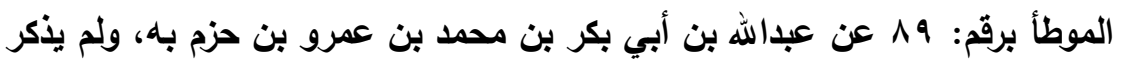

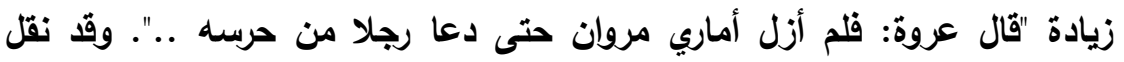

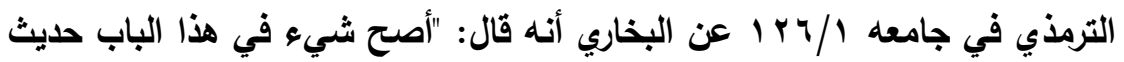

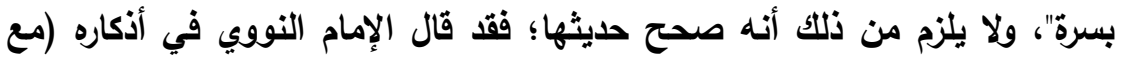

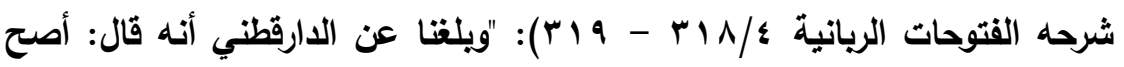

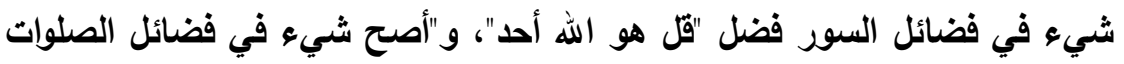

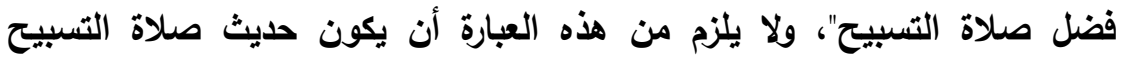

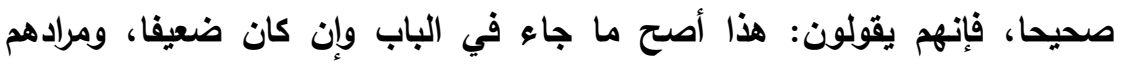

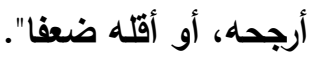

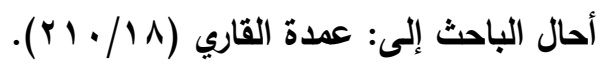

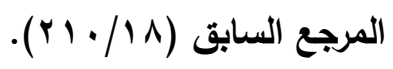
مجلة كلية أصول الدين والدعوة بأسيوط / العدد السابع والثلاثون 9 الـ بم - الجزء الثالث 
إزالة إيهام القائلين بوجود

الجهالة في بعض الفالين بوجال

(أ) ... (ب) أنه يحتمل أن يكون الحديث من روايـة علقمة وحميد عن

ابن عباس .

واستبعد العيني احتمال سماعهما جواب ابن عباس فقال: لو كان علقمـة

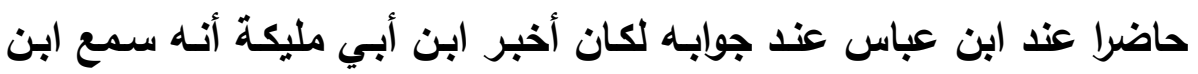

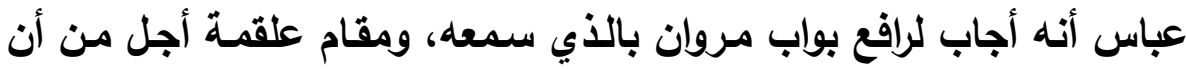
يخبر عن رجل مجهول الحال بخبر قد سمعه عن ابن عباس وترك ابن بـان

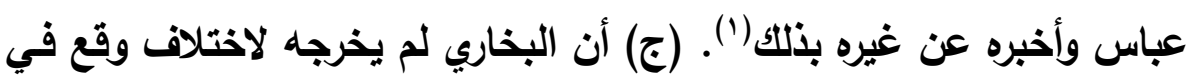

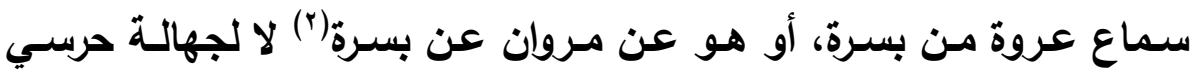

مروان فقط" انتهى كلام الباحث ونقله (זّ). قلت: تقدم التنبيه في المسألة الثالثة على عدة أخطأ ارتكبها الباحث في نقله منه قوله "وقد أجيب عن جهالة رافع بأمرين ..."، مع ذكره ثثلاثة أجوية،

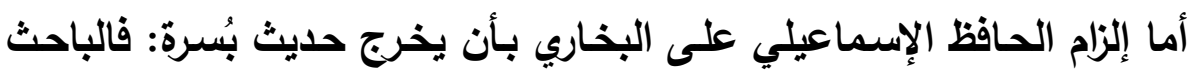

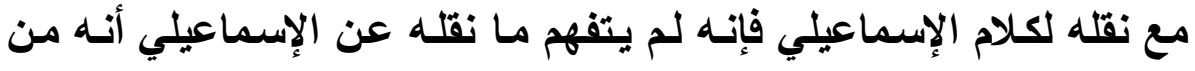

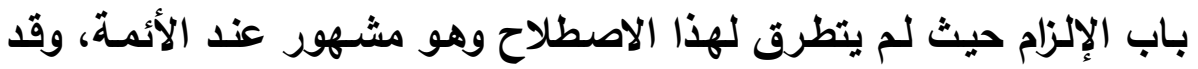
ألف الدارقطني كتـاب "الإلزامـات .." يريـ مثل هذا النـوع من الإيراد على

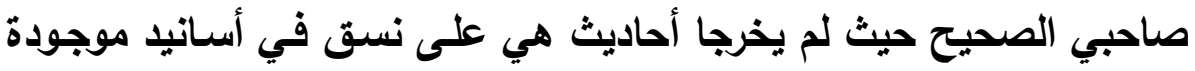

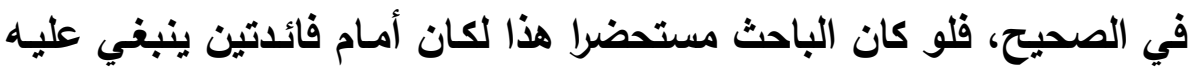

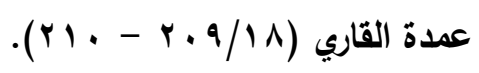

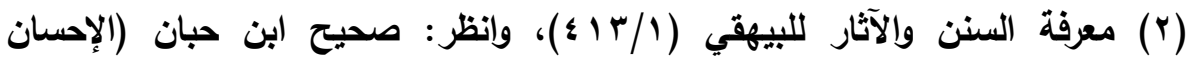
(

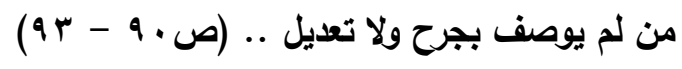
مجلة كلية أصول الدين والدعوة بأسيوط / العدد السابع والثثلاثون 9 ا ـ بم - الجزء الثالث 
ذكرهما: الأولى: لا يلزم من إلزام الإسماعيلي صاحب الصحيح أن يخرج مثل

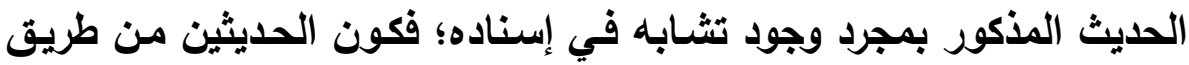
بواب مروان عن مروان مجرد إلزام ليس بلازم على صاحب الصحيح، وفات

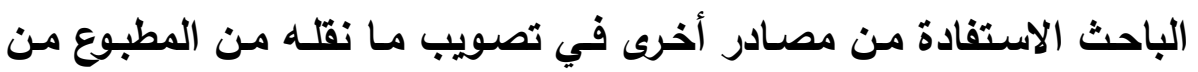

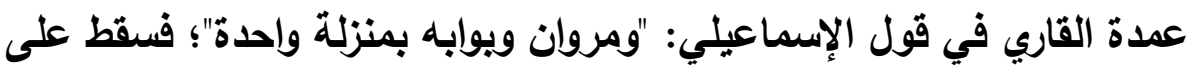
العيني فيما يظهر لي لفظ "حرسي" قبل "مروان" لأن الكلام على وجود بواب

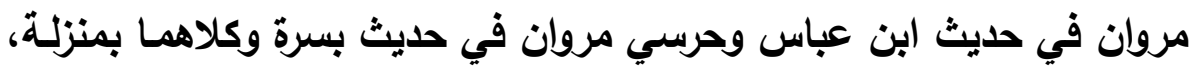

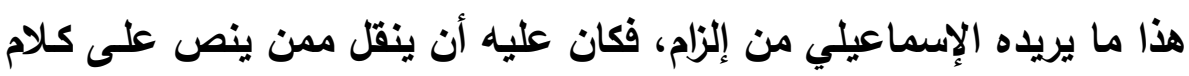
الإسماعيلي نصا، ويعض هذه المصادر بين يديه ينقل منها كالجواهر والدرر

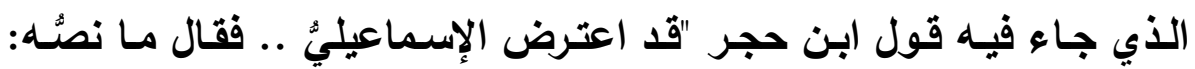

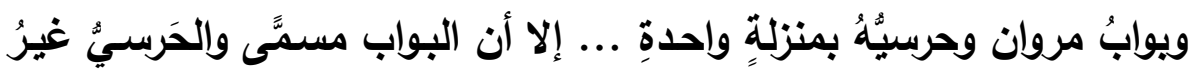

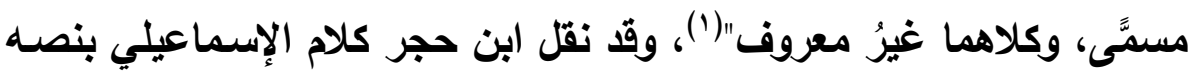

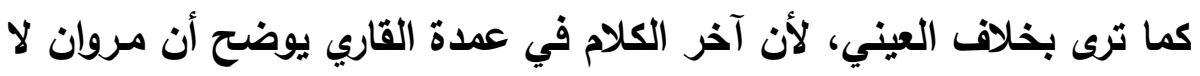

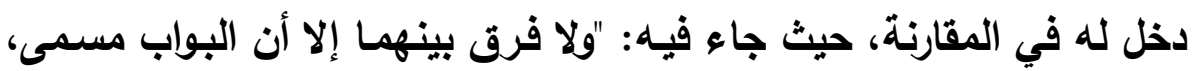

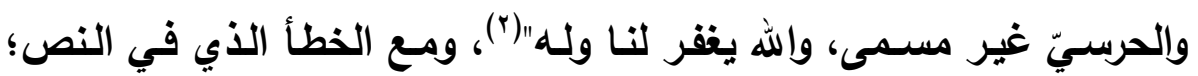
فإنه لم يذكر لنا تحليلا لجعل مروان ويوابه بمنزلة واحدة؟! بل واله اكتفى بتحليل

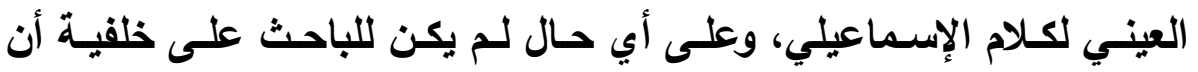

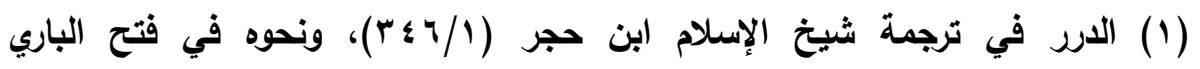

$$
\begin{aligned}
& \text { ( ) }
\end{aligned}
$$

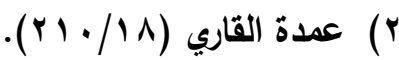


الإسماعيلي أصلا يعيب على البخاري إخراج حديث مروان (')، وكان الواجب على الباحث إزاء هذا النقل أن يبدي موققه ورأيه ويجيب عن تساؤل: ما حال مرويات مروان بن الحكم عند الإسماعيلي وهل يخالف غيره من أئمة الحديث

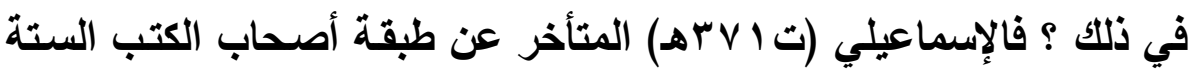
تكلم في مروان في غير هذا الموضع الذي صويناه، وعاب على البخاري

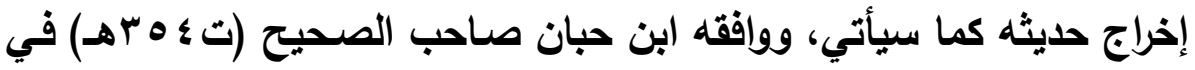

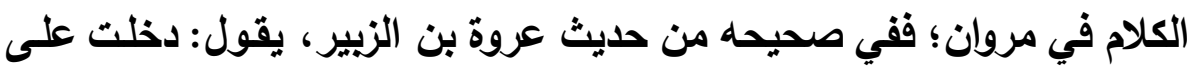

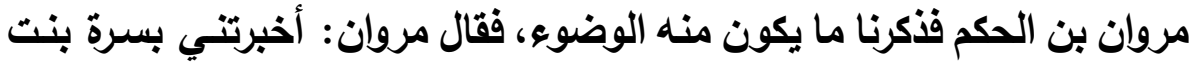

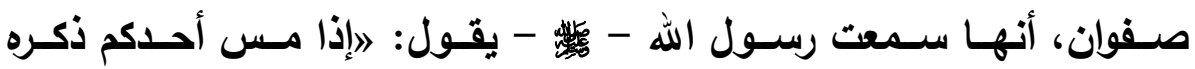

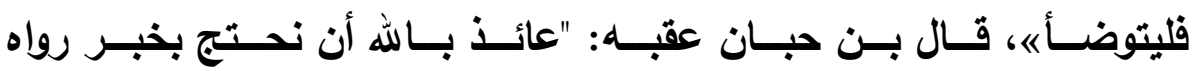

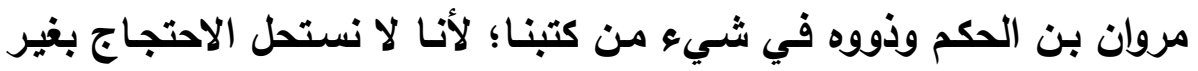

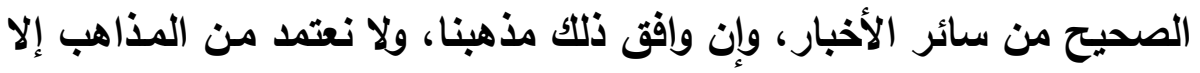

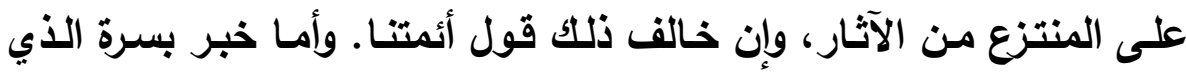

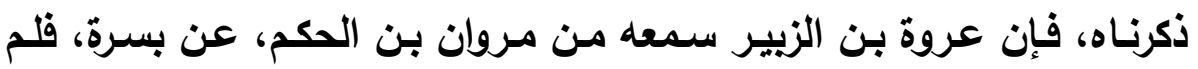
يقتعه ذلك حتى بعث مروان شرطيا لله إلى بسرة فسألها، ثم آتاهم فأخبرهم بمثل ما قالت بسرة، فسمعه عروة ثانيا عن الثرطي، عن بسرة، ثم لم يقتعه

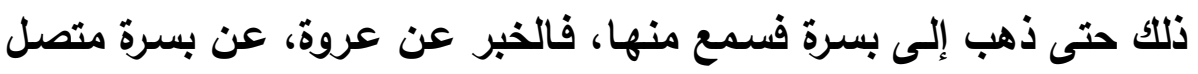

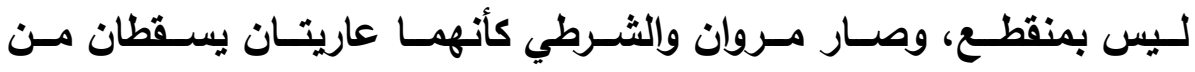

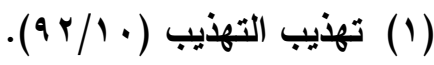
مجلة كلية أصول الدين والدعوة بأسيوط / العدد السابع والثثلاثون 9 ا ـ بم - الجزء الثالث 
الإسناد"(1)، قلت: كذا فهم ابن حبان من تصرف عروة في هذا الحديث أنه لا يعتمد على مروان في الرواية، وهذا مردود بأمرين: أن عروة يثبّت مروان في

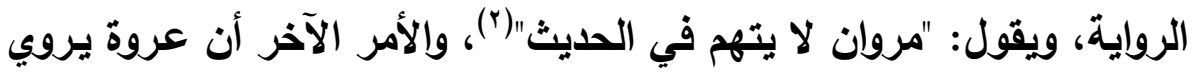
غير هذا الحديث عن مروان، وإنما كان من عروة التثبث في هذا الحديث

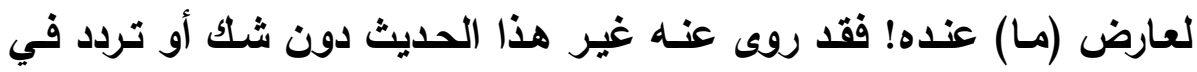
أخذه، وطائفة من تلك الأحاديث في صحيح البخاري (ّ) بل روى عن مروان

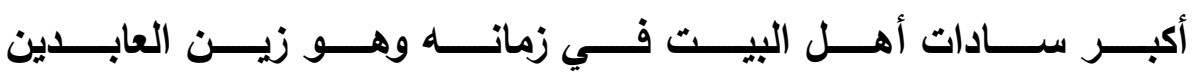
علي بن الحسين بن علي بن أبى طالب في صحيح البخاري وغيره كما روى عنه الصحابي سهل بن سعد وهي أيضا في صحيح البخاري، ومـا نتكلم فيه هنا هو باب الرواية وضبطها، فهؤلاء على جلالتهم مـا رووا عنـه إلا لصدقه في الروايـة، وأمـا أعمالـه فقد قـال الـذهبي: "لـه أعمـال مويقـة. نسـأل الله السـلامة، رمسى طلحة بسـهم وفعل وفعل"( ؛)، ولنعتبر كـلام الإسـماعيلي وابن مولن

الإحسان في تقريب صحيح ابن حبان لابن بلبان: كتاب: الطهارة - ذكر خبر فيه

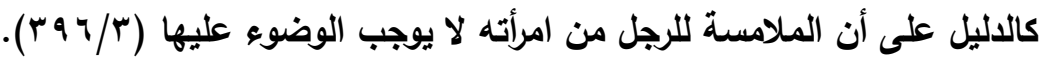
هدي الساري (ص ب ؟ \& ).

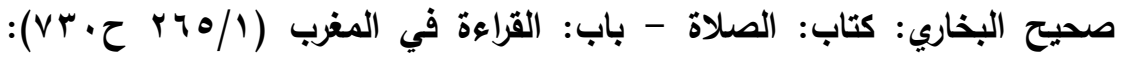
عروة بن الزبير عن مروان بن الحكم قال: "قال لي زيد بن ثابت: "ماعد للك تقرأ في

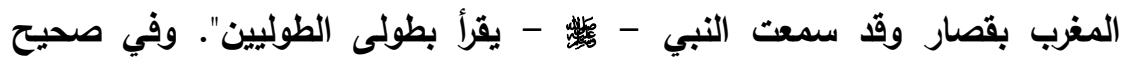

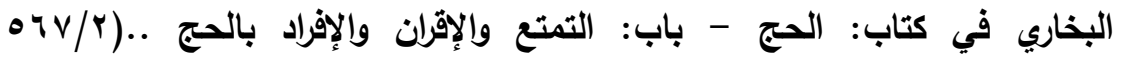

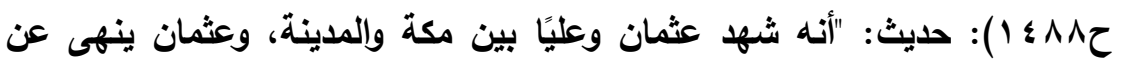

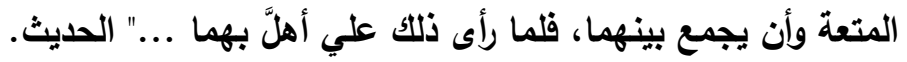

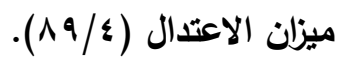
مجلة كلية أصول الدين والدعوة بأسيوط / العدد السابع والثثلاثون 9 ا ـ بم - الجزء الثالث 
حبان من جملة الاعتراضات التي جاء جواب ابن حجر عليها في الافاع عن

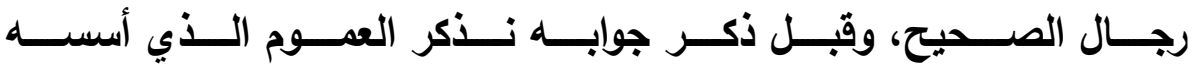
ابن حجر بقوله: "وقبل الخوض ينبغي لكل منصف أن يطلم أن تخريج صاحب المبل

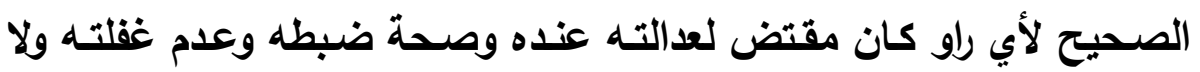

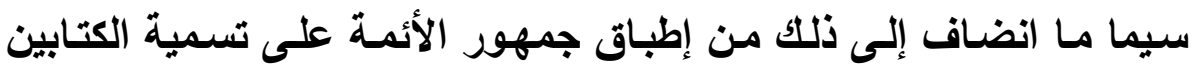
بالصحيحين، وهذا معنى لم يحصل لغير من خرج عنه في الصحيح فهو

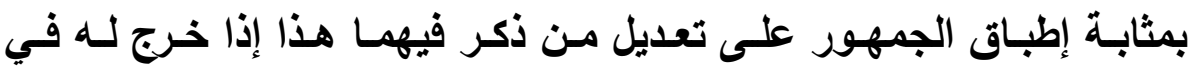

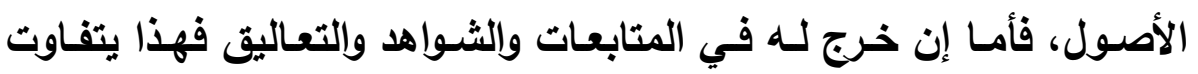

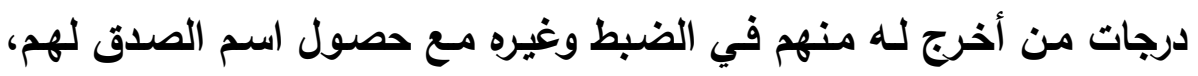
وحينئذ إذا وجدنا لغيره في أحد منهم طعنا فذلك الطعن مقابل لتعديل هذا

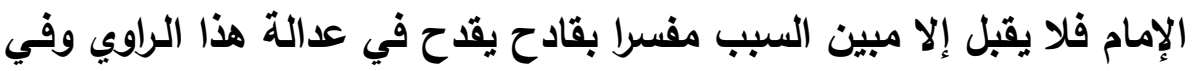

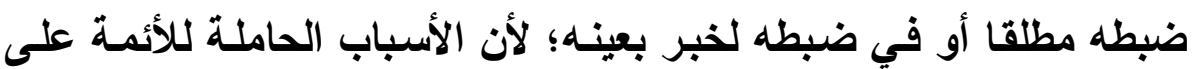

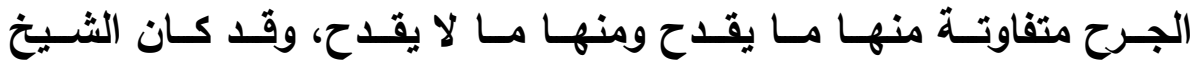
أبو الحسن المقسي يقول في الرجل الذي يخرج عنه في الصحيح: هذا جاز

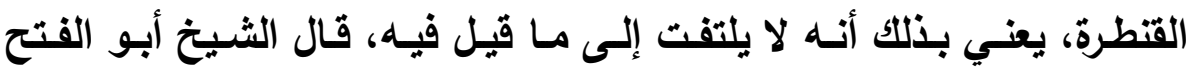

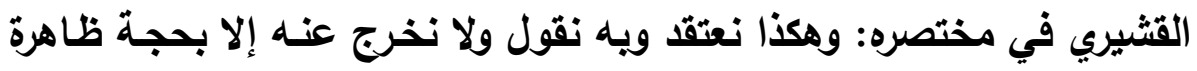

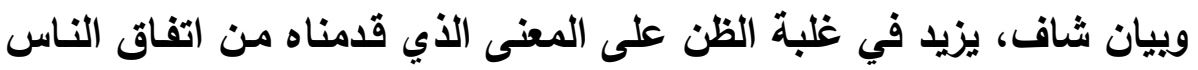
بعد الثـيخين على تسمية كتابيهمـا بالصـيحين، ومسن لـوازم ذلكت تعديل

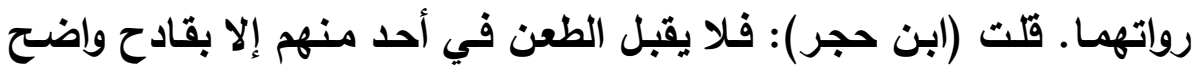
مجلة كلية أصول الدين والدعوة بأسيوط / العدد السابع والثلاثون 9 ـ ـ بم - الجزء الثالث 
إزالة إيهام القائلين بوجود

الجهالة في بعض الفالين بوجال

.."(1). وللشيخ طاهر الجزائري في توجيه النظر كلام مفيد بعد ذكره لمروان وكلام ابن حجر السابق، فقد قال الجزائري: "والذي ينبغي أن يقف عليه كل راغب في علم الأثر أن الإمـام البخاري كان جل قصده أن يكون الراوي قد صدق فيما رواه عنه من غير نظر إلى أمر آخر .."(؟). وهذا الكـلام الرصبن يكون أولحى بـه في رد تكلف من تكلّف القول بجهالة بعض رجال الصحيح والبحث فيمن لم يوصف بجرح أو تعديل فيهما.

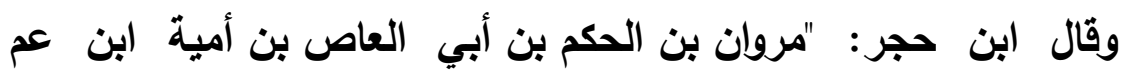
عثمان بن عفان، يقال: له روئة؛ فإن ثبتت فلا يعرج على من تكلم فيه(ّ)، وقال عروة بن الزبير: "كان مروان لا يتهم في الحديث"، وقد روى عنه سهل بن سعد الساعدي الصحابي اعثمادا على صدقه، وإنما نقموا عليه أنه رمى

$$
\begin{aligned}
& \text { (1) (1) هلدي الساري (ص ع^ץ). }
\end{aligned}
$$

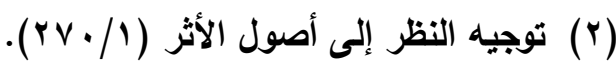

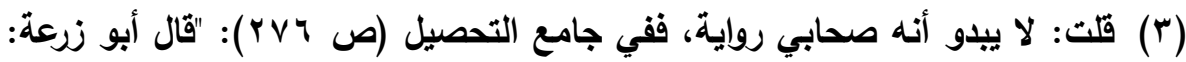

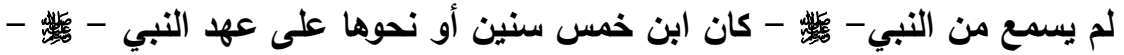

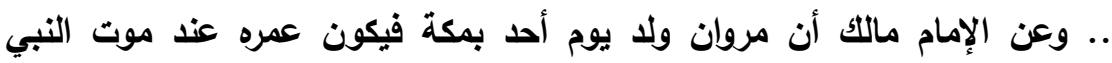
-

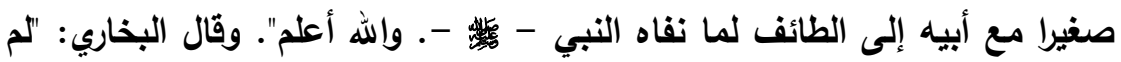

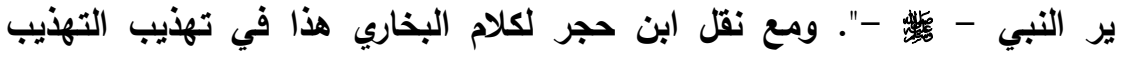

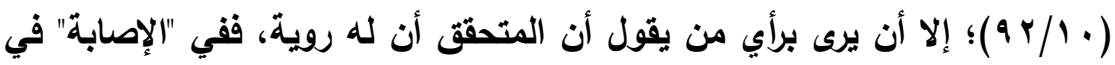

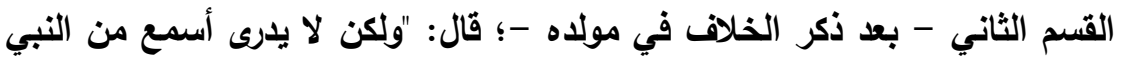

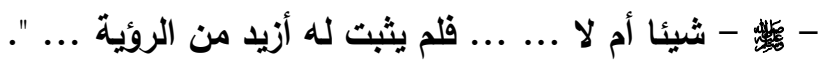


طلحة يوم الجمل بسهم فقتله(') ثم شهر السيف في طلب الخلافة حتى جرى ما جرى، فأما قتل طلحة فكان متأولا فيه كما قرره الإسماعيلي وغيره، وأما ما بعد ذلك فإنما حمل عنه سهل بن سعد وعروة وعلي ابن الحسين وأبو بكر بن عبدالرحمن بن الحارث، وهوّلاء أخرج البخاري أحاديثهم عنه في صحيحه لما كان أميرا عندهم بالمدينة قبل أن يبدو منه في الخلاف على ابن الزبير ما بدا - والله أعلم - وقا اعتمد مالك - على حديثه ورأيه - والباقون سوى مسلم" ()، وقول ابن حجر : "قبل أن يبدو منه في الخلاف على ابن الزبير"؛ إنما أخذه من الإمام ابن حزم وق نقله بنصه ابن حجر نفسه في كتابه التلخيص بعد أن تعقب أيضا هناك كلام الإسماعيلي ملزما البخاري إخراجه حديث مروان عن بسرة لأجل أخرج نظيره هنا عن مروان، فقال هناك: "وأما الطعن في مروان: فقد قال ابن حزم: "مروان ما نعلم له جرحة قبل خروجه على أمير المؤمنين عبدالله بن الزبيز - م - ولم يلقه عروة قط إلا قبل خروجه على أخيه لا بعد خروجه؛ هذا ما لا شك فيه"(")، ومع ذكر ابن حجر السابق: أن الإسماعيلي يرى أن مروان تأول قتل طلحة؛ يخالفه رأي آخر عن الإسماعيلي ينقله الحافظ نفسه، وهو في التهذيب: "عاب الإسماعيلي على البخاري تخريج حديثه، وعد من مويقاته أنه رمى طلحة أحد العشرة يوم الجمل، وهما جميعا مع عائشة فقتل، ثم وثب على الخلافة بالسيف،

(1) وهناك من يقول لم يشبت قتل مروان لطحة. انظر: شرح سنن بن ماجه لمغلطاي

$$
\begin{aligned}
& \text {. ( } \leqslant 1 \leqslant / 1) \\
& \text { هاي الساري (ص ب ؛ ؛ ). }
\end{aligned}
$$

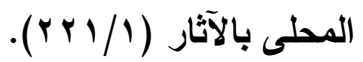


واعتذرت عنه في مقدمة شرح البخاري ..."(") فهذا النص إثارة لنقد الإسماعيلي إخراج حديث مروان، وهو قتله طلحة - - لكن كيف يعيبه ويراه متأولا؟! واستقر كلام ابن حجر في الهـي المتأخر مع كلامه المتقدم في التهذيب - بالجملة - على عدم الالتفات لنقد الإسماعيلي على صاحب الصحيح، وهذا هو الأي يعنينا هنا، وفي أيي يمكن بمجموع النقلين الواردين عن الإسماعيلي تحصيل مذهب الإسماعيلي في مروان بأنه لا يحتج بها، وكونه متأولا يُراد منه إبعاد لوازم عدم تأوله لو قيل بتعمده! وكأن الرواية أهون في عدم قبولها من الخوض في القول بتعمد قتله لطلحة ... وهذا مسلك في لأيي أخف على الإسماعيلي من أن يواجه به صحابة وتابعين - سبق ذكرهم - قد تعاملوا مع مروان بالطاعة وعدم الخروج عليه، والرواية عنه حتى انتهى إلى الأئمة من يقبل رأيه وروايته كالإمام مالتك، وأيا كان الأمر فرواية مروان هنا لحفظه وضبطه مقبولة، وكفى دليل على ذلك رواية من روى عنه من صاحبة وتابعين أجلاء، والطعن في حديث مروان مرجوح وإن كان ذلك رأي غير واحد كالإسماعيلي وابن حبان كما سبق، وقبول روايته هو المتجه الأي يوافق صنعة البخاري ومسلم في صحيحهما على ما تقدم من كلام ابن حجر السابق من عدم الطعن على رواية مروان في روايته من طريق من سماهم، وأعم منه أن الرواية وضبطها مقدمة على مجرد النظر في من في باب العدالة المختلف في التعليل بها والمنازِع له موقف في تأويل مرتكب خارمها من عدمه، وإذا كان هذا الدفع عن الصحيح لإخراجه رواية مروان فحرسيه أسهل دفعا؛ لكون دعوى الجهالة أخف من الطعن في العدالة، لذا لإناله

$$
\text { (1) (1) هدي الساري (ص ؟ ؛ ؛). }
$$


أقول للباحث نقلك في قول الإسماعيلي السابق: "ومروان ويوابه بمنزلة واحدة"؛ أبعد من كون الرواية فيها جهالة بواب مروان فيما لو ثبت النص؛

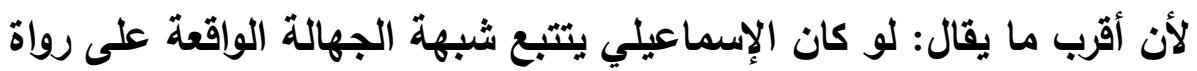

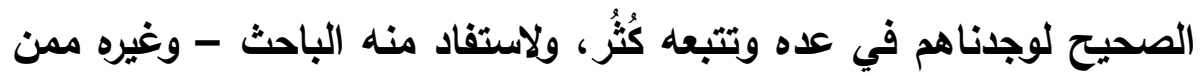

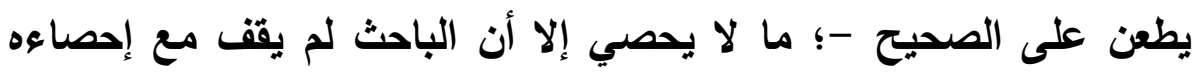
المزعوم إلا ما وقف عليه من كلامه هنا فحسب!! والإسماعيلي يطلم بعناية

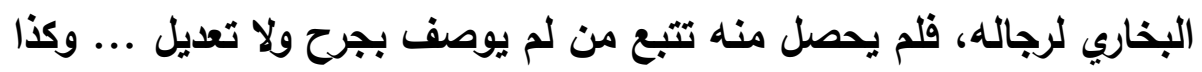

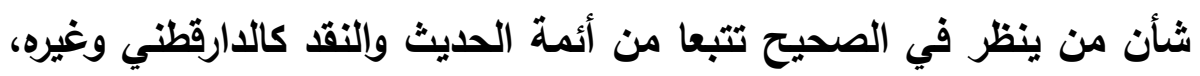

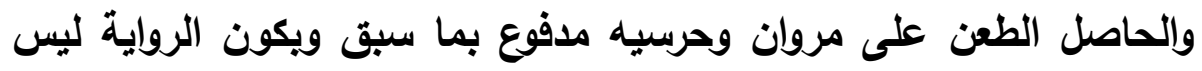
فيها نكارة أصلا، فنقا الإسماعيلي المنقول يقابله اتفاق صاحبي الصحيح

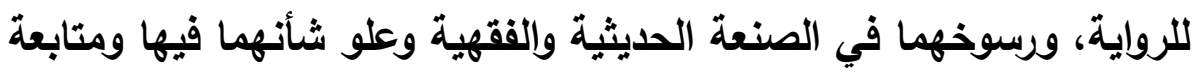

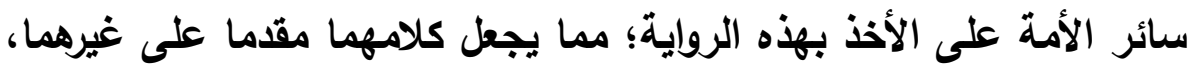

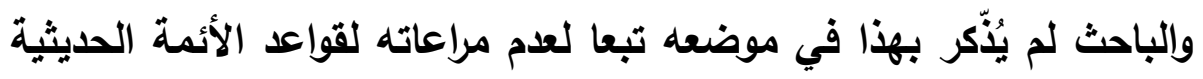

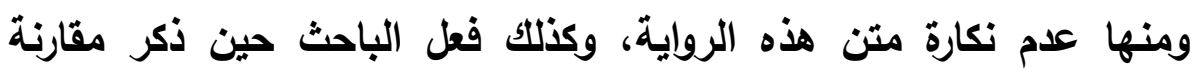

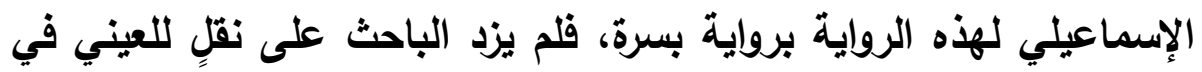

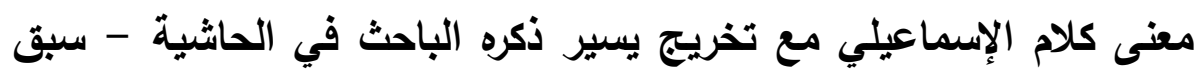

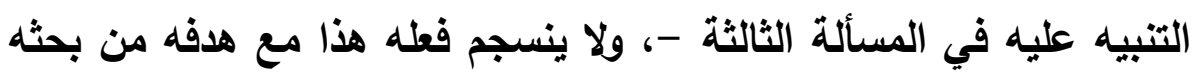
ونتائجه ولا مع مراد كلام الإسماعيلي نفسه. وما نقله الباحث في الرد على هذا الإلزام بقوله: (ج) أن البخاري لم لم

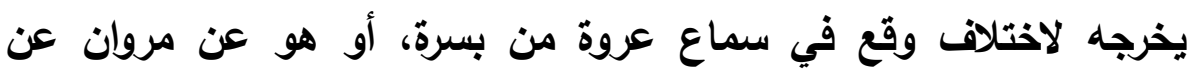


بسرة(1) لا لجهالة حرسي مروان فقط". قلت: هذا كلام الباحث ولم يوضحه تماما على طريقة تخريج علل الحديث هنا! لكن يُستفاد من إجماله هذا أن هناك اختلاف (اضطراب) في حديث بسرة؛ جعل البخاري يعضده بجهالة الحرسي! فلم يورده البخاري في الصحيح للأمرين! وهذا كلام لم يقتعي لا من حيث الانفراد ولا من حيث التركيب، ولا يمكن نسبته - بدون تحري للبخاري: لا من جهة جهالة الحرَسي لما تقدم، ولا من جهة نسبة القول للبخاري بوجود الاختلاف في حديث بسرة، والباحث قد ذكر شيئا من تخريج حديث بسرة - في حاشيته - عند أول ذكر كلام الإسماعيلي يُفهم منه أن البخاري لا يرى بقاء اختلاف الراوية في حديث بسرة، ولنتقل كلام الباحث في تخريجه حيث قال: "روى النسائي في سنته 1/ 1. 1 / - كتاب: الطهارة باب: الوضوء من مس الأكر برقم: \& 1 أمن طريق الزهري عن عبدالله بن أبي بكر بن عمرو بن حزم أنه سمع عروة بن الزبيز يقول: ذكر مروان في إمارته على المدينة أنه يتوضأ من مس الأكر إذا أفضى إليه الرجل بيده، فأنكرت ذللك وقلت: لا وضوء على من مسه، فقال مروان: أخبرتتي بسرة بنت

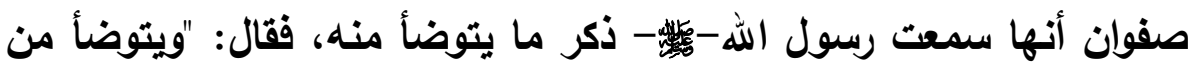
مس الأكر! قال عروة: فلم أزل أماري مروان حتى دعا رجلا من حرسه،

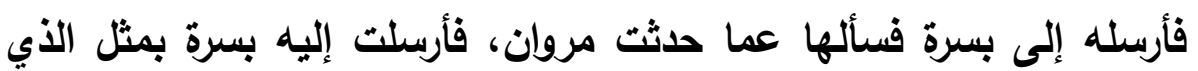

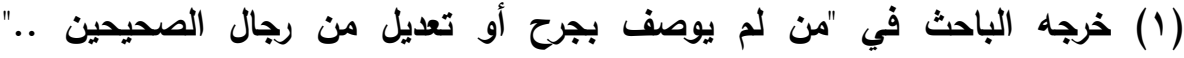

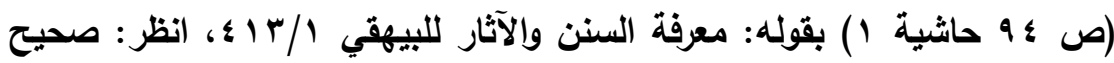

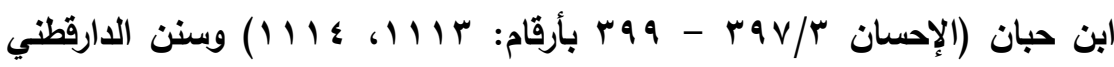

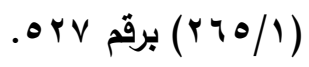




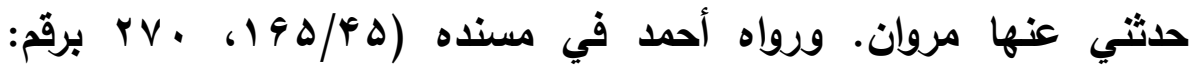

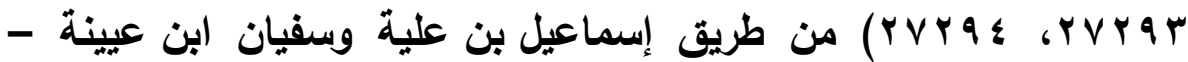
فرقهما - عن عبدالله بن أبي بكر بن حزم به، لكن رواه مالك في الموطأ برقم: 19 عن عبدالله بن أبي بكر بن محمد بن عمرو بن حزم به، ولم يذكر زيادة "قال عروة: فلم أزل أماري مروان حتى دعا رجلا من حرسه ..". وقد نقل الترمذي في جامعه (1/ / 1 ) عن البخاري أنه قال: "أصح شيء في هذا الباب حديث بسرة"، ولا يلزم من ذلك أنه صحح حديثها؛ فقد قال الإمام النووي في أذكاره (مع شرحه الفتوحات الرياتية ؟/ 1 اب - 9 اب): "ويلغنا عن الدارقطني أنه قال: أصح شيء في فضائل السور فضل "قّل هو الله أحد"، و"أصع شيع في فضائل الصلوات فضل صلاة التسبيح"، ولا يلزم من هذه العبارة أن يكون حديث صلاة التسبيح صحيحا، فإنهم يقولون: هذا أصح ما جاء في الباب وإن كان ضعيفا، ومرادهم أرجحه، أو أقله ضعفا"(1). قلت: الباحث لم ينقل شيئا يؤيد زعمه بأن رأي البخاري في الرواية وقوع اختلاف منعه من إخراج الحديث في صحيحه، واكتفى بمناقشة مقولة البخاري: "أصح شيء في هذا الباب حديث بسرة"، وأن هذا لا يلزم منه أن البخاري يرى صحة الرواية، وكأن هَم الباحث أن الحديث ليس صحيحا عند البخاري، وفاته أنه لا يلزم من العبارة تضعيف - بل تصحيح البخاري هنا أقرب كما سيأتي -، وكون حليث بسرة أصح عند البخاري ما ورد في معناه ومن حديث طلق ״إنما هو بضعة منكه، ولو كان في حديث بسرة اختلاف (اضطراب) لكانت

(1) "من لم يوصف بجرح أو تعديل من رجال الصحيحين .." (ص ا9 حاشية 1). مجلة كلية أصول الدين والدعوة بأسيوط / العدد السابع والثثلاثون 9 اــم - الجزء الثالث 
علته أشد من علة حديث طلق الذي تكلم الأئمة فيه لعلة أخف - وهي أن حديث طلق يرويه عنه ابنه قيس بن طلق، وهو ليس بالقوي عند أهل الحديث(1) -؛ فعلى هذا حديث طلق أصح في الباب إذا ما قورن بين العلتين! وهذا بعيد أن يقوله البخاري الذي لم يخرج الحديثين، إذ يلزم من يرى أصح ما في الباب أن يكون عنده أنظف إسنادا من غيره - مع احتمال تصحيحه والعمل به -، ويؤكد ما أقول - وهو الأي فات الباحث سبره قول الترمذي: "سألت محمدا عن أحاديث مس الأكر، فقال: أصح شيء عندي في مس الأكر حديث بسرة ابنة صفوان والصحيح عن عروة عن مروان عن بسرة"(؟)، فُهْهم من هذا أن رأي البخاري: ليس في حديث بسرة اختلاف بل يرجح هاهنا بوضوح إحدى الطرق التي حكى الباحث الاختلاف فيها، فكان على الباحث ذكر سبب أقرب لعدم إخراج البخاري لحديث بسرة ويكون فيه رد على إلزام الإسماعيلي إن كان يريد مناقشة كلام الإسماعيلي بالبحث العلمي، والأقرب في عدم إخراجه الحديث وجود التعارض بين حديثي طلق ويسرة، وتعارضه ليس فقط في اختلاف الأئمة في تصحيح أحدهما وتضعيف الآخر - على أريين متقابليَن(ّ) - والأخذ بمدلول أحد الحديثين دون الآخر، ثم لوجود تلك الآثار القوية المختلفة في مذاهب الصحابة على القول بمدلول كل حديث وكذا الائمة بعدهم من تابعين وغيرهم؛ مما جعل الإمام البخاري يعرض عن إخراج الحديث هذا الحديث لتعارض مدلوله مع

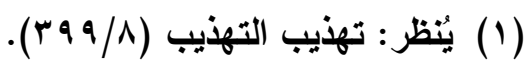

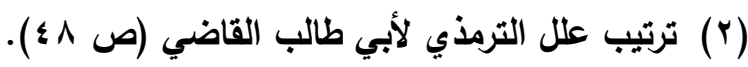

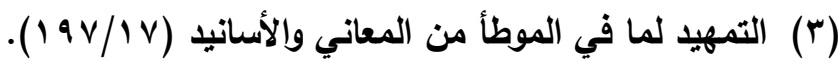


الآخر، وقوة مذاهب الصحابة والتابعين، وقد وقع في مناظرة أئمة الحديث من

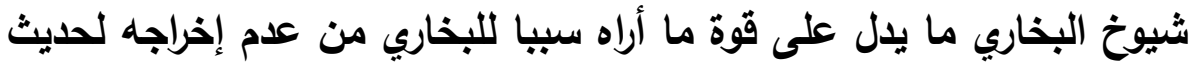

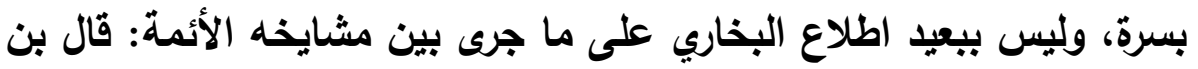
المنذر: "حكى رجاء المروزي عن أحمد بن حنبل ويحيى ابن معين أنهما

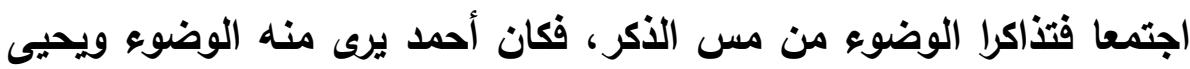

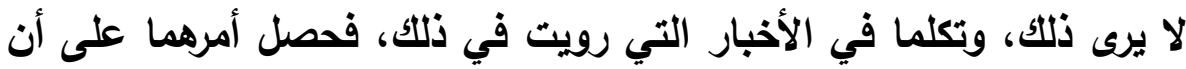

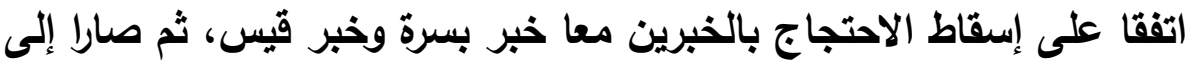
الأخبار التي رويت عن الصحابة، فصار أمرهما إلى أن احتج أحمد بحديث

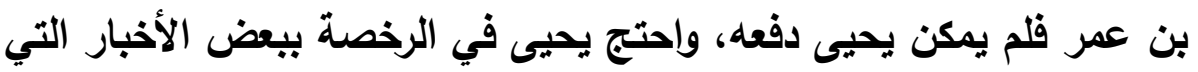

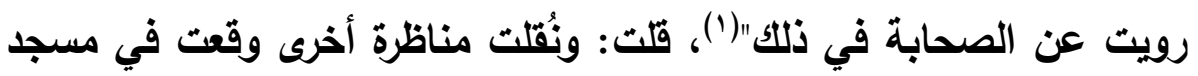
الخيف بين علي بن المديني ويحيى ابن معين - وكان أحمد بن حنبل بينهما

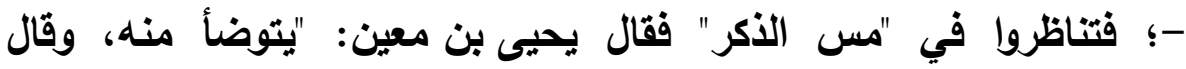

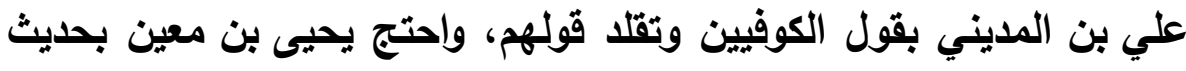
بسرة بنت صفوان، واحتج علي ابن المديني بحديث قيس بن طلق (القصة...)

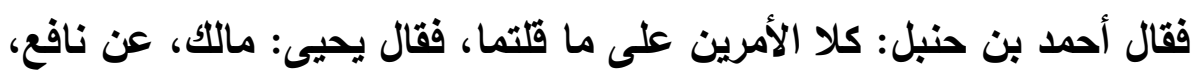
عن ابن عمر أنه توضأ من مس الذكر. فقال علي: كان بن مسعود يقول: لا

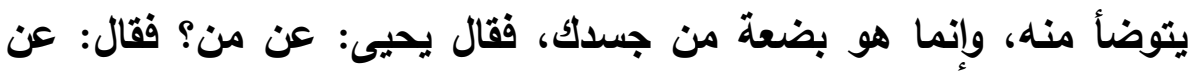

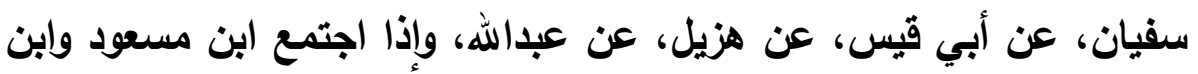

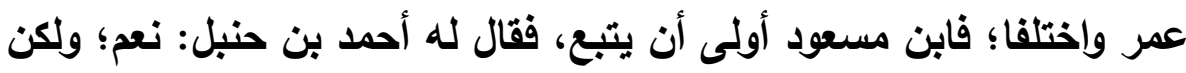

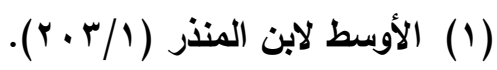


أبو قيس الأودي: لا يحتج بحديثه، فقال علي: حثثي أبو نعيم ثنا مسعر،

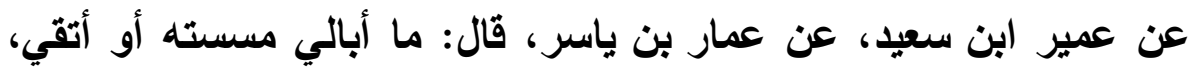

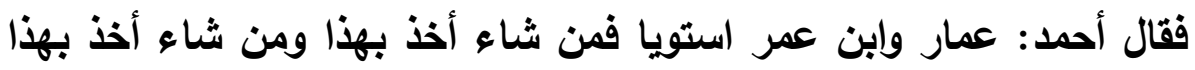

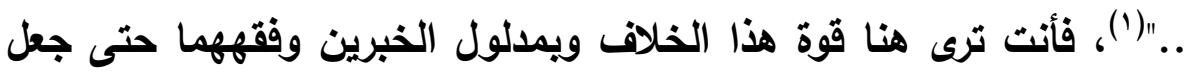
بعض الأئمة ينحى منحى الجمع - وعدم ترك الحديثين - والقول بالاستحباب

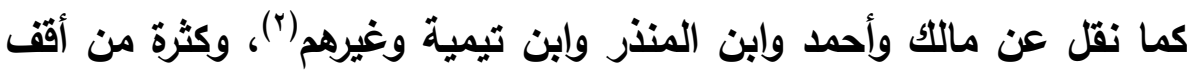

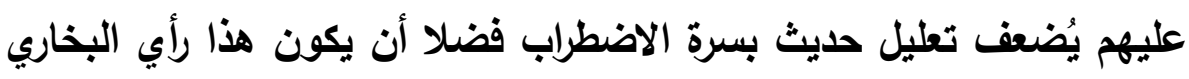

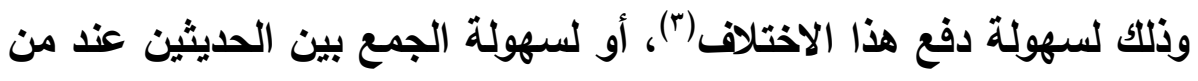
يقبلهما، ومن هذا الأخير قول بن خزيمة في صحيحه: "باب استحباب

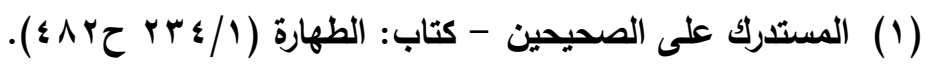

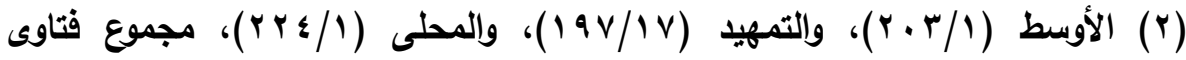

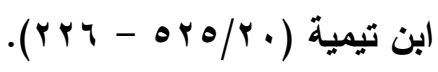

(r) لست بصدد التوسع في حليث بسرة لكن يكفينا قول ابن حجر: "وقد جزم

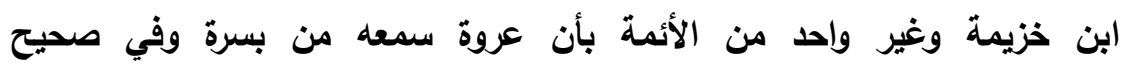

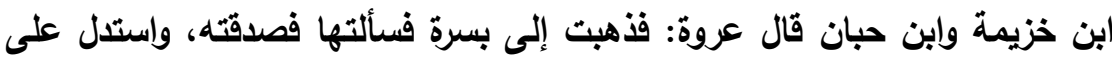

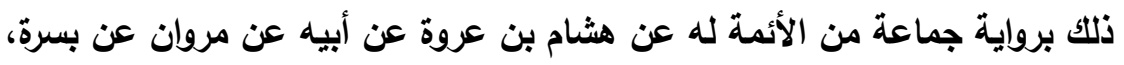

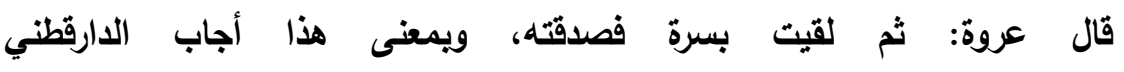
وابن حبان، وقد أكثر بن خزيمة وابن حبان والدارقطني والحاكم من سياق طرقه بما اجتمع لي في الأطراف التي جمعتها لكتبهم، ويسط الدارقطني في علئ وله الكلام عليه

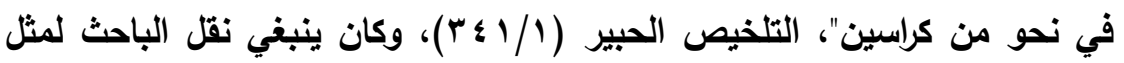
هذا أو الإحالة لبعض كتب العلل التي ذكرت الخلاف إلا إن كان يخشى من إزالة الاختلاف المذكور عند من سينقل عنهم أو يحيل لكتبهم. مجلة كلية أصول الدين والدعوة بأسيوط / العدد السابع والثثلاثون 9 ا ـآم - الجزء الثالث 
إزالة إيهام القائلين بوجود

الجهالة في بعض الفالين بوجال

الوضوء من مس الأكر"، ثم أسند عن هشام، عن أبيه، عن مروان، عن

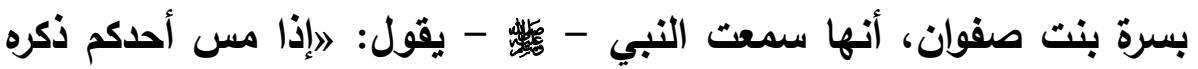

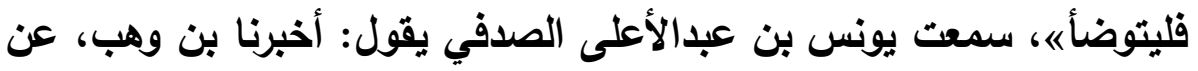
مالك قال: 》أرى الوضوء من مس الذكر استحبابا ولا أوجبهی)، ثنا

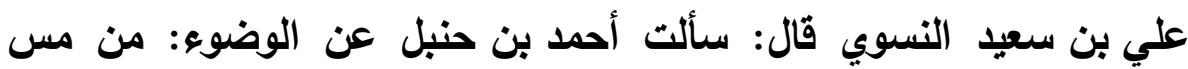

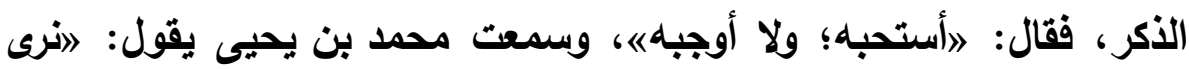
الوضوء من مس الذكر استحبابا لا إيجاباه بحديث عبدالله بن بدر، عن قيس

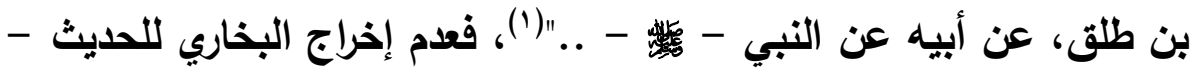
وكذا مسلم - لاختلاف من سبقه في تصحيحيه وقوة الخلاف في تعارض إنه

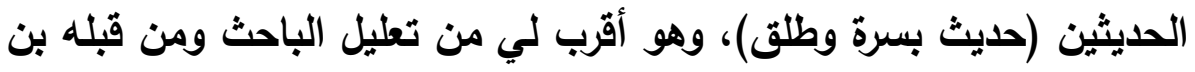

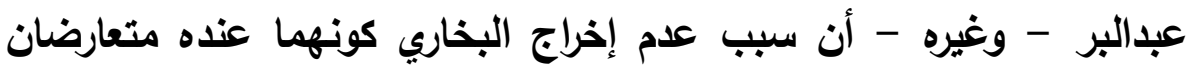

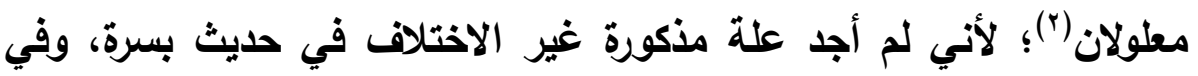

صحيح ابن خزيمة: كتاب: الوضوء - باب: استحباب الوضوء من مس الذكر =

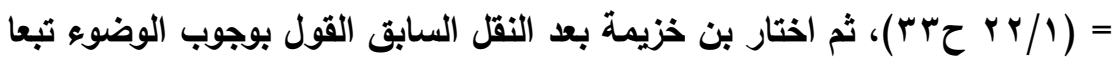

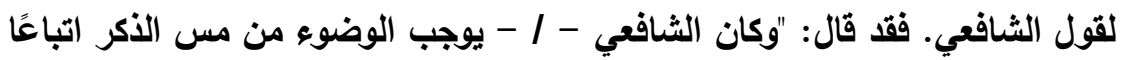

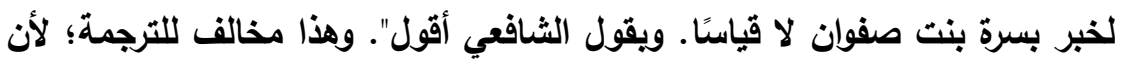

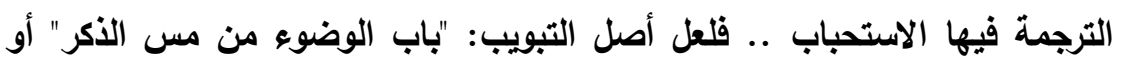
نحو هذا، والله أعلم.

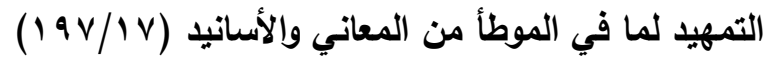
مجلة كلية أصول الاين والدعوة بأسيوط / العدد السابع والثلاثون 9 الـ بم - الجزء الثالث 
كلام البخاري السابق في سؤال الترمذي له يردٌ هذا التعليل(')، فإن كاتت هناك علة أخرى فتاك سبب منع البخاري من الإخراج، بل أفهم من سياق البخاري السابق الأي نقله الترمذي تصحيح الحديث؛ لأن قول البخاري: "والصحيح عن عروة عن مروان عن بسرة" يعني سلامة هذا الإسناد من علة خفية، ويبقى أن ظاهره على شرط البخاري - عدا بسرة لم يخرج لها وهي صحابية من المبايعات الأُول(r) -، ويبعد أن يكون الحديث ضعيفا عنده، وقد رجح هذه الطريق التي يقبل مخرجها - عروة عن مروان -، ثم وققت على كلام للحافظ ابن حجر يقول بكل تقرير السابق والحمد لله؛ حيث قال بعد نقله لاعتراض الإسماعيلي وإلزامه: "البخاري لا يُعلُّّ بمثل هذا الاختلاف: إما كان دائرًا على ثقات على شرطه. وأمَّا كونُه لـ يخرّج حديث بُسرة، وهو شبيه بهذا الحديث في الاختلاف فيه على عروة وهل سمعه من مروان عن بسرة، أو من حرسيِّ مروان، عن بسرة، أو لقِيَ بُسرَة فشَافَهها به، فقدِ اختلفَ الرُّواةُ فيه على الأوجه الثلاثة. ونحن، وإن سلَّمنا أنَّ هذا الاختلاف لا يضرٌ الخبر، لأنَّ مروانَ مِنْ رجال البخاري. لا كما توهَّم بعضُ النَّاس أنَّهَ لا يجوز الاحتجاج به، فعروة قد سمع الخبرَ منه أولاً على كل حال، وإنَّما أراد الاستثبات فيه،

(1) وقث رأى الحازمي هذا التعليل سبيا في عدم إخراج صاحب الصحيح للحديث؛ حيث

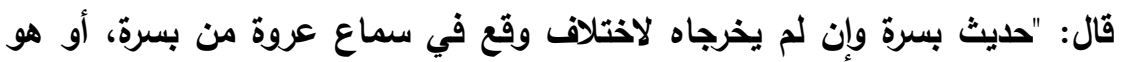
عن مروان، عن بسرة ...". الاعتبار في الناسخ والمنسوخ من الآثار (ص ه ه ؛).

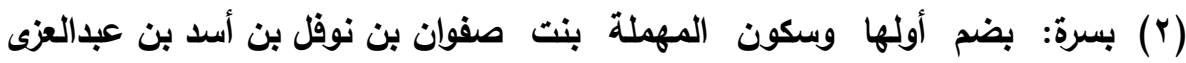

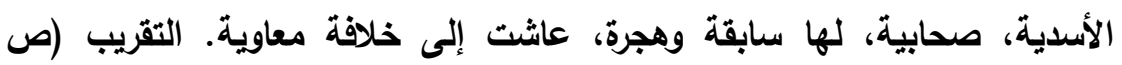

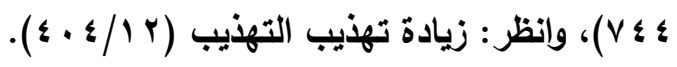


فأرسل الحرسيَّ ليستثبتها فيه. ولولا أنَّ الحرسيَّ المذكور كان عند عروة

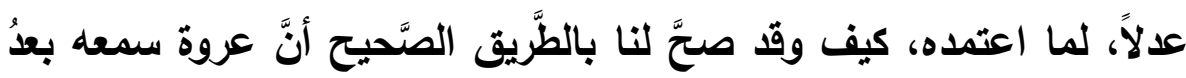
رواه فقد

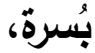
مِنْ ابن خزيمة في "صحيحه" وابن حِبَّان في "صحيحه" أيضًا عنه(")، عن محمد

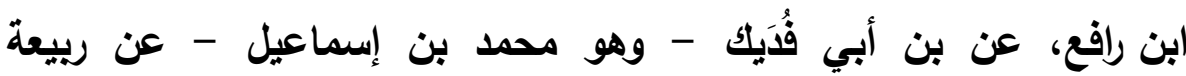
ابن عثمان، عن هثام بن عروة، عن أبيه، عن مروان، عن بُسرة، به. قال

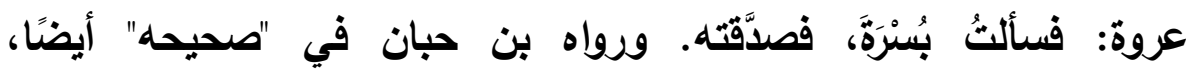

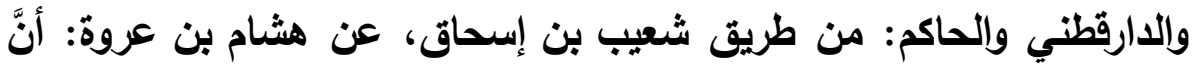

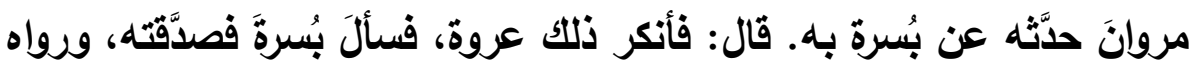

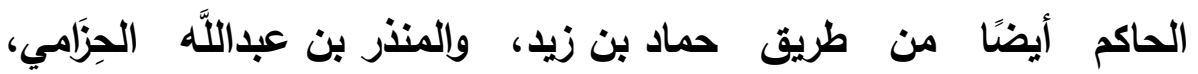

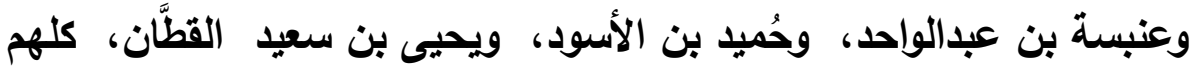

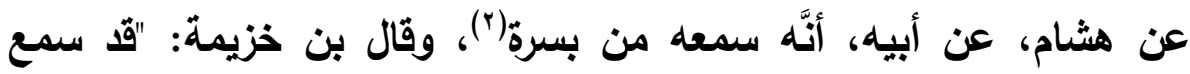
عروة خبرَ بُسرة منها، لا كما توهمَّه بعضُ النَّاس أنَّ الخبر واهٍ لطعنه في

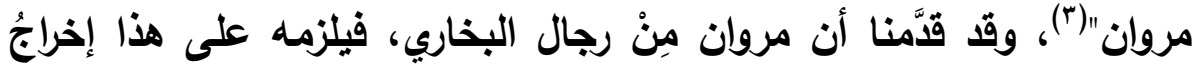

(1) يُنظر : صحيح ابن خزيمة: كتاب: الوضوء - باب: استحباب الوضوء من مس الذكر

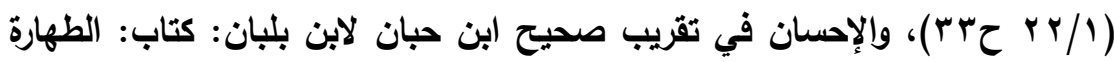

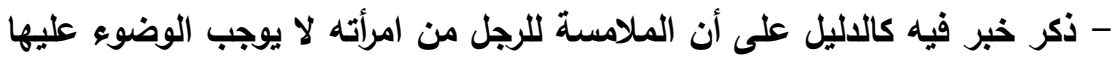

$$
\begin{aligned}
& \text { ( } 111 \text { r } 29 \% / r)
\end{aligned}
$$

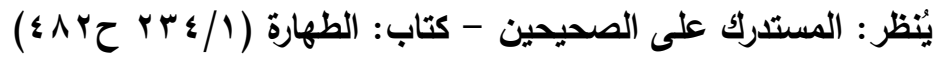

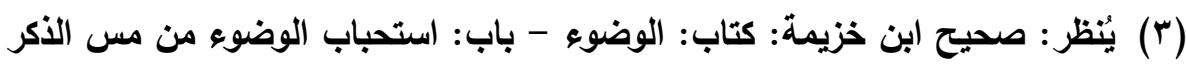

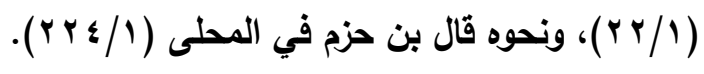
مجلة كلية أصول الدين والدعوة بأسيوط / العدد السابع والثثلاثون 9 ابـ بم - الجزء الثالث 
حليثه، إلا أنا نقول: يحتمل أن يكون فيه عنده علةٌ غيرُ هذا الاختلاف لم

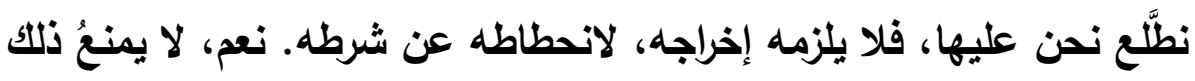

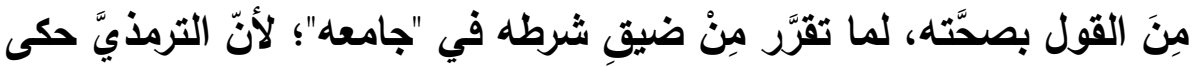

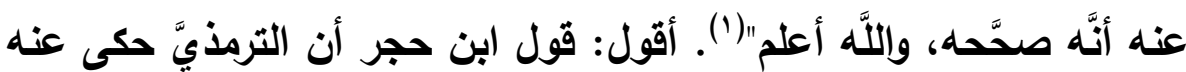

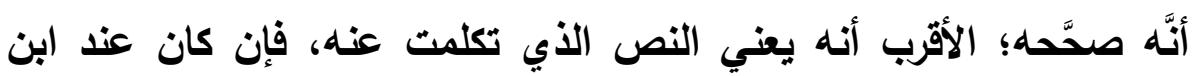
حجر نص صريح فالحجة أبلغ في بلوغ تحليلي، والحمد لله ..

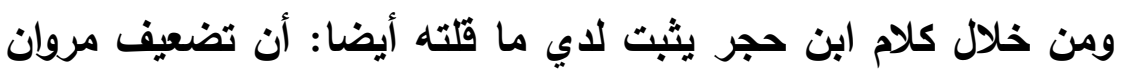
وحرسيه ليس من مذهب البخاري؛ ولذا اضطر الإسماعيلي لإلزامه إخراج

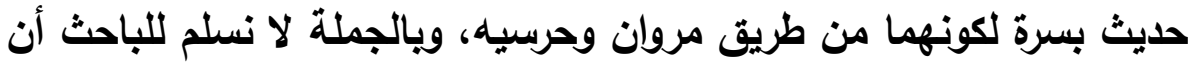
تكون العلة هي الاختلاف للنص السابق في علل الترمذي، وفي ذكر ابن عبدالبر التعارض بين الحديثين - دون الإعلال - سببا في عدم إخراج البخاري للحديث هو شيئا مما ذكرته من أسباب ترك الإمام البخاري لإخراج

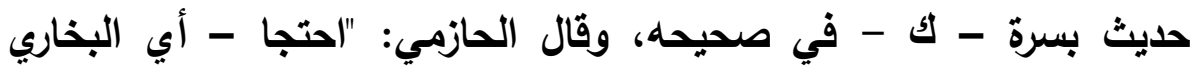

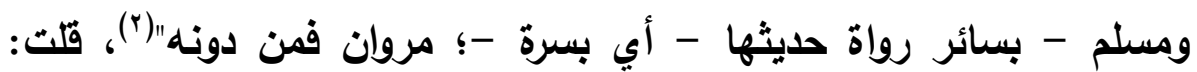
كلامه يلخل مروان، وليس من رجال مسلم عند من ترجم لهاب(")، لكن كلام

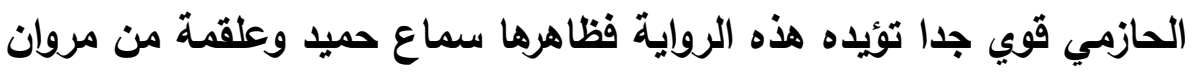

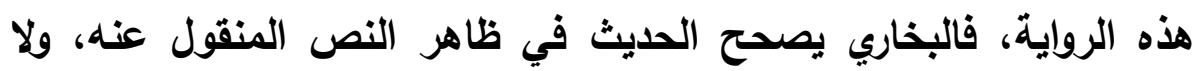

$$
\begin{aligned}
& \text { الجواهر واللدر ( ( } \\
& \text { قاله الحازمي في الاعتبار (ص ه ؛ ). }
\end{aligned}
$$

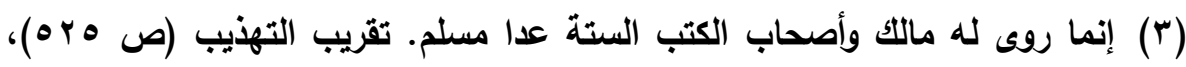

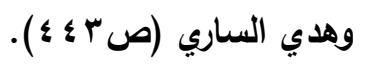


يلزمه إخراجه في صحيحه لمجرد هذه المقارنة: وهي كون الحيثين من طريق مروان وحرسيه، لأن ذاك مدفوع جملة؛ بما نقله غير واحد - ومنهم

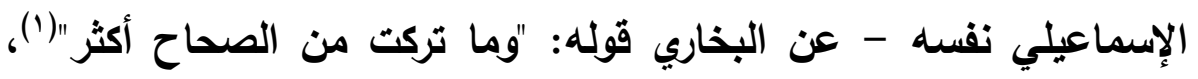

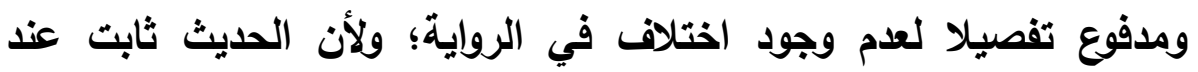
البخاري من رواية عروة عن مروان عن بسرة عند البخاري ومروان من رجال

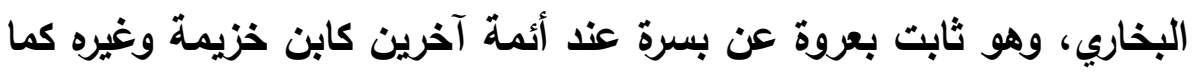

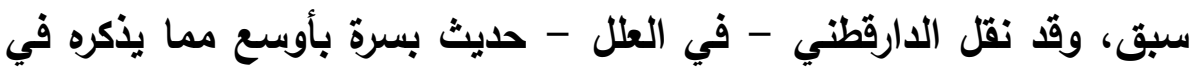
حايث قيل فيه اختلاف في حديث؛ حتى قال ابن حجر : "بسط الدارقطني في

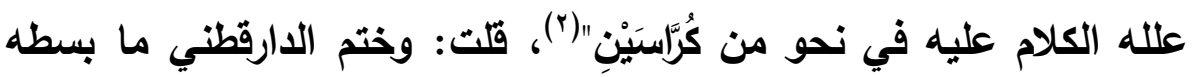

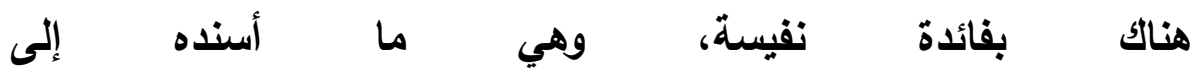
أبي داود السجستاني قال: قلت لأحمد بن حنبل: "حديث بسرة في مس الأكر ليس بصحيح! قال: بل هو صحيح، وذلك أن مروان حدثهم عنها، ثم جاءهم الثم الرسول عنها بذلك"(")، ففضلا عن وضوح صحة الحديث عند الدارقطني إلا

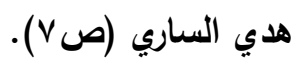

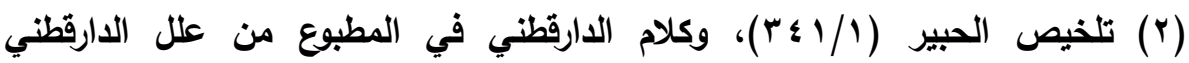

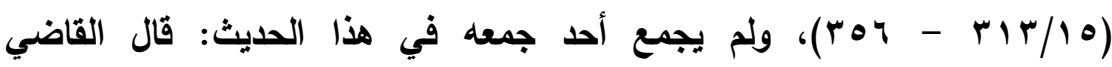

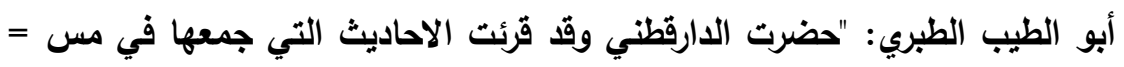

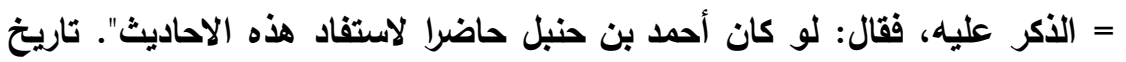

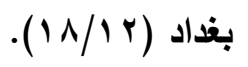

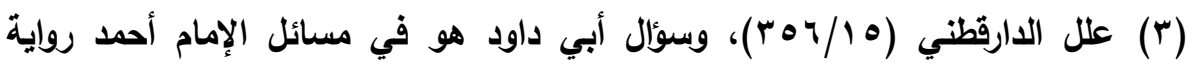

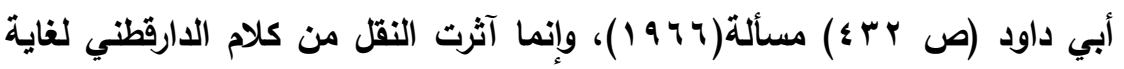
تدرك من سياقي. 
أن في هذا النقل ما يثبت أن حرسي مروان مقبول الرواية عند أحمد لأجل قبول إرساله وتصديق خبره عند عروة، فقول أحمد: "ثم جاءهم الرسول عنها هنا بذلك"، ومعناه فقبلوا خبره، ويكون أخذ الحديث بعد ذلك عروة عن بسرة زيادة

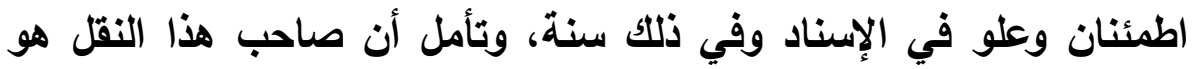

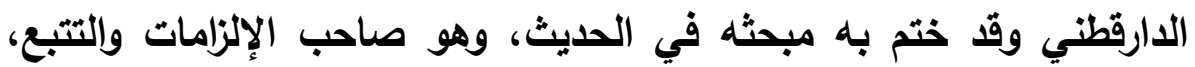
وشأن حديث مروان عن ابن عباس شأن حديث بسرة عند غير واحد من

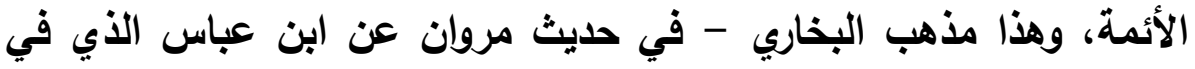

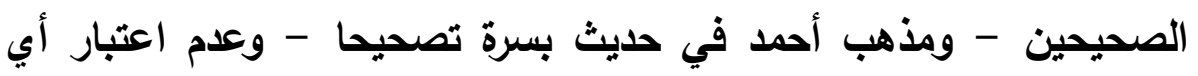
تعليل سبيه مروان أو حرسيه -، وعاد الأمر أن الحديثين صحيحان،

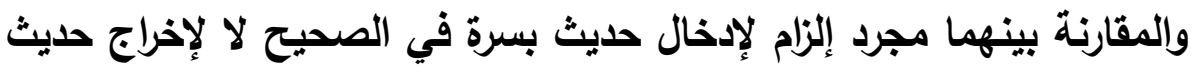

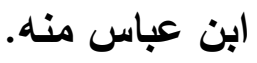

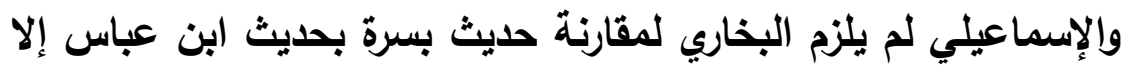
من جهة وجود بواب مروان في حديث ويوابه (حرسيه) في آخر، فلم يأتِ في

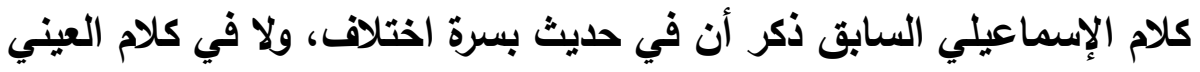

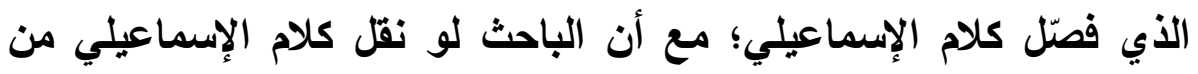

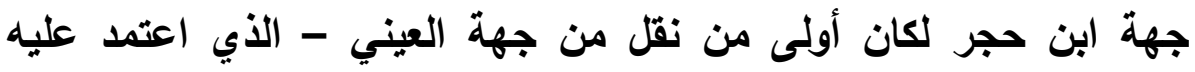

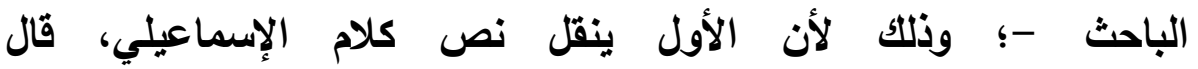

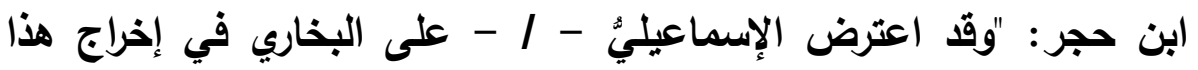

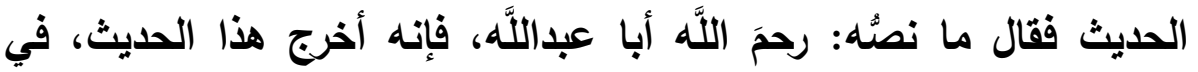
"الصحيح"، مع الاختلاف فيه على ابن جريج، فقال عبدالرزلق وهثام: عنه،

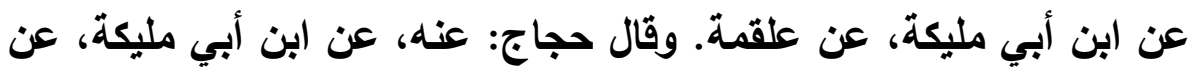




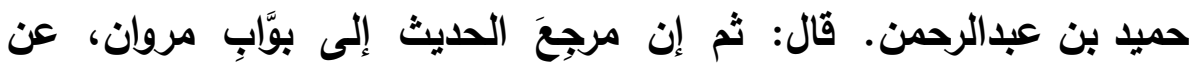

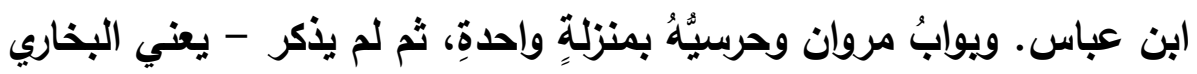

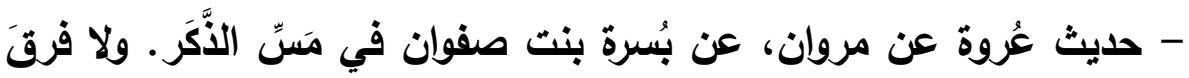

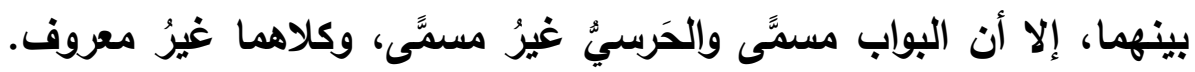

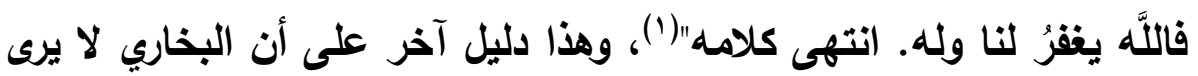

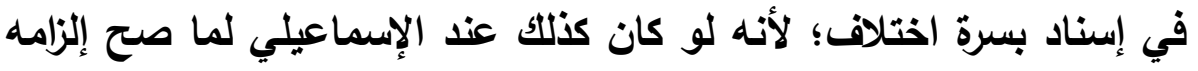

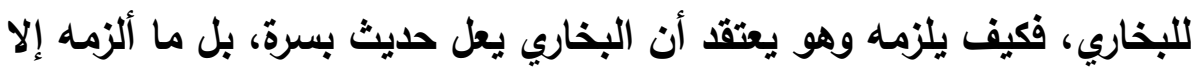

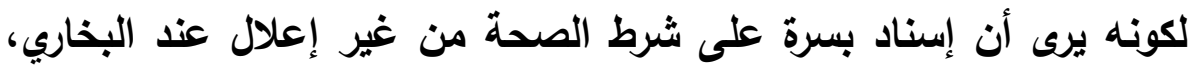

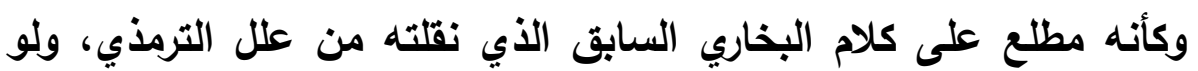

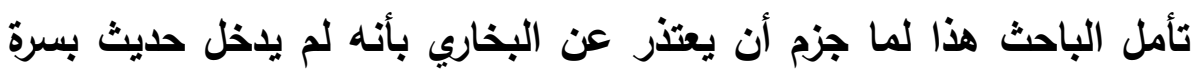
في كتابه لوجود علة الاختلاف في إسناده، ولو وقف على على كلام الحازمي في إني

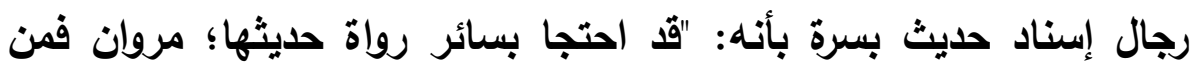

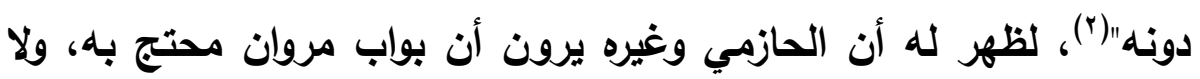

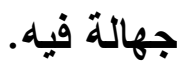

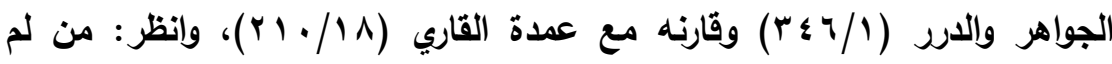

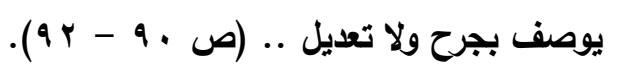

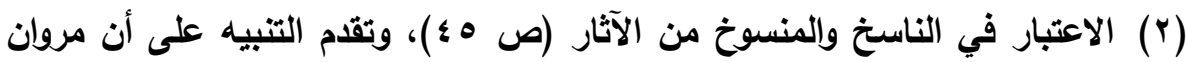

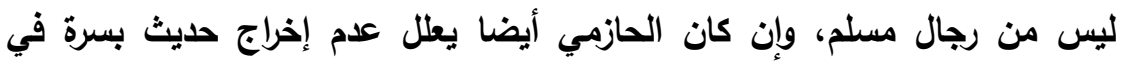

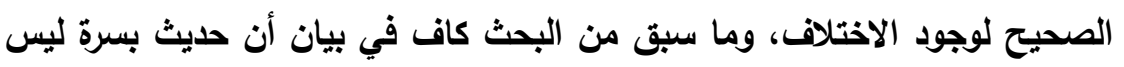

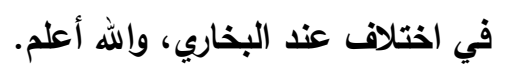


المسـألة الخامسـة: روايـة رافـع عـن ابـن عبـاس علـى غيـر شـرط

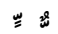

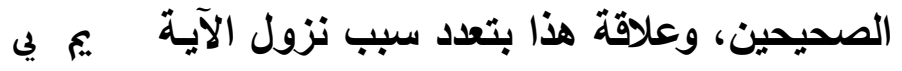

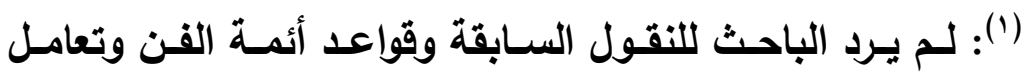
العلماء مع حديث الصحيح أن تستقيم، ولو حتى في بقاء الرواية في الأصول

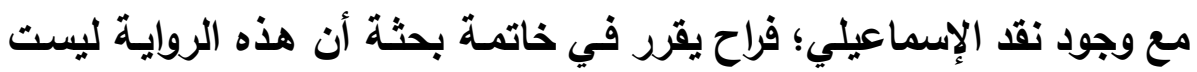

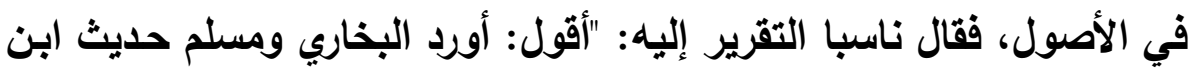

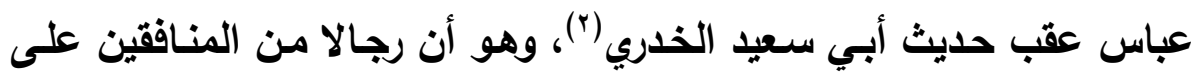

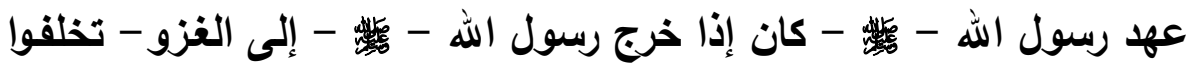

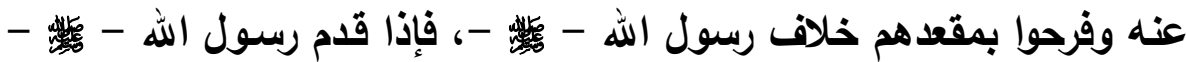

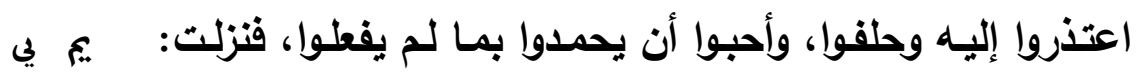

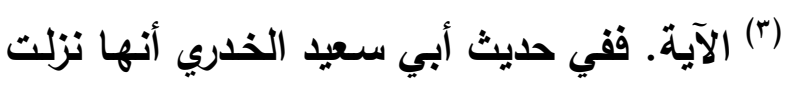

في المنافقين الذين اعتذروا عن الغزوة، وفي حديث ابن عباس أنها فيمن

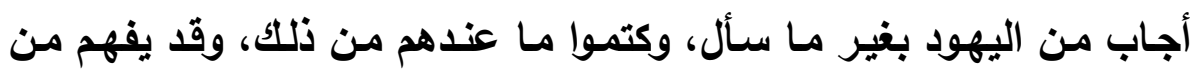

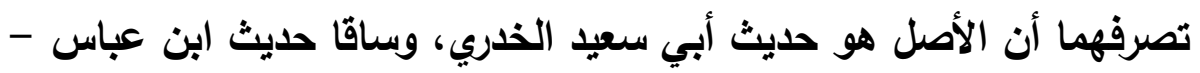

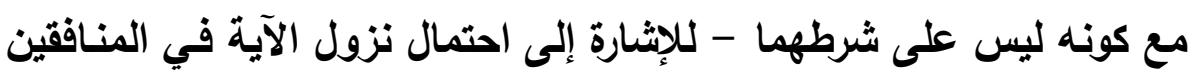

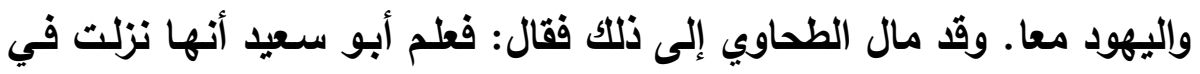

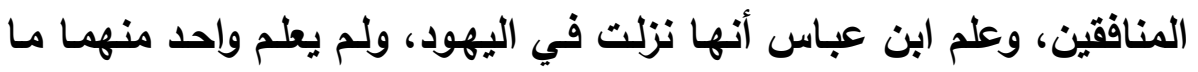

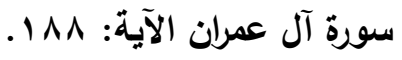

$$
\begin{aligned}
& \text { تقدم تخريجه قريبا. }
\end{aligned}
$$

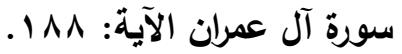
مجلة كلية أصول الدين والدعوة بأسيوط / العدد السابع والثلاثون 9 الـ بم - الجزء الثالث 
علم الآخر، فكان نزولها في الحقيقة في السببين جميعا لا في أحدهم دون الآخر"، هذا كلام الباحث ثم نقل عن ابن حجر كلامـا من الفتح بنحو كـلام الطحاوي(')، في هذه الترجمة هذا الموضع الذي أرى شيئا فيه رأيه، ومـا عدا أجراه كالمسلمات لا يتعرض لتصويب ولا ترجيح فيمـا يعرضـه! ومـع ذلك في كلام الباحث هنا رأي الطحاوي وابن حجر هو تعدد سبب النزول؛ لكنه قال قبله مستتبطا مـن طريقة إيـراد صـاحبي الصـيح للحديثين أن حديث ابن عباس ليس على شرطهما حيث جاء عقب حديث أبي سعيد الذي هو على شرط الصحيح! ثم يقول: مـال إلى هذا الطحاوي وابن حجر وهو أن للآيـة سببي نزول، لكن لم يميلا إلى قولـه في كون حديث ابن عباس ليس على شـرطهما! وأقول: إذا كـان للآيـة سـبيان فالأقرب في الحديثين أنهمـا على شرطهما، وذاك أبعد عن التكلف إلا هرويا من توثيق ضمني لرافع! وهذا مـا يريده الباحث - البعد عن التوثيق الضمني -! ولعله لو تأمل منفعته لبحثه لقال به دليلا لما ذكره من التأصيل للقاعدة وإبقاء لوجودها: بأن المستور لو روى لله صاحب الصحيح في الأصول لكان توثيقا له بذلك .. وترجمة رافع أحسن التراجم لبقاء دعواه ومـا سطره في عنوان بحثنه .. لأن سـائر التراجم ظاهرة في عدم الرواية لها بالأصول لوجود المتابعات والثـواهد الواضحة في المرويات وقد نقلها الباحث مشكورا، ويؤيد بقاء رواية رافع في الأصول أن سبب النزول الذي ذكره ابن عباس في كون الآيـة في أهل الكتاب أقوى

(1) شرح مشكل الآثار (9/0 19 - .9). وكلام الباحث في "من لم يوصف بجرح أو تعديل .." (ص \& 9 ( ) مجلة كلية أصول الدين والدعوة بأسيوط / العدد السابع والثثلاثون 9 اـ بم - الجزء الثالث 


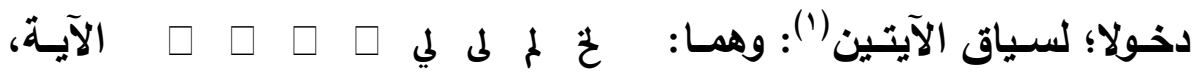

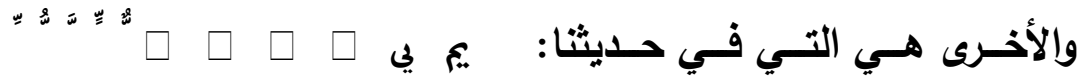
الآيـة، ولذا رجح روايـة ابن عباس سبيا للنزول إمـام المفسرين ابن جرير

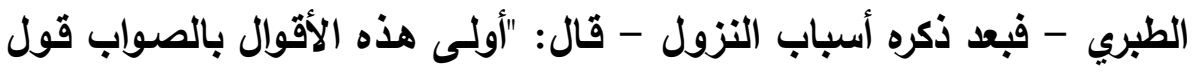

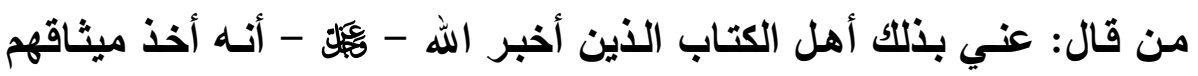

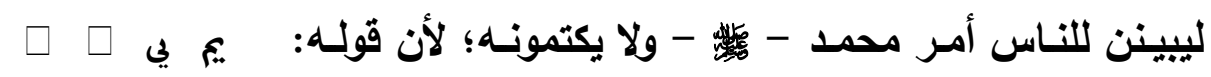
الآية، في سياق الخبر عنهم وهو شبيه بقصتهم، ميع اتفاق أهل

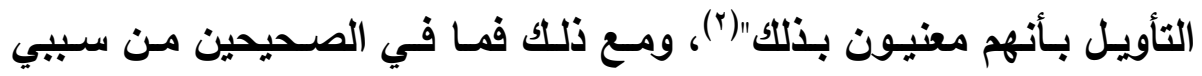
النزول متعينان؛ لكونهما متفقا على روايتهما ولا مانع من تعدد سبب النزول

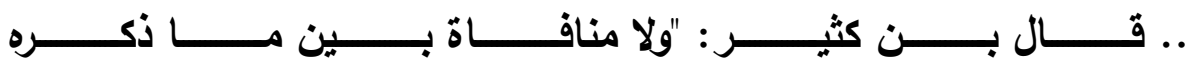
(بن عباس وما قاله هؤلاء(الصحابة الذي رووا أنها نزلت في المنافقين)؛ لأن

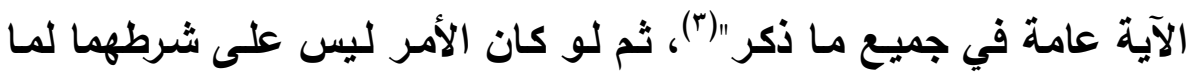

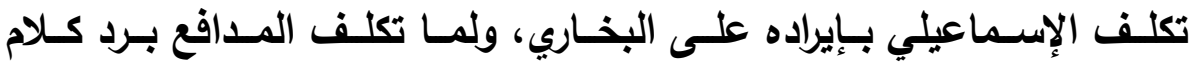
الإسماعيلي بغير القول إنه ليس على شرطه واستراح؛. والحاصل ما وقع من الباحث مجازفة لا يصح استدلال بمجرد ترتيب

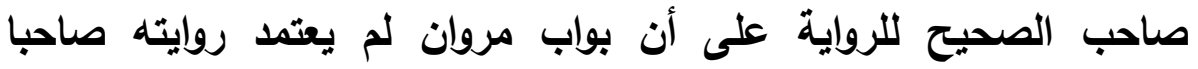

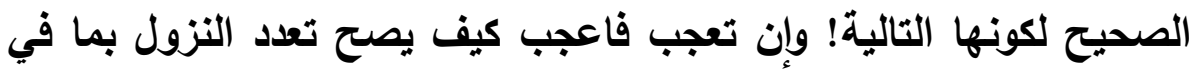
الصحيح وأحدهما - الأولى - على الشرط بخلاف الأخرى، وكلام الطحاوي

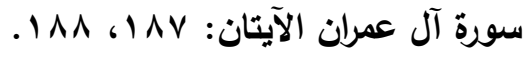

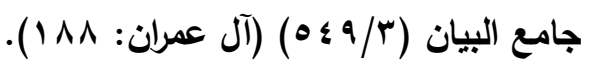

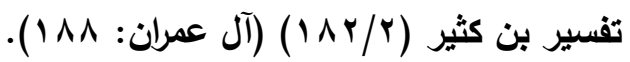


مع كلام ابن حجر وإن أفاد في تعدد النزول للآية - وعندي الأمر واضح بتعدد النزول للحديثين المتفق عليهما من دون طريقة الباحث - لكنه لا

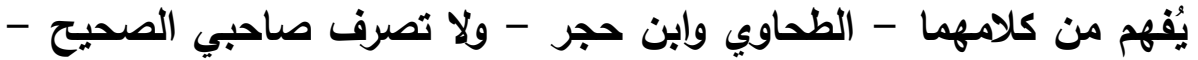
أن الأصل هو حديث أبي سعيد الخدري، وأن حديث ابن عباس ليس على الئ

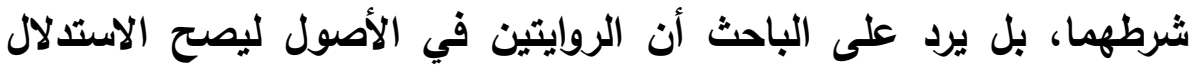

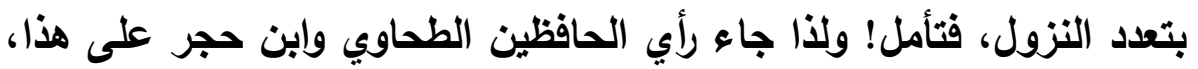
وهذا المقتضي للباحث القول به؛ ما لم يكن معارض قوي يخرجه إلى غيره!

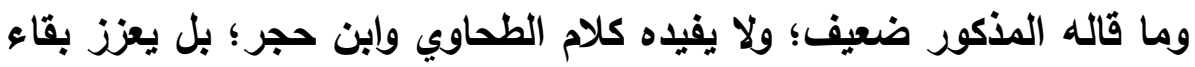
الرواية على الثرط؛ لقوة المستدل على تعدد النزول بكون أخرجهما صاحبا

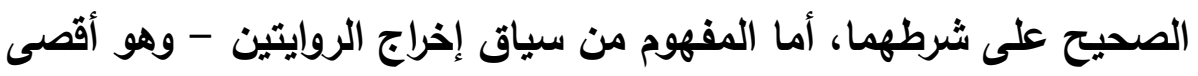
ما عند الباحث -؛ فسياق الباحث وكلامه بكون الرواية الثانية اللاحقة - ماتئ

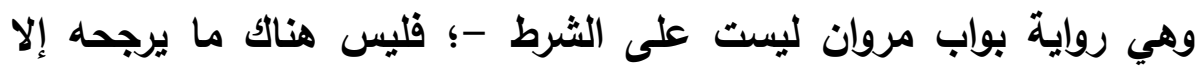

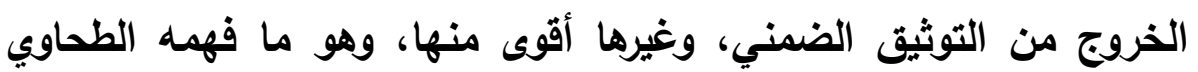
وغيره أن إخراج الروايتين لبيان تعدد النزول كما سبق = تعدد سبب الفي النزول

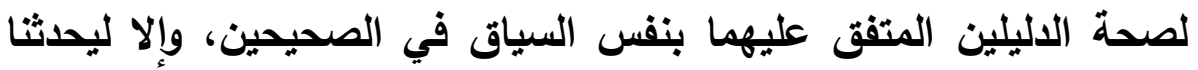

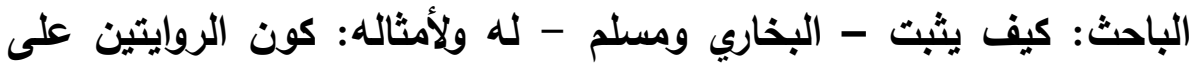
شرطهما مرادهما لتعدد النزول بصحة الحديثين عندهما؛ إلا بإخراج الروايتين على هذا الحد الذي روياه به .. وأسترعي هنا سورة آل عمران وآياتها الغالبة في ردّ عقائد أهل الكتاب وإلمنافقين، وهي في أهل الكتاب الكتاب أكثر مما هي في المنافقين؛ لذا جعل مدلول رواية ابن عباس على غير شرطهما بعيد ولو

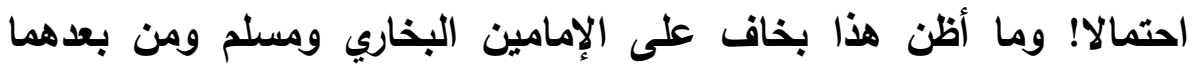

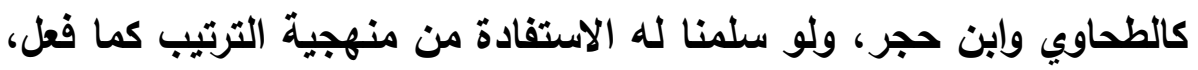
مجلة كلية أصول الدين والدعوة بأسيوط / العدد السابع والثلاثون 9 ا ـ بم - الجزء الثالث 
فلماذا لا يقول به في جعل رواية حميد بن عبدالرحمن وقد رواها البخاري

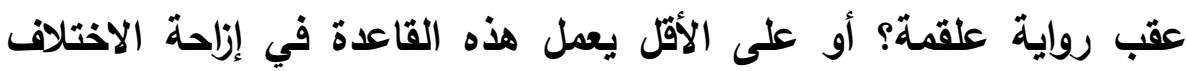

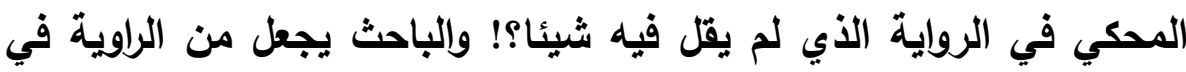

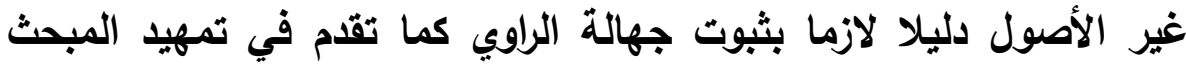

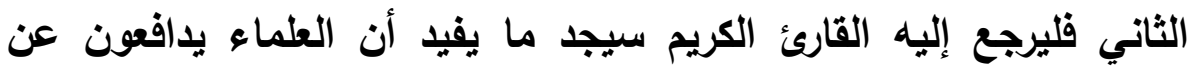
الرواة الموصوفين بذلك ولو كانت مروياتهم في غير الأصول.

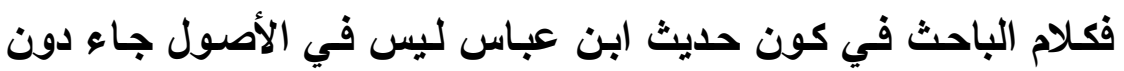

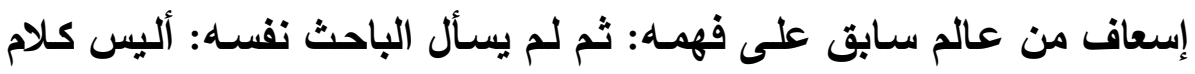

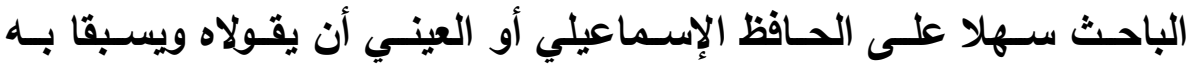
الباحث! ولو قالاه لكان فيه غنية عن كل ما ذكراه من اعتراض - وهما عمدة الباحث في كلامهما حول بواب مروان - فلم يقع ولو بالإثـارة في كلامهما

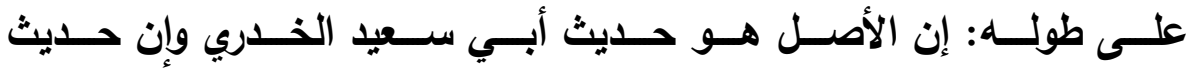
ابن عباس ليس على شرطهما ..!! ولو تفهم الباحث عموم كلام الإسماعيلي

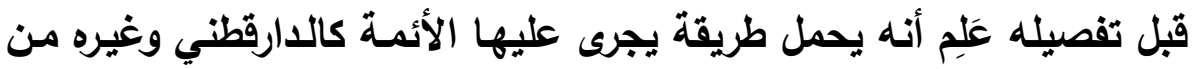

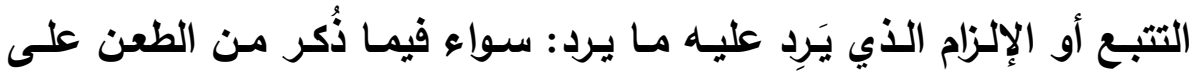

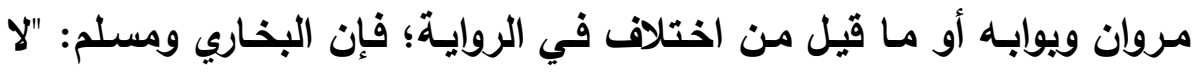
يخرجان من الحديث إلا ما لا علة له أو له علة إلا أنها غير مؤئرة عندهما

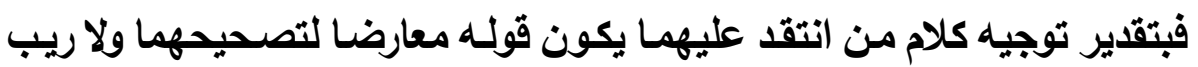

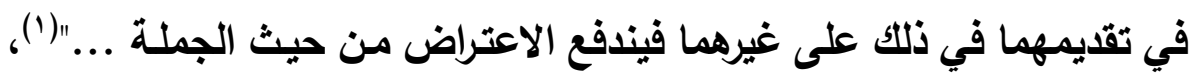

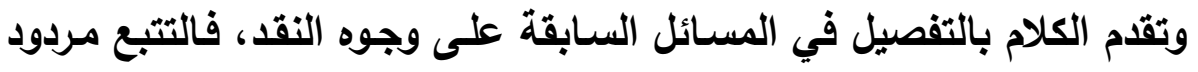


بأن رأي صاحب الصحيح أولى من غيره، والإلزام بحديث بسرة ليس بلازم؛ فقد ترك صاحبا الصحيح من الحديث ما لا يحصى وانتقيا ما يحسن الإخراج

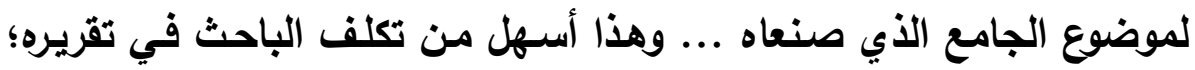

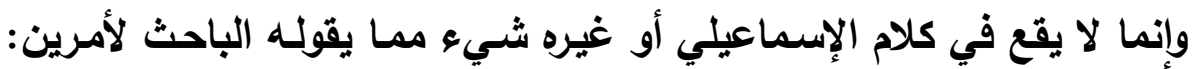

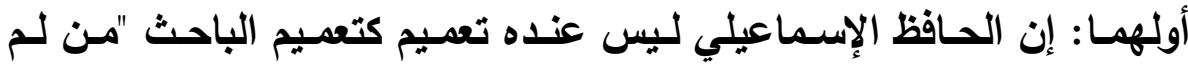
يوصف بجرح أو تعديل في الصحيح" وإلا لكان الإسماعيلي - وهو الحافظ لئي المستخرج - متتبعا لجميع الرواة الذين يشـلهم هذا الوصف! ولـم يفعل

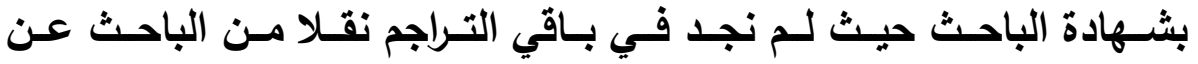

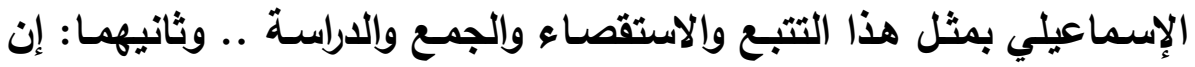

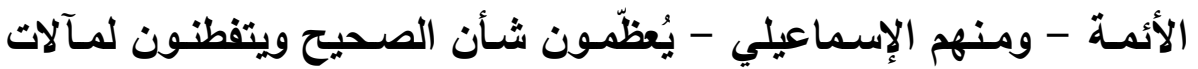

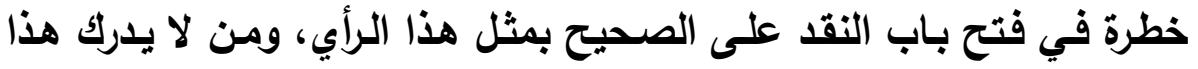
ويفعل خلافه فهو بعيد عن الذوق السليم ويقع في الهنات والمفاسد الخطرة!

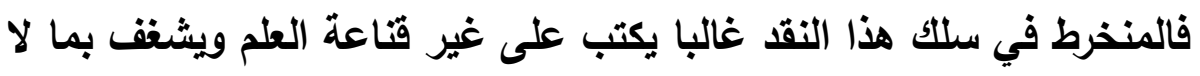

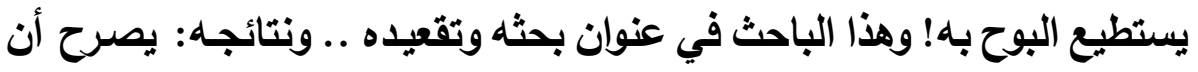

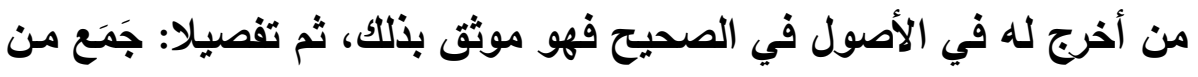

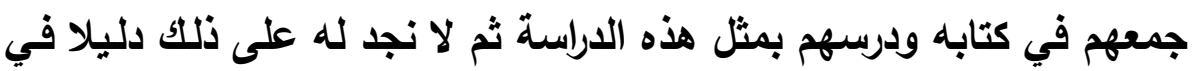

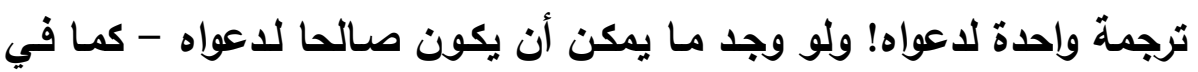

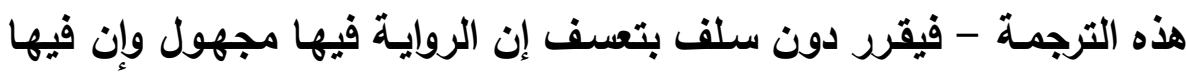

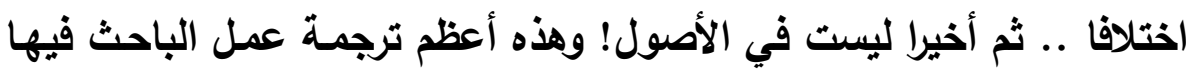

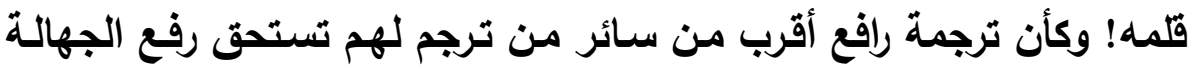
عنها - على اعتقاد الباحث بأنه من رواة الإسناد -، إذ بها سيثبت الباحث مجلة كلية أصول الدين والدعوة بأسيوط / العدد السابع والثثلاثون 9 ا ـ بم - الجزء الثالث 
وجود رواة في الصحيح وثققوا بالرواية لهم أصولا، ولسُدّ الباب على الطاعن

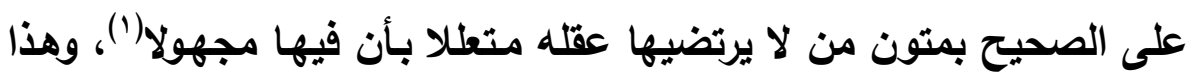
مـا لا يريـده الباحث! ليقحى وجهود مجهولين في الصـيح، وهـم جميع مَنَ ذكرهم بلاليل أنهم لم يُخرّج لهم في الأصول وعلى هذا النسق ذكر جميع رواة بحثة، ولعمر الله لو جاء من لا يرتضسي منهجية البحث فيكتفي من إحصاء الباحث للرواة بأنهم مجهولون، فينطلق لأحاديثهم فيضعفها ولـو كانت في غير الأصول! ولذا بحثه بنتائجه صحيحة على أن جميع الرواة ممن تنالهم شبهة الجهالة كانت الرواية عنهم على غير شرط الصحة، أما قضية التوثيث الضمني الذي يستفيل منها الرواة بمجرد إخراج صساحب الصحيح لهم = لا نجد لهم مقعد صدق في بحثه إلا تقعيدا يُرضي به مخيفه! فضري ضره وشري شره ووقد تحت الرماد جمره! ولو جاء باحث بعده يريد أن يستفيا من بحثه هـا فـي هـذه الحيثيـة لمـا ظفر بالمقصـود إلا دندنـة: هنـاك في الصـحيح مجاهيل! وقد تقدم أنّ للباحث عوار واضـح حيث نسب فيمن جمعهم إلى عنوان بحثه "وأن رواية البخاري ومسلم لراو في الأصول توثيق له" ثم لم نجد شيئا يؤيده ولو احتمـالا! ومـع إحصائه القليل فأغلب مرويـات الرجال الذين ذكرهم(r) روايتهم في الصحيحين بالشـواهد والمتابعات بـإقراره(r)، وأمـا الذين

(1) كحديث صحيح البخاري: "إذا وقع الذباب في شراب أحدكم فليغمسه ثم لينزعه .."

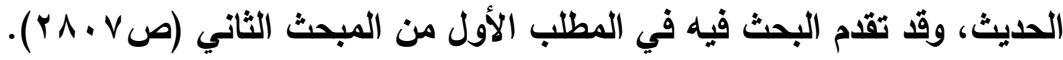

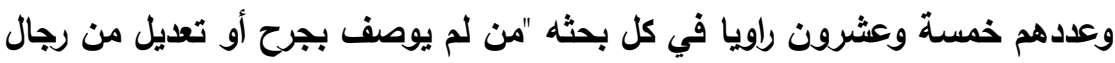

$$
\text { الصحيحين ..". }
$$

(r) كما في (ص عـ إ) في نتائجه، وقد ذكر ذلك بإجمال مخل! مجلة كلية أصول الدين والدعوة بأسيوط / العدد السابع والثلاثون 9 ا ـ بم - الجزء الثالث 
إزالة إيهام القائلين بوجود

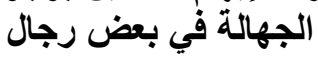

فاتوه ولم يذكرهم في بحثه وهم أكثر بكثير ممن ذكرهم(') من أهملهم بالذكر هم على هذا النحو وأغلب روايتهم بالشواهد والمتابعات ثم ليس للواحد منهم إلا الحديث الواحد، أو الحديثان، وريما الثلاثة، أما فوقها فهو نادر جدا، فلو !! والعجيب أن الباحث لا يرى راويـا روى له أصحاب الصحيح في الأصول حيث قال في نتيجة r ا من نتائجه: "أن مرويـات هؤلاء (أي من لـ يوصفوا بجرح ولا تعديل) أغلبها في المتابعات والثواهد، ومنها مـا سيق لبيان وهم،

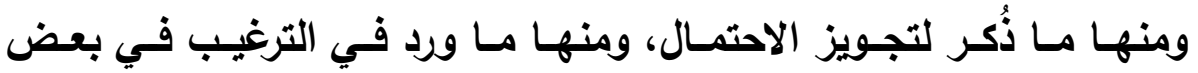
الأذكار"()!! إذن ليس هناك راو أخرج له البخاري أو مسلم في الأصول عند الباحث لقولهه: "مرويـات هؤلاء"، مـع أنه في نتيجة سـابقة برقم 9 قال: "أن روايـة الشيخين لراو في الأصول سوإن كان مستورا - تعتبر توثيقا لهه"(r)! وفي عنوان بحثه قبل هذه العبارة: "تأصيل قاعدة .." فأين هم أيها الباحث وأنت لا تـراهم بعينيك ولـم تـنص عليهم بيديك! فعجبنـا مـن هذا التنـاقض الواضــح، والتخـالف الفاضـح؛ وفـي المثـل السـائر : "أصــلح وقابـل، وأفســـ وقابـل"! والقـارئ البسـيط يـرى بعـ هـا أن مثـل هـذه الأبحـاث خطيـرة في نتائجها؛ فإن لم تكن رصينة محكمة تعزز من رتبـة الصحيحين المستقرة في مي النفوس، وتبعد الشبه حولهما؛ فِان البحث حين ذاك يُشك في أمره! ودوافع صاحبه، ولا يشفع له ملاحة عنوانه؛ فإن أكْثر المساوئ تَحت قناعها:

(1) (نظر ما تقلم من القضية الاولى في إحصاء من لم يوصف بجرح ولا تعديل.

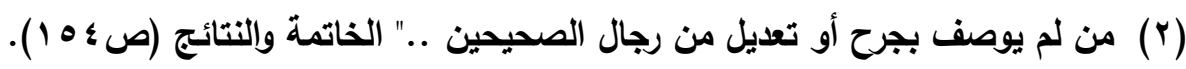

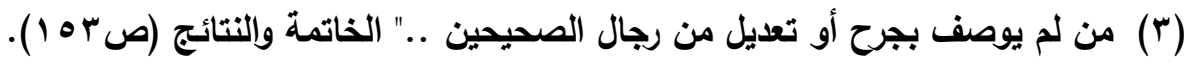
مجلة كلية أصول الدين والدعوة بأسيوط / العدد السابع والثلاثون 9 ا ـ بم - الجزء الثالث 
إزالة إيهام القائلين بوجود

الجهالة في بعض الفالين بوجال

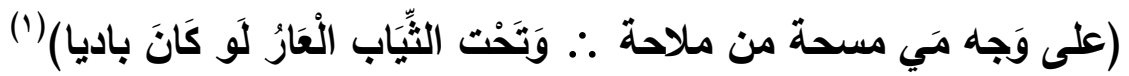
ورافع هذا خامس خمسة أدخلهم الباحث بحثّه ولا ينبغي دخولهم جمعا ودراسة! والأربعة الباقون هم: r - محمد بن كعب بن مالك بن أبى القين الأنصاري السلمي المدني:

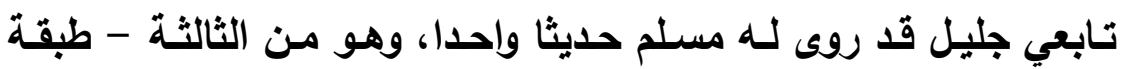
وسطى التابعين -، فوأسفاه على رجل تابعي من رجال مسلم "ثقة قدة" قد جهّله الباحث بحجة أنه لم يرو عنه غير راويين، وأنه لم يجد توثيقا في ترجمته في هن تهذيب الكمال وتوابعه غير قول ابن حجر في التقريب: "ثقة"(؟)؛ فلم يرتضه!! فأبقاه مجهولا، ثم راح يثبت الجهالة بكونـه متابَعا على روايته في "صحيح مسلم"(ّ)، وقد فات الباحث أن الحق مـع ابن حجر؛ لأن الإمـام أحمد قال -

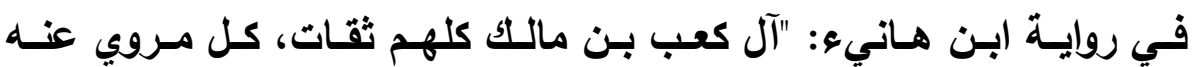
الحديث"(؛)، قال ابن رجب شارحا: "يعني: كل من روى عنه الحديث من أولاد كعب بن مالك وذريته فهو ثقة"(•). ولم يذكر هذا الباحث لقصوره.

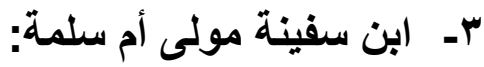

(1) البيت للشاعر ذُي الرُّمَّةِ غَيْلَانَ بن عقبة العدوي، وعقبه:

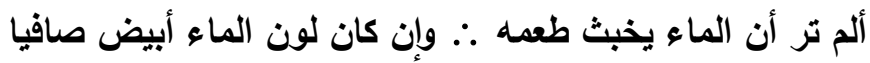

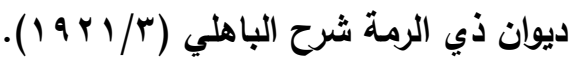

$$
\begin{aligned}
& \text { تقريب التهذيب (ص ع ـ •). }
\end{aligned}
$$

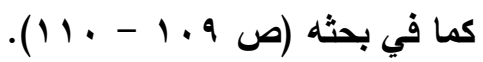

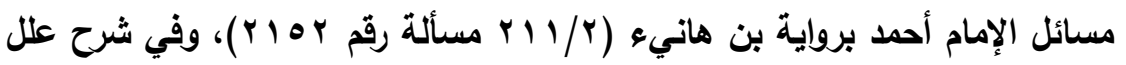

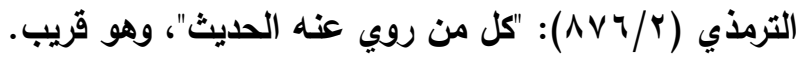

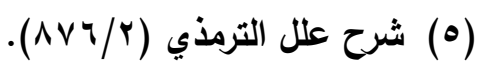




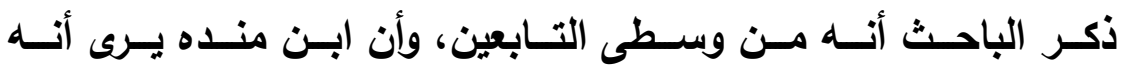

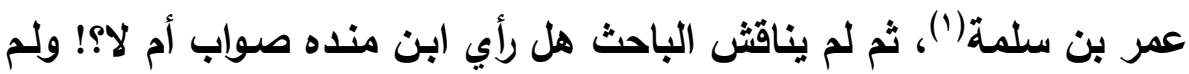

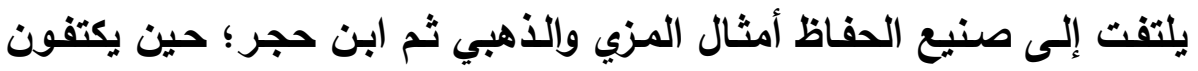

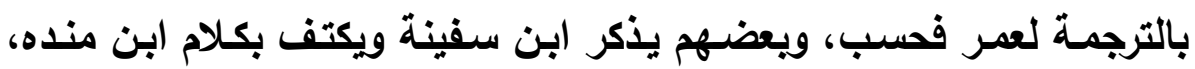

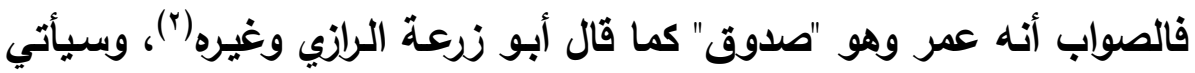
مزيد تفصيل فيه في مطلب "دعوى الدراسة". צ- عبدالله بن يزيد النخعي الكوفي: مذكور في رجال مسلم له حديث واحد، وقد ذكره الباحث على شرط

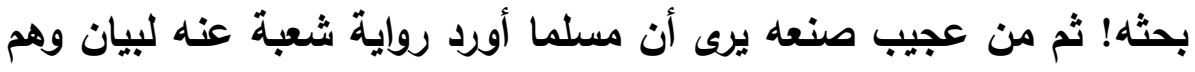

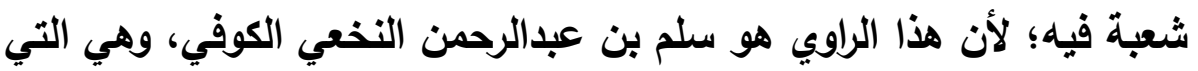

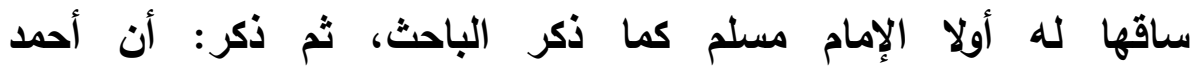

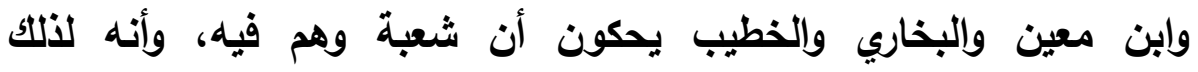

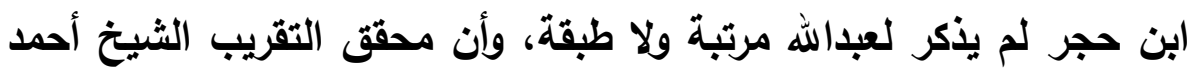

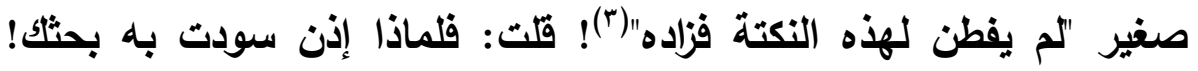

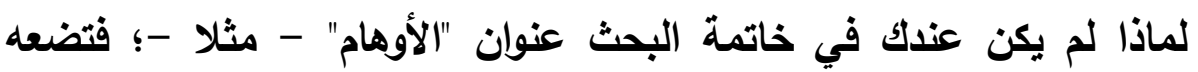

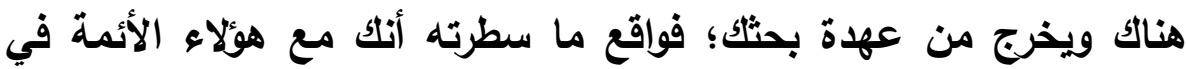

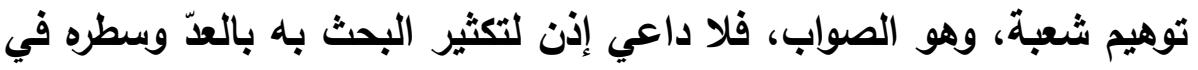

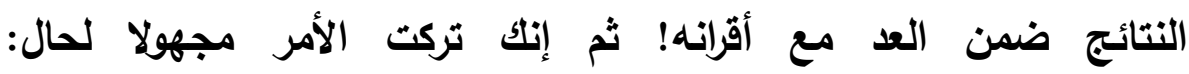

$$
\begin{aligned}
& \text { (1) كما في بحثه (ص س ا (1). }
\end{aligned}
$$

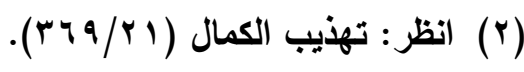

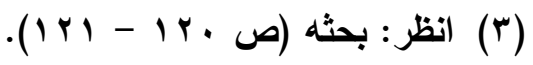


إزالة إيهام القائلين بوجود

الجهالة في بعض الفالين بوجال

"سلم بن عبدالرحمن النخعي الكوفي"! ولا ينبغي إغفال توثيق أحمد وابن معين والعجلي والدارقطني وغيرهم (1)!

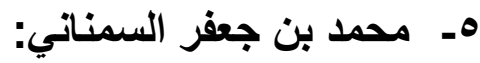

من شيوخ البخاري الذين عرف حديثهم البخاري وسبره، ويكفينا فيه أن الباحث أقر على نفسه - زلة - بأنه حافظ؛ فقد صدّر ترجمته بعد آخر اسمه - بهـــا الوصـف - بقولــه: "محمـــ بـن جعفـر الســنـاني القومســي، أبو جعفر بن أبى الحسين الحافظ خ ت ق: .."(؟). فهوعلاء خمسـة رواة ليسـوا من شـرط البحث أمسا رافع فعلى الأرجـح أنها ليس أحد رواة الإسناد، ولو كان راويـا لكان مقبولا كما تقدم، وأمـا الباقون الأربعة فهم ثقات عدا عبدالله بن يزيد النخعي الكوفي فذكره وهم، كلهم من التابعين عدا الأخير من شيوخ البخاري. وأدرس نماذج أخرى أسردهم باعتبار الطبقات على وفق مـا في تقريب

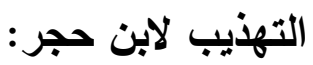
فمن الطبقة الثانية: צ- إبراهيم بن عبدالرحمن بن عوف القرشي الزهري - Y -، خ م("): لم يأكره الحافظ ابن حجر بجرح أو تعديل ولا قال فيه: "مقبول"، وهو من

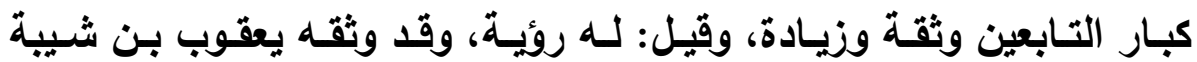
والنسائي وغيرهما (')

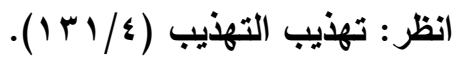

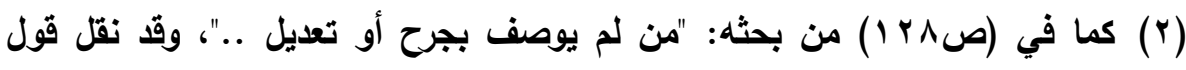

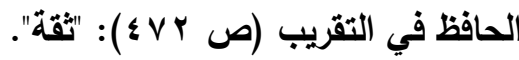

$$
\text { تقريب التهذيب (ص الو (9). }
$$


إزالة إيهام القائلين بوجود

الجهالة في بعض الفالين بوجال

- خ خالا بن عمير العدوي البصري. م "مقبول"(r):

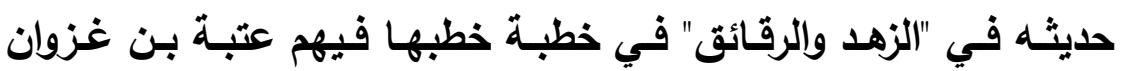

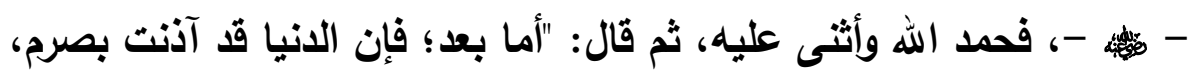
وولت حذاء ..." الحديث("). وقد أدرك الجاهلية كما صرحت بـه روايـة مسلم

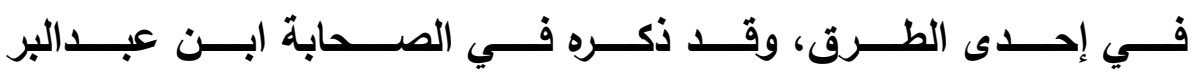
وابن قانع وغيرهما، وقال عبدان: لا أدري أله روئية أم لا!(ء). قلت: وأقل مـا يقال: بأنه من كبار التابعين وقدمائهم (•). وتابعه في حديثه هذا شويس أبو

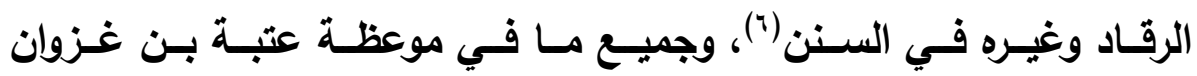
- هوليه. - يشهر لله ما في الباب عند مسلم في صحيحه وغيره.

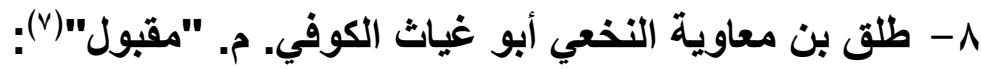
قال قال أيضا ابن حجر في تقريبه: "تابعي كبير مخضرم"، وقال الذهبي: "ثقة مقل"(^)، قلت: حديثه بالثواهد عند مسلم، ففي صحيح مسلم لله حديث واحد في "الأدب" يرويه عن أبي زرعة بن عمرو بن جرير، عن أبي هريرة

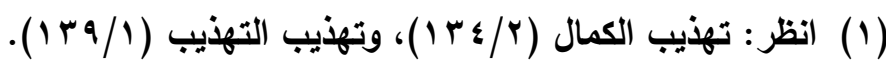

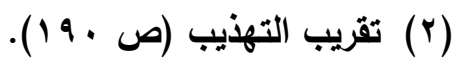

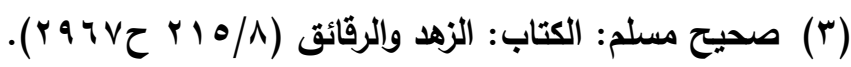

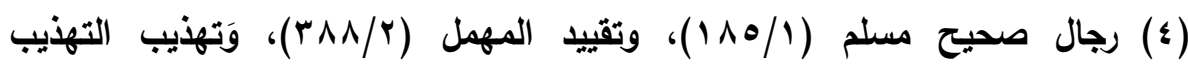

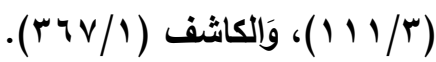

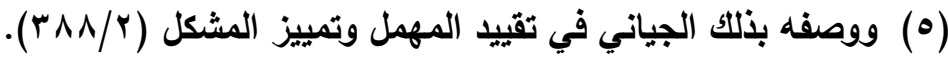

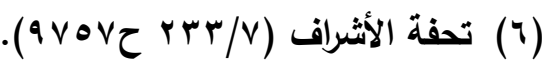

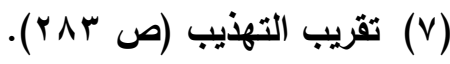

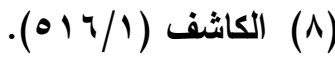




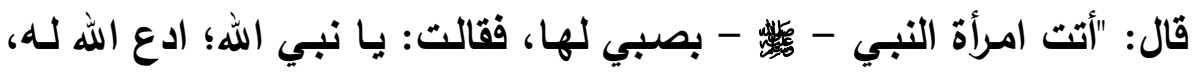
فلقد دفنت ثلاثة، قال: دفنت ثلاثة قالت : نعم، قال: لقد احتظرت بحظار شديد من النار". وقد ذكر قبله الإمام غير حديث عن أبي سعيد وأبي هريرة

فيمن مات لله ثلاثة من الولاد (1).

9- مالكك بن مالك بن جُعشم بن مالك بن عمرو المدلجي. خ "مقبول"(؟): وقال ابن حجر : "أبوه مالكك بن جعشم لـم أر من ذكره في الصـحابة، فالظاهر أنه مات في الجاهلية، فيكون لمالك بن مالك إدراك"(")، وحديثه من هن طريـق بـن شـهاب، عن عبدالرحمن بـن مالـك المـلجي - وهـو ابـن أخي سراقة بن مالك بن جعم -؛ أن أباه أخبره أنه سمع سراقة بن جشم يقول: وذكر حديثه الطويل في الهجرة(؛)، قال ابن حجر: "ليس له ولا لأخيه سراقة ولا لابنه عبدالرحمن في البخاري غير هذا الحديث"(ه)، وحديثه هذا بالشواهد فقد خرج البخاري عن أنس والبراء بمعناه(؟). من الطبقة الثالثة:

$$
\begin{aligned}
& \text { صحيح مسلم: كتاب: الأدب ( ( } \\
& \text { تقريب التهزيب (ص r r) (1) }
\end{aligned}
$$

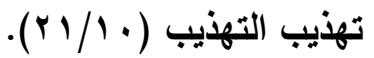

صحيح البخاري: كتاب: الجهاد، باب: هجرة النبي - تهاب: - وأصحابه إلى المدينة

$$
\text { . ( } 1 \leqslant r / r)
$$

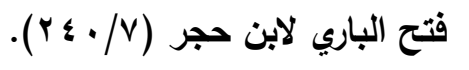

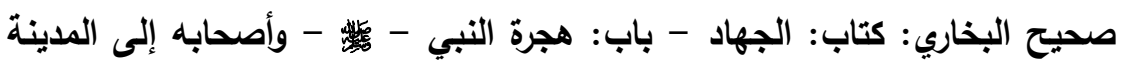

$$
\text { . (1 } 1 \leqslant r r-1 \leqslant r \mu / r)
$$


إزالة إيهام القائلين بوجود

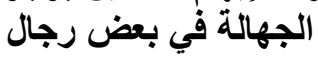

• 1 - إبـر اهيم بـن عبـالرحمن بـن عبـدالله بـن أبـي ربيعـة المخزومسي المسـني. خ

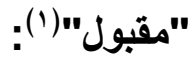

أمه أم كلثوم بنت أبي بكر الصديق وله رواية عن أمه وخالته عائشة(؟)، ذكره ابن حبان في" الثقات "(ّ)، ونقل ابن حجر عن ابن القطان قوله: "لا يعرف لله حال(؛)، وفي إكمال تهذيب الكمال: "قال ابن خلقون: هو "ثقة مشهور". وصحح الحاكم حديثه في مستدركه"(•). له حديث واحد في صحيح البخاري عنه عن عن جابر بن عبدالله - م - قال: "كان بالمدينة يهودي وكان يسلقني في تمري إلى الجداد وكانت لجابر الأرض التي بطريق رومة فجلست فخلا عاما، فجاعني اليهودي عند الجداد، ولم أجد منها شيئا، فجعلت أستنظره إلى قابل فيأبى! فأخبر بذلك التبي - ف "امشوا نستنظر لجابر من اليهودي". فجاؤوني في نخلي فجعل التبييكلم اليهودي، فيقول: أبا القاسم؛ لا أنظره! ... الحديث بطوله(؟). وفي هذه الترجمة فيها شبهٌ بتصيد الباحث لكلام الإسماعيلي في ترجمة رافع - وإن كانت هذه الترجمة ليست في بحثه -، فهنا قال ابن حجر: "وقد استثكل

$$
\begin{aligned}
& \text { تقريب التهذيب (ص ا9). }
\end{aligned}
$$

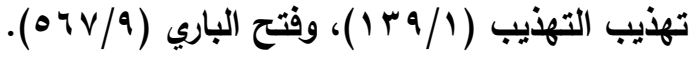

$$
\begin{aligned}
& \text { (الثقات لابن حبان (؟/ ( ). }
\end{aligned}
$$

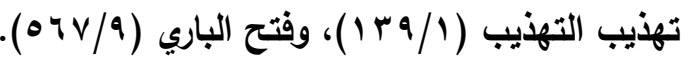

(0) إكمال تهذيب الكمال (1/ • ؛ ؟)، والحديث المشار إليه هو في قصة صنع سفينة نوح

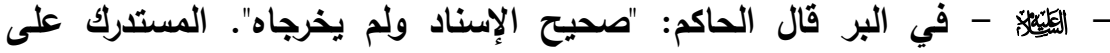

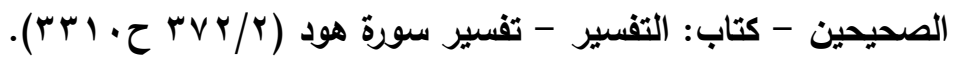

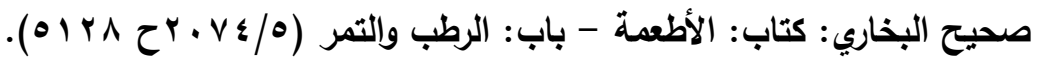


الإسماعيلي ذلك وأثشار إلى شذوذ هذه الرواية فقال: هذه القصة - يعني

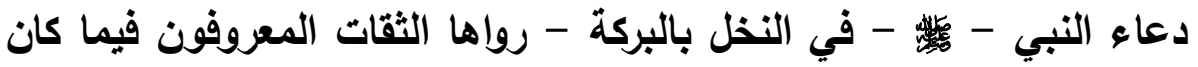

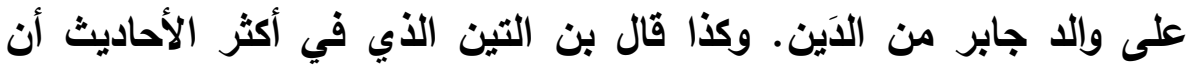
الآين كان على والد جابر. قال الإسماعيلي: والسلف إلى الجذاذ مما لا يجيزه

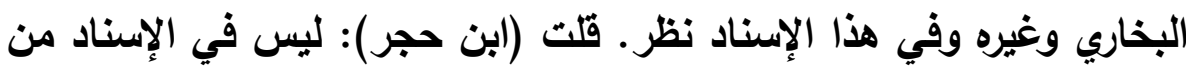
ينظر في حاله سوى إبراهيم، وقد ذكره بن حبان في ثقات التابعين، وروى

عنه أيضا ولده إسماعيل والزهري، وأما بن القطان فقال: لا يعرف حالهة" ('). 11

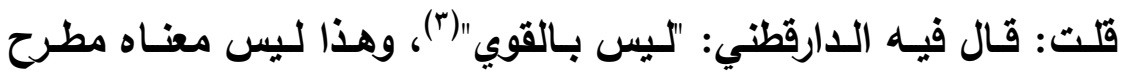
الحديث، ومـع ذلك لـم يعتمده البخاري بـل أخرج لـه حديثا واحدا في البيوع

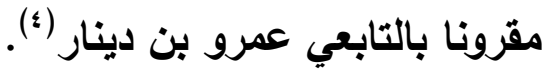

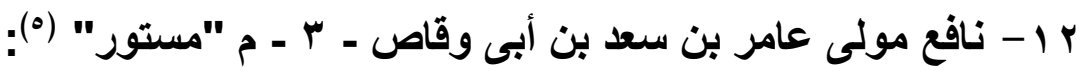

(1) تهذيب التهذيب (1/9/1)، وفتح الباري (1/9/9)، وانظر: زيادة الثقات

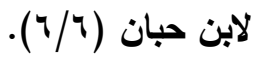

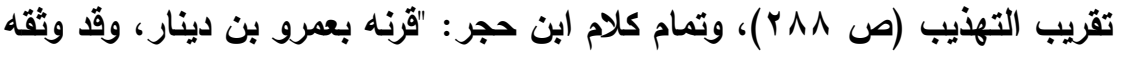

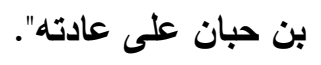

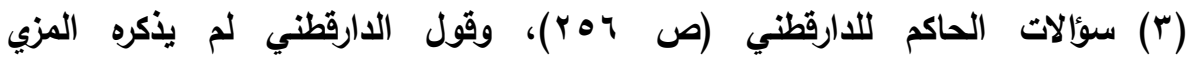
وابن حجر في تهذيبهما، واستدركه مغلطاي على التهذيب للمزي. انظر: إكمال

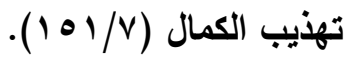

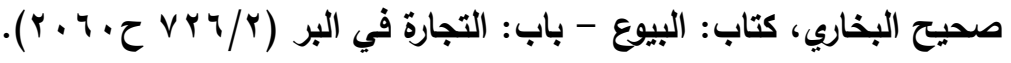

$$
\begin{aligned}
& \text { تقريب التهذيب (ص البهاري، هـه). }
\end{aligned}
$$


قلت: حليثه عند مسلم: عن عامر بن سعد بن أبي وقاص، قال : كتبت إلى جابر بن سمرة مع غلامي نافع، أن أخبرني بشيء سمعته من رسول الله الأسلمي يقول: "لا يزال الدين قائما حتى تقوم السـاعة، أو يكون عليكم اثـا عشـر خليفـة، كلهـم مـن قريش". وسـمعته يقـول: عصسيبة مسن المسـلمين يفتحون البيت الأبيض، بيث كسرى - أو آل كسرى. وسمعته يقول: إن بين يـدي السـاعة كذابين فاحذروهم. وسـعته يقول: إذا أعطى الله أحدكم خيرا

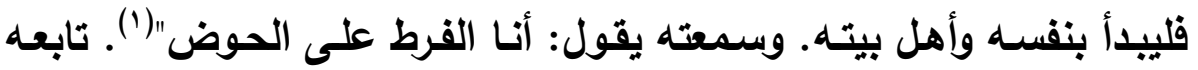
عليـه جماعـة مسن التـابعين، وهــم الثـعبي وعبــالملك بـن عميـر وسـماك ابن حرب عن جابر. ذكر حديثهم - مع تفرق لفظه عنهم - مسلمُ في نفس الباب(ץ)، وفي مواطن أخر()، إلا أن حرف "إذا أعطى الله أحدكم خيرا فليبدأ بنفسه وأهل بيته" لم أجد لله متابعة عند مسلم لكن لله شاهد عنده عن غير واحد من الصحابة(؛)، ولجميع لفظه شواهد مفرقة في صحيح مسلم وغيره

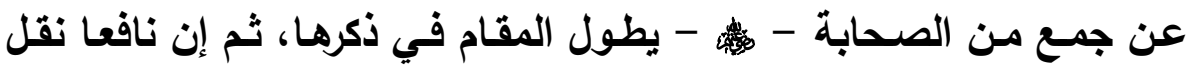
الكتاب؛ فلو كان غير مأمون عند عامر مولاه لما أرسله، ويقزّبه أنّ جابرا هو

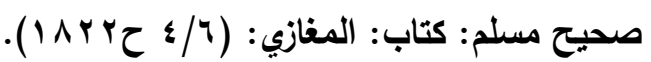

$$
\begin{aligned}
& \text { المصدر السابق. }
\end{aligned}
$$

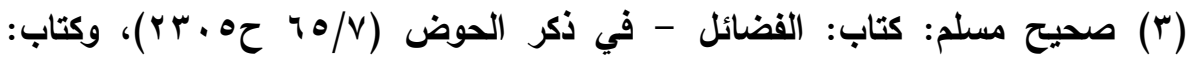

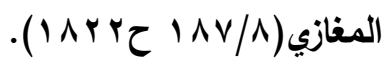

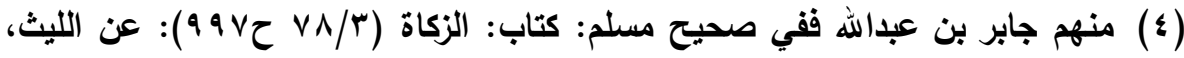

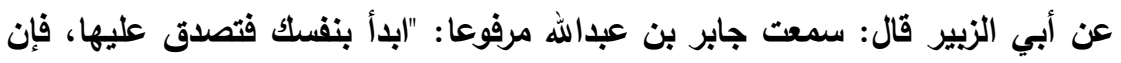

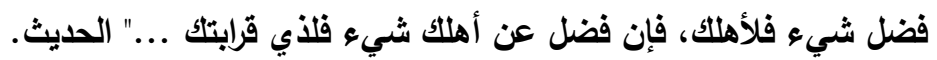
مجلة كلية أصول الاين والدعوة بأسيوط / العدد السابع والثلاثون 9 الـ بم - الجزء الثالث 
ابن عمة عامر؛ لأن أم الأول هي خالدة بنت أبي وقاص أخت سعد (')، فلا

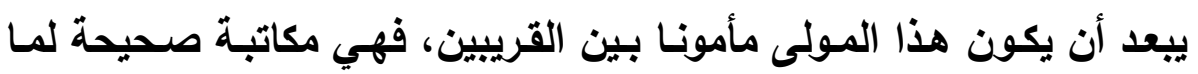

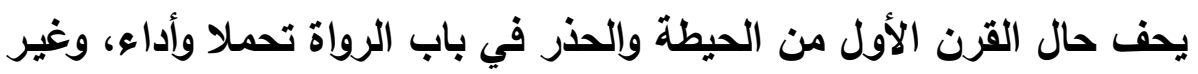

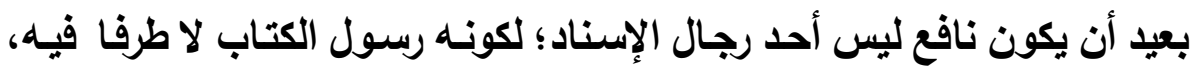

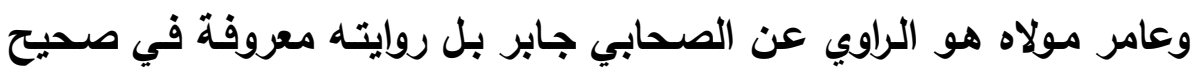

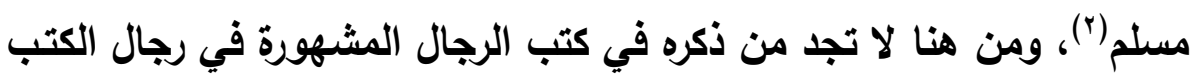
الستة غير الحافظ ابن حجر في تهذيبه مستدركا على الحافظ المزي عدام

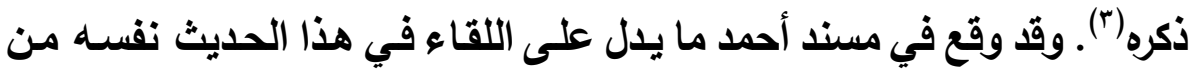

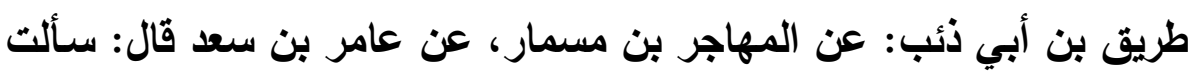

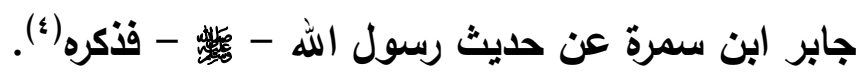
ومن السادسة الذين عاصروا صغار أتباع التابعين: rا 1 - أمية بن صفوان بن عبدالله بن صفوان بن أمينة بن خلف أبن الجمحي. م "مقبول")(0):

قلت: قال مغلطاي: "ذكره أبو حاتم بن حبان في "جملة الثقاته، وخرج

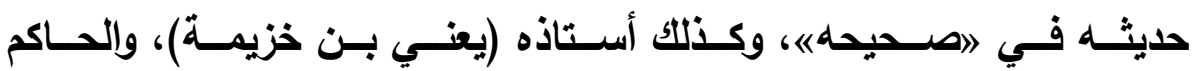

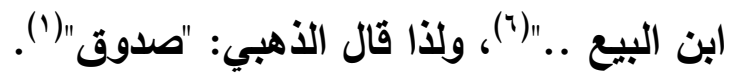

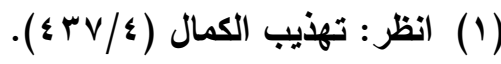

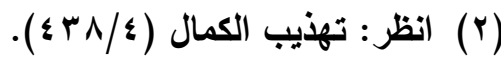

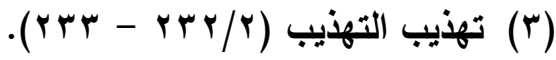

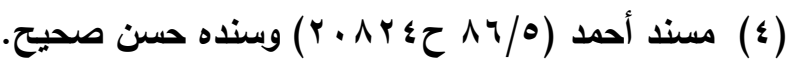

$$
\begin{aligned}
& \text { (0) تقريب التهذيب (ص\& (1) (1). }
\end{aligned}
$$

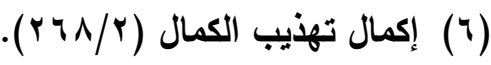


إزالة إيهام القائلين بوجود

الجهالة في بعض الفالين بوجال

ع ا - عمر بن إسحاق المدني، مولى زائدة. م "مقبول"(؟):

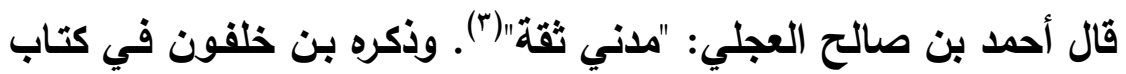

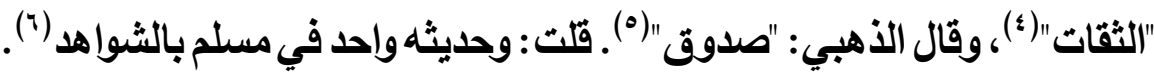

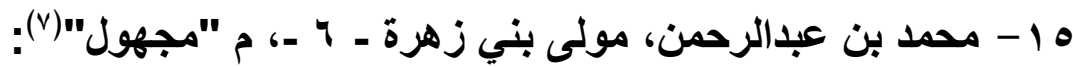
قلت: كذا وقع في تهذيب الكمال ومن تابعه كالتقريب أن مسلما أخرج له(^)، وروايته عند البخاري أكثر في صحيحه من مسلم، قال الكلاباذي:

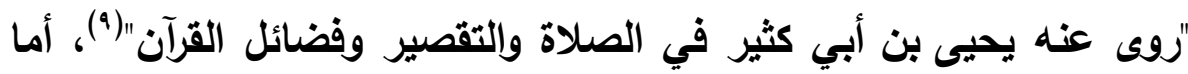
الأي في الصلاة(·) والتقصير - أي أبواب قصر الصلاة - (')؛ فإنه قد

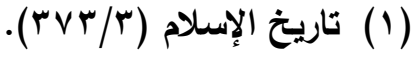

$$
\begin{aligned}
& \text { (r) تقريب التهذيب (ص • (؟) ). }
\end{aligned}
$$

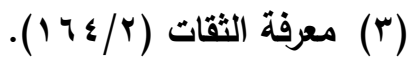

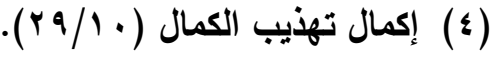

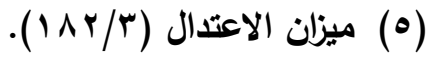

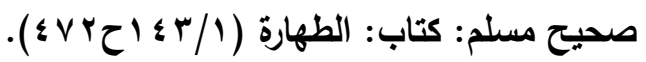

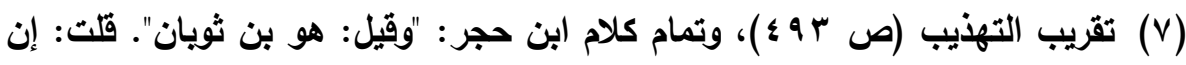
كان بن ثويان، فقد وثقّه غير واحد وقال أبو حاتم: "لا يسأل عن مثله". يُنظر:

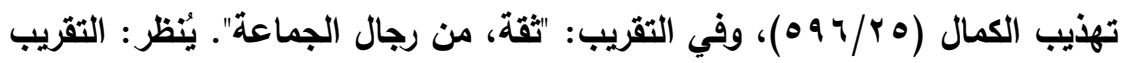

$$
\text { (ص) (صن }
$$

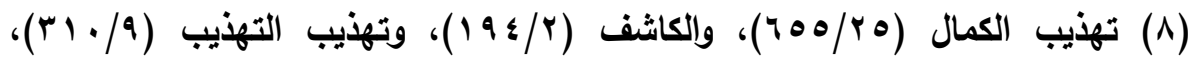

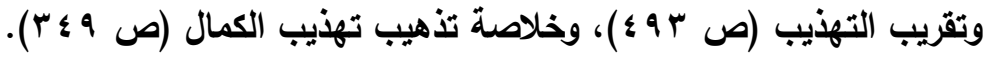

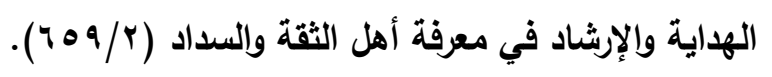

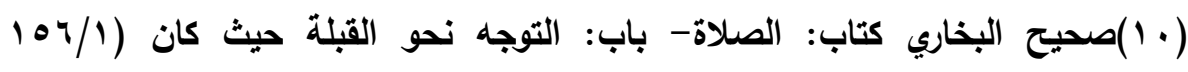

(rq) مجلة كلية أصول الدين والدعوة بأسيوط / العدد السابع والثلاثون 9 الـ بم - الجزء الثالث 


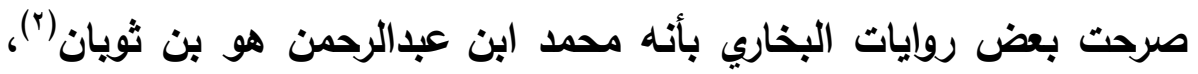

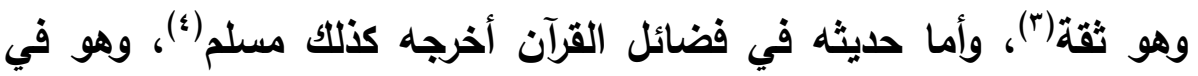

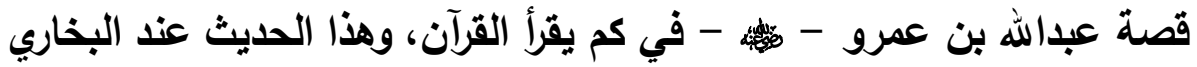
ومسلم: "عن شيبان عن يحيى، عن محمد بن عبدالرحمن مولى الرئ

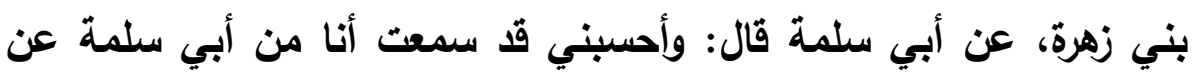

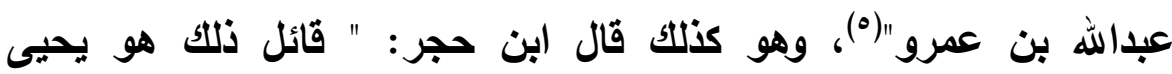

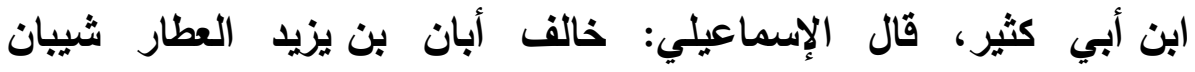

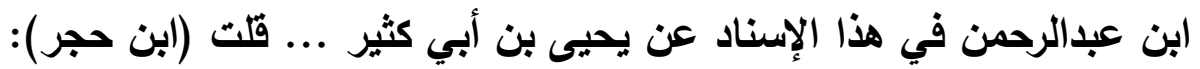

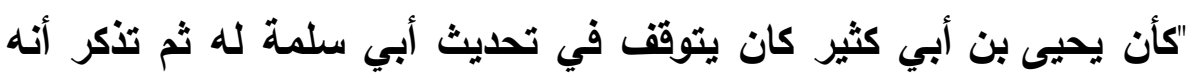

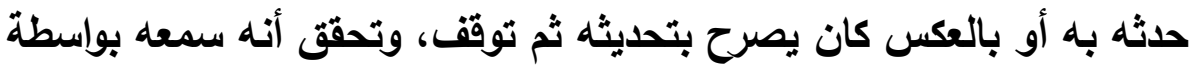

صحيح البخاري: كتاب: الصلاة - باب: صلاة التطوع على الدواب وحيثما توجهت به

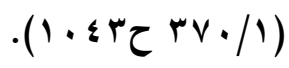

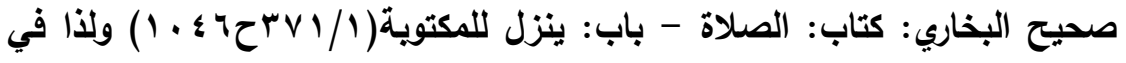

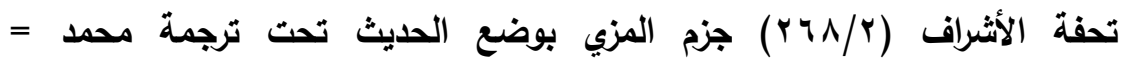

= ابن عبدالرحمن بن ثويان القُرشيُّ أبي عبدالله المدنيُ، عن جابر .

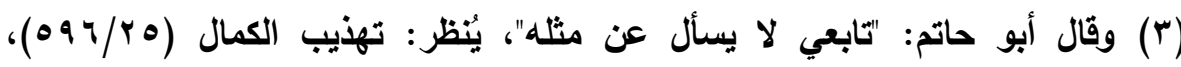

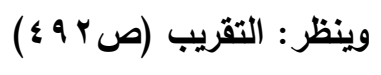

(؛ ) وليس لله إلا هذا الحديث في مسلم، قال بن منجويه: "محمد بن عبدالرحمن مولى الئ بني زهرة، روى عن أبي سلمة في الصوم، روى عنه يحيى بن أبي كثير". رجال

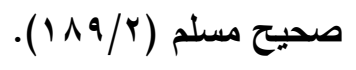

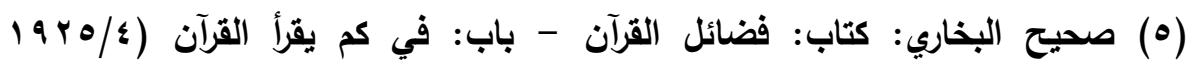

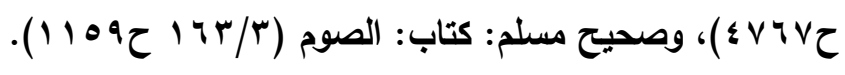


إزالة إيهام القائلين بوجود

الجهالة في بعض الفالين بوجال

محمد ابن عبدالرحمن، ولا يقدح في ذلك مخالفة أبان؛ لأن شيبان أحفظ من

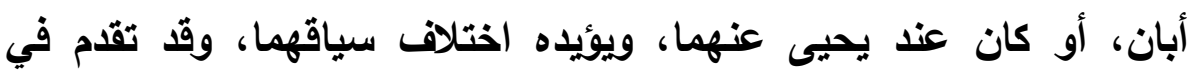

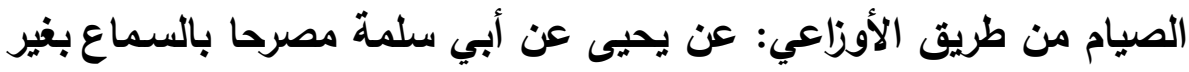

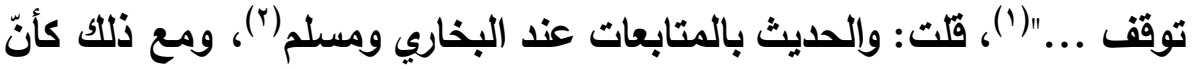

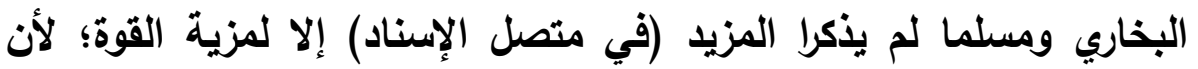

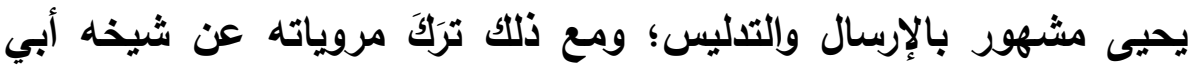

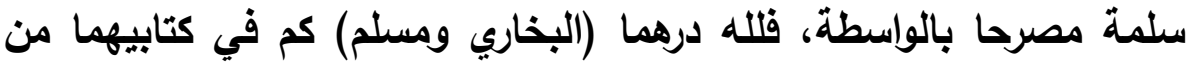
نكت بديعة! الأمر نفسه فيما انفرد به البخاري من الحديثين السابقين فرواية داية

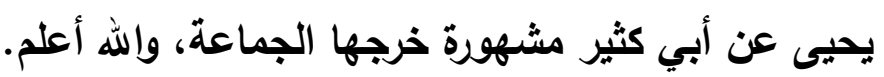

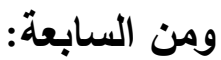

17 - مهاجر بن مسمار الزهري، مولى سعد المدني. م" مقبول"(r): قال محمد بن سعد: "ليس بذاك، وهو صالح الحديث". وقال البزار في

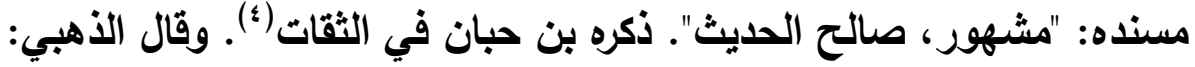

$$
\text { "ثقة"(0). وحديثه بالشواهد في مسلم (1). }
$$

$$
\text { فتح الباري (9 ( }
$$

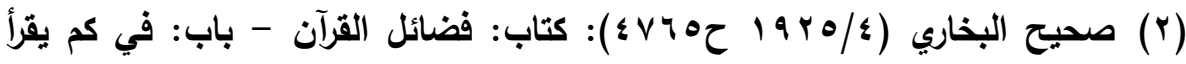

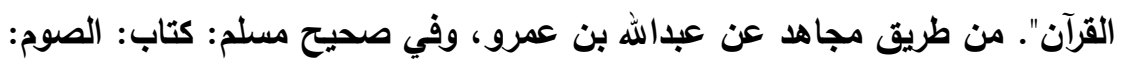

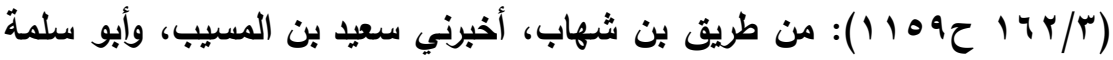
بن عبدالرحمن: أن عبدالله بن عمرو بن العاص فنكره مطولا في قصة.

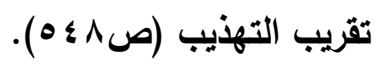

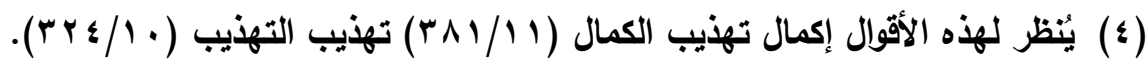

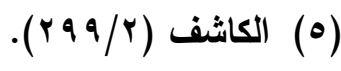
مجلة كلية أصول الدين والدعوة بأسيوط / العدد السابع والثلاثون 9 الـ بم - الجزء الثالث 
إزالة إيهام القائلين بوجود

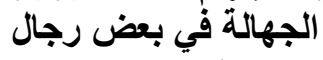

\section{ومن الثامنة:}

I V قا نقل مغلطاي وابن حجر - في تهذيبه - : "أخرج ابن خزيمة حديثه في "صحيحه": "إذا استيقظ أحدكم من منامه فلا ياخل يده في الإناء حتى يغلها ثلاث مرات ..." من طريق جابر بن إسماعيل مقرونا بابن لهيعة، كلاهما عن عقيل عن ابن شخهاب عن سالم بن عبدالله عن أبيه مرفوعا به، ثم قال ابن خزيمة: "(بن لهيعة ليس ممن أخرج حديثه في هذا الكتاب إذا تفرد برواية، وإنما أخرجت هذا الخبر؛ لأن جابر بن إسماعيل معه في الإسناد

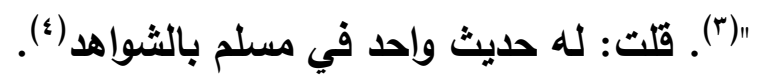
ومن طبقة الرواة عن البخاري:

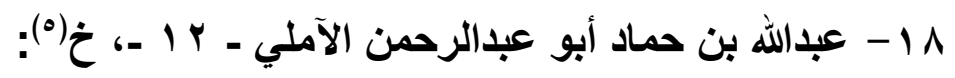
لم يذكره الحافظ ابن حجر بجرح أو تعديل ولا قال فيه: "مقبول"، ووقع في موضعين في صحيح البخاري، الأول منهما: حدثا عبدالله، حدثا سليمان

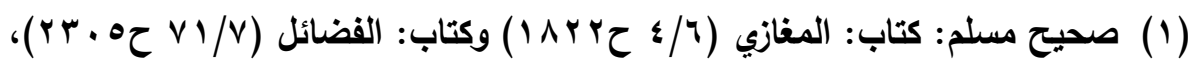

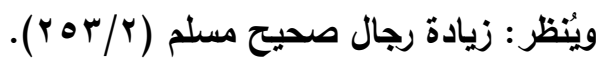

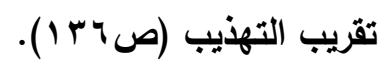

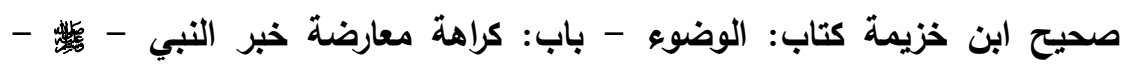

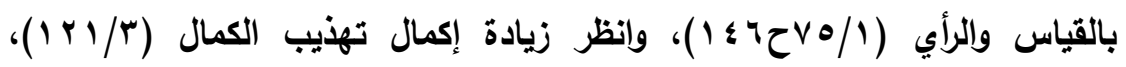

$$
\text { وتهذيب التهذيب (rV/r) }
$$

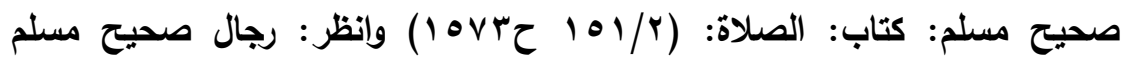

$$
\text { تقريب التهذيب (ص . . (1) (1). }
$$


إزالة إيهام القائلين بوجود

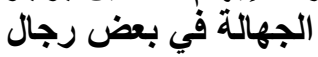

بن عبدالرحمن وموسى بن هارون قالا: حدثا الوليا بن مسلم، حدثنا عبدالله

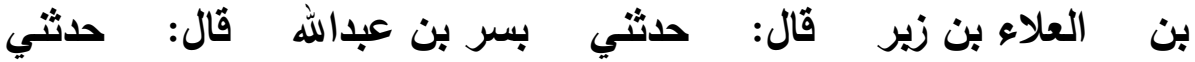
أبو إدريس الخولاني قال: سمعت أبا الدرداء يقول: "كانت بين أبي بكر وعمر محاورة، فأغضب أبو بكر عمر، فانصرف عنه عمر مغضبا، فاتبعه أبو بكر: يسأله أن يستغفر له! فلم يفعل! حتى أغلق بابه في وجهه!! فأقبل أبو بكر

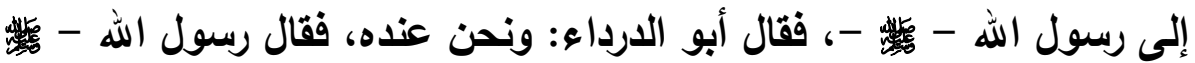
- - "أما صاحبكم هذا فقد غامر". قال: وندم عمر على ما كان منه، فأقبل

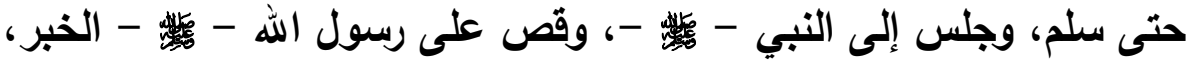
قال أبو الدرداء: وغضب رسول الله - - - وجعل أبو بكر يقول: والله - يا

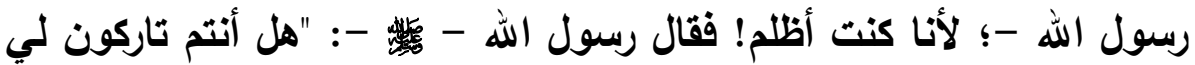
صاحبي، هل أنتم تاركون لي صاحبي! إني قلت: يا أيها الناس إني رسول الله إليكم جميعا، فقلتم: كذبت. وقال أبو بكر: صدقت"(1)، والموضع الآخر: حدثي عبدالله، قال: حدثي يحيى بن معين، حدثا إسماعيل بن مجالد، عن بيان، عن ويرة، عن همام بن الحارث قال: قال عمار بن ياسر : "أريت رسول

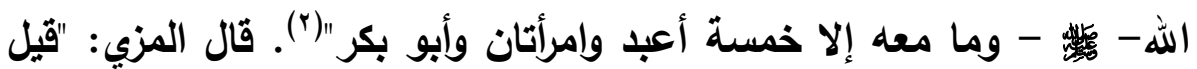
إنه عبدالله بن حماد الآملي، ويحتمل أن يكون عبدالله بن أبي الخوازمي؛

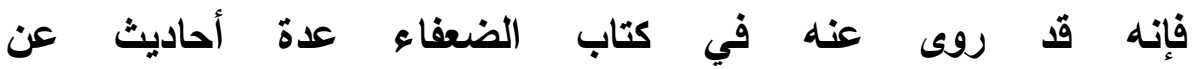

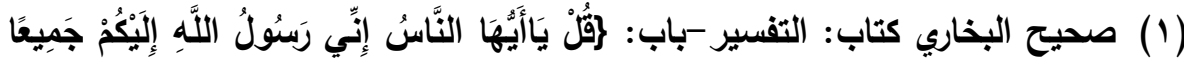

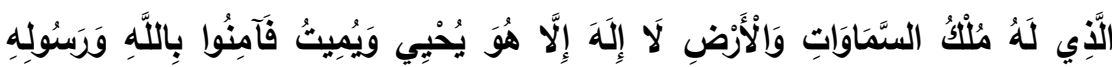

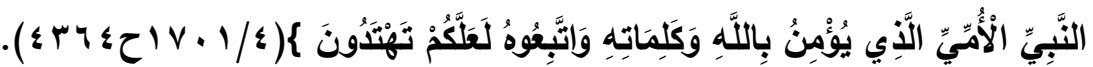

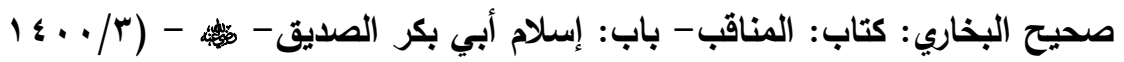

.$(r \wedge \circ \vee \tau$ 
سليمان بن عبدالرحمن سماعا وتعليقا. والله أعلم"(1)، وجزم الذهبي في السير

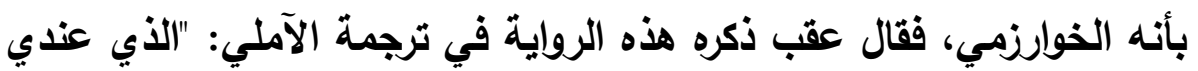

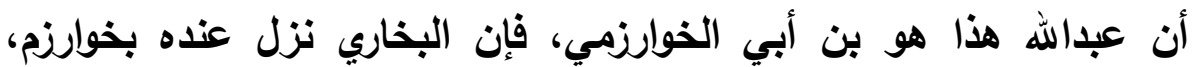

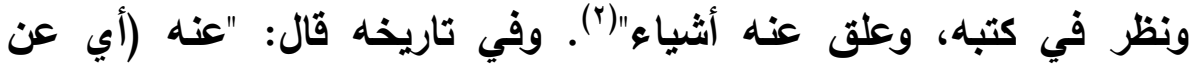

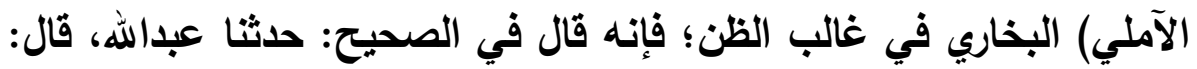

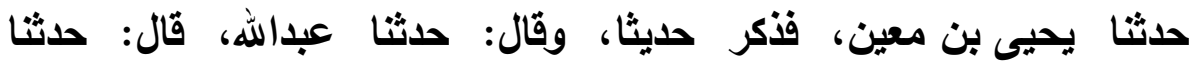

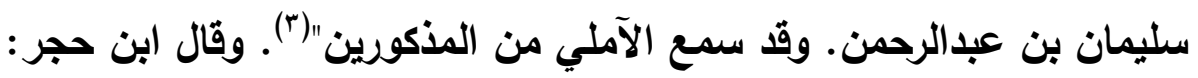
"قال بن السكن في روايته: حدثني عبدالله بن محمد، فتوهم أبو علي الجئ الجياني

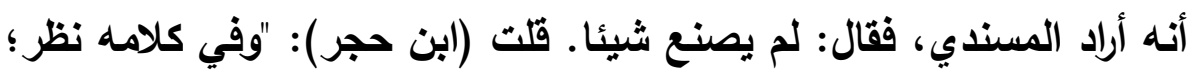
فقد وقع في تفسير التوية: حدثنا عبدالله بن محمد، حدثنا يحيى بن الن معين.

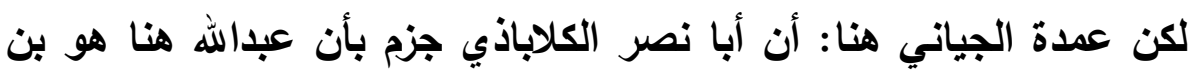

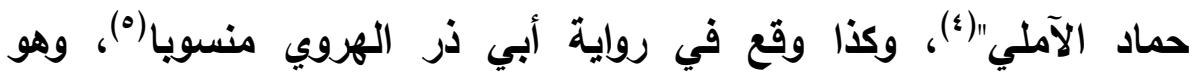

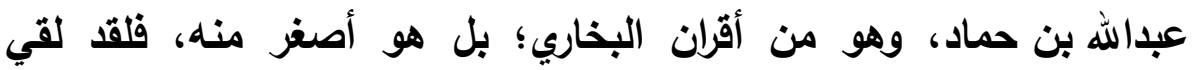

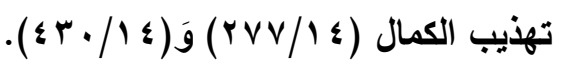

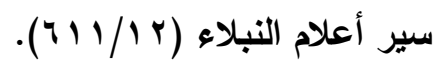

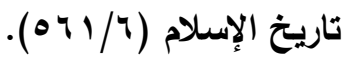

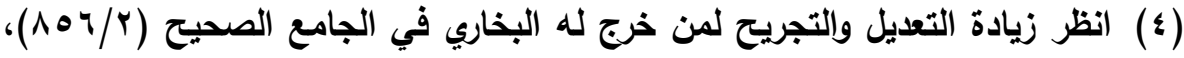

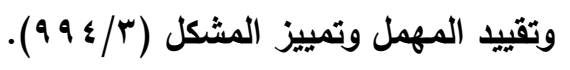

(0) وهو في المطبوع من صحيح البخاري (///. . ؛ 1): "باب: إسلام أبي بكر الصديق -

$$
\text { ." }
$$


البخاري يحيى بن معين، وهو أقدم من ابن معين"(1). قلت: والآملي وصفه

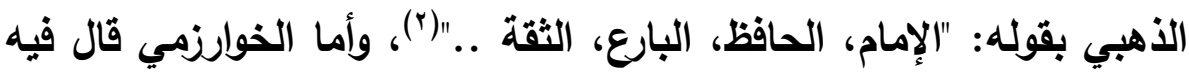
الأهبي: "قاضي خوارزم، ومحدثها، رحال، حافظ"("). وكلاهما في عداد طلبته الأين لم يكثر عنهم وأخذ عنهم سنة المحلثين، وهم في طبقة جعلها ابن حجر آخر طبقة في تقسيم شيوخ البخاري في الصحيح، فقال: "الطبقة الخامسة: قوم في عداد طلبته في السن والإسناد، سمع منهم للفائدة

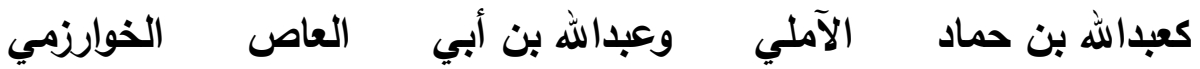
وحسين بن محمد القباني وغيرهم، وقد روى عنهم أشياء يسيرة وعمل في الرواية عنهم بما روى عثمان بن أبي شيبة عن وكيع قال: لا يكون الرجل عالما حتى يحدث عمن هو فوقه وعمن هو مثله وعمن هو دونه. وعن البخاري أنه قال: لا يكون المحدث كاملا حتى يكتب عمن هو فوقه وعمن هو مثله وعمن هو دونهه"(؛) قلت: ومع ذلك فالحديثان المذكوران متابَعان في

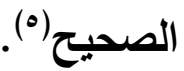

(1) فتح الباري لابن حجر (V/V/V))، ونحوه في تهذيب التهذيب (19/0)، وانظر:

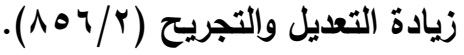

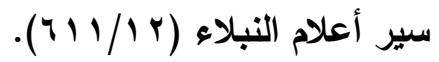

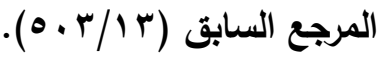

$$
\begin{aligned}
& \text { هاي الساري (ص ه \& \&). }
\end{aligned}
$$

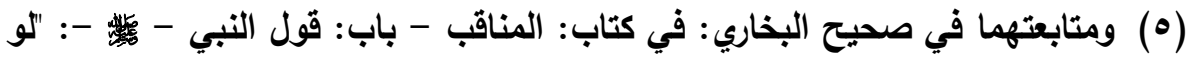

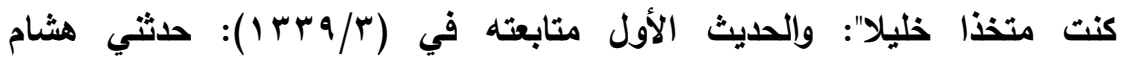
ابن عمار، حدثا صدقة بن خالد، حدثا زيد بن واقد، عن بسر بن عبيدالله، بنحوه، 
هذا ما أمكن ضرب مثاله، وفي حال التوسع لابد من التنبيه على ما يقع

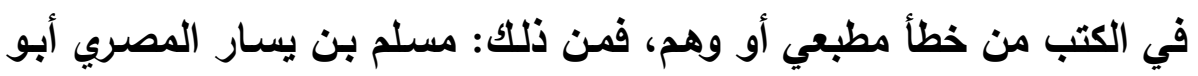

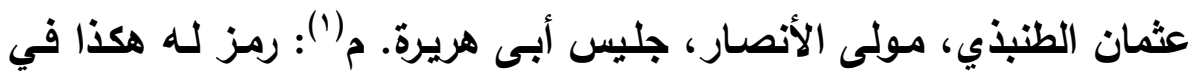

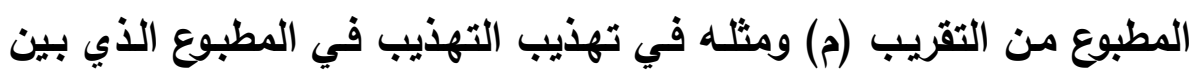

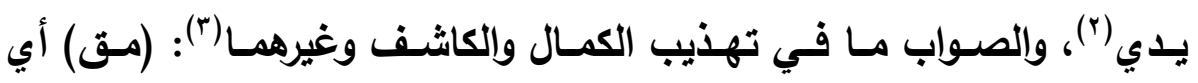

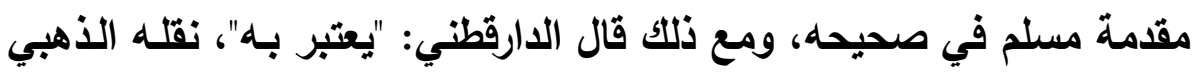

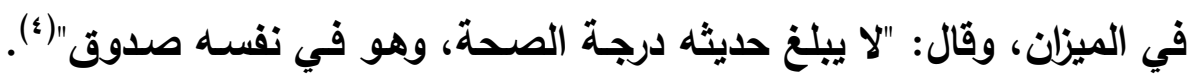

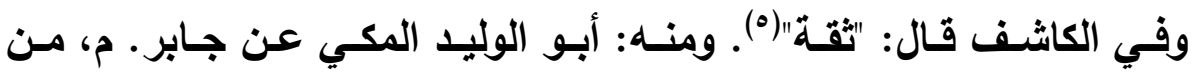

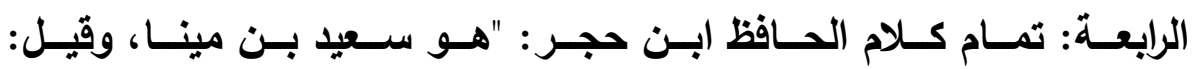

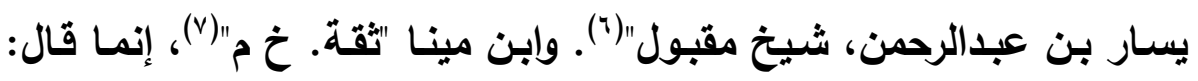

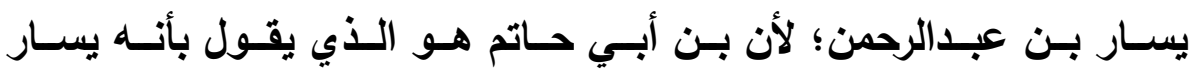

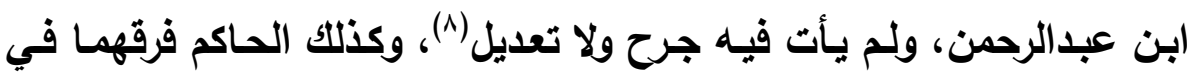

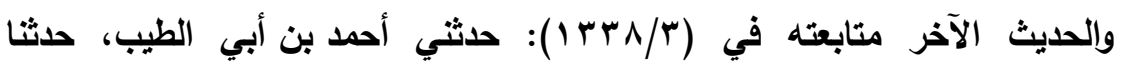

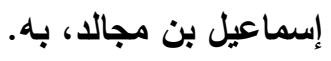

$$
\begin{aligned}
& \text { تقريب التهزيب (ص اسه). }
\end{aligned}
$$

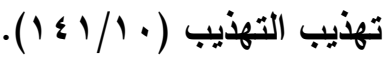

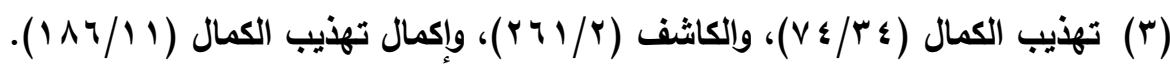

$$
\begin{aligned}
& \text { ميزان الاعتدال (ع/V • I). }
\end{aligned}
$$

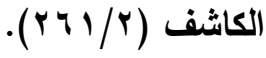

$$
\begin{aligned}
& \text { تقريب التهزيب (ص r^^). }
\end{aligned}
$$

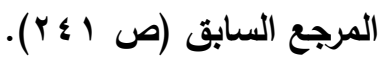

$$
\begin{aligned}
& \text { الجرح والتعديل (r/9 • • (r). }
\end{aligned}
$$


المـدخل (1)، فقـال ابـن حجـر عـى هـذا الاحتمـال: "مقبـول" وكلاهمـا يكنى أبـا الوليـد، وليس عند ابـن منجويـه إلا واحد هـو أبـو الوليــ المكي سـعيد ابن مينا الثقة(؟)، فالأقرب أنه هو ولعل الحاكم تابع بن أبي حاتم في قوله. ومنه: محمد بن عبدالله بن قيس بن مخرمة بن المطلب المطلبي: في التقريب: "مقبول من السادسـة(ז)، وذكر المقدسي صساحب الكمـال أن روايته في الصحيحين، فعلى هذا هو على شرط البحث لكن تعقبه المزي بقولـه:" لم أقف على رواية واحد منهما له". أب أنه وهم ذكر (خ م)، قال د/ بشار عواد: "جاء في حواشي النسخ من تعقبات المؤلف على صـاحب "الكمال "قولـه: "لم أقف على رواية واحد منهما له". وَقَال الثيخ محمد عوامة معلقا على طبعته من التقريب: "(قتصر المضيف هنـا على رمـز "م" فقط، وهـي التهذيبين ونسـة الميرغني أيضـا خ م (كـا) لكن قال المضسيف آخر الترجمـة "ذكر صاحب الكمال أن الشيخين أخرجا لـه. وَقَّال المزي: لم أقف على رواية أحد منهمـا" قلت: ليس في نسخة تهذيب الكمال المصورة شيء من هذا (كذا) فيكون الرمز في "التهذيبين "للشيخين إنما هو متابعة لصاحب الكمال ... الخ " وكلام الثيخ بن عوامة هذا - حفظه الله - فيه قلة تدقيق وذهول، إذ لم أعثر أولا على نسخة من تهذيب الكمال رقمت لهذه الترجمـة برقمي البخاري ومسلم حتى يصح قوله "وفي التهذيبين "، فلا أعلم من أين جاء بهذا الدليل.

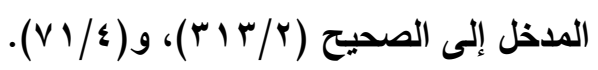

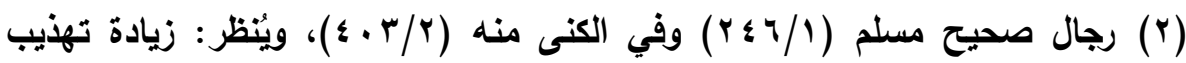

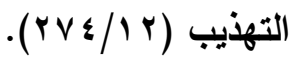

$$
\begin{aligned}
& \text { تقريب التهذيب (ص } 9 \text { (1) ). }
\end{aligned}
$$


إزالة إيهام القائلين بوجود

الجهالة في بعض الفالين بوجال

ثم غلط الحافظ ابن حجر في نقله، ولم يلر أن المزي قال هذه العبارة، ولكن من عادته إمـا يذكرها في حاشية نسخته وليس في متن الترجمة والنسخة السـقيمة التي اعتمـدها الثـيخ ليس فيها تعليقـات المؤلـف فكـان عليـه أن يستظهر أكثر من نسخة قبل إطلاق هذا الكلام، فتأمل وتدبر، والثيخ بن عوامة عالم جيد. نفع الله به". انتهى كلام د/بشار (1). ومنـه: إبراهيم بن خالد اليشكري - 1 - 1 -، لـ يذكره الحافظ ابن حجر بجرح أو تعديل ولا قال فيهه: "مقبول"، وهو شيخ لمسلم، بحسب رمز طبعة عوامة بـ (م)(r)، فعلى هذا هو على شرط البحث لكن في طبعة غيره (مق) أي مقدمة مسلم()، وهو الصحيح كما في سائر المصادر (؛). وهناك رواة كُثر ممن لم يوصفوا بجرح ولا تعديل يقع للباحث الوهم فيهم لوجود رمز (خ أو م) والحق ليست لهم روايـة مسندة ولـم أذكرهم هنـا اكتفاء بما مر في المطلب الثاني من المحث الثاني في قاعدة (9) - لا يُعدّ من رجال الصحيحين - أو أحدهما - إلا من له رواية مسندَة .. والله أعلم وأحكم

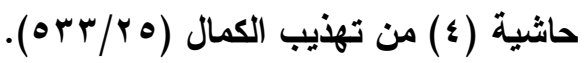

$$
\begin{aligned}
& \text { تقريب التهذيب (ص ه ^). }
\end{aligned}
$$

(r) انظر : تقريب التهذيب، تحقيق: أبي الأشبال - طبع: دار العاصمة - (ص V • ( ).

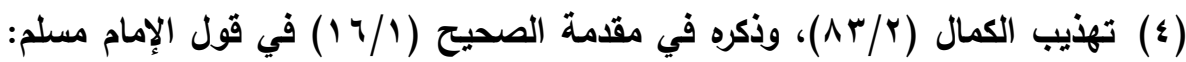

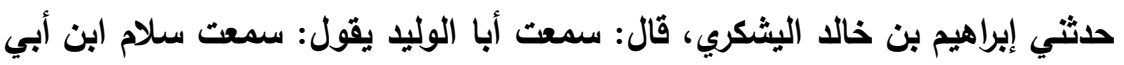
مطيع يقول: سمعت جابرا الجعفي يقول: "عندي خمسون ألف حديث عن النب النبي -

$$
\text { ." - 紫 }
$$


إزالة إيهام القائلين بوجود

الجهالة في بعض رجال

. آخر البحث .. وصلى الله وسـلم على محمد وآله وصحبه أجمعين ومَن

تبعهم بإحسان إلى يوم الدين .. 
إزالة إيهام القائلين بوجود

الجهالة في بعض الفالين بوجال

\section{الخاتمة والنتائج}

لعل بحثي هذا يتابع خطوات أئمتنـا السـائرة على حمايـة جناب ثوابت

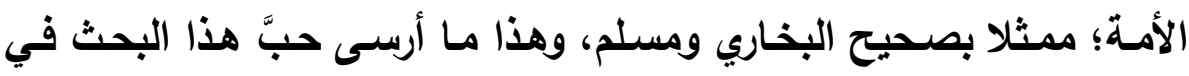

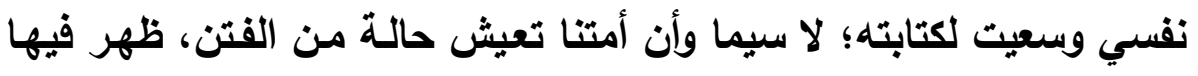
مَن يتطاول على ثوابت الدين، ويشكك المسلمين في عقيدتهم وشريعتهم.

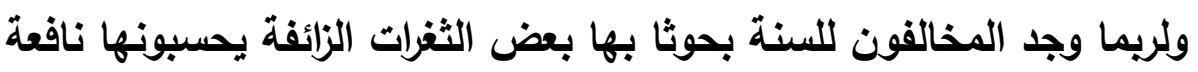

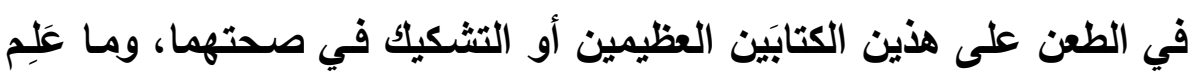
هؤلاء أن الكتابَين من ثوابت الأمة. وفي هذه الخاتمة أبرز نتائج هذا البحث بالآتي:

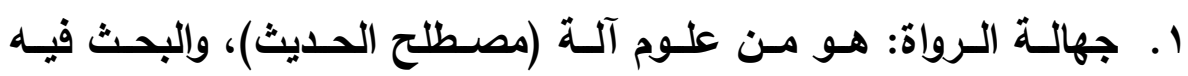
بثمولية يُعدّ من أبرز سمات أئمسة الحديث في خدمة الحة الحديث النبوي

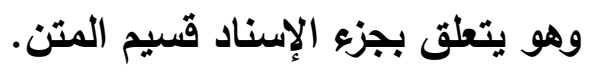
r. r. الجهالة: هي إحدى أسباب عدم قبول الحديث.

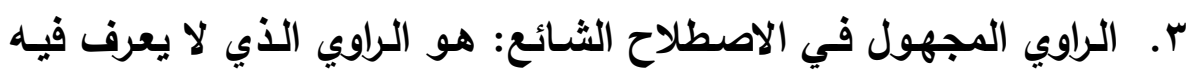

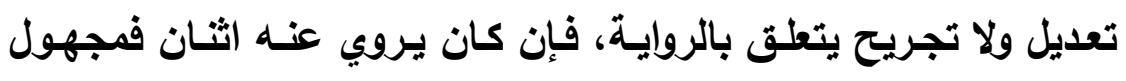

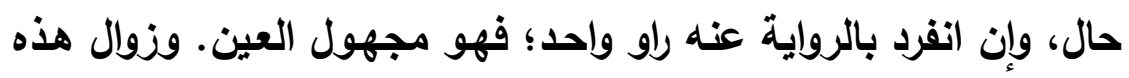
الجهالة يكون بتوثيق صريح أو ضمني من معتبر .

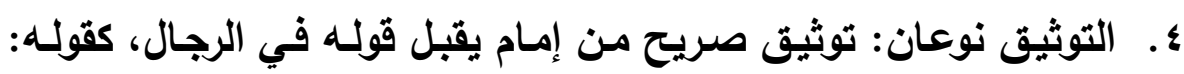

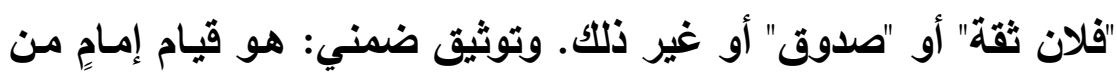

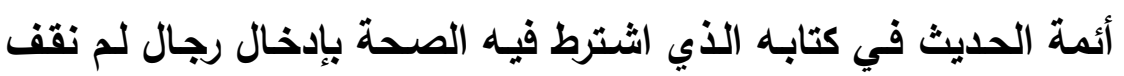
على مَن ضعفهم ولا مَن وثَثهم صراحة . . . 
إزالة إيهام القائلين بوجود

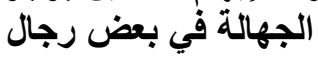

ه. للتوثيق الضـني صور أبرزهـا إخراج من يشـترط الصحة - ولـو على تساهله كالحاكم في مستدركه فإنها موثق عنده ضمنا -؛ فما نجده مثلا في صحيحي البخاري ومسلم من وجود رجال لـم نقف على مَن ضعفهم ولا مَن وثقهم صراحة؛ لكنّ وجود رواة كهوّلاء في الصحيحين يُعدّ توثيقا ضـمنيا عند إمـامي الصنعة أبـي عبدالله محمد بـن إسـماعيل البخـاري

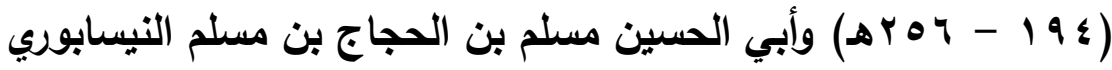

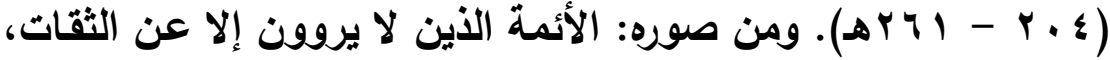
أو تصحيح إمـام معتبر لحديث (مـا) أو استـلال إمسام بحديث فيـه أحد هؤلاء الرواة الذين لم يأت فيهم توثيق ولا تضعيف فهم موثقتون ضمنا عند من روى لهم أو صحح لهم ... 7. عدم انتفاع رواة بالتوثيق الضمني لتفردهم بحديثٍ، وحديثهم هذا جاء في فضائل الأعمال لما يقع فيها من تسـاهل وعلى هذا جاعت عبارات المتقدمين ومنهم الإمـامُ ابن مهدي إذ يقول: "إذا روينـا الثواب والعقاب وفضائل الأعمال تسـاهلنا في الأسـاتيد، وسمّّحنا في الرجال، وإذا روينا في الحلال والحرام والأحكام تشددنا في الأسانيا وإنتقدا الرجال". V. القائدة من تسمية الإمـامَين البخاري ومسلم كتابيهما بـ "الصحيح": أنها

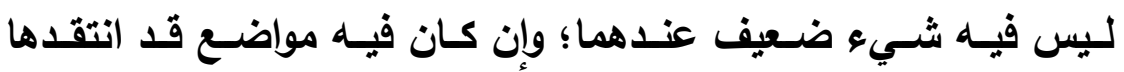
غيرهما؛ فقد أجيب عنها في موضعه، وعلى ذلك وقع اتفاق الأمة بصحة حديثهما، وقد صح عنهما ما يدل على أنهما ما أدخلا في الجامع إلا مـا صـح عندهما. ورواة أسـانيدهم مقبوليو الروايـة إلا أن التعامـل مـع رواة الصحيحين ليس لـه اعتبار واحد .. يقاس بـه جميع الرواة دون النظر مجلة كلية أصول الدين والدعوة بأسيوط / العدد السابع والثثلاثون 9 اــم - الجزء الثالث 
إزالة إيهام القائلين بوجود

الجهالة في بعض المالين بوجال

في مقدار الإكثار أو الانتقاء في رواية الثيخين لهم أو الرواية لهم في

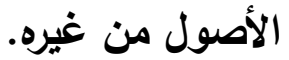

^. فيما وققت عليه بحث جمع ودرس فيه صاحبُه "مَن لم يُوصف بجرح أو أو

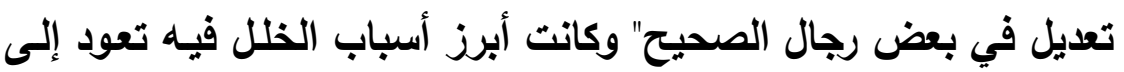

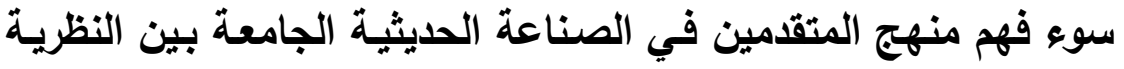

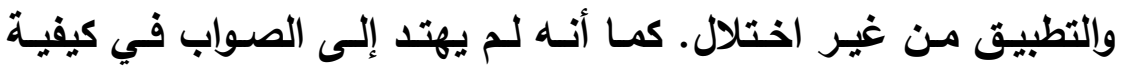
تعامله مع نصوص أطلقها المتأخرون ميع المتقدمين؛ إذ ليس كل عملٍ

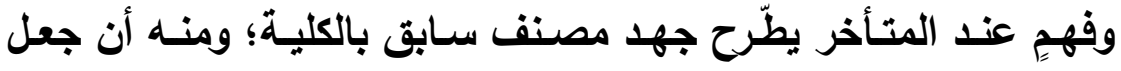

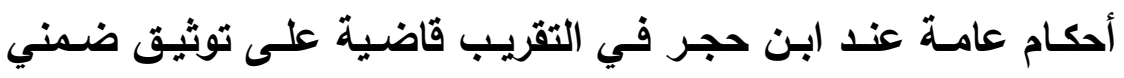

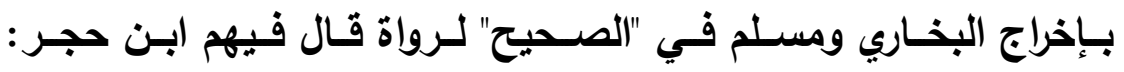
"مقبـول"، وكتأصسيل تـرك توثيـق العجلـي وابـن حبـان جملـة وتفصيلا لتساهلهما. 9. الكتابة في خدمة الصحيحين لا ينبغي أن تترك مجالا لنزع مكاتتهما، لذا

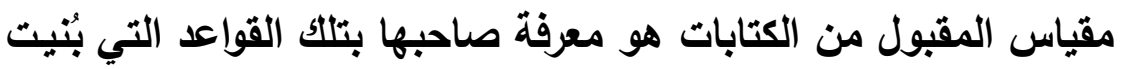

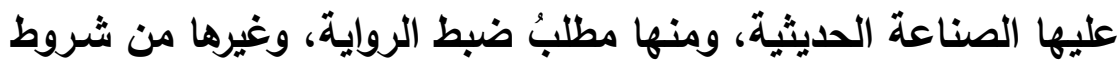
الصحة وكونها لا ينفصل عن تطبيقاتها الموجودة في صحيحي البخاري

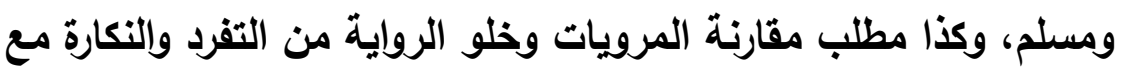

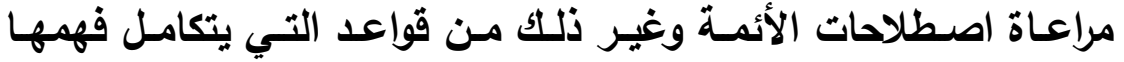

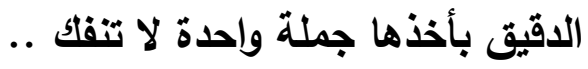

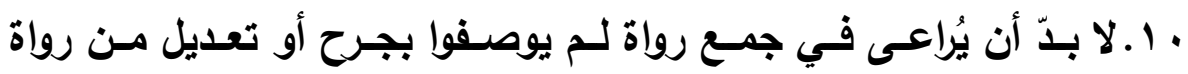

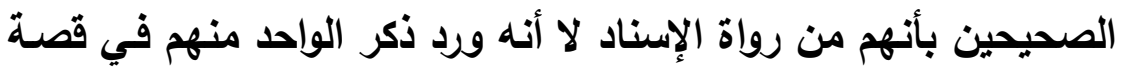
مجلة كلية أصول الدين والدعوة بأسيوط / العدد السابع والثلاثون 9 الـ بم - الجزء الثالث 
- أو نحوها - في الرواية. والتوصيف بوجود من لم يوصف بجرح أو تعديل ليس معناه بالضرورة مجهول.

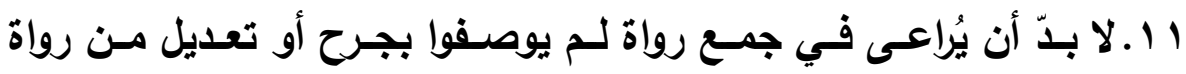

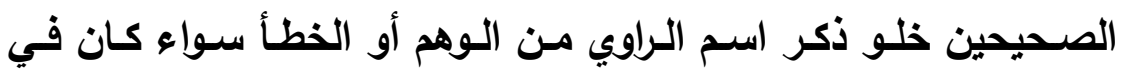

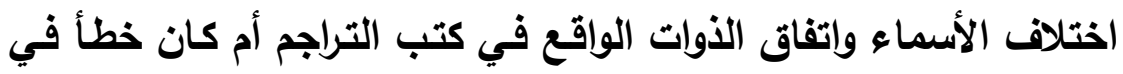

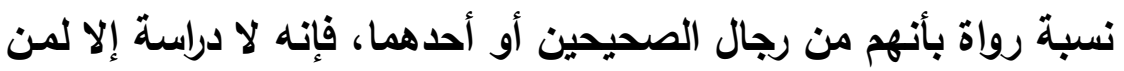
ثبت أنه من رجال الصحيح ولم يوصف بجرح أو تعديل غير ملتبس براو آخر موصوف بجرح أو تعديل.

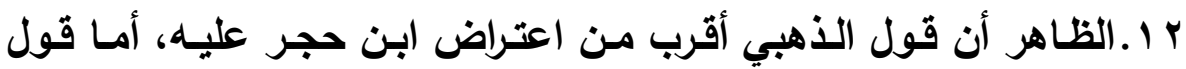

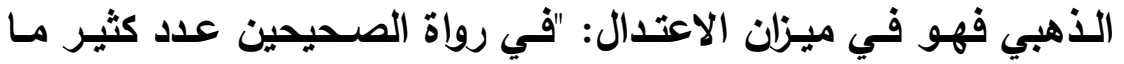

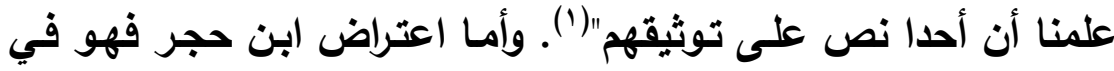

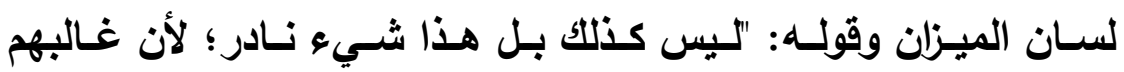

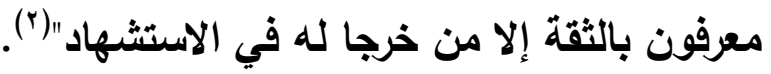

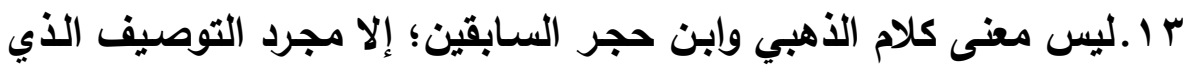

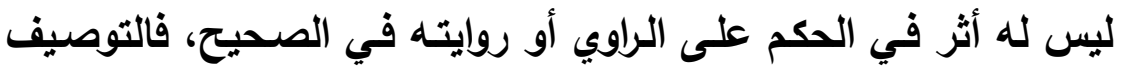
بوجود من لم يوصف بجرح أو تعديل ليس معناه بالضرورة مجهولا؛ لأنه النه

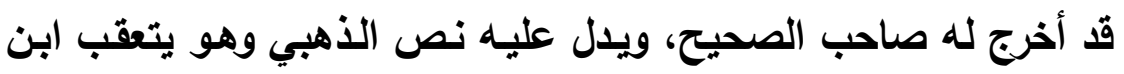
القطان الفاسي بقوله: "ابن القطان يتكلم في كل من لم يقل فيه إمام

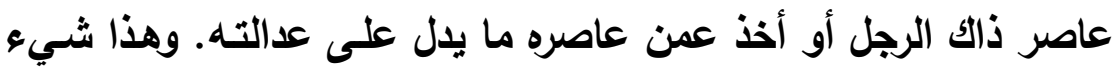

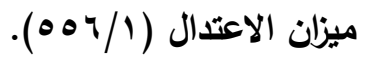

$$
\begin{aligned}
& \text { لسان الميزان (r/0). }
\end{aligned}
$$
مجلة كلية أصول الدين والدعوة بأسيوط / العدد السابع والثلاثون 9 الـ بم - الجزء الثالث 
إزالة إيهام القائلين بوجود

الجهالة في بعض الفالين بوجال

كثير، فقي الصحيحين من هذا النمط خلق كثير مستورون، مـا ضعفهم

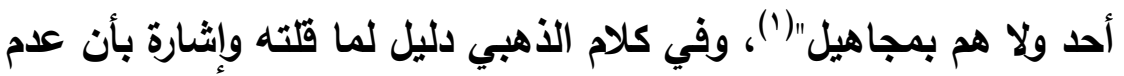
التضعيف كاف بمنفعة راوي الصحيح برفع الجهالة عنه طالمـا لـه روايـة في الصحيح، ويهذا جزم ابن حجر بأنهم ثقات لإخراج صساحب الصحيح، ومما يقوله: "فمن زعم أن أحدا منهم مجهول؛ فكأنـه نـازع المصنف في دعواه أنه معروف، ولا شكك أن المدعي لمعرفته مقدم على من يدعي عدم معرفته لما مع المثبت من زيادة العلم، ومع ذلك فلا تجد في رجال الصحيح أحدا ممن يسوغ إطلاق اسم الجهالة عليه أصلا"(؟)، فينبغي أن يؤخذ رأي الحافظين في هذا الباب، وقد كان من السـهل عليهمـا جمع هولاء الرواة في مؤلف خاص - وقد ألّقا أعظم من ذلك -؛ فتركوه فيما يظهر لقلة فائدته أو خثية من مآلاته!. ـ 1 .ليس هنـاك مـن صـتف مسن المتقدمين كتابـا خاصسا يجمـع فيـه مـن لـم يوصف بجرح أو تعديل من رجال الصحيح أو أفرد مصنفا خاصسا لنقد أحاديث الصحيح بعلة كهذه، وفي هذا دليل كاف لرد مزاعم من رام حول هذا الموضوع بتأليف خاص، وإن جرت مناقشات من أئمة وإلزامـات على البخـاري - أو مسـلم - بوجـود راو ليس هنـاك مـن وثقهـه فبإن إعراض الأئمة عن الإعلال بوجود الجهالة كاف بترك النقد بمثل هذا، نعم يذكر الإسماعيلي شيئا قليلا من هذا يجمعه مع إشكالاته الأخرى حول حديث ما في الصحيح لكن لم يُسلّم له ذلك، وتركه الإشكال لأكثر الرواة الذين مجلة كلية أصول الدين والدعوة بأسيوط / العدد السابع والثثلاثون 9 ا ـ بم - الجزء الثالث 
ليس فيهم توثيق شـاهد على أقول، وتلقف وجود إثكال هنا أو هناك خطير على صاحبه إن سلمت طويته.

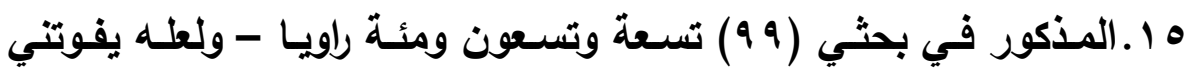

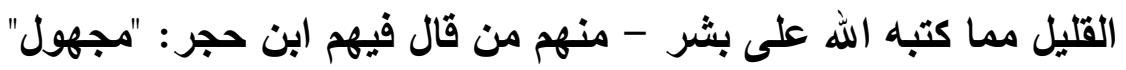

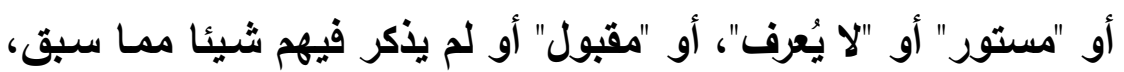

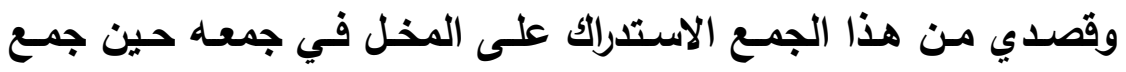

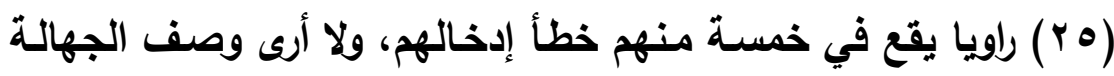
واقعـا على أحد من هؤلاء على مـا تقدم مسن كـلام الحسافظين الذهبي

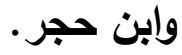
17 .لـم أرد التصدي لإفراد البحث بجمـع الرواة - ولا أرى ذلك - لكنـه جاء

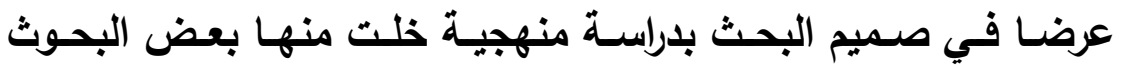

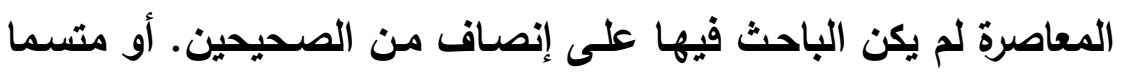
بالحذر في الحكم بالجهالة على بعض رجال الصحيح التي هي إحدى إهى أسباب الطعن في الراوي، ويموجبها يُردّ الحديث! أو متسما بالموضوعية

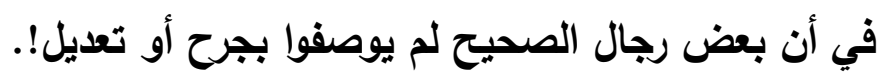

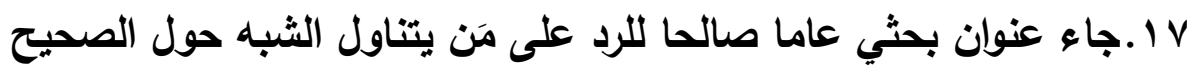

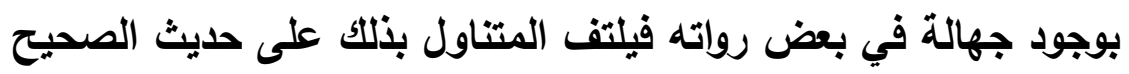

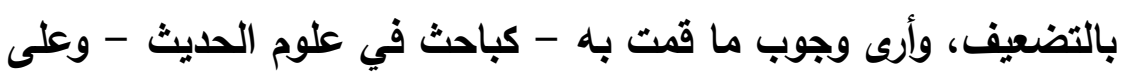

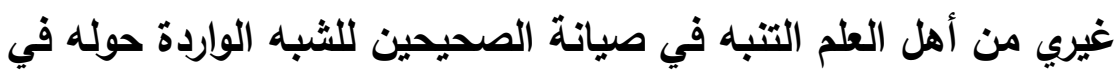
عصرنا هذا الذي يتسارع فيه أعداوئا للنيل من ثوابتنا، ويزداد الأمر خطورة حين تكون بعض تلك الثبه صادرة من أبناء جلدتا بحسن نية! 
وفي الردود على كلٍ بالبحث العلمي الرصين نفعا عظيما للباحثين والمحبين للسنة النبوية وأهل نحلتها الذين لا يعدلون عن كلام الأئمة إلى شيء غير منقول ويالاحتمال من غير سلف لا يسوَّغ في المعقول: انقُل لنا إنْ كنت تبغي الهُّى ... فنحن قُ جُئنا بما عندنا

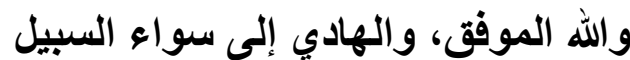
وصلى الله وسلم على محمد وآله وصحبه أجمعين ومَن تبعهم بإحسان إلى الى الى يوم الاين. 
إزالة إيهام القائلين بوجود

الجهالة في بعض المالين بوجال

\section{الإصادر}

ا. الإحسان في تقريب صحيح ابن حبان بترتيب ابن بلبان لعلاء الدين

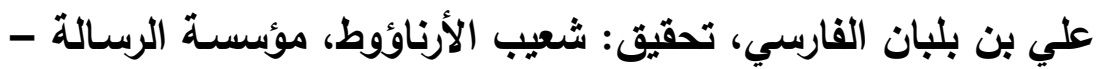

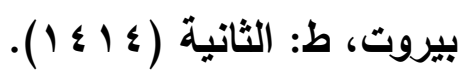

r. الآداب الثرعية والمنح المرعية لأبي عبدالله محمد بن مفلح المقدسي،

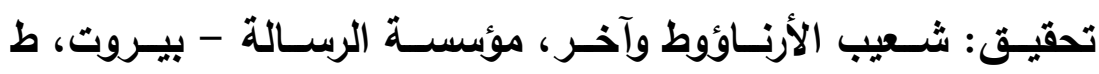

$$
\text { ( }(1 \leqslant 1 \mathrm{~V})
$$

r. أسـد الغابـة في معرفـة الصـحابة لأبـي الحسن علـي بـن أبـي الكرم

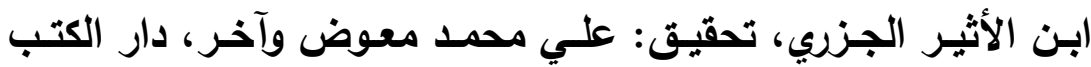

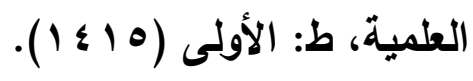

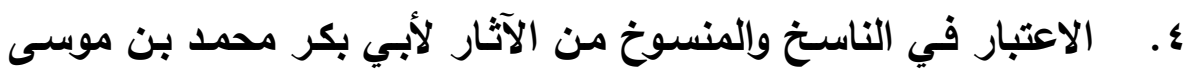

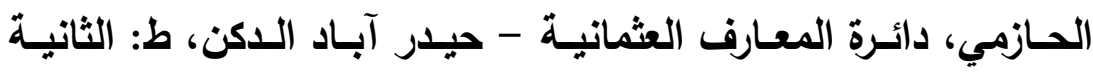

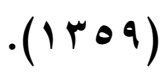

ه. الاعتصام لأبي إسحاق إبراهيم بن موسى الثـاطبي، المكتبة التجاريـة

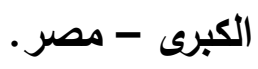

4. إعلام الموقعين عن رب العالمين لمحمد بن أبي بكر الزرعي، تحقيق:

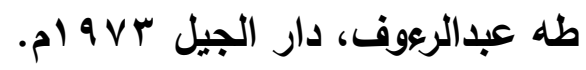

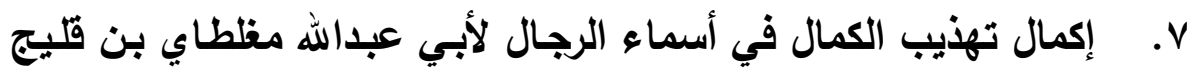

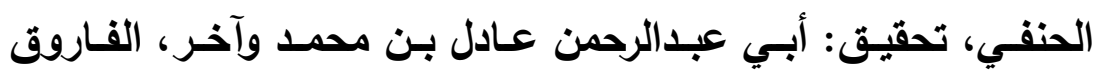

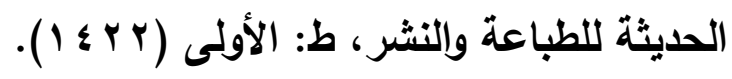

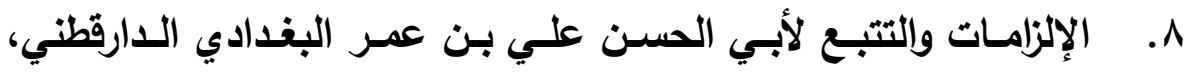


إزالة إيهام القائلين بوجود

الجهالة في بعض الفين بوجال

تحقيق: مقبل بن هادي الوداعي، دار الكتب العلمية، بيروت - لبنان،

$$
\text { ط: الثانية (0 • ع 1) ). }
$$

9 ـ انتقاض الاعتراض في الرد على العيني في شرح البخاري لأبي الفضل أحمد بن علي ابن حجر العسقلاني، تحقيق: حمدي بن عبدالمجيا السلفي وصبحي بن جاسم السامرائي، مكتبة الرشد - الرياض، ط:

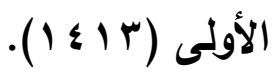

• 1 ـ الأنوار الكاشفة لما في كتاب "أضواء على السنة" من الزلل وإلتضليل والمجازفة لعبدالرحمن بن يحيى المعلمي اليماني، المطبعة السـلفية/

$$
\text { عالم الكتب - بيروت (7 ، ع 1). }
$$

1 ا. الأوسط في السنن والإجماع والاختلاف لأبي بكر محمد بن إبراهيم ابن المنذر النيسابوري، تحقيق: أبي حماد صغير أحمد حنيف، دار طيبة -

$$
\text { الرياض، ط: الأولى (0 . \& 1). }
$$

r ا. الباعث الحثيث في اختصـار علـوم الحـيث لأبـي الفـداء إســاعيل ابن عمر بن كثير، تحقيق: أحمد محمد شـاكر، دار الكتب العلميـة،

$$
\text { بيروت - لبنان، ط: الثانية. }
$$

با ـ بيان الوهم والإيهام في كتاب الأحكام لابن القطان أبي الحسن علي ابن

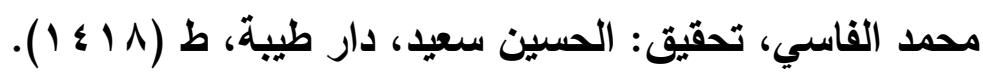
ع ا ـ تاريخ بن معين (رواية الدوري) لأبي زكريـا يحيى بن معين البغدادي، تحقيق: أحمد محمد نور سيف، مركز البحث العلمي وإحياء التراث

$$
\text { الإسلامي - مكة المكرمة، ط: الأولى (9 } 9 \text { ب 1 ). }
$$

ه 1 ـ تاريخ الإسدلام وَوَفيات المشاهير وَالأعلام لأبي عبدالله محمد بن أحمد 
الأهبي، تحقيق: بشار عوّاد معروف، دار الغرب الإسـلامي، ط: الأولى

$$
\text { . ( }
$$

7 ا ـ تاريخ بغداد لأبي بكر أحمد بن علي الخطيب البغدادي، تحقيق: د/ بثــار عـواد معـروف، دار الغـرب الإســلامي - بيـروت، ط: الأولـى

$$
\text { ( }(1 \leq r r)
$$

IV ت ـ الحفـة الأشراف بمعرفة الأطراف لأبي الحجـاج يوسف بن عبدالرحمن المـزي، تحقيـق: عبدالصـمد شـرف الـدين، المكتـب الإســلامي، ط:

$$
\text { الثانية(r • ع 1) ). }
$$

1 ا. ـ تــريب الـراوي في شـرح تقريـب النـواوي لعبـالرحمن بـن أبـي بكر السيوطي، تحقيق: عبدالوهاب عبداللطيف، مكتبة الرياض الحديثة الرياض.

9 1. ترتيـب علـل الترمـذي الكبيـر لأبـي طالب القاضـي، تحقيـق: صـبحي

$$
\text { السامرائي وآخرين، عالم الكتب - بيروت، ط (9 م ـ ـ 1). }
$$

• . . التعـديل والتجـريح لمسن خـرج لـه البخــاري فـي الجـامع الصــيح، لأبسي الوليد سـليمان بـن خلف البـاجي الأندلسـي، تحقيق: أبـي لبابـة

$$
\text { حسين، دار اللواء للنشر والتوزيع - الرياض، ط: الأولى (ج ـ 1). }
$$
ا Y. تفسير القرآن العظيم لابن كثير، تحقيق: سامي بن محمد سـلامة، دار

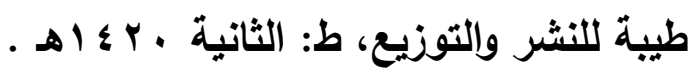
r.r. . تفسير عبدالرناق الصنعاني لأبي بكر عبدالرزاق بن همام الصنعاني،

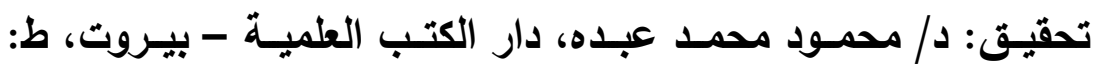

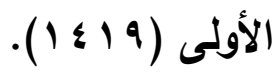




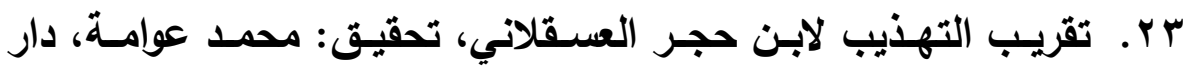

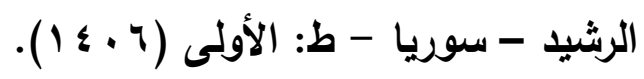

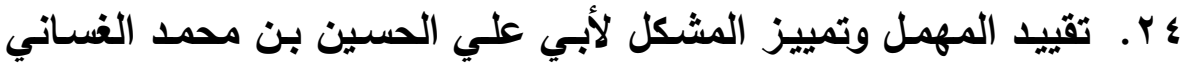
الجياني، تحقيق: علي بن محمد العمران وآخر، دار عالم الفوائد، ط:

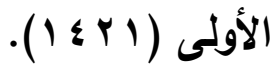

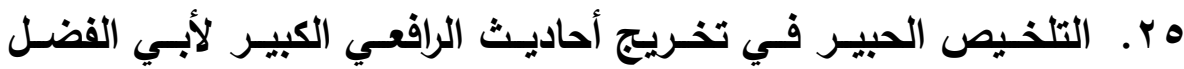

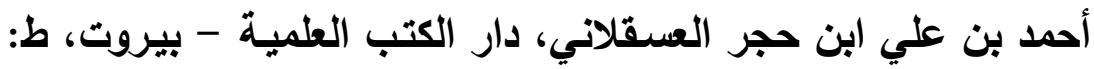

$$
\text { الأولى (19 (19 1) ). }
$$

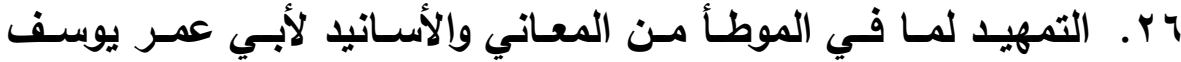

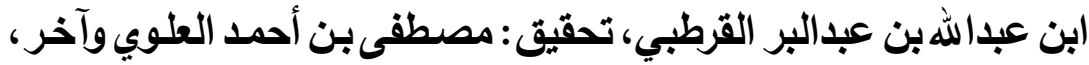

وزارة عموم الأوقاف والثؤون الإسلامية - المغرب، ط ( I I v ).

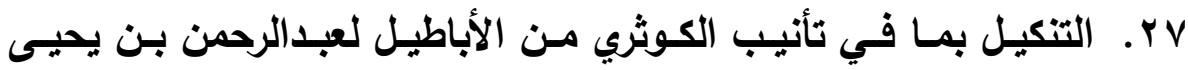
المعلمي العتمي اليماني، مـع تخريجات وتعليقات: محمد ناصر الدين

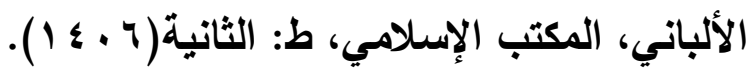

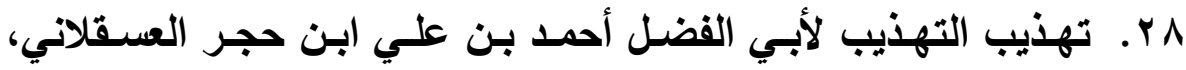
مطبعة دائرة المعارف النظامية، الهند، ط: الأولى ( آ Y I I).

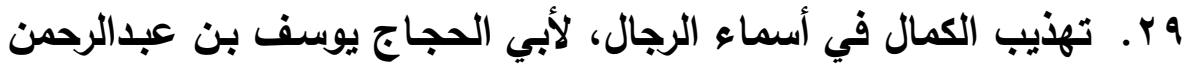
المزي، تحقيق: د/ بثـار عواد معروف، مؤسسـة الرسالة - بيروت -

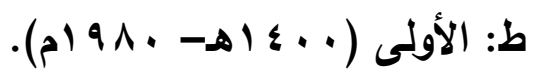

• ب. توجيه النظر إلى أصول الأثر لطاهر بن صالح السمعوني الجزائري،

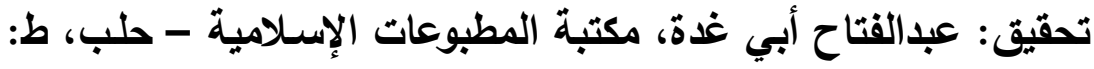

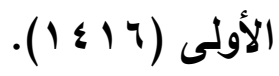


اب. الثقات لأبي حاتم محمد بن حبان، تحقيق: د/ محمد عبدالمعيد خان

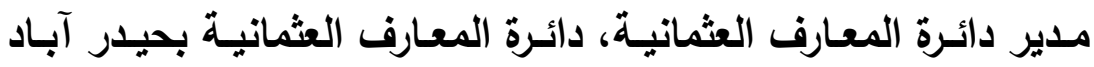

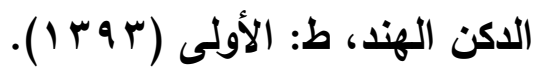

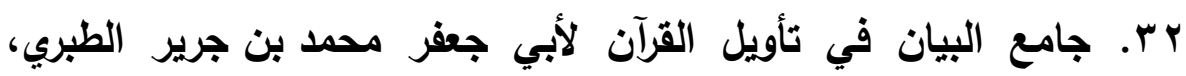

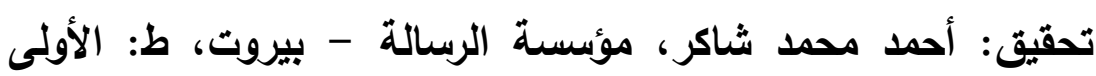

$$
\text { ( }(1 \leq r \cdot)
$$

rr. جامع التحصيل في أحكام المراسيل لأبي سعيد بن خليل بن كيكلدي (لعي

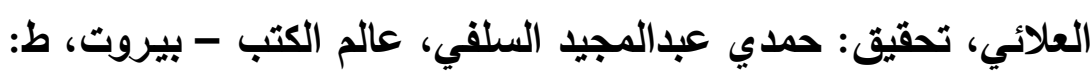

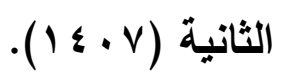

ء r. الجامع الأخلاق الراوي وآداب السامع لأبي بكر أحمد بن علي الخطيب

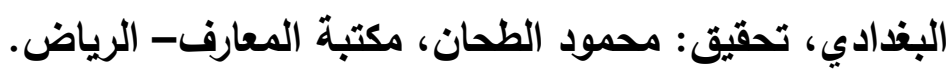
هr. الجرح والتعديل، لأبي محمد عبد الرحمن بن أبي حاتم الرازي، طبعة:

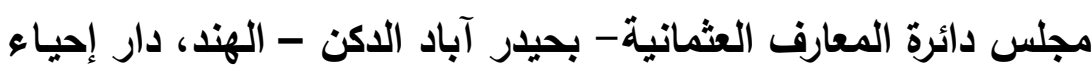

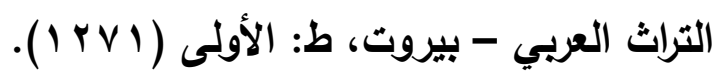

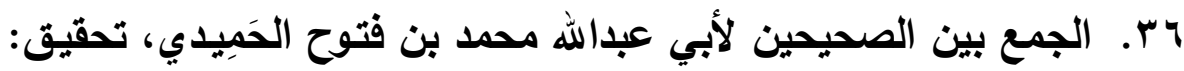

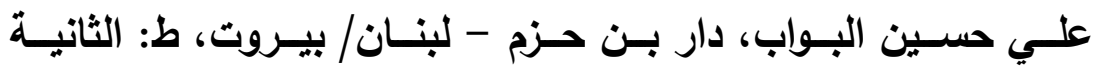

$$
\text { ( }) \text { ( } 1 \leqslant r)
$$

VV. خلاصـة تذهيب تهذيب الكمـال في أسماء الرجال لأحمد بن عبدالله

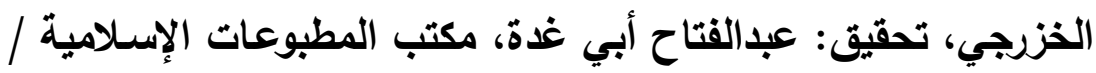

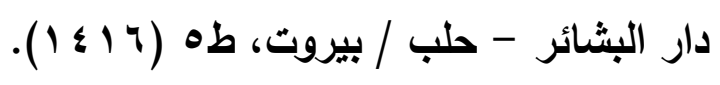




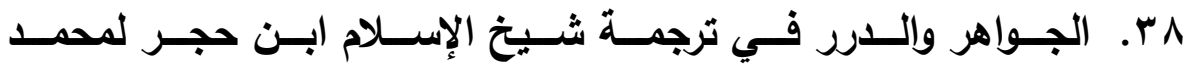
ابـن عبـالرحمن السـخاوي، تحقيـق: إبـراهيم بـاجس عبدالمجيد، دار ابـن حـزم للطباعـة والنشـر والتوزيـع، بيـروت - لبنـان، ط: الأولـى

q r. دفاع عن السـنة ورد شـبه المستشـرقين والكتـاب المعاصـرين لمحمد

$$
\text { أبي شُُهبة، مكتبة السنة - مصر، ط: الأولى (9 } 9 \text { (1). }
$$

• ع. الدفاع عن الصحيحين دفاع عن الإسـلام، حققه: د/ محمد بن عزوز - مركز التراث الثقافي المغريسي بالدار البيضـاء، طبع دار ابن حزم،

$$
\text { الطبعة الأولى منه (ع آس أهـ). }
$$

اء ـ ديوان ذي الرَّمَة غيلان بن عقبة العدوي، ومعه شرح أبي نصر الباهلي

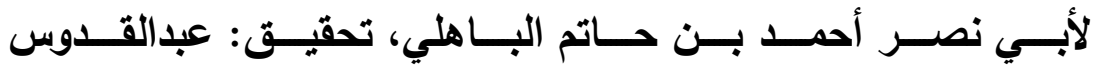
أبي صالح، مؤسسة الإيمان جدة، ط: الأولى (r ـ ا ).

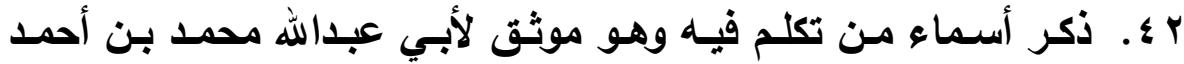
الأهبي، تحقيق: محمد إبراهيم الموصلي، مكتبة المنـار - الزرقاء، ط:

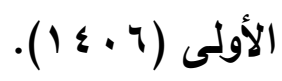

بـ. رجـال صـيح مسـلم لأبسي بكر أحمد بـن علـي بـن مَنْجُويَه، تحقيق:

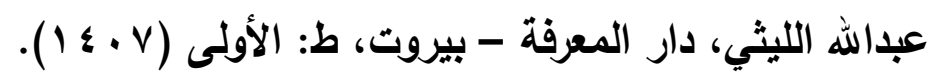

ع ـ. الرفـع والتكميل في الجـرح والتعـديل لمحمـد عبدالحي أبـي الحسـنات اللكنـوي الهنـدي، تحقيـق: عبـدالفتاح أبـي غـدة، مكتب المطبوعـات

$$
\text { الإسلامية - حلب، ط: الثالثة (v • ع l). }
$$

ه ــ الـرواة الثقـات المـتكلم فيهم بمـا لا يوجب ردهـ لأبسي عبدالله محمــ 
ابـن أحمـد الـذهبي، تحقيـق: محمـــ إبـراهيم الموصـلي، دار البشــائر

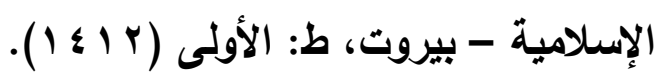

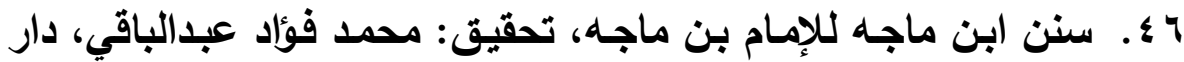

$$
\text { الفكر - بيروت. }
$$

\&V

$$
\text { الفكر - بيروت. }
$$

^ ـ. . سنن الدارقطني للإمام الدارقطني، تحقيق: السيد عبدالله هاشم يماني

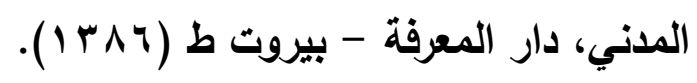

9 ؛ـ السنن الكبرى للبيهقي، تحقيق : محمد عبدالقادر عطا، مكتبة الباز -

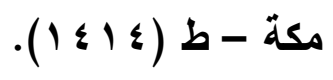

• ه. سـؤلات أبي داود للإمسام أحمد بـن حنبل في جرح الـرواة وتعديلهم

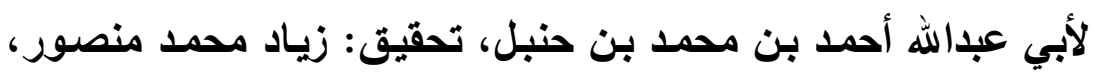

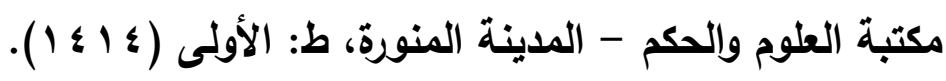

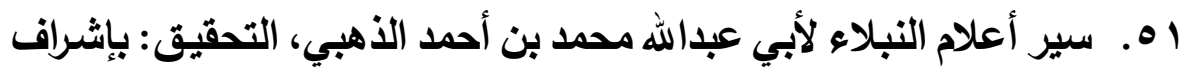
الثيخ شعيب الأرناؤوط، مؤسسة الرسالة، ط: الثالثة (ه ـ ـ 1 ).

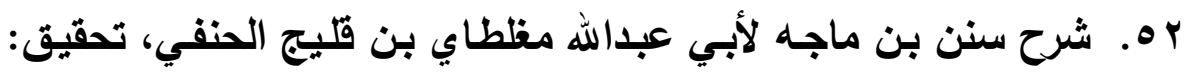

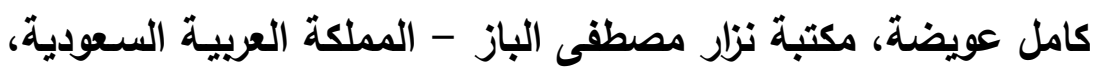

$$
\text { ط: الأولى (9 (1) (1). }
$$

rه ـ شرح علل الترمذي لعبدالرحمن بن أحمد بن رجب الامشقي، الحنبلي،

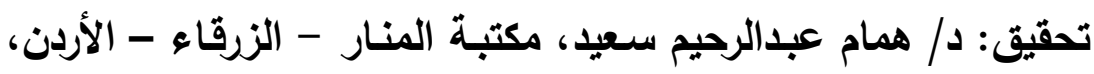

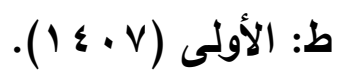
مجلة كلية أصول الاين والدعوة بأسيوط / العدد السابع والثلاثون 9 ا ـ بم - الجزء الثالث 
؛ ه. شرح مشكل الآثار لأبي جعفر أحمد بن محمد بن سـلامة الطحاوي،

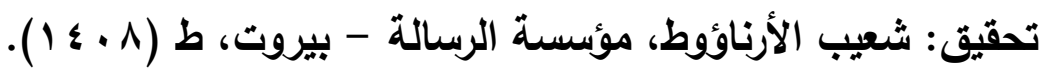

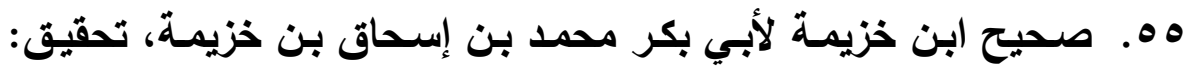
محمد مصطفى الأعظمي، المكتب الإسلامي - بيروت.

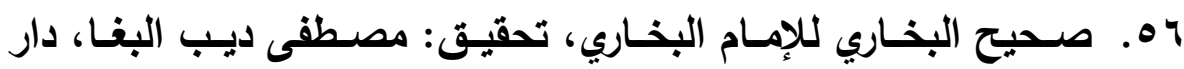

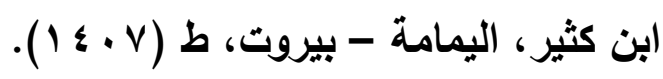

OV

$$
\text { عبدالباقي، دار إحياء التراث العربي - بيروت. }
$$

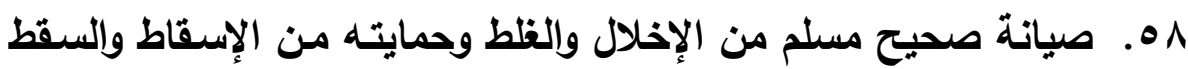
لعثمان بن عبدالرحمن المعروف بابن الصـلاح، تحقيق: موفق عبدالله

$$
\text { عبدالقادر، دار الغرب الإسلاهي - بيروت، ط: الثانية (1 م ـ 1 ). }
$$

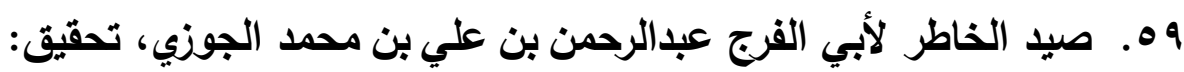

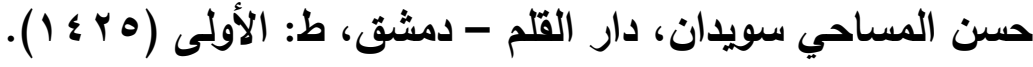

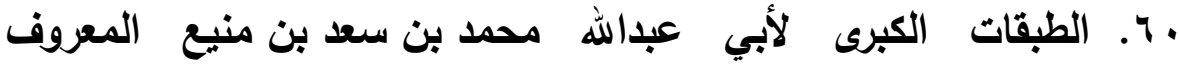

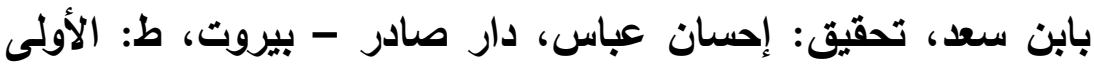

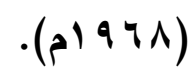

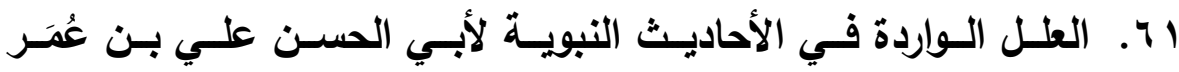

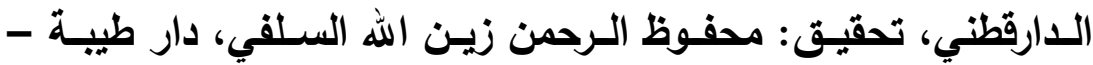

$$
\text { الرياض، ط: الأولى (0 ـ ـ 1 ). }
$$

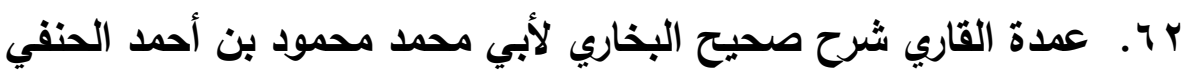
بلر الدين العيني، دار إحياء التراث العربي - بيروت. 
إزالة إيهام القائلين بوجود

الجهالة في بعض الفالين بوجال

rآ. فتح الباري بشرح صحيح البخاري لابن حجر العسقلاني، دار المعرفة

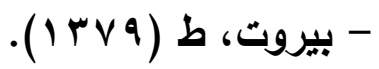

ء 7. فتح الباقي بشرح ألفية العراقي لأبي يحيى زكريا بن محمد الأنصاري،

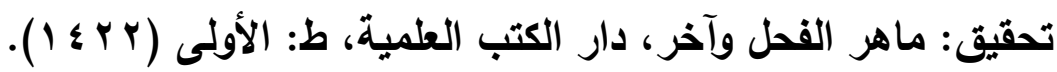

ه 1. فتح المغيث بثرح الفيـة الحديث لمحمد بن عبدالرحمن السخاوي،

تحقيق: علي حسين علي، نشر مكتبة السنة - مصر، ط (ع ب ؟ ا ).

74. فهرسة بن خير الإثبيلي لأبي بكر محمد بن خير الإشبيلي، تحقيق:

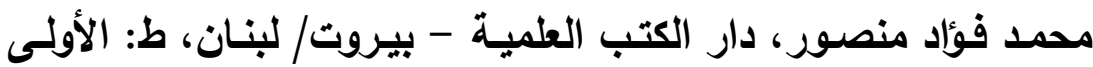

$$
\text { (1 }(19)
$$

TV الكاشف في معرفة من له روايـة في الكتب العتة لأبي عبدالله محمد

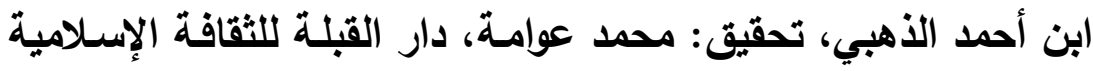

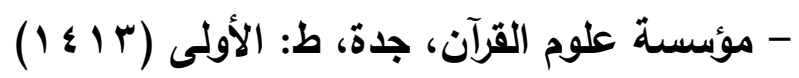

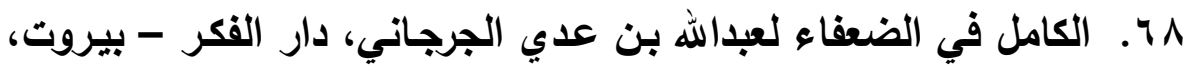

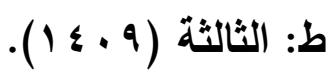

9 7. الكفاية في علم الرواية،، لأحمد بن علي بن ثابت أبي بكر الخطيب

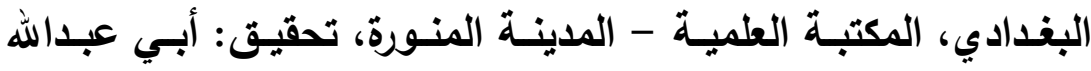

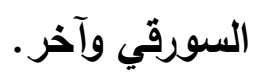

• . ل . لسان العرب لمحمد بن مكرم بن منظور الأفريقي المصري، دار صادر

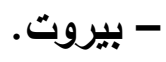

V. V. لسان الميزان لأحمد بن علي بن حجر أبي الفضل العسقلاني، تحقيق:

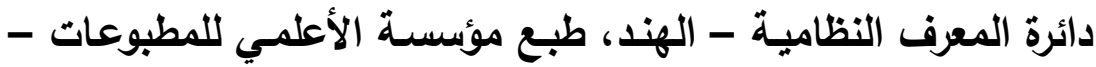


إزالة إيهام القائلين بوجود

الجهالة في بعض الفين بوجال

$$
\text { بيروت، ط: الثالثة (7 • ع 1). }
$$

Vr. . مبتكرات اللآلكئ والدر في المحاكمة بين العيني وابن حجر لعبدالرحمن البوصيري، تحقيق: رائد صبري، مكتبة الرشد، ط: الأولى ( ب ع 1 ). VT. مجموع القتاوى لأبي العباس أحمد بن عبدالحليم بن تيمية، تحقيق: أنور الباز - عامر الجزار، دار الوفاء، ط: الثالثة (ד ؟ \& 1). ع V. المحـــث الفاصــل بــين الــراوي والــواعي لأبــي محمـــ الحسـنـ ابن عبدالرحمن بن خلاد الرامهرمزي، تحقيق: محمد عجاج الخطيب،

$$
\text { دار الفكر - بيروت، ط: الثالثة(ع • ؛ 1). }
$$

ه v. المحلى بالآثار لابن حزم، تحقيق: أحمد محمد شـاكر، مكتبة التراث القاهرة.

V7. المدخل إلى الصحيح لأبي عبدالله الحاكم محمد بن عبدالله المعروف بابن البيع، تحقيق: ريبع بن هادي عمير المدخلي، دار الإمام أحمد -

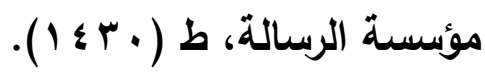
المـدخل إلـى كتـاب الإكليـل لأبـي عبـدالله الحـاكم محمـد بـن عبـدالله . VV المعروف بابن البيع، تحقيق: فؤاد عبدالمنعم أحمد، نشر دار الدعوة الإسكندري. V^. مسـائل الإمسام أحمــ روايـة بـن هـانئ لإسـحاق بـن إبراهيم بـن هـانئ النيسـابوري، تحقيـق: زهير الثـاويش، المكتب الإسـلامي، ط: الأولـى

$$
\cdot(1 \leq \cdot \cdot)
$$


V9 . . مسـائل الإمـام أحمـد روايـة أبـي داود السجستاني لأبسي داود سـليمان

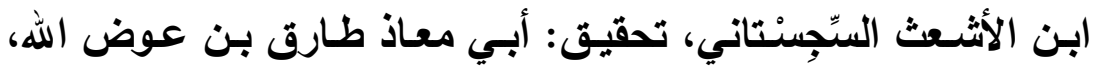

$$
\text { مكتبة (بن تيمية، مصر، ط: الأولى ( •Y \& 1 ). }
$$

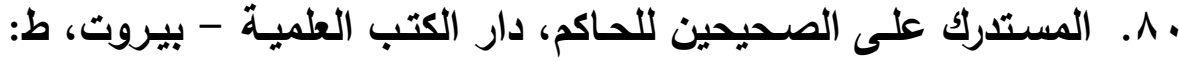

$$
\text { الأولى (11 (11 ) (1). }
$$

1 1. مسند الإمام أحمد لأحمد بن حنبل، مؤسسة قرطبة - القاهرة.

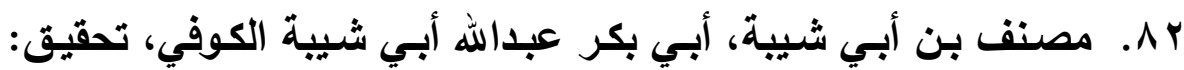

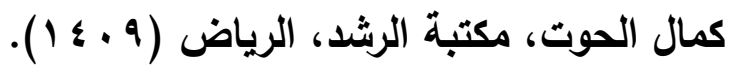

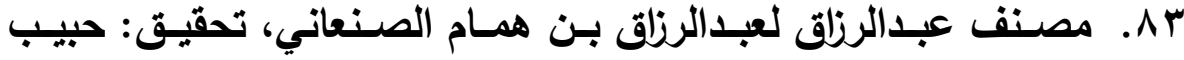

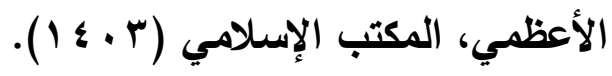

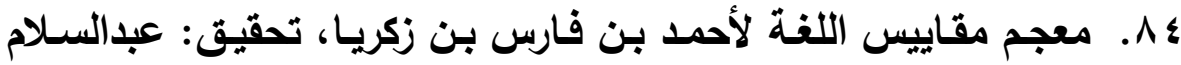

$$
\text { محمد هارون، دار الفكر، ط (9 9 م 1 ). }
$$

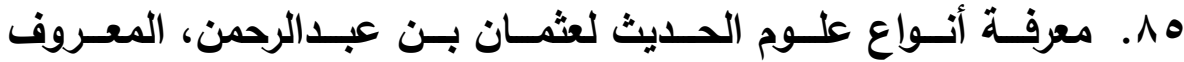
بابن الصلاح، تحقيق: مـاهر ياسين الفحل وآخر، دار الكتب العلمية،

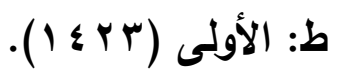

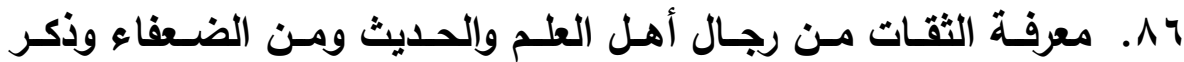

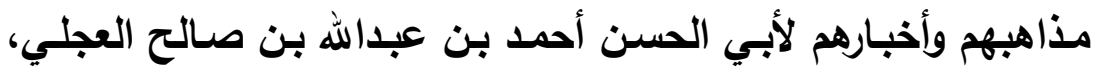
تحقيق: عبدالعليم عبدالعظيم البستوي، مكتبة الدار - المدينة المنورة

$$
\text { - السعودية، ط: الأولى (ه ـ ـ ـ 1 ). }
$$

AV

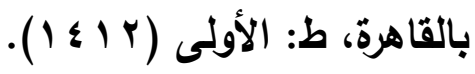


إزالة إيهام القائلين بوجود

الجهالة في بعض الفين بوجال

1^. من لم يوصف بجرح أو تعديل من رجال الصحيحين -جمع ودراسـةمع تحقيق مذاهب الأئمة في حكم روايـة المستور، وتأصيل قاعدة أن

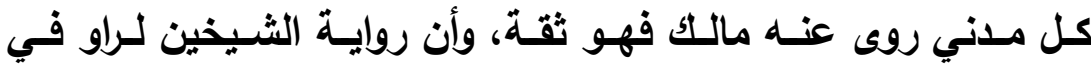
الأصسول هي توثيق لـه لأحمد أشـرف عمر لبي، حولية كليـة أصول

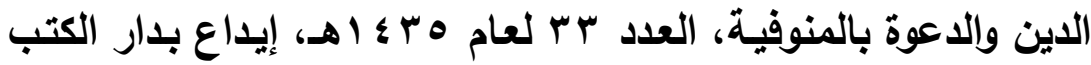

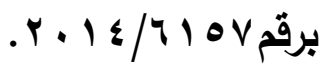

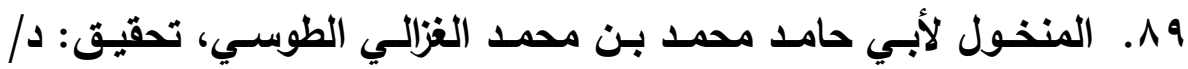
محمد حسن هيتـو، دار الفكر المعاصـر - بيروت لبنـان، دار الفكر

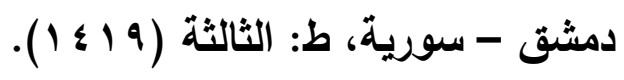

• 9. المنهـاج شـرح صـحيح مسـلم بن الحجـاج للنـوي، دار إحيـاء التراث

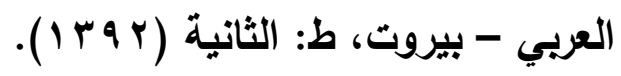

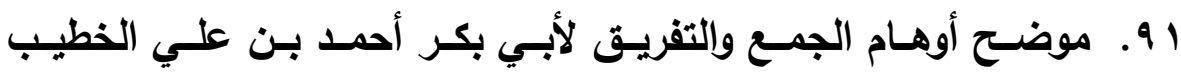

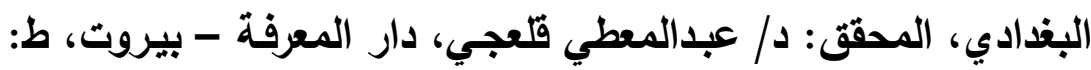

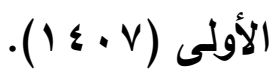

r . . الموطـأ - بروايـة يحيـى الليثـي للإمــام مالـك، تحقيـق: محمـد فؤاد

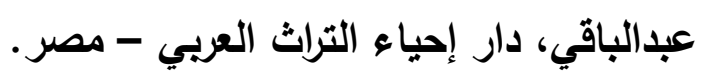

ب9. ـ الموقظة في علم مصطلح الحديث لأبي عبدالله محمد بن أحمد الأهبي،

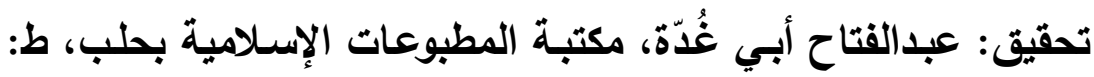

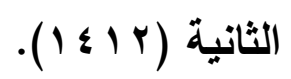

؟ . . ميزان الاعتدال في نقد الرجال لأبي عبدالله محمد بن أحمد الذهبي،

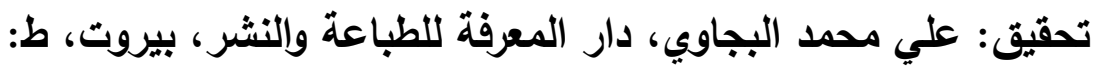

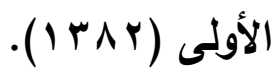


هو. نزهة النظر في توضيح نخبة الفكر في مصطلح أهل الأثر لأبي الفضل أحمد بن علي ابن حجر العسقلاني، تحقيق: عبدالله ابن ضيف الله الرحيلي، مطبعة سفير بالرياض، ط (Y Y ؛ I).

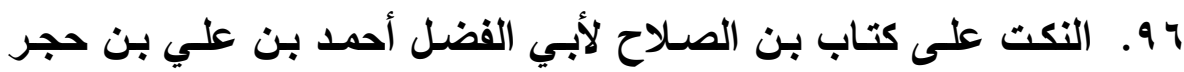

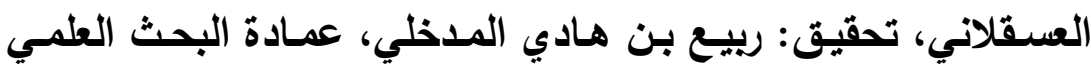

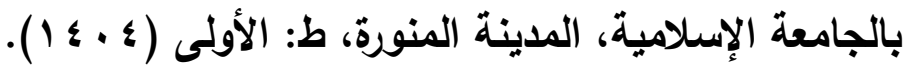

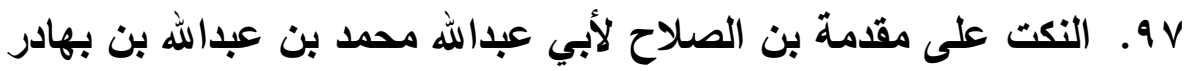

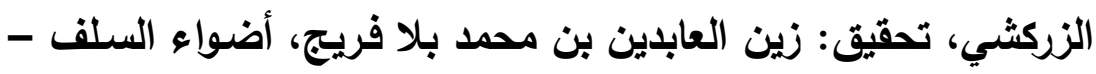
الرياض، ط: الأولى (9 (1 ؛ 1).

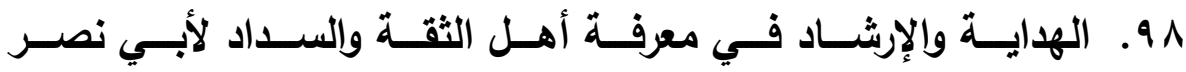

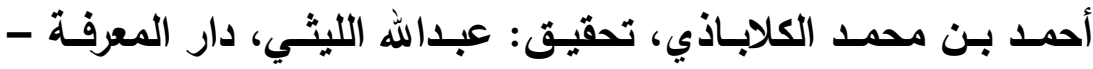

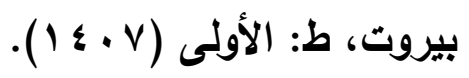

99 9. هدي الساري مقدمة فتح الباري لابن حجر العسقلاني، دار المعرفة -

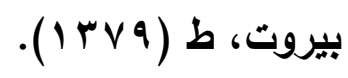

. . . . اليواقيت والدرر في شرح نخبة ابن حجر لعبدالرؤوف المناوي، تحقيق:

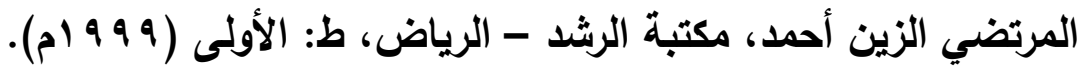
ب 